ANA KARINA AMORIM CHECCHIA

\title{
O QUE JOVENS ALUNOS DE CLASSES POPULARES TÊM A DIZER SOBRE A EXPERIÊNCIA ESCOLAR NA ADOLESCÊNCIA
}

\footnotetext{
Dissertação apresentada ao Instituto de Psicologia da Universidade de São Paulo como parte dos requisitos para obtenção do título de Mestre em Psicologia.
}

São Paulo

2006 


\title{
O QUE JOVENS ALUNOS DE CLASSES POPULARES TÊM A DIZER SOBRE A EXPERIÊNCIA ESCOLAR NA ADOLESCÊNCIA
}

\begin{abstract}
Dissertação apresentada ao Instituto de Psicologia da Universidade de São Paulo como parte dos requisitos para obtenção do título de Mestre em Psicologia.
\end{abstract}

Área de concentração: Psicologia Escolar

Orientadora: Profa. Dra. Marilene Proença Rebello de Souza

São Paulo

2006 
AUTORIZO A REPRODUÇÃO E DIVULGAÇÃO TOTAL OU PARCIAL DESTE TRABALHO, POR QUALQUER MEIO CONVENCIONAL OU ELETRÔNICO, PARA FINS DE ESTUDO E PESQUISA, DESDE QUE CITADA A FONTE.

Catalogação na publicação

Serviço de Biblioteca e Documentação

Instituto de Psicologia da Universidade de São Paulo

Checchia, Ana Karina Amorim.

$O$ que jovens alunos de classes populares têm a dizer sobre a experiência escolar na adolescência / Ana Karina Amorim Checchia; orientadora Marilene Proença Rebello de Souza. -- São Paulo, 2006.

234 p.

Dissertação (Mestrado - Programa de Pós-Graduação em Psicologia. Área de Concentração: Psicologia Escolar) - Instituto de Psicologia da Universidade de São Paulo.

1. Psicologia escolar 2. Adolescência 3. Ensino fundamental 4. Escola I. Título.

LB1051 


\section{O QUE JOVENS ALUNOS DE CLASSES POPULARES TÊM A DIZER SOBRE A EXPERIÊNCIA ESCOLAR NA ADOLESCÊNCIA}

ANA KARINA AMORIM CHECCHIA

BANCA EXAMINADORA

Nome e assinatura

Nome e assinatura

Nome e assinatura

Dissertação defendida e aprovada em 
Aos meus dois grandes amores, que irradiam a minha vida, meu marido, Marcelo e nossa filhinha, Marina.

À querida "Voca", minha avozinha, Liliosa (in memorian), que sempre estará comigo, em meu coração. 


\section{AGRADECIMENTOS}

À querida Marilene Proença Rebello de Souza, que desde a Graduação me apóia, ensina, incentiva e orienta, com seriedade e dedicação. $O$ carinho, investimento, respeito $e$ reconhecimento presentes em sua orientação inspiram minha postura profissional.

À Marília Sposito, titular da banca no Exame Geral de Qualificação, Wanda Junqueira Aguiar, titular na Qualificação e Defesa, Adriana Marcondes Machado, titular na Defesa e Paulo Albertini, suplente na Defesa, por sua cuidadosa leitura e relevantes contribuições a este trabalho.

Aos jovens alunos, sem os quais esta pesquisa não seria possível, pela sua participação e seus ensinamentos sobre a experiência escolar na adolescência. Aos professores, diretora, coordenadora e funcionários da escola, por me acolher e propiciar a realização deste trabalho.

Ao $C N P q$, pelo financiamento concedido à pesquisa.

À Alice Torquetto Soares, pela sua indispensável contribuição ao longo do trabalho de campo, como auxiliar de pesquisa.

À querida Lygia Viégas ("Arretadinha"), por seu precioso apoio durante todo esse processo e aos demais caros colegas do "grupo de orientandos", pela escuta e por suas relevantes considerações sobre o projeto de pesquisa e a dissertação: Anabela Almeida Costa e Santos, Marcelo Domingues Roman, Flavia Ashbar, Roseli Caldas, Giuliana Templi, Zaira Leal e Jane Cotrin.

À Renata Ashbar, pela cuidadosa revisão do texto da dissertação. 
A meus pais, Cirleu e Izolda e irmãos, Gustavo e Léo, sempre presentes, pelos atos e palavras de apoio e carinho. À minha nova família, Sergio, Dóris, Gui, Sônia, Cristiane e Gil, que também me apoiaram e acolheram. $E$ aos parentes e amigos que, mesmo distantes, estão tão próximos.

À Santana, pela indispensável ajuda ao cuidar, com carinho, de Marina, nos momentos em que me dediquei ao trabalho.

A Antônio, que acompanhou toda a minha trajetória acadêmica, pelo constante incentivo e afeto.

À querida Danielle Merino Teraoka, por seu inestimável apoio e amizade.

A todos os amigos, pelo suporte oferecido e pelos momentos de descontração, também importantes neste processo.

A meu querido companheiro, Marcelo, pelo imprescindível amparo, escuta, carinho, amor e compreensão e pelas opiniões sobre este trabalho.

À minha filha, Marina, pela descoberta de uma nova e intensa forma de amar. 


\section{ERRATA}

No "Sumário", onde se lê "Anexo XVII - Cd-rom contendo os anexos I a XVII ...", ler: Anexo XVII - Cd-rom contendo os anexos I a XVI.

Na página 232, onde se lê "OZELLA, Sergio (org). 'Apresentação'. (...) Cortez, 2003", ler: OZELLA, Sergio (org). "Apresentação" (...) Cortez, 2003a.

Na página 41, onde se lê "Os autores do livro (...) organizado por Ozella (2003)", ler: Os autores do livro (...) organizado por Ozella (2003a).

Na página 2, onde se lê "Percebe-se, então, em autores que são referência (...) a fatores intrasubjetivos (Aguiar, Bock e Ozella, 2001, p. 164)", ler: Percebe-se, então, em obras de autores que são referência (...) a fatores intrasubjetivos, como apontam Aguiar, Bock e Ozella (2001, p. 164), que questionam essa concepção. 


\section{SUMÁRIO}

RESUMO

p. i

ABSTRACT

p. ii

APRESENTAÇÃO

p. iii

1. INTRODUZINDO QUESTÕES SOBRE ADOLESCÊNCIA E ESCOLARIZAÇÃO... p. 1

a) Explicitação sobre o referencial teórico utilizado: uma abordagem crítica em Psicologia Escolar.

b) Apontamentos gerais sobre a adolescência.............................................................. p. 8

b.1) Delimitação do conceito: adolescência ou juventude?................................... p. 9

b.2) A adolescência como um fenômeno social e historicamente constituído: contribuições das Ciências Sociais.

2. PSICOLOGIA E ADOLESCÊNCIA: UMA HISTÓRIA MARCADA PELA NATURALIZAÇÃO DESSE FENÔMENO

a) $O$ predomínio de uma concepção naturalizante........................................................ p. 21

b) A naturalização em questão: uma concepção sócio-histórica sobre a adolescência no campo da Psicologia p. 41

3. CAMINHOS PERCORRIDOS PELA PESQUISA: APONTAMENTOS SOBRE O

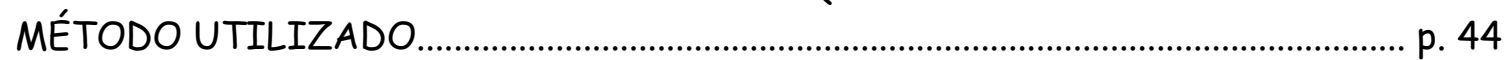

a) Participantes.......................................................................................................... p. 45

b) Trajetória do trabalho de campo................................................................................ p. 46

b.1) Procedimento da pesquisa........................................................................... p. 49

c) Análise

4. O QUE DIZEM OS JOVENS ALUNOS................................................................. 58

a) $A$ condição de alunos adolescentes......................................................................... p. 58

a.1) Ser adolescente ............................................................................................ p. 58

a.2) Ser aluno adolescente.................................................................................. p. 70

b) Relação com demais participantes do contexto escolar........................................... p. 80

b.1) Relação com professores.......................................................................... p. 80

b.2) Relação com diretora e coordenadora..................................................... p. 87

b.3) Relação com funcionários............................................................................ p. 90

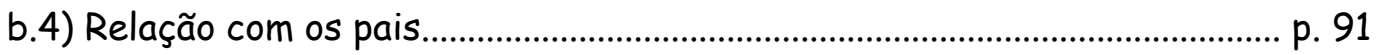

b.5) Relação entre jovens alunos e seus pares.................................................... p. 92 
c) Considerações e sentimentos relativos ao dia-a-dia escolar.................................... p. 94

d) Críticas e propostas referentes à educação escolar................................................. p. 101

d.1) Críticas apresentadas pelos jovens alunos................................................... p. 101

d.2) Propostas para a melhoria do quadro educacional..................................... p. 112

e) Recado dos jovens para a sociedade: o Partido dos Adolescentes da Nação...... p. 120

5. CONSIDERAÇÕES SOBRE ADOLESCÊNCIA E ESCOLARIZAÇÃO À LUZ DE UMA PRESPECTIVA CRÍTICA EM PSICOLOGIA ESCOLAR ........................................ p. 129

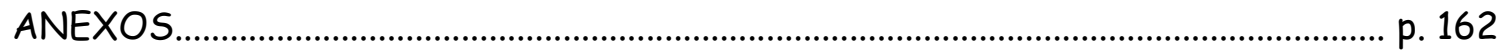

Anexos I a XIII - Material utilizado e elaborado na pesquisa de campo (roteiros, cartas, temas dos encontros, documento produzido pelos alunos e letras de música).

Anexo XIV - Transcrição de um encontro em grupo com os alunos.. p. 181

Anexo XV - Transcrição de uma entrevista individual com uma aluna. p. 208

Anexo XVI - Transcrição de uma entrevista individual com uma professora

Anexo XVII - Cd-rom contendo os anexos I a XVII e a transcrição dos demais encontros em grupo com os alunos e entrevistas individuais com alunos e educadores 


\section{RESUMO}

CHECCHIA, Ana Karina Amorim. O que jovens alunos de classes populares têm a dizer sobre a experiência escolar na adolescência. São Paulo, 2006, 234p. Dissertação (Mestrado). Instituto de Psicologia, Universidade de São Paulo.

Esta pesquisa tem como objetivo investigar a versão de jovens alunos de classes populares sobre a experiência escolar na adolescência, com base em uma abordagem crítica em Psicologia Escolar. O procedimento da pesquisa envolveu a realização de seis encontros em grupo, inspirada na proposta de "Grupos Focais", e entrevistas individuais com oito estudantes da oitava série do Ensino Fundamental de uma escola estadual em São Paulo, pertencentes a classes populares. Diante disso, atentou-se para o discurso dos jovens sobre: a) a condição de alunos adolescentes, b) a relação entre os participantes do processo educacional, c) a vivência do dia-a-dia escolar e d) a qualidade do ensino. Nesta pesquisa, os adolescentes enfatizam a necessidade de romper com a imagem pejorativa que lhes é socialmente atribuída e valorizam o debate sobre educação e política. Preocupam-se com a qualidade do ensino nas escolas públicas e ressaltam a relevância em se propiciar a comunicação entre os participantes do contexto escolar; apresentam como propostas para melhoria do quadro educacional o efetivo incentivo do Governo à Educação e o investimento na infra-estrutura das escolas e na formação de professores. Revelam uma experiência escolar predominantemente atravessada pela não-escuta, desrespeito e humilhação, em um contexto no qual se reproduzem estereótipos relativos à adolescência; e explicitam uma articulação entre rótulos vinculados à condição de adolescentes e à de alunos de classes populares. Com esta pesquisa, espera-se contribuir para a compreensão dos processos escolares, bem como indicar caminhos teórico-metodológicos que rompam com a hegemonia da naturalização da adolescência no campo da Psicologia, enfatizandose a constituição social e histórica desses fenômenos. 


\begin{abstract}
CHECCHIA, Ana Karina Amorim. What poor class young people have to say about their school experience during adolescence. São Paulo, 2006, 234p. Dissertação (Mestrado). Instituto de Psicologia, Universidade de São Paulo.
\end{abstract}

With the support of critical approach to school Psychology, our study aims at investigating the poor class young people's version about their school experience during adolescence. The research achieved six group meetings, inspired by the "Focal Group" proposal, individual interviews with eight students of the eighth period of Fundamental School in São Paulo, belonging to popular classes. Therefore we paid attention to young people's discourse on a) the condition of adolescent students, b) the relation among the participant of the educational process, c) school everyday living, d) the low quality of public school. In this study we realize that the adolescents emphasize the need to leave the pejorative image which is socially attributed to them. They valorize debates about education and politics. They also are worried about the quality of public school teaching and point out the relevance of promoting communication among people who belong to the school context; as proposal to the improvement of educational situation they suggest the government's incentive to Education and investment both in school infrastructure and in teacher's development. Besides, they reveal a school experience marked by the impossibility to be heard, disrespect and humiliation, in a context which reproduces stereotypes of adolescents. They also explain an articulation between labels linked to adolescent conditions and poor class students. We hope that this study may contribute to the understanding of school process, as well as to show theoretical and methodological ways which rupture with the hegemony of the naturalization of the adolescence in the field of Psychology, giving importance to the social and historical constitution of these phenomena. 


\section{APRESENTAÇÃO}

No primeiro semestre de 1998, ao cursar a disciplina Psicologia Escolar e Problemas de Aprendizagem I no terceiro ano de graduação em Psicologia no Instituto de Psicologia da USP, pude entrar em contato com vários textos e autores que muito me instruíram e trouxeram importantes contribuições para minha formação acadêmica e atuação profissional. Dentre as descobertas que iluminaram meu caminho de estudo e investigação nessa área, destacam-se os ensinamentos relativos a uma abordagem crítica em Psicologia Escolar, fundamentada na obra de Maria Helena Souza Patto.

A consideração de aspectos institucionais, sociais, históricos e políticos implicados nos fenômenos escolares, em oposição a sua naturalização, bem como a necessidade de atentar para a versão dos participantes envolvidos no contexto escolar, buscando-se compreender a problemática educacional, consistem em elementos dessa abordagem bastante relevantes e pelos quais apresento grande interesse.

A leitura da dissertação intitulada Representação da escola em crianças da classe trabalhadora (Cruz, 1987), em que se investiga o trajeto da representação de crianças sobre a escola ao longo de seu primeiro ano de escolaridade, motivou-me a aprofundar o estudo acerca da versão dos alunos sobre a experiência escolar, tendo como foco, agora, os adolescentes, cuja faixa etária não costuma ser priorizada nas pesquisas desenvolvidas na área de Psicologia Escolar. 
O desejo de atentar para o tema referente à adolescência e escolarização também decorre de minha experiência de trabalho com os jovens. O contato com os adolescentes evidenciou o fato de que esses jovens têm muito a dizer e ensinar (inclusive, a respeito do processo de escolarização na adolescência), o que desvela a importância de ouvi-los. Além disso, durante esse contato, os jovens expressaram seus questionamentos e sentimento de indignação perante a situação social, econômica e educacional do Brasil. Essa percepção aponta uma total discrepância em relação às concepções vigentes sobre a adolescência na nossa sociedade (que recebem influências de teorias que naturalizam e patologizam este fenômeno, conforme será apontado ao longo desta Dissertação), segundo as quais o adolescente seria um alienado ou rebelde sem causa, que vive uma fase inerentemente confusa e complicada.

Sendo assim, a necessidade de se intensificar o estudo sobre adolescência e escolarização, bem como de se questionar a naturalização desses fenômenos consistem em elementos precursores desta pesquisa, que tem como objetivo investigar a versão de jovens alunos de classes populares, estudantes da oitava série em uma escola pública de São Paulo, sobre a experiência escolar na adolescência. Busca-se, com isso, contribuir para a elucidação de questões referentes à relação entre adolescência e escolarização, com base em uma abordagem crítica em Psicologia Escolar.

Diante de tais considerações, será descrita, a seguir, a estrutura do texto desta Dissertação: 
No primeiro capítulo, são introduzidas questões referentes à adolescência $e$ escolarização, contextualizando-se o objetivo e as perguntas norteadoras desta pesquisa. Explicita-se o referencial teórico que embasa este trabalho e se elucida o conceito de adolescência utilizado, atentando para sua dimensão etária (ou seja, para a delimitação da faixa etária a que corresponde) bem como para sua constituição social e histórica.

O segundo capítulo apresenta teorizações proferidas no campo da Psicologia acerca da adolescência, com referências à concepção hegemônica calcada na naturalização desse fenômeno e a uma visão crítica que enfatiza sua constituição sócio-histórica.

No terceiro capítulo, são apontados a trajetória do trabalho de campo, os participantes e o procedimento da pesquisa, elucidando-se, assim, o método utilizado.

O quarto capítulo condensa a análise do material obtido na pesquisa de campo, apresentando o discurso dos alunos acerca do tema investigado, ou seja, evidencia a versão desses jovens sobre a experiência escolar na adolescência.

No último capítulo, são sintetizados os aspectos centrais referidos ao longo da Dissertação e se estabelece uma articulação entre esses elementos e afirmações proferidas por autores em trabalhos recentes. Apontam-se considerações relativas à adolescência e escolarização a partir do embasamento teórico em uma abordagem crítica em Psicologia Escolar. 


\section{INTRODUZINDO QUESTÕES SOBRE ADOLESCÊNCIA E ESCOLARIZAÇÃO}

A concepção vigente na Psicologia sobre adolescência tem sido, freqüentemente, marcada por uma visão naturalizante e a-histórica acerca desse momento da vida do homem, estando presentes, em muitos estudos, estereótipos relativos a essa fase. Autores como Aguiar, Bock e Ozella (2001) referem-se a tais aspectos ao contextualizar a visão da Psicologia sobre o adolescente e apontam a idéia de que, desde o início do século $X X$, evidencia-se o predomínio de uma concepção marcada pela universalização e naturalização do adolescente, "produzida $e$ reproduzida pela cultura ocidental, assimilada pelo homem comum e pelos meios de comunicação em massa e reafirmada pela Psicologia tradicional" (Op. cit. p. 164)‥

Dentre as produções relativas a esse tema, destacam-se as obras de Stanley Hall, Aberastury e Knobel, que se tornaram referência para o estudo sobre adolescência, exercendo influência em trabalhos recentes realizados, inclusive, no Brasil. De acordo com esses autores, desequilíbrios e instabilidades são inerentes ao jovem e correspondem a alguns dos traços que compõem uma crise preexistente a esse momento da vida. Nesse sentido, a adolescência é caracterizada por conflitos, inquietações, rebeldia (vista de forma pejorativa), vulnerabilidade acentuada, dispersão e irresponsabilidade, atribuídos ao funcionamento psíquico dos adolescentes

\footnotetext{
${ }^{1} O$ processo de naturalização do comportamento humano é fruto de concepções de homem e de sociedade, vigentes nos séculos XIX e XX, cuja influência abrange vários campos da Ciência, incluindo a Psicologia. A esse respeito, ver Patto (1984;1996).
} 
(Stanley Hall, 1925; Debesse, 1946; Aberastury, 1980; Knobel, 1981a, 1981b; Anna Freud, 1986; Bossa, 1998; Levisky, 2000).

Desse modo, enquanto Stanley Hall (1925) e Aberastury (1980; 1981) referemse à adolescência como uma fase inevitavelmente difícil, turbulenta e confusa ${ }^{2}$, Debesse (1946, p.10) reporta-se à existência de uma "juventude eterna", considerando um equívoco pensar que essa apresenta variações ao longo da História e Knobel (1981, p. 29) faz alusão à "Síndrome Normal da Adolescência", descrevendo uma sintomatologia típica a esse período.

Percebe-se, então, em autores que são referência no campo da Psicologia, o caráter patológico e natural conferido à adolescência, cuja inserção histórica é negligenciada ao se condicionar a realidade biopsicossocial a fatores intrasubjetivos (Aguiar, Bock e Ozella, 2001. p. 164).

A preocupação em superar essa abordagem hegemônica no campo da Psicologia é apontada por autores que apresentam uma visão crítica acerca desse fenômeno, atentando para sua constituição social e histórica. Com base nessa perspectiva, ressalta-se a relevância em considerar as "condições concretas da vida social que geram a construção (...) da adolescência", que não é tida como uma fase natural do desenvolvimento humano e, sim, "um momento significado, interpretado e construído [historicamente] pelos homens" (Contini, 2002, p.14; Aguiar, Bock e Ozella, 2001, p. 168). Desse modo, defende-se a idéia de que o jovem não seria algo "por natureza",

\footnotetext{
${ }^{2}$ Aspectos reiterados por Anna Freud, Bossa e Levisky (op. cit).
} 
mas sim, um parceiro social, cujo modelo para construção pessoal é atravessado pelas relações sociais (2001, p. 168).

A ênfase na constituição social e histórica dos fenômenos (tanto da adolescência quanto da escolarização), em oposição à sua naturalização, consiste em um aspecto norteador deste trabalho. Tal questão será elucidada a seguir, diante da apresentação do referencial teórico que embasa esta pesquisa, bem como de considerações gerais sobre o conceito de adolescência.

A) Explicitação sobre o referencial teórico utilizado: uma abordagem crítica em Psicologia Escolar

O movimento crítico na área de Psicologia Escolar foi evidenciado a partir do final dos anos 1970, atingindo maior expressão no início dos anos 1980, com a publicação dos livros Introdução à Psicologia Escolar ${ }^{3}$ e Psicologia e Ideologia: uma introdução crítica à Psicologia Escolar (Patto, 1984). Em tais produções, Maria Helena Souza Patto denuncia a naturalização e o caráter ideológico presentes em concepções e práticas hegemônicas no campo da Psicologia e, especificamente, da Psicologia Escolar. A esse respeito, enfatiza:

Cabe aos que produzem, ensinam e praticam a psicologia, tomar consciência do modo pelo qual teorias, métodos e técnicas que naturalizam os homens, isto é, tornam-no coisa cuja compreensão prescinde de sua inserção no processo histórico, têm contribuído para esse estado de coisas. (...) A Psicologia quase toda move-se nos limites estreitos do senso comum. Por achar desnecessário o contato

\footnotetext{
${ }^{3}$ (Patto, 1997 - publicado originalmente em 1981).
} 
com o conhecimento gerado por outras Ciências Humanas - já que elas tratam da 'sociedade', enquanto a Psicologia centra-se no estudo do 'individuo' - continua a não perceber que o que lhe parece natural é social, que o que parece a-histórico é histórico. (1997, pp. 439, 464).

Patto elucida a idéia de que o pensamento crítico abrange a investigação das raízes dos fenômenos estudados, em oposição à sua naturalização ${ }^{4}$. Nesse sentido, com base nos fundamentos do pensamento marxista $e$, portanto, nos princípios do materialismo histórico dialético ${ }^{5}$, a autora atenta para a constituição social e histórica dos fenômenos escolares. Desse modo, contribui para a consolidação de uma concepção crítica em Psicologia Escolar, enfatizando a complexidade de fatores implicados no processo educacional, ao apontar elementos sociais, históricos, institucionais, políticos e ideológicos envolvidos nesse contexto:

\begin{abstract}
A possibilidade de pensamento crítico - do pensamento que vai à raiz do conhecimento, define seus compromissos sociais e históricos, localiza a perspectiva que o construiu [e] descobre a maneira de pensar e interpretar a vida social da classe que apresenta esse conhecimento como universal (...) - implica saber que o "dado" (ou seja, o modo pelo qual a realidade se oferece como algo dotado de características próprias e já prontas) é ponto de partida sempre abstrato (porque reificado) da busca do que se oculta sob o senso comum, sob os estereótipos e preconceitos, sob a versão corrente do que se pretende conhecer.
\end{abstract}

\footnotetext{
${ }^{4}$ Considerações acerca do pensamento crítico na Psicologia escolar também são elucidadas por Meira (2000) e Tanamachi (2000).

${ }^{5}$ Patto refere-se às influências das obras de Marx, Heller e Chauí (dentre outros autores) em seu trabalho e explicita que "o enquadramento teórico subjacente [a suas produções] tem como pressuposto a determinação histórico-social da ação humana" (1984, 2; 1996, p.4). Sendo assim, em $A$ produção do fracasso escolar, Patto afirma: "Partindo do modo materialista histórico de pensar esta relação é que afirmamos a necessidade de conhecer (...) a realidade social na qual se engendrou uma determinada versão sobre as diferenças de rendimento escolar existentes entre crianças de diferentes origens sociais" (1996, p.9).
} 
(...) Na área específica da Psicologia voltada para questões escolares

(...) a atenção à estrutura social e à história da educação e da política educacional num país capitalista dependente fundamenta uma visão crítica da escola enquanto instituição social que reproduz em seu interior o estado de coisas em vigor na sociedade que a inclui. (...) [Essa visão crítica propicia] a elucidação de processos que se dão na vida diária escolar, em suas relações com as dimensões econômica, política e cultural da sociedade brasileira (1997, p. 464; 467).

A partir das considerações apontadas por Patto nos anos 1980, outros psicólogos passaram a expressar a tendência desse movimento crítico na área de Psicologia Escolar, intensificando os estudos ancorados em tal perspectiva ${ }^{6}$. Em produções recentes, alguns autores explicitam elementos que compõem a concepção teórica e a atuação de psicólogos escolares que privilegiam uma abordagem crítica $^{7}$ e, dentre tais elementos, será destacada, neste trabalho, a relevância em atentar para as versões dos participantes do contexto escolar acerca do processo educacional $e$, especificamente, em propiciar a expressão dos alunos.

A importância de favorecer a comunicação no ambiente escolar $e$ o acesso às diferentes versões apresentadas pelos participantes envolvidos nesse contexto, a fim de contribuir para a ruptura de cristalizações presentes em seu discurso e "resgatar a história não documentada do processo de escolarização" ${ }^{8}$, é apontada por Kupfer (1997) e Souza (2000), segundo as quais:

\footnotetext{
6 A análise das produções realizadas ao longo desse movimento crítico é apresentada por Tanamachi (2000) e Meira (2000; 2003).

${ }^{7}$ Ver Psicologia escolar: teorias críticas e Psicologia Escolar: práticas críticas - organizados por Marisa Meira e Mitsuko Antunes (2003).

${ }^{8}$ Souza, 2000.
} 
O objetivo do trabalho do psicólogo na escola é o de abrir um espaço para a circulação de discursos (...). Os discursos institucionais tendem a produzir repetições, mesmice, na tentativa de preservar o igual e garantir sua permanência. Contra isso, emergem vez por outra falas de sujeitos, que buscam operar rachaduras no que está cristalizado. É exatamente como 'auxiliar de produção' de tais emergências que um psicólogo pode encontrar seu lugar (Kupfer, 1997, pp. 54-6) ${ }^{9}$.

Essa história [não documentada] não está nos arquivos escolares, mas precisa ser reconstituída a partir de referenciais teórico-críticos, tendo como elemento fundamental as diferentes versões ou os diferentes significados que os diversos protagonistas atribuem ao processo de escolarização e suas dificuldades, analisando a presença estatal e como essa presença é interpretada e transformada em práticas na vida diária escolar (Souza, 2000, p. 129).

Com base em tais pressupostos, Souza e Machado (1997, p. 47) enfatizam que o trabalho de intervenção do psicólogo na escola envolve a escuta relativa à versão dos alunos sobre sua experiência escolar, priorizando-se a criação de "espaços de expressão e comunicação, onde a criança fala de seu aprendizado, de sua vida escolar e mostra suas potencialidades". Ou seja, valoriza-se a "expressão dos significados que os alunos possuem a respeito do seu lugar na escola" e do processo de escolarização (Souza e Checchia, 2003, p. 133).

Ao enfatizar a necessidade de se ouvir os alunos, Freller (1997) salienta que "elas [crianças] não sofrem caladas com as práticas escolares que precisam ser profundamente repensadas (...), mas também têm algo a dizer. Querem e podem falar, precisando, pois, de alguém para escutá-las" (p. 122 - grifos nossos).

\footnotetext{
${ }^{9}$ Nesse sentido, Souza refere-se à importância de "contribuir para o rompimento de discursos institucionalmente cristalizados, dentre outras formas, pela abertura de espaços de expressão para discursos reprimidos e aclaramento destes" (1997, p. 102).
} 
Deve-se, ainda, ressaltar a escassez de pesquisas desenvolvidas na área de Psicologia Escolar, nas quais comparecem as vozes dos alunos. Ao se referir a esse aspecto, Patto (1996) afirma que "o discurso das crianças (...) que freqüentam a rede educacional brasileira" tem sido "invariavelmente substituído por um discurso retórico e questionável sobre elas. A importância de ouvi-las ainda não foi incorporada à pesquisa" nessa área ${ }^{10}$.

Outro aspecto a ser destacado consiste no fato de que nas produções realizadas na Psicologia Escolar predomina o estudo voltado ao processo educacional de crianças (com ênfase no Ciclo I do Ensino Fundamental) ${ }^{11}$, sendo escasso o enfoque acerca da escolarização na adolescência, o que revela a necessidade de se intensificar a investigação relativa a esse tema ${ }^{12}$.

Diante das considerações apresentadas até este momento, percebe-se a relevância em priorizar, no campo da Psicologia, a crítica a concepções psicológicas vigentes calcadas na naturalização dos fenômenos escolares, bem como da adolescência, enfatizando-se sua constituição social e histórica. Evidencia-se, ainda, a importância de aprofundar, na área da Psicologia Escolar, a reflexão sobre a relação entre adolescência e escolarização, com base em uma abordagem comprometida com uma ética profissional que:

${ }^{10}$ Essa afirmação foi proferida por Patto em 1990 (ano da primeira edição do livro A produção do fracasso escolar). É importante destacar que essa constatação permanece válida, já que o discurso dos alunos apenas se encontra presente em poucas pesquisas mais recentes, realizadas nessa área - como no trabalho de Freller (1993), por exemplo.

${ }^{11}$ Percebe-se, inclusive, que nas citações acima, há referências aos alunos como "crianças".

${ }^{12}$ A restrição de trabalhos voltados a essa questão foi evidenciada ao longo do processo de levantamento bibliográfico nesta pesquisa. 
...reside na indignação diante da humilhação e das práticas disciplinares e pedagógicas que retiram do sujeito seu status de ser pensante. E, ao considerar a não naturalização das ações humanas, das práticas sociais e pedagógicas, essa ética possibilita 0 aprofundamento da crítica teórico-metodológica no campo do conhecimento da Psicologia (Souza e Checchia, 2003, p. 134).

Ressalta-se, então, a necessidade de contribuir para o questionamento de estereótipos endossados por teorizações psicológicas que rotulam e silenciam o sujeito, tanto em sua condição de aluno quanto de adolescente.

Partindo-se de tais considerações, esta pesquisa tem como objetivo investigar a versão de jovens alunos de classes populares, estudantes da oitava série em uma escola pública de São Paulo, sobre a experiência escolar na adolescência. Para dar subsídios a tal investigação, procura-se atentar para o que esses alunos têm a dizer acerca das seguintes questões: Como é ser um aluno adolescente? Como se dá a relação entre esses estudantes e os demais participantes do processo educacional? Qual a visão dos jovens alunos sobre o dia-a-dia escolar e a qualidade do ensino?

Com isso, busca-se contribuir para reflexões referentes à relação entre adolescência e escolarização, com base em uma abordagem crítica em Psicologia Escolar.

\section{B) Apontamentos gerais sobre a adolescência}

Tão relevante quanto a elucidação do referencial teórico que norteia esse trabalho é a explicitação do conceito de "adolescência" utilizado nesta pesquisa, que 
envolve uma alusão à dimensão etária, bem como à constituição social e histórica desse fenômeno, apontadas a seguir.

\section{B.1) Delimitação do conceito: adolescência ou juventude?}

Essa questão será esclarecida com base em uma estipulação acerca da faixa etária que compreende a juventude e a adolescência. Nessa pesquisa, baseamo-nos nas considerações apresentadas por Sposito (2002), segundo a qual tal estipulação deve envolver uma análise das "condições sociais em que se opera o desenvolvimento dos ciclos de vida em sociedades como a brasileira". Sendo assim, tendo como referência estudos demográficos realizados no Brasil, a autora integra à juventude os segmentos etários de 15 a 24 anos, admitindo uma flexibilidade com relação à atribuição desses limites de idade (p. 10).

Em relação à delimitação desse segmento etário, Sposito $(1997$, p. 39) ressalta que há, na sociedade brasileira, uma tendência à antecipação do "início da vida juvenil" para idades inferiores a 15 anos, já que certos elementos considerados característicos da passagem da dependência infantil para a completa autonomia do adulto (como a inserção no mercado de trabalho) estão se antecipando na experiência de vida de grande parte da população.

Um aspecto central a ser destacado consiste no fato de que, ao se referir aos trabalhos desenvolvidos na área demográfica, Sposito (1997, p. 39) enfatiza a relevância dos estudos realizados por Madeira, que delimita no interior da faixa etária 
da juventude um segmento relativo à adolescência. Segundo essa autora, dentro do grupo etário juvenil (que abrange de 15 a 24 anos), encontram-se, entre 15 e 19 anos, os adolescentes. Nesse sentido, a juventude compreenderia um conjunto etário mais amplo em que estariam inseridos os adolescentes ${ }^{13}$.

Diante disso, é importante ressaltar que a realização de nossa pesquisa envolveu a investigação acerca da versão de estudantes da oitava série do Ensino Fundamental sobre a experiência escolar na adolescência. Como os alunos que cursavam a oitava série compreendiam, em sua maioria, a faixa entre 14 e 16 anos de idade, esse foi o grupo etário contemplado nesse trabalho.

Sendo assim, de acordo com as idéias apontadas acima, consideramos a adolescência um segmento do "amplo conjunto denominado juventude" (Sposito, 1997, p. 39); portanto, os participantes dessa pesquisa podem ser referidos tanto como "alunos adolescentes" (já que atentamos para a faixa etária até os 16 anos), quanto como "jovens alunos" (partindo-se do pressuposto de que a juventude abrange um grupo etário em que a adolescência se insere).

Deve-se salientar que, embora essa delimitação do segmento etário contribua para os esclarecimentos apontados acima, tal critério não consiste em um aspecto suficiente para contemplar a diversidade de fatores implicados na conceituação da

${ }^{13}$ A consideração da faixa etária relativa à adolescência enquanto um segmento do conjunto juvenil também é apontada por Schmidt (2001), que atribui as idades entre 12 e 24 anos à juventude, situando entre 12 e 18 anos a adolescência, com base no Estatuto da Criança e do Adolescente. Esse autor acrescenta que, de acordo com a Organização Internacional da Juventude/UNESCO, os limites de idade referentes à juventude corresponderiam à faixa entre 14 a 25 anos, cujo período inicial (dos 14 aos 18 anos) seria denominado de adolescência (p. 186). 
adolescência como um fenômeno social e historicamente constituído. Essa complexidade é enfatizada por autores em trabalhos desenvolvidos no campo das Ciências Sociais e, no tópico seguinte, serão apontadas breves considerações acerca de idéias apresentadas por alguns dentre esses autores, relativas a tal questão ${ }^{14}$.

\section{B.2) A adolescência como um fenômeno social e historicamente constituído: contribuições das Ciências Sociais}

Inicialmente, deve-se ressaltar que o historiador Philippe Ariès foi um dos primeiros autores a contribuir para a elucidação da dimensão social e histórica da adolescência. Em seu livro intitulado História Social da Criança e da Família (1978) originalmente publicado em 1960 -, o autor elucida a consolidação da adolescência como uma categoria social na modernidade, explicitando sua constituição histórica em oposição à naturalização desse fenômeno. Sendo assim, Ariès (1978) situa o nascimento da adolescência no contexto de extensão do isolamento dos jovens e crianças na escola e na família. A esse respeito, o autor explicita que:

$\mathrm{Na}$ Idade Média a educação das crianças era garantida pela aprendizagem junto aos adultos $e$, a partir de sete anos, as crianças viviam com uma outra família que não a sua, (...) com um tipo de educação que mergulhava imediatamente a criança na sociedade $e$ encarregava a sociedade de treiná-la a desempenhar seu papel. (...) A partir do século XV (...), ao contrário, a educação passou a ser fornecida cada vez mais pela escola (...) [que se tornou] o instrumento

${ }^{14}$ É interessante notar que, enquanto nos trabalhos realizados no campo da Psicologia predomina a utilização do termo "adolescência" (priorizando-se a dimensão psicológica desse fenômeno), na maioria dos estudos da Sociologia emprega-se o termo "juventude" (enfatizando-se sua dimensão social) - tal aspecto também é apontado por Groppo (2000). 
normal da iniciação social, da passagem do estado da infância ao do adulto (pp. 231; 242).

Ariès acrescenta que a adolescência foi confundida com a infância até o século XVIII, firmando-se efetivamente apenas no século XX, principalmente após a Primeira Guerra Mundial; "daí em diante, a adolescência se expandiria, empurrando a infância para trás e a maturidade para frente", tornando-se tema literário e foco de preocupação entre políticos e moralistas (pp 41-7). O autor esclarece, ainda, que a distinção entre o período final da infância (por volta dos 12 ou 13 anos de idade) e a adolescência decorreu "do estabelecimento progressivo e tardio de uma relação entre a idade e a classe escolar" ${ }^{\prime 15}$, bem como da difusão dos ensinos secundário e superior a partir do final do século XIX (pp. 176-7).

A essas considerações, deve-se acrescentar que a consolidação da adolescência ou, de forma mais ampla, da juventude ${ }^{16}$ como um grupo social foi intensificada por progressivas transformações ocorridas durante a modernidade, tal como apontam Rama (1990) e Abramo (2005).

De acordo com Rama (1990), conforme as sociedades modernas se constituem enquanto organizações sociais mais complexas, essas passam a exigir um tempo mais prolongado de formação e conhecimento por parte da população, que pode adquiri-los por meio de inserção em instituições educativas especializadas. Sendo assim, o autor

15 Até o início do século XVIII, crianças a partir de 10 anos a jovens com 25 anos freqüentavam as mesmas classes; e, até o início do século XIX, não se fazia distinção entre a segunda infância e a adolescência (p. 176).

16 Termo utilizado pelos autores citados a partir deste momento. 
enfatiza que uma das implicações da extensão desse período mínimo necessário para a formação em instituições educativas consiste em um parcial afastamento dos jovens em relação a seu grupo familiar, enquanto se intensifica a socialização entre pares (ou a interação entre os próprios jovens, com base na criação de um padrão coletivo para eles mesmos) - fenômeno que apresenta relevante contribuição para a consolidação da juventude enquanto um grupo social (p. 206).

Ao mencionar o prolongamento do período mínimo exigido para a formação escolar, bem como o adiamento da inserção dos jovens no mercado de trabalho, Abramo (2005) salienta que a "dedicação ao estudo em uma instituição escolar" e a suspensão das obrigações relativas ao trabalho passaram a consistir em elementos centrais socialmente vinculados à condição juvenil (p. 41).

Além disso, deve-se ressaltar que, segundo Rama (pp. 208-9), esse padrão coletivo não implica a homogeneização da juventude, que abrange distintas "subculturas" que configuram diversos modos de ser jovem ${ }^{17}$, em função das formas de inserção na sociedade e de acesso ao poder, ao conhecimento (educação) e às práticas culturais, que variam de acordo com a classe sócio-econômica em que o jovem está inserido - ou, de modo mais amplo, à conjuntura social vigente.

Por fim, Rama (p. 206) refere-se ao conceito de juventude como o período em que, embora o indivíduo apresente condições biológicas para reprodução (em função da maturação sexual) e para produção social (decorrente da maturação física e mental

\footnotetext{
${ }^{17}$ Aspecto a ser apontado a seguir.
} 
para trabalhar), a sociedade não reconhece plenamente sua habilidade para desempenhar essas atividades; esse intervalo entre tal potencial e seu reconhecimento social apresenta uma variação histórica ${ }^{18}$.

A esse respeito, Sposito (1997, p. 10) acrescenta que, nos últimos anos, houve a superação de um modelo de passagem para a vida adulta que implicava a necessidade de que se concretizassem três condições: "a partida da família de origem, a entrada na vida profissional e a formação de um casal". Segundo a autora, houve uma transformação na delimitação desses critérios, com o prolongamento do período de permanência na escola $e$ as diferenciadas condições de acesso ao mercado de trabalho, sem que essa inserção implicasse a saída da casa dos pais ou a constituição de uma nova família (ou de uma "nova unidade conjugal"). Nesse contexto, algumas atividades anteriormente atribuídas aos adultos passaram a ser desempenhadas pelos jovens, como, por exemplo, o exercício da "sexualidade adulta", dissociada da reprodução ou do estabelecimento de laços conjugais.

Ao atentar para a consideração acerca da adolescência (ou da juventude) como um fenômeno social e historicamente constituído ${ }^{19}$, é importante ressaltar, ainda, as considerações apresentadas por alguns autores em relação à idéia da "pluralidade de juventudes" ou da diversidade de formas de se vivenciar a condição juvenil ${ }^{20}$.

\footnotetext{
${ }^{18} \mathrm{Tal}$ como enfatiza Sposito (1993).

${ }^{19}$ A fim de aprofundar o estudo sobre a juventude como um fenômeno social e historicamente constituído, ver Mannheim (1968;1982), Foracchi (1972), Bourdieu (1983) e Melucci (1992).

${ }^{20}$ A questão da distinção entre as "juventudes" é introduzida por Bourdieu (1983).
} 
Quanto a isso, Margulis e Urresti (1998) explicitam a necessidade de atentar para a complexidade do contexto social e histórico em que se configuram as distintas maneiras de ser jovem (pp. 14-5). Deste modo, os autores criticam a restrição do conceito de juventude à condição de um grupo homogêneo, à mera "categoria etária" ou aos atributos de determinada classe social a que pertencem os jovens (aspectos que devem ser considerados, mas não como excludentes ou determinantes para a definição desse termo).

Nesse sentido, esses autores afirmam que as diversas modalidades de ser jovem envolvem a articulação entre uma variedade de elementos, tais como a idade, o gênero, a classe social e o contexto sócio-histórico. E enfatizam que a juventude (em sua pluralidade) configura-se como uma "categoria socialmente constituída", que possui uma dimensão simbólica e que deve ser analisada com base nos aspectos materiais, históricos e políticos implicados na estrutura social vigente (p. 17).

Essa complexidade de fatores envolvidos na constituição social e histórica da juventude (ou das juventudes) vem sendo apontada por outros autores em trabalhos recentes. Em seu livro Juventude: Ensaios sobre Sociologia e História das Juventudes Modernas (2000, p. 15), Groppo também contribui para a consideração acerca da juventude como uma categoria social que sofre transformações ao longo da história e que consiste em uma "representação e uma situação social simbolizada e vivida com muita diversidade" em função das distinções culturais, étnicas, de gênero e de classe social. 
Sendo assim, o autor reitera a idéia de uma "pluralidade de juventudes", enfatizando a diversidade de modos de ser jovem, com atitudes, valores, símbolos e sentimentos próprios, presentes em distintos subgrupos que emergem no interior da organização sócio-cultural. Groppo destaca, portanto, que a pluralidade de juventudes deve ser situada neste contexto social:

A multiplicidade das juventudes não se funda num vazio social ou num nada cultural, não emerge de uma realidade meramente diversa, ininteligivel e esvaecida. Tem como base experiências sócio-culturais anteriores, paralelas ou posteriores que criaram e recriaram as faixas etárias e institucionalizaram o curso de vida individual projetos e ações que fazem parte do processo civilizador da modernidade (...) e da configuração das sociedades contemporâneas (op. cit., pp. 19; 27).

Outro autor que se refere, em trabalho recente, à dimensão sócio-histórica da juventude, ressaltando a diversidade envolvida nesse fenômeno é Schmidt (2001), que ilustra essa questão, por meio da seguinte afirmação:

Os conceitos de juventude e adolescência indicam fenômenos históricos e sociais (não existem do mesmo modo em todas as épocas históricas e em todos os meios de uma determinada sociedade), com diversidades internas (os segmentos juvenis de uma mesma geração podem ser, em algumas dimensões, tão diferentes entre si quanto de uma geração para outra), mas cujos componentes compartilham elementos culturais e atitudinais comuns, próprios da sua geração ( $p$. $186)^{21}$.

\footnotetext{
${ }^{21} \mathrm{Tal}$ como foi apontado anteriormente, este autor situa a adolescência no segmento inicial da faixa etária que abrange a juventude - ou seja, entre 12 e 18 anos, no interior da faixa entre 12 e 24 (p. 186).
} 
Assim, diante de tais considerações, evidencia-se o fato de que o conceito de juventude (ou de adolescência) não se restringe a uma categoria homogênea, mas apresenta uma pluralidade e uma complexidade de fatores que devem ser contextualizados na configuração social. Em contraposição a uma referência abstrata à "juventude", como se fosse possível condensar as especificidades das diversas formas de ser jovem em uma categorização fixa, é importante discernir e explicitar a que jovens se está referindo: jovens trabalhadores e/ou estudantes, moradores de centros urbanos, de comunidades rurais, da classe média, alta ou baixa, homens, mulheres etc ${ }^{22}$. Assim como não há apenas uma maneira de ser adulto, não há um único modo de ser jovem; além disso, as pessoas ocupam vários papéis simultaneamente, sem se limitar à condição adulta ou juvenil.

No entanto, essa condição adulta ou juvenil também não pode ser negada ou ignorada. Ser uma criança estudante, um jovem aluno ou um estudante adulto não são situações ou experiências correspondentes. A cada um desses momentos da vida são socialmente atribuídas representações, funções e atividades a serem desenvolvidas, que serão apropriadas e desempenhadas sob diversas formas - tal atribuição também varia entre distintas sociedades, além de sofrer transformações ao longo da história em uma mesma sociedade. Sendo assim, a juventude, enquanto um fenômeno social $e$ historicamente constituído, deve ser contextualizada na configuração da estrutura social em que está inserida.

${ }^{22}$ Essa ênfase à não-abstração da juventude também é apontada por Souza (2003b). 
Por fim, um último aspecto a ser destacado consiste no modo como a juventude vem sendo socialmente tematizada na conjuntura brasileira. Em seu texto "Considerações sobre a tematização social da juventude no Brasil" (1997), Abramo refere-se ao caráter histórico de concepções socialmente difundidas a respeito dos jovens e enfatiza que a juventude simboliza e reflete os conflitos e dilemas da sociedade contemporânea, expressando as angústias, medos e esperanças presentes no contexto social. Além disso, a autora afirma que a juventude apenas desperta interesse e atenção na medida em que representa uma ameaça para a manutenção da ordem social (pelo fato de o jovem se desviar do rumo à integração social; de um grupo juvenil propor alguma ruptura ou transformação na sociedade; ou de uma geração ameaçar alterar a transmissão da herança cultural).

Ao apresentar um panorama histórico da construção social sobre os jovens no Brasil, Abramo (1997, p. 30) evidencia a idéia de que, nos anos 1950, o "problema social da juventude" era associado a um atributo considerado praticamente inerente à condição juvenil: sua "predisposição generalizada para a transgressão e delinquiência", expressa pelos "rebeldes sem causa". Nesse momento, a concepção difundida desde o século XIX acerca da adolescência como uma "fase de vida truculenta e difícil, inerentemente perturbadora" ou "um momento em si patológico", passa a assumir uma dimensão social ${ }^{23}$.

\footnotetext{
${ }^{23}$ Nesse sentido, segundo Abramo (p. 29), a juventude representa um problema na medida em que é vista como um "objeto de falha, disfunção ou anomia no processo de integração social; $e$ (...) como tema de risco para a própria continuidade social".
} 
Nos anos 1960 e início de 1970, o problema passou a abranger toda uma geração juvenil que ameaçava a manutenção do status quo em diversos âmbitos (político, cultural e moral) devido a uma atitude de contestação à ordem social, que implicou o desencadeamento de atos concretos visando a sua transformação ${ }^{24}$ (p. 31). Posteriormente, com o "refluxo" destes movimentos juvenis, a representação sobre os jovens dos anos 1960 passou a envolver uma imagem idealizada acerca dessa geração, considerada "idealista, generosa, criativa, que ousou sonhar e se comprometer com a mudança social". No entanto, nos anos 1980 , volta a se difundir uma imagem negativa sobre a juventude, tida como "individualista, consumista, conservadora, indiferente aos assuntos públicos e apática", em oposição à idealização referente aos jovens dos anos 1960 (p. 31).

De acordo com Abramo (p. 32), nos anos 1990 há um retorno da concepção difundida nos anos 1950 referente à juventude como portadora de problemas de comportamento, com atitudes de desvio ao ajuste ou à integração social. Porém, um elemento que se destaca como aspecto marcante dessa imagem sobre os jovens nos anos 1990 consiste na marca da violência que, associada ao desregramento e ao desvio (bem como ao vandalismo, em alguns casos), é atribuída aos jovens, com ênfase nos que ocupam espaços públicos, como as ruas, e se envolvem em diversas formas de ação,

\footnotetext{
24 Abramo exemplifica tal afirmação referindo-se a "movimentos estudantis e de oposição aos regimes autoritários, contra a tecnocracia e todas as formas de dominação, movimentos pacifistas, as proposições contracultura e o movimento hippie" (p. 31).
} 
individuais e coletivas ${ }^{25}$. Sendo assim, segundo a autora, os jovens (freqüentemente vinculados à criminalidade, à drogadição e aos comportamentos anti-sociais) são considerados "vítimas e promotores de uma dissolução do social", o que evidencia o resgate da juventude como um problema social ou como "depositária do medo" referente à possibilidade de ruptura com a ordem vigente $e^{26}$.

Atualmente, esta concepção acerca da juventude como problema social permanece presente em discursos difundidos em diversos âmbitos da sociedade, endossados por produções acadêmicas e pela opinião pública, que contam com os meios de comunicação, atores políticos, agentes culturais e trabalhadores sociais como aliados na propagação dessa representação, tal como aponta $A b r a m o{ }^{27}$ (p. 29). Além disso, a autora enfatiza que, diante da propagação dessa imagem sobre os jovens, esses deixam de ser ouvidos ou considerados sujeitos capazes de refletir, agir, dialogar e propor idéias relevantes que contribuam para o enfrentamento de questões emergentes em nossa sociedade.

Alguns dos elementos apontados acima são reiterados por teorizações proferidas no campo da Psicologia, conforme será apontado no próximo capítulo.

\footnotetext{
${ }^{25}$ A autora refere-se a "meninos de rua, arrastões, surf ferroviário, gangues e galeras" (p. 32).

${ }^{26}$ A idéia da juventude como um "problema social" também é apontada pela autora ao se referir à "abordagem funcionalista" da Sociologia, por meio da qual se reitera essa concepção.

27 Inclusive, a autora exemplifica a influência de tal concepção na formulação de políticas governamentais com a realização de programas voltados para o enfrentamento dos "problemas sociais que afetam a juventude" (p. 26).
} 


\title{
2. PSICOLOGIA E ADOLESCÊNCIA: UMA HISTÓRIA MARCADA PELA NATURALIZAÇÃO DESSE FENÔMENO
}

\begin{abstract}
Neste capítulo, será explicitada a concepção vigente e hegemônica sobre a adolescência no campo da Psicologia, atentando para teorizações apontadas por psicólogos cujas obras se tornaram referência para o estudo acerca desse tema, bem como para sua influência em produções realizadas no Brasil. Ao longo do texto, serão evidenciadas a naturalização, universalização e patologização da adolescência nas formulações teóricas acerca desse conceito; e, finalmente, será enfatizada a necessidade de superação dessa recorrente concepção, priorizando-se a consideração da adolescência como um fenômeno social e historicamente constituído.
\end{abstract}

\section{A) O predomínio de uma concepção naturalizante}

Um primeiro aspecto a ser apontado consiste no fato de que o termo "naturalização" é utilizado, nessa pesquisa, no sentido de se atribuir um caráter natural ou a-histórico a determinado fenômeno, tal como Aguiar, Bock e Ozella (2001) elucidam ao criticar a concepção naturalizante acerca da adolescência, com base na qual essa é considerada uma "fase natural do desenvolvimento humano", cujas características são tidas como universais e inerentes a essa etapa da vida, de modo a ser "ocultada" sua constituição social e histórica. 
Além disso, deve-se salientar que, embora haja referências, em textos citados a seguir, a mudanças biológicas (físicas ou fisiológicas) que ocorrem ao longo da adolescência - denominando-se 'puberdade' esse período de transformações no corpo, associadas à maturação sexual - será priorizada, neste capítulo, a dimensão psicológica presente nas considerações apresentadas pelos autores em questão, a começar por um dos psicólogos pioneiros em difundir suas teorizações sobre esse tema - Stanley Hall.

No início do século XX, Stanley Hall, considerado o fundador da psicologia da adolescência, divulgou um amplo estudo científico sobre esse fenômeno, em seu livro intitulado Adolescence - its psychology and its relation to physiology, antropology, sociology, sex, crime, religion and education (1925 - originalmente publicado em 1904).

Nesse extenso trabalho (dividido em dois volumes, totalizando aproximadamente mil e quatrocentas páginas), Stanley Hall refere-se às dimensões física, emocional, cognitiva, moral e religiosa dessa fase do desenvolvimento, atribuindo-as, essencialmente, a fatores biológicos, fisiológicos e genéticos envolvidos nesse processo ${ }^{1}$. Um aspecto central apontado por Stanley Hall consiste na apresentação de sua "teoria da recapitulação", fortemente influenciada pela teoria da evolução, de Darwin. Segundo o autor, o desenvolvimento individual recapitula a

\footnotetext{
${ }_{1}^{1}$ Além da leitura do livro de Hall (1925), recomenda-se o acesso ao texto de Gallatin (1942), que contribui para a compreensão acerca dessas considerações apresentadas pelo autor.
} 
história da espécie humana ${ }_{\Perp}$ ou seja, cada estágio do desenvolvimento humano corresponderia a uma etapa da evolução da espécie (1925, I, pp. viii;1)2.

Nesse sentido, Stanley Hall considera a adolescência um período de transição entre o nível mais primitivo e o mais evoluído (ou civilizado) e a caracteriza como a etapa mais turbulenta da evolução, ou a fase mais crítica da vida. Com relação a esse aspecto, o autor afirma que a adolescência é tipicamente marcada por tempestades, tensões, contradições e instabilidades (incluindo rápidas flutuações de humor) ${ }^{3}$ e que, nesse momento da vida, ocorrem diversas e bruscas transformações físicas e mentais, os impulsos dos adolescentes se intensificam $e$ se consolida a formação da personalidade (1925, I, pp. xiii-xv; II, pp. 70-83) ${ }^{4}$.

Por fim, deve-se ressaltar que, embora Stanley Hall considere a influência do "ambiente", o autor enfatiza a determinação biológica e genética nesse processo, explicitando, portanto, uma concepção naturalizante sobre esse fenômeno.

\footnotetext{
${ }^{2}$ De acordo com o autor: "In this process the individual in a general way repeats the history of its species, passing slowly from the ptotozoan to the metazoan stage, so that we have all travessed in our own bodies ameboid, helminthoid, piscian, amphibian, anthropoid, ethnoid, and we know not how many intercarly stages of ascent" (1925, I, p.2).

3 Segundo Gallatin (1942, p. 26), Stanley Hall foi "o primeiro psicólogo a caracterizar a adolescência como um período de tempestade e tormenta".

${ }^{4}$ Tais considerações podem ser ilustradas pelas seguintes afirmações de Stanley Hall: "It is the most critical stage of life, because failure to mount almost always means retrogression, degeneracy, or fall. (...) Development is less gradual and more saltatory, suggestive of some ancient period of storm and stress when old moorings were broken and a higher level attained. (...) We here see the instability and fluctuation now so characteristic. The emotions develop by contrast and reaction into the opposite. (...) Character, temperament, emotions and appetites are changed. (...) The most important and basal of these are connected with the fact that powers and faculties, essentially non-existent before, are now born, and of all the older impulses and instincts some are reinforced and greatly developed (...) It is the age of... rapid fluctuation of mood (...) and character and personality are taking form" (1925, I, pp. xiii;xv.; II, pp. 70-5).
} 
O caráter natural e universal da adolescência também foi ressaltado por Debesse (1946), segundo o qual o adolescente atravessa uma fase que não deve ser considerada mera transição entre a infância e a "maturidade", mas um período que apresenta suas especificidades, problemas, leis e funções (p. 14). A universalidade e a não historicidade desse fenômeno são enfatizadas pelo autor ao considerar que essas leis seriam fixas e que a própria juventude não se modificaria ao longo do tempo:

Acreditar que (...) cada geração tem a sua juventude profundamente diversa da da geração precedente é uma ilusão de moralista amador e apressado. (...) Por detrás do aspecto vário da juventude existe a juventude eterna, notavelmente idêntica a si própria no decurso dos séculos, nas suas tendências, nas suas leis de desenvolvimento, na sua maneira de representar o mundo das coisas e dos seres. São estas permanências que é necessário descobrir e definir (p. 10 grifos nossos).

Além de Stanley Hall, outros autores cujas obras tornaram-se uma importante referência para o estudo sobre a adolescência foram os psicanalistas argentinos Aberastury e Knobel. Os livros Adolescência (Aberastury, 1980) e Adolescência Normal (Aberastury e Knobel, 1981) exerceram notável influência sobre as pesquisas realizadas acerca desse tema na América Latina e, especificamente, no Brasil, conforme será explicitado posteriormente.

Segundo Knobel", a adolescência, considerada "uma espécie de entidade nosológica"6, consiste em uma fase intensamente marcada por conflitos, dificuldades,

\footnotetext{
${ }^{5}$ Psicanalista e Psiquiatra erradicado no Brasil, atual professor Emérito da UNICAMP.

${ }^{6}$ Segundo o Novo Dicionário Aurélio da Língua Portuguesa (Ferreira, 2004), Nosologia significa "o estudo das moléstias".
} 
incertezas, turbulências, desequilíbrios e instabilidades (1981a, p. 10; 1981b, p. 30).

Essas características seriam, de acordo com o autor, universais e típicas desse período da vida, configurando um quadro denominado por Knobel como Síndrome Normal da Adolescência:

O adolescente passa por desequilibrios e instabilidades extremas (...), períodos de elação, introversão, alternando com audácia, timidez, descoordenação, urgência, desinteresse ou apatia, que se sucedem ou são concomitantes com conflitos afetivos, crises religiosas nas quais se pode oscilar do ateísmo anárquico ao misticismo fervoroso, intelectualizações e postulações filosóficas, ascetismo, condutas sexuais dirigidas para o heteroerotismo e até a homossexualidade ocasional. Tudo isto é o que eu chamei de uma entidade semipatológica ou, preferindo, 'uma síndrome normal da adolescência' (1981b, p.28).

Diante disso, Knobel enfatiza, em seu texto, mecanismos intrapsíquicos implicados na "crise essencial da adolescência", ressaltando a idéia de Aberastury, segundo a qual o adolescente realiza três lutos fundamentais: o luto pelo corpo infantil perdido; o luto pelo papel e identidade infantis; e o luto pelos pais da infância - aos quais o autor acrescenta o luto pela bissexualidade infantil (p. 10). Sendo assim, Knobel afirma que a necessidade de elaboração desses lutos "obriga o adolescente a recorrer normalmente a manejos psicopáticos de atuação, que identificam sua conduta"; no entanto, a diferença entre o adolescente normal e o psicopata consiste no fato de que este "persiste com intensidade no uso deste modo de comportamento" (1981a, p. 11). 
Ou seja, segundo Knobel, a passagem por esses lutos implica o surgimento de condutas de desafeto, crueldade com o objeto, indiferença $e$ falta de responsabilidade, que são típicas da psicopatia, mas que também configuram o quadro da "adolescência normal"; porém, enquanto no psicopata essa conduta é "permanente e cristalizada", no adolescente normal é um "momento circunstancial e transitório" (1981b, p. 38). Como se pode perceber, essa afirmação associa-se à idéia de que a adolescência corresponde a uma fase inevitavelmente difícil, porém passageira, já que esse momento de exacerbação dos conflitos está circunscrito a um intervalo entre o período da infância e da vida adulta: conforme o próprio autor salienta, a criança entra na adolescência (quando se intensificam as dificuldades e incertezas) e depois passa para a "maturidade estabilizada" do mundo adulto (1981b, p. 30)7.

Buscando sintetizar as características da adolescência, Knobel descreve a seguinte "sintomatologia" que integraria a Síndrome Normal da Adolescência:

1) Busca de si mesmo e da identidade; 2) tendência grupal; 3) necessidade de intelectualizar e fantasiar; 4) crises religiosas (...); 5) deslocalização temporal, onde 0 pensamento adquire as características do pensamento primário; 6) evolução sexual manifesta (...): 7) atitude social reivindicatória com tendências anti ou associais de diversa intensidade; 8) contradições sucessivas em todas as manifestações da conduta, dominada pela ação, que constitui a forma de expressão conceitual mais típica deste período da vida; 9) uma separação progressiva dos pais; e 10) constantes flutuações do humor e do estado de ânimo (1981b, p. 29).

\footnotetext{
${ }^{7}$ A recorrência de tal idéia em pesquisas produzidas no Brasil será explicitada posteriormente, quando se fizer referência aos textos de Aguirre (1953) e Bossa (1998).
} 
Ao discorrer sobre os tópicos acima, o autor explicita a associação entre essa crise essencial da adolescência e aspectos referentes ao funcionamento psíquico implicados nesse processo, afirmando, por exemplo, que "as lutas e rebeliões externas do adolescente não são mais do que reflexos dos conflitos de dependência infantil que ainda persistem" e que se constituem como identificações em massa decorrentes da necessidade de defesa egóica, por meio das quais os jovens se desprendem de situações infantis e vivenciam o perigo a $e$ incerteza da entrada no mundo adulto (1981b, pp. 27; 53)

Em relação à atitude social reivindicatória, apontada como um dos sintomas dessa Síndrome, Knobel acrescenta que "a juventude revolucionária (...) tem em si o sentimento místico da necessidade de mudança social" e que suas reivindicações consistem em uma "cristalização na ação do que já ocorreu no seu pensamento"; ou seja, diante da frustrante realidade social, as intelectualizações, as fantasias e a

\footnotetext{
8 A título de ilustração, podem-se destacar as seguintes idéias expressas por Knobel, que também elucidam a associação entre essa Síndrome e o psiquismo: "as mudanças de humor são típicas da adolescência e é preciso entendê-las sobre as bases dos mecanismos de projeção e de luto pela perda de objetos"; "poder chegar à genitalidade na procriação é um feito biopsicodinâmico (...) que caracteriza a turbulência $e$ a instabilidade da identidade adolescente"; "o ego realiza tentativas de conexão prazerosa (...) que nem sempre consegue (...); eis aí o retorno a si mesmo autista, que é tão singular no adolescente e que pode dar origem a esse sentimento de solidão tão característico dessa típica situação de frustração e desalento e desse aborrecimento que 'costuma ser uma característica distintiva do adolescente'" (1981b, pp. 30;58). Dentre tais considerações, deve-se ressaltar que o aborrecimento é apontado pelo autor como um atributo típico dos adolescentes.
} 
tendência grupal transformam-se em pensamento ativo, sendo concretizadas em ações políticas $^{9}$ (1981b, p. 54).

Deve-se ressaltar o fato de que Knobel chega a se referir à influência do "meio" (termo utilizado pelo autor) em que o adolescente se insere, porém prioriza a determinação de aspectos biológicos e psicológicos no fenômeno da adolescência. Em relação a esse aspecto, o autor afirma que "as modificações do meio vão determinar a expressão da normal anormalidade do adolescente, mas de nenhuma maneira podemos condicionar toda a realidade biopsicológica desse processo evolutivo às circunstâncias exteriores" (1981a, pp. 10-1).

Sendo assim, Knobel faz alusão à importância de se atentar para a implicação do contexto sócio-cultural nesse processo ${ }^{10}$, porém enfatiza a necessidade de se realizar um "embasamento psicobiológico" por meio do qual se atribuem características universais à adolescência (1981b, p. 24). Segundo o autor, em função da crise essencial da adolescência, nessa fase da vida o sujeito se tornaria mais suscetível a sofrer os impactos da "realidade frustrante", o que se intensificaria diante da vulnerabilidade especial do adolescente para assimilar projeções dos pais e da sociedade (1981a, pp. 10-1). Enfim, Knobel alega que o "problema da adolescência"

\footnotetext{
9 Segundo o autor, "o que se pode explicar como o manejo onipotente do mundo que precisa lucubrar o adolescente como compensação, encontra na realidade frustrante uma imagem espetacular do seu superego cruel e restritivo. As partes sadias do seu ego se põem a serviço de um ideal que permite modificar essas estruturas sociais e coletivas e surgem assim grandes movimentos de conteúdo valioso e nobre para o futuro da humanidade" (1981b, p. 54).

10 De acordo com Knobel: "não há dúvidas de que o elemento sócio-cultural influi com um determinismo específico nas manifestações da adolescência" (1981b, p. 25).
} 
deve ser considerado um processo universal influenciado por condições peculiares de cada cultura, que poderão favorecê-lo ou dificultá-lo (1981b, p. 26).

É interessante notar que Aberastury ressalta, em seus textos, a importância de se considerar a relação entre adolescência e sociedade, afirmando que "toda a adolescência leva, além do selo individual, o selo do meio cultural, social e histórico". E, ao se referir ao contexto social, a autora chega a afirmar que, por detrás do "disfarce da adolescência difícil", estaria uma "sociedade difícil, incompreensiva e hostil", que busca a manutenção de suas rígidas estruturas; acrescenta, ainda, que ao invés de usar o termo "crise da juventude", dever-se-ia falar em "uma forma de crise dos jovens dentro de uma sociedade em crise" (1980, pp. 28;31; e 1981, p. 16).

No entanto, paradoxalmente, a autora refere-se à crise da adolescência e, ao longo dos textos, descreve e enfatiza os determinantes intra-psíquicos e o caráter universal desse fenômeno, caracterizado como "o momento mais difícil da vida do homem" (1980, p. 29) e "um período de contradições, confuso, ambivalente e doloroso" (1981, p. 13). Nesse sentido, segundo a autora, a "problemática do adolescente" se iniciaria com as mudanças corporais e com a definição de seu papel na procriação, seguindo-se às mudanças psicológicas, priorizadas em seus textos $(1981, \text { p. 16) })^{11}$.

\footnotetext{
${ }^{11}$ A fim de ilustrar as considerações da autora, podemos citar a seguinte afirmação: "Durante o processo do crescimento corporal, muitas vezes um adolescente mostra-se subitamente provocador, onipotente e nega a dor face ao passado perdido (...). A negação do sofrimento seria uma das patologias mais graves da adolescência, condicionando, às vezes, crises de rebeldia que levam a condutas anti-sociais e autodestrutivas (...) e iniciação precoce na vida sexual e em condições precárias ou de perigo. São condutas pseudogenitais, apoiadas muitas vezes pelo ambiente, e que encobrem angústias muito intensas e situações fóbicas vencidas com atitudes contrafóbicas" (1980, p. 26 - grifos nossos).
} 
Desse modo, Aberastury considera que um dos problemas centrais dessa fase "crucial e decisiva" consiste na busca da identidade (além da questão relativa à elaboração dos três lutos, apontada anteriormente), sendo que o contexto familiar e o cultural podem contribuir, prejudicar, retardar ou precipitar o desenvolvimento do adolescente, porém, não podem impedir que esse elabore tais processos (1980, p. 27; 1981, p. 90). Portanto, embora mencione a relevância em atentar para o contexto social em que os jovens se inserem, a autora prioriza, assim como Knobel, a implicação de mecanismos intra-psíquicos no fenômeno da adolescência, atribuindo os "típicos" problemas dessa fase a aspectos psicodinâmicos, considerando o meio social como um facilitador (ou não) de tais conflitos.

Por fim, deve-se ressaltar o caráter atual das idéias apresentadas por esses dois autores. Em texto recente, Knobel (2000) reitera as considerações apontadas por ambos, alegando haver constatado, ao longo desses anos, a presença da Síndrome Normal da Adolescência em diversos países, inclusive no Brasil, onde a verificou em diferentes classes sociais - de modo a afirmar que "as modalidades mais 'manifestas' da conduta podem variar, porém as condições gerais são iguais" (p. 49). Diante disso, o autor relata que estaria repetindo as afirmações proferidas anteriormente, pois seriam completamente atuais e conclui que pouco se avançou no estudo sobre a adolescência, sendo, portanto, necessário "reler o já escrito para não apresentar pseudo 'descobertas', às vezes enfeitadas de neologismos incompreensíveis" (p. 50). 
Outros dois psicanalistas que também descreveram mecanismos intrapsíquicos envolvidos no fenômeno da adolescência, exercendo forte influência sobre os estudos acerca desse tema, foram Anna Freud e Eric Erikson. Apontaremos, a seguir, breves considerações apresentadas por esses autores, atentando para a concepção expressa por ambos sobre a adolescência, sem, portanto, alongarmo-nos em explicações específicas referentes ao funcionamento psíquico relativo a essa fase do desenvolvimento.

Anna Freud (1986) considera a adolescência um período de intensas perturbações no equilíbrio psíquico, decorrentes do forte acúmulo de impulsos sexuais que ocorre na puberdade e do retorno dos conflitos da sexualidade infantil (pp. 117; 118 125; 129) ${ }^{12}$. Sendo assim, essa fase seria naturalmente marcada por contradições $e$ instabilidades, tal como expressa a autora, ao caracterizar os adolescentes, por meio do seguinte trecho de seu texto:

Os adolescentes são excessivamente egoístas, considerando-se 0 centro do universo e o único objeto de interesse e, entretanto, em tempo algum de sua vida ulterior são capazes de tanta abnegação e dedicação. Formam as mais apaixonadas relações de amor, para rompê-las tão abruptamente quanto as iniciaram. Por um lado, atiramse entusiasticamente à fruição da vida da comunidade $e$, por outro lado, possuem uma irresistivel ânsia de solidão. Oscilam entre a cega submissão a um líder autoritário e a rebelião insolente contra toda e qualquer autoridade. São egoístas e materialistas, mas, ao mesmo tempo, cheios de um idealismo grandioso. São ascéticos, mas, subitamente, mergulharão na indulgência instintiva do mais primitivo caráter. Por vezes, seu comportamento em relação a outras pessoas é turbulento e irrefletido; contudo, são extremamente sensíveis. Seus

\footnotetext{
12 Para aprofundar essa questão, ver Anna Freud (1986) e Gallatin (1978, pp. 51-78), o qual contribui para a elucidação de tais idéias apresentadas pela autora.
} 
estados de espírito variam entre o otimismo leviano e o mais sombrio pessimismo. Algumas vezes, dedicam-se ao trabalho com infatigável entusiasmo e, outras vezes, são preguiçosos, desleixados e apáticos (pp. 117-8).

Ao generalizar e categorizar as atitudes dos adolescentes, referindo-se a tais variações de conduta como instabilidades ou "incompreensíveis e irreconciliáveis contradições" atribuídas a fatores intra-psíquicos dessa etapa do desenvolvimento, Anna Freud evidencia, assim como Knobel, o caráter universal da adolescência, considerando-a uma fase inevitavelmente turbulenta. Inclusive, na introdução do livro Adolescência Normal, Knobel endossa a idéia de Anna Freud, segundo a qual "seria anormal a presença de um equilíbrio estável durante o processo adolescente" (Aberastury e Knobel, 1981, p. 9).

Eric Erikson, em seu livro Identidade, Juventude e Crise (1972), considera que a adolescência consiste em uma "fase normal de crescente conflito" caracterizada, essencialmente, por uma "crise normativa" - uma crise que se configura enquanto norma nesse período do desenvolvimento: a confusão de identidade (pp. $132 ; 163)$.

Ou seja, segundo o autor, os adolescentes vivenciam, necessariamente, uma crise de identidade e, nessa etapa do ciclo vital, a promessa de encontrar a si próprio e a ameaça de se perder de si mesmo encontram-se intimamente ligadas (p. 245). Sendo assim, a formação de identidade configura-se enquanto uma relevante 
preocupação para os adolescentes, que devem atravessar e elaborar essa crise ao longo desse período (p. 129).

Durante esse processo, de acordo com Erikson, os adolescentes necessitam de uma "moratória", ou seja, de um "período de espera" oferecido pela sociedade, para que os jovens possam integrar os elementos da identidade e "testar os fundamentos de alguma verdade, antes de vincular os poderes do corpo e do espírito a um segmento de ordem existente" (pp. 129:237) ${ }^{13}$.

A leitura de textos produzidos no Brasil referentes à adolescência evidencia a influência das concepções apontadas acima, com predomínio, portanto, de uma ênfase no caráter natural e universal desse fenômeno, tido como um inevitável período de crises ou turbulências, associadas a fatores intra-psíquicos. A seguir, serão destacadas considerações de alguns de seus autores, que explicitam tal afirmação.

Segundo Aguirre (1953), a adolescência consiste em uma fase de dúvidas, inquietações e ansiedades típicas dessa "idade difícil, ingrata ou de tormenta", que seriam minimizadas com o passar do tempo, ao se atingir a estabilidade da vida adulta (pp. 8:18). A autora enfatiza que os principais determinantes dos "desajustamentos" dessa fase seriam os distúrbios, dificuldades e problemas emocionais dos adolescentes e ressalta a necessidade de que tais aspectos sejam estudados (p. 9). Aguirre acrescenta que a crise da adolescência pode ser agravada pelos meios familiar

\footnotetext{
${ }^{13}$ Com relação a esse aspecto, Erikson esclarece que "por moratória psicossocial entendemos um compasso de espera nos compromissos dos adultos e, no entanto, não se trata apenas de uma espera. É um período que se caracteriza por uma tolerância seletiva por parte da sociedade e uma atividade lúdica por parte do jovem" (p. 157).
} 
e social devido a "distúrbios, conflitos, desorganização ou super-proteção da família; falta de compreensão e consideração por parte de pais e professores, ordens, imposições; injustiças e marginalidade" (p. 16).

Em seu livro Características do comportamento do adolescente brasileiro, Ulhoa (1974) busca atentar para as diferenças comportamentais entre o adolescente brasileiro do meio urbano e o do meio rural, procurando evidenciar a idéia de que os problemas da adolescência assumem um caráter particular em função do contexto sócio-econômico, que influencia o desenvolvimento psíquico do jovem (pp. 7:124).

Embora Ulhoa afirme que não haveria um único tipo de adolescente brasileiro $e$, sim, "adolescentes relacionados às estruturas sócio-econômicas", a autora conclui a pesquisa ressaltando que a adolescência corresponde a um período de desequilíbrio, independentemente do contexto sócio-cultural e "o que diferencia um ser do outro é a amplitude desta crise, as formas que ela reveste, a solução que the é dada" (p. 127). Nesse sentido, acrescenta que os problemas dos adolescentes brasileiros seriam universais, já que o inconsciente é universal; porém, os jovens expressam os conflitos típicos dessa fase de modo particular, em função do contexto social em que se inserem (p. 129).

O predomínio de pesquisas realizadas no Brasil cujos autores enfatizam essa concepção referente à adolescência como uma fase naturalmente marcada por dificuldades e tensões também é apontada por Pfromm Neto (1976, pp. 8; 97-100). O autor ilustra esse quadro, descrevendo estudos realizados entre os anos de 1949 e 
1963 por pesquisadores como Jorge, Brasil, Lucena e Van Kolck, em diferentes Estados brasileiros (principalmente São Paulo, Rio de Janeiro e Minas Gerais), cujos métodos de pesquisa consistiram na utilização de testes psicológicos respectivamente o teste de Rorschach, o Psicodiagnóstico Miocinético (PMK), testes projetivos (desenho da figura humana) ou "provas de personalidade".

O ponto em comum entre esses estudos consiste na conclusão de que os adolescentes apresentam intensas dificuldades, problemas, conflitos e ansiedades, decorrentes de fatores intrasubjetivos, o que reitera a concepção da adolescência como uma fase tipicamente turbulenta. Pfromm Neto destaca algumas afirmações desses pesquisadores, que ilustram esse aspecto, tais como a consideração de que os adolescentes expressam agressividade, dificuldade de controle dos impulsos, egocentrismo, exibicionismo, tendência à revolta e predomínio da emotividade; que os jovens vivenciam uma forte angústia decorrente de seu falho esquema referencial de existência, que conduz ao complexo de inferioridade; e que esses sentimentos de inferioridade e insegurança prejudicam os contatos sociais dos adolescentes (pp. 8; 97-100).

Outro aspecto apontado por Pfromm Neto consiste na seguinte observação relativa à tendência geral das pesquisas referentes à adolescência, desenvolvidas em diferentes campos do conhecimento: enquanto grande parte dos estudos em que são considerados os fatores sócio-culturais implicados nesse fenômeno decorrem de pesquisas realizadas por sociólogos ou antropólogos, as informações sobre os aspectos 
do desenvolvimento físico dos adolescentes são proferidas por biólogos, fisiologistas ou médicos e o conhecimento acerca dos problemas emocionais da adolescência, anormalidades mentais e de personalidade deriva, prioritariamente, de estudos realizados por psiquiatras ou psicólogos (p. 18).

Diante de tal afirmação, é importante atentar para a cisão entre os campos do conhecimento nas produções referentes à adolescência e, portanto, para a necessidade de se romper com tal fragmentação, buscando realizar pesquisas que enfatizem a articulação entre diferentes áreas, a fim de contribuir para a compreensão de aspectos implicados na complexidade que abrange o fenômeno em questão. Além disso, deve-se ressaltar a relevância de se realizarem pesquisas no campo da Psicologia, que não compactuem com essa ênfase nos problemas emocionais dos adolescentes ou com a consideração da adolescência como uma fase naturalmente problemática, mas sim, como um fenômeno social e historicamente constituído, tal como será apontado posteriormente.

Pesquisas recentes realizadas no Brasil também evidenciam a influência dessa concepção sobre a adolescência como um período inevitavelmente conflituoso. No seu texto "O normal e o patológico na adolescência", Bossa (1998) ilustra tal aspecto, referindo-se a esse fenômeno como uma "fase crítica da vida", em que "conflitos das fases estruturantes da personalidade do sujeito são atualizados, provocando alterações no comportamento" dos adolescentes, os quais apresentam atitudes que Ihes são características (pp, 212;218). Sendo assim, segundo a autora, os jovens, em 
meio ao "turbilhão" em que vivem, brigam, contestam, desafiam, viciam-se, afrontam $e$ aprontam... (p. 216), até que passem por essa fase e não mais se comportem como típicos adolescentes, ou seja, até que atinjam a maturidade:

... Quando você sentir-se único entre os demais e os outros se tornarem razão para você crescer e melhorar; quando aceitar que as coisas, as pessoas, fatos, situações, sonho e realidade, tudo é estruturalmente mutável e evolucionário; quando você for capaz de tolerar frustrações com dignidade; quando puder amar sem bloqueios e sem preconceitos; quando for capaz de se assumir como homem ou mulher; quando puder construir sozinho sua independência afetiva e econômica: e, quando, finalmente, puder traçar para si o próprio destino, e responsabilizar-se por seus atos e opções, terá passado pela adolescência. Terá chegado à maturidade ( $p$. 217).

A influência das obras de Aberastury, Knobel e Erikson no texto de Bossa é explicitada pela autora, que cita e endossa as considerações desses psicólogos acerca do fenômeno da adolescência. Nesse sentido, Bossa reitera o conceito de Síndrome Normal da Adolescência (bem como seu caráter universal) e associa os conflitos dessa fase a fatores intrapsíquicos, como a questão dos quatro lutos fundamentais e da formação de identidade, apontados pelos autores acima.

As idéias apresentadas por Aberastury e Knobel também são endossadas por Levisky ${ }^{14}$ em textos recentes $(1998,2000)$ - inclusive, o prefácio de um de seus livros (1998) foi redigido pelo próprio Knobel. Assim como esses autores, Levisky refere-se à adolescência como uma fase de inevitável instabilidade $e$, apesar de apontar a relevância da influência social nesse processo, afirma que "qualquer que seja o

\footnotetext{
${ }^{14}$ Psicanalista e Psiquiatra, formado em São Paulo.
} 
contexto sociocultural, a adolescência será sempre um período de crise $e$ desequilíbrio" (1998, pp. 26;35).

Diante disso, o autor acrescenta que esses conflitos são decorrentes do "turbilhão de transformações incontroláveis e involuntárias" ocorridas durante a puberdade (mudanças corporais, estruturais e fisiológicas) e das repercussões psicológicas da inserção dos adolescentes na comunidade dos adultos, bem como de aspectos do funcionamento psíquico nessa etapa do desenvolvimento ${ }^{15}$ (pp. 26:38;52). Além disso, Levisky enfatiza que essa crise é universal, apresentando variações referentes à intensidade ou ao modo de expressão em cada cultura.

Segundo Levisky, na sociedade ocidental contemporânea, esse quadro conflituoso da adolescência se intensifica. A velocidade com que valores tradicionais são abalados e a infinidade de oportunidades de experiências oferecidas aos jovens torna esse período de formação de identidade mais complexo; além disso, conforme o autor afirma, o contexto social contraditório "contribui para incrementar os conflitos do adolescente, cujo processo, por si só, é rico em contradições" (pp. 26;30;33).

Ao explicitar o caráter contraditório da adolescência, o autor a descreve como um período marcado por "conformismo, apatia, impotência, rebeldia, desfaçatez,

${ }^{15}$ Com relação à implicação de fatores intrapsíquicos nesse processo, o autor afirma, por exemplo, que "nessa etapa da evolução psicossexual, o jovem revive, consciente ou inconscientemente, situações do passado. Essa transição será vivida com maior ou menor dificuldade, sendo que as características da passagem pela adolescência dependerão de suas experiências infantis, das relações afetivas primárias, das características de sua iniciação na vida social, do modo de resolução das relações triangulares por ocasião do conflito edipiano, de suas angústias e temores, os quais nessa ocasião poderão ser, de alguma forma, revividos por ele" (p. 35). 
indiferença (...), tendência à passagem ao ato e baixos teores de responsabilidade", (2000, p. 21 - grifos nossos). Essa tendência à passagem ao ato é explicitada pelo autor, que se refere à tendência natural do adolescente a agir antes de pensar ou a atuar, no sentido do acting-out psicanalítico ${ }^{16}$. E a rebeldia é associada ao funcionamento psíquico dos jovens: "a agressão, a rebeldia, as reivindicações intrafamiliares são formas de manifestação desse fenômeno psíquico do adolescente. Fenômeno que ele também emprega contra a sociedade, a qual representa o papel controlador exercido pelos pais"; a tal afirmação acrescenta-se a idéia de que "o jovem, por meio de contestações e reivindicações, externaliza os conflitos de valores e de autonomia que carrega dentro de si" (pp. 54; 56).

Além disso, ao se referir à questão da violência na adolescência, o autor considera que as diversas formas de expressão da violência presentes na sociedade contemporânea servem como modelo de identificação e como um meio de "autoafirmação" do adolescente, cujo ego se apresenta de modo "instável e vulnerável às pressões sociais e às influências externas"; sendo assim, intensificam-se as "atuações violentas dos adolescentes sobre a sociedade" (pp. 20-24). A esse respeito, o autor acrescenta:

16 "Os adolescentes, por suas características biopsicossociais, tendem espontânea $e$ naturalmente a passar ao ato, com maior tendência a descarregar seus impulsos agressivos $e$ sexuais diretamente, através do processo primário. (...) Com frequiência os adolescentes pensam depois da ação ter sido realizada. Percebem, não raro, as conseqüências de seus atos afetivos após a ocorrência dos fatos. Freqüentemente a fragilidade egóica e a predominância de mecanismos psíquicos primitivos diminuem suas possibilidades de postergar, substituir, ponderar ou reprimir eficazmente a satisfação de seus desejos" (2000, p. 21 - grifos nossos). 
Os 'atos irresponsáveis' [dos jovens] (dirigir sem habilitação, atos de vandalismo) não são nem mais nem menos perniciosos que aqueles que Ihes são apresentados diariamente por meio da violência da mídia, ou de mecanismos políticos repletos de corrupção (...). [A] violência está fazendo parte dos processos identificatórios, como padrão de conduta e forma de auto-afirmação [do adolescente] (...), que se faz presente através da rebeldia, da revolta, de manifestações agressivas (...) Os adolescentes, em busca de sua identidade adulta, reproduzem, imitam ou estabelecem conluios conscientes $e$ inconscientes, como forma de contestação e de auto-afirmação; esse sistema dissociado e dissociante colabora para a psicotização da sociedade e conseqüente aumento da violência (2000, pp. 20-24; 1998, p.27 - grifo nosso).

Diante das considerações apontadas até então, evidencia-se a recorrência de teorizações ancoradas em uma visão universal e a-histórica acerca da adolescência no campo da Psicologia, proferidas desde os primeiros estudos até as mais recentes produções sobre esse tema.

Essa concepção vigente e hegemônica dos trabalhos realizados no meio acadêmico também está presente nos atuais discursos e práticas profissionais de psicólogos, conforme Ozella elucida em recente pesquisa publicada no artigo intitulado "A adolescência e os psicólogos: a concepção e a prática dos profissionais" (2003) ${ }^{17}$. Ao entrevistar psicólogos em diferentes áreas de atuação (de educação, saúde, trabalho e jurídica), Ozella constata o fato de que esses profissionais reproduzem, no discurso sobre o conceito de adolescência e sobre sua prática, essa visão naturalizante, patologizante e universal acerca desse fenômeno.

\footnotetext{
${ }^{17}$ Esse texto consiste em um capítulo do livro organizado por esse autor, citado no próximo item.
} 
B) A naturalização em questão: uma concepção sócio-histórica sobre a adolescência no campo da Psicologia

A necessidade de questionar e superar essa concepção hegemônica é intensamente enfatizada por psicólogos, tais como os que priorizam uma visão crítica sobre a adolescência, ressaltando a relevância em atentar para a constituição histórica e social desse fenômeno. Os autores do livro intitulado Adolescências construídas: a visão da psicologia sócio-histórica, organizado por Ozella (2003), explicitam sua concepção de homem ancorada na Psicologia Sócio-Histórica ${ }^{18}$, seguindo os princípios filosóficos do materialismo histórico e dialético (p. 8). Sendo assim, consideram o homem "um ser histórico com características forjadas de acordo com as relações sociais contextualizadas no tempo e no espaço histórico em que ele vive", estabelecendo-se uma relação dialética entre esse e a sociedade, "na medida em que esse ser se constrói ao construir a sua realidade" (p. 8) ${ }^{19}$.

Com base em tal referencial, ao criticar o predomínio de uma visão universalizante e patologizante sobre a adolescência no campo da Psicologia, esses autores apresentam uma visão sócio-histórica acerca desse fenômeno, considerando-o uma criação histórica da humanidade, ou seja, um período construído, interpretado $e$ significado historicamente pelos homens (p. 9).

\footnotetext{
18 Tendo como referência as obras de Vigotski, Luria e Leontiev.

19 Tais idéias são apontadas no capítulo referente à "Apresentação" desse livro organizado por Ozella, fazendo-se alusão às considerações explicitadas por Bock (uma de suas autoras), em seu texto intitulado "A psicologia sócio-histórica: uma perspectiva crítica em psicologia" (2001), também elucidadas por Bock em "As influências do Barão de Münchhausen na Psicologia da Educação" (2000).
} 
Essa idéia também é explicitada por alguns autores desse livro - Aguiar, Bock e Ozella - em um texto intitulado "A orientação profissional com adolescentes: um exemplo de prática na abordagem sócio-histórica" (2001). De acordo com tal concepção, a adolescência não deve ser considerada uma fase natural do desenvolvimento, mas sim, um momento criado "historicamente pelo homem, nas relações sociais, enquanto um fato $e$ [que] passa a fazer parte da cultura enquanto significado". Desse modo, a partir da construção de tais significações sociais, os jovens adquirem referências para a constituição de sua identidade (2001, pp. 168-9).

Com relação a tais afirmações, Ozella (2002) esclarece que a adolescência se constitui historicamente enquanto representação e enquanto fato social e psicológico, cujo significado é construído culturalmente, "na linguagem que permeia as relações sociais" e, portanto, deve ser compreendida a partir de sua inserção na totalidade social. Sendo assim, contrariamente às alegações de Aberastury e Knobel, de acordo com Ozella, essas condições sociais não são apenas facilitadoras (ou não) do desenvolvimento de certas características dos jovens, mas são constitutivas da adolescência e produtoras de referências para a formação dos sujeitos adolescentes:

Fatos sociais surgem nas relações e os homens atribuem significados a esses fatos. Definem, criam conceitos que representam esses fatos. São marcas corporais, são necessidades que surgem, são novas formas de vida decorrentes de condiçôes econômicas, são condições fisiológicas, são descobertas científicas, são instrumentos que trazem novas habilidades e capacidades para o homem. Quando definimos a adolescência como isto ou aquilo, estamos construindo significações a partir de realidades sociais e de marcas que serão referências para a constituição do sujeito. (...) Dentro de uma perspectiva sócio-histórica só é possivel compreender qualquer fato a 
partir de sua inserção na totalidade, na qual este fato foi produzido. É importante perceber que a totalidade social é constitutiva da adolescência, ou seja, sem as condições sociais, a adolescência não existiria ou seria essa da qual falamos. (...) Estamos falando de condições sociais que constróem uma determinada adolescência. (2002, pp. 21-2).

Por fim, diante de tais considerações, deve-se salientar a necessidade de se superar a concepção vigente $e$ hegemônica no campo da Psicologia sobre a adolescência, considerada uma fase inevitavelmente confusa e conflituosa, naturalmente caracterizada por comportamentos como a instabilidade, a rebeldia, a vulnerabilidade acentuada e a falta de responsabilidade; um período turbulento, mas passageiro, normalmente patológico, previsivelmente instável e rigidamente caótico. Ou seja: um fenômeno histórico, cuja historicidade é cientificamente negada; um processo socialmente constituído, tido como universal; e um momento significado e construído pela humanidade, sendo naturalizado.

Partindo-se, portanto, da consideração da adolescência como um fenômeno social e historicamente constituído, foi realizada a pesquisa em questão, cujo método de investigação será explicitado no próximo capítulo. 


\section{CAMINHOS PERCORRIDOS PELA PESQUISA: APONTAMENTOS SOBRE O MÉTODO UTILIZADO}

Neste capítulo, serão apresentados os participantes, a trajetória do trabalho de campo e o procedimento utilizado na pesquisa.

A princípio, é importante ressaltar que, no período em que foi realizado o trabalho de campo (segundo semestre de 2004), o objetivo da pesquisa consistia em "investigar concepções de jovens alunos e educadores (da oitava série em uma escola da Rede Estadual de São Paulo) acerca do fenômeno da adolescência, visando atentar a suas possíveis implicações para o processo de escolarização" ${ }^{1}$.

No entanto, ao longo das reuniões de orientação e diante das pertinentes considerações apontadas pelos membros da banca do Exame de Qualificação (realizado no primeiro semestre de 2005), evidenciou-se a necessidade de uma maior delimitação do foco da pesquisa. Sendo assim, intensificando-se a coerência com o material obtido por meio do trabalho de campo, o objetivo passou a corresponder à investigação acerca da versão desses jovens alunos sobre a experiência escolar na adolescência. Desse modo, buscou-se atentar para o que esses estudantes têm a dizer sobre a condição de alunos adolescentes; a relação entre esses e os demais

\footnotetext{
1 Deve-se ressaltar que um dos temas estudados ao longo do período de elaboração $e$ aperfeiçoamento do projeto inicial de pesquisa consistiu na relação entre adolescência $e o$ processo de escolarização no Ensino Médio. Um importante trabalho que contribui para a reflexão acerca desse tema intitula-se Ensino Médio: Múltiplas vozes, publicado em 2003.
} 
participantes do processo educacional; a vivência do dia-a-dia escolar e a qualidade do ensino.

Outro aspecto a ser apontado consiste no fato de que nesta pesquisa foi utilizada uma abordagem qualitativa de estudo de caso, em função de permitir o "estudo aprofundado de uma unidade em sua complexidade e em seu dinamismo próprio" (André, 1995, p.49). A esse respeito, Yin acrescenta que o estudo de caso deve ser adotado quando se busca investigar "fenômenos sociais complexos (...) e contemporâneos inseridos em algum contexto da vida real" (2001, pp. 19 e 21).

Sendo assim, ao utilizar o estudo de caso como método de investigação nesta pesquisa, procurou-se atentar para a relação entre fenômenos complexos $e$ contemporâneos, ou seja, adolescência e escolarização visando apreender, a partir da versão de um grupo de jovens, elementos que compõem a experiência escolar de alunos de classes populares, na adolescência.

\section{A) Participantes}

Os participantes da pesquisa foram oito adolescentes (quatro moças e quatro rapazes) de classes populares, na faixa etária entre 14 e 16 anos, estudantes da oitava série do Ensino Fundamental de uma escola da Rede Estadual de São Paulo. O critério para seleção dos alunos será explicitado no próximo tópico e seus nomes (bem como o da escola e dos demais participantes do contexto escolar) foram alterados pela pesquisadora, sendo utilizados nomes fictícios. 


\section{B) Trajetória do Trabalho de Campo}

O trabalho de campo foi realizado durante o segundo semestre de 2004, nos meses de setembro a dezembro, em uma escola estadual localizada em um bairro periférico da cidade de São Paulo. Essa escola, que será nomeada nesta pesquisa como E.E. Clodomiro Martins, abrange o Ciclo II do Ensino Fundamental ( $5^{a}$ a $8^{a}$ série sendo ministradas aulas para $7^{a}$ e $8^{a}$ séries no período da manhã e $5^{a}$ e $6^{a}$ séries à tarde) e Educação de Jovens e Adultos (à noite).

De acordo com o "Plano de Gestão Quadrienal 2003/2006" da escola, essa atende a uma clientela de aproximadamente 1300 jovens e adultos cuja situação econômica é apontada como "de classe média baixa ou pobre" . Seu prédio tem três andares, com 14 salas de aula (além de 2 salas para "aulas de reforço"), biblioteca, quadra de esportes (descoberta), laboratório de informática e sala de vídeo. Há grades em todas as janelas $e$, durante as aulas, as portas costumam ser trancadas, ficando as chaves sob domínio dos educadores e inspetores de alunos.

No bairro em que a escola se localiza, encontra-se uma grande favela situada ao lado de um centro comercial cujas ruas são asfaltadas. A Clodomiro Martins foi construída em um setor movimentado do bairro, em frente a uma rua com asfalto, íngreme e larga, onde há freqüente circulação de automóveis.

Meu primeiro contato com essa escola consistiu em uma visita na qual apresentei a proposta da pesquisa para a coordenadora pedagógica (Simone) e para a

\footnotetext{
${ }^{2}$ A situação de pertencerem às classes populares também é explicitada pelos jovens alunos (participantes da pesquisa) ao abordar essa questão em distintos momentos do seu discurso.
} 
diretora (Tereza); ambas me acolheram muito bem e demonstraram interesse pelo tema em questão, com grande disponibilidade para me auxiliar quando necessário -atitudes que permaneceram durante todo o processo do trabalho de campo ${ }^{3}$. Em tal conversa com a diretora, após seu consentimento para a realização da pesquisa, combinamos o cronograma das atividades, com possibilidade de alterações que se fizessem necessárias ao longo deste período.

Diante disso, apresentei-me, bem como a minha pesquisa, para os professores, funcionários e alunos, explicitando-lhes o objetivo e o procedimento, para contextualizar minha inserção na escola.

A fim de convidar os alunos para participar da pesquisa, tal apresentação envolveu o processo de entrada nas quatro salas de $8^{a}$ série, com exposição da estrutura do trabalho de campo ${ }^{4}$. Assim, os jovens interessados preencheram uma ficha de inscrição (ANEXO IV) e os participantes foram sorteados com base nos seguintes critérios: deveriam ser selecionados 4 moças e 4 rapazes, buscando-se abranger o maior número de salas de $8^{a}$ série; e a faixa etária deveria ser de 14 a 16 anos, procurando-se contemplar estas três idades.

Algumas considerações a respeito desse processo de apresentação da pesquisa aos educadores, funcionários e alunos devem ser destacadas. Diante da exposição da

3 A primeira pessoa a me receber foi a coordenadora pedagógica, que me conduziu, posteriormente, para conversar com a diretora. $O$ roteiro de apresentação da pesquisa para a diretora, bem como a carta de autorização para sua realização, encontram-se em anexo (ANEXOS I e II).

${ }^{4} O$ roteiro de apresentação da pesquisa para os alunos segue em anexo (ANEXO III). 
pesquisa aos professores (realizada na sala de reunião, durante o horário de intervalo), alguns criticaram a postura de pesquisadores que, ao entrar em contato com o contexto escolar, além de redigir trabalhos em que desqualificam os educadores, não retornam a campo com o texto elaborado ${ }^{5}$. Esse fato endossa a relevância em não se instituir um caráter ofensivo ou depreciativo na pesquisa, bem como em se realizar uma leitura, junto aos participantes, do texto redigido ao final do processo, além de buscar que a pesquisa ofereça contribuições para a instituição em que se efetivou o trabalho de campo.

A exposição da pesquisa aos funcionários (inspetores de alunos) foi solicitada por esses, os quais, ao longo de todo o trabalho de campo foram muito solícitos, propiciando grande auxílio, sempre que necessário.

Durante tal apresentação aos jovens alunos, esses enfatizaram a importância e necessidade de serem ouvidos, bem como de se romper com estereótipos relativos aos adolescentes, demonstrando interesse pelo tema da pesquisa. Além disso, ao longo deste processo de exposição da pesquisa aos alunos, tornou-se necessário desmistificar o trabalho do psicólogo, atrelado a uma concepção vigente $e$ estereotipada acerca deste profissional, fortemente associada à atuação clínica. Ou seja, diante da minha apresentação enquanto psicóloga e da contextualização deste trabalho como uma pesquisa de mestrado na área de Psicologia Escolar, muitos alunos manifestaram a idéia de que os encontros em grupo (apontados a seguir) propostos

\footnotetext{
${ }^{5}$ Conforme os professores afirmaram: "essas pessoas vêm aqui e depois só 'metem o pau' na gente, enfiam o que escreveram na prateleira e dão as costas".
} 
como procedimento do trabalho de campo teriam um caráter de 'terapia' - e que isto seria "coisa de louco", conforme afirmaram6. Assim, foi preciso romper com tal concepção e delimitar o papel desses encontros no contexto da pesquisa; após tais esclarecimentos, um maior número de alunos se inscreveu (totalizando 32 inscrições).

Após a seleção dos participantes, conversei com os adolescentes a fim de reafirmar seu interesse em fazer parte da pesquisa, além de reiterar o seu procedimento (bem como a questão do sigilo implicado nesse processo) ${ }^{7}$, confirmar a possibilidade de estarem presentes nos dias e horários combinados e entregar a carta de autorização a ser assinada pelos pais ou responsáveis (ANEXO V). Diante disto, foi realizado o procedimento de pesquisa, que será explicitado a seguir.

\section{B.1) Procedimento da pesquisa}

\section{b.1.1) Encontros em grupo com os jovens alunos}

A realização dos encontros em grupo com os alunos foi inspirada na proposta de "Grupo Focal", que, segundo Cruz Neto, Moreira e Sucena (2001), consiste em uma técnica de pesquisa na qual se reúne um determinado número de pessoas que fazem parte do público-alvo em questão, com objetivo de "coletar, a partir do diálogo e do debate com e entre eles [membros do grupo], informações acerca de um tema específico" (pp. 163-4).

\footnotetext{
${ }^{6}$ Inclusive, uma aluna argumentou que iria se inscrever pois estaria precisando de um trabalho terapêutico.

${ }^{7}$ Aspecto já apontado na apresentação em sala de aula, conforme indicado no "ANEXO III".
} 
De acordo com esses autores, a técnica de Grupos Focais propicia que os participantes apresentem, de modo simultâneo, suas concepções e conceitos (convergentes e/ou divergentes entre si) acerca de determinado tema, favorecendo a discussão entre os integrantes do grupo; promove-se, portanto, uma "fala em debate": "A fala que é trabalhada nos grupos focais não é meramente descritiva ou expositiva; ela é uma 'fala em debate', pois todos os pontos de vista expressos devem ser discutidos pelos participantes" (op. cit, p. 164).

Sendo assim, os autores afirmam que o número de participantes de um grupo focal deve "ser pequeno o suficiente para que todos tenham a oportunidade de expor suas idéias e grande o bastante para que os participantes possam vir a fornecer consistente diversidade de opiniões", o que os leva a considerar como número mínimo, quatro e, máximo, doze (p. 171). Além disso, o tempo de duração do debate deve oscilar entre uma e duas horas.

A técnica de Grupos Focais envolve, ainda, a participação de um "mediador" e de um "observador". Segundo os autores, o mediador executa a função central, sendo responsável pela condução e conclusão dos debates, bem como pela motivação dos participantes, interagindo com estes (p. 166). Ao observador cabe a execução da análise e da avaliação do processo, podendo exercer, ainda, as funções de "relator" (anotando as falas, nomeando-as e atentando para a linguagem não-verbal dos participantes) e de "operador de gravação" - realizando-a em função do equipamento utilizado para o registro dos debates (pp. 166-7). 
Por fim, os autores enfatizam que, para a realização do Grupo Focal, deve-se elaborar um "roteiro de debate", com questões referentes a tópicos centrais a serem discutidos, a fim de se propiciar o levantamento de informações relevantes para a pesquisa (pp. 169-70).

Em relação à trajetória desse procedimento de pesquisa, deve-se destacar que, a princípio, seriam realizados quatro encontros de discussão com os alunos, visando-se propiciar um ambiente de debate entre os jovens sobre a experiência escolar na adolescência. Porém, ao longo dos encontros, os alunos manifestaram interesse em elaborar um documento com as propostas de um partido político fictício ("PAN Partido dos Adolescentes da Nação") criado pelos próprios participantes durante este processo de discussão em grupo.

Dadas a relevância de tal iniciativa dos alunos (com propostas referentes, inclusive, à educação), sua adequação ao tema ${ }^{8}$ e a possibilidade de enriquecimento do material de pesquisa, foram realizados dois "encontros extras" a fim de se efetivar a elaboração desse documento; no primeiro, os alunos iniciaram a redação de tais propostas, finalizando-a no segundo. Nesse último, os jovens acrescentaram ao texto redigido no primeiro encontro extra, propostas elaboradas individualmente (em suas casas) e que foram selecionadas pelo grupo, em regime de votação9

Desse modo, foram realizados seis encontros em grupo com os alunos, sendo quatro para discussão do tema e dois para elaboração de tal documento. Ao longo dos

\footnotetext{
${ }^{8}$ Um dos eixos da análise (capítulo 4) refere-se a "críticas e propostas relativas à educação".

${ }^{9} \mathrm{O}$ documento final encontra-se em anexo (ANEXO VI).
} 
encontros de discussão, foram debatidas questões referentes à experiência de ser aluno adolescente, à relação entre os jovens estudantes e os demais personagens envolvidos no contexto educacional e à vivência do dia-a-dia escolar na $8^{a}$ série $e^{10}$. Além disso, no último encontro foram discutidas letras de duas músicas sugeridas pelos alunos, cujo tema refere-se à questão da adolescência, fazendo-se uma associação entre este fenômeno e o processo de escolarização (as letras dessas músicas também se encontram anexadas - ANEXO VIII).

Esses encontros ocorreram na sala de vídeo da escola, fora do horário de aula ${ }^{11}$, com uma hora e meia de duração e foram registrados por meio de um gravador, contando-se com a colaboração de uma auxiliar de pesquisa, que desempenhou a atividade de "relatora" - tal como foi apontado acima, segundo Cruz Neto, Moreira e Sucena (pp. 166-7) $)^{12}$. Sua função consistiu em relatar trechos do diálogo dos alunos, nomeando-os (a fim de facilitar sua identificação durante a transcrição), além de operar o gravador e auxiliar a transcrever o material dos debates. Outra contribuição da auxiliar de pesquisa, que se configurou enquanto aspecto de grande relevância, refere-se às discussões realizadas sobre os aspectos emergentes no grupo ${ }^{13}$.

Deve-se, ainda, ressaltar o fato de que, ao longo dos encontros em grupo, os alunos demonstraram grande interesse em discutir os temas abordados, expressando

\footnotetext{
${ }^{10}$ Segue, em anexo, o roteiro de questões trabalhadas em cada encontro (ANEXO VII).

${ }^{11}$ Logo após o término da última aula.

${ }^{12}$ Trata-se da participação de Alice Torquetto Soares, aluna de graduação em Psicologia.

${ }^{13}$ Após cada encontro, esta compartilhava comigo as impressões obtidas ao longo do encontro, auxiliando a constatação de importantes elementos presentes nesse processo.
} 
avidamente suas opiniões (em várias ocasiões, os jovens falavam ao mesmo tempo, sendo necessário interrompê-los momentaneamente para que todos fossem ouvidos), com empenho e concentração. Inclusive, manifestaram o desejo de realizar mais encontros, a fim de prosseguir a discussão, chegando a apontar a necessidade de um espaço para esse tipo de diálogo (ou escuta e comunicação) no contexto escolar.

É importante destacar que durante as discussões realizadas nesses encontros, os adolescentes apresentaram opiniões convergentes e divergentes acerca dos temas em questão, de modo a suscitar o aprofundamento de suas argumentações, bem como mudanças em relação à concepção inicial apontada pelos alunos, além de idéias elaboradas coletivamente (como a proposta e redação do documento referente ao "PAN"14); e, ao longo desse processo, evidenciaram-se sentimentos e contradições presentes no discurso dos alunos. Tais aspectos elucidam, portanto, a pertinência da utilização desse procedimento como meio de propiciar a expressão dos participantes sobre o tema da pesquisa.

\section{b.1.2) Entrevistas individuais com os alunos}

Após a finalização dos encontros de discussão com os alunos, foi realizada uma entrevista semi-dirigida (ou "semi-estruturada" - cf. Queiroz, 1983, p. 47) com cada adolescente, a fim de que os jovens pudessem acrescentar individualmente considerações acerca do que foi debatido em grupo, incluindo aspectos referentes aos

\footnotetext{
${ }^{14}$ Conforme foi apontado anteriormente.
} 
assuntos que mais lhe despertaram interesse, assim como os que não foram discutidos, mas que os alunos julgassem relevantes.

Para elaborar o roteiro de entrevista com os alunos, foram ouvidas as gravações dos encontros em grupo, elencando-se alguns pontos centrais a serem abordados com maior profundidade ${ }^{15}$. Atentou-se, inclusive, para aspectos apontados por cada aluno ao longo dos encontros, selecionando-se temas específicos a serem desenvolvidos por cada participante.

\section{b.1.3) Entrevistas individuais com educadores}

Conforme se explicitou no início deste capítulo, no período em que foi realizado o trabalho de campo, o objetivo da pesquisa era mais amplo e envolvia a participação de alunos e educadores. Sendo assim, foram realizadas entrevistas semi-dirigidas individuais com a diretora, a coordenadora e quatro professores da oitava série da escola em questão, visando-se investigar suas concepções acerca do fenômeno da adolescência, bem como aspectos referentes à relação entre tais profissionais e os jovens estudantes. Esses educadores foram selecionados em função da recorrência com que foram mencionados no discurso dos adolescentes; ou seja, entrevistaram-se os quatro professores mais referenciados (os dois mais valorizados e os dois mais criticados) pelos alunos, bem como a coordenadora e a diretora, a quem aqueles fizeram alusão em distintos momentos.

\footnotetext{
${ }^{15}$ Segue em anexo este roteiro de entrevista com os alunos (ANEXO IX).
} 
Embora o objetivo e o foco da pesquisa tenham sido redefinidos, alguns elementos apontados pelos educadores em tais entrevistas foram destacados ao se realizar a análise referente ao discurso dos alunos, em função de contribuições oferecidas para elucidação de questões apresentadas pelos adolescentes.

Enfim, deve-se ressaltar que as entrevistas foram registradas por meio da técnica do gravador (conforme Queiroz, 1983), com exceção de uma, em que o professor não consentiu a utilização do aparelho, sendo realizado o registro por escrito durante o seu discurso. Após a transcrição (sendo preservadas as falas literais, erros gramaticais e gírias dos entrevistados), as entrevistas foram devolvidas aos participantes, a fim de que pudessem fazer as alterações que julgassem necessárias, complementando ou excluindo termos ou trechos da entrevista transcrita, sendo incorporada à pesquisa esta versão final do texto.

Seguem em anexo os roteiros utilizados para entrevistas com professores (ANEXO X), com a diretora e a coordenadora (XI), bem como o cronograma de todas as atividades realizadas enquanto procedimento do trabalho de campo (XII). Também estão anexadas as transcrições de um encontro em grupo com os alunos (ANEXO $X I V)$, bem como das entrevistas individuais realizadas com uma aluna (XV) e com uma educadora (XVI), além de uma tabela com a explicitação das siglas utilizadas em tais transcrições $(X I I I)^{16}$.

${ }^{16}$ Os demais encontros em grupo com os alunos, bem com as entrevistas individuais com os jovens e os professores foram gravados em cd (no qual se encontra todo o material produzido ao longo da pesquisa de campo), anexado a esta dissertação. 
No período de em que se finalizava o processo de redação da dissertação, os adolescentes e os educadores entrevistados foram contatados e houve um retorno da pesquisadora à escola para apresentação da pesquisa a esse grupo de alunos e ao de tais educadores. Além disso, combinou-se uma posterior visita à escola para a exposição acerca deste trabalho aos demais participantes do contexto escolar.

\section{C) Análise}

O material obtido ao longo desse processo foi analisado com base na proposta de André (1983, pp. 66-71), referente à "análise de prosa", que consiste em uma "forma de investigação do significado dos dados qualitativos" e possibilita a obtenção de uma "visão profunda e multidimensional dos fenômenos", levantando-se questões a respeito do conteúdo do material, de modo a incluir mensagens explícitas ou implícitas presentes no conteúdo do material coletado. Sendo assim, ao levantar tais questões, atentou-se para as mensagens e significações de seu conteúdo e para o contexto dos dados, bem como para o quadro teórico em que se situa o fenômeno estudado, retomando-se os objetivos da pesquisa e as questões centrais que norteiam esse trabalho.

Deve-se, ainda, ressaltar que, ao longo do desenvolvimento da pesquisa, "tópicos e temas [foram] gerados a partir do exame dos dados e de sua contextualização no estudo"; esses temas foram freqüentemente revistos e reformulados, com base nos princípios teóricos e pressupostos da investigação realizada (André, op. cit., p. 67). 
Diante de tal explicitação acerca do método utilizado, passaremos, no próximo capítulo, à análise do material obtido por meio dos encontros em grupo e entrevistas individuais com os jovens alunos. 


\section{O QUE DIZEM OS JOVENS ALUNOS}

Eles [adultos] pensam que tudo que a gente vai falar é coisa que... sabe? Coisa besta, coisa que não tem nenhum valor! Mas pode ter muito mais valor do que eles pensam! (Janaína, $4^{\circ}$ Encontro)

Janaína, Denis, Adriana, João, Cristina, Jhonatan, Tamara e Evaristo são jovens alunos de uma escola pública em São Paulo, que apresentam sua versão sobre a experiência escolar na adolescência ${ }^{1}$. Esses jovens explicitam considerações acerca da condição de alunos adolescentes, da relação com os demais participantes do contexto educacional e dos sentimentos relativos à vivência do dia-a-dia na escola; apontam críticas e propostas referentes à educação escolar e elaboram um documento como um meio de expressão, a fim de transmitir uma mensagem para a sociedade. Tais aspectos consistem nos temas elucidados ao longo do capítulo em questão.

\section{A) A CONDIÇÃO DE ALUNOS ADOLESCENTES}

\section{A.1) Ser adolescente}

Janaína: Eu acho ótimo. Por causa que é assim: é a fase que você sai com seus amigos, você conhece pessoas novas. É a fase de descobrir tudo que você não sabia antes.

(1 Encontro)

\footnotetext{
${ }^{1}$ Os nomes citados acima são fictícios, assim como os de todas as pessoas mencionadas ao longo da dissertação, cujos nomes originais foram substituídos (pela pesquisadora) por pseudônimos.
} 
Denis: Quando você quer sair, assim, tem que depender do seu pai, da resposta que ele der. Isso é ruim... E de dinheiro, também.

João: Eterno prisioneiro!

Adriana: A minha mãe fala: "Enquanto você tiver na minha casa, você vai fazer o que eu mandar".

Janaína: Isso ai é horrivel!

Adriana: Aí elas falam: "Quando você tiver seus 18, 20 anos, arruma seu emprego, compra sua casa e vai viver sua vida"!

(1 Encontro)

Os alunos referem-se à adolescência como uma fase que envolve descobertas, diversão, amadurecimento, desafios, responsabilidade e dependência em relação aos pais. Em seu discurso, explicitam que ser adolescente implica vivenciar novas experiências, incluindo as relativas à sexualidade; divertir-se com os amigos, sendo os laços de amizade intensamente valorizados pelos alunos - de modo geral, ao se referir aos momentos de descontração e lazer, destacam atividades ligadas a esporte, música e cinema, além de festas e passeios a shoppings ou à casa de amigos -; e amadurecer, desenvolvendo-se física e mentalmente. Esses seriam, segundo os alunos, aspectos positivos envolvidos nesse processo: "O bom é que vai amadurecendo, entendendo mais a vida..."/ "Ficar numa rodinha com seus amigos, conversando, zoando..." "As garotas..." (Cristina, Janaína e João - $1^{\circ}$ e $3^{\circ}$ Encontros).

No entanto, esses jovens ressaltam que na adolescência também se apresentam desafios como a inserção em uma sociedade violenta e competitiva, na qual devem cuidar de si próprios, sem mais contar com a proteção direta dos pais, e se esforçar para começar a conquistar seu espaço no mercado de trabalho. 
Em seu discurso, os alunos enfatizam, ainda, a questão da responsabilidade. Esse termo é proferido pelos jovens, tanto no sentido de "qualidade ou condição de responsável"2 , quanto no que se refere a compromisso, cargo ou tarefa. Com relação ao primeiro significado, os adolescentes salientam que têm responsabilidade, opondo-se ao que consideram consistir na imagem socialmente difundida acerca dos jovens, vistos como irresponsáveis. Nesse momento, o conceito em questão será vinculado à idéia de compromisso, conforme se explicita a seguir.

Alguns jovens iniciam o discurso a respeito desse tema afirmando que os adolescentes não teriam responsabilidades ou compromissos, de modo a ocupar seu tempo com atividades de lazer ou descanso: "Eu acho que a adolescência é a melhor fase que a pessoa passa. (...) Porque... sei lá. Sem responsabilidade..."/"É. Só jogo bola todo dia!" /"[Por enquanto] É só vida boa, soneca toda tarde..." (Adriana, Denis e Jhonatan $-1^{\circ}$ e $3^{\circ}$ Encontros).

No entanto, ao longo da discussão sobre esse assunto, os alunos (incluindo os citados acima), enfatizam que os adolescentes têm responsabilidades, porém, suas obrigações são distintas das dos adultos: enquanto aqueles devem estudar, apresentar um bom desempenho na escola e ajudar nos serviços domésticos, os adultos devem trabalhar para garantir sua sobrevivência e/ou de sua família. Nesse sentido, consideram que a saída da adolescência e a entrada na vida adulta se estabelece

\footnotetext{
${ }^{2}$ Conforme o Novo dicionário Aurélio da língua portuguesa (Ferreira, 2004).
} 
quando se "começa a sustentar a casa", ou seja, quando se tem como responsabilidade a obrigação de manter financeiramente a si próprio e/ou à família.

A questão do trabalho na adolescência também é abordada pelos jovens ao se referir ao emprego, tanto como um meio de obtenção de um salário para seu usufruto, inclusive como um modo de adquirir certa independência financeira, quanto como uma forma de contribuir para a arrecadação do orçamento familiar: "É bom trabalhar porque a gente começa a ter mais independência e responsabilidade, né? Ter as nossas coisas..., porque, senão, pra comprar um sapato precisa falar: 'Pai, compra?' e ele fala: 'Ah, não. Não tenho dinheiro'. Pô, é chato!' (Tamara - $3^{\circ}$ Encontro). Ao considerar uma de suas preocupações a obtenção de um emprego, cuja necessidade se intensifica diante da situação de pertencerem às classes populares, como meio de auxiliar o pagamento das despesas da família, tal como evidenciam, os adolescentes enfatizam que a aquisição de um emprego na adolescência é dificultada em função da imagem socialmente atribuída aos jovens, vistos como irresponsáveis e displicentes ${ }^{3}$ :

Janaína: Acho que nossa grande preocupação é o emprego; é porque você quer ajudar sua família...

(...) Tamara: A gente que é pobre... tem que ficar aqui ajudando, batalhando...

(1 $1^{\circ}$ Encontro e Entrevista)

Adriana: Acham que nós somos novos, não sabemos trabalhar, não temos capacidade de ter a responsabilidade de um emprego, prefere dar emprego para os mais velhos, que têm coisas pra pagar: [que] o adolescente só quer saber de roupa, calçado, shopping, festa.

(1 Encontro)

\footnotetext{
${ }^{3}$ A questão referente à imagem socialmente difundida acerca dos adolescentes consiste em um relevante tema, que será aprofundado posteriormente.
} 
Outro elemento ressaltado pelos alunos consiste na dependência em relação aos pais. Ao serem questionados acerca dos aspectos negativos da adolescência, fazem alusão, de imediato, a esse tema, referindo-se tanto à dependência financeira, quanto à falta de autonomia ou à submissão a ordens e limites estipulados pelos pais ou responsáveis. Embora um aluno tenha destacado que na adolescência se começa a conquistar certa liberdade:" [Eu vou falar do que tem de bom em ser adolescente]. Meu pai já tá deixando do meu pé, já tá liberando dinheiro na mão. Dá pra namorar mais..." (Jhonatan $-2^{\circ}$ Encontro), tal dependência é forte alvo de críticas por parte dos demais jovens do grupo:

João:...Porque tem que sair pra balada, de "rapel", de casa, assim: pendurado na cordinha (...), fugindo!

(Entrevista)

Adriana: Eu nunca saio de casa; é difícil! Eu queria vir aqui no (?) e ela: "Ai, minha filhinha, você nunca saiu de casa, por que vai sair agora? Eu nunca vou crescer pra ela. Eu nunca vou ter idade suficiente pra poder sair pra uma balada...

(1 Encontro)

Conforme se pode evidenciar no trecho acima, o tema da dependência associase a uma relevante questão presente no discurso dos alunos: a vivência dessa fase como um momento de transição entre a infância e a vida adulta. Com relação a esse aspecto, os adolescentes fazem alusão à idéia de que são tratados como crianças em situações nas quais se endossa a dependência relativa aos pais, enquanto deixam de ser considerados como tal diante de certas obrigações. 
Ou seja, segundo os jovens, ao serem impedidas as saídas à noite e restritos o horário em que devem retornar a suas casas e o acesso ao dinheiro (cuja limitação baseia-se, de acordo com os alunos, na imagem de que o jovem não seria capaz de utilizá-lo de forma responsável), passam a ser vistos como crianças, tendo sua autonomia cerceada. Porém, nos momentos em que lhes é designada a execução de determinadas funções (como atividades domiciliares, por exemplo) deixam de ser considerados crianças - sendo possível inferir que, em tais circunstâncias, são-lhes exigidos compromisso e responsabilidade, características socialmente vinculadas aos adultos:

Denis: Mas tem hora que tratam o adolescente como criança; só pode sair até meianoite!

Janaína: É, daí dá raiva!

Karina:...Então, pra que coisas vocês são crianças?

Juntos: Sair!

(...) Denis: Dizem que o adolescente não pode ter dinheiro na mão porque não vai saber gastar. Lógico que vai saber!

Karina: E em que casos vocês não são crianças?

Denis: No dia das crianças! Não ganhei nada!

(...) Janaína: Pra fazer as coisas [obrigaçôes]. Na hora de fazer alguma coisa, ninguém é criança, mas na hora de sair, todo mundo é criança!

Karina: E o que vocês acham disso?

João: Injustiça! (...) Ou é criança ou não é criança!

(1 Encontro)

Um aspecto relevante a ser destacado no discurso dos jovens consiste em suas considerações acerca da imagem que lhes é socialmente atribuída. Ao se referir à visão dos adultos (ou da sociedade em geral) a respeito dos adolescentes, esses explicitam a idéia de que são vistos, predominantemente, como vândalos, vagabundos, 
irresponsáveis, revoltados e "aborrecentes" - "aborrecidos com tudo" e que "aborrecem [a] todos" (Janaína e João - $3^{\circ}$ Encontro). Sendo assim, esses alunos enfatizam uma visão pejorativa da sociedade com relação aos jovens, cujas características são associadas à violência, displicência, ociosidade, rebeldia $e$ imaturidade:

Karina: Que idéias, que imagem vocês acham que as pessoas na sociedade têm sobre os adolescentes? As pessoas pensam: "o adolescente é..."?

Denis: Vândalos.

Adriana: É, exatamente.

Janaína: Vagabundo, que não quer fazer nada, só quer vida boa.

Adriana: Quer tudo na mão.

Janaína: É, eles pensam isso. A maioria das pessoas.

Karina: E vândalo, assim, como...?

Denis: De quebrar, de brigas.

Adriana: Pichações. (...) [E] falam que (...) adolescente é revoltado.

(1 Encontro)

João: [Os adultos pensam que adolescente é] Tudo de ruim! (...) Irresponsáveis! Cristina: Adorrecente! (...) Que faz tudo errado, não tá nem aí pra nada. Jhonatan: Só gasta dinheiro pra ir pra festa..

$\left(2^{\circ}\right.$ Encontro)

Associada a tal imagem, está a idéia, apontada pelos adolescentes, de que suas afirmações e opiniões costumam ser menosprezadas ou desconsideradas pelos mais velhos, de modo a não se ouvir o que têm a dizer. A necessidade de serem ouvidos é bastante enfatizada pelos jovens, sendo, inclusive, evidenciada em seu discurso nos momentos em que se referem aos encontros em grupo (realizados ao longo da pesquisa 
em questão) como uma rara oportunidade de expressão ${ }^{4}$. Nesse sentido, ressaltam a importância de se propiciarem espaços de discussão em que possam expressar suas idéias, debater e refletir sobre diversos temas (tais como a experiência escolar, adolescência, sexualidade, violência e política). Enfim, essa questão referente à nãoescuta e ao descrédito relativo aos adolescentes pode ser explicitada por meio das seguintes afirmações:

João: O problema é que a gente não é levado a sério! Cristina: Ah, porque muitas pessoas criticam o adolescente, né?... Muita gente critica...

Janaína: E muitas vezes as pessoas não ouve nossa opinião. [?] Eu não sei te explicar. Por exemplo: você quer a opinião de uma coisa, aí você começa a falar lá, aí ninguém quer saber, porque você é adolescente, sabe? Não ouve o que você tem pra dizer. Aí se vai outra pessoa adulta, eles ouvem! Aí é ruim, também!

Adriana: O mais velho fala a mesma coisa que você falou, só que em outras palavras, aí: "Ai, é isso mesmo!... e não sei o quê"! (...) Aí eles acham: "Você é adolescente, não sabe nada da vida, quer dar palpite, por quêe?"; "Nunca passou por [sacrifício na vida] nenhum".

Karina: Por que vocês acham que isso acontece? O que passa na cabeça das pessoas quando não estão nem aí pra o que o adolescente fala?

Adriana: Acho que porque eles também nunca foram ouvidos.

João: [Acham que o adolescente é] inexperiente.

Janaína: De vez em quando o adolescente tem mais experiência que algumas pessoas, tem muito mais experiência..., não que já passou, só de ver o que tá acontecendo.

( $1^{\circ}$ Encontro)

4 Por causa que muita gente não ouve a gente, ai uma pessoa [pesquisadora] vem e fica perguntando. É legal./ A gente discutiu um assunto que hoje em dia tá muito interessante pra gente, porque os adultos falam muito da gente e a gente não gosta.../Ah, porque a gente teve a chance que a gente queria de poder expressar tudo o a gente queria.../Porque qualquer adolescente gosta de falar o que pensa, tem assunto pra debater, pra discutir, mas não tem com quem discutir.../Acho que foi bom. Ainda mais pra fazer um 'livro' [dissertação]; acho que vai dar uma oportunidade boa pra os adolescentes se explicar, pra falar que a gente não é 'aborrecente!! (Entrevistas). 
Tamara: É verdade isso de a gente não ser ouvido! Eu acho que eles pensam que a gente é muito besta, que a gente não tem nem responsabilidade!

(Entrevista)

Ainda em relação à visão pejorativa sobre os adolescentes, os alunos se referem a estereótipos vinculados à imagem socialmente atribuída a jovens de classes populares. Em seu discurso, evidenciam a idéia de que são vistos como marginais (ou como "menores" infratores) ou usuários de drogas, explicitando situações em que foram alvo de preconceitos relativos a sua classe social associados à condição de adolescentes:

João: A polícia acha que os jovens são tudo marginal! Só eu já fui enquadrado umas três vezes! (...) É humilhante a polícia te enquadrar só pelo jeito que você é, só pela roupa que você veste...

(...)Janaína: Eles já enquadram e chegam procurando se você tem droga! Só porque você é adolescente?! Só porque...sabe? Pensa que todo mundo usa isso?

(...)Tamara: ...Por exemplo, se você [adolescente] faz alguma coisa, o repórter fala "Você usa droga? Você faz isso?" Você vê muito aí na... "Cidade Alerta".. Eles falam: "Marginal é isso. Tá vendo? É um 'menor"!!! (...) [Se o adolescente não se veste bem, já pensam] "Ah, é favelado! É maconheiro!" (...) Eu já morei na favela. Senti muito preconceito! Muito preconceito!

(...) Janaína: Falam que é traficante..., é ladrão...

(4. Encontro)

Jhonatan: Um dia tava eu e mais dois moleques [no supermercado] e a gente só tava zoando, né? A gente só foi comprar batata e umas bolachas. A gente entrou, aí veio 0 segurança, perguntou se a gente tava com alguma coisa, falou pra gente levantar a camisa. Aí a gente não levantamo, né? A gente falou: "Você tem alguma prova?" E nem foi ele; ele falou que foi um cliente que falou que a gente tava pretendendo pegar alguma coisa. (...) A gente tava mal vestido, tava de chinelo...

(Entrevista)

Janaína: [Quando olham um jovem pobre, pensam que ele é] Marginal. (...) Pensa que ele não tem nada de bom pra oferecer (...). [Mas] o pobre tem coisa pra expressar, tem uma pá de coisa pra ensinar porque ele passa por muito mais dificuldade!

(Entrevista) 
Percebem-se, no discurso desses jovens, rupturas e reproduções relativas a essa visão pejorativa acerca dos adolescentes. Em certos momentos, criticam essa imagem que lhes é atribuída, ressaltando a necessidade de se romper com tais estereótipos, como quando redigem o documento com as propostas do Partido dos Adolescentes da Nação, reportando-se à importância de se explicitarem suas virtudes em oposição à desqualificação de sua imagem, salientando que são responsáveis, que possuem "muitas idéias em mente" e desejam "demonstrar que não [são] aborrecentes ${ }^{\prime \prime}$. A esse respeito, acrescentam:

Karina: Então, quando se fala "adolescente", na cabeça deles, vem tudo isso [a idéia de que são irresponsáveis, displicentes...]?

Janaína: Vem , só que eles não pensam nenhum lado positivo, porque tem gente que tem vontade de aprender as coisas, se esforça, mas eles não pensam nisso, só vêem pelo lado ruim, só.

(...) Adriana: ... Todo mundo já foi adolescente um dia! Não tem que sair criticando a gente! (...) Não é só o adolescente, revoltado. Tem muita gente revoltado com a vida, revoltado com alguma coisa; não é só o adolescente.

(...)

Janaína: ... "O que eles falam sobre o jovem não é sério!" (...); eles só sabem falar mal do jovem, não reconhecem ele como humano e sim como um animal.

(...) Tamara: ... [O adolescente] pode ter mais responsabilidade que um adulto; [e] tem adulto que tem a mentalidade de uma criança. (...) [E] eles têm que pensar, entendeu, que a gente quer uma coisa pra gente, assim, não ficar aí falando que a gente é marginal, não. Que é isso?

$\left(1^{\circ}\right.$ e $4^{\circ}$ Encontros)

\footnotetext{
5 Tais considerações também serão explicitadas no tópico referente ao "recado dos jovens para a sociedade: propostas do Partido dos Adolescentes da Nação".
} 
Embora nos trechos acima os jovens questionem os estereótipos atribuídos aos adolescentes de modo geral ${ }^{6}$, em outros momentos nos quais explicitam a imagem que esses próprios jovens apresentam acerca de seus pares, reproduzem o discurso até então criticado, enfatizando que muitos adolescentes seriam vândalos e vagabundos. Porém, ao longo de todo o seu discurso, ao fazer alusão a si mesmos, opõem-se a tal categorização, ressaltando características como responsabilidade e seriedade inclusive, consideram-se "bons adolescentes", já que estudam, ajudam os pais e não Ihes dão "tanto trabalho", conforme afirmam ${ }^{7}$. Essa oposição entre a imagem sobre si mesmos e a referente a seus pares é explicitada por meio das seguintes afirmações:

Karina: $O$ que vocês acham disso [que os adultos vêem os adolescentes como irresponsáveis ou vândalos]?

João: Isso é um mau juízo que eles fazem de nós!

(...) Janaína: Enem todos os adolescentes são assim. Não é porque um é, que todos têm que ser.

(...) João: Depende do adolescente. (...) Eu gosto muito de política, eu faço meus planos pro futuro. Tenho responsabilidade, também.

(...) Juntos: Eu sou um bom adolescente!

$\left(1^{\circ}\right.$ e $2^{\circ}$ Encontros $)$

João: A maioria dos adolescentes são vândalos!

(...) Denis: É, de 100\%, 70 é!

(...) João: Eu me salvo!

Janaína: São poucos [que se salvam] (...) Porque, tipo assim, quando eles saem pra se divertir, eles saem pra ficar arranjando briga com as pessoas. A maioria é assim.

(...) Adriana: Eu acho que nesse século XXI os adolescentes são muito folgados! [?] Não pensam em trabalhar, não pensam em fazer nada!

$\left(1^{\circ}\right.$ e $2^{\circ}$ Encontros)

\footnotetext{
${ }^{6}$ Referindo-se tanto a si mesmos quanto a seus pares.

7 Os alunos apontam distinções entre o "bom adolescente" e o "adolescente ideal", alegando que o "ideal" seria "perfeito" (o que corresponde ao jovem que "não sai, fica trancado no quarto, lê o dia inteiro", "só fica estudando", limpa a casa, "leva o cafezinho na mesa"...), enquanto o "bom" seria dedicado, obediente, mas que também "gosta de viver a vida dele", reiterando-se, portanto, a submissão em ambos os modelos apontados pelos jovens.
} 
Além de tais considerações, os jovens fazem alusão a diferenças entre gerações, apontando distinções entre valores e costumes difundidos no contexto social em que seus pais estavam inseridos, quando jovens, e os padrões socialmente estabelecidos e vinculados à juventude, atualmente. Em relação a esse aspecto, afirmam que, enquanto seus pais eram jovens, havia menos violência na sociedade e a educação (em sentido amplo) era mais rígida e opressora, em comparação à liberdade, inclusive sexual, a que se referem nos dias de hoje.

Deve-se destacar que, embora os adolescentes mencionem a liberdade sexual na conjuntura atual, evidenciam a falta de diálogo ou discussão acerca desse tema, tanto na esfera particular (em casa, com seus pais), quanto na pública (na instituição escolar, por exemplo) $)^{8}$ E, ainda a esse respeito, explicitam uma imagem romantizada acerca da expressão sexual durante a juventude de seus pais:

João: Meu pai, quando era adolescente, ele pescava...

Denis: Él Ó as idéia!

João: [Jogava] pedrinha no rio. [Denis: catava cobra]. Catava porco.

Janaína: E a violência também [era diferente]. E minha mãe fala que namoro, essas coisas, também; que hoje tá muito avançado.

João: Só depois de casar, beijava!

Adriana: "Quando eu namorava com seu pai, era eu aqui, ele na esquina jogando pedrinha. Hoje, não. Hoje já querem sair se agarrando"!

Denis: E também a educação que eles tiveram antigamente foi mais rígida, né? Não tinha essa liberdade que a gente tem hoje.

(...) Adriana: Alguns pais prendem. Minha mãe nunca conversou comigo sobre isso. Graças a Deus que eu tenho uma irmã!

(1 Encontro)

\footnotetext{
${ }^{8}$ Poucos, dentre os membros do grupo, referem-se à existência de diálogo sobre a sexualidade com seus pais.
} 
Por fim, ao discutir esse aspecto, introduzem questões relativas ao gênero, elucidando diferenças entre valores, papéis e condutas socialmente atribuídos a moças e rapazes. Tais aspectos são debatidos pelos adolescentes, que apontam rupturas $e$ reproduções com relação a estereótipos vinculados ao gênero:

Karina: E aí também tem diferença entre homem e mulher? Janíana/Tamara: Teeem!

Janaína: Por exemplo, eu, que tenho um irmão (...); ele é só um ano mais novo, mas só que tem diferença. Por causa que ele trabalha e tudo, mas só que ele não faz nada em casa. Agora eu que tenho que ficar me matando lá, arrumando a casa. Isso é errado!

(...)

Adriana: Tem [casos em que] a menina gosta do cara, se entrega pra ele e aí o cara tá numa rodinha e a menina passa: "(..) Era virgem (...), não vale mais nada; é uma vagabunda, agora". Eu já ouvi.

$\left(4^{\circ}\right.$ e $1^{\circ}$ Encontros $)$

(...) Denis: Eu acho que a mulher é diferente. Sei lá, é mais sensivel [João: É mais pura]. Se ilude mais fácil e... se apaixona muito rápido. (...) Você dá um beijo e ela já quer casar daqui uma semana.

Adriana: Eu sou assim.

Janína: Eu não. (...) [Mas] é difícil homem se apaixonar.

João: Eu me apaixonei cinco vezes...

(...) Adriana: [Os homens acham que as mulheres são como] vaso de cristal, que se cair, vai quebrar, tem que ser cuidadinha. Não se tocam que as mulheres estão tomando conta.

(...) João: Eu sou um homem feminista; enquanto os homens estão no poder, ele se acha. Tem algumas mulheres no poder, mas daqui a dois, sete anos, todas vão estar no poder ou, então, igualitariamente, em comum acordo.

$\left(1^{\circ}\right.$ Encontro $)$

\section{A.2) Ser aluno adolescente}

Karina: Como é, pra vocês, ser um aluno adolescente?

Janaína: É chato!

Denis: Éda hora!

Adriana: Você tá na escola, tá pensando "Meu namorado ali e eu aqui estudando..." 
João: Depende da situação.

Denis: É bem legal, aqui você faz seus amigos, brinca pra caramba...

Adriana: Zoa os professores.

João: E também depende do aluno. Um aluno "cdf", por exemplo, um bom aluno... pra ele a escola é um saco, ele fica copiando lição durante seis horas, não olha pro lado (...). Mas para os alunos mais...

Denis: ...Despojados...

João: ...Pra eles o dia passa rápido, porque eles fica... fica só fazendo "vandalisse" (...); conversa, joga cadeira.

(...) [Karina: Janaína, você tava falando que é chato ser um aluno adolescente. Por quê?]

Janaína: Porque eles [professores] cobram muito da gente, muito, muito, muito!

(1 Encontro)

Ao serem questionados sobre a condição de alunos adolescentes, reportam-se a elementos presentes na experiência escolar na adolescência, destacando o relacionamento entre os alunos, com a valorização dos laços de amizade no ambiente escolar, incluindo referências a momentos de diversão vivenciados nesse contexto. Além disso, fazem alusão à idéia de que lhes são dirigidas muitas cobranças ou exigências por parte dos professores e apontam o distanciamento entre a obrigação do estudo e seus demais interesses (como o namoro, por exemplo). Salientam, inclusive, o desgaste envolvido na vivência da rotina das aulas, intensificado ao se apresentar uma dedicação acirrada aos estudos, como seria o caso dos "bons alunos", em contraposição ao descaso atribuído aos alunos tidos como indisciplinados $e$ "vândalos".

Percebe-se que, nesse trecho, os jovens reproduzem a imagem socialmente difundida acerca dos adolescentes, vinculada ao vandalismo e à violência, associando 
tais características aos alunos considerados indisciplinados. Sendo assim, explicitam uma visão acerca do aluno adolescente calcada na articulação entre indisciplina e vandalismo. A idéia de que muitos dentre os jovens alunos são vândalos também pode ser expressa por meio do seguinte trecho:

João: A maioria dos adolescentes são vândalos.

Karina: Vocês concordam? Vocês acham que tem muitos adolescentes que são vândalos?

Cristina: Na escola, sim.

(...) João: Vândalo [são] as pessoas que jogam uma carteira, uma cadeira pela sala (...), aqueles que atrapalham a aula, tiram a paciência do professor.

Cristina: Pichar, também. Pichar o muro.

Jhonatan: Pichar carteira.

João: Roubar.

( $2^{\circ}$ Encontro $)$

Inclusive, um dos jovens acrescenta a questão da marginalidade, alegando que alguns alunos tidos como indisciplinados seriam futuros traficantes: "Tem gente que vem [pra escola], igual ao $X_{7}$ e $X_{8}$; eles vêm só pra zoar!l Mas eles são os futuros mendigos ou traficantes! Alguns deles, eu tenho certeza!" (Tamara e João - $4^{\circ}$ Encontro). A imagem e os estereótipos associados à condição de alunos adolescentes consiste em um relevante aspecto a ser apontado ao longo de todo o capítulo em questão.

Em contraposição à visão sobre os jovens alunos indisciplinados e vândalos, apresentam sua concepção acerca dos considerados "bons alunos", além de se reportar à caracterização do "aluno ideal". Segundo os adolescentes, o aluno ideal seria o que se dedica com afinco aos estudos, realizando as atividades propostas com intensa 
concentração, de modo a não conversar com os colegas durante a aula. Um bom aluno empenha-se em estudar, realizando as tarefas solicitadas, porém, embora não seja 'indisciplinado' (ou não faça "bagunça", como afirmam), conversa, ocasionalmente, com os colegas na sala de aula. Ao enfatizar a idéia de que, além de ser disciplinado, o aluno deve demonstrar interesse pelas aulas, os jovens apontam esse último atributo como prioritário para a caracterização de um bom aluno:

João: [O aluno ideal] é aquele que só faz lição!...

(...) Jhonatan: Aluno bom é aquele que conversa, faz a atividade, o trabalho (...). Um comportamento bom é não bagunçar, fazer o dia-a-dia da lição...

(...) João: Tem aluno que é bom, mas por causa dos outros alunos, fica ruim, aí o outro fica pior ainda. Daí a sala inteira já tá jogando carteira um no outro!

$\left(2^{\circ}\right.$ e $4^{\circ}$ Encontros $)$

Evaristo: [Pra ser um bom aluno] é só ter interesse. Não adianta ser quietinho e não ter interesse.

Jhonatan: Ter interesse nas aulas, no professor...

João: Isso quer dizer que se eu quero brigar com todo mundo, bater em todo mundo e for interessado e prestar atenção na aula, eu vou ser um bom aluno?

Denis: Vai. Ele só vai ser um anti-social, mas vai ser um bom aluno.

Tamara: Vai ser aquele centro das atenções. Éo cara que bate em todo mundo: "Ó, não olha pra ele, que ele vai te dar um soco" (...). Vai ser o cara popular, igual esses filminhos que eu assisto na "Sessão da Tarde".

( $4^{\circ}$ Encontro)

Outro aspecto apontado consiste na distinção entre a experiência escolar na adolescência e na infância ou vida adulta; ou, mais especificamente, na oposição entre ser aluno adolescente e ser aluno criança ou adulto. Os jovens alegam que a experiência escolar na infância é prazerosa e lúdica; e que a relação entre professores $e$ alunos se estabelece de forma mais harmoniosa que na adolescência, já que os professores tratam as crianças com respeito, carinho e atenção (ao invés de xingar ou 
maltratar, como fazem com os adolescentes, tal como afirmam), enquanto as crianças também os respeitam:

Janaína: Aluno criança, eles [professores] dão mais atenção. Eles não ficam maltratando (porque, as vezes, eles ficam maltratando [os adolescentes], assim). Eu acho que era melhor [ser] aluno criança. (...) Se eles (...) maltratar, as crianças chamam a mãe e dá o maior barraco na escola.

(...)

Evaristo: Com os alunos crianças, eles [professores] sabem que têm que ter respeito, não vai intimar, se o aluno tá conversando, não vai xingar.

(...)

Jhonatan: A criança respeita mais o adulto do que o adolescente. (...) É mais frágil perto do adulto. O adolescente já é mais forte. Aí, a criança, tipo, fica com medo, né? (...) O adolescente já não; (...) se o adulto levanta a voz, ele levanta também! (...) Os professores (...) tratam [os alunos crianças] com mais carinho...

(Entrevistas)

João: Com criança, eles [professores] iam ser mais meigos.

Jhonatan: Se fizessem bagunça, iam só dar uns tapinhas no bumbum e mandavam sentar.

(...) João: Se jogasse uma carteira no professor, ele: "Você é um menino mau; eu vou falar pra sua mãe!" [falando baixinho, sem gritar].

(...) Cristina: [Professor] pensa que criança não entende [não tem consciência do] que faz...

(...) João: [Então] trata bem! Dá docinho, até... dá doce, dá bala.

( $2^{\circ}$ Encontro)

Adriana: Muda tudo! Muda a relação ente o aluno e o professor, o professor acha que... (...) que você [adolescente] é vândalo, essas coisas. E da criança, não vai pensar isso (...) Quando eu vejo uma criança, eu falo: "Ai, que bonitinho!". Ninguém vai falar pro adolescente: "Ai, que adolescente bonitinho"!

(Entrevista)

Nesse último trecho, uma aluna introduz a questão da imagem atribuída (pelos próprios jovens) às crianças, em oposição à visão pejorativa acerca dos adolescentes. Em relação a esse aspecto, os jovens fazem alusão à idéia de que, durante a infância, os alunos são inocentes, ingênuos e serenos; porém, ao ingressar na adolescência, 
'aprendem' a ser 'indisciplinados, maliciosos e maldosos' - evidenciando-se, assim, o

caráter moralista de suas proposições. Nesse sentido, os alunos acrescentam:

Denis: Era legal, porque criança tem inocência (...) não era tão pesado o clima que nem aqui (...). Não tem briga... Brigou, fica de mal do outro; aqui, não. (...) [O professor] chama atenção uma vez só..., ela já se toca. (...). Se [a criança não for boazinha], também, é muito mais fácil fazer ela ser um bom aluno, do que um adolescente (...) Porque é mais inocente, não tem muita maldade que nem o adolescente (...). [que] fala do erro dos outro, taca giz nos outro. Criança não tem isso. Na primeira série, você não vê ninguém tacando giz no outro, apagador nos outro. (...) Elas são disciplinadas porque não aprenderam a ser indisciplinadas. Aí, depois aprende, todo mundo aprende; não tem como fugir do mal desse mundo aqui!

(Entrevista)

João: Era muito louco! Você ainda não tinha malícia, era inocente, despreocupado, não tava nem aí com a vida, só pensava em brincar. (...) [O professor] vê uma criança falando palavrão: "Ah, que bonitinho, que fofo!". Se vê um adolescente: "Ô, moleque, cala a boca! Vou passar sabão na tua boca!". Tem uma (...) enorme diferença! 0 professor gruda em você, no aluno adolescente (...); você tá la sentado e fala bem baixinho: "Não vou fazer a lição". Aí ele vem: "Não vai fazer a lição? Tchau, vai embora!" Aí, você tá escrevendo, a sala inteira conversando, ele chega: "Nego, pra fora!"; o professor fica na tua cola!

(Entrevista)

Percebe-se, no conjunto de trechos apontados acima, uma idealização, presente no discurso dos jovens, acerca da experiência escolar $e$, inclusive, da relação professor-aluno, na infância. A esse respeito, deve-se ressaltar que, ao serem questionados acerca do seu histórico escolar, a maioria dos alunos afirmou não se lembrar da experiência relativa ao processo de escolarização na infância, recordandose, a princípio, apenas dos anos posteriores ao ingresso na quarta série do Ensino Fundamental. 
Ao contrapor a experiência escolar na adolescência e na vida adulta, os jovens consideram que a relação entre professores e alunos adultos é calcada no respeito e no diálogo, em oposição ao vínculo estabelecido com alunos adolescentes:

João: Se professores forem dar aula pra adulto, ia ficar conversando com o adulto. Porque eles, adultos, têm conversas.

(...) Tamara: Com os adultos tem mais respeito porque os adultos já podem dar na cara. Falou mais alto, o bicho pega! E com a gente, não... Acho que a gente é muito besta! Engole as coisas...

$\left(2^{\circ}\right.$ e $3^{\circ}$ Encontros $)$

Adriana: Tem professores que faltam com respeito [com os adolescentes]. Pensam assim: "Porque é adolescente, vou falar, mesmo!". Se fosse pessoa mais velha que tivesse ali sentado, duvido que falasse!

(...) João: Se fosse um adulto, por exemplo, de 30 anos, que pegasse a cadeira $e$ jogasse, o professor ia dar risada!

(1 Encontro)

É interessante notar que o mesmo argumento utilizado anteriormente por um jovem para justificar a não-submissão dos alunos adolescentes aos professores (referente à idéia de que aqueles revidariam as ofensas proferidas por esses) é apontado, nesse trecho, por outra aluna, a fim de alegar uma afirmação oposta (de que os jovens se submeteriam, "engolindo" tais acusações por parte dos professores).

Outro aspecto relativo à condição de jovens alunos, associa-se à questão do trabalho na adolescência ${ }^{9}$. Ao fazer alusão a esse tema, os alunos destacam alcances $e$ limites implicados na busca por se conciliar o trabalho ao estudo. Quatro, dentre os oito participantes da pesquisa, afirmaram que estavam trabalhando ou já o haviam

\footnotetext{
${ }^{9}$ Elemento citado no início do capítulo.
} 
feito, exercendo funções como as de atendente em vídeo-locadora, garçons ou garçonetes, ou confeccionando bijuterias. Esses jovens salientam as vantagens de se trabalhar, reportando-se à aquisição de independência, responsabilidade $e$ experiência, e alegam que seu emprego não prejudica os estudos (ou vice-versa), já que reservam um tempo do dia para realizar as atividades da escola; porém, em seu discurso, evidenciam a dificuldade e o desgaste que também podem estar envolvidos no empenho em se conciliar esses dois compromissos:

Adriana: Acho que eu me sinto valorizada! Trabalhar e estudar não é qualquer um que leva! E não é meu primeiro emprego; eu já trabalhei como garçonete, saía meia-noite de lá pra acordar às seis horas. Eu tava agüentando muito bem, só que eu tava achando que tava me atrapalhando muito aqui na escola, aí saí e arrumei esse outro (...) que é das duas e meia às sete horas da noite.

(Entrevista)

Tamara: ... Eu faço o possível pra tirar a melhor nota! O possível, mesmo! Nossa, quando eu chego em casa, saio do serviço nove horas (...), chego em casa quase dez e meia, sozinha, à noite... me dá um medo...! Chego à noite, cansada, minha avó afobada, meu pai... eles perguntam como foi o serviço... Você já não consegue dormir, mesmo. Aí tem trabalho [da escola] pra mim fazer, acabo dormindo tarde, às vezes eu nem durmo, quando eu olho já é cinco horas,... não dá tempo nem de deitar na cama, já tenho que ir pra escola e estudar.

(Entrevista)

Por fim, elucidam suas expectativas em relação ao futuro, referindo-se à intenção de seguir carreira política, militar (na Aeronáutica ou no Exército) ou ser policial, fazer faculdade de Direito, Turismo, Odontologia, Educação Física, Veterinária, Biologia ou Medicina, além de curso de Fotografia ou de Dança. Alguns alunos apresentam idéias vagas ou indefinidas a respeito de uma escolha profissional, explicitando o distanciamento entre essa tomada de decisão e sua concretização: 
Karina: $O$ que você espera do seu futuro?

Denis: Se eu não seguir carreira militar na Aeronáutica, vou fazer Direito e virar juiz ou vereador (...). [Penso em terminar o terceiro colegial e] me alistar; se eu seguir carreira, vou ser major. Senão, vou fazer faculdade, né?

(...) Karina: Então, se você for seguir carreira política, você pensa em fazer faculdade de Direito?

Denis: Pra me aprimorar, pra saber como posso me atacar, como posso me defender, porque a maioria dos partido é tudo punido porque fez o que não podia pela lei tal, tal, tal. Se eu fizer Direito, não vou cometer esses erros.

(Entrevista)

João: Físico nuclear. Não, não é uma boa... Eu prefiro ser analista de sistema.

Karina: E o que precisa pra ser analista de sistema?

João: Não sei.... Ou então ser professor de Educação Física ou mecânico; mecânico ganha cinco mil! (...) Eu só quero ser uma coisa que não precisa de faculdade! Vocalista de uma banda! Pronto! Perfeito!

Karina: E tá livre...?

João: Não. Precisa estudar as cordas vocais!

$($...)

João: Vou fazer um curso de anatomia [pra ser professor de Educação Física]. [?] (...) Se não existir [esse curso], aí, vamo entrar na faculdade.

Karina: E o que precisa pra entrar na faculdade?

João: A primeira coisa é ter dinheiro e o resto minha mãe que sabe. Vou perguntar pra ela.

( $3^{\circ}$ Encontro e Entrevista)

Karina: $O$ que você espera do seu futuro?

Jhonatan: Ah, não sei!

Karina: Tá longe, ainda?

Jhonatan: Tál

(Entrevista)

De modo geral, os jovens referem-se à idéia de estudar em faculdades particulares, conciliando o trabalho e o estudo, a fim de viabilizar seu pagamento, bem como fazer cursos técnicos ou profissionalizantes, visando a um futuro emprego. Ao abordar esse tema, apontam obstáculos implicados no processo seletivo para ingresso 
em universidades públicas, tais como o acesso ao ensino de melhor qualidade, ou a uma formação mais ampla (com cursos complementares à grade escolar), de alunos que pertencem a famílias com maior poder aquisitivo, em detrimento dos de classes populares:

Denis: ...Eles [que têm dinheiro] estudaram mais que a gente; por exemplo, na nossa idade, já fizeram curso de inglês, espanhol (...). [E] a escola deles é paga, né? [Melhor]...

Tamara: Mas (...) a gente também pode cursar [uma faculdade pública]. Eu sei que é difícil, entendeu? (...) Um amigo do meu pai já estudou em escola pública e conseguiu. Tem que ralar muito, tem que estudar pra caramba!

( $3^{\circ}$ Encontro)

Janaína: Preciso ter um trabalho, pra mim poder pagar [a faculdade], que é muito caro. Turismo é 500 e pouco [reais] (...); é mó caro!

(...)

Tamara: Eu espero uma coisa boa.., melhor. (...) Como eu trabalho, eu divido uma parte do dinheiro pra mim gastar e outra pra mim guardar. (...) Quando falam: "Nossa, Tamara, tá cedo, ainda!", eu falo: "Não, gente, é bom guardar um dinheiro agora porque é uma possibilidade que você vai ter de entrar numa faculdade". (...) Eu vou tentar na USP (...); acho que vai ser meio difícil conseguir entrar. (...) Mas aqui tem faculdades [particulares] ótimas (...); vou tentar entrar numa...

(Entrevistas)

João: Eu prefiro fazer o curso do Senai que eu fiz, agora vou fazer o técnico (...). Se você sair com diploma de lá, você consegue trabalho em qualquer lugar, também. (...) Eu tô fazendo o curso (...) de mecânica; fiz agora a prova pra saber se vou fazer o de caldeireiro, porque quanto mais curso eu fizer, mais difícil ficar desempregado.

( $3^{\circ}$ Encontro e Entrevista) 


\section{B) RELAÇÃO COM DEMAIS PARTICIPANTES DO CONTEXTO ESCOLAR}

\section{B.1) Relação com professores}

Karina: Que imagem vocês acham que os seus professores têm de vocês, alunos adolescentes?

Janaína: Acho que eles pensam que nós somo tudo uma merda!

João: Se pudesse, jogaria todos nós no inferno!

Karina: Por quê?

Janaína: Por causa que a maioria fica faltando com respeito com os professores. Alguns, nem todos.

(...) João: Porque eles, ao invés de ver a nossa imagem, de cada um, eles vêem a imagem de todos. Se todos são ruim, nós tamos no meio.

Denis: Se tipo, entre nós quatro, um é bom e três é ruim...

Janaína: $O$ outro que é bom vai ser [visto como] ruim, também.

(...)

João: Péssima imagem! (...) Porque eles tão sentados aqui e o Denis ali; e o Denis levanta e joga uma cadeira. O professor vai olhar: "Esses alunos! Esses alunos, meu Deus do céu... são vagabundos"!

(...) Adriana: Tem professores que falam que aluno adolescente é revoltado.

(1 $1^{\circ}$ Encontro)

Segundo esses estudantes, os professores apresentam uma visão pejorativa sobre os alunos adolescentes, considerando-os vagabundos, rebeldes, agressivos $e$, reproduzem, portanto, os estereótipos socialmente vinculados aos jovens. Desse modo, de acordo com aqueles, os professores generalizam essa concepção, associando tal imagem aos demais alunos, com base em atitudes de desrespeito ou de indisciplina apresentadas, em sala de aula, por alguns dentre esses, conforme enfatizam ${ }^{10}$.

Um relevante aspecto a ser ressaltado em relação a essa imagem consiste na idéia apresentada pelos jovens de que alguns professores demonstram sentir medo

${ }^{10}$ É interessante notar que, nesse trecho, os adolescentes também reproduzem essa visão depreciativa acerca de seus pares, reportando-se aos alunos "ruins", cujas atitudes seriam generalizadas pelos professores. 
dos alunos adolescentes. Em seu discurso, associam esse medo à visão acerca dos alunos tidos como vândalos, marginais ou violentos; sendo assim, afirmam que os professores sentem-se ameaçados por seus alunos, com receio de serem agredidos ou violentados. De acordo com esses jovens, os professores que demonstram medo são os também considerados maus professores - cuja relação com os alunos se estabelece de forma truncada, calcada em estereótipos, desrespeito e descrença (conforme será explicitado posteriormente):

Janaína: Tem alguns [professores] que têm muito medo [dos alunos]!

Karina: Você acha que eles têm medo do quê?

Janaína: Sei lá, de alguém bater neles, esses negócio..., por causa do vandalismo. Acho que eles têm medo de um aluno, por exemplo, assaltar a casa deles..., sei lá.

(Entrevista)

João/Janaína: [Medo] de morrer!

(...) Karina: Medo por quê? Acham que vocês são o quê?

João: Marginais! Bandidos!

Denis: Maconheiro!

Jhonatan: Ladrão. (...) Trombadinha!

( $3^{\circ}$ Encontro)

João: A [professora de Matemática], se você chega nela e fala: "Aíl Se você não me der dez conto e cinco [notas] "A" no semestre, eu te mato". Ela pega a carteira, te dá cem conto, te dá sete " $A$ "!

(1 Encontro)

Karina: E como os alunos reagem quando percebem que o professor tá com medo? Tamara: A gente tira mó sarro deles! (...) Porque a gente fala zoando e eles levam na base do sério!

( $3^{\circ}$ Encontro)

A aluna citada acima descreve uma cena que ilustra a relação entre professores e alunos atravessada pelo medo e pela ameaça, calcados nessa imagem estereotipada acerca dos jovens alunos: 
Tamara: ...A [professora de Matemática] falou que ia ligar pra minha mãe, eu falei: "Se a senhora ligar, pode ligar, mas eu vou lá na diretoria e falo que a senhora me xingou de ladra". (...) [Ela] xingou, mesmo! Eu fui lá e falei pra dona Simone [coordenadora]: "(...) Ou você tira essa batatona aí da sala ou eu vou matar ela!" [Risos]. Aí, cheguei na sala e falei: "Toma cuidado comigo, hein? Quando ver um corpo gordo boiando no Rio Tietê é a senhora que vai tar boiando". Aí ela: "Você tá me ameaçando?", "Eu não só ameaço, eu faço!". Nunca mais ela me xingou. (...) Até hoje ela tem medo de mim! Ela olha assim pra minha cara meio desconfiada... eu falei: "Não fala comigo, não!"

(Entrevista)

Os adolescentes também fazem alusão ao desrespeito que permeia a relação professor-aluno, descrevendo situações em que xingamentos e palavrões são proferidos por professores, além de cenas de agressão e humilhação. Ocasiões em que os alunos desrespeitam e agridem os professores também são destacadas pelos jovens: "O aluno com o professor, hoje em dia, pelo menos, não tem mais respeito, bate em professor, briga, ignora. Professor não tem o respeito que tinha antigamente" (João-Entrevista) ${ }^{11}$.

Outro aspecto importante a ser enfatizado consiste nas idéias apresentadas pelos alunos em relação aos critérios utilizados por esses para avaliar os professores. Os jovens referem-se aos que consideram bons professores, ressaltando como virtudes o fato de que esses impõem limites e mantêm a ordem em sala de aula (ou seja, têm autoridade) e são didáticos, empenhando-se em transmitir o conteúdo ministrado e demonstrando interesse em que os alunos o assimilem; que investem,

\footnotetext{
${ }^{11}$ Tais situações serão apontadas no tópico sobre "considerações e sentimentos relativos ao dia-a-dia escolar".
} 
portanto, no processo de ensino-aprendizagem, propondo atividades que incitem o estudo e esclarecendo as dúvidas dos alunos ${ }^{12}$.

Além disso, enfatizam que os bons professores "entendem os adolescentes", estabelecendo uma relação em que estão presentes o respeito mútuo e a crença no potencial dos jovens alunos. É interessante notar que, ao se referir à imagem que os bons professores apresentam acerca dos alunos adolescentes, alegam que aqueles consideram alguns jovens 'vândalos', porém, acreditam em seu potencial: "[Eles acham] que alguns [alunos] são vândalos; mas alguns!" / "Na verdade, eles acham que uns alunos são vândalos, mas têm conserto" (Jhonatan e João - $2^{\circ}$ Encontro). As idéias apontadas acima podem ser ilustradas por meio das seguintes afirmações:

Adriana: O professor Vanderlei, ele é assim: quanto mais você souber, mais ele quer que você saiba.

(...) Denis: Ele é o cara! Esse é o professor mais respeitado.

Karina: E como ele consegue esse respeito?

Adriana: Ele dá respeito pra gente, não ofende ninguém.

João: Ele põe ordem na sala. (...) Ele tem uma cultura muito grande também (...); ele passa uma segurança.

$\left(1^{\circ}\right.$ Encontro)

Cristina: $O$ professor bom é aquele que também se dá bem com o aluno, né? Que respeita o aluno, que tem respeito...; que entende o adolescente...

$\left(2^{\circ}\right.$ Encontro $)$

Adriana: ...Ele é um bom professor, ele manda o aluno ir na frente pra falar o que não entendeu, passa pesquisa, manda você explicar o que você pesquisou, passa muita leitura...

12 Os jovens fazem referências, inclusive, a bons professores que demonstram prazer em dar aula, fazendo-o mais por opção que por necessidade, o que consiste em um aspecto valorizado pelos alunos: "[Para melhorar a qualidade do ensino, deveria] Pôr bons professores na escola, que realmente estejam interessados em ensinar! Como o [professor de Português] e a de Educação Artística (...) Ela dá aula porque ela gosta! De coração, de alma! (...) Porque ela não precisaria trabalhar!' (João - Entrevista e $3^{\circ}$ Encontro). 
Karina: $O$ que você acha que daria pra ser feito pra melhorar a qualidade de ensino? Janaína: Acho que era professores com mais capacidade, como o [professor de Português], assim. Nós vamos ter o SARESP, aí ele já ta ensinando a gente como é pra fazer. Vai ter muito esse negócio de leitura, vai ter texto, aí a gente tem que responder uma pá de pergunta sobre o texto. Ele já tá ajudando a gente, já tá explicando pra gente poder passar. Acho que devia ter professor igual a ele. (...) Ele fala assim: "Quando você for prestar algum concurso, vai cair isso"; ele ajuda bastante!

(Entrevista e $1^{\circ}$ Encontro)

Sendo assim, os adolescentes elucidam a distinção entre um bom professor (que se empenha em ensinar) e um professor "bonzinho" ("legal") ou permissivo: "O [professor de Português] é chato, mas explica bem".I" Por isso que ele tem respeito, porque ele é chato! O [de Matemática] tentou ser legal e ficou daquele jeito... (...) Geralmente o mais chato é o que explica melhor" (Jhonatan e João - $2^{\circ}$ e $3^{\circ}$ encontros).

Nesse sentido, os alunos consideram maus professores os que não explicam bem a matéria, demonstrando certo descaso com a transmissão e a assimilação do conteúdo por parte dos alunos, bem como falta de critérios para avaliação, além de não apresentar uma postura firme, com autoridade em sala de aula, desrespeitando os estudantes e sendo, por esses, desrespeitados:

Tamara: Ela passa na lousa e nem explica nada! Então, todo mundo copia e no outro dia sabe que vai ter a correção, mesmo! Aí todo mundo copia, ela dá nota, ela vai dando nota..., ela nem explica! 
Cristina: [Um mau professor] é aquele que não explica bem, que tanto faz, como tanto fez... Se o aluno entendeu, entendeu; se não entendeu, vai ficar sem entender.

(...) João: ...São aqueles que não respeita e dá muita liberdade pro aluno. (...) No primeiro dia de aula, ele [professor] falou: "Primeiro dia, não tem aula". Daí, ficou nessa por uma semana! Aí, depois ele passou lição na lousa, ninguém copiava... todo mundo começava a jogar coisa nele! Ele não tá nem aí!

(...) Cristina: Marca prova sem...; "Amanhã vai ter prova"! Não quer nem saber se a gente entendeu a lição!

(...) Jhonatan: Outro dia ele mandou fazer uma prova e, assim que eu acabei, ele colocou "E". "Por que você colocou 'E'?" "Porque você merece"!

( $2^{\circ}$ Encontro)

\section{Um complemento a tais considerações: a relação professor-aluno, segundo os professores}

Em entrevistas individuais realizadas com professores, esses explicitam alguns aspectos apresentados até então pelos adolescentes, que contribuem para a elucidação de tais questões ${ }^{13}$. Um elemento central a ser destacado consiste na distinção que se evidencia entre o discurso dos professores valorizados e o dos criticados pelos jovens.

Com relação à imagem que os educadores atribuem aos alunos adolescentes, enquanto Lucila $e$ Ronaldo (os quais os alunos criticam) reproduzem a visão pejorativa associada à idéia de que aqueles seriam revoltados (ou rebeldes) e displicentes,

\footnotetext{
${ }^{13}$ Foram entrevistados quatro professores, sendo dois - Alberta e Vanderlei (respectivamente, de Educação Física e de Português) - considerados, pelos alunos, "bons professores" e dois Lucila e Ronaldo (ambos de Matemática) - tidos como "maus professores". É importante ressaltar que nesse tópico não será realizada uma análise acerca de todo o material obtido por meio de tais entrevistas e, sim, destacados elementos que contribuem para a elucidação de aspectos apontados pelos alunos.
} 
Alberta e Vanderlei não vinculam uma imagem depreciativa aos jovens em geral $e$, quando fazem alusão a tais características, acrescentam contraposições às mesmas:

Ronaldo: Os adolescentes de hoje, em geral, são rebeldes e agem como se fossem auto-suficientes. (...) Na minha opinião, eles agem dessa forma porque vivem as crises de identidade (...) São mimados desde o seu lar ao estabelecimento de ensino, (...) [em que] são promovidos para séries sem mérito. ${ }^{14}$

(Questionário)

Lucila: Eu acho que eles estão bem revoltadinhos, sabe? Revoltados. (...) Não querem fazer nada... Eu acho que eles não têm perspectiva de futuro, mesmo, né? Então, nada interessa! (...) Jogam as coisas, papel... aquela coisa de adolescentes, de provocar, mesmo.

(...)

Vanderlei: Essa questão da destruição (de destruir as coisas) aparece em poucos alunos (...) Ainda bem que são poucos! Por isso ainda vale à pena trabalhar com jovens.

(...)

Alberta: Pra mim, de certa forma, eles já são uns vencedores; (...) alguém na vida que está conseguindo viver no meio disso daqui, alguns estudando e estudando bem, outros não (...). [Tem] a rebeldia, essas falações altas, esse tentar se impor, tentar ver até onde eles conseguem dominar os adultos, se mostrar diferentes. Mas, ao mesmo tempo, eles são daqueles assim: se você aceita alguma coisa deles [demonstra interesse por eles], eles te recebem (aceitam) em seu meio; (...) e têm responsabilidade.

(Entrevistas individuais)

O relato dos professores acerca da experiência de dar aula para adolescentes também ilustra aspectos relevantes, incluindo questões apontadas pelos jovens alunos. Em seu discurso, Lucila enfatiza o desgaste e a 'desesperança' envolvidos nesse processo e evidencia o caráter circunstancial de sua vinculação a alunos adolescentes

\footnotetext{
${ }^{14}$ Deve-se ressaltar que o sistema educacional vigente (e, em especial a política da Progressão Continuada) é mencionado e criticado pelos quatro professores, que associam a falta de sentido em estudar numa estrutura educacional em que os alunos são aprovados independente da assimilação do conteúdo. Essa questão é abordada pelos alunos e será explicitada no tópico sobre "críticas e propostas referentes à educação escolar".
} 
(ou seja, dá aula para jovens alunos por motivos ocasionais e não por opção). Vanderlei

e Alberta explicitam o prazer em dar aula para adolescentes, demonstrando carinho e crença no potencial desses jovens - o que consiste em elementos valorizados pelos alunos:

Lucila: [Não escolhi dar aula para os adolescentes]. O próprio curso dá direito a [dar aula] de quinta a Ensino Médio e essa escola só tem o Fundamental (...); com a reestruturação, todo mundo veio pra cá (...), não foi opção. É bastante desgastante, porque suga muito a gente, sabe? (...) [Karina: $O$ que mais marcou nessa trajetória?] Sabe que agora na minha cabeça não tem nada... que marcou? (...) Cai na rotina, né? (...) [Karina: Que esperanças você tem?] Se continuar do jeito que está [com a Progressão Continuada], a tendência é só piorar, né? (...) $O$ ano que vem, se Deus quiser, eu me aposento (...); estou cansada! É muito desgastante, não é fácil!

(...)

Vanderlei: Sempre gostei de trabalhar com adolescentes. (...) $O$ jovem ensina muita coisa, faz com que você cresça e tire conclusões claras a respeito da vida. (...) Eu acredito no potencial dos alunos, senão, não daria aula. (...) [O que mais marcou nessa trajetória foi] a satisfação de alguns alunos, mesmo a curto prazo, de terem apreendido certos conhecimentos e revelarem isso através de redações e posturas. Tenho coisas escritas [pelos alunos] que guardo a sete chaves, coisas muito bonitas, escritas com muito carinho. $O$ carinho é muito importante. (...) Quero o bem deles, quero o sucesso deles; faço de tudo pra que eles tenham sucesso.

(...)

Alberta: Eu adoro [dar aula pra jovens]! (...) Eu me sinto realizada! (...) Tenho um carinho especial [pelos alunos adolescentes]; (...) [e] acredito piamente [no seu potencial]. (...) [Falo pra eles:] "Você pode conseguir! Vai à luta!"; quando [ex-alunos que batalharam e conseguiram] vêm aqui, eu falo: "Esse daqui foi meu aluno, começou como vocês, é daqui mesmo, dessa comunidade"; e eles ficam assim: "Nossa!". (...) É muito gratificante, porque você vê essa criançada crescer, eles voltam e você [pensa]: (...) "Gente, ele está fazendo uma coisa que preste e eu tive um negocinho [uma participação] aí"!

(Entrevistas individuais)

\section{B.2) Relação com diretora e coordenadora}

Tamara: Todo mundo gosta da Simone [coordenadora]! Se fizesse uma pesquisa pra mudar a diretora, com certeza a escolhida ia ser a Simone. Porque ela ouve a gente, 
entendeu? Ela dá vários conselhos (...). Mas a diretora, mal vem aqui pra escola. Quando vem, só quer dar uma de autoridade...

João: [Ela é meio arrogante. ${ }^{\star}$ ] (...) [E] quando eu fui pra diretoria porque briguei com $X_{4}$ [um aluno], ela olhou pra minha cara: "Ah, você tem maior cara de marginal!!

Tamara: Ó, tá vendo?

$\left(3^{\circ}{ }^{*}\right.$ e $\left.1^{\circ}\right]$ Encontro $)$

Cristina: ...A Simone entende os alunos. Ela acompanha a gente, tipo assim (...); ajuda a gente. (...) Ela tem paciência.

(...) Janaína: Ela ouve!

João: ... É aquela pessoa que se você abraça ela, ela te abraça de volta, você beija ela, ela te beija de volta.

(...) Adriana: ... Ela brinca com todo mundo, fala de igual pra igual!

$\left(1^{\circ}\right.$ e $2^{\circ}$ Encontros $)$

Ao se referir à sua relação com a coordenadora e com a diretora, os alunos evidenciam, novamente, a importância de serem ouvidos. Consideram que a diretora (Tereza) apresenta uma postura autoritária, além de estar ausente e distante dos alunos; inclusive, durante os encontros em grupo, os adolescentes demonstraram não saber quem era a diretora da escola - alguns afirmaram pensar que seria Simone (coordenadora) e outros também não sabiam seu nome.

Nesse sentido, enfatizam a idéia de que não costuma haver diálogo com Tereza, que, segundo os jovens, não propicia o esclarecimento ou a discussão acerca do motivo pelo qual os alunos foram encaminhados à diretoria: "Quando vai pra diretoria porque brigou, (...) daí ela não pergunta o motivo, (...) ela simplesmente olha assim... dá advertência pros dois ou suspensão" (João - $1^{\circ}$ Encontro). A esse respeito, tal aluno acrescenta: "Se você falar simplesmente que veio pedir giz, ela fala: (...) 'Que que [você] fez dessa vez?'". 
Em contrapartida, valorizam a relação estabelecida com a coordenadora (Simone), marcada, segundo os adoelscentes, pela presença, escuta, compreensão, apoio e carinho. Os alunos sentem-se ouvidos e acolhidos por Simone, que thes representa uma importante fonte de apoio (alguém a quem podem recorrer), consistindo em uma figura de referência para os alunos no contexto escolar.

\section{Relação diretora-aluno e coordenadora-aluno, segundo elas mesmas}

De acordo com Tereza (diretora), os adolescentes testam limites e são contestadores. Seu relacionamento com os alunos baseia-se, essencialmente, no contato estabelecido enquanto circula pela escola e quando alunos são encaminhados para a diretoria (ou quando sua presença é solicitada pelo professor em sala de aula) ou em situações nas quais algum estudante se destaca por participar de projetos específicos da escola, de modo a não se relacionar com os demais alunos. Além disso, considera os jovens da oitava série mais distantes que os alunos mais novos:

Tereza: [Os adolescentes] testam um pouco o limite na escola (...), contestam o que você fala (...), questionam. (...) Eu sou muito de ficar pelos corredores, circular; (...) agora, aqueles alunos que não dão problema disciplinar e não são aqueles de destaque, acabam meio que ficando... . Então, às vezes eu cruzo com algum aluno: "Oi, diretora!", e eu não conheço, nem sabia que era aluno meu. (...) Aquele [aluno] com 12 anos me agarra no corredor, ele me beija, ele quer conversar, é esse negócio de contato, mesmo; ele não tem receio de se aproximar de mim (...). Um aluno de oitava série não se aproxima de jeito nenhum!

(Entrevista)

Em seu discurso, Simone evidencia as considerações apontadas acima pelos alunos. Embora faça alusão à idéia de que os adolescentes são rebeldes e desejam 
chamar atenção, a coordenadora explicita o prazer em se vincular e trabalhar com os jovens alunos, enfatizando o respeito, o carinho, a crença em seu potencial, o apoio e a escuta que atravessam tal relação:

Simone: Os adolescentes em geral, acho que são rebeldes, querem chamar atenção... (...) Acho que se conseguirmos fazer uma boa orientação, ele melhora muito. E muitas vezes o carinho, sabe? Muitas vezes você elogia um aluno adolescente e ele muda de atitude. (...) Ele quer carinho também. (...) Eles vêm bastante [conversar], porque eu não brigo, eu não xingo, eu estou ali com eles o tempo todo, estou vendo e falando: (...) "Por que você não faz isso? (...) Fulano, entra na sala de aula, vai lá, colabora, faz a sua parte e tal". (...) Ah, é uma relação boa, legal, mas na hora que ele senta aqui e eu tenho que falar com ele, que eu tenho que falar sério, eles ouvem (...); eles me respeitam. (...) Eu gosto muito de adolescente (...), de estar sabendo sobre tudo do adolescente..., observando, saber o que ele está pensando... falando! (...) [Gostava de dar aula pros jovens]; nossa! E como! (...) [Eles sabem] que podem contar...; (...) eu ouço, considero (...). As pessoas estão precisando falar, conversar.

(Entrevista)

\section{B.3) Relação com funcionários}

João: O Paulo [inspetor de alunos] é legal!

Janaína: A Taís [inspetora de alunos] tem um jeito chato. Ela não fala meu nome, já fala brigando!

(...) João: A Taís é a única funcionária que não é uma boa funcionária, quer dizer, não é muito legal. Tipo, quando eu fui buscar a caixa de som lá embaixo, aí cada vez que encontrava com ela: "Vai pra sua sala! (...) Vai agora pra sua sala! Tchau! Some!".

Adriana: Ela fala com arrogância!

(...) João: Agora o Bento [porteiro] é muito legal!

Denis: Ele é legal...; que ele conhece a escola inteira!

$\left(1^{\circ}\right.$ Encontro)

Ao serem questionados sobre a relação entre funcionários e alunos, os jovens referem-se aos inspetores de aluno (Paulo e Taís) e ao porteiro da escola (Bento). Em seu discurso, os adolescentes valorizam o vínculo estabelecido com Paulo e Bento, que, de acordo com os primeiros, relacionam-se com os alunos de forma amistosa, mantendo 
um contato cordial com os demais participantes do contexto escolar. No entanto, criticam o modo como a inspetora de alunos se relaciona com os estudantes, afirmando que essa apresenta uma postura autoritária e arrogante.

Sendo assim, percebe-se, novamente, a valorização, por parte dos jovens alunos, do afeto e da cordialidade, em oposição ao autoritarismo, nas relações que constituem o ambiente escolar.

\section{B.4) Relação com os pais}

João: Meus pais, pelo menos, só vêm na reunião de pais.

Karina: E como é essa reunião de pais, o que acontece?

João: Os professores falam tudo o que tem que falar dos alunos [se é um bom ou mau aluno]

(...) Karina: E seus pais conversam com vocês depois da reunião...?

Jhonatan: Conversa, não; reclama! (...) Minha mãe repete tudo o que o professor fala que eu faço: que o problema é o comportamento.

( $2^{\circ}$ Encontro)

De acordo com os adolescentes, a participação dos pais no contexto escolar limita-se a visitas à escola quando convocados pela diretora, a fim de tratar de algum assunto que essa julgue referir-se a seus filhos, ou durante as reuniões entre pais e professores. Diante de tais situações, o foco do contato entre esses participantes consiste em exposições, por parte da diretora ou dos professores, sobre o rendimento ou o comportamento dos alunos na escola. Segundo os jovens, geralmente, após a realização dessas reuniões, os pais conversam com os filhos, reproduzindo o discurso proferido pelos educadores sobre esses últimos. 
Percebe-se que, nesse modelo apresentado acima, a interlocução se dá entre pais e educadores, sendo os alunos objetos e não sujeitos da discussão. Inclusive, nesses espaços, é favorecida a explicitação da versão dos educadores sobre o tema em questão ("os professores falam"), reproduzida pelos pais, ao invés de se efetivar uma discussão que envolva a escuta das diferentes versões (de pais, educadores $e$ alunos) sobre o processo de escolarização.

A relevância de se propiciar um espaço de comunicação entre esses participantes no contexto escolar, em que se efetive tal diálogo, é apontada pelos jovens alunos, que propõem a realização de discussões entre professores, pais e alunos, em que esses exponham sua visão (com críticas e propostas) sobre o processo educacional, abrangendo o debate sobre o comportamento dos alunos, a qualidade de ensino e a relação professor-aluno ${ }^{15}$.

\section{B.5) Relação entre os jovens alunos e seus pares}

Janaína: [Alegria na escola é] Conversar com os amigos.

(...) João: Pra mim, alegria [na escola] é ter aquele seu amigo diário, mano! (...) Os namoros...

( $3^{\circ}$ Encontro)

Karina: Como é a relação aqui, entre vocês, alunos adolescentes?

João: Depende do aluno. Se for folgado, minha relação é de dar porrada! Se for um aluno legal, eu tenho uma boa atitude com ele, converso com ele, ajudo ele. Tipo, eu nunca vou deixar um amigo na mão.

\footnotetext{
${ }^{15}$ Tais idéias serão explicitadas no tópico sobre "Críticas e propostas referentes à educação escolar".
} 
(...) Cristina: Tem muitos adolescentes aqui na sala que pensa que manda aqui na escola... vamos supor, que acha que é o melhor da escola, então, pode mandar: "Me espera na saída, que vou te catar!"...

Jhonatan: [Os alunos se relacionam] com muita intimidade (...), assim, de brincar, faz montinho, dá tapinha na bunda, fica abraçado.

(...) Karina: $E$ aí, no intervalo, o que acontece entre os alunos?

João: Depende; os alunos que brigam, muita gente passa quieto. Todos, todos têm seu grupo...

( $2^{\circ}$ Encontro)

Os laços de amizade entre os alunos, bem como os relacionamentos amorosos, consistem no aspecto mais valorizado pelos jovens no contexto escolar ${ }^{16}$. Os adolescentes referem-se à cumplicidade entre os alunos, que se agrupam, sendo companheiros e solidários entre amigos e parceiros, assim como às disputas e brigas entre colegas.

Ao fazer alusão a seus pares, os jovens alunos explicitam uma imagem pejorativa acerca dos mesmos, considerando-os indisciplinados, displicentes, vândalos e irresponsáveis; reproduzindo, portanto, essa visão que lhes é socialmente atribuída. Nesse sentido, acrescentam: "[Tem] gente que não quer nada com nada, sobe em cima da cadeira, fica zoando, quebra a lâmpada, cospe, (...) assim, na cara de pau... e ninguém faz nada!" I "[O aluno] ficou grande, não respeita mais os alunos, os professores, os diretores". (Tamara e Cristina - $4^{\circ}$ Encontro e Entrevista).

${ }^{16}$ Esse aspecto também será apontado no próximo tópico, referente às "considerações e sentimentos relativos ao dia-a-dia escolar". 
Enfim, segundo os adolescentes, alunos desrespeitam e são desrespeitados, humilham e são humilhados, agridem e são agredidos. Situações que ilustram esses elementos serão apontadas a seguir, no próximo tópico.

\section{c) CONSIDERAÇÕES E SENTIMENTOS RELATIVOS AO DIA-A-DIA ESCOLAR}

Karina: E como é o dia-a-dia da escola aqui na oitava série?

Janaína/Evaristo/Denis: Zoeira!

Jhonatan: Beijo. Paquera.

Karina: Que mais? O que acontece? Vocês chegam, têm as aulas...

Tamara: A gente chega, vai pras aulas, os professores vão ver se vão sair [pra outra sala], se vão vir. [Janaína: A gente fica conversando]. Aí bate o sinal, aí vem aquela 'multuação' na porta da sala: "Eu preciso falar com você", "Na hora do intervalo", "Não, vem aqui, agora!"

Karina: Tem uns cinco minutos de intervalo entre as aulas, que fica aquela-Tamara: 'Multuação'. "Eu tenho fofoca, acabou de chegar!"

(...)[Tamara: Cada hora tem seu momento; momento de estudar, momento de namorar... $\left.{ }^{\star}\right]$

(...)

Karina: O que acontece dentro da sala de aula, normalmente?

Tamara: Muita bagunça!

Janaína: Muita conversa.

Evaristo: Muitas discussões.

Karina: Em toda aula?

Tamara: Não, tem diferença entre professores, assim: na aula do Vanderlei, ninguém discute! (...) Porque ele tem autoridade! (...) Ele vai embora, aí começa [a bagunça]. (...) Na aula dele, todo mundo fica quieto (...); e a gente respeita ele, porque ele respeita a gente, também! Agora outros professores chegam já gritando... como eles querem respeito com a gente? A gente acaba zoando, mesmo! Eu falo: "Eu zôo, mesmo!".

Jhonatan: Tem gente até que bate boca com os alunos!

$\left(3^{\circ}\left[{ }^{*} e 4^{\circ}\right]\right.$ Encontro $)$ 
Ao se referir ao dia-a-dia escolar na oitava série, os adolescentes destacam elementos presentes no vínculo estabelecido entre os alunos (colegas, amigos $e$ parceiros), ressaltando as conversas dentro e fora da sala de aula, incluindo os curtos diálogos interrompidos pelo término do breve intervalo entre as aulas, de modo a enfatizar os laços de amizade e os relacionamentos amorosos (com "paqueras", "ficadas" ou namoros) que se configuram no ambiente escolar.

A bagunça $e$ as discussões, apontadas como aspectos que ilustram ou caracterizam o dia-a-dia nas salas de aula, são temas recorrentemente abordados pelos jovens. No trecho citado acima, introduzem a idéia de que a bagunça é produzida em contextos nos quais se estabelece uma relação entre professor e aluno atravessada pelo desrespeito e pela falta de autoridade por parte do primeiro. Sobre essa questão, um aluno afirma que, nesses contextos, em meio à agitação em sala, a concentração para execução das atividades propostas é reduzida, favorecendo-se a dispersão e adesão ao grupo: "Não dá [pra ficar sentado o tempo todo]. Eu sento lá na frente, tô fazendo lição, tá todo mundo brincando aqui atrás. Eu olho pra trás, tá todo mundo se divertindo, zoando. Aí, eu vou fazer o quê? Tem que ir, também!" (Jhonatan $-2^{\circ}$ Encontro).

Em alguns momentos de seu discurso, os adolescentes atribuem a bagunça ao comportamento de alunos tidos como indisciplinados, "que ficam só fazendo vandalisse" (João - $2^{\circ}$ Encontro). Desse modo, ao responsabilizá-los pela produção da bagunça ou da indisciplina na escola, consideram que tais alunos devem modificar seu 
comportamento: "Os alunos têm que ser um pouquinho melhor./[Ter] um bom comportamento, [que] é não bagunçar, fazer o dia-a-dia da lição..." (João e Jhonatan $4^{\circ}$ Encontro).

Ao longo da discussão sobre esse tema, os adolescentes referem-se a outros elementos implicados na produção da indisciplina, tais como a ausência de atividades recreativas no contexto escolar. Nesse sentido, os alunos evidenciam a relevância e a necessidade de se investir em atividades de esporte e lazer na escola, inclusive como um meio de diversão, expressão e extravasamento da energia represada durante as aulas expositivas. Além disso, explicitam a importância de se propiciarem, em sala de aula, momentos de descanso ou descontração após a realização das tarefas, questionando a exigência de se manterem praticamente imóveis durante todo o período de aulas (ou turno diário escolar):

Denis: $O$ aluno, pra ele aprender, também tem que estar tendo lazer na escola (...), esporte, uma quadra, uma bola pra jogar! (...) Você só aprende bem quando você se diverte também! Aí você vai saber a hora de brincar e a hora de estudar. (...) Agora, não; a gente não tem nada pra fazer..., a pessoa vai zoar na sala, mesmo!

(Entrevista)

Jhonatan: ...Mas professor tem que dar um tempo pra bagunçar. Tem que passar lição e ter a hora da alegria.

Tamara: Se a gente não bagunçar, também não vai ter graça. Acho que tem que ser não aquela bagunça pesada, tem que ser aquela coisa levinha.

( $4^{\circ}$ Encontro)

João: Se a gente já acabou a lição, nós somos livres: "Façamos o que quiserdes"! Porque já acabou a lição. Já aprendemo o que tinha que aprender. Então, vamo dar um rolê pela sala (...). Porque quando acaba a lição, o que deveríamos fazer? Fazer isso [sentar, cruzar os braços e levantar a cabeça]? Cruzar os braços não precisa, mas se abaixar a cabeça, o professor já acha que você tá dormindo.

(...) Denis: Não somo mutante pra ficar parado! 
João: Mutante, não; robộ!

$\left(1^{\circ}\right.$ e $2^{\circ}$ Encontros $)$

Ao se referir às discussões (ou ao "bate boca", como afirmam) entre os participantes do contexto escolar, os adolescentes ilustram cenas e situações em que xingamentos e palavrões são proferidos por professores aos alunos, fazendo alusões a insultos como: "Tá parecendo cadela no cio", "Cala a boca, sua vagabunda", "Bixold" ou "Veado", dentre outros. ${ }^{17}$ Com relação a esse aspecto, uma aluna acrescenta: "Tem professores que faltam com respeito também. Pensam assim: 'Porque é adolescente, vou falar, mesmo'. Se fosse pessoa mais velha que tivesse ali sentado, duvido que falasse!"(Adriana, $1^{\circ}$ Encontro). Deve-se, portanto, ressaltar que uma especificidade a ser destacada, referente a esses tipos de xingamento dirigidos aos jovens alunos, consiste no fato de estarem associados à questão da sexualidade ou a estereótipos atribuídos aos adolescentes.

De forma geral, os alunos expressam sentimentos de humilhação, vergonha, indignação e alegria relativos à vivência do dia-a-dia escolar. Os jovens referem-se a situações em que estudantes e professores são humilhados, como alvo de agressão ou ridicularizações:

Jhonatan: Ela [professora] gosta de tirar sarro. Tipo... humilhar! (...) João: [O professor] deu um rodo nele [no aluno] (...) [bem no meio da testa*]; e derrubou ele no chão. (...) Eu imagino como ele deve ter se sentido humilhado! (...) Na hora o X. [aluno] ficou lá jogado, com uma cara estranha, meio chorando.

\footnotetext{
${ }^{17}$ Segundo os jovens, enquanto alguns professores utilizam-se de muitos palavrões, quando os alunos o fazem, são encaminhados para a diretoria da escola.
} 
(...) Cristina: Eu acho que o Professor Ronaldo, por ele ser baixinho, meio gordinho, [os alunos] ficam zoando com ele, xingando (...). Acho que ele também deve se sentir mal, por ele ser professor, ele também quer respeito. Mas (...) pra ele querer respeito ele também tem que respeitar os alunos.

$\left(2^{\circ}\left[{ }^{*}\right.\right.$ e $\left.3^{\circ}\right]$ Encontro $)$

Outras cenas de agressão física por parte alunos e professores são apontadas pelos adolescentes:

Cristina: Ele [professor] quase me machucou, só porque eu tava conversando com uma menina; eu peguei, sentei, ele foi lá, puxou minha cadeira com tudo, quebrou tudo... caiu tudo no chão!

(...) Janaína: [Também teve aluno agredindo professor]. Ela foi até expulsa! Acho que o professor mandou ela ir pra fora da sala, ela (...) foi lá e bateu no professor.

$\left(2^{\circ}\right.$ e $3^{\circ}$ Encontros)

O sentimento de humilhação também é explicitado pelos alunos ao fazer alusão a situações em que se é alvo de preconceito. Nesse sentido, elucidam o predomínio do preconceito relativo à aparência física e à raça (em contraposição ao vinculado à condição sócio-econômica, que não se evidencia, segundo os alunos), no contexto escolar. Ao discutir esse tema, ilustram situações em que negros são humilhados em função da cor de sua pele - metade dos participantes da pesquisa refere-se à sua raça como negra (Jhonatan, Tamara, Janaína e Evaristo). Diante disso, apresentam como propostas para a educação o incentivo ao respeito e o combate à discriminação:

Tamara: Aqui dentro da escola não tem [preconceito com relação à situação financeira]. Acho que todo mundo é igual.

Janaína: [...Porque a maioria das pessoas aqui é tudo que mora na favela. Não tem nada de "ah, você é mó pobre"*]. Eu acho que aqui na escola tem preconceito, só que assim, de cor. Porque uma pá de gente fica zoando com o Jhonatan...

Tamara: ...Só que eu acho assim, que deveria ter, sei lá, mais respeito pela gente, porque a gente também é ser humano! 
Janaína: ...Agora, assim, de pobreza, eu nunca vi; é mais de se a pessoa é gorda, feia, tem cabelo ruim, esses negócio!

( $4^{\circ}$ Encontro $\left[{ }^{*}\right.$ e Entrevista $\left.]\right)$

Jhonatan: A [professora] fica me chamando de "apagão".

(...) Tamara: O Jhonatan é humilhado.

(...) Jhonatan: Mas eu também humilho, hein?

( $3^{\circ}$ Encontro)

Jhonatan: Colocar [como proposta pra educação, ter] mais respeito... menos discriminação (...) Por causa da zoeira. Gostam muito de zoar tipo assim: se a pessoa tem um defeito, começam a zoar, é normal.

(Entrevista)

O sentimento de vergonha é apontado pelos alunos quando se reportam ao constrangimento envolvido no ato de responder em voz alta às questões apresentadas pelos professores. De acordo com os jovens, esse aspecto se associa ao receio de errar e ser ridicularizado diante dos colegas em sala de aula:

Janaina: De vez em quando [dá] medo de arriscar, responder errado.

(...)Adriana: Vergonha.

Janaína: Assim, quando eu fico pensando comigo, eu vejo que tava certa, mas não gosto de falar.

João: Qualquer pergunta que o professor faz pra sala inteira responder, eu respondo baixinho, mas só que depois os que ouve o que eu falei, se aproveita da minha resposta. [Se o aluno responde errado], todo mundo zoa ele!

(1 Encontro)

Segundo os adolescentes, o fato de serem julgados injustamente e punidos por algo que não realizaram ou serem os únicos repreendidos em um contexto no qual consideram que os demais alunos estão envolvidos os deixa indignados. Além disso, referem-se à ausência $e$ ao autoritarismo por parte da diretora, como algo que os indigna: 
Karina: Na escola, o que acontece que deixa vocês indignados?

Denis: Às vezes acontece alguma coisa com outra pessoa e ele [professor] já acha que é você: "Vai pra fora!"; e nem foi nós...

Janaína: É verdade. Ou também quando tá todo mundo conversando, igual a ontem. [A professora só ficou olhando pra gente, com as outras pessoas ela não falou nada]; só ficou chamando nossa atenção. Falou que ia abaixar a nota e não sei o quê...

Tamara: Isso que me deixa mais indignada!

Jhonatan: A diretora [também], que nem aparece aí e quando aparece, quer dar suspensão!

( $3^{\circ}$ Encontro)

Por fim, ao ressaltar o sentimento de alegria no contexto escolar, fazem alusão, exclusivamente, à relação dos alunos entre si, destacando os laços de amizade e os relacionamentos amorosos, ou seja, endossam as afirmações proferidas no início desse tópico. Nesse sentido, de acordo com os adolescentes, é por meio dessas formas de relacionamento que os jovens alunos vivenciam momentos de alegria em meio aos demais sentimentos relativos à vivência do dia-a-dia escolar:

Karina: Não tem alegria na escola?

Jhonatan: A minha alegria é mulher.

João: Alegria é conhecer gente!

Janaína: Conversar com os amigos.

Evaristo: Fofoca do fim de semana.

(...) Jhonatan: Alegria pra mim é sair da escola, sabendo que o outro dia é sábado.

(...) João: Pra mim, alegria é ter aquele seu amigo diário, mano!

(...) Karina: E além das amizades?

Janaína: Ah, só!

João: Os namoros.

Denis: A paisagem [as garotas].

( $3^{\circ}$ Encontro) 


\section{D) CRÍTICAS E PROPOSTAS REFERENTES À EDUCAÇÃO ESCOLAR}

\section{D.1) Críticas apresentadas pelos jovens alunos}

Karina: Qual você acha que é o maior problema da educação hoje?

Denis: ...Eu acho que é a falta de orientação do pessoal da direção, assim. O aluno, pra ele aprender, também tem que estar tendo lazer na escola! Não tô falando balada, bebida, essas coisas... mas lazer, esporte, uma quadra, uma bola pra jogar, uma escola pintada, cadeiras decentes! Tendo o monitoramento da escola funcionando bem, não tem como não funcionar. (Agora, não! A gente não tem nada pra fazer..., a pessoa vai zoar na sala, mesmo!)

(...) Karina: Então, você acha que deveria ter um espaço pra isso...

Denis: Mas não é especificamente ter espaço. Espaço tem, não tem é capacidade de equipar o lugar. Tem a quadra, mas não tem bola! De que adianta? Tem cantina, mas não tem nada pra comprar!

(Entrevista)

Tamara: ...Porque a minha sala eu acho que tem muita gente... tem 48 pessoas! (...) Com aquele barulho que tem lá, pelo amor de Deus, não dá pra fazer as coisas! (...) No reforço... [tem] nove pessoas. Aí tem uma aula diferente, né? É poucas pessoas, então todo mundo presta mais atenção e a professora comanda mais a sala...

(Entrevista)

Karina: E o que vocês acham disso, de ficar mudando de professor?

Tamara: É super ruim!

João: Ah, é da hora!

Evaristo: Quem acaba pagando o pato é a gente.

Tamara: Meu caderno tá todo dividido.

Janaína: E, assim, quando nós começa a aprender aquela matéria..., aí depois o [outro] professor passa uma coisa que não tem nada a ver com aquela que a gente já tava aprendendo.

(...) Tamara: .... Isso atrapalha!

( $3^{\circ}$ Encontro)

Os trechos acima ilustram críticas apontadas pelos jovens relativas a aspectos institucionais, tais como: a concentração de um grande número de alunos por sala, que interfere na qualidade e no rendimento da aula; a mudança de professores ao longo do ano letivo, prejudicando a continuidade e a coerência do conteúdo ministrado; e a falta 
de investimento na infra-estrutura da escola e em atividades voltadas ao lazer, afetando o processo de aprendizagem e propiciando a configuração de um contexto em que se insere a produção da indisciplina, tal como se evidencia no trecho acima.

Ao criticar a qualidade do ensino, esses jovens consideram que o maior problema da educação escolar consiste no descaso de professores em transmitir e explicar o conteúdo a ser lecionado, bem como no comportamento dos alunos, ou mais especificamente, no desrespeito, na indisciplina e na falta de interesse atribuídos aos estudantes ${ }^{18}$ :

Evaristo: Acho que [o maior problema da educação escolar] é os alunos e os professores. Sei lá, os alunos não tão com vontade de aprender. Eu também não gosto, mas precisa, senão, não vou ser ninguém na vida. Minha mãe sempre fala isso: "Precisa estudar, senão aí é que vai ser mais discriminado ainda!"

(Entrevista)

Cristina: [O maior problema é] Xingar os professores, jogar giz no professor, jogar papel no professor, pichar a escola. Ah, de alunos, mesmo... falta de respeito com 0 outro, ficar brigando, machucando eles mesmos.

(Entrevista)

João: Os professores. (...) Não vou generalizar, porque tem professor bom. Mas muitos professores são vagabundo, chega e senta ou passa qualquer coisa, eles não impõe respeito, por isso não têm respeito e ninguém vai confiar.

(Entrevista)

Janaína: $O$ ensino precisaria ser melhorado, porque o ensino tá muito ruim, eu acho. Por causa que da aula de matemática não sei fazer quase nenhuma lição, porque a professora explica rapidão e os aluno também fica conversando, não dá pra entender nada. Aí a professora fala que tavam conversando, não explica mais, e mesmo prestando atenção, eu não consigo entender nada! A gente vai perguntar pra ela, ela

\footnotetext{
${ }^{18}$ A falta de interesse e o desrespeito são apontados pelos adolescentes ao se reportar tanto aos alunos quanto aos professores (considerando que esses demonstrariam falta de interesse em aprender ou em ensinar).
} 
explica com a maior rapidez, ela mesmo faz a conta lá e pronto: "Faz igual eu fiz". Grande coisa, né? Não dá pra entender nada!

(Entrevista)

Tamara: $\hat{O}$, ensino ruim! [E o que tem de ruim?] Tudo! Professor, aluno... é professor que não tem vontade de dar aula... Igual o [professor de Matemática]: segunda-feira (...) só fez a chamada, sentou na cadeira, não fez nada, nada, nada! "Professor, o senhor não vai passar lição, não?" "Ah, não tô com vontade de passar lição" "Então não tô com vontade de ficar na sua aula". Aí ele: "Ah, pode conversar, pode fazer o que quiser". A turma tava quase quebrando a carteira lá e ele rindo pra todo mundo!

(Entrevista)

Além de se referir a professores e alunos, alguns jovens também fazem alusão à direção da escola: "[O maior problema também é] A direção (...) A diretora não faz nada aqui dentro da escola! Nunca vi ela falando alguma coisa pros alunos", "E também a diretora (...) [que] mal vem pra escola e, quando ela vem, acha que ela manda!" (Jhonatan e Tamara - Entrevista).

A idéia de que professores, alunos e diretores seriam os principais responsáveis pela qualidade da educação escolar está presente no discurso desses jovens, sendo explicitada ao culpabilizá-los pela problemática educacional:

Karina: O que faz uma escola ser uma boa escola?

Janaína: Os alunos.

João: Os professores e os alunos.

Tamara: E a diretora, também. Porque se você tiver um professor porcaria..., a diretora, nem se fala... e os alunos também...

(...)

Karina: Quando a educação não é de qualidade ou quando tem repetência..., existe um culpado por isso?

João: Sim. O professor.

Tamara: $O$ diretor.

Denis: O quê?! Os alunos!

João: $O X_{11}$ e o $X_{12}$ [alunos] são os mais vândalos que eu já conheci na minha vida; em 14 anos de vida! Mas eles não são vândalos na aula do Vanderlei! 
Jhonatan: É o aluno. O aluno, se ele quiser, ele passa, não tem nenhum professor nem ninguém que não faça ele passar. Que nem os "c.d.c.", não sei. ["C.d.f."?] É, "c.d.f.". Se ele faz tudo, fica quieto, na dele, faz tudo..., é claro que vai passar!

(Entrevista)

Adriana: Tem professor que não tá nem aí e o aluno também já não tá nem aí... já era! E tem professor que é bem rígido, como o Vanderlei. Então, se ele pega no pé de um aluno, por mais desinteressado que o aluno seja, ele vai procurar se esforçar também! (...) João: Se for um professor bom, tipo o [professor de Português] (...), quem quer aprender, na aula dele vai aprender com certeza. (...) Mas já com o [professor de Matemática], mesmo quem quiser aprender, não vai aprender nada.

Janaína: É mesmo, porque ele não sabe explicar.

(Entrevista e $1^{\circ}$ Encontro)

Com relação a esse aspecto, alguns jovens responsabilizam os demais participantes do contexto escolar (além dos citados acima), incluindo os coordenadores, pais e inspetores de alunos:

Tamara: Acho que [o maior problema da educação] são os alunos; que não respeitam os professores. E também os professores, que não respeitam os alunos. E dos pais, também, que não educam os filhos e os filhos acham que a escola é a casa deles. Então, acho que na verdade a culpa é de todo mundo. Não é só do professor, do aluno ou dos pais; é de todo mundo. (...) E também a diretora (...) [que] mal vem pra escola...

(Entrevista)

Denis: É a... escola inteira, assim... em geral, desde os professores ao coordenador, inspetor, alunos, todo mundo.

(Entrevista)

A culpabilização dos alunos pelo fracasso escolar é explicitada por alguns adolescentes, ao vincular a repetência à não aprendizagem dos estudantes, atribuindo essa última ao baixo nível intelectual, à indisciplina ou à falta de interesse dos alunos. 
Ou seja, ao estabelecer uma relação de causa e efeito entre a reprovação escolar e a aprendizagem (considerando que o aluno reprova porque ele não aprende), bem como entre a aprendizagem e seu coeficiente intelectual, sua motivação ou comportamento (com base no pressuposto de que o aluno não aprende porque tem QI baixo, não tem interesse, atenção, faz bagunça ou tem preguiça), esses jovens apontam o aluno como sujeito e foco da produção do fracasso escolar:

Karina: E a oitava $A$ ?

Denis: É só de repetente.

João: A oitava A é uma boa sala, porque eles repetiram, então eles já têm o exemplo, não querem repetir de novo.

Cristina: Eles não conseguem aprender, não porque eles não querem, porque, tipo, se já passou de ano, mesmo...

Denis: Acho que é porque não tem QI alto.

João: Acho que eles têm capacidade; (...) o mesmo tanto que todo mundo tem. Simplesmente não usa seu potencial.

Karina: $O$ que vocês acham, não só na oitava $A$, mas em qualquer oitava, quando o aluno não aprende, o que acontece pra que isso aconteça ${ }^{19}$ ?

João: Ele não presta atenção.

Janaína: Falta de interesse.

João Ele não quer.

Adriana: Eu acho que é também a companhia que fica ao redor.

[Tamara: Bagunça] ${ }^{\star}$

(...) João: Aluno que quer, aprende! (...) É, mas já com o [professor de Matemática], mesmo quem quiser aprender, não vai aprender nada.

(...)

Karina: A pergunta não é nem porque o aluno não aprende, mas: o que acontece pra que não tenha aprendizagem ou pra que tenha repetência?

Adriana: Preguiça de vir pra escola.

João: Às vezes o aluno não aprende porque não quer, às vezes porque o professor não ensina.

$\left(1^{\circ}\left[{ }^{*} e 3^{\circ}\right]\right.$ Encontro $)$

\footnotetext{
${ }^{19}$ É interessante notar que, ao formular a questão dessa forma, a pesquisadora reproduziu por esse instante a idéia de que "o aluno não aprende", ao invés de se referir à produção da nãoaprendizagem, tal como fez anterior e posteriormente.
} 
No final do trecho acima, retomam-se as questões relativas ao esforço pessoal dos alunos e à responsabilização dos professores pela qualidade do ensino, sendo ambos (professores e alunos) culpabilizados pelo fracasso escolar. Além disso, nesse fragmento do encontro em grupo, uma adolescente (Cristina) introduz um aspecto referente ao sistema de avaliação e reprovação, fazendo alusão à idéia de que esses alunos que foram retidos na oitava série estariam, a priori, aprovados, o que interferiria no processo de aprendizagem; a esse respeito, outra jovem acrescenta: "Essa sala era pra ser um projeto. Cadê o projeto? Tão dizendo que essa sala já passou..." (Tamara - $3^{\circ}$ Encontro) $)^{20}$.

Ainda em relação à culpabilização dos alunos, os adolescentes evidenciam a atribuição de rótulos aos alunos "repetentes". Associada à idéia de que esses são sujeitos e foco do fracasso escolar, está a imagem explicitada por alguns jovens acerca dos alunos que foram retidos. Conforme apontado acima, de acordo com os adolescentes, a repetência e a não aprendizagem estão associadas ao comportamento e à falta de interesse e atenção por parte do aluno; tal concepção apresenta coerência com a consideração de que aqueles alunos seriam displicentes (sem interesse pelo estudo) e indisciplinados, como ilustra o seguinte trecho:

Tamara: [A oitava A é] sem futuro! Eles não querem nada! Só zoam; não fazem lição... (...) Jhonatan: Que não quer nada com a vida! Só quer zoar, bagunçar, fumar maconha. (...) Karina: Algum de vocês já repetiu? Tamara: Eu. Karina: E o que se fala dos alunos repetentes?

20 Esse aspecto será abordado posteriormente em um subitem referente ao sistema de avaliação e reprovação. 
Tamara: Dizem que não presta, são tudo vagabundo, não fazem nada... Karina: E você acha o quê?

Tamara: Que é verdade!

( $3^{\circ}$ Encontro)

Ao contextualizar sua experiência relativa à reprovação escolar, a adolescente afirma que todos os alunos de sua sala foram reprovados e associa esse fato à postura da professora que costumava faltar às aulas e não se empenhava em transmitir $e$ explicar o conteúdo aos alunos: "A professora faltava, não dava matéria. E quando ela dava, só passava e não explicava, então ninguém tava nem aí, mesmo, e a sala toda repetil' (Tamara - Entrevista). Ao afirmar que havia sido reprovada, outra aluna explicita críticas à qualidade do ensino e ao sistema de avaliação e reprovação (tema que será apontado a seguir):

Adriana: Onde eu estudava (...), os professores davam prova, mas pra ficar livre logo de você, se você tirasse nota baixa, ele metia logo um 10. Aí eu, burra, pensei: "Não aprendi nada"! Daí, tinha uma última prova, um provão, eu faltei e aí repeti, pra recuperar.

Karina: Por que você acha que foi burrice?

Adriana: Porque eles ensinam sempre a mesma coisa!

(1 Encontro)

\section{O sistema de avaliação e reprovação}

Os alunos explicitam críticas referentes ao sistema de avaliação e reprovação, elucidando relevantes elementos implicados nesse processo. Com relação à avaliação, os jovens afirmam que os professores estipulam as notas (ou os conceitos) dos alunos com base na realização de trabalhos e provas, na verificação dos cadernos $e$ em 
função de seu comportamento. No entanto, fazem alusão à arbitrariedade envolvida em um sistema de avaliação em que alguns professores não utilizam critérios bem definidos ou coerentes para atribuição desses conceitos aos alunos; e em que provas são aplicadas e imediatamente corrigidas na lousa (sendo entregues pelos alunos após a cópia das respostas) ou realizadas com consulta, o que, de acordo com os adolescentes, não possibilita a avaliação da assimilação do conteúdo ministrado:

Adriana: Onde eu estudava (...), os professores dava prova, mas pra ficar livre logo de você, se você tirasse nota baixa, ele metia logo um 10.

(1 Encontro)

Cristina: Eles [professores] passam lição na lousa e, se o aluno quer copiar, copia; se não quer copiar, ele também não fala nada, dá nota. Se o aluno fez, fez; se não fez, dá nota do mesmo jeito!

(Entrevista)

Evaristo: A prova que ele [professor] deu na minha sala, ele deu D pra todo mundo. Karina: Como assim?

Evaristo: Ele olhava assim, olhava, olhava... sua prova: D; sua prova: D.

Tamara: Mas tipo, ele já vai dando as respostas, ninguém faz nada. Ele vai colocando e todo mundo já vai copiando.

( $3^{\circ}$ Encontro)

Janaína: ...Eu acho ruim prova que tem consulta (...). A gente só lê o texto [no caderno] e escreve, não vai aprender nada desse texto! (...) Apesar que é difícil [sem consulta], só que a gente também tem que se esforçar. Se eu for fazer uma prova sem consulta, não vou fazer nada! Porque a gente já ta acostumado desde a quinta série aqui, só prova com consulta, com consulta, com consulta. Quando tiver uma prova sem consulta, como você vai fazer? Teve um dia que a professora passou uma prova de geografia, sem consulta, era uma pergunta só e eu não consegui fazer! E era em dupla, ainda; a gente não conseguiu fazer a prova!

(Entrevista)

Percebe-se, com base nos trechos acima, que, nesse processo, as notas ou conceitos são estipulados independentemente da efetiva transmissão e assimilação do 
conteúdo ministrado, tal como uma aluna explicita ao afirmar: "Ela [professora] (...) explica uma vez, já é pra todo mundo aprender e no final do bimestre só mostra o caderno e tira A. Copiando a lição tá bom demais, só que não interessa se você aprendeu ou não" (Adriana - Entrevista). Sendo assim, os jovens evidenciam situações em que a aprendizagem não é produzida nesse contexto educacional, porém, esse fato se torna acobertado por meio de um sistema de avaliação arbitrário. $O$ fato de serem atribuídas notas altas aos alunos apesar de não se produzir a aprendizagem é explicitado pelos adolescentes, tal como ilustra o seguinte fragmento de entrevista:

Janaína: ...Eu tenho nota boa, só que eu não sei fazer. Tipo assim, do que eu sei fazer, ela [professora] não dá prova, do que eu não sei fazer, ela dá prova.

Karina: Mas aí você tira nota boa?

Janaína: Aí a sala inteira fica olhando pra cara dela e ela ainda dá nota, lál (...) Ninguém da sala sabe, só alguns que ficam sentados na frente. Até os que estão na frente ainda não sabem muito bem, você pergunta pra eles... a maioria não sabe. Aí é ruim!

(Entrevista)

Com relação a esse aspecto, os jovens acrescentam a idéia de que os alunos são aprovados independente da transmissão e assimilação do conteúdo, fazendo alusão, inclusive, ao fato de haver na oitava série alunos que não foram alfabetizados. Desse modo, introduzem críticas referentes ao sistema de reprovação/aprovação ${ }^{21}$, ressaltando o critério utilizado para a retenção dos alunos na oitava série relativo à obtenção de um grande numero de faltas às aulas ao longo do ano letivo:

\footnotetext{
${ }^{21}$ Algumas considerações acerca do sistema de reprovação nas escolas de Ensino Fundamental da rede estadual de São Paulo (com referências à Progressão Continuada), serão apontadas no próximo capítulo.
} 
Karina: Vocês acham que isso pode acontecer [que é possível passar de ano sem saber o conteúdo]?

Janaína: Eu acho que pode! Porque eu mesmo não sei uma pá de coisa, mas eu tô aí, com nota boa, mas eu não sei fazer.

(...) Tamara: Mas sabe porque, também? Porque os professores, eles começam uma matéria hoje, amanhã eles põem outra (...); e complica demais, demais...!

(...)

Tamara: Igual a aqui [na escola]. Na oitava série tem gente que não sabe ler!

( $4^{\circ}$ Encontro)

Janaína: Tem uma menina na minha sala que ela não sabe escrever, ler, nem nada; e ela não se esforça pra fazer nada!

( $3^{\circ}$ Encontro)

João: No Ez [escola], eu ia uma vez por semana...

Karina: E mesmo assim, você foi aprovado?

João: Fui.

Tamara: [Pra ser aprovado] precisa ter no máximo 250 faltas.

Denis: No mínimo.

Tamara: $A X_{18}$ [aluna] tá com 198.

Karina: Vocês acham isso [250 faltas] muito ou pouco?

Juntos: Muito! Nossa!

(...) Tamara: Em uma semana, você ganha 25 faltas. Imagine em 12 meses, quantas faltas que não dá? O ano tem 365 dias, metade do ano fica faltando!

( $3^{\circ}$ Encontro)

De acordo com os adolescentes, as notas obtidas por meio de atividades realizadas ao longo do ano, o comportamento dos alunos e a quantidade de faltas correspondem aos critérios para reprovação na oitava série; e, ao final do ano letivo, se os alunos não apresentam 'desempenho satisfatório' em algum desses aspectos, o Conselho de Classe (composto por professores) determina sua aprovação ou reprovação. A esse respeito, uma aluna endossa a idéia de que o número de faltas é, por vezes, prioritário em relação aos demais critérios; ou seja, se um aluno obtiver 
uma nota ou conceito final insuficiente, mas apresentar um número de faltas compatível com o limite estipulado, pode ser aprovado:

Karina: Vocês conhecem alguém que tirou nota baixa e foi reprovado?

(...) Tamara: Eu conheço. A X $X_{16}$ [aluna]. (...) Mas é porque ela nunca vinha pra escola. Karina: Por falta...

Tamara: Não, tem mais uma pessoa... deixa eu ver... X 17 . Ela veio, fez a prova (...). Ela fazia as coisas. Foi pelos pontos, né? Precisava ter tirado 2 e pouco...

( $3^{\circ}$ Encontro)

Tamara: Se entrar alunos vagabundo na escola, ó... fica o ano todo sem fazer nada e ainda passa! Passa porque eles [professores] não querem ver de novo a pessoa (...). Éo Conselho [que decide se o aluno passa de ano] (...). E o Conselho é feito por professores. (...) Se tiver dois que quer te reprovar e o resto quer te passar, você passa.

Karina: Não conta a nota...?

Tamara: É, tipo, nota conta. Mas se você não tiver nota e não faltou no ano, você passa! ( $4^{\circ}$ Encontro)

Além disso, os adolescentes discutem sobre a função do SARESP - Sistema de Avaliação de Rendimento Escolar do Estado de São Paulo. Enquanto alguns jovens se referem a essa avaliação, cuja pontuação não implica sua aprovação ou reprovação, como um meio de investigação acerca do nível de conhecimento dos alunos, outros alegam que a nota obtida nessa prova pode acarretar (ou propiciar) a retenção do aluno na oitava série. Percebe-se, portanto, que esses estudantes fazem inferências com relação à sua função, que não parece ser-lhes explicitada ou esclarecida:

Karina: Mas, então, não tem uma prova (...) que faz a pessoa repetir?

Janaína: Tem. O SARESP.

Karina: O SARESP faz repetir?

(...) Jhonatan: O SARESP, já falaram, que não repete.

Tamara: Não repete. [É um teste] do conhecimento que a gente tem.

(...) Evaristo: O SARESP é só um teste pra gente ter conhecimento do que vai ter 0 ano que vem.

( $4^{\circ}$ Encontro) 
Janaína: ...E quando chega na oitava, tem esse provão, aí [o aluno que tiver nota ruim] não passa.

Karina: E é o SARESP que faz passar ou não passar?

Janaína: Não, ele não faz passar, mas só que ele também ajuda (...) Ajuda pra ver o conhecimento do aluno, se ele tá indo bem. Só que tem que fazer de 15 pra cima de pontos. Se fizer 14, ou fica retido ou eles dão recuperação, né? (...) Eu não sei se agora é assim, mas antigamente era. Agora todo mundo fala que não é assim, mas eu não sei. Por que ano passado a gente teve, só que não podia reprovar, então... mas esse ano vai reprovar.

(Entrevista)

\section{D.2) Propostas para a melhoria do quadro educacional}

Além de apontar as referidas críticas, os adolescentes apresentam propostas para a melhoria do quadro educacional. Com relação à infra-estrutura escolar, os jovens se referem ao investimento $e$ melhor aproveitamento dos recursos $e$ equipamentos presentes nas instituições escolares; esse aspecto é explicitado pelo grupo de alunos ao fazer alusão a elementos relativos à estrutura de sua escola, tais como: pintura e cobertura da quadra de esportes, efetiva utilização das salas de vídeo e de computação, viabilização de atividades de esporte e lazer e inclusão de lanches na cantina, como uma opção distinta da refeição (ou da "comida de almoço") oferecida.

Uma outra proposta enfatizada pelos adolescentes associa-se à concepção (apontada anteriormente) de que professores e alunos seriam principais responsáveis pela qualidade do ensino. Com base nessa idéia, ao serem questionados acerca de que medidas seriam necessárias para haver uma melhoria no quadro educacional, os jovens afirmam que deveria haver "bons professores" (empenhados em transmitir o conteúdo 
de forma didática e efetiva, que acreditem no potencial dos alunos e os respeitem), sendo-lhes oferecidos cursos a fim de aprimorar seu conhecimento, além de uma "conscientização" por parte dos alunos ("ter essa consciência de não fazer nada de errado, respeitar pra ser respeitado"), que também deveriam se empenhar em estudar:

Evaristo: Os alunos têm que ter mais desempenho pra aprender, mais vontade de estudar.

(4 Encontro)

Janaína: Acho que era professores com mais capacidade, como o [professor de Português], assim. (...) [Precisava ter um] ensino bom, também; os professores acreditar nos alunos e respeito. (...) Ter professor com mais vontade de ensinar e com disposição, também; tem uns que vêm, ensinam rapidão e aí sai.

(Entrevista)

Cristina: [O professor] poderia incentivar mais o aluno, explicar direito, fazer questão que o aluno aprenda.

(Entrevista)

Denis: Ah, tinha que ter professores bem mais treinados, também. Mesmo depois da faculdade, tinha que ter uns cursos pra aprimoramento das coisas.

(Entrevista)

Evaristo: "Os alunos [deveriam] se esforçar pra aprender e os professores se esforçar pra ensinar".

(Entrevista)

É interessante notar que, partindo da concepção de que a qualidade da educação depende da motivação e do esforço pessoal do professor, os adolescentes apresentam a proposta de que o salário dos professores deveria ser proporcional à efetividade do ensino e da aprendizagem em suas aulas: "Ganhar pelo ensino. Se estiver ensinando, ganha bem"; "Salário por educação: (...) se o professor pelo menos 
tentar e a gente ver que ele tá se esforçando, aí ele recebe. (...) Se ensina mais, recebe mais; se ensina menos, recebe menos" (João - Encontro Extra I e Entrevista). Com relação a essa idéia, uma aluna acrescenta: "Se você não dá uma aula boa e que a sala tá aprendendo, você não vai receber seu salário. Rapidinho ele [professor] ia começar a dar aula bem melhor!" (Tamara - Entrevista).

Em outros momentos do discurso dos adolescentes, ao considerar que o quadro educacional não depende exclusivamente de professores, alunos ou diretores, mas envolve a participação de pessoas externas ao ambiente escolar ("de quem tá fora da escold"), os jovens se referem a contribuições que governantes poderiam fornecer à qualidade de ensino. Nesse sentido, propõem uma atuação do prefeito direcionada à elaboração e efetivação de projetos voltados para educação, incluindo a comunicação com representantes das escolas a fim de investigar a situação educacional vigente, informando-se sobre os problemas e necessidades presentes nas instituições escolares, de modo a colaborar para a sua resolução:

Cristina: ... O prefeito também pode ajudar!

(...) João: [Fazendo] projetos!

Janaína: Tem que fazer projeto e agir!

( $4^{\circ}$ Encontro $)$

Cristina: Ele [prefeito] poderia... Não vou dizer comparecer nas escolas, mas sempre tá ligando, mandando e-mail, não sei... vendo como tá a educação na escola, vendo o que ele pode fazer pra ajudar. Quer dizer, ele pode fazer muita coisa, né? Mas é ter comunicação com a escola, com todas as escolas, pra poder ajudar, ver o que tá faltando.

(Entrevista) 
Outro relevante aspecto a ser apontado consiste na discussão dos jovens acerca da proposta, apresentada por esses durante um encontro em grupo, referente à idéia de incluir monitores (adultos) nas salas de aula, a fim de auxiliar os professores a "manter a ordem, disciplina e progresso da sald" e "instalar equipamentos de vigilância (câmeras) nas escolas públicas".

Ao debater esse tema, alguns adolescentes alegam que a melhoria do quadro educacional implicaria o investimento na segurança e na instauração da ordem na escola, reforçando-se a autoridade, a vigilância e o controle sobre o comportamento dos alunos. Nesse sentido, ao propor a instalação de câmeras nas salas de aula, endossa-se a prerrogativa de vigiar e punir os estudantes, buscando combater o caos e a desordem na escola. No entanto, os demais jovens do grupo questionam essa proposta, referindo-se ao caráter opressor presente em tal medida, que seria desnecessária e cercearia a liberdade dos alunos no ambiente escolar, onde vigoram outros mecanismos de opressão:

Denis: ... Ter mais segurança, mais vigilância, prestar atenção no aluno. (...) Ser mais rigoroso nas coisa errada que o pessoal faz.

(...) Jhonatan: ... Colocar mais ordem na escola (...). Tem que ter mais autoridade.

(...) Tamara: ...Policiamento dentro da escola.

(Entrevistas e $4^{\circ}$ Encontro)

Denis: Instalação de câmeras de vigilância nas escolas públicas.

(...) João: Tem que colocar [as câmeras] porque daí não vai ter aquela coisa que um faz alguma coisa e não fala que fez.

Tamara: Só que já vai ter aqueles ajudantes [monitores] e eles vão ficar tomando conta da sala. Então, não vai precisar de câmera. (...) Só porque a câmera tá aqui, Lo aluno I não vai fazer nada? Quem quiser fazer, faz!

(...) Denis: Mas se ver pela câmera ela vai ser punida!

Tamara: Punida!!! Meu, que...!!! Ó, não vai dar certo! 
(...) Janaína/Tamara/Jhonatan: Não concordo que tenha câmera na sala.

(Encontro Extra II)

Janaína: O aluno não vai nem poder conversar, vai tá tudo gravado lá? Isso daí já é abuso, eu acho! (...) Isso de ficar vigiando, fica chato pro professor e pro aluno também, pra quem estiver na escola fica muito chato. (...) Se ficar um ajudante só olhando pra gente, se você conversar pra pedir uma borracha, já vai tá o ajudante falando um monte, e [ainda] vai tá as câmeras...!

(Entrevista)

Tamara: ...Não vai adiantar de nada! (...) Câmera poderia até ser pra segurança, mas pra vigiar os alunos...! Já tem um monte de grade!

(Entrevista)

"Não precisaria instalar equipamentos de vigilância nas escolas públicas, pois iria parecer uma prisão; só deveria ter câmeras no fundo das quadras ou pátio para verem se tem alguém com maconha ou outros tipos de drogas, mas nas salas de aula não haveria necessidade".

(Documento produzido por Janaína com propostas para o PAN) ${ }^{22}$

Ao discutir a idéia de haver monitores (ou ajudantes) em sala de aula, os jovens consideram que sua função não deveria se restringir ao auxílio para que se mantenha a ordem na sala, mas envolveria o esclarecimento de dúvidas dos alunos sobre o conteúdo ministrado, durante a aula: "Se o professor tá ensinando, você fala: 'Você pode me ajudar?'; se você quer uma opinião, uma ajuda, você fala com o ajudante, 0 professor vai estar ocupado" (Janaína - Entrevista).

Com relação a esse aspecto, os jovens acrescentam a proposta de se estabelecer, fora do horário de aula, um espaço em que os professores esclareçam as

\footnotetext{
22 A transcrição de suas propostas encontra-se no final do anexo referente ao "Encontro Extra II", em que essas foram discutidas pelos alunos em grupo. Essas também foram incorporadas à versão final do documento referente ao Partido dos Adolescentes da Nação, que segue em anexo.
} 
dúvidas apresentadas pelos alunos. A realização desse contato individual com 0 professor é endossada por uma adolescente que se refere ao constrangimento produzido diante da exposição de alguma dúvida perante os colegas em sala de aula: " $A$ maioria dos alunos tem vergonha também de perguntar alguma coisa. Porque aí o pessoal fica: 'Ai, que burro, que burro!" (Janaína - Entrevista). O trecho abaixo ilustra essas idéias, apresentadas inicialmente por uma aluna (Janaína), cujas propostas foram discutidas em grupo e incorporadas ao documento referente ao PAN:

"Deveria sim ter ajudantes para que pudessem ajudar a manter a disciplina $e$ progresso na sala, mas também para ajudar os alunos que precisassem tirar suas dúvidas. Deveria também ter um dia especial para que cada aluno tirasse a dúvida com o professor ou marcar um horário depois da aula para fazer perguntas da matéria que não entendell.

(Partido dos Adolescentes da Nação)

Um relevante aspecto apontado pelos jovens consiste na necessidade de se propiciar a comunicação entre os participantes da escola. Ao introduzir essa questão, uma aluna apresenta a proposta de que, nas reuniões entre pais e professores, além de se conversar sobre o comportamento dos alunos, os pais deveriam expor sua visão acerca do contexto escolar, referindo-se à qualidade de ensino na escola (incluindo questões institucionais envolvidas nesse processo), de modo a se discutir alternativas para a resolução dos problemas apontados.

Nesse sentido, os pais poderiam ser porta-vozes dos jovens alunos, que não costumam ser ouvidos: "Os pais [poderiam] reclamar também (...) do ensino, das coisas que têm na escola (...).. Eles [professores] iam ouvir, eles não íam ter como ficar 
falando um monte... do adolescente!' (Janaína - Entrevista). Com base em tais considerações, apresenta-se a seguinte idéia:

"Os pais dos alunos deveriam participar das reuniões de pais e falar o que estão achando do ensino da escola, o que deveria melhorar, o que deveria mudar, dar opiniões para que a educação melhore. E os pais deveriam ser obrigados a ir nas reuniões, principalmente os pais dos aluno que dá muito trabalho".

(Partido dos Adolescentes da Nação)

A importância de se ouvir os alunos adolescentes também é enfatizada por esses ao ressaltar a necessidade de diálogo entre alunos e professores. Em relação a tal aspecto, os adolescentes propõem a efetivação de um espaço de comunicação entre esses participantes do contexto educacional, em que se propicie a expressão dos alunos sobre questões relativas ao dia-a-dia escolar, incluindo elementos referentes à relação professor-aluno e à sua visão sobre a qualidade do ensino na escola:

Janaína: Acho que eles [professores] também deviam fazer reunião com os alunos! (...) Porque os professores também não sabem o que a gente tá pensando, né? Eles não vão adivinhar! Podem pensar: "Eu acho que eles tão achando que minha aula tá boa", mas na realidade, não; não tá boa. (...) Porque se começar a puxar... todo mundo começa a falar. (...) Aí eles iam entender o que a gente tá querendo dizer pra eles! Que a gente não diz, né? (...) Deveria... fazer umas perguntas, tipo assim: o que você acha que devia melhorar? O que você tá achando da escola? Dar umas idéias. Igual aqui [no grupo]. Podia dar uma folha pra gente responder; ia ser uma boa idéia! Aí devia falar de tudo que tá acontecendo... de professor-aluno, desses negócios. (...) A gente não pode só ficar esperando pelos outros fazer pela gente. A gente também tem que dar as idéias da gente, né?

(Entrevista)

Associada a essa questão, encontra-se a proposta, apresentada pelos alunos, de serem instituídos no ambiente escolar espaços em que se possibilite a expressão, o debate e a troca de informações sobre temas como a experiência escolar, 
adolescência, drogas, sexualidade, política e violência: "Na minha opinião, acho que a escola devia fazer um dia pra falar! (...) Com alguém..., psicólogo...; conversar, mesmo, sobre tudo que tá se passando na escola, como é a adolescência..." / "Porque qualquer adolescente gosta de falar o que pensa, tem assunto pra debater, pra discutir, mas não tem com quem discutir!" (Tamara e João - Entrevista).

Além das considerações apontadas até então, os adolescentes acrescentam propostas gerais relativas ao quadro educacional, referindo-se ao investimento em: construção e infra-estrutura de creches, escolas e faculdades; atividades de lazer $e$ cultura; orientação e material fornecidos para professores e na fiscalização de aplicações financeiras voltadas para a educação. Tais idéias foram apresentadas inicialmente por um aluno (Denis) ${ }^{23}$, discutidas pelo grupo e selecionadas, em regime de votação, para incorporação ao documento do Partido dos Adolescentes da Nação:

- Pôr policiais circulando no ambiente escolar.

- Equipar os professores com materiais de qualidade, e assim com mais recursos a aprendizagem será mais detalhada.

- Atividades esportivas com freqüência nas escolas.

- Investir no grêmio das escolas.

- Reformar grande parte das escolas públicas em um curto espaço de tempo.

- Acabar com as escolas de lata, e em seus lugares construir escolas de concreto.

- Construir e equipar as creches para que as mães fiquem tranqüilas ao irem trabalhar.

- Visitas freqüentes a teatros, cinemas e outras formas de cultura, tudo gratuito ou ao menos mais baratos.

- Construção de novas FA TECS, faculdades do Estado.

- Investir nas faculdades gratuitas, exigindo maior número de vagas nos vestibulares;

- Construção de bibliotecas públicas de fácil acesso à população.

- Aulas de orientação aos professores, com psicólogos especializados em comportamento de crianças e adolescentes.

${ }^{23}$ A versão completa das propostas apresentadas pelo aluno é citada no anexo referente ao II Encontro Extra, em que foram discutidas pelo grupo de adolescentes. 
- Fiscalizar todas as transações de dinheiro, material, merenda e atividades, que vierem do governo ou qualquer outra instituição à escola.

(Partido dos Adolescentes da Nação)

No tópico seguinte, serão apontadas as demais propostas presentes nesse documento elaborado pelos alunos.

\section{E) RECADO DOS JOVENS PARA A SOCIEDADE: $O$ PARTIDO DOS}

\section{ADOLESCENTES DA NAÇÃO}

"Nós somos o congresso de adolescentes indignados com a atual situação do país. E queremos demonstrar que não somos aborrecentes, nossas opiniões são óbvias $e$ diretas [e] temos responsabilidade suficiente para expor nossas opiniões.

Somos julgados injustamente, principalmente pela nossa situação financeira e pelos atos de vandalismo de uma minoria de jovens que não tem alta conscientização e respeito pelo ambiente onde vivem".

(Partido dos Adolescentes da Nação)

Essa é a introdução de um documento elaborado pelos jovens, por meio do qual visam transmitir uma mensagem para a sociedade. Nesse texto, os alunos expressam suas idéias e apresentam propostas referentes à educação ${ }^{24}$, saúde, violência, transportes e emprego, que se configuram enquanto proposições de um partido político fictício, criado por eles, intitulado "Partido dos Adolescentes da Nação"25.

\footnotetext{
${ }^{24}$ Apontadas no tópico anterior.

${ }^{25}$ A versão final desse documento segue em anexo (ANEXO VI).
} 
Um aspecto essencial, destacado pelos jovens ao redigir tal documento (e presente ao longo de todos os encontros), consiste na relevância e necessidade de se romper com a visão pejorativa, socialmente difundida, acerca dos adolescentes. Nesse sentido, ressaltam a importância de serem priorizadas e divulgadas suas virtudes ("podemos mostrar o que temos de qualidade"), salientando que apresentam "muitas idéias em mente", que têm responsabilidade (tanto no sentido de comprometimento quanto no de compromissos ou "obrigações") e conscientização política, em oposição à imagem de displicentes, "aborrecentes", irresponsáveis e alienados. Inclusive, contrapõem-se aos estereótipos sociais que lhes são atribuídos, associados ao preconceito referente a sua condição sócio-econômica, calcados na concepção de que os adolescentes seriam vândalos ou marginais, tal como ilustra o trecho acima.

A respeito desse último elemento, percebem-se novamente, em seu discurso, rupturas e reproduções relativas à concepção vigente na sociedade sobre os adolescentes. Ao discutir a redação de tal parágrafo introdutório, enquanto os jovens elaboram tais considerações com base na imagem que apresentam sobre si mesmos, evidenciam uma crítica referente a essa visão depreciativa que lhes é socialmente vinculada; porém, ao fazer alusão a seus pares, reiteram esses estereótipos, conforme ilustra o seguinte fragmento:

Denis: ... e pelos atos de vandalismo que uma minoria, que não tem a nossa -João: A maioria faz vandalismo!

Denis: Ah, gente! Mas nós tem que defender nosso lado, também! Vai falar que é a maioria? Aí eles vão falar: "Vocês são vândalos!"

(Encontro Extra I) 
Ao longo de todo o processo de produção desse documento, os alunos debateram, com afinco, questões referentes à conjuntura política vigente, bem como sobre alcances e limites da ação política dos jovens. Deve-se ressaltar que os encontros em grupo foram realizados durante o segundo semestre de 2004, período de candidatura e eleição ao cargo de Governador do Estado de São Paulo; tal contexto se configurou como base para discussões acerca desse tema.

Um primeiro elemento a ser apontado a esse respeito consiste na explicitação do apreço, por parte dos adolescentes, em se interar e debater assuntos relacionados à política, o que se opõe à concepção estigmatizada acerca dos jovens, socialmente vistos como alienados. Sendo assim, durante o primeiro encontro em grupo, os alunos manifestaram tal interesse ${ }^{26}$, bem como o desejo de se tornar eleitores aos 16 anos (voto facultativo) e se envolveram em argumentações acerca do Programa Eleitoral em vigor e das propostas dos candidatos a Governador do Estado de São Paulo; ao discutir esses temas, fizeram aproximações entre tais aspectos $e$ o modo como esses se concretizam ou se efetivam, com base na experiência pessoal ou na realidade que vivenciam:

Karina: E essa idéia de que adolescente não quer saber de política, (...) é alienado? João: Nada a ver! Tô sempre discutindo com a minha mãe pra ver quem é o melhor político... (...) Mó legal!... Eu vou querer tirar [o título de eleitor aos 16 anos] e vou querer votar.

\footnotetext{
${ }^{26}$ Embora uma aluna (Janaína) tenha afirmado não gostar de discutir esse tema, participou ativamente dos debates, argumentando e apresentando contribuições em distintos momentos, inclusive na elaboração do documento do Partido dos Adolescentes da Nação.
} 
(...) Janaína: Eu odeio política! Não converso de política. Eu não vou querer [tirar o título aos 16], porque, sei lá, eu acho muito chato. (...) Eu acho [chato], ter que ficar assistindo aqueles políticos. Ai, é horrível!

(...) João: Todos nós temos que votar no melhor pra nossa cidade. Porque se nós ficar pensando assim (...); se ninguém votar, voto em branco, em branco, em branco..., vai pro que tá ganhando.

(...) Denis: Eu vou [tirar o título]. Eu adoro política! [E também a gente precisa exercer] nossa cidadania.

(1 Encontro)

Adriana: A Marta só não vai ganhar porque só quer saber de enfeitar a cidade; ninguém come cimento ou come pedra!

(...) João: A Marta fez 21 CEUs.

Denis: Mas você vai lá e não tem vaga pra entrar. Eaî? (...) Minha prima diz que esse CEU parece o inferno.

João: É nada, o que parece o inferno é essa escola de latinha. Lá no CEU é tudo perfeito. Tem cinema, quadra, teatro... (...) Tô aprendendo a tocar violão lá.

(...) Denis: E a saúde? Ela falou que ia reformar não sei quantos hospital... [João: Fazer o quê, mano?] Não fez uma cama pro doente; se liga! Que que adianta ter CEU pro pessoal lá, se tá todo mundo doente na cama? Que adianta ter piscina, se tem neguinho que não pode sentar na cama, com soro na veia..., que adianta?

(...)

Janaína: Tem um negócio também que apareceu na televisão: algumas pessoas que são bem de vida tá com renda mínima e quem precisa mesmo, não tá ganhando.

Adriana: Eu tava tirando 15 reais do Bolsa-escola.

(...) Denis: Pelo amor de Deus! 25 reais e fala que tem não sei quantas famílias beneficiadas! Isso é uma esmola!

(1 Encontro)

A partir de tal discussão, os jovens propõem a criação do PAN - Partido dos Adolescentes da Nação - e elaboram proposições referentes à saúde, educação, emprego, transporte e violência, voltadas para o Estado de São Paulo ${ }^{27}$.

De modo geral, com relação à saúde, apontam a necessidade de investir na infra-estrutura de postos de saúde $e$ hospitais (envolvendo construções $e$

\footnotetext{
${ }^{27}$ De acordo uma aluna, tais idéias deveriam abranger todos os Estados do país, ao invés de se restringir a São Paulo.
} 
equipamentos, funcionamento e atendimento de qualidade), bem como no acesso da população a medicamentos. As medidas relativas ao aumento do índice de emprego envolvem, de acordo com os jovens, o investimento na qualidade do ensino de cursos profissionalizantes gratuitos e redução de impostos cobrados a empresas, a fim de incentivar suas instalações nas cidades, de modo a propiciar o aumento da oferta de emprego (inclusive para jovens e idosos).

Sobre o transporte, enfatizam a importância de incentivo à produção, comércio e exportação de automóveis, combustíveis e peças automobilísticas nacionais, além da construção de ciclovias, dentre outras medidas. E a respeito da violência, explicitam a valorização da vigilância, do controle e punição à criminalidade, fazendo alusões à aprovação da pena de morte ou prisão perpétua, bem como ao treinamento $e$ intervenção de policiais e à alteração no código penal, visando minimizar a corrupção $e$ a impunidade $e^{28}$

Por fim, os alunos apresentam uma proposta referente ao "Dia dos Adolescentes", com base na idéia de serem realizadas, uma vez por mês, festas e atividades culturais gratuitas voltadas para os jovens, priorizando-se a segurança local, bem como a confiança e a colaboração de pais e filhos ${ }^{29}$.

28 Enquanto alguns alunos endossavam rigorosas medidas de combate ao crime, outros as contestavam; as proposições acima foram debatidas pelo grupo e aprovadas em regime de votação.

${ }^{29}$ Em outro contexto, uma aluna enfatiza: "Tem que fazer alguma coisa pra gente se divertir, mas também, o mundo não é só diversão!" (Janaína - $4^{\circ}$ Encontro). 
Além disso, ao introduzir a discussão sobre alcances e limites da ação política dos jovens, os alunos ressaltam a necessidade de engajamento por parte da juventude, que deve se unir e lutar pelos seus direitos e pela melhoria do quadro social:

Janaína: ...E também que a gente não pode parar de lutar, senão, nunca vai mudar. (...) Tem que ficar lutando até conseguir!

Tamara: Igual diz aqui [na letra da música "Não é sério"]: "a juventude tem que estar a fim e tem que se unir" cada vez mais. E tentar mostrar pros adultos que a gente não é aborrecente; que a gente pode ser capaz de conseguir o que a gente quer, entendeu? Karina: E como faz pra se unir? Parece uma coisa tão longe, tão distante...

Tamara: Todo mundo tem que colocar um propósito no coração e dizer: "Pô, a gente tem que conseguir, nem que a gente tenha que fazer greve lá na Praça da Sé, mas...". Não, é verdade! Por que eles conseguem aumento? Porque vão lá na Praça da Sé! Janaína: A gente tem que começar a lutar pelos direitos!

( $4^{\circ}$ Encontro)

Ao fazer uma aproximação entre esse discurso e sua efetividade (referindo-se ao seu próprio poder de ação, bem como ao de seus pares), alguns adolescentes consideram-se impotentes em contribuir para a transformação do quadro social, além de alegar que a juventude, de modo geral, não poderia alterar a realidade, associando tal afirmação à idéia de que os jovens não possuem autoridade ou oportunidade de expressão; ou seja, vinculam essa impotência à imagem socialmente instituída sobre os jovens, bem como ao fato de não serem ouvidos, tal como ilustra o seguinte trecho:

Karina: Mas, então, o que vocês pensam que vocês, que estão sentados aqui hoje, poderiam fazer pra mudar alguma coisa?

João: Nós, nada!

Tamara: É! (...) Olha, não é por nada não, mas os jovens não têm poder de nada!l Não querendo tirar com a gente, não, mas a gente não tem poder de nada! Se os prefeitos não têm poder nem pra comandar a vida deles direito, imagine o mundo... (...) Como a gente vai tentar mudar se a gente não tem uma...

Evaristo: ...Autoridade!

Tamara: Uma oportunidade..., uma autoridade! Como a gente vai tentar mudar, se eles não dão nenhuma chance, porque quando a gente vai falar (...). [acham] que a gente é 
uma perturbação! É uma coisa que a gente não é, entendeu? Eles têm que pensar que eles já passaram por essa fase (...), só que a gente quer uma coisa melhor pra gente [e] pros outros...! Só que eles não dão chance, não dá oportunidade da gente falar! Então fica..., sinceramente... fica uma porcaria!

Sendo assim, partindo do pressuposto de que a juventude não teria o poder de propiciar uma transformação social, um aluno acrescenta a idéia de que os jovens seriam o "futuro da nação", alegando, entretanto, que apenas 'futuramente', quando se consagrassem como adultos, poderiam intervir na conjuntura vigente, tornando-se políticos, por exemplo: "A única esperança, de verdade, que eu tenho, é porque nós somos o futuro. Quando [Denis] ganhar a presidência, pode fazer alguma coisa pros nossos filhos, ou pelo menos pra próxima geração" (João - $4^{\circ}$ Encontro).

Ao longo do debate sobre esse tema, os alunos salientam que a juventude pode intervir e contribuir para a concretização de mudanças na sociedade, afirmando que os jovens devem se unir e se envolver em projetos coletivos, como na fundação de Organizações Não Governamentais (ONGs) e na elaboração de projetos voltados para os adolescentes. Além disso, partindo dessa questão, uma aluna alega que os jovens deveriam apresentar condutas e propostas distintas das vinculadas à imagem pejorativa que lhes é atribuída, de modo a suscitar o questionamento e a ruptura com relação a essa visão depreciativa socialmente difundida (que, inclusive, a própria aluna reitera):

Janaína: A gente poderia fazer [alguma coisa pra mudar]. Teria que ter mais força de vontade! 
João: E nos unir a outras pessoas. (...) Uma pessoa sozinha não [tem poder]. (...) pode ser jovem, velho, adolescente..., uma pessoa sozinha, não faz nada!

Janaína: Tipo, criar uma ONG. [João: Com projetos] ... pra ajudar o adolescente.

Cristina: Tem que ter bastante pessoas, pra ver se todas concordam com o projeto $e$ vai cada um fazendo sua parte.

( $4^{\circ}$ Encontro)

Janaína: Eu acho que a gente tem poder sim, mas tem que saber usar. Tem que usar com atos bons, sabe? Tem que fazer uma coisa que a pessoa fica assim: "Nossa, um adolescente fez isso?". É difícil, mas você tem que fazer isso, ai ele vai se tocar mais. Agora, os adolescentes fazem as mesmas coisas: é pichando escola, quebrando tudo. Eles têm que fazer, tipo assim, vê uma coisa quebrada, ia lá, unia uma turma: "Vê se nós consegue arrumar isso daqui". Aí todo mundo vai falar: "Nossa, um adolescente deu essa idéia?". Tem que ter umas idéias assim, diferente! (...) Invés das pessoas falar mal dos adolescentes, [deviam] falar bem, porque aí eles vão ficar sentidos... e vão começar a melhorar. (...) Porque se ficar falando mal, aí eles vão ficar fazendo só isso.

(Entrevista e $4^{\circ}$ Encontro)

O aspecto apontado acima, referente à necessidade de se elaborarem propostas e se efetivarem projetos ou políticas públicas voltadas para os adolescentes é explicitado no seguinte trecho em que também evidenciam seu poder de eleger um representante político, elucidando, portanto, uma forma de participação política dos jovens:

Tamara: ... Igual os políticos; eles só prometem coisas pros adultos e pra gente, nada. (...) Porque, sinceramente, não é por nada não, mas os adolescente tá esquecidos. Porque todo mundo... eles só tão lembrando dos adultos, prometendo, prometendo. (...) Eles acham que a maioria desses negócio de política aí, eles pensam que é só adulto que vota; mas não! Tem muita gente, assim, com dezesseis anos, que vota. E a maior parte é a gente que elege, mesmo. Então, acho que eles têm que participar e tentar... e não só ficar prometendo coisas pros adultos [mas] também pra gente. Porque a gente é humano! A gente não é animal!

( $4^{\circ}$ Encontro)

Finalmente, um último elemento a ser destacado consiste na valorização, por parte dos jovens, da divulgação desse documento $e$, portanto, da possibilidade de 
expressão e transmissão de suas idéias e proposições, vistas, inclusive, como propostas que deveriam ser acessadas e efetivadas por representantes políticos. A esse respeito, os alunos acrescentam:

Karina: Dos assuntos que a gente conversou, o que mais te interessou? Tamara: Ah, foi o projeto do PAN! (...) Porque você tava falando que vai levar pra USP e esse negócio de ir pra USP, pô! Sei lá... o Presidente podia ir lál Até o Prefeito podia ir lá na USP, dar uma olhada lá na biblioteca...; se ele folheasse e desse uma olhada no nosso projeto pra fazer alguma coisa...

(Entrevista)

João: O que tá escrito aí é o que o prefeito (...) devia fazer pela cidade (...). Eu vou mandar pro Lula esse documento! Vou tirar uma xérox e mandar pro Palocci, o ministro!

(Entrevista e $4^{\circ}$ Encontro)

Denis: O primeiro documento tem que ser bonito, pra ficar no museu de arte!

(Encontro Extra I) 


\section{CONSIDERAÇÕES SOBRE ADOLESCÊNCIA E ESCOLARIZAÇÃO À LUZ DE}

\section{UMA ABORDAGEM CRÍTICA EM PSICOLOGIA ESCOLAR}

Neste último capítulo, serão elucidados os aspectos centrais apontados no decorrer desta dissertação, estabelecendo-se uma articulação entre demais trabalhos realizados acerca do tema em questão e o material obtido nessa pesquisa, cujo objetivo consistiu em investigar a versão de jovens alunos de classes populares sobre a experiência escolar na adolescência. Desse modo, seguindo-se o percurso realizado ao longo desse trabalho, serão enfatizadas, a princípio, considerações relativas à adolescência como um fenômeno social e historicamente constituído e, então, destacados alguns pontos principais referentes à escolarização desses jovens alunos, analisados com base em uma perspectiva crítica em Psicologia Escolar.

Um primeiro elemento a ser reiterado consiste no fato de que, diante do levantamento bibliográfico sobre a adolescência no campo da Psicologia, evidencia-se o predomínio de uma concepção naturalizante acerca desse fenômeno, endossada por meio de formulações teóricas proferidas por psicólogos (dentre os quais destacam-se Stanley Hall, Aberastury e Knobel) cujas obras foram consolidadas como referência para o estudo sobre esse tema, de modo a exercer forte influência em produções subseqüentes, inclusive em textos publicados recentemente no Brasil. 
Com base em teorizações calcadas na universalização e patologização da adolescência, essa é considerada por tais autores uma fase naturalmente conflituosa e turbulenta, típica e inevitavelmente difícil, caracterizada por crises, desequilíbrios e instabilidades, atribuídos ao funcionamento psíquico dos adolescentes. Dentre as condutas apresentadas como distintivas desse período da vida, devem ser ressaltadas a irresponsabilidade, o "aborrecimento", o vandalismo e a rebeldia (também associados pelos autores a fatores intra-psíquicos), que merecem destaque por consistir em aspectos mencionados pelos participantes da pesquisa em questão.

Essa concepção hegemônica no campo da Psicologia é questionada por psicólogos que priorizam a constituição social e histórica da adolescência, compreendida como um fenômeno construído historicamente, criado e interpretado pelos homens, cuja significação varia ao longo da História e de acordo com a conjuntura social em vigor e com as relações, normas e valores que se configuram em determinado contexto social ${ }^{2}$. A necessidade de se superar a visão naturalizante acerca da adolescência e de se intensificarem estudos e produções no campo da Psicologia em que se enfatize sua dimensão social e histórica configura-se como um dos aspectos norteadores dessa dissertação.

Considerar a construção social e histórica da adolescência implica atentar para o fato de que esse fenômeno foi instituído pelo homem enquanto uma categoria social na modernidade, de modo a se situar seu "nascimento" no contexto de extensão do

\footnotetext{
${ }^{1}$ No sentido pejorativo do termo.

${ }^{2}$ Aguiar, Bock e Ozella (2001) e Ozella (2002, 2003).
} 
isolamento das crianças $e$ adolescentes na escola e na família ou, mais especificamente, no século XVIII, consolidando-se efetivamente a partir do século $X X^{3}$ - o que evidencia uma criação histórica recente, em oposição à sua naturalização. Deve-se ressaltar que essa consolidação da adolescência (ou, de forma mais ampla, da juventude) ${ }^{4}$ enquanto um grupo social foi intensificada por progressivas transformações da modernidade, tais como o prolongamento do período mínimo exigido para a formação escolar e o adiamento da inserção no mercado de trabalho. A dedicação ao estudo e a suspensão das obrigações trabalhistas tornaram-se aspectos centrais associados à condição juvenil ${ }^{5}$.

Enfatizar a constituição sócio-histórica da adolescência também envolve a consideração de que as representações, significações, atributos e papéis socialmente vinculados aos adolescentes apresentam variações em uma mesma sociedade ao longo da História, bem como entre distintas conjunturas ou contextos sociais. Diante disso, deve-se atentar, nessa pesquisa, para o modo como esses elementos se configuram na sociedade brasileira contemporânea.

Conforme foi explicitado no início desse trabalho, de acordo com Abramo (1997), a tematização social sobre os jovens ${ }^{6}$ a partir da década de 1990, no Brasil, é predominantemente marcada por referências à violência, associada à caracterização

\footnotetext{
${ }^{3}$ Ariès (1978).

${ }^{4}$ Relembrando que o conceito de juventude utilizado nesse trabalho compreende um conjunto etário mais amplo em que estão inseridos os adolescentes (com a juventude abrangendo a faixa entre 14 ou 15 a 24 anos, dentre a qual encontram-se, entre 14 e 19 anos, os adolescentes). ${ }^{5}$ Rama (1990) e Abramo (2005).

${ }^{6} \mathrm{O}$ modo como a juventude vem sendo socialmente tematizada reflete as representações que lhes são atribuídas no contexto social em que se insere.
} 
da juventude como portadora de "problemas de comportamento", com atitudes desviantes em relação ao ajuste ou à integração social ${ }^{7}$. Sendo assim, vistos como transgressores, delinqüientes, rebeldes, violentos ou vândalos, os jovens são freqüentemente associados à criminalidade, drogadição ou comportamentos antisociais. Tais estereótipos veiculados pela opinião pública, propagados pelos meios de comunicação e endossados por produções acadêmicas, estão presentes (com rupturas e repetições) no discurso dos participantes da pesquisa, como será elucidado posteriormente.

No texto intitulado "Condição juvenil no Brasil contemporâneo", Abramo contribui para a elucidação de tal questão, apresentando considerações que se acrescentam às apontadas até então. Com base em uma recente e ampla pesquisa realizada com jovens brasileiros ${ }^{8}$, a autora explicita "traços e sentidos da condição juvenil na conjuntura atual" referindo-se ao fato de que a vinculação à família de origem, o estudo, o trabalho e a diversão consistem em elementos significativamente presentes na vida dos jovens na atualidade, apresentando-se "variações na forma, grau

\footnotetext{
7 Abramo refere-se, então, à visão socialmente difundida sobre a juventude como um "problema social" ou "depositária do medo" referente à ameaça de ruptura com a ordem social vigente.

8 A pesquisa "Perfil da Juventude Brasileira", uma iniciativa do "Projeto Juventude/Instituto Cidadania" em parceria com o Instituto de Hospitalidade e o Sebrae, envolveu a realização de entrevistas (questionários) com 3.501 "jovens entre 15 e 24 anos, de ambos os sexos, representantes de todos os segmentos sociais, residentes em áreas urbanas e rurais de 198 municípios" brasileiros (p. 370); a pesquisa de campo foi realizada no final de 2003 e a análise do material obtido foi divulgada no livro Retratos da juventude brasileira: análises de uma pesquisa nacional - Abramo; Branco [orgs.] (2005). Alguns dentre os artigos que compõem esse livro serão citados ao longo deste capítulo em função de suas contribuições sobre o tema em questão.
} 
e qualidade com que são vividos, segundo as desigualdades de idade, gênero e classe" (2005, pp. 40;67).

De modo geral, a autora afirma que, de acordo com os dados de tal pesquisa, o tradicional modelo de transição para a vida adulta, que envolveria a saída do núcleo familiar de origem, casamento e filhos, não corresponde à realidade vivenciada pela maioria dos jovens nos dias de hoje ${ }^{9}$. A esse respeito, Abramo acrescenta que, dentre os elementos constitutivos da condição juvenil atual, encontram-se a vinculação à família de origem e início da atividade sexual dissociada da função reprodutiva ou do estabelecimento de laços conjugais; além disso, a inserção no mercado do trabalho (concretizada ou como aspiração) também se configura como um relevante fator na vida dos jovens, bem como o estudo e a diversão.

Ainda em relação à constituição social e histórica da adolescência, deve-se ressaltar a necessidade de não restringir esse conceito a uma categoria homogênea ou abstrata, mas atentar para as singularidades implicadas nas distintas adolescências, ou seja, nas diferentes formas de vivenciar a condição de adolescentes, com condutas e significações que apresentam variações de acordo com a classe social, a raça, o gênero e o contexto sócio-histórico em que os jovens estão inseridos ${ }^{10}$.

\footnotetext{
${ }^{9}$ Essa constatação ilustra a idéia proferida por Sposito (1997) referente à superação do modelo tradicional de transição pra a vida adulta - apontada no início dessa dissertação. Com relação a esse aspecto, Abramo explicita que tais fatores (saída da casa dos pais, casamento $e$ filhos) apresentam-se como uma exceção entre os adolescentes (considerados entre 15 e 17 anos), estando presentes entre os jovens na faixa etária mais avançada (entre 21 e 24), correspondendo à vivência de um quinto dos jovens no total.

$10 \mathrm{Tal}$ como Margulis e Urersti (1998), Groppo (2000) e Schmidt (2001) enfatizam ao se referir à pluralidade de juventudes, conforme foi apontado na introdução desse trabalho.
} 
Aguiar e Ozella (2006) $)^{11}$ contribuem para a explicitação desse aspecto ao enfatizar a necessidade de se compreender a adolescência a partir de sua contextualização "na realidade concreta (...) e não de um modo abstrato, universal, descolado das formas concretas de existências dos sujeitos". A esse respeito acrescentam:

Como uma primeira questão mais geral, destacamos a idéia de que não existe 'uma adolescência'. As diferentes classes, idades, culturas, gêneros, se configuram em elementos constitutivos de diferentes adolescências. Com isto, não estamos dizendo que não existam marcas que atravessem todos eles (adolescentes), não estamos negando as mudanças biológicas, as mudanças no desenvolvimento cognitivo, mudanças estas que, com certeza, geram novas necessidades e motivos nos sujeitos. No entanto, não podemos esquecer que (...) os adolescentes (como todos os seres humanos) vão constituindo suas necessidades nas relações com o mundo material/social e, da mesma forma, ou seja, nas relações sociais vividas, encontrarão os objetos possiveis de satisfação de tais necessidades (p. 2).

Com base em tal consideração, Aguiar e Ozella apresentam nesse texto uma análise dos dados obtidos em uma pesquisa realizada com adolescentes em São Paulo ${ }^{12}$, por meio da qual se visava, "a partir da fala dos adolescentes sobre o que é ser adolescente, apreender elementos constitutivos/determinantes desta vivência" (p. 1). Sendo assim, ao investigar a concepção sobre adolescência e o significado da passagem para a vida adulta, esses autores enfatizam as singularidades e os

\footnotetext{
${ }^{11}$ Manuscrito submetido à publicação em abril de 2006.

12 Segundo os autores, "essa pesquisa foi realizada entre os anos de 2000 e 2003, dentro de um projeto de Iniciação Científica e contou com a participação de alunos da Faculdade de Psicologia da PUCSP", envolvendo a análise de entrevistas (questionários) com "856 adolescentes dos gêneros masculino e feminino, com idade entre 14 e 20 anos, pertencentes às classes sociais de $A$ a $D$ e de três grupos étnicos: brancos negros e orientais, distribuídos segundo sua representatividade no município de São Paulo" (pp. 1-2).
} 
elementos em comum presentes no discurso dos adolescentes, atentando para as variações relativas a cada dimensão: classe social, gênero, raça e idade. Nesse sentido, ressaltam a idéia de que se constituem diferentes necessidades e significados associados a essas distintas vivências em cada segmento:

Destacando a determinação de gênero, os nossos adolescentes nos mostraram que a vivência neste aspecto é extremamente diferenciadora, revelando diferentes necessidades, motivos e formas de satisfazê-los e, conseqüentemente, diferentes significados. No entanto, a trama que constitui os significados é extremamente complexa, pois, mesmo avaliando o peso do gênero, não podemos esquecer as determinações de classe, cultura [etnia] e idade, todas elas sendo constitutivas dos significados produzidos (p. 25).

Com relação a esse aspecto, é importante esclarecer que atentar para a 'pluralidade de adolescências' não implica negar ou ignorar os elementos constitutivos desse fenômeno. Ou seja, conforme foi explicitado até então, a adolescência foi historicamente constituída enquanto uma categoria social, atravessada por representações, condutas e valores socialmente atribuídos, que variam ao longo da História e do contexto social em que se inserem. Nesse sentido, deve-se ressaltar a positividade da adolescência, compreendida como um momento da vida, social $e$ historicamente interpretado, a que são associados condutas e significações próprias, que configuram a condição de adolescente (ou a condição juvenil) em determinada conjuntura social $e$, que, portanto, não coincidem com o que se institui socialmente sobre a infância ou a vida adulta. 
Inclusive, enfatizar sua positividade envolve atentar para a singularidade da adolescência, priorizando os elementos que compõem essa condição, sem restringi-la a uma etapa de transição entre a infância e o mundo adulto, cujas características seriam intermediárias entre uma fase e outra da vida e, portanto, descrita a partir do que lhe falta (ou seja, com referências ao que se deixou de ser ou ao que será) e não do que lhe é próprio, ou como um processo inacabado, cuja finalização realizar-se-ia na vida adulta - a etapa pretensamente madura, lapidada ${ }^{13}$.

Esse aspecto também é apontado por Abramo (2005), ao salientar "a importância de examinar as condições da vivência juvenil e não apenas os modos da passagem para a vida adulta", isto é, "os processos que marcam a juventude como singularidade, abrindo para os jovens dificuldades e possibilidades específicas e não somente o modo pelo qual os jovens deixam de ser jovens" (p. 45).

Desse modo, deve-se ressaltar que a adolescência se constitui como um fenômeno singular, porém não deve ser reduzida a uma categoria homogênea ou abstrata, já que as significações e condutas que lhes são socialmente atribuídas, bem como a apropriação das mesmas, apresentam variações de acordo com a cultura, a classe social, a raça, o gênero e a idade, configurando-se distintas formas de se vivenciar a condição de adolescentes.

${ }^{13}$ Como vimos no capítulo sobre "Adolescência e Psicologia", essa idéia da adolescência como uma fase de transição que deve ser atravessada para que se atinja a "maturidade estabilizada" do mundo adulto é apresentada por psicólogos como Knobel (1981), Aguirre (1953) e Bossa (1998). 
Diante disso, é importante explicitar que os participantes dessa pesquisa são adolescentes de classes populares, moças e rapazes entre 14 e 16 anos, negros e brancos, estudantes de uma escola pública na capital de São Paulo ${ }^{14}$.

Antes de fazer alusão aos elementos presentes no discurso desses jovens alunos, devem ser destacados dois aspectos relativos ao estudo sobre adolescência e escolarização. $O$ primeiro consiste na necessidade de se intensificar e aprofundar 0 estudo acerca desse tema no campo da Psicologia Escolar (priorizando-se uma abordagem crítica nessa área), em que predominam pesquisas referentes ao processo educacional de crianças e não de adolescentes.

O segundo corresponde à relevância de se explicitar essa condição de adolescentes (ou, de forma mais ampla, a condição juvenil), sem fazer referências à categoria de "alunos", de modo abstrato, em pesquisas que venham a se dedicar ao processo escolar no Ciclo II do Ensino Fundamental (ou no Ensino Médio). Esse aspecto também é enfatizado por Dayrell (2002), diante de um amplo levantamento sobre a produção acadêmica discente no programa de pós-graduação (dissertações e teses defendidas entre os anos de 1980 e 1998) sobre o tema da juventude no campo da Educação $0^{15}$.

\footnotetext{
${ }^{14}$ Deve-se ressaltar que as dimensões relativas à condição de estudantes, brasileiros e de classes populares foram as mais enfatizadas ao longo dessa pesquisa. As especificidades referentes ao gênero e à raça comparecem em momentos pontuais, quando se faz alusão aos trechos do discurso dos alunos em que esses discutem esses temas (sobre distinções entre moças e rapazes ou sobre o preconceito racial). Uma análise em que são priorizadas essas singularidades é realizada por Aguiar e Ozella (2006).

${ }^{15}$ Essa pesquisa foi divulgada no trabalho intitulado Juventude e escolarização (1980-1998), coordenado por Marilia Sposito (2002)
} 
Ao analisar, especificamente, os trabalhos referentes à temática "juventude e escola", Dayrell evidencia a escassez de pesquisas que se voltam para a condição juvenil dos alunos, ou seja, para uma visão sobre o jovem que não se restrinja à condição de aluno de forma homogênea ou abstrata, sem atentar para as especificidades e diversidades que compõem a experiência juvenil em suas relações com o processo de escolarização. Nesse sentido, o autor enfatiza a necessidade de se priorizar a consideração dos alunos como jovens reais, "incorporando características e demandas específicas de uma determinada idade da vida construída socialmente", incluindo as dimensões relativas à idade, gênero, etnia e origem social, que constituem experiências distintas (pp. 75, 84):

O jovem tem sido pouco tematizado pela pesquisa educacional que incide sobre a instituição escolar. (...) A grande maioria delas [pesquisas] tem como foco a reflexão sobre a instituição escolar, [em que] o jovem aparece, na sua condição de aluno (...), mas pouco nos dizem sobre os sujeitos reais que a freqüentam cotidianamente. (...) [Em muitos trabalhos] os jovens reais, subsumidos no papel de aluno, não se constituem objetos de investigação por parte dos pesquisadores. Evidencia-se aí um paradoxo: a razão de ser da escola é o aluno, e é exatamente esse ator o menos conhecido.

(...) Ainda é preciso avançar na compreensão da juventude e das suas relações com a escola, (...) [com] estudos que reflitam, por exemplo, sobre os tempos vividos pelos educandos na especificidade da sua idade, de sua condição humana, de gênero, de sua cultura e sociabilidades (...); que apreendam de modo denso as formas diversas que constroem a experiência juvenil contemporânea, no Brasil, em sua relação com a escola (Dayrell, 2002, pp. 81, 84-5).

A esse respeito, Sposito (2002) acrescenta a idéia de, que embora haja um significativo volume de pesquisas relativas à juventude no campo da Educação, "ainda 
há um desconhecimento sobre a condição juvenil da sociedade brasileira, marcada por recortes intensos nas desigualdades sociais, culturais e étnicas que oferecem para pesquisa a realidade plural da juventude" (p. 22).

Percebe-se, portanto, a necessidade de se aprofundar o estudo sobre juventude ou adolescência e escolarização, sem que haja abstração com relação à condição de alunos ou, conforme apontado anteriormente, à de adolescentes, que devem ser contextualizados na realidade concreta em que estão inseridos, atentando para as singularidades e pluralidade de vivências e significações implicadas em ambos os fenômenos a que se referem - adolescência e escolarização.

Sendo assim, na pesquisa em questão, enfatiza-se a idéia de que os participantes não são alunos abstratos, nem adolescentes abstraídos, mas sujeitos que vivenciam convergências, diversidades e especificidades envolvidas na condição de alunos adolescentes.

Diante de tais considerações, deve-se ressaltar o fato de esses jovens alunos expressaram, ao longo dos encontros em grupo e entrevistas individuais, relevantes aspectos referentes à experiência escolar na adolescência, cujos temas principais serão apontados a seguir.

Inicialmente, é importante destacar que um elemento central presente em diversos momentos do discurso desses alunos consiste na explicitação de rupturas $e$ repetições relativas à imagem pejorativa socialmente difundida acerca dos adolescentes. Ao se referir à visão que os adultos (ou a sociedade em geral) 
apresentam sobre os jovens, esses fazem alusão à idéia de que são vistos, predominantemente, como imaturos, irresponsáveis, vagabundos, vândalos, revoltados e 'aborrecentes' (ou seja, "aborrecidos com tudo" e que "aborrecem [a] todos"), além de marginais ou usuários de drogas. Em relação a esses dois últimos aspectos, os jovens ilustraram situações em que foram alvo de preconceitos referentes a sua classe social associados à condição de adolescentes, evidenciando o fato de que tais estereótipos vinculados à adolescência são intensificados ao se reportar a jovens de classes populares ${ }^{16}$

Conforme foi evidenciado anteriormente, esses atributos compõem a imagem socialmente instituída sobre os adolescentes, proferida pela opinião pública $e$ endossada por formulações teóricas, tendo-se a Psicologia como forte aliada nesse processo, por meio das quais são reiterados estereótipos atribuídos aos adolescentes, relativos à violência, criminalidade, drogadição, displicência, ociosidade, imaturidade e rebeldia.

Ao longo de seu discurso, os adolescentes enfatizam a necessidade de se romper com essa imagem estereotipada, questionando-a e ressaltando a relevância de

\footnotetext{
${ }^{16} \mathrm{O}$ fato de se intensificar a atribuição de rótulos referentes à violência e à marginalidade aos adolescentes pobres é enfatizado por Sposito (1996), segundo a qual: "...tendemos a caminhar para um terrível processo de estigmatização, quando a esses atributos [a alienação e o consumismo] acrescentamos, ao se tratar de jovens pobres, a qualificação de violentos $e$ marginais. De um lado, associamos violência, marginalidade, à pobreza, como se esses termos exprimissem uma relação linear de causa e efeito (...); de outro, não buscamos compreender, quando a violência e a marginalidade se fazem presentes, os seus significados para um enorme contingente da população a quem se retirou o direito de projetar o futuro, apresentando somente o não-emprego, o não-salário, a ausência de direitos e de espaços de convivência cultural como alternativas de vida" (p.100 - grifos nossos).
} 
se priorizar e divulgar um outro olhar sobre os jovens, atentando-se, inclusive, para suas virtudes em oposição a tal visão estritamente depreciativa. Nesse sentido, ao redigir um documento como meio de expressão, visando transmitir um 'recado para a sociedade', elucidam o desejo de demonstrar que não são "aborrecentes" e salientam o fato de que apresentam muitas idéias em mente, além de responsabilidade, tanto no sentido de comprometimento quanto no de compromissos ou obrigações $e$ conscientização política (em oposição à consideração de que os jovens seriam alienados $\left.{ }^{17}\right)$.

Quanto a esse aspecto, percebe-se que, embora esses jovens façam referências aos adolescentes de modo geral (reportando-se tanto a si mesmos quanto a seus pares), em alguns trechos nos quais questionam essa imagem que lhes é socialmente atribuída, a ruptura com relação a tal visão está predominantemente presente nos momentos em que fazem alusão a si mesmos. Porém, em diversas ocasiões nas quais explicitam a imagem que esses próprios jovens apresentam acerca de seus pares, reproduzem o discurso até então criticado, de modo a reiterar tais estereótipos, considerando que a maioria dos adolescentes são vândalos, vagabundos e displicentes ${ }^{18}$.

\footnotetext{
${ }^{17}$ A idéia de que os jovens são vistos como alienados também é elucidada por Venturi e Bokany (2005), ao se referir à imagem socialmente difundida sobre "os jovens brasileiros deste início de século", tidos como "despolitizados" - além de "conservadores, comportamentalmente caretas e politicamente passivos" (p. 351).

${ }^{18}$ A dissociação entre a imagem que os adolescentes apresentam acerca de si mesmos e a referente a seus pares também é enfatizada por Salles (1995;1998). Partindo da concepção de representação social, com Moscovici como um dos autores de referência, a autora realiza uma pesquisa com alunos adolescentes e outros participantes do contexto escolar, buscando
} 
A esse respeito, deve-se destacar que, ao reproduzir tal visão estigmatizada, vinculando-a aos demais jovens alunos, afirmam que muitos, dentre esses, "ficam só fazendo 'vandalisse'" na escola $e$, de acordo com um adolescente, alguns dos estudantes que vão à escola "só pra zoar" seriam "futuros mendigos ou traficantes".

Por fim, deve-se ressaltar que, de acordo com esses jovens, a visão pejorativa que lhes é socialmente instituída também é reproduzida por professores. A esse respeito, acrescentam a idéia de que, diante de tal imagem acerca dos alunos adolescentes tidos como violentos, vândalos ou marginais, alguns educadores demonstram sentir medo, com receio de serem agredidos ou violentados.

Essa questão referente a rupturas e repetições, presentes no discurso dos adolescentes, relativas à imagem que lhes é socialmente atribuída também é explicitada por Aguiar e Ozella (2006). Ao analisar o material obtido por meio de uma pesquisa realizada com adolescentes", esses autores afirmam que "uma das características mais marcantes em todos os adolescentes, de todas as classes, dos dois sexos, de todas as faixas etárias e das [três] raças, é a reprodução de concepções socialmente instituídas sobre o que vem a ser adolescência" (p. 6).

Os autores orientam essa discussão no sentido de explicitar a idéia de que os adolescentes reproduzem a concepção a-histórica, reiterada por teorizações

\footnotetext{
"entender como os diversos componentes da representação social do adolescente e da adolescência se articulavam em torno de uma estrutura central" (1995, p. 27). Em sua pesquisa, a autora constata que "ao falar de si mesmos, os adolescentes descrevem as angústias que sentem, as dificuldades que vivem, as preocupações com o futuro, mostrando-se, sob esse ângulo, pouco enquadrados na representação social que eles mesmos elaboram do adolescente $e$ da adolescência genericamente" (1998, p. 152).

${ }^{19}$ Essa pesquisa já foi mencionada anteriormente, neste mesmo capítulo.
} 
realizadas no campo da Psicologia ${ }^{20}$, acerca da adolescência, tida como uma fase naturalmente marcada por crises, turbulências, conflitos, ambigüidade e rebeldia. Sendo assim, evidenciam que "os próprios adolescentes se vêem segundo essa perspectiva, se apropriam da idéia socialmente construída do que é ser adolescente, numa demonstração da eficácia ideológica de tal conceito, que é assumido pelo jovem como expressão de sua autêntica forma de $\operatorname{ser}^{\prime \prime}$ (p. 6). Por fim, a esse respeito, acrescentam que, embora a maioria dos jovens apresente semelhanças "no que se refere às concepções naturalizantes de adolescente, percebem-se algumas diferenças em relação a algumas marcas que costumeiramente caracterizam a adolescência como uso de drogas, conflitos e crises, rebeldia etc" (p. 7).

Além das considerações apresentadas até então acerca de tais rupturas e repetições, deve-se ressaltar que outro elemento central, intensamente enfatizado pelos jovens alunos na pesquisa que realizamos, consiste na necessidade e relevância de serem ouvidos.

Em relação a esse aspecto, explicitam o descrédito atribuído às afirmações e opiniões proferidas aos adolescentes, associando-o a essa visão pejorativa que lhes é socialmente conferida. Ou seja, afirmam que, com base em tais estereótipos, os jovens não são levados a sério e suas opiniões são menosprezadas ou desconsideradas (vistas como "coisa besta, que não tem nenhum valor"), de modo a não se ouvir o que têm a dizer.

\footnotetext{
${ }^{20}$ Que também foram referidas ao longo dessa dissertação, bem como nesse capítulo.
} 
Essa articulação entre a imagem estereotipada e a não-escuta referente à fala dos jovens é elucida por Sposito (1996) e Abramo (1997). Segundo Sposito:

O estereótipo (...), aliado íntimo do preconceito (...), não permite que interroguemos o sujeito - nesse caso o aluno jovem - ao qual atribuímos determinadas características a priori e negamos o direito de fala, isto é, nos negamos a escutar o que ele teria a nos dizer sobre si mesmo. Mais ainda, a heteronomia anula qualquer processo de autonomia, pois acabamos por considerar que o jovem é incapaz de produzir orientações a partir de si mesmo, e que as definições que Ihes são imputadas exteriormente são as suas próprias definições (1996, p.99).

Sobre esse aspecto, Abramo acrescenta:

Como encarnação de todos os dilemas e dificuldades com que a sociedade ela mesma tem se enfrentado (...), [os jovens] nunca podem ser vistos, ouvidos e entendidos, como sujeitos que apresentam suas próprias questões, para além dos medos e esperanças dos outros. Permanecem, assim, na verdade, semi-invisiveis, apesar da sempre crescente visibilidade que a juventude tem alcançado na nossa sociedade, principalmente no interior dos meios de comunicação (1997, p. 32).

Os jovens alunos também evidenciam a importância de propiciar sua expressão no contexto escolar, valorizando, inclusive, a realização dos encontros em grupo como uma rara oportunidade de expor suas idéias ${ }^{21}$. Nesse sentido, referem-se à necessidade de serem instituídos na escola espaços de discussão em que possam

\footnotetext{
${ }^{21}$ Deve-se ressaltar que (conforme foi apontado no capítulo sobre o "método") a realização dos encontros em grupo propiciou a discussão abrangendo convergências e divergências entre os alunos, com o aprofundamento de suas argumentações, bem como o surgimento de idéias elaboradas coletivamente (com a redação do documento referente ao "Partido dos Adolescentes da Nação"), evidenciando-se a relevância e pertinência da utilização de tal procedimento como meio de propiciar a expressão dos participantes sobre o tema da pesquisa.
} 
expressar suas opiniões, debater, refletir e se informar sobre temas como a experiência escolar, adolescência, sexualidade, política, drogas e violência.

Ao fazer alusão ao fato de que não são ouvidos no ambiente escolar, esses alunos também enfatizam a relevância de se efetivar a comunicação entre os participantes do contexto educacional e, particularmente, de se estabelecer o diálogo entre professores e alunos, a fim de que esses possam elucidar sua visão sobre os aspectos implicados no processo de escolarização (abordando questões relativas ao dia-a-dia escolar, incluindo elementos referentes à relação professor-aluno, bem como a suas considerações sobre a qualidade do ensino).

Percebe-se, portanto, que esses adolescentes reiteram a importância de se atentar para a versão dos alunos sobre o processo de escolarização e propiciar a "circulação da palavra" no ambiente escolar, favorecendo a comunicação entre seus participantes, bem como a expressão dos "discursos reprimidos" nesse contexto, tal como enfatizam autores que privilegiam uma abordagem crítica em Psicologia Escolar $^{22}$.

Sendo assim, esses jovens refletem uma articulação entre o fato de não serem ouvidos enquanto alunos (pelos demais participantes do contexto escolar) e enquanto adolescentes (pelos membros da sociedade em geral), consagrando-se, então, a nãoescuta como um elemento que configura ou atravessa a condição desses alunos adolescentes.

22 Conforme foi apontado na introdução desse trabalho, com referências a Souza (2000), Freller (1997), Souza e Machado (1997) e Souza e Checchia (2003). 
Diante da elucidação de tais questões, serão destacados, a partir de então, alguns temas centrais abordados pelos jovens alunos ao longo da pesquisa de campo.

A respeito da condição de alunos adolescentes, revelam que a adolescência envolve descobertas e diversão, mas também desafios, amadurecimento, dependência (em relação aos pais) e responsabilidade (no sentido de compromissos ou obrigações). A esse respeito, explicitam que suas responsabilidades são distintas das dos adultos, pois enquanto seus compromissos consistem em estudar, apresentar bom desempenho na escola e ajudar nos serviços domésticos, os adultos devem trabalhar para garantir sua sobrevivência e/ou de sua família. Nesse sentido, referem-se à obrigação de "sustentar a casd" como um elemento que marca a saída da adolescência e entrada na vida adulta ${ }^{23}$.

Esses adolescentes evidenciam que o trabalho também está presente em suas vidas $^{24}$, considerando uma de suas maiores preocupações a obtenção de um emprego a fim de auxiliar o pagamento das despesas da família, cuja necessidade se intensifica

\footnotetext{
${ }^{23}$ Essa idéia também é apontada pelos participantes da pesquisa cujos dados foram analisados por Aguiar e Ozella (2006). De acordo com esses autores, ao se referir à passagem para a vida adulta, os adolescentes "das classes $D$ e $E$, [de gênero] masculino, de todas as idades $e$ predominantemente negros" fazem alusão ao aumento de cobranças e "à preocupação com o sustento da família" e as adolescentes "de classe $D$ e $E$, brancas e negras" desse grupo mencionam, dentre outros aspectos, a dupla jornada de trabalho da mulher adulta que tem a tarefa de oferecer "melhores condições para [seus] filhos" (pp. 12-3;16). A esse respeito, Aguiar e Ozella acrescentam: "Interessante observar que todos os adolescentes (classes, etnias, idades) tratam a idéia de entrada na vida adulta como algo natural, que inevitavelmente é assim, por conta de características dos próprios adolescentes e da sociedade, entendidos de uma forma a-histórica e natural" (p.16).

${ }^{24}$ A metade dos participantes estava trabalhando ou já havia trabalhado. Esse fato também é apontado por Abramo (2005) que, ao analisar os dados da pesquisa "Perfil da Juventude Brasileira" (referida anteriormente), constata que "o trabalho, como atividade ou como aspiração, é uma realidade para metade deste grupo etário" (ou seja, dos adolescentes).
} 
diante da situação de pertencerem às classes populares. $E$, ao se referir à experiência de conciliar o trabalho ao estudo, os jovens alunos ressaltam as vantagens de se trabalhar e alegam que uma atividade não prejudicaria a outra, porém, revelam em seu discurso o desgaste envolvido nesse processo ${ }^{25}$.

Além disso, reportam-se à vivência da adolescência como uma fase de transição entre a infância e a vida adulta ${ }^{26}$ (queixando-se do fato de serem tratados ora como crianças, ora como adultos), bem como às distinções relativas a costumes, padrões, valores e papéis socialmente difundidos entre as diferentes gerações (com referências à educação menos opressora e maior liberdade sexual na sociedade atual, embora evidenciem a falta de diálogo sobre a sexualidade nas esferas pública e privada) e entre moças e rapazes.

Com relação a esse último aspecto, os jovens também apontam rupturas $e$ reproduções acerca de estereótipos vinculados ao gênero: enquanto alguns (de ambos os sexos) consideram as adolescentes sensíveis, puras, frágeis e passíveis de se iludir e se apaixonar com maior facilidade, outros questionam essa imagem; inclusive, algumas adolescentes criticam a atribuição da função do trabalho doméstico às moças, assim como os rótulos que lhes são instituídos relativos à expressão da sexualidade ${ }^{27}$.

\footnotetext{
${ }^{25}$ A complexidade presente na relação entre o trabalho e a escolarização é apresentada por Paparelli (2001). Sposito também faz alusão a esse tema ao analisar a pesquisa "Perfil da Juventude Brasileira" (2005).

${ }^{26}$ Aspecto mencionado anteriormente nesse capítulo.

${ }^{27}$ As significações e vivências relativas ao gênero na adolescência são evidenciadas por Aguiar e Ozella (2006).
} 
Os jovens enfatizam quer ser aluno adolescente envolve a vivência de momentos de diversão no contexto escolar (referentes ao relacionamento com seus pares $^{28}$ ), mas também de cobranças e desgaste. $E$, ao fazer comparações entre a experiência escolar na adolescência e na infância ou vida adulta, valorizam as duas últimas, idealizando-as. Consideram que na infância o processo de escolarização é, via de regra, essencialmente prazeroso e lúdico, de modo a se estabelecer uma harmoniosa relação entre professor $e$ aluno, atravessada pelo carinho, respeito $e$ atenção; e que as crianças são ingênuas, inocentes e serenas, aprendendo a ser indisciplinadas, maliciosas e maldosas na adolescência - explicitando, inclusive, um caráter moralista em suas proposições.

A idéia de que a escolarização na infância é geral ou prioritariamente marcada por tais elementos deve ser questionada, tendo-se em vista a ampla gama de pesquisas realizadas no campo da Psicologia Escolar, dentre as quais devem ser destacados os trabalhos de Patto (1996) e Cruz (1987), que ilustram claramente a dimensão de sofrimento, desrespeito, humilhação e agressões vivenciadas por crianças de classes populares no processo escolar em instituições públicas de ensino fundamental.

Por fim, ao se referir às expectativas para o futuro, os alunos fazem alusão à perspectiva de estudar em faculdades particulares (e conciliar o trabalho ao estudo a fim de viabilizar seu pagamento), bem como ingressar em cursos técnicos ou profissionalizantes, em busca de um futuro emprego. Remetem-se aos obstáculos

\footnotetext{
${ }^{28}$ Aspecto a ser apontado quando forem mencionados demais elementos relativos à vivência do dia-a-dia escolar.
} 
implicados no acesso ao ensino superior, tanto a universidades públicas (diante do excludente processo seletivo), quanto a particulares (em função da não concretização da obtenção de um emprego que possibilite o pagamento das altas taxas de mensalidade). Sendo assim, evidenciam o caráter dual da educação brasileira, em que, desde o Ensino Básico, apresentam-se distinções entre a qualidade do ensino destinado a pobres e ricos (que têm acesso, inclusive, a satisfatórios cursos complementares para sua formação) e, então, a dimensão de exclusão que se configura em todo o processo de escolarização nas classes populares ${ }^{29}$.

De modo geral, ao se referir à relação com os demais participantes do contexto escolar, os adolescentes explicitam a valorização do diálogo, apoio, escuta, carinho e respeito, presentes no relacionamento entre poucos participantes no ambiente escolar, atravessado, fundamentalmente, pelo desrespeito.

${ }^{29}$ Com relação a essa dualidade no ensino, Patto (1997) acrescenta que "ao contrário do que afirma a ideologia liberal, o Estado, nas sociedades capitalistas - e isso é mais óbvio nas sociedades capitalistas do Terceiro Mundo - não está a serviço de todos os cidadãos, mesmo porque os interesses de dominantes e dominados são inconciliáveis. Num país como o Brasil, é cada vez mais evidente que o Estado serve aos interesses do capital e investe em educação somente na medida exigida por esses interesses. (...) A democratização do ensino ainda é utopia, não só porque o sucesso e a permanência delas [crianças de classes populares] na escola são dificultados ou impedidos por práticas e processos institucionais que oprimem e excluem, mas também porque a escola democrática só será possível numa sociedade verdadeiramente democrática" (pp. 289:439).

Além disso, ao se referir à criação de cursos profissionalizantes destinados a classes populares, Patto (1996), afirma que "esse tipo de escola secundária consagra o dualismo educacional. (...) Tudo se passa, tanto no âmbito do discurso educacional como no da legislação, como se as faculdades e aptidões das classes trabalhadoras fossem inferiores e como se seus integrantes tivessem como vocação o trabalho braçal. (...) É como se houvesse uma adolescência apta a pensar e a exercer as profissões mais valorizadas socialmente - a que pertence às classes dominante $e$ intermediária - e outra a agir e a exercer profissões manuais - a que pertencem às classes dominadas" (p. 103). 
Deve-se destacar que, ao descrever os atributos dos considerados "bons professores", além de apontar a autoridade (em oposição ao autoritarismo), didática e o investimento no processo de ensino-aprendizagem (com empenho na transmissão e na assimilação do conteúdo ministrado), ressaltam a idéia de que esses entendem os adolescentes e acreditam em seu potencial ${ }^{30}$. De fato, os aspectos referidos até então estão presentes no discurso dos educadores (professores e coordenadora) valorizados por esses alunos.

Por outro lado, ao criticar a postura apresentada pelos tidos como "maus professores", apresentam uma descrição oposta à anterior, com o estabelecimento de uma relação truncada, marcada por uma visão estereotipada acerca dos jovens alunos $^{31}$, fazendo alusão, inclusive, ao medo e à ameaça que atravessam essa relação, calcada na imagem socialmente difundida sobre os adolescentes, vistos como vândalos ou marginais.

A respeito das considerações e sentimentos relativos ao dia-a-dia escolar, os jovens evidenciam a valorização do vínculo estabelecido entre seus pares no contexto escolar e, ao descrever o dia-a-dia na escola, também fazem alusão à bagunça e discussões presentes nesse ambiente. A produção da bagunça ou da indisciplina é atribuída, pelos adolescentes, ora aos alunos ("que ficam só fazendo

30 Ao investigar as "representações" apresentadas por alunos da terceira série do Ensino Médio acerca do "bom professor", Camargo (2000) destaca, dentre outros aspectos, a consideração de que "o bom professor é aquele que ensina e se relaciona bem com os alunos".

31 A visão depreciativa sobre os adolescentes está presente no discurso dos professores criticados por aqueles. 
vandalisse"), ora aos professores (em função da falta de autoridade em sala de aula) ou a ambos (diante do desrespeito mútuo entre eles). No entanto, os jovens também apontam aspectos institucionais implicados nessa produção, por exemplo, a ausência de atividades recreativas (esporte e lazer) na escola como um meio de expressão $e$ extravasamento da energia represada durante as aulas expositivas. $E$, em relação às discussões, destacam xingamentos proferidos por professores, associados à questão da sexualidade ou a estereótipos instituídos sobre os adolescentes.

Nesse contexto, expressam sentimentos de vergonha e humilhação, referindose a situações em que professores e alunos (inclusive entre si mesmos) são sujeitos e alvos de agressões, ridicularizações e preconceito relativos à aparência física ou à raça, bem como de indignação diante de julgamentos ou punições impertinentes ou da postura autoritária e distante por parte dos participantes da escola. Além disso, fazem alusão à relação entre amigos e parceiros (ou seja, aos laços de amizade e relacionamentos amorosos) como única fonte de alegria no ambiente escolar ${ }^{32}$.

Ao apresentar críticas e propostas referentes à educação escolar, ilustram aspectos institucionais que configuram um contexto adverso à qualidade do ensino em escolas públicas, tais como a concentração de um grande número de alunos por sala, a falta de investimento na infra-estrutura da escola e em atividades voltadas ao lazer, além de mudanças de professores ao longo do ano letivo.

\footnotetext{
32 Experiências de discriminação, humilhação e desrespeito no contexto escolar também são apontados pelos jovens alunos participantes da pesquisa "Perfil da juventude Brasileira", conforme Sposito (2005) evidencia.
} 
É importante destacar que esses elementos refletem o descaso do Estado em destinar verbas para a remuneração e contratação de professores (e demais funcionários), para a construção de um maior número de escolas ou de salas de aula em cada unidade escolar, ou, de modo mais amplo, para a efetivação de um ensino de qualidade para alunos de classes populares ${ }^{33}$.

Em distintos momentos de seu discurso, os adolescentes responsabilizam, principalmente, alunos e professores (além dos demais participantes do contexto escolar) pela má qualidade do ensino, evidenciando, inclusive, a idéia de que a efetivação do ensino e da aprendizagem depende da motivação ou do esforço pessoal dos educadores e estudantes, alegando que "o aluno que quer, aprende" e que "os alunos deveriam se esforçar pra aprender e os professores se esforçar pra ensinar". Ao culpabilizar os alunos pela produção do fracasso escolar, esses adolescentes estabelecem uma relação de causa e efeito entre reprovação escolar e aprendizagem, associando essa última ao coeficiente mental (não tem QI alto), ao comportamento (bagunça) ou à falta de interesse (e de atenção) atribuídos aos alunos.

\footnotetext{
${ }^{33}$ Nesse sentido, Patto (1997) refere-se à idéia de "uma escola pública destruída pelo desinteresse secular do Estado brasileiro em oferecer de fato um ensino de qualidade às classes subalternas". E acrescenta que "a produção do fracasso escolar está assentada, em grande medida, na insuficiência de verbas destinadas à educação escolar pública e sua malversação (...). Falta de dinheiro significa educadores mal pagos e aí tem início uma cadeia de fatos cujo resultado último é a má qualidade do ensino oferecido." Nessa cadeia, estão incluídos: a necessidade de se intensificar e ampliar a jornada de trabalho, a desvalorização desses educadores, a falta de tempo para dedicação à leitura e estudo, "condições materiais de trabalho em geral precárias - prédios em más condições físicas, falta de material didático e de consumo, falta de funcionários, períodos escolares muito curtos etc", dentre tantos outros fatores (pp. 289-90;464).
} 
Percebe-se, portanto, a influência de uma dentre as tradicionais explicações 'científicas' sobre a produção do fracasso escolar no discurso desses adolescentes. Em meio à densa elucidação e contextualização histórica referente a tais teorizações, realizada por Patto (1996), deve-se destacar apenas que, de acordo com a autora, a partir da década de 1920, foi difundida no Brasil a concepção de que o fracasso escolar seria decorrente da falta de talento, dom ou "aptidão natural" de alunos de classes populares tidos como "anormais", a quem eram atribuídos baixos índices de coeficiente de inteligência. Tal concepção baseia-se nos pressupostos da Escola Nova calcados no ideário liberal por meio do qual se preconiza a pretensa igualdade de oportunidades e a valorização do mérito ou esforço pessoa $\beta^{34}$ - aliados aos da Psicologia Diferencial, cuja função principal consistia em diagnosticar os mais "aptos" ou os "anormais" por meio dos testes psicométricos de inteligência (pp. 20-1;40$3 ; 54 ; 62-3 ; 86-7)^{35}$

Um relevante aspecto a ser ressaltado a esse respeito consiste no fato de que a culpabilização do jovem aluno pelo fracasso escolar envolve a articulação entre as

34 O caráter ideológico implicado na valorização do esforço pessoal no contexto educacional também é apontado por Bock (2000).

${ }^{35}$ Além dessa teorização, Patto (1996) explicita as explicações que reiteram a culpabilização de alunos de classes populares pelo fracasso escolar, referindo-se à atribuição desse último a: "problemas de ajustamento", complicações ou desvios afetivo-emocionais vinculados ao ambiente familiar, considerado "desajustado" ou 'desestruturado', desses alunos tidos como "crianças-problema" (concepção embasada na teoria ambientalista, calcada em pressupostos psicanalíticos, difundida no Brasil a partir da década de 1930); ou a deficiências no desenvolvimento decorrentes da "carência cultural" a que os alunos das classes populares estariam sujeitos, tidos, portanto, como 'crianças carentes' (com base na teoria da carência cultural, difundida, principalmente, a partir da década de 1970) (pp. 43-5; 94). Patto também evidencia o caráter ideológico presente em tais proposições, em Psicologia e Ideologia (1984). 
teorizações apontadas acima e os estereótipos socialmente instituídos sobre os adolescentes.

Ao se referir aos alunos "repetentes", além de associar a repetência à não aprendizagem vinculada ao baixo nível intelectual, à falta de interesse em aprender ou à indisciplina, reiteram a idéia de que esses alunos "não querem nada da vida, só querem zoar, bagunçar, fumar maconha" e que "são tudo vagabundo". Desse modo, fazem alusão, portanto, à irresponsabilidade, displicência ou 'vagabundagem' (além da drogadição), elementos que configuram a imagem socialmente conferida aos jovens. Sendo assim, nesse processo de culpabilização, esses estudantes refletem e endossam uma vinculação entre rótulos relativos à condição de alunos de classes populares (com base nas teorizações acima) e à de adolescentes - ou, prioritariamente, à de jovens pobres.

Inclusive, deve-se salientar que esses adolescentes estabelecem uma associação entre indisciplina e violência ou vandalismo (que também compõem essa imagem difundida sobre os jovens). Nesse sentido, a bagunça ou indisciplina é referida pelos mesmos como "vandalisse" (os alunos "mais despojados" ficam "só fazendo vandalisse"), fazendo alusão a atitudes como conversar, atrapalhar a aula, tirar a paciência do professor, além de jogar cadeiras, pichar ou quebrar objetos da escola e roubar. Sendo assim, algumas condutas que seriam tidas como expressão de 'indisciplina' são consideradas vandalismo dos jovens alunos, e esses são vistos, 
portanto, não apenas como "bagunceiros" ou "indisciplinados", mas como violentos ou "vândalos".

No entanto, os adolescentes não se restringem à responsabilização dos participantes do contexto escolar pela má qualidade do ensino ${ }^{36}$, mas também elucidam críticas referentes ao sistema de avaliação e reprovação, de modo a ilustrar alguns aspectos implicados nesse processo. De forma geral, evidenciam a arbitrariedade que impera no sistema de avaliação, em que as notas ou conceitos são estipulados independentemente da efetiva transmissão e assimilação do conteúdo e em que a não produção da aprendizagem é mascarada por meio da aprovação dos alunos (também arbitrária, desvinculada da apreensão ou do ensino do conteúdo referente à determinada série), tendo-se como critério prioritário para reprovação a obtenção de um grande número de faltas.

Sendo assim, embora não sejam informados acerca do termo "Progressão Continuada", esses adolescentes descrevem claramente, por vivenciar suas implicações, elementos centrais que configuram essa política educacional

\footnotetext{
${ }^{36}$ Um último aspecto importante a ser destacado sobre essa questão consiste no fato de que, assim como os alunos, os professores (ou os demais participantes) também não devem ser culpabilizados pela problemática educacional, que envolve a implicação de diversos fatores (institucionais, políticos, ideológicos etc), conforme foi apontado na introdução dessa dissertação. A esse respeito, Patto (1997) acrescenta que: "Não se pode responsabilizar os professores pelas mazelas da escola pública fundamental, uma vez que eles também são produtos de uma formação insuficiente, porta-vozes de uma visão de mundo da classe hegemônica e vítimas da desvalorização profissional e de uma política educacional burocrática, tecnicista e de fachada" (p. 289).
} 
implementada nas escolas de Ensino Fundamental da rede estadual de São Paulo ${ }^{37}$. Seus apontamentos são condizentes com a análise realizada por Viégas (2002) e Patto (2000), segundo as quais:

Trata-se de um 'faz de conta'; do seu escamoteamento ou da criação de uma nova e mais sutil modalidade de exclusão no interior da escola (...). Tentar acabar com a 'cultura da repetência' sem enfrentar os fatores que de fato participam da produção da má qualidade do ensino faz apenas com que os alunos passem pela escola, mas sem aprender, formando-os precariamente. Assim, torna-se inevitável afirmar que, no contexto atual da escola pública paulista, muitos alunos de fato deixaram de ser reprovados, mas passaram a ser aprovados por decreto, ou seja, a Progressão Continuada tem sido, sim, sinônimo de Promoção Automática (Viégas, 2002, pp. 152;167).

A política atual caracteriza-se por tentativas de internalização escolar dos expulsos (...) democratizar a escola significa, nessas reformas, muito mais pôr em andamento a marcha pelos sucessivos graus escolares, sem reprovações, do que oferecer uma boa formação intelectual. Na concepção dos planejadores, democratizar a escola tem sido principalmente abrir a porta trancada das séries subseqüentes, importando pouco a qualidade do ensino (Patto, 2000, pp. 193-5).

As propostas apresentadas pelos jovens envolvem, de modo geral, uma atuação presente e efetiva dos governantes direcionada para implementação de projetos voltados à educação; o investimento em construção e infra-estrutura (além do melhor aproveitamento dos recursos já existentes) de escolas, creches e faculdades (com aumento do número de vagas nas faculdades públicas); e fornecimento de cursos e material de qualidade aos professores.

\footnotetext{
${ }^{37}$ Uma primorosa análise crítica a respeito das repercussões referentes à implementação da Progressão Continuada nas escolas públicas, com base no discurso de educadores, é realiza por Viégas (2002).
} 
Além disso, consideram que deveria haver "bons professores" (comprometidos com a transmissão e assimilação do conteúdo), reiterando, inclusive, a valorização do esforço pessoal dos participantes em ensinar ou aprender (com referências à proposta de que o salário dos educadores seja proporcional à efetividade do ensino) e do respeito entre eles. Propõem, ainda, a viabilização da comunicação entre os participantes, resgatando a questão da importância da escuta no contexto escolar (incluindo espaços para esclarecimento de dúvidas a respeito do conteúdo ministrado, além da efetivação do diálogo entre professores e alunos e de discussão de temas diversos).

Deve-se destacar que, além de tais medidas, alguns alunos defenderam a idéia de "instalar equipamentos de vigilância" e "manter a ordem, disciplina e progresso da sald", sob a prerrogativa de se investir na segurança ${ }^{38}$ e sanar a desordem na escola, reforçando a vigilância, controle e punição sobre os jovens alunos. É interessante notar que, nessa última proposição, esses jovens reproduzem os dizeres da bandeira nacional, que reflete a ideologia capitalista, por meio da qual se combate o caos, a desordem, o questionamento e a ruptura do sistema em vigor, a serviço da manutenção do status quo. Embora alguns alunos concordassem com tais medidas, outros contestaram seu caráter opressor, de modo a não serem eleitas diante da votação para inclusão na versão final do documento do PAN.

38 A questão da segurança também está presente na proposta referente à presença de "policiais circulando no contexto escolar". 
Por fim, diante das considerações apontadas até então, percebe-se que esses jovens alunos enfatizam a necessidade de se investir na melhoria qualidade do ensino público, demonstrando sua preocupação com a efetiva transmissão e assimilação do conteúdo e, portanto, o desejo de uma formação digna e sólida ${ }^{39}$. Sendo assim, embora os laços de amizade consistam em um aspecto significativo para os alunos no contexto escolar, esses refletem uma concepção acerca da escola que não a restringe a um espaço de interação entre amigos e parceiros - cuja dimensão deve ser valorizada (inclusive, em função de sua relevância no processo de socialização dos jovens) -, mas também almejam a instituição de ensino como um espaço de aquisição e apreensão do conhecimento, em que vigore o respeito, o diálogo e a compreensão.

Ao transmitir seu recado para a sociedade, os jovens enfatizam a necessidade de se romper com os estereótipos que lhes são socialmente atribuídos, enfatizando o fato de serem "julgados injustamente, principalmente pela (...) situação financeird" e apresentam propostas pertinentes, em sua maioria, referentes à educação, saúde, transporte, emprego e violência. Deve-se ressaltar que a ênfase na vigilância, no controle e punição (presente no debate sobre educação) é reiterada na discussão sobre a violência, por alguns alunos (e contestada por outros) que apresentam rigorosas e repressoras medidas de combate ao crime $e^{40}$.

39 Inclusive, o interesse apresentado pelos jovens alunos em discutir aspectos relativos à educação também é apontado por Sposito (2005, p. 109) que, com base nos dados obtidos por meio da pesquisa "Perfil da Juventude Brasileira", afirma que a educação consiste em um dos temas apontados pelos jovens que lhes desperta interesse.

40 Esse aspecto também é apontado por Venturi e Bokany (2005) que, com base nos dados na pesquisa "Perfil da Juventude Brasileira", afirmam: "...em relação à segurança pública $e$ 
Em contraposição à imagem instituída sobre os jovens, visto como alienados, esses adolescentes demonstraram grande interesse em debater a conjuntura política vigente no país, apresentando questionamentos e argumentações acerca das propostas e da atuação política de alguns governantes, além de criar um próprio partido político fictício, de modo a elaborar suas proposições, apontadas acima.

Com relação à ação política dos jovens, embora aleguem, em certos momentos, que esses seriam impotentes para propiciar mudanças na sociedade (referindo-se, inclusive, a si mesmos), em outros, enfatizam seu poder de ação, referindo-se à participação em projetos coletivos e ressaltando a necessidade de engajamento por parte da juventude, que deveria se unir e lutar por seus direitos e pela melhoria do quadro social. Apesar de não fazerem referências a alguma experiência em que houvessem concretizado sua própria atuação em tais projetos coletivos, expressaram o desejo de se envolver em outras formas de participação política, como o de se tornar eleitores aos 16 anos ou membros do Grêmio Estudantil em sua escola ${ }^{41}$.

combate à violência, encontram-se opiniões contraditórias, dentre as mensuradas na pesquisa: a maioria dos jovens aprova a proibição de venda [e porte] de armas de fogo (...) ao mesmo tempo em que é a favor, em algum grau, da presença de polícia nas escolas (91\%), da realização de exames toxicológicos 'para detectar uso de drogas entre os estudantes' (83\%); do rebaixamento da idade penal $(75 \%)$ (...) e divide-se quanto à legislação da pena de morte ( $48 \%$ a favor, $50 \%$ contra)" (p. 366).

${ }^{41}$ Um dos alunos afirmou haver se candidato para compor o Grêmio da escola, formando uma "chapa" com propostas voltadas para sua instituição escolar, porém, outro grupo venceu as eleições. Deve-se ressaltar a necessidade de que o Grêmio Estudantil se configure como um espaço em que se efetive a expressão $e$ intervenção dos alunos no contexto escolar (com apresentação de propostas relativas, inclusive, a questões institucionais). A implementação dos Grêmios nas escolas é incentivada pela legislação, que os reconhece como uma "entidade autônoma [que] zela pelos interesses de todos os estudantes da escola onde atua"- Lei Federal 7.398, de 04/11/85; Comunicado SE, de 26/09/86; Comunicado CEI / COGSP, de 27/11/87. 
Inclusive, ao elaborar o documento do PAN, os adolescentes valorizam a possibilidade de expressão (e, portanto, de serem ouvidos) e divulgação de suas idéias e propostas, voltadas para o bem coletivo ${ }^{42}$.

Por fim, diante de tais considerações, evidencia-se a relevância em atentar para o que os jovens alunos têm a dizer e ensinar: revelam uma experiência escolar predominantemente atravessada pela não-escuta, pelo desrespeito e humilhação, em um contexto no qual a indisciplina é tida como vandalismo e em que os estudantes são vistos como "aborrecentes", irresponsáveis, rebeldes, violentos ou marginais e tidos como fonte de medo e ameaça; apontam uma preocupação com a qualidade do ensino nas escolas públicas, ilustrando o caráter dual da educação no Brasil em que vigora a precariedade do ensino destinado às classes populares, regido sob uma política educacional que se esforça em ocultar a sua defasagem; evidenciam a necessidade de se romper com a imagem que socialmente instituída sobre os jovens, difundida pela opinião pública e endossada por teorizações naturalizantes; e, ainda, explicitam uma articulação entre rótulos relativos à condição de adolescentes e à de alunos de classes populares.

\footnotetext{
${ }^{42}$ Não será aprofundada, nessa pesquisa, a discussão sobre a ação política dos jovens; deve-se, apenas ressaltar que, referindo-se aos autores que analisam os dados da pesquisa "Perfil da Juventude Brasileira" sobre esse tema, Abramo e Branco (2005) ressaltam que "apesar de distintas interpretações [entre tais autores], o que parece importante ser ressaltado é que não se pode generalizar nem atribuir como essência de uma geração ou de uma condição juvenil os atributos de conservadorismo e alienação ou os de rebeldia ou contestação" (p. 21). E, ao questionar a imagem acerca dos jovens como conservadores e alienados, Venturi e Bokany (2005) acrescentam que "o conservadorismo e a suposta alienação dos jovens (...) é, nada mais, o reflexo do conservadorismo e do baixo associativismo em torno de causas comuns que, em que pesem os avanços graduais nas últimas décadas, seguem dando o tom na sociedade brasileira" (p. 368).
} 
Enfim, esses adolescentes transmitiram seu recado. Resta saber se serão ouvidos ou permanecerão silenciados sob a máscara dos estereótipos que lhes são socialmente atribuídos e endossados pelas ciências que objetivam estudá-los. 
ANEXOS 


\section{ANEXO I \\ ROTEIRO DE APRESENTAÇÃO DA PESQUISA PARA A DIRETORA DA ESCOLA}

- Iniciar me apresentando como (psicóloga) mestranda em Psicologia Escolar na USP.

- Apresentar o contexto e o objetivo da pesquisa: investigar a imagem de alunos e professores sobre a adolescência (alunos - experiência de ser aluno adolescente; experiência escolar na adolescência), para que eles ajudem a entender um pouco melhor como estas imagens permeiam o contexto escolar. Explicar que eu gostaria de investigar isso para tentar, com a ajuda do que eles têm a dizer, contribuir para a reflexão sobre a relação entre adolescência e escolarização, na área de Psicologia Escolar (que costuma voltar-se, principalmente, para o Ciclo I do EF).

- Apresentar o método da pesquisa: 1 entrevista individual com cada participante (4 professores e 8 alunos) e 4 encontros em grupo com os alunos; e conversar sobre possibilidade de dias e horários mais propícios para a realização destas entrevistas e encontros (incluir questão de ser fora do horário de aula o grupo). Falar que para realização dos encontros em grupo, contarei com uma "auxiliar de pesquisa", que irá ajudar na gravação e transcrição do material.

- Conversar sobre a apresentação da pesquisa para os alunos: sobre a possibilidade de passar em todas as salas de $8^{a}$ série e falar sobre o conteúdo desta apresentação aos alunos, assim como sobre o critério para seleção (sorteio).

- Esclarecer que não se trata propriamente de uma investigação do funcionamento desta escola em si, mas de uma questão mais ampla, que é a relação entre adolescência e escolarização (experiência escolar na adolescência).

- Falar sobre a questão do sigilo (o nome da escola, bem como dos participantes será preservado) e acrescentar que um exemplar da dissertação será entregue para a escola, como agradecimento e possível contribuição para a mesma.

* Questão do pedido de autorização dos pais (menores de 18 anos). 


\section{ANEXO II \\ CARTA DE AUTORIZAÇÃO PARA REALIZAÇÃO \\ DA PESQUISA NA INSTITUIÇÃO}

À Diretora da E.E. "X" ,

Eu, Ana Karina Amorim Checchia, aluna de mestrado em Psicologia Escolar do Instituto de Psicologia da Universidade de São Paulo, orientanda da Prof ${ }^{a}$. Dr ${ }^{a}$. Marilene Proença Rebello de Souza, venho, por meio desta, solicitar autorização para a realização de uma pesquisa nesta escola, cujo objetivo consiste em investigar as concepções de adolescência em professores e alunos da $8^{a}$ série do Ensino Fundamental, bem como suas possíveis implicações para o processo de escolarização.

Para tanto, pretende-se realizar uma entrevista com cada participante (quatro professores e oito alunos da $8^{a}$ série), assim como quatro encontros em grupo com estes mesmos estudantes - realizados fora do horário de aula, a fim de evitar a ausência dos alunos nas atividades escolares.

Agradeço, desde já, por sua atenção e colaboração e comprometo-me a fornecer à escola, ao final da elaboração desta pesquisa, um exemplar da dissertação de mestrado, como forma de reconhecimento, gratidão e possivel contribuição para esta instituição escolar.

Atenciosamente,

Marilene Proença Rebello de Souza

Ana Karina Amorim Checchia

(orientadora)

(mestranda)

São Paulo, de setembro de 2004. 


\section{ANEXO III \\ ROTEIRO DE APRESENTAÇÃO DA PESQUISA PARA OS ALUNOS}

- Passar em todas as salas de $8^{a}$ série, me apresentar e apresentar a pesquisa: falar que estou fazendo uma pesquisa sobre a visão de alunos $e$ professores sobre a adolescência. Assim, gostaria de ouvir o que os alunos têm a dizer sobre a experiência de ser um aluno adolescente (visão sobre a adolescência, sobre a experiência escolar na adolescência).

- Falar que eu gostaria de fazer um convite aos alunos para participar da pesquisa. Explicar que vamos formar um grupo com 8 alunos de $8^{a}$ série, para conversar sobre a experiência de ser um aluno adolescente e sobre a experiência escolar da adolescência.

Explicar que serão 4 encontros em grupo (a gente vai se encontrar duas vezes por semana, tento uma hora e meia de duração o encontro; então, no total, a gente vai se encontrar durante 2 semanas). E, depois de terminados esses encontros em grupos, eu farei uma entrevista com cada aluno para que ele possa acrescentar alguma coisa sobre o que foi conversado em grupo.

- Falar sobre a importância do sigilo: que todo o material da pesquisa (tanto nas entrevistas como nos encontros em grupo), os nomes da escola e das pessoas que estão falando não são identificados - então, as outras pessoas não ficam sabendo quem falou o quê (inclusive, na pesquisa, ou se inventam nomes diferentes ou coloca um número para representar cada participante) e não se conta pra algum professor ou diretor (etc.) o que tal aluno falou.

- Explicar o critério de seleção: os alunos interessados em participar irão se inscrever e serão sorteados 8 alunos no total. 


\section{ANEXO IV \\ FICHA DE INSCRIÇÃO PARA PARTICIPAÇÃO NA PESQUISA}

Nome:

Idade:

Série e classe:

Sexo: ( ) Feminino ( ) Masculino

Telefone:

Bairro:

Pode participar dos encontros em grupo nos dias e horário combinados (dias e horário )$?$

( ) $\operatorname{sim}(\quad)$ Não

FICHA DE INSCRIÇÃO PARA PARTICIPAÇÃO NA PESQUISA

Nome:

Idade:

Série e classe:

Sexo: ( ) Feminino ( ) Masculino

Telefone:

Bairro:

Pode participar dos encontros em grupo nos dias e horário combinados (dias e horário )?

( ) $\operatorname{sim}(\quad)$ Não

FICHA DE INSCRIÇÃO PARA PARTICIPAÇÃO NA PESQUISA

Nome:

Idade:

Série e classe:

Sexo: ( ) Feminino ( ) Masculino

Telefone:

Bairro:

Pode participar dos encontros em grupo nos dias e horário combinados (dias e horário )?

( ) $\operatorname{sim}(\quad)$ Não 


\section{ANEXO V \\ CARTA DE AUTORIZAÇÃO PARA OS PAIS DOS ALUNOS SELECIONADOS}

São Paulo, 13 de outubro de 2004.

\section{PEDIDO DE AUTORIZAÇÃO}

Meu nome é Ana Karina Amorim Checchia, sou aluna de mestrado em Psicologia Escolar do Instituto de Psicologia da Universidade de São Paulo, orientanda da Prof ${ }^{a}$. Dra . Marilene Proença Rebello de Souza, e estou realizando uma pesquisa na escola " $X$ " sobre adolescência e escolarização, para investigar a imagem de alunos e professores sobre a adolescência.

Para fazer esta pesquisa, vou fazer uma entrevista com 4 professores e 8 alunos da $8^{a}$ série, além de 4 encontros (de uma hora e meia de duração) em grupo com estes alunos. Por isso, peço sua autorização para seu filho participar desta pesquisa, com a realização da entrevista e dos encontros (estes encontros em grupo acontecerão nos dias e ... de outubro, das ..... às ......).

Desde já, agradeço a atenção e a colaboração e me comprometo a deixar, ao final da realização da pesquisa, um exemplar desta dissertação de mestrado na escola " $X "$ ".

Atenciosamente,

Marilene Proença Rebello de Souza (orientadora)

Ana Karina Amorim Checchia (mestranda)

\section{AUTORIZAÇÃO}

Eu, (nome do pai ou responsável)

responsável pelo aluno (nome do aluno)

autorizo-o a participar da pesquisa sobre adolescência e escolarização na escola "X".

(Assinatura do pai ou responsável)

São Paulo, de de 2004. 
ANEXO VI

DOCUMENTO ELABORADO PELOS ALUNOS

1

PAN

Tiós somes u congresso de addescentes indiginados com a: atual Ditueusato do país.

\& queremos desmonstrar que näo. somies aborrecentes, nessas opéhiges séo Áras e eliretas, témos respensabilidade suficiente parce expor nosspes apiniors. Somos fulgades in ustatamente, principalimente pela inossa sitiacáo finanuma minbaria dos fovens que nöo tern alta conscientizacieco el respito pelo andinente wade vinem.

$$
\text { : Propestas: }
$$

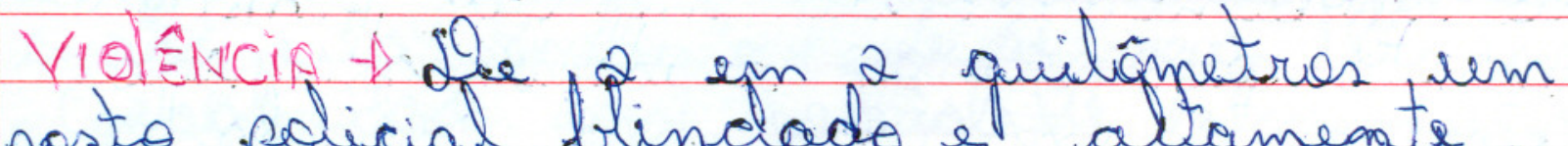
posto pricial blindado e altamente - mudipar o cócligo penal radicalmente para que a leordypcióo e a impunidade defan diminuldas socirdaqu.

Culas de orientasea em géral (bexio, - hes escolas e unidodes puélicas.

GAUDE $\rightarrow$ mais saude para a sorida de com pastor hem lquapados, médicos bem preforados para um ateradimento methor it mais humano iom 50\% dos pestor públicos funcianando 24 horas or outros $50 \%$ funcionando nosfins cle semana. Construcéos de mais 168-A 
2

hospitais posto en prontidoo de andor láncia. E rontrde dop ln etro maís rígido com a queqlidade das camisi. mhas definiféo del limite dos preces elos reméclios - viracág de fármacias públicas ra queal neneterie remédib re baiso do clisto.

EMPRE $\triangle$ Cursos prafiszienalizantes gratuitos com cassingl de qualidade com monitores attamente qualificadon com equipamentor em boo condicaio de usa.

Liminuicáo dos iprostor pora que a populascoor vidignamente, e que as impresas se instalem en soot Paulo, dan. do portunidade de imprea priancipalmente aos fovens e idoson, que sao Oflicializar is nundedores sorisdads. Oficializar es nundedores artesoón. EDVCACAO $\rightarrow$ Lezem. nas salas de aula afudantes cedultos que afudem a manter a disciplina e o progússo da sala;, mas também para ayudar os alunos que prexiswassem tirar suas dividas. especial para sue cada aluno tivrasse asdividas tam a professior ou sara tirar suas qúvidar.

Cos pais dos alunos deverivana participar dan rewareás de pais e folar Le pque estä achando dophusino da 


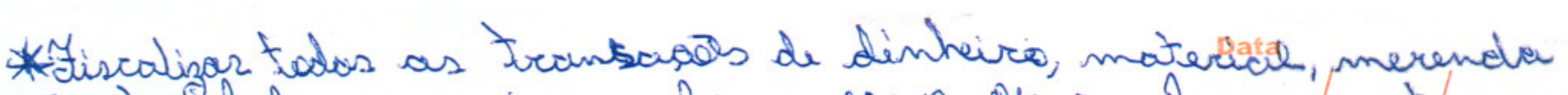
e ratividades, que vierem do governo ele qualquea sutra instituifar ta escala.

deveria mudar, dar opiniós para que a educacéco melhore. El os pais devériam ser obrigados a ir vas reunióes, principalnemte gs pais dos alunos que

MAIS PROPOSTAS

EdUCACÁ̄O:

- Por policicies circulando no cembiente es. colar.

- Equipar as professores con materiais de qualidade, e assim com mais recursos a reprendizagen. Séra snais detallada. - Citades isportivas com frequêneía nas. ezcolan.

- Imestir no grémio dos escolas - Reformar grande parte das escolas púllicas.

- Ccalar com cen escolas de lata, e en sens lugares construir escalas de conceto. - Construir es equipes as vreches para que. as mães fiquem tranquilas ao itrem trabas. - Visitas frequentes a Teatron "cimemas i autros formos de cultura, tudo aratuito ar ao.

- Construcaco de novas FATECS. facudades do

- Investir nas faculdodes aratuitas, excigindo - Construcenimero de vagos mpo vostibulares - Construcéo de billiotecar públicas de fácil asserso a pepulacáo

- Cuslas de brientacióo cos professores, com pitologos especializedolos en camportamento de criancas e adolescentes. *

$168-$ 
SALODE

- Equipar e reformar todos es pastos do cidade. - Cassturcias el reforma de nova labo. rátoriar nacionaís.

- hegaciar con labrátorios estrangeiros, estalelecendo um padräo de preco inais acosínel as remédion que vierem de fiora. - Equipar e reformar arande parte dos haspi-

- Equipar es reformar as frotas de ambilion- Ner postar móveis treafegrando pos toda rejelade. na qual a sopulaséo marearía rensultas e receberiva remedios sem sair da frente de

- Cintes de marcar cutras consultes, ratesoler as que fá está marcadas

- Criar uma arande rede de farmácios púllícoss cam distribuicea de remédios gratuitos, e Teria remédion sora distrifuir

- Criar postos de soúde equipedos es especializados somente do atendimento ca gestante.

Civar poston equipados e espreializadion pomenTe ar atendimento ao idaso, no fqual ele teria transporte, remédiv, vacinas, tudo gratuito

- Criacaro de pedíatrias péblicas, equipadas, cam vernédios, vacinas, pacologon etc...

- Fiscalizar todos as transaceés de renédois es equipamentos, que vieren do estade ou qualquar

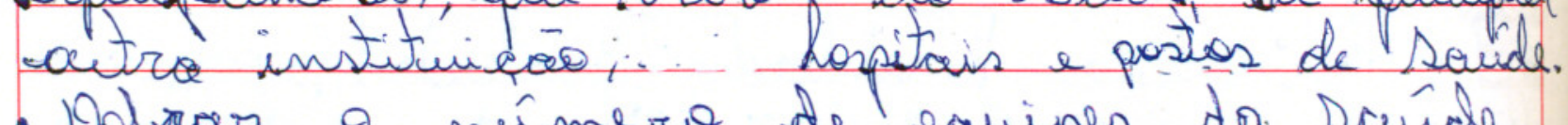
- Lobrar o némero de equipes do scúide de familia 
5

VIOlENCIA

- Duplicar rondas noturnas

- Colaboracá̃o

dees forcas armardas em sitreaçâs que perderema of controle NÕ. Inicictiva de plicia fuecot. (indir

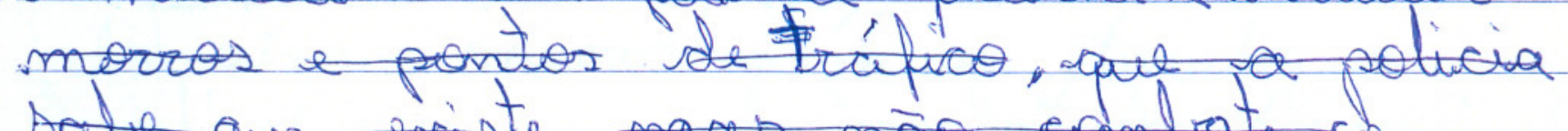
sabe que sxiste nos combate com putro firmel.

- Invesir mo treinamento de cáes farefadores, pora ausiliar e melhorar o desempenhe policial

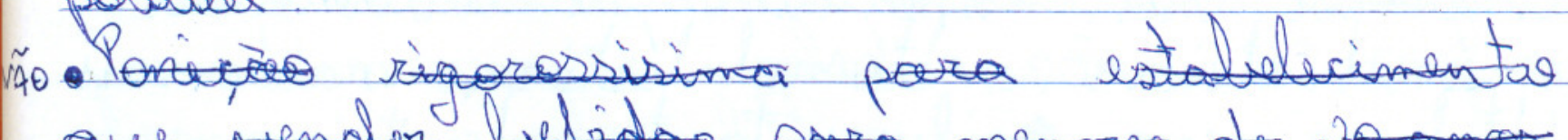

- Reestrutunar e relquipar as casas de detanceso, triplicando o m de policiceir que nelas se encontram; evitando asrim novas rebeliós e feugres nas ccedfias.

- Cupravacáa da pena de morte no Brasill Lam séria fusticall.

- Aprovacieo da puisáo perpétua no Brasil

- Treinamento rigoroso nas acadenias de polícia

- Un salário diquno a plicial

- Vuma colaboracia mensal a familia que perdus kean inte queriduo que exercica essa prohisāo

- Fiscalizarifo rigorosa en transacéos nacionais a internacionaits de armas e equi. pament ses da policia.

- Uniaro entre as duas poĺcicas militar a cirif foumando una sé

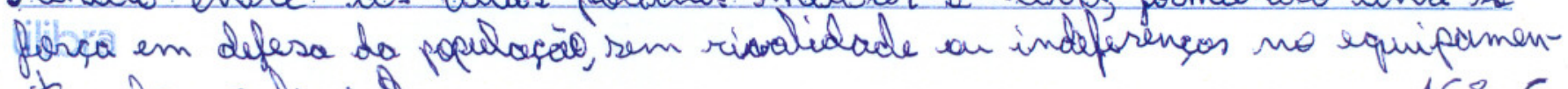
to do policia.

$168-C$ 
Transportes

- A sriagáo da le que olrigarara as ind trices automolilísticas situcedor aqui no Brauil, a contruivem somente cuitonorvis mavidos a alcod, pä́s é um cambrestével menor poluente e de fabricacão nocional. - Brasil gasta menor cam a petróluo oque está U\$ 50,00 um barril, ce atrairia muito mairs emprego pora a zana rural.

- Investir una exportacéo de autanóveis de indústricas autornobilístivers nacionai - Utilizar un anilue tanto de turisosmo quanlo nos ánilues coletivas, pecas de em presas macionains (pneus, motors, itc...)

- Aplicar a rede passa répido

- Implantar câmeras de vigilancia nos ônilus, inilindo assim assaltantes, - docar tanbém policiais e petectores de metais na entrada dos ônilus.

- Triplicar as. unidades da ämetropo litana, dando a lles um treinamento rigoraso, e equipamento de qualidade. - Por em prâtuca as lis de trânsito que fó exastern mas não säo cumpridas

- Construir cirlorices en toda grande 1.P., sais é un transporte náo poluenta $\therefore$ de baisco custo. 
7

Dia dos Cidolusentes

* Gootaríamos que tivébemos uma vez

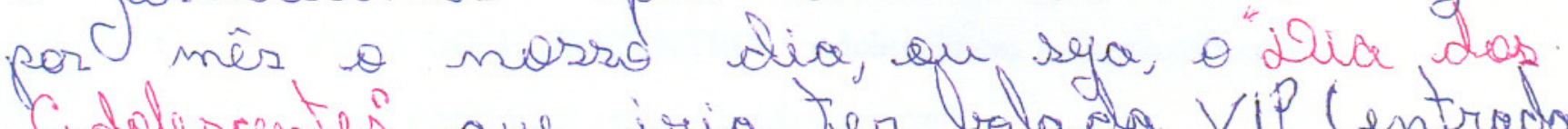
Cidoluscentis que iria ter balada VIP (entrada grátis), Shoubs, passicios, com bourtante seguran tra para que os paip anfiem na balada te no seu propiou filho, sean precisar levar irmấs mais novos, sem amolarioo. Queremos a colaboracére e a confianea daz pais a dos fillor.

Cessinaturas:

Sä̃ Paulo 22 dovembro de 2004

$k_{2}$

blode

$X D_{i}$

i) $k 00 / 1$

P.JAma

$c_{2}$

C.I J.BECA

168: 


\section{ANEXO VII \\ ROTEIRO DE TEMAS/QUESTÕES ELABORADOS PARA \\ REALIZAÇÃO DOS ENCONTROS EM GRUPO}

\section{TEMA DO $1^{\circ}$ ENCONTRO : Adolescência e Escolarização}

Questão central: como é ser um aluno adolescente?

A) Como é, pra vocês, ser adolescente? (O que vocês acham de ser adolescente?)

Vocês acham que existem características que são típicas da adolescência?

O que vocês pensam sobre o jovem de hoje?

Como vocês acham que o jovem é visto pela sociedade?

Vocês acham que existem diferenças entre os jovens da geração de vocês e os jovens da geração de seus pais?

B) Como é ser um aluno adolescente? (adolescente estudando na $8^{a}$ série) Como vocês, enquanto jovens alunos, sentem que são vistos pelos seus professores? $E$ pelos outros funcionários da escola (diretora, coordenadora, inspetora de alunos)? E pelos pais?

Vocês acham que o fato de vocês serem jovens afeta de alguma forma a visão que eles têm sobre vocês? Como; por quê? 


\section{TEMA DO $2^{\circ}$ ENCONTRO: Visão dos adolescentes sobre \\ a relação professor-aluno (e demais personagens)}

Questão central: como é a relação entre seus professores e os jovens alunos?

A) O que vocês acham da maneira como os professores se relacionam com os alunos adolescentes? E os alunos, com os professores?

- Que visão ou imagem vocês acham que os professores têm dos alunos? ${ }^{1} E$ como vocês se sentem diante disto (ou o que vocês acham disso)? ${ }^{2}$

- Que visão vocês têm sobre os professores? Para vocês, como é um bom professor? E um mau professor? ${ }^{3}$

- Vocês acham que existe alguma diferença entre a visão que o bom e o mau professor tem sobre o adolescente?

- E vocês acham que existe alguma diferença entre a relação do professor com um aluno adolescente e com um aluno adulto ou criança? Qual? Por quê?

B) [Como é a relação entre o diretor e os alunos (e vice-versa)? Como é a experiência de contato com o diretor? Que visão vocês acham que o diretor tem dos jovens alunos? E como é a relação com o coordenador? Vocês sentem diferenças entre a relação (e a visão) do diretor e do coordenador com (sobre) os alunos? Quais? Como os demais funcionários da escola se relacionam com os alunos (e vice-versa)? $]^{4}$

- Como os alunos se relacionam entre si em sala de aula? E fora da aula? Vocês se envolvem em alguma atividade extra-curricular (grêmio)?

- Em que situações os pais entram em contato com a escola? Como é a relação entre a escola e os pais (como isso repercute na rel. com filhos)?

\footnotetext{
${ }^{1}$ Resgatar se (e como) o fato de serem adolescentes influencia nessa visão e na relação.

${ }^{2}$ Houve alguma situação na relação com os professores que foi marcante para vocês? Qual? Por quê?

3 Como seria uma boa relação entre professor $e$ aluno? ( $O$ que precisaria acontecer para se estabelecer essa boa relação?).

4 Resgatar estas questões, cuja discussão que já iniciamos no primeiro encontro.
} 


\section{TEMA DO $3^{\circ}$ ENCONTRO: Reflexões dos jovens alunos sobre a experiência escolar}

Questão central: o que vocês estão achando de estudar na $8^{a}$ série?

A) Como é para vocês viver o dia-a-dia escolar na $8^{a}$ série? O que acontece nesse dia-a-dia? O que vocês acham dessa rotina?

- Vocês fazem algo para quebrar essa rotina ou ir além dela (por exemplo, alguma atividade extracurricular - participação em algum projeto realizado na escola; organização de eventos escolares)? E como é vivido o intervalo? ${ }^{5}$

- O que vocês mais gostam desta experiência escolar? E o que mais thes incomoda? Por quê? Como seria, na opinião de vocês, uma boa experiência escolar? O que precisaria ter e acontecer neste processo?

B) Para vocês, qual é o sentido de estudar (na $8^{a}$ série)? Para que serve? E vocês acham que está sendo possível atingir esse objetivo? Por quê?

- O que vocês acham do conteúdo das matérias que é transmitido em aula? Como é, na opinião de vocês, um conteúdo bem dado? (E mal dado?)

- Como funciona o sistema de avaliação e reprovação? O que vocês acham desse sistema?

- Durante o percurso de escolarização (até hoje), que conquistas vocês tiveram? Que contribuições este processo lhes trouxe (ou em que lhes acrescentou)? E do que vocês sentiram falta ou o que vocês acham que este processo não pôde oferecer? Por quê?

- O que vocês acham da qualidade do ensino? ${ }^{6}$ Por quê? $E$ vocês acham que existe algum culpado por isso? Quem seria $(m)$ ?

- Vocês têm alguma idéia, alguma proposta para melhorar esta situação?

\footnotetext{
${ }^{5}$ Vocês costumam fazer alguma atividade fora da escola (lazer)?

${ }^{6}$ No primeiro encontro, afirmaram que o "ensino é ruim" - importante aprofundar.
} 


\section{TEMA DO $4^{\circ}$ ENCONTRO (Encerramento)}

Tema central: discussão sobre letras de músicas que tratem dos temas discutidos.

\section{Atividade:}

Pedir para que os alunos levem músicas (letra $e c d$ ), juntamente com mais alguma produção dos próprios alunos (que quiserem) - como composição própria de letras de música, poesia, textos... - que tratem dos temas abordados ao longo dos encontros, a fim de discutirmos sobre as mesmas.

\section{TEMA DOS ENCONTROS EXTRAS}

\section{- $1^{\circ}$ ENCONTRO:}

Início da elaboração em grupo do documento com as propostas do "PAN"

\section{- 2 ENCONTRO:}

Finalização do documento, com votação das propostas trazidas individualmente pelos alunos e redação do texto final. 


\title{
ANEXO VIII \\ LETRAS DAS MÚSICAS DISCUTIDAS PELOS ALUNOS
}

\author{
NÃO É SÉRIO
}

(Charlie Brown Jr.)

\begin{abstract}
Eu vejo na TV
O que eles falam sobre o jovem não é sério

$O$ jovem no Brasil nunca é levado a sério

Eu vejo na TV

O que eles falam sobre o jovem não é sério

Não é sério
\end{abstract}

Sempre quis falar, nunca tive chance

Tudo o que eu queria estava fora do meu alcance

Sim, já, já faz um tempo

Mas eu gosto de lembrar

Cada um, cada um; cada lugar, um lugar

Eu sei como é difícil

Eu sei como é difícil acreditar

Mas essa porra um dia vai mudar

Se não mudar, pra onde vou?

Não cansado de tentar de novo

Passa a bola, eu jogo o jogo

A polícia diz que eu já causei muito distúrbio

O repórter quer saber porque eu me drogo, o que é que eu uso

Eu também senti a dor

E disso tudo eu fiz a rima

Agora já to por conta, pode crer que eu tô no clima

Eu tô no clima... (segue a rima)

Revolução na sua mente, você pode, você faz

Quem sabe, mesmo, é quem sabe mais

Também sou rimador, também sou da banca

Aperta um forte, que fica tudo à pampa

Eu tô no clima... (segue a rima)

Eu tô no clima

Chegando por aqui Negra Lee

Família RZO, vários malucos só

O que eu consigo ver é só um terço do problema 
É o sistema que tem que mudar

Não se pode parar de lutar

Senão, não muda

A juventude tem que estar a fim

Tem que se unir

$O$ abuso do trabalho infantil é ignorância

Só faz destruir a esperança

$\mathrm{Na} T V$, o que eles falam sobre o jovem não é sério

Não é sério

Deixa ele viver...

É o que liga.

\section{MINHA VOZ \\ (Almagem)}

Não pense que vou combater com violência A violência cega que você me traz

Não pense que vou combater com intolerância

A ignorância intolerante que eu não quero mais.

É pra essa guerra que eu guardei as minhas armas

A consciência, o pensamento livre, a expressão.

Não subestime a inteligência desse povo

Pois se cega os olhos, ainda resta um coração.

Minha voz, já não cala mais

Voa pelo ar, vai buscar a paz.

Se o grito de socorro daquela criança

Fosse capaz de comandar uma revolução

E derrubar os muros de desconfiança,

Hipocrisia e falta de educação.

É pra esses homens que eu guardei minhas verdades.

E o povo ri com a mão na boca e protege os dentes que ainda não caíram E que bravamente como o próprio povo insiste de teimoso em sobreviver Até quando eu vou olhar pro céu crivado de bala $E$ ver uns com muito, outros com tão nada.

Um país assim é que eu não quero pros meus filhos não... 


\section{ANEXO IX \\ ROTEIRO DE ENTREVISTA COM ALUNOS}

- Durante os encontros em grupo, conversamos sobre: como é para vocês ser adolescente; a imagem que os adultos têm sobre o adolescente; a experiência de ser um aluno adolescente; a relação entre os alunos e as pessoas que fazem parte da escola; as propostas do PAN; e as letras das músicas.

O que você achou desses encontros em grupo? Qual foi assunto que mais the interessou? Por quê?

- Tem alguma coisa que você gostaria de acrescentar sobre esses assuntos? E tem algum assunto sobre o que não conversamos, mas que você acharia importante?

- Em um dos encontros, você falou que (...); eu gostaria que você falasse um pouco mais sobre isso [questão específica por aluno].

- Quando vocês escreveram as propostas do PAN (Partido dos Adolescentes da Nação), vocês disseram que 'são julgados injustamente, principalmente pela situação financeira'. O que você acha disso?

- Com o PAN, vocês criaram propostas para violência, saúde e educação. Pra você, qual seria o maior problema da educação? Por quê? E como você acha que daria para melhorar essa situação?

- Conversamos sobre como é ser um aluno adolescente e eu gostaria que você se lembrasse, agora, do começo de sua experiência escolar (começou a estudar na primeira série ou fez pré-escola?). Como era ser aluno, quando criança? O que mais The marcou durante este processo (até a quarta série)? E que diferenças você sente entre ser um aluno criança e adolescente? Por quê?

- Agora, pensando sobre o futuro: que expectativas você tem para o futuro (quando terminar o terceiro colegial)? O que você pretende fazer e o que é preciso para conseguir isso?

- Gostaria de acrescentar mais alguma coisa? Muito obrigada. 


\section{ANEXO X \\ ROTEIRO DE ENTREVISTA COM PROFESSORES}

- O que você acha dos adolescentes de hoje em geral?

- E o que acontece para que eles sejam assim, na sua opinião? ${ }^{7}$

- Que diferenças você sente que existem entre a geração dos jovens de hoje e a geração de jovens de sua época?

- E como são, na sua opinião, os alunos adolescentes? (Por quê?)

- Como você sente que é a sua relação com os jovens alunos?

- Você sente alguma diferença entre a relação com os jovens alunos desta escola e de outra escola em que você deu (ou dá) aula? Qual? A que você atribui essa diferença?

- E com relação às quatro turmas de $8^{a}$ série dessa escola: na sua opinião, existem diferenças entre cada sala? $O$ que você acha da $8^{a}$ A (dos alunos 'repetentes' e da proposta de montar essa sala)? Na sua opinião, o que leva à repetência?

- Você acha que o fato de os jovens alunos serem assim (...) interfere de alguma forma na sua prática de ensino ${ }^{8}$ Como?

- Como você se sente dando aula para as $8^{a}$ séries? Você sempre deu aula para os jovens? O que o levou a optar por isso? E para você hoje, qual é o sentido (e a motivação) em dar aulas para os adolescentes?

- Qual foi o fato que mais the marcou durante sua trajetória enquanto professor destes jovens alunos? Por quê? Que satisfações este processo the trouxe? E que frustrações? E hoje, que esperanças você tem, enquanto professor?

\footnotetext{
${ }^{7}$ Ou: o que os leva a ser assim, na sua opinião?

${ }^{8}$ Ou: você orienta de alguma forma a sua prática de ensino em função de os alunos serem assim?
} 


\section{ANEXO XI \\ ROTEIRO DE ENTREVISTA COM DIRETORA/COORDENADORA}

- O que você acha dos adolescentes de hoje em geral?

- E o que acontece para que eles sejam assim, na sua opinião?

- Que diferenças você sente que existem entre a geração dos jovens de hoje e a geração de jovens de sua época?

- E como são, na sua opinião, os alunos adolescentes? Por quê??

- Muito se fala nessa escola sobre a $8^{a} A$. $O$ que você pensa sobre os alunos dessa turma? (E sobre essa proposta de agrupá-los em uma sala)? Na sua opinião, o que acontece para que haja repetência?

- $O$ que você espera de seus alunos que terminam a $8^{a}$ série? A escola tem ou teve algum projeto educacional com alunos de $5^{a}$ a $8^{a}$ séries? (pedir para detalhar).

- Em que situações você estabelece contato com os jovens alunos? $E$ como você sente que é a sua relação com os mesmos?

- Que imagem você sente que os jovens alunos fazem sobre você? Por quê? $E$ você concorda com essa imagem a seu respeito?

- Você trabalha como diretora/coordenadora há muito tempo? (falar um pouco sobre a trajetória) $O$ que mais lhe marcou durante essa sua experiência?

- Você participou de alguma palestra ou formação sobre a juventude e o jovem atual? Há alguma atividade com jovens que você se lembre de ter feito ou participado? E de que forma você acha que poderia contribuir para o processo de escolarização desses jovens alunos? 


\section{ANEXO XII \\ CRONOGRAMA DAS ATIVIDADES REALIZADAS NO TRABALHO DE CAMPO}

- Setembro:

$4^{a}$ Semana: - primeiro contato com a escola e apresentação da pesquisa para a diretora.

- Outubro:

$1^{a}$ Semana: - apresentação e convite aos alunos para participar da pesquisa.

$3^{a} / 4^{a}$ Semana: - divulgação dos selecionados e realização dos encontros em grupo

$19 / 10-1^{\circ}$ encontro

$21 / 10-2^{\circ}$ encontro

$25 / 10-3^{\circ}$ encontro

$27 / 10-4^{\circ}$ encontro 9

- Novembro:

$2^{a}$ Semana: - entrevistas com os alunos.

$3^{a}$ Semana: - entrevistas com professores, diretora e coordenadora.

- Dezembro:

$1^{a}$ a $3^{a}$ Semana: - transcrição e devolutiva das entrevistas.

- Janeiro:

Finalização da transcrição do material obtido e revisão das entrevistas devolvidas.

${ }^{9}$ Os encontros extras foram realizados nos dias 26/10 e 17/11. 


\begin{abstract}
ANEXO XIII
TABELAS COM LEGENDAS DAS SIGLAS UTILIZADAS NAS TRANSCRIÇÕES DE ENTREVISTAS E ENCONTROS EM GRUPO
\end{abstract}

Tabela Geral

\begin{tabular}{|c|c|}
\hline Sigla & Legenda \\
\hline A1 a A4 & ALUNAS \\
\hline O1 a O4 & ALUNOS \\
\hline Pa1 e Pa2 & PROFESSORAS \\
\hline Pr1 e Pr2 & PROFESSORES \\
\hline$D$ & DIRETORA \\
\hline$C$ & COORDENADORA \\
\hline Fa & FUNCIONÁRIA \\
\hline Fo1 e Fo2 & FUNCIONÁRIOS \\
\hline$E$ & Outras esColas \\
\hline$X$ & Outros alunos \\
\hline
\end{tabular}

Tabelas específicas

- Alunas (A1 a A4) e Alunos (O1 a O4)

\begin{tabular}{|c|c|c|c|}
\hline Sigla & Legenda & Sigla & Legenda \\
\hline A1 & Janaína & O1 & Denis \\
\hline A2 & Adriana & O2 & João \\
\hline A3 & Cristina & O3 & Jhonatan \\
\hline A4 & Tamara & O4 & Evaristo \\
\hline
\end{tabular}

- Educadores: Professoras (Pa1 e Pa2), Professores (Pr1 e Pr2), Coordenadora (C) e Diretora (D)

\begin{tabular}{|c|c|}
\hline Sigla & Legenda \\
\hline Pa1 & Alberta \\
\hline Pa2 & Lucila \\
\hline Pr1 & Vanderlei \\
\hline Pr2 & Ronaldo \\
\hline C & Simone \\
\hline D & Tereza \\
\hline
\end{tabular}


- Funcionária (Fa1) e Funcionários (Fo1 e Fo2)

\begin{tabular}{|c|c|}
\hline Sigla & Legenda \\
\hline Fa1 & Taís \\
\hline Fo1 & Bento \\
\hline Fo2 & Paulo \\
\hline
\end{tabular}


ANEXO XIV

\section{PRIMEIRO ENCONTRO EM GRUPO COM OS ALUNOS}

K: Hoje a gente vai conversar sobre adolescência. Primeiro eu queria saber como é para vocês ser adolescente, o que vocês acham de ser adolescente.

A2: Eu gosto.

K: Você gosta?

A2: Eu acho que é a melhor fase que a pessoa passa.

$\mathrm{K}$ : Por que é a melhor fase?

A2: Porque, sei lá. Sem responsabilidade. Sem ... é.

K: Diz o que você acha. Você concorda?

O1: Concordo.

$\mathrm{K}$ : Você acha que é sem responsabilidade?

O1: É. Só jogo bola todo dia.

K: Por que é sem responsabilidade? Por que o adolescente não tem responsabilidade?

A2: Não, responsabilidade tem. Mas eu tô falando assim, você sendo adolescente você tem sua mãe, seu pai. Então, porque de maior você tem que pagar conta, tem que trabalhar... Se você trabalha, assim, tem todas as responsabilidades.

K: Quais são as responsabilidades dos adolescentes?

A2: Pelo menos a minha é meu emprego, minha escola, estudo.

A1: Arrumar a casa também. Ter nota boa.

K: Mas, qual é então a diferença entre a responsabilidade do adolescente e do adulto?

A1: Porque o adulto tem que ficar se preocupando com várias coisas.

A2: Conta para pagar, aluguel para pagar.

A1: É, compra. Fica no sufoco, assim.

$\mathrm{K}$ : Adolescente não tem que se preocupar com dinheiro?

A2: Eu me preocupo com dinheiro só pra comprar minhas coisas.

$K$ : Então, não é para se sustentar, é pra comprar as coisinhas que você quer? E você, o que você acha de ser adolescente?

A1: Eu acho ótimo. Por causa que é assim, é a fase que você sai com seus amigos, você conhece as pessoas novas. É a fase de descobrir tudo que você não sabia antes.

$K: O$ que vocês estão descobrindo, que vocês não sabiam antes?

A1: Eu nada.

(Risadas)

K: Mas vocês não falaram que é a fase das descobertas? O que existe de descoberta na adolescência?

(Pequeno silêncio)

A1: Por exemplo, beijar. Porque beijar, na hora que você começa beijar..., aí depois você não quer mais parar.

O1: É que as vezes vocês acha que [vai ser] uma coisa diferente, quando você não é adolescente.

$\mathrm{K}$ : Como assim?

O1: Acha que vai achar beleza, tudo legal, mas quando passa a conviver, mesmo, vê que não é tão só maravilha. 
A2: Meu irmão que fala "Você acha que o mundo gira ao seu redor, não é assim, tem que abrir o olho, ter cabeça, porque tem muita coisa lá fora que você vai ter que enfrentar, não vai estar protegida pela sua mãe, e aí quando chegar na idade de 20, 22 anos" [vai ter que] enfrentar lá fora.

$K$ : E sobre isso que o $O 1$ tava falando, que acha que assim, que antes de ser adolescente você tem uma idéia de que o mundo é tudo de bom e na adolescência já começa a mudar? É na adolescência que já muda?

O1: É.

K: Que visão que a gente começa a ter na adolescência sobre o mundo?

A1: Que tem que tomar cuidado.

$\mathrm{K}$ : Cuidado com o quê?

A2: Com suas amizades.

A1: É, principalmente, porque tem muitas amizades que não dá [que no começo é] uma beleza e depois só ficam falando mal de você.

A2: [Tem que tomar cuidado com os] lugares onde freqüenta.

A1: É, principalmente com os lugares que freqüenta. Fica preocupada com tiroteio aí, esses negócios...

K: De violência?

O1: E quando é adolescente tem que ser só melhor, senão se lasca depois. Tem que ser melhor que os outros. Fazer de tudo pra tentar ser melhor que os outros para ter seu espaço. Se não... Ou você corre atrás, ou você fica [bem atrás].

$K: E$ isso acontece na escola também ou não, de ter que ser o melhor, isso acontece onde? O1: Ah, na escola nem tanto. Todo mundo é tudo igual, da mesma forma. Agora sendo em outros lugares assim...

K: Onde, por exemplo? Dá uma idéia de onde.

A2: Posso falar?

$\mathrm{K}$ : Pode.

A2: Emprego.

K: Emprego?

O1: É.

A2: Eles querem os melhores. Escola também... você tem que ser o melhor.

O1: E hoje em dia (...) você pode ser o mais esforçado possível...

A1: Eles não querem nem saber.

K: Na adolescência também tem então esta preocupação de emprego?

A1: Acho que a nossa grande preocupação é emprego. É porque você quer ajudar sua família, assim porque sabe, você tem vontade de ajudar, mas não pode trabalhar por causa da sua idade, aí fica mó ruim.

A2: E tem o preconceito também. Tem umas histórias de lugares que não pega adolescente por causa da idade.

K: Então tem um preconceito? Nesta história de emprego tem uma coisa de ajudar a família, mas existe um preconceito de que não contrata porque...

A2: Porque não tem muita experiência. Mas como é que a gente vai fazer se ninguém dá chance?

K: Você tava falando do preconceito, das pessoas que não te chamam porque é adolescente. Mas que preconceito é esse, que tem a ver com a pessoa ser adolescente? 
A2: Acha que nós somos novos, não sabemos trabalhar, não temos capacidade de ter a responsabilidade de um emprego, prefere dar emprego para os mais velhos, que tem coisas para pagar; [que] o adolescente só quer saber de roupa, calçado, shopping, festa.

K: Então, que idéias, imagem, vocês acham que as pessoas na sociedade têm sobre os adolescentes? As pessoas pensam: "o adolescente é...?".

O1: Vândalos.

A2: É, exatamente.

A1: Vagabundo, que não quer fazer nada, só quer vida boa.

A2: Quer tudo na mão.

A1: É, eles pensam isso. A maioria das pessoas.

$K$ : E vândalo assim como?

O1: De quebrar, de brigas.

A2: Pichações.

K: Então quando se fala "adolescente" na cabeça deles vem tudo isso?

A1: Vem, só que eles não pensam nenhum lado positivo, porque tem gente que tem vontade de aprender as coisas, se esforça, mas eles não pensam nisso, só vêem pelo lado ruim, só. A2: A maioria.

K: E vocês acham o quê disso, das pessoas pensarem isso sobre os adolescentes? Vocês acham que é assim mesmo?

A2: Eu acho que não. Porque foi uma fase que eles também passaram.

A1: E nem todos os adolescentes são assim. Não é porque um é, que todos têm que ser.

A2: Não é porque o 01 é, eu tenho que ser, a $A 1$ tem que ser.

(Risadas)

K: O1, o que você ia falar?

O1: Eu acho que é assim mesmo, ué.

K: Você acha que adolescente é vândalo, é.....

01: É, de 100\%, 70 é!

K: $70 \%$ você acha que é? Vocês acham? É isso mesmo, tem que dar a idéia de vocês.

O1: $70 \%$ é.

K: Que idéia vocês fazem dos adolescentes, os outros jovens de hoje? Como vocês acham que eles são?

A2: Eu acho que neste século XXI os adolescentes são muito folgados!

$\mathrm{K}$ : Folgado como, em que sentido?

A2: Folgados. Não pensam em trabalhar, não pensam em fazer nada!

$K:$ E por que eles não querem trabalhar?

A2: Porque tem os pais.

K: Que sustentam....?

(O2 chegou e retomamos com ele a discussão, contando sobre o que havíamos conversado)

$\mathrm{K}: 02$, e pra você, ser adolescente é...?

02: Uma droga!

K: Por que uma droga, o que tem de ruim?

O2: Sinceramente, depende. Ser adolescente pro O1, por exemplo, deve ser uma coisa boa, pra mim não.

K: Por que não é uma coisa boa para você?

O2: Só tomo fora, sou feio, magro.

(Risadas)

O1: É a lei de Deus!!! 
O2: $E$ isso nunca vai mudar. Ou pelo menos pode mudar depois que passar a adolescência, posso encorpar.

(Risadas)

K: $O$ que pode mudar depois da adolescência, ser diferente?

O2: Ter minha vida própria.

K: Como assim, dá um exemplo.

02: Casar, ter meus filhos, conforto, ter a minha casa.

O1: Acho que entendi o ponto que ele quis botar. Ele quis botar que ele passando da adolescencia, se depender dele mesmo [ele não vai precisar do dinheiro pra ninguém, entendeu ? Vai pegar o dinheiro dele, comprar as coisas dele com dinheiro dele].

$\mathrm{K}: \dot{E}$ isso O2?

O2: $\dot{E}$

K: Você tava falando que é uma droga ser adolescente. Sobre esta coisa de ficar se achando feio, você acha que acontece com outros adolescentes, de olhar "Ai Meu Deus, isto aqui está crescendo mais do que isto, isto tá desengonçado, como eu sou feio?"

O2: É porque eu sou estranho. Eu sou diferente dos outros adolescentes.

K: Você acha que você é diferente dos outros em que?

O2: Fazendo uma comparação com o 01, mesmo. Não sei se o cara se acha feio ou não...

O1: Eu acho.

O2: Se se acha forte ou não...

K: Você acha que você é único adolescente que se olha no espelho e reclama de como você é?

O2: Provavelmente.

$\mathrm{K}: \mathrm{O}$ que vocês acham disso?

A1: Eu acho que não. Tem muitos adolescentes que é desse jeito também, que se acha feio, não vive a vida.

O2: Já tentei viver a vida e levei 48 foras!

$K: E$ o que foi esta tentativa de viver a vida? O que é tentar viver a vida?

O2: Eu ia pelo menos três vezes por semana na balada, tentei viver a vida.

A1: Mas também viver a vida não é só ficar saindo, tem muita coisa para fazer que você pode viver sua vida.

$\mathrm{K}$ : Além de sair, por exemplo?

A2: Trabalhar.

O1: E você também não pode se achar bonito se comparando com os outros.

A1: É mesmo.

A2: Você tem que gostar de você mesmo.

O1: Se nem você se ama, quem vai te amar?

O2: Minha mãe!

A2: Tirando ela.

$K$ : E o que mais tem de ruim na adolescência?

O2: Não tem muito tempo disponível.

K: O seu tempo fica em função do quê?

O2: Estudo de manhã, faço lição mais tarde, e de noite, se eu não vou na igreja, aí eu fico em casa fazendo exercício.

(Barulho)

$\mathrm{K}$ : Mas e vocês, juntando com $\mathrm{O2}$, o que acham que tem de ruim na adolescência? 
O1: Quando você quer sair, assim, tem que depender do seu pai, da resposta que ele der. Isso é ruim... e dinheiro também.

O2: Eterno prisioneiro.

A2: A minha mãe que fala "Enquanto você estiver na minha casa você vai fazer o que eu mandar".

A1: Isso ai é horrível!

A2: Aí elas falam "Quando você tiver seus 18, 20 anos, arruma seu emprego, compra sua casa e vai viver sua vida"!

A1: E muitas vezes as pessoas não ouve nossa opinião.

$\mathrm{K}$ : Como assim? Fala um pouquinho mais sobre isso.

A1: Eu não sei te explicar. Por exemplo, você quer a opinião de uma coisa, aí você começa a falar lá, aí ninguém quer saber, porque você é adolescente, sabe? Não ouve o que você tem pra dizer. Aí se vai outra pessoa adulta, eles ouvem! Aí é ruim também!

$\mathrm{K}$ : Se a pessoa adulta fala a mesma coisa que o adolescente, o adulto é ouvido e o adolescente não? Vocês concordam, vocês acham que isso acontece?

A2: O mais velho fala a mesma coisa que você falou, só que em outras palavras, aí: "Ai, é isso mesmo! E não sei o quê!".

O2: Ou repete nas mesmas palavras!

A2: É. Aí eles acham "Você é adolescente não sabe nada da vida, quer dar palpite, por que?"; "Nunca passou por [sacrifício na vida] nenhum".

$\mathrm{K}$ : Por que vocês acham que isto acontece? $O$ que passa na cabeça das pessoas quando não estão nem aí para o que o adolescente fala ou faz?

A2: Acho que porque eles também nunca foram ouvidos.

O2: [Acham que o adolescente é] inexperiente.

A1: De vez em quando o adolescente tem mais experiência que algumas pessoas, tem muito mais experiência... não que já passou, só de ver o que tá acontecendo.

A2: Na família mesmo.

A1 e O1: É.

O1: [Mas tem hora que tratam o adolescente como criança], só pode sair até meia noite!

A1: É, daí dá raiva!

K: Pois é. Algumas horas vocês são crianças, e outras horas vocês não são crianças. Pra

algumas coisas vocês são crianças, para outras não. Então, pra que coisas vocês são crianças?

Juntos: Sair!

O1: Ter muito dinheiro na mão.

K: Não pode ter muito dinheiro na mão porque não vai ter responsabilidade pra usar?

O1: É.

A2: Não pode trabalhar.

O2: [Dizem que o adolescente não pode ter dinheiro porque não vai saber] gastar. Lógico que vai saber.

A1: Eu também sei.

$K:$ e em que casos vocês não são crianças?

O1: No dia das crianças! Não ganhei nada!

A1: Pra fazer as coisas [obrigações]. Na hora de fazer alguma coisa, ninguém é criança, mas na hora de sair todo mundo é criança!

$K:$ E o que vocês acham disso?

O2: Injustiça! 
K: Por quê?

O2: Porque é, ué!

O1: Ou é criança ou não é criança!

A1: A gente também tem direito de viver nossa vida, igual eles vivem a da deles.

A2: Minha mãe nunca me conta nada quando ela era adolescente, essas coisas, mas de vez em quando ela deixa escapar "Quando eu namorava Fulano de Tal, aí ele chegava aqui na esquina, fui ficar com o outro ali" e eu "Ah mãe, a senhora fez, mas não deixa eu fazer!" O1: Meu pai que fala "Faça o que eu digo, não faça o que eu faço".

K: Hum... eles falam isso?

O1: Falam.

K: E que idéia, que imagem vocês acham que os pais de vocês têm sobre vocês? Acham que vocês são o que?

O2: Irresponsável.

O1: Minha mãe fuma e não quer que eu fume. Meu pai bebe e não quer que eu beba. E quem são eles para querer me dar exemplo se eles fazem?

A2: Eu acho que a minha mãe deve ter orgulho de mim. Não tenho muita amizade, sou muito caseira... [mas eu não gosto de ser assim]. Eu gosto de sair, mas só que ela que não deixa. K: Ela não deixa. Então tem como se fosse um jeito ideal, um adolescente ideal, perfeito? Como é que seria este adolescente perfeito?

02: Não sai, fica trancado no quarto, lê o dia inteiro.

A1: É, lê... só fica estudando.

K: Só estuda?

A1: É.

O2: O pai acorda, a casa tá limpa..., fica no quarto...

A2: [Leva o] cafezinho na mesa.

O2: Cafezinho na mesa? Então, eu sou um exemplo!

O1: Eu também, antes de ir para a escola, eu que faço.

O2: Mas eu faço para minha família. Eu acordo mais cedo.

K: Vocês estavam falando dos pais de vocês, que idéia os pais tem sobre vocês e aí o 02 começou falar "irresponsável". O que mais?

A2: Eu nunca saio de casa, é difícil. Eu queria vir aqui no (?), e ela: "Ai minha filhinha, você nunca saiu de casa, por que vai sair agora?". Eu nunca vou crescer para ela. Eu nunca vou ter idade suficiente para poder sair para uma balada...

A1: Minha mãe não é assim. Ela deixa eu sair, ela fala para mim tomar cuidado, de vez em quando ela até sai comigo. Desde pequena minha mãe conversou muito comigo sobre esses negócio.

K: Que negócios?

A1: De adolescência assim. Ela já passou, ela me fala. Ela não fica escondendo. Ela fala tudo para mim. Chega em mim e conversa. Ela é bem minha amiga.

$K$ : E você ia falar alguma coisa, O2?

O2: Minha mãe conversa comigo, tudo mais, mas ela já chegou a me dizer que preferia que eu não tivesse nascido.

(Barulho. Risadas)

K: E por que ela preferia que você não tivesse nascido?

O2: Numa briga que nós tivemos. Foi quando ela descobriu que eu saía de noite.

K: $O$ que aconteceu, ela descobriu...

O2: Ah, "Eu preferia que você não tivesse nascido se for para ser do jeito que você é". 
K: E o que você achou disso?

O2: Já perdoei.

K: Já perdoou?

O2: Já.

K: E eu queria perguntar... a gente tava falando aqui o que tem de ruim na adolescência.

Adolescência é só coisa ruim?

Juntos: Não!

K: Então também tem coisa boa? Então agora a gente vai falar sobre este outro lado da adolescência. O que tem de bom na adolescência?

O2: As garotas.

A1: Festas, assim... que tem muitas festas que são muito legais.

A2: Amigos.

O1: Loucura.

$\mathrm{K}$ : As loucuras, que loucuras?

O1: Ué, sei lá!

(Falam ao mesmo tempo)

A2: Fazer as coisas escondido.

A1: Ficar numa rodinha com seus amigos, conversando, zoando. É legal!

A2: Falar mal da mãe.

A2: Meu irmão fala que a gente só fala besteira.

$\mathrm{K}$ : Ele é mais velho?

A2: Tem 23 anos. Eu falo "Olha quem tá falando". Já foi adolescente. Todo mundo já foi adolescente um dia. Não tem que sair criticando a gente.

$K$ : Então, quem já foi adolescente critica quem é agora?

A1/A2: É.

K: Vocês estavam falando, vamos voltar um pouquinho na história dos pais. Os pais de vocês já foram adolescentes. Vocês acham que têm diferença da geração de vocês hoje, dos jovens de hoje e dos jovens da época dos pais de vocês?

(Falam juntos)

O2: Meu pai quando era adolescente ele pescava...

O1: É! Ó as idéia!

O2: [Jogava] pedrinha no rio.

O1: Catava cobra. - O2: Catava porco.

O1: É.

A1: A violência também [era diferente]. E a minha mãe fala que o namoro, essas coisas, [também]; que hoje tá muito avançado.

O1: Só depois de casar beijava!

A2: "Quando eu namorava com seu pai, era eu aqui, ele na esquina jogando pedrinha. Hoje não. Hoje já querem sair se agarrando"!

O1: E também a educação que eles tiveram antigamente foi muito rígida, né? Não tinha essa liberdade que a gente tem hoje.

$\mathrm{K}: \mathrm{O}$ que mais tem de diferença entre a geração de jovens dos pais de vocês e dos de hoje? A1: A maioria das meninas, não são todas, mas a maioria, são muito assanhadas, muito mesmo. Ela fica com o garoto e já fala (?)...

A2: Ah, tem uma coisa que eu acho errado também. Por exemplo, os menino, fica com um aqui, aí fica outra lá e outra lá, aí tá a turminha de amigos dele. Aí passa as menina. Aí os 
meninos fica zoando "Maior catador, catou aquela, maior garanhão". Aí se a menina faz, fica "galinha, vagabunda, não presta".

A1: É. $_{\text {. }}$

A2: É diferente [isso], entre os adolescentes mesmo.

K: Então quer dizer que existe diferença entre os meninos e as meninas na adolescência?

O1: Quanto mais, melhor.

A2: Pros homens.

O2: Eu não penso do jeito que o 01 pensa. Eu não fico, eu namoro. Eu não sei, se eu tiver uma namorada, eu namoro sério, até que a menina me dê um pé na bunda.

A2: Até casar. Eu já namorei, dá muita dor de cabeça.

O1: Eu não quero casar não.

A1: Também não. Não penso nada em casamento.

A2: Quero ter meu emprego, morar em uma casa e meu marido na outra.

O1: Quero morar em um apartamento sozinho.

O2: Eu [não] aguento morar sozinho. Eu posso morar pelo menos com crianças, porque eu gosto de criança. Por isso eu quero ter meus filhos.

O1: Eu quero morar sozinho para levar quem eu quiser para o apartamento.

A1: Eu também, por causa que muitas vezes quando você quer sair, seu namorado ou marido, né, se você casar, não deixa, e aí você tem que ficar presa, fazendo as coisas para ele, não é certo.

A2: Já viveu sua adolescência, sua vida obedecendo alguém, sua mãe, seu pai, aí o namorado, marido, pra continuar obedecendo...

O2: Isso varia do namorado. Por exemplo, se minha namorada me ama, que ela vai buscar com outro?

O1: Só busca quem não está satisfeita. Tem aquele ditado que diz que "arroz e feijão todo dia, enjoa".

K: A gente tava falando antes uma coisa assim: uma coisa sou eu, e outra coisa são os outros. A gente estava falando no começo "Eu, adolescente, sou uma pessoa responsável, estudo, tal". Os outros adolescentes como é que são? Aí vocês estavam discutindo. Você tava dizendo que a maioria você acha que são mesmo vândalos. Vocês acham que a maioria dos jovens, sem ser vocês...

O1: Eu me salvo.

A1: São poucos.

K: São poucos que se salvam? Por que? O que acontece?

A1: Porque, tipo assim, quando eles saem, eles não saem pra se divertir, eles saem pra ficar arranjando briga com as pessoas. A maioria é assim. Olha pra você e "Que que foi, que que foi?", já começa uma briga.

O2: Os que não são, deixa eu ver bem a palavra, 'vândalos', são, como eu posso dizer, 'putos'.

$\mathrm{K}$ : Como assim?

O2: Um fica agarrado o outro, pulando em cima do outro, fica encochando o outro. Isso enche né?

A1: É.

K: Então só tem isso ou vândalo, não tem mais outra coisa?

O2: Tem sim. Tem boas pessoas.

$\mathrm{K}$ : Como é que são estes bons adolescentes?

O1: Dedicado, obediente. 
K: Aí a gente vai entrar numa diferença. Uma coisa é o adolescente ideal e a outra é um bom adolescente. Existe diferença? A gente tava falando antes do ideal, aquele que não faz nada, que...

O2: $O$ ideal é o prefeito e o bom adolescente não chega a ser perfeito.

A1: É aquele que também gosta de viver a vida dele.

K: Vocês estavam comentando quando tavam falando do adolescente ideal que ia ser um saco ser este adolescente ideal. Você tava falando "Eu não queria ser assim". E este bom adolescente?

Juntos: Eu sou um bom adolescente.

K: Por que vocês são uns bons adolescentes?

O1: Ué...

A2: Porque eu ajudo minha mãe...

O1: Eu também.

A2: Trabalho, estudo.

O1: Eu também.

A1: Converso com a minha mãe.

O2: Eu acho que, sei lá, eu pelo menos não dou tanto trabalho para minha mãe, porque, tá certo que eu não tô mais conversando muito com ela, porque ela geralmente conversa mais com a minha irmã. Eu fico o dia inteiro jogado no quarto lá fora, assisto tv e faço exercício, quando eu volto do Senai.

$K$ : E você O1, você tava falando...

O1: Eu também não dou trabalho pros meus pais.

K: Não dá trabalho?

O1: Um pouquinho dá, né?

O2: [Sou] um bom menino.

K: Eu queria perguntar uma última coisa sobre a adolescência mesmo: vocês acham que tem característica que é só do adolescente? Tem coisa que só o adolescente é, ou não?

A1: Eu acho que não.

K: Não tem característica típica, o adolescente é aquele que faz isso, que o adulto não faz, e a criança não faz?

A1: Tem alguns adultos também que faz as mesmas coisas que nós fazemo. Por exemplo, colocar piercing, tatuagem, tem gente mais velha que põe. Tem gente mais velha que gosta de balada. Então.....

K: Não tem uma coisa que é só da adolescência?

(Concordam que não há uma característica típica)

K: Agora eu queria perguntar uma outra coisa: como é pra vocês ser um aluno adolescente?

A1: É chato!

O1: É da hora!

A2: (...) Você tá na escola, tá pensando "Meu namorado ali e eu aqui estudando"...

O2: Depende da situação.

(Falam juntos)

O1: É bem legal! Aqui [na escola] você faz seus amigos... Brinca pra caramba.

A2: Zoa os professores.

O2: $E$ também depende do aluno. Um aluno "cdf", por exemplo, um bom aluno, pra ele a escola é um saco, ele fica copiando lição durante seis horas, não olha para o lado, mas copia a lição. Já para alunos mais...

O1: ...Despojados... 
O2: ...Pra eles o dia passa rápido, porque eles fica... fica só fazendo "vandalisse".

O1: Pra mim não.

A1: Fica conversando.

O2: Conversa, joga cadeira.

A2: Eu converso assim, mas...

O1: Não somo mutante pra ficar parado!

O2: Mutante não, robô!

A2: Mas tem professores que entra na sala de aula, não quer saber de dar aula.

A1: Quando [o aluno] começa zoar, e começa chutar, aí fala "Aí, se você não parar vou colocar lição na lousa".

02: O Pr2 é o pior!

01: Coitado!

O2: Ele passa lição...

A1: Ele não ensina.

O2: Todo mundo joga bolinha de papel na cabeça dele, chuta ele, abre a camisa dele e ele não faz nada!

A2: Ele passa lição e deixa lá e não explica direito.

A1: E explica rapidão. Se a sala tá bagunçando, ele não quer nem saber. Na minha sala é assim.

O1: [Eu desconfio] que ele tem problemas mentais. Ele já teve três pontes de safena no peito, ele não bate bem.

$\mathrm{K}$ : Mas isso que vocês estavam falando: se a sala percebe que o professor não tá dando bola, que ele continua fazendo, o que acontece na sala?

O2: Alguns copiam a lição.

A1: Mas é poucos na minha sala.

O2: Um ou dois.

A2: Acho que o professor fala assim "Tô aqui pra ensinar, aprende quem quer, vou fazer minha parte".

$K: O$ que vocês acham disso?

$O$ ?: Tem gente que não pensa assim.

A2: Ele tá na razão dele. [Não tem que ficar se matando pra ganhar mixaria, pra ficar ensinando um monte de burro e ainda ficar levando nome, nome feio.]

O2: Tem gente que não pensa assim, que pensa "Eu já consegui ser professor, agora eu fico sentado, vou ganhar meu dinheiro do mesmo jeito".

A1: É mesmo, muitos professores falam isso na sala.

$K: A 1$, você tava falando que é chato ser um aluno adolescente. Por que?

A1: Porque eles cobram muito da gente, muito, muito, muito!

K: Cobram muito?

A1: Na minha sala sim.

A2: Tem professores que faltam com respeito também. Pensam assim "Porque é

adolescente, vou falar mesmo". Se fosse pessoa mais velha que tivesse ali sentado, duvido que falasse!

A1: É verdade!

K: Isso que eu queria saber de vocês. Que imagem vocês acham que os professores têm de vocês, alunos adolescentes?

A1: Acho que eles pensam que nós somo tudo uma merda!

O2: Se pudesse jogaria todos nós no inferno! 
K: Por que?

A1: Por causa que a maioria fica faltando com respeito com os professores. Alguns, nem todos.

K: Por isso esses professores acham que os adolescentes são "uma merda"?

A1: Tipo assim, passa prova, aí todo mundo tira nota ruim... conta muito isso.

O1: Eu acho que nóis também não é santo, não!

K: Por que não é santo?

O2: Tem muita gente aqui que faz muita bagunça.

(Falam juntos)

$\mathrm{K}$ : Antes de continuar, $\mathrm{O} 2$ você estava dizendo que acha que eles queriam "mandar tudo pro inferno". Por que vocês acham isso?

O2: Por que eles ao invés de ver a nossa imagem, de cada um, eles vêem a imagem de todos. Se todos são ruim, nós tamos no meio.

K: Generaliza, acha que todo mundo é uma coisa só? E essa coisa só é o que? É tudo ruim, é tudo o quê?

O1: Não. Se tipo, entre nós quatro, um é bom e três é ruim...

A1: $O$ outro que é bom vai ser [visto como] ruim também.

O2: Uma maçã podre estraga as outras; apesar que eu ainda não estou estragado.

O1: Nem eu.

A2: E às vezes tem uma professora que entra na sala de aula, ela não dá aula né, como eu tava falando... E a turminha das meninas, eu fico com as meninas lá da frente, a gente faz a turminha assim, fica uma muvuquinha...

O1: Eu domino atrás. Lá na sala [é assim] "E aí rapaz, quem é o número 1?" "Eu".

A2: Aí a professora fica falando "Putinha aí, fica falando de macho, não sei o que, só quer saber disso e aquilo outro".

K: Acha que porque tá falando de homem é "putinha"?

A2: É. Tem uma menina que ela começou a gritar, do nada, né? Deu a louca nela, ela olhou pra professora, aí a professora olhou assim para ela e falou "Cala a boca sua vagabunda"!

A1: "Tá parecendo cadela no cio" também.

A2: Aí chamou ela de outros nomes feio, lá.

O2: Então quer dizer que homem pode até ver Playboy e mulher não pode falar de homem?

A1: É.

K: Que a gente estava falando; a diferença entre homem e mulher.

O1: Machismo.

$\mathrm{K}$ : Tem machismo aqui na escola?

O2: Eu sou provavelmente o único homem feminista que tem neste mundo.

K: Você é único homem feminista?

O1: Todo lugar no mundo [só] tem machista.

$K$ : E como é o machismo aqui na escola?

O1: Todas meninas que catar mais de um já...

O2: Mulher não pode falar de homem, mas homem pode falar de mulher.

$\mathrm{K}$ : Você tava falando no caso de uma professora que xingou de vagabunda. Existe isso de xingamento, do professor xingar o aluno de alguma coisa?

A1: [Muito]

$\mathrm{K}$ : Existe muito? Mas eles xingam do quê?

A2: Por exemplo, xingou essa menina de vagabunda, depois de puta..., do nada!

A1: Quando fala assim "Tá parecendo cadela no cio", também. É horrível! 
A2: Na minha sala tem dois casais, né? Os professores ficam perguntando se eles já fizeram alguma coisa...

O1: É engraçado o Pr2, ele chama os meninos de veado. "Vá seus veados do mato, seus veados do asfalto".

$\mathrm{K}$ : Tem diferença?

A2: Do mato é de onde ele morava, do asfalto é da cidade grande.

O1: A professora [de " $x$ " matéria] fala pior: "Fica quieto se não vou enfiar (?) no seu cu".

A1: É.

A1: Tem dia que ela fala, assim, para os meninos, quando tão fazendo maior bagunça,

"Parece que os meninos tá tudo menstruado". Nada a ver! Ela é doidona também.

O2: Lógico, nós perturba eles!

A2: [Ela fala muito] palavrão.

A1: E quando algum aluno fala, né..., manda para diretoria.

A2: [? - falou algo sobre 'bater']

$\mathrm{K}$ : Acontece isso, de o aluno também ir lá, bater?

O2: Apesar que isso nunca aconteceu com Pr1.

O1: Ele é o cara! Esse é o professor mais [respeitado]

$\mathrm{K}: \mathrm{E}$ como ele consegue esse respeito?

A2: Ele dá respeito pra gente, não ofende ninguém.

O2: Ele põe ordem na sala.

O1: O Pr1 é o cara!

$\mathrm{K}$ : E ele tem que imagem de vocês adolescentes?

O1: Ah, ele sempre tenta ensinar o melhor.

A1: É, porque ele fala assim: "Quando você for prestar algum concurso, vai cair isso", ele ajuda bastante. Apesar que as aula dele é meio chata, porque ele só fala a aula inteira.

O2: Quando eu fui fazer a prova para entrar no Senai, ele foi quem mais me ajudou. Ele [me indicou os] livros "Usa este livro, este livro, que tem tudo". E ele ainda falou "Nestas provas sempre cai $A B C D$, se você não conseguir, você faz a regra do chute, a que você viu que não tinha nada a ver, as que sobraram você tira no dois ou um".

K: Então, vocês tão falando que ele tem um respeito e ele respeita o adolescente? Pelo que vocês tão falando, parece que ele tá se preocupando com vocês.

?: É, se preocupa.

O2: Dependendo da aula, ele brinca com nós também.

(Falam juntos)

A2: Ele é sério.

A1: Tem alunos também que não dá nem pra brincar.

A2: Na minha sala, acho que é a sala que tem mais vândalos, né? Aí a coisa mais difícil que tem é ele dar um sorriso na minha sala de aula.

K: Mas o que você estava falando é que ele impõe limites, então?

O2: É.

K: Como é que ele impõe esse limite? É gritando?

O1: Não!!

O2: Não, teve um dia que jogaram um lápis nas costas dele, ele mandou metade da sala para diretoria. Ele falou "Deixa eu ver quem eu acho que jogou. Você, você, você". Depois a D

falou "Quem aqui tem mais manha, lábia? Você pode sair, você também pode".

K: Então quer dizer, parece que ele respeita e é respeitado, pelo que vocês estão falando... 
A1: Não, ele não é o mais respeitado. Assim, porque ele tem o hálito ruim, aí fica todo mundo zoando.

O1: Não, não é hálito, ele tem um problema no esôfago. Mas nunca vi ninguém chegar [e dizer na cara dele que ele tem bafo ruim, xingando ele, por exemplo].

A1: Eu já vi.

K: Mas na sala de aula, enquanto ele tá dando aula, acontece isso que vocês tavam falando, de jogar papel..

Juntos: Na aula dele, não!!

O2: Se jogar, acontece a mesma coisa que eu falei, vai metade da sala para a diretoria!

K: Então esse tipo de respeito tem? Vocês tavam falando que tem professor que parece que não ta nem aí, daí os alunos não respeitam, mas ele não. Na sala de aula....

A2: Tem vezes que ele manda todo mundo calar a boca, e se alguém jogar um papel, ele humilha mesmo as pessoas!

O2: Ele tem uma cultura muito grande também. Fala espanhol, latim, francês. Escreve em grego, lê em grego!. Ele tem mó cultura, ele passa uma segurança!

O2: Uma professora que eu acho que põe ordem também é a Pa1. Ela põe ordem, até bate se for o caso!

O1: Ah, ela já deu uma porrada --

(Falam ao mesmo tempo)

A1: Ela brinca bastante.

O1: Ela bate brincando. Não é uma agressão.

A2: Mas quando é pra falar sério, ela [também é] séria.

O2: Eu gosto dessa professora, porque ela faz a gente fazer força, mesmo. Ela é quem faz a gente fazer exercício de verdade. Ela não é aquela professora que pega uma bola e faz assim (gesticula)

A?: [Não só fala] "Faz o que você quiser".

O2: Ela não. Manda a gente fazer abdominal, pra gente ficar com o braço forte.

A1: Ela fala assim, que é pra gente fazer o exercício pra ficar "com a barriguinha bonitinha no verão". Pra gente não passar vergonha.

K: Então, vocês acham que ela tem um cuidado, assim, com vocês?

O2: É. Ela é uma ótima professora!

A1: É mesmo!

A2: Mas no outro dia ninguém consegue andar!

O1: É, isso, é!

O2: É o efeito, você tem que ficar assim por uma semana, mas depois...

(Falam juntos)

K: Eu queria perguntar mais uma coisa. A gente tava falando da visão que os professores têm de vocês. Tem professores que parece que respeitam, tem professores que parece que respeitam menos, que dizem que adolescente é isso, é aquilo, a menina adolescente é chamada de 'vagabunda'... e os meninos? Vocês falaram mais das meninas.

A2: Elas não são loucas de falar nada para os meninos!

A1: Os meninos ameaçam até de matar. Ano passado uma professora, não lembro quem era, foi ameaçada de morte, porque foi falar lá de um menino.

K: Então acontece isso dos meninos não serem muito insultados... e vocês acham que os professores têm medo dos meninos adolescentes?

O2: Tem.

$\mathrm{K}$ : Todos professores? 
A1: Não.

O2: Depende do aluno. $O$ aluno, por exemplo, eu. Ela sabe que eu sou inofensivo, eu não vou matar ela. Na verdade tem muitos professores que têm medo. A Pa2, se você chega nela e fala "Aí, se você não me der dez conto e cinco [notas] "A" no semestre, eu te mato". Ela pega a carteira, te dá cem conto, te dá sete "A"!

K: Então vocês percebem quem são os professores que têm medo, os professores que não têm...

A1: A Pa1 não tem medo não! Nem um pouquinho!

$K$ : $E$ o que vocês acham que a Pa1 pensa de vocês adolescentes, que vocês são o quê?

O1: Máquina!

O1: Em qualquer um, ela chega chegando!

A2: Ela não tem muito diálogo com a gente, ela passa os exercícios e pronto. Conversa um pouco, mas...

$\mathrm{K}$ : Mas, você tava falando que você não gosta muito dela. Por quê?

A2: Não é que eu não gosto dela, são os exercícios que ela passa.

O2: Sai toda doída depois.

A1: Eu gosto dos exercícios dela.

O2: Eu gosto.

O1: Eu também.

A1: Só que tem dia que ela pega muito pesado.

A2: Pega pesado demais!

O2: Eu gosto principalmente quando ela pega pesado, porque, depois mesmo que fique doendo, você fica mais forte. É porque eu não faço só o exercício dela. Faço exercício em casa,também.

K: A gente tá aqui falando da visão dos professores. E a diretora? Vocês acham que ela acha-

O2: É aquela que parece a Marta Suplici ou a outra?

A1: A que parece a Marta Suplici nunca tá aqui.

O2: É, nem aparece!

K: É a D, a que vocês dizem que parece a Marta Suplici. Então, vocês não sabem direito quem é a diretora?

A1: Pensei que é a $C$, lá.

$K: A D$ é diretora e a $C$ é coordenadora.

A1: A diretora nunca tá aqui!

O1: É. Nunca tá aqui!

O2: A D na verdade é meio arrogante!

O1: Eu só vejo ela quando vou para diretoria, só.

O2: Eu também. Ela é meio arrogante.

K: Arrogante, como é que é? Por exemplo, quando vai para diretoria. Só tem contato com a diretora quando vão para diretoria porque são levados pra lá por algum motivo?

A?: Eu nunca [tive contato] com ela.

O2: Ou quando vai pedir giz, alguma coisa... Mas se você chegar na frente dela, ela já fala "Que que você fez agora? Mais uma, você está expulso".

$K:$ Então, ela não ouve--?

A2: [Só faz] mandar.

K: Então não tem muito contato?

O2: Ela pensa que manda mais [aqui na escola]. 
O1: Ela não pensa, ela manda, ué! Fazer o quê?

K: Então quer dizer, às vezes vocês podem chegar na diretoria por qualquer outro motivo, não tem nada a ver com o que fizeram na sala de aula, ela já vai achando que vocês fizeram? A1: Pra mim, não.

O2: Se você falar simplesmente que veio pedir giz, ela fala "Que que você tá fazendo aqui, que que fez desta vez?"!

O1: Ela até me conhece já.

K: De quando você foi na diretoria? Como é a reação dela quando a pessoa vai para diretoria?

O1: Normal ué! Senta e --

O2: [Quando] vai pra diretoria porque brigou ou pra pedir alguma coisa?

K: Porque brigou.

O2: Daí ela não pergunta o motivo.

K: Não?

O2: Não.

K: O que ela faz então?

O2: Ela simplesmente olha assim..., dá advertência para os dois ou suspensão.

A2: [Sem saber o que aconteceu.]

$\mathrm{K}$ : Sem entender o que aconteceu.

O2: Já a C é tão legal!! Ela fala "Por que vocês brigaram?" Daí, se tipo você fala, ["Eu tava quieto no meu canto,] daí ele veio e enfiou o dedo no meu olho". Daí ela vai mandar eu para a sala e dar advertência para ele. E ainda vai falar parabéns para mim!

A2: E ela ainda fala "Por que você fez isso, não faça isso com seu amiguinho"! Tenta fazer a união.

K: Então tá. Qual a diferença entre D e C?

A1: Porque a $C$ sempre tá presente!

O1: Ela é legal!

K: E como é esse jeito dela estar presente? Tão falando que ela entende mais--

A2: Ela está pra ajudar a gente.

A1: O dia que eu tava passando mal e queria ir embora, só que não podia ir sozinha, né, aí ela foi lá, ligou na minha casa, pediu pra minha mãe me buscar, minha mãe veio, aí ela ficou conversando com minha mãe...

O1: Ela ouve a história, e fala pra você consertar. Ela fala "Você vai fazer de novo?" "Não" "Se fizer de novo vocês sabem né?"

A1: Ela ouve!

O2: Ela dá uma segunda chance!

K: Vocês estão falando que ela ouve e dá uma segunda chance. Isso de ouvir é importante, vocês tavam falando--

A1: E dá conselho.

$K$ : Vocês tavam falando antes que "Ai Meus Deus, ninguém ouve o que o adolescente fala" $e$ vocês estão falando aqui de uma pessoa que ouve o que vocês têm a dizer; e parece que isso faz toda a diferença, pelo que vocês tão falando...

O2: Ela é extremamente melhor! É aquela pessoa que se você abraça ela, ela te abraça de volta, você beija ela, ela te beija de volta.

A1: Os meninos brinca com ela, ela brinca também. Quem tinha que ser diretora era ela!

O2: Ela é a diretora ideal!

A1: É. 
K: Como é que é então, uma diretora ideal?

O2: Ela!

A2: Eu acho que se ela fosse a diretora ela seria [toda grossa].

$\mathrm{K}$ : Como assim? O que ia mudar?

A2: Eu acho que quanto mais alto no topo você estiver, mais você vai estar... Tipo a diretora e ela, ela é a vice. A outra é a diretora, né?

$\mathrm{K}$ : Vocês concordam com ela, que quanto mais alto...

O1: É, ué !

A1: Eu acho que depende da pessoa. Eu acho que ela ia continuar a mesma.

O2: Ia mesmo!

$\mathrm{K}$ : Existe diretora boa?

O2: Existe.

A2: Ah, existe. Eu já tive!

K: Então quer dizer que a diretora pode estar lá no topo...

O2: A diretora da minha antiga escola, ela até me dava carona para casa, me emprestava dinheiro, era legal.

$\mathrm{K}$ : E os funcionários aqui? Tem a Fa, que é inspetora...

O2: O Fo2 é legal.

K: Quem é Fo2? Também é inspetor de alunos?

A1: É. A Fa tem um jeito chato. Ela não fala meu nome, já fala brigando!

$K: E$ vocês acham que ela acha o quê sobre o adolescente?

A1: Não sei, porque eu acho que ela também é. Ela tem uma carinha de criança!

O2: Agora o Fo1 é muito legal.

O1: Ele é legal, que ele conhece a escola inteira!

$K: A 2$, o que você ia falar?

A2: Que acho que a Fa tem uns 18 anos.

K: Então ela é adolescente?

A1: É

O2: O Fo1, ele é muuuiiiito legal mesmo, muito louco! A gente passa na rua "O Seu Fo1, tá indo pro bar?", e ele "Não, vou comer um lanche, vou comer um lanche". O cara é legal! O2: A Fa é a única funcionária que não é uma boa funcionária, quer dizer, não é muito legal. Tipo, quando eu fui buscar a caixa de som lá [pra usar lá] embaixo, aí cada vez que encontrava com ela "Vai pra sua sala, vai pra sua sala, vai agora pra sua sala, tchau, some"! A2: Ela fala com arrogância!

sente adolescente!

A1: É.

K: Por que você acha isso?

A2: Porque ela brinca com todo mundo, fala de igual para igual!

O2: Ela volta a ter 15, 14 anos. É legal!

K: Diferente de D?

(Muito barulho externo)

K: Como vocês estavam contando do outro professor que não coloca limite, daí todo mundo aproveita...

O2: Se você não impor respeito, aí ninguém vai te dar respeito. Você vai ser zoado, vai tomar tapa.

A2: Quem quer respeito, tem que dar respeito também.

$K$ : E parece que isso não é assim só aqui na escola... 
O2: Ah, mas [é importante] esse negócio de dar respeito; tem que ter respeito.

A2: Claro que é!

O2: O Pr2, quando ele chegou, ele respeitava todo mundo. Ele chegava "Oi, não vai ter lição hoje"!

O1: É.

O1: Às vezes dá até dó!

A1: É, dá maior dó!

A2: [Mas tem sala que se] aproveita disso.

O2: É, oitava D é a pior sala. O Pr2 quase sempre chora.

O1: Ah não é. A oitava $A$ é pior.

O2: O Pr2 chega [e parece até que quer] chorar.

A1: Dá maior dó.

$K$ : Então vocês tavam falando que a oitava $D$ é a pior, qual que é a pior?

O1: Não, não é. Na oitava $D$ quem faz zoeira é só o $X 1$ e o X2. Na minha sala é o X3...

O2: É só? X4, X5, X6, X7 ... [fala o nome de vários alunos], o X8, não, porque é aluno novo. $E$ todos, todos, todos. $X 9$ não zoa, mas só que é zoado.

K: Mas vocês acham que existe entre os professores essa idéia de qual é a pior oitava série?

O2/A2: Existe.

O1: A nossa é a mais melhor.

A2: $A$ oitava $D$ sempre foi a pior. Agora a oitava $D$ tá em primeiro, a $C$ em segundo...

A2: [Eu acho que] é a $B$.

K: E a oitava A?

O1: É só de repetente.

A2: Ninguém fala da $A$.

A1: (?) vai ficar igual eles, repetindo.

O2: A oitava $A$ é uma boa sala, porque eles repetiram, então eles já têm o exemplo, não querem repetir de novo.

K: Você acha?

A2: Alguns, acho que vão repetir tudo de novo.

A1: Também acho.

A2: Eles não conseguem aprender, não porque eles não querem, porque, tipo [se já passou de ano, mesmo...]

O1: [Acho que é porque] não tem QI alto.

K: Você diz que acha que eles não aprendem porque eles pensam "Pra que aprender?" e você tá dizendo que é porque não tem $Q I$ alto. O que vocês acham?

O2: [Acho que eles] têm capacidade.

A1: Também acho.

O2: O mesmo tanto de capacidade que todo mundo tem. Mas simplesmente não usa seu potencial.

K: $O$ que vocês acham, não só na oitava $A$, mas em qualquer oitava, quando o aluno não aprende, o que acontece pra que isso aconteça?

O2: Ele não presta atenção.

A1: Falta de interesse.

O2: Ele não quer.

A2: Eu acho que é também a companhia que fica ao redor. 
O2: Ah, mas só que tem gente que tem coordenação motora suficiente pra escrever $e$ conversar ao mesmo tempo.

A2: Que adianta você escrever -

O2: [Tem que chegar em casa e estudar]. Eu chego em casa, eu leio o que eu fiz.

A1: Eu não.

K: Vocês falaram de três coisas: falta de interesse, falta de vontade, que é a mesma coisa ou ficar conversando com outras pessoas ou falta de QI, capacidade.

O2: Capacidade todos têm.

K: Algum de vocês já chegou a repetir o ano?

A2: Eu já. Onde eu estudava, no $E$, os professores davam prova, mas pra ficar livre logo de você, se você tirasse nota baixa, ele metia logo um 10. Aí eu burra pensei "Não aprendi nada". Daí tinha uma última prova, um provão, eu faltei e aí eu repeti, pra recuperar.

$\mathrm{K}$ : Por que você acha que foi burrice?

A2: Porque eles ensinam sempre a mesma coisa!

O2: Aluno que quer, aprende!

K: E depende só do aluno?

O2: Do professor também. Se o professor for bom, tipo o $\operatorname{Pr1}$, tem gente que não aprende nada na aula dele; fica quieto, mas também não faz lição. Quem quer aprender na aula dele, vai aprender com certeza!

A1: É mesmo!

K: Vocês acham que depende um tanto do professor, um tanto do aluno? É isso?

O2: É, mas já com o Pr2, mesmo quem quiser aprender, não vai aprender nada!

A1: É mesmo, porque ele não sabe explicar.

O1: Falaram que ele é ex-policial, quis virar professor agora. Não tem nem --

O2: Eu acho que ele é samurai, porque ele tem um corte aqui na barriga.

O1: É ponte de safena.

A1: Ele passa umas coisas que não tem nada a ver.

A2: O professor $\operatorname{Pr1}$, ele é assim: quanto mais você souber, mais ele quer que você saiba.

Porque assim, na aula dele eu tirei uma nota vermelha. Aí ele olha pra mim "A2, você tá ruim hem, vai, se esforça, não fica atrás". Quanto mais ele puxar de você, melhor.

$K$ : Essa idéia do que acontece que o aluno não aprende. A pergunta não é nem por que o

aluno não aprende, mas: o que acontece para que não tenha aprendizagem, ou pra que tenha repetência?

O2: Depende.

A2: Preguiça de vir pra escola.

O2: Às vezes o aluno não aprende porque não quer, às vezes porque o professor não ensina.

$\mathrm{K}: \mathrm{O}$ que mais?

(Silêncio)

K: Vocês acreditam que a pessoa nasce com uma inteligência e então tem gente que nasce com inteligência, tem gente que nasce burra?

A1/A2: Não.

O2: Não. Na verdade, eu tenho a mesma inteligência que ela, que ele...

A1: Só que tem que saber usar.

O2: Tem que saber usar.

A2: Mas tem muita criança que nasce superdotado né, sabendo o nome dos países, tudo.

Coisa que [eu, por exemplo, teria que] ralar se eu quiser aprender.

O1: Mas tem gente também que nasce com retardamento mental. 
K: Mas o que é saber usar a inteligência?

O2: Saber usar é tipo, você [tá vindo pra] aula. Você não vai ser idiota o suficiente para não aprender. Você não vai ser idiota o suficiente pra acordar cedo, sair da sua cama, vir pra escola, agüentar aquele bafo horrível do professor e...... não fazer nada?!

A1: Eu concordo. Melhor ficar em casa.

A2: E outra coisa também sobre usar a inteligência. [Por exemplo] o professor fez uma pergunta, aí perguntou pra mim e eu, pra não forçar muito a cabeça, falei que não sabia. Quando eu cheguei em casa [pensei] "Eu sabia, porque eu não pensei um pouquinho pra responder?"

A1: De vez em quando também é medo de arriscar, responder errado.

K: E esse medo? Vocês acham que existe na sala um medo de falar uma bobagem?

(Falam juntos)

A2: Vergonha.

A1: Assim, quando eu fico pensando comigo, eu vejo que tava certa, mas não gosto de falar.

O2: Qualquer pergunta que o professor faz pra sala inteira responder, eu respondo

baixinho, mas só que depois os que ouve, fala o que eu falei, se aproveita da minha resposta. A2: É

K: Mas, e se uma pessoa vai e responde uma coisa errada, o que acontece na sala de aula?

O2: Todo mundo zoa ele.

A1: É mesmo.

O1: Eu não tô nem aí...

K: Mas existe muito aqui nesta escola, isto de dizer "Olha, aqueles ali são repetentes, são burros". Existe isso de burrice aqui?

O2: O professor [falou pro pai] "Olha, seu filho, não vou falar que ele é burro, mas não é inteligente".

K: Já ouviram isso de outros professores também?

A1: Eu já ouvi.

A2: Eu nunca ouvi.

O2: O Pr1 faz a mesma coisa: "Ele não é burro, mas também não é inteligente. Mas se ele quiser aprender alguma coisinha, pode aprender, mas isso não significa que ele é inteligente". Ou seja, chamou o cara de burro, indiretamente.

$K:$ E essa ameaça aí de que se vocês não estudarem viram como os repetentes da oitava $A$, como é isso?

O2: Eu não tenho medo.

A1: Eu também não.

O2: Minha maior preocupação não é isso. Minha maior preocupação é repetir de ano, daí eu vou ter que sair do Senai. Se for pra ficar na escola, posso ficar até os 50 anos na escola. A1: Minha maior preocupação é, tipo, [quando] eu passar de ano, porque isso aqui é muito abaixo do nível, eu tenho medo de chegar lá depois e não saber nada. Ano que vem vou pra outra escola. Mas eu não vou estudar aqui não, tá muito ruim.

$K$ : Vocês acham que o ensino daqui está muito ruim?

A1: Eu acho, mas não é os professores que faz a escola, é os aluno.

O2: Apesar que na escola inteira eu só acho que tem dois bons professores que é a Pal e o Pr1. E a Pal ainda é de (" $x$ " matéria). Se ela fosse de matemática, eu já teria aprendido! $K$ : Vocês tavam falando que quem faz a escola, o ensino, é o aluno, mas agora vocês estavam falando esta história de que o professor também conta. E a direção, coordenação, não conta? 
O1: (falou algo do tipo que a diretora nem aparece na escola)

O2: Depende da diretora. Tipo um aluno que briga, vai pra diretoria uma vez, aí de novo, de novo, mil vezes. Aí "Se você for mais uma vez pra diretoria, você vai ser expulso" e ele "Se eu for expulso, eu nunca mais vou poder sair de casa, minha mãe vai me odiar".

A1: Mas tem alguns que não pensa assim não.

A2: Antes de ser expulso não tão nem aí.

O2: Pior que eu não posso dar o mínimo trabalho pra minha mãe. Qualquer coisa que ela manda, eu sou obrigado a fazer. Não tem outra alternativa, porque se não, ela vai ter uns problemas [de saúde]. Ela já teve [um problema]. Daí se ela irritar muito, eu tenho medo do que pode acontecer.

K: Agora eu quero perguntar uma outra coisa. Vocês tavam falando da imagem que os professores fazem de vocês alunos.

O2: Péssima imagem!

K: Por que péssima imagem?

O2: Porque eles tão sentados aqui e o $O 1$ ali; e o $O 1$ levanta e joga uma cadeira. $O$ professor vai olhar "Esses alunos! Esses alunos... meu Deus do céu, são vagabundos"!

K: "Estes alunos são vagabundos". Vocês acham que o fato de vocês serem adolescentes influencia nesta imagem que eles têm do aluno?

A1: Eu acho que sim.

O2: Sim.

A2: Eu acho que sim, que nem ele falou, ele tá quieto, ele joga a cadeira. Aí acho que o professor associa "Um faz, todos fazem".

A1: É.

K: Mas isso ai é por que é aluno... é adolescente... ou é aluno adolescente?

O2: É tudo.

A1: É porque é adolescente.

O2: Se fosse um adulto, por exemplo, de 30 anos que pegasse uma cadeira e jogasse, 0 professor ia dar risada.

A1: Ou se fosse uma criança. Eles iam conversar com a criança.

O2: Iam falar "Você é um menino mau".

A1: É.

$\mathrm{K}$ : Junta o que eles acham sobre adolescente, aquelas coisas ruins que a gente tava falando de vândalos, e junta o que acha dos alunos e fica esta mistura de coisas: "Aí é porque é adolescente, que faz isso"--

O2: Fica aquela péssima imagem.

A2: Tem professores que falam que aluno adolescente é revoltado.

$K: O$ que vocês acham disso?

O2: Existe adolescente revoltado.

A2: Não é só o adolescente revoltado. Tem muita gente que é revoltado com a vida, revoltado com alguma coisa, não é só o adolescente.

O2: [É, mesmo] Por que você acha que têm pessoas que matam?

A2: É.

K: Então não é uma coisa que é só da adolescência? Porque existe uma coisa que é assim: porque é adolescente é revoltado. Vocês acham que existe associação?

A1: Não.

O2: Mas na verdade existe mais adolescentes revoltados que adultos. Adulto revoltado tem sua própria vida. Ele é revoltado, sei lá, ele deve ter suas questões. $O$ adolescente, ele vai 
ser revoltado porque alguns pais não gostam dele, por causa dos professores, porque só tira nota ruim, só toma fora...

A1: Por causa que os amigos ficam zoando.

A2: Você é revoltado, O2?

O2: Um pouco.

K: A questão toda é achar assim, por exemplo: "Porque é adolescente então é...", aí vem um pacote de coisas. Então é isso que a gente tá questionando. Será? Eu tinha perguntado se vocês acham que têm características só do adolescente e vocês tão falando que não. Existe uma coisa que pode ser revolta em relação ao mundo, que criança, adolescente, adulto pode ter. Não é porque é adolescente que é revoltado... É isso que vocês tão dizendo?

Juntos: É.

K: Tem mais alguma coisa que vocês queriam falar sobre a experiência de ser adolescente? A1: Ah, eu acho ótimo!

K: Vocês tavam falando sobre o que têm de ruim; e sobre o que têm de bom, vocês falaram "Sair à noite, conhecer gente nova, novas experiências". O2, o que você acha que tem de novas experiências na adolescência?

O1: Sexo.

A1: Eu ia falar isso.

O2: É que eu não achei a palavra adequada.

$K: E$ 'sexo' não é adequado?

A1: Melhor que falar outra coisa.

O2: Mas não é fazer sexo, é imaginar sexo.

A2: Se eu falar [essas coisas], minha mãe me mata!

O2: Porque creio que ambos os homens aqui já teve aquela fase de se trancar no banheiro $e$ ficar lá 2, 3 horas.

O1: Vixi! 3 horas é bastante!

K: Mas e essa coisa que você tá falando "Minha mãe me mata se eu falar sobre essas coisas"? Então ainda existe hoje? Vocês tavam falando da diferença dos pais de vocês quando eram jovens, que não podia nada e aí hoje é tudo liberado, só que ao mesmo tempo-A2: Alguns pais prendem. Minha mãe nunca conversou comigo sobre isso. Graças a Deus que eu tenho uma irmã.

O2: Meu pai, por exemplo, pergunta. "O2, você tá fumando O2?" Se eu falasse que sim, ele não ia falar nada. Ele fala "Você já bebeu, O2?" "Você sabe pai, bebo champagne todo Ano Novo" e ele "Já caiu de bêbado, O2?" e eu "Uma vez". Isso aconteceu comigo duas vezes, mas eu só contei uma. Ele pergunta, mas ele não cobra. Ele fala o que é melhor pra mim, mas ele não cobra nada. "Se você quiser ir numa balada, se você quiser transar, à vontade, mas depois acerta as contas com Deus".

A1: Mas fala assim--

A2: ...Porque ele é um homem.

A1: Isso que eu ia falar agora. Pra mulher eles não falam nada disso.

A2: Muito pelo contrário.

$\mathrm{K}$ : Como é que é?

A2: A preocupação da mãe é a barriga.

K: É a barriga a preocupação da mãe? Que mais?

A1: Eu acho que não é legal você engravidar cedo, por causa que você perde a sua vida, vai ter que ficar criando uma criança. Eu acho que não é legal.

$\mathrm{K}$ : Mas é só por causa da barriga que pra mulher é diferente? 
A1: Pode ficar [falada]. Porque tipo assim, falam né - eu não sei - que quando você começa a fazer..., você não consegue mais parar. Pode ficar com, tipo,

O2: A honra [pode ficar suja]

O1: [Tem a] DST.

$K$ : Agora assim, mulher e homem podem pegar DST, mas existe aí uma outra diferença que a gente tá falando: por que pro homem que também pode pegar a doença, é permitido ter relação sexual, sem que ele fique com uma fama ruim...?

O2: O meu pai todo dia chega e pergunta "O2, você ainda é virgem, você ainda é virgem?"

K: Tem essa preocupação, então?

O2: Ele fala com aquele sorriso querendo ouvir um "Não". Quando minha irmã está com o namorado dela, meu pai sobe no quartinho que tem lá em cima e fica olhando assim por um buraquinho, olhando os dois, qualquer coisa assim, que tenta descer a mão, aí meu pai desce "Vai embora, cachorro".

K: Aquilo que o 02 tá falando tem tudo a ver com o que a gente tava falando de diferença de homem e mulher. $O$ homem tem toda essa cobrança da sociedade "O homem virgem não pode, com tantos anos já tem que ter tido relação sexual e a mulher não, tem ficar virgem". $O$ que vocês acham disso?

O2: Virgem até o resto da vida.

A?: Guardar pra terra.

A2: Tem homem que não é virgem, não é nada, e a menina gosta do cara, se entrega pra ele, e aí o cara tá numa rodinha e a menina passa "Era cabaça, era virgem, tirei, não vale mais nada. É uma vagabunda agora". Eu já ouvi.

$\mathrm{K}:$ O1, concorda?

O1: Eu acho que é mais certo o homem ter mais liberdade do que a mulher.

A1/O2: Eu não acho.

O1: Eu acho que a mulher é diferente. Sei lá, é mais sensível.

O2: É mais pura.

O1: Se ilude mais fácil e... se apaixona muito rápido.

O2: É mesmo.

$\mathrm{K}:$ E vocês, mulheres, o que acham disso?

O1: Você dá um beijo nela e ela já [quer casar daqui uma semana].

A1: É mesmo.

A2: Eu sou assim.

A1: Eu não. Eu já me iludi fácil... porque mulher sofre muito quando ela se apaixona. É difícil ela terminar o namoro --

O2: Homem quando não tá mais apaixonado por uma [mulher, se já passa] na esquina e tem outra, tá apaixonado [pela outra].

O1: É.

A1: É difícil homem se apaixonar. Eu acho.

(Falam ao mesmo tempo)

O2: Eu me apaixonei ciiinco vezes. Levei três foras. Dois não foram fora [só um]; eu namorei com ela por três anos. Ela destruiu minha vida quando terminou.

A1: Eu acho super legal homem falar isso.

K: Vocês tavam falando mulher é tudo isso, homem é tudo aquilo. O 02 acabou de dizer "Eu sou homem e penso uma coisa que não é isso". 001 tava falando "A mulher dá um beijo e quer casar". Será que toda mulher--

A1: Não. 
O2: Só as inocentes.

A2: Eu acho que os homens querem as mulheres assim como--

O2: Objetos.

A2: Vaso de cristal, que se cair vai quebrar, tem que ser cuidadinha. Não se tocam que as mulheres estão tomando conta.

K: Será que a mulher é esse potezinho de cristal, frágil, indefeso?

A1: Não.

O2: É exatamente por isso eu sou um homem feminista. Enquanto os homens estão no poder, ele se acha. E quando as mulheres estiverem no poder? Quando cada mulher que estiver no poder mandar em alguns homens, pelo menos nos mais--

O1: Babacas.

K: E será que não existe mulher que já está no poder?

A1: A minha mãe que diz que tá no poder.

K: Porque você está falando "No dia em a mulher chegar". Mas será que não existe?

O2: Por enquanto, tem algumas mulheres no poder, mas daqui a um dois, sete anos,

provavelmente todas as mulheres vão estar no poder ou então pelo menos igualitariamente, em comum acordo. Porque este é o meu mundo, onde as mulheres e os homens são contentes e pacificamente amorosos.

A1: É legal isso.

O1: Eu acho que a mulher nunca vai dominar o mundo, rapaz!

A1: Por que não?

O1: Sei lá, meu! --

A1: Se você pensa assim, vá para a Síria, ou Arábia, onde os homens mandam nas mulheres!

A2: O1, você falou que "Eu acho que as mulheres nunca vai dominar o mundo", mas cuidado que elas já podem estar dominando!

A1: É mesmo!

K: Na política como é que tá isso?

O1: Só tem a Marta de mulher.

A1: Nossa prefeita, por exemplo, é mulher.

A2: A Marta só não vai ganhar porque [só quer saber de enfeitar a cidade]; ninguém come cimento ou come pedra. Quem vai ganhar é o Serra, com certeza. Mas não por ele ser homem; pelas idéias dele.

A1: É que nenhuma mulher se candidatou à presidência. Se se candidatasse, poderia ganhar.

A2: A Vani do Partido Verde.

O1/O2: É do Prona.

O2: Partido Verde é aquele cara lá, o Papai Noel.

O1: Enéas é do PAN.

O2: Não, eu tô falando aquele cara lá.

(Falam sobre a fisionomia do político, ironizando e dando risadas)

O1: [E aquela propaganda do "Peroba neles"! Ridícula!]

K: Então assim, vocês estão por dentro do que está acontecendo na política.

O1/O2: Eu tô.

O1: Se não me engano, se a pessoa ela não tirou o título de eleitor (? - barulho externo)

O2: Se não tira título de eleitor, fica um pouco mais difícil para arranjar serviço, trabalho.

O1: Você viu o Canoa? Não sei como esses cara se candidata.

A1: É mesmo

O1: Fica só lendo, não tem naturalidade, não sabe falar, não tem idéia própria. Ridículo! 
K: Vocês estão com quantos anos agora?

O1/A1: 14

O2: 15

A2: 16

K: Vocês podem tirar título de eleitor aos 16 . E aí, o que vocês pensam, vão querer tirar?

O2: Eu vou querer tirar e vou querer votar.

A1: Eu não vou querer, porque, sei lá, eu acho muito chato. Por enquanto eu não quero não.

Só quando for preciso mesmo, obrigatório. Aí sim.

K: Você acha chato?

A1: Eu acho, tem que ficar assistindo aqueles políticos. Ai, é horrível!

$K:$ E vocês, assistem?

A1: Eu não assisto não. Só vi acho que no Fantástico.

$\mathrm{K}:$ O1, você vai querer tirar o título de eleitor?

O1: Eu vou. Eu adoro política!

O2: Todos nós temos que votar no melhor pra nossa cidade. Porque se nós fica pensando assim-

O1: [A gente precisa exercer] nossa cidadania.

O2: Se ninguém for votar, voto em branco, em branco, em branco, em branco, vai pro que tá ganhando.

O1: Mas a Erundina é muito esquisita. Parece o Pingüim do Batman.

K: O1, você falou que gosta de política, né? Você vai querer seguir uma carreira política?

O1: Eu vou.

O2: Vai ser governador.

O1: [Quero ser juiz e ir pra política] Aí já vou conhecer leis, tudo, já vai ser mais fácil.

$K: E$ o que você vai querer fazer quando chegar na política?

$\mathrm{O} 1: \mathrm{Ei}$, até lá tem muito tempo pra pensar ainda!

O2: Você vai ser o quê? Senador, presidente?

O1: Vou me candidatar pra governador de São Paulo.

O2: [Já pensou se só tiverem] mulheres se candidatando?

O1: Vou fazer um protesto!

K: E essa idéia de que adolescente não quer saber de política, que adolescente é alienado?

O2: Nada a ver! Tô sempre discutindo com a minha mãe pra ver quem é o melhor político.

Ela fala que é o Serra e eu falo que é a Marta.

O1: Não gosto do PT, não.

A1: Eu odeio política! Não converso de política.

O1: A Marta tem [o problema do] secretário. O secretário da Marta é o do Pitta.

O2: Mas ela provou... ela fez os CÉUS, fez 21 CEUs.

O1: 21 CEUs, mas você vai lá e não tem vaga pra entrar! E aí?

O2: Duas faculdades. Não, a maioria dos meus amigos estão lá.

O1: O Serra fez o melhor programa do mundo!

A2: E ele não era nada.

O1: Ministro.

K: Você tava falando que tem amigos que tavam no CEU...

O2: Muitos amigos.

K: Vocês conhecem alguém que tá no CEU?

O2: Muitas pessoas...

A1: $E$ umas meninas que estudavam aqui, agora tão lá no CEU. 
O1: [Minha prima diz] que esse CEU parece o inferno.

O2: É nada, o que parece um inferno é esta escola de latinha. Lá no CEU é tudo perfeito.

Tem cinema, quadra, teatro...

A1: Piscina.

O2: Eu tô aprendendo a tocar violão lá no CEU.

A1: Eu [queria fazer (?)], só que tava cheio.

O2: Lá tem o CEU Saúde, onde eu instalei jogos em todos os computadores.

O1: Olha a verba que esta prefeita tinha, comparando com o Fernando Henrique! O Serra fez muita coisa quando ministro. Fez a campanha da Catarata que deu visão para o pessoal aí.

O2: E quem renovou as frotas de ônibus? E quem--

O1: Olha o dinheiro que ela tinha, filho! O Serra tinha, supondo, 500 mil pra gastar e ela três milhões.

O2: Mas ainda assim, o Fernando Henrique era o presidente. Ele podia mandar mais verba pro--

A2: Agora vem cá. O Lula é o presidente. O que o Lula tá fazendo? Que que você acha que a Marta vai fazer?

O2: Ah, em dois anos, eles tão mandando mais verba pra prefeitura que pro governo.

$K: E$ depois dizem que adolescente não têm idéia sobre política...

A1: Eu não gosto.

O1: Adoro política!

O2: Mó legal!

K: Vocês já ouviram isso?

O1: Lógico. Agora, nossa, horário político é ridículo. João Manoel... o desgraçado não sabe nem o que falar e quer ir pra propaganda política. (Imita-o) Não sabe nem falar e já quer se candidatar a prefeito!

O2: É que ele vai naquela "Pô, se eu falar 'Peroba neles', os cara vai achar engraçado e votar em mim".

$K$ : E o que vocês acham que deveria ser feito, então, quais as propostas para poder resolver os problemas da sociedade?

A2: Saúde e emprego.

O1: Saúde.

A1: Segurança.

O1: A saúde melhorando.... Só segurança e aí?

O2: Na verdade, a construção dos CÉUs deu muito emprego pra professores, vigilantes--

O1: Pelo amor de Deus! A Marta não fez um leito de hospital, gente! Um leito!

O2: Ela vai começar Saúde agora.

O1: Vai fazer agora? De que adianta? E quem morreu ontem? Vai adiantar alguma coisa fazer amanhã?

O2: E quem não morreu? Ela vai fazer o CEU Saúde, igual ela falou que ia fazer o CEU e o bilhete único.

$\mathrm{K}:$ E além de segurança--?

O1: O bilhete é maior ladrão. Você põe 50 na lotérica e chega no buzão tem 25.

O2: Só se for com o seu cartão.

O1: O quê? Meu amigo já fez B.O (boletim de ocorrência) contra essa porcaria.

O1: Essa lotérica rouba pra caramba!

O2: Então a culpa é da lotérica, não do bilhete único. 
A2: Quem ta acabando com o Serra é esse vice dele.

O1: Ah, mas o Serra é competente.

O2: E se o Serra for viajar?

A2: Mas você acha que ele vai abandonar o cargo dele de prefeito? Ele lutou tanto pra isso.

O2: $O$ outro foi viajar pelo mundo inteiro.

O1: O Geraldo Alkimim, é ele chegou com um projetinho de 13 milhão, só.

O2: Ô 01, na verdade são 13 milhões.

K: E tem promessas aí que não são cumpridas pelos políticos?

O1: É, todo prefeito, não conheço um que fez tudo que falou.

O2: O presidente não tá fazendo o que falou, mas a prefeita sim.

O1: E a saúde? Ela falou que ia reformar não sei quantos hospital--

O2: Fazê o quê, mano?

O1: Não fez uma cama pro doente; se liga!

O1: Que que adianta ter CEU pro pessoal ir lá, se tá todo mundo doente na cama? Que adianta ter piscina, se tem neguinho que não pode sentar na cama com soro na veia, que adianta?

K: O que tem que ter, então? Segurança é uma conseqüência...

O1: Emprego e saúde. É o que tem que vir primeiro.

A1: E dar mais chance para o adolescente, eu acho.

O2: Isso!!

K: Por que?

A1: Porque ele tá precisando, eu acho.

O1: A gente é o futuro do Brasil.

O2: É, igual o Serra falou que a Marta tá gastando milhões de cargo com cargo de confiança--

A1: Tem um negócio também que apareceu na televisão. Algumas pessoas que são bem de vida tá com renda mínima e quem precisa mesmo não tá ganhando.

A2: Eu tava tirando 15 reais do Bolsa-escola.

O2: Quatro feiras.

O1: Pelo Amor de Deus! 25 reais e fala que tem não sei quantas famílias beneficiadas. Isso

é uma esmola!

$K$ : E vocês adolescentes têm, então, uma proposta pra melhorar a sociedade--?

O2: Eu vou criar o PDAN- Partido dos adolescentes da nação.

K: E o que ia ter aí no Partido dos Adolescentes da Nação?

O1: [Podia ser] PAN, a mesma coisa, Partido dos adolescentes da nação.

$K$ : E o que o PAN ia falar?

O2: 01 pra presidente, prefeito, governador. Eu pra-

A1: Eu não ia ser nada.

$\mathrm{K}: O$ que ia ter no PAN?

O1: Muitas idéias.

O2: Ele ia tratar principalmente da Saúde, eu principalmente do emprego, porque quem tem emprego tem dinheiro pra pagar o convênio.

A2: Segurança.

O1: Convênio tinha que ser de graça.

O2: Emprego.

A2: Esse negócio de ter que pagar pra quando você morrer, ter caixão, essas coisas. Tem gente que explora até um real de quem não pode. 
O1: A Marta cobra taxa de luz, enquanto não tem nem poste de luz.

A1: É.

O1: Taxa de lixo!!

A1: É, isso aí é um absurdo!!

K: A gente pode pensar mais nesse PAN. Quem sabe a gente pode colocar essas propostas de vocês no papel, ai todo mundo vai ler as idéias do PAN. Vamos fazer isso?

O2: Vamos, é uma boa!

K: No último encontro a gente escreve o que o PAN propõe e isso pode ficar registrado lá na pesquisa!

A2: Com nosso nome?

K: Não, porque é sigiloso.

O2: Voltando a falar sobre a política, uma boa idéia seria empregos para os mais jovens e também continuar com esse negócio de taxa do lixo, taxa de luz, porque, olha só, isso na verdade foi um grande pretexto, porque eles tavam pegando o dinheiro destas taxas para ajudar a construir os CÉUs.

O1: Eu tô indignado com os CÉUS. Vai ter neguinho saindo pelas janelas e você quer saber de CÉU?

O2: É lógico, milhares de pessoas que moram na favela tão estudando no CEU.

O1: E aí, ué??!!

K: Pessoal, nosso tempo acabou, mas depois a gente pode conversar sobre o que deixa vocês indignados e o que a gente pode colocar nesse PAN.

Juntos: Legal!

K: Então, pessoal... muito, muito obrigada! 


\section{ANEXO XV \\ TRANSCRIÇÃO DE ENTREVISTA INDIVIDUAL COM \\ A ALUNA JANAÍNA (A1)}

K: Nos encontros em grupo a gente conversou sobre um monte de coisas. Só para você lembrar um pouquinho, a gente conversou sobre como era ser adolescente, sobre o que os adultos acham dos adolescentes, sobre como era ser aluno adolescente, sobre a relação entre vocês e as pessoas aqui da escola, alunos, professores, coordenação, todo mundo. Vocês escreveram as propostas do PAN e a gente conversou sobre as músicas também. $O$ que você achou desses encontros?

A1: Achei ótimo!

K: Por quê?

A1: Ah,por causa que muita gente não ouve a gente, aí uma pessoa vem e fica perguntando. É legal. E também pra conhecer os outros, a opinião de cada um. Que cada um tem uma opinião, né?

K: Você ouviu a opinião de todo mundo e falou a sua. De tudo o que a gente conversou, o que mais te interessou?

A1: As músicas eu acho que me interessou mais.

$\mathrm{K}$ : No encontro que a gente conversou sobre as músicas você falou bastante, mesmo! E por que te interessou mais falar das músicas?

A1: Porque [o que fala] nas músicas é o que acontece mesmo. E eu gostei ainda mais da primeira música.

K: Inclusive, com relação a essa música, você falou sobre aquela coisa de olhar 0 jovem $e$ já achar que porque é jovem é drogado, é marginal. Aí vocês falaram também sobre a história de olhar o jovem pobre. Pra você, o que você acha quando olham um jovem pobre, pensam que ele é o quê?

A1: Marginal, eu acho. Pensa que ele não tem nada de bom pra oferecer e de ter muita coisa do que um rico pode ter. Acho que rico já tem dinheiro, mas a alegria, esses negócios, não tem. $O$ pobre tem coisa pra expressar, tem uma pá de coisa pra ensinar porque ele passa muito mais dificuldade. $O$ rico nem passa dificuldade. Agora, o pobre que se lasque!

$K$ : E quando vocês escreveram o PAN, logo no comecinho, falaram que queriam dizer que vocês não são "aborrecentes" e que vocês ficam muito indignados porque acham que são julgados por causa da situação financeira. $O$ que você acha disso?

A1: Eu acho que é verdade!

$\mathrm{K}$ : Por que é verdade?

A1: Por causa que a maioria das pessoas dá mais oportunidade pra quem é rico, tem mais curso pra rico. Agora, acho que eles deveriam fazer um negócio pro pobre também, ter cursos, porque não é só rico que precisa, a gente também, que é pobre, precisa muito mais do que eles, né?

K: Então, você acha que o fato de vocês serem pobres faz com que as pessoas pensem o quê?? 
A1: Pensam que nós somos marginal, esses negócios!

$\mathrm{K}$ : Aquilo que você estava falando, né? Você sente isso, já sentiu isso acontecer com você ou com alguém conhecido?

A1: Tem esses negócios. Só na televisão que passa, mas na vida real nunca vi. Mas tem uma amiga da minha sala, parece que é (?), não sei se ela é ou não, mas todo mundo fica zoando com ela: "Ah, aquela lá não se esforça pra nada".

$K: A$ que você falou que não sabe ler e escrever?

A1: É. Mas só que ela também não se esforça, tem que se esforçar.

$\mathrm{K}$ : Vocês aqui têm essa coisa de ficar falando se alguém é mais pobre, ou menos pobre...?

A1: Não, porque a maioria das pessoas aqui é tudo que mora na favela.

$K$ : A maioria mora aqui.

A1: Na favela " $x$ ".

$K$ : Então não tem muito essa diferença de "alguém é mais pobre do que eu".

A1: Aqui não. Não tem nada de "ah, você é o maior pobre". Não tem esses negócio aqui nessa escola. Mas em outras, com certeza, né?

$\mathrm{K}$ : Você sente alguma coisa de professores achando alguma coisa pelos alunos serem pobres ou não?

A1: Eu não sinto.

K: Quando vocês estavam falando do PAN, fizeram propostas pra saúde, educação, emprego. A da educação deu pra começar e não deu pra terminar. O que você acha da educação, qual é o maior problema da educação hoje?

A1: Em que sentido?

K: Da educação escolar. O que tem de problema, o que está acontecendo que precisaria ser melhorado?

A1: $O$ ensino precisaria ser melhorado, porque o ensino tá muito ruim, eu acho. Por causa que da aula de matemática não sei fazer quase nenhuma lição, porque a professora explica rapidão e os aluno também fica conversando, não dá pra entender nada. Aí a professora fala que tavam conversando, não explica mais, e mesmo prestando atenção, eu não consigo entender nada! A gente vai perguntar pra ela, ela explica com a maior rapidez, ela mesmo faz a conta lá e pronto: "Faz igual eu fiz". Grande coisa, né? Não dá pra entender nada!

K: Vocês estavam falando que com vocês mesmos acontece de passar de ano sem saber. $O$ que você acha disso?

A1: Ah, eu acho isso horrível! Igual meu irmão, ele não sabe nada, nem tá vindo mais pra escola porque minha mãe quer que ele repita por falta.

K: Quem?

A1: Meu irmão. Ele estuda aqui na sétima série, as nota dele tá ruim, ele falta pra caramba, aí minha mãe deixou ele sem vim pra escola porque ela quer que ele repita, porque ele não sabe nada, tabuada do dois ele sabe mais ou menos, aí a do três já... [não sabe].

K: Mas se ele só tiver nota ruim, mas ele vir, aí ele passa?

A1: Passa! Da quinta, sexta e sétima, passa! E quando chega na oitava, tem esse provão, aí não passa.

K: Que provão? 
A1: É o SARESP.

$K:$ E é o SARESP que faz passar ou não passar?

A1: Não, ele não faz passar, mas só que ele também ajuda.

$\mathrm{K}$ : Ajuda como?

A1: Ajuda pra ver o conhecimento do aluno, se ele tá indo bem. Só que tem que fazer de 15 pra cima de pontos. Se fizer 14, ou fica retido ou eles dão recuperação, né?

K: Então o SARESP pode fazer você ficar de recuperação ou ficar retido, se você não tem um número de pontos mínimo.

A1: Eu não sei se agora é assim, mas antigamente era. Agora todo mundo fala que não é assim, mas eu não sei. Porque ano passado a gente teve, só que não podia reprovar, então... mas esse ano vai reprovar.

K: A oitava é diferente, né?

A1: Se você tiver falta e nota mal, assim, você repete. Se você tiver nota mal, você repete. E se você não vim, também repete. Nem precisa vim pra escola, porque você vai passar!

K: Você tava falando [no encontro em grupo] que mesmo pra repetir na oitava tem que ter mais de 200 faltas.

A1: É.

$K$ : E mesmo na oitava vocês podem passar para o primeiro colegial sem saber...

A1: É. Igual eu, eu não sei os negócio de matemática e eu vou passar. Eu tenho nota boa, só que eu não sei fazer. Tipo assim, do que eu sei fazer, ela [professora] não dá prova, do que eu não sei fazer, ela dá prova!

K: Mas aí você tira nota boa?

A1: Aí a sala inteira fica olhando pra cara dela e ela ainda dá nota, lá!

K: Então, a nota não mede o que a pessoa sabe e o que ela não sabe?

A1: Ninguém da sala sabe, só alguns que ficam sentado na frente. Até os que estão na frente ainda não sabem muito bem, você pergunta pra eles... a maioria não sabe. Aí é ruim.

K: A gente está falando da experiência de ser aluno adolescente, só que eu queria perguntar uma coisa antes. Quando você começou a estudar, estudou na préescola ou entrou na primeira série?

A1: Na pré-escola.

K: Você lembra alguma coisinha de como era ser aluna lá na pré-escola?

A1: Era legal!

$\mathrm{K}: \mathrm{O}$ que acontecia?

A1: Por causa que a gente nem sabia ler, aí passava uma liçãozinha lá... Tinha bastante coisa pra pintar, depois chegava a hora de brincar. Aí todas as sextasfeiras, não lembro, tinha um dia da semana que era só brincar, levava brinquedo, brincava de tudo. Acho que era de sexta-feira, podia levar boneca, corda..., era muito legal! Eu gostava!

K: Era bom ser aluna na pré-escola, né? E depois na primeira série você estudou em que escola?

A1: NaE4. 


\section{K: Ficou até que série?}

A1: Até a quarta, porque é só até a quarta série.

$K: E$ o que você achava de estudar lá?

A1: Era mó bom porque, nossa, em geral era ótimo! A lição que passava era boa... tudo! Eu tinha mó dificuldade pra escrever, aí sempre a professora ficava me ajudando..., todos os alunos. Tinha uns que já sabia escrever, mas outros não. Eu não sabia, ela ficava me ajudando, era mó bom!

$\mathrm{K}$ : Aí você aprendeu?

A1: Nossa, é a melhor escola que eu estudei até hoje!

K: É mesmo?

A1: Se tivesse até a oitava série, eu não ia sair de lá! Ia ficar estudando lá até agora.

K: E lá a relação do professor com o aluno como era? Você falou que a professora ajudava. Era uma professora, né?

A1: É. Só que na terceira série a gente tinha duas, ficava dividido, e na quarta também era duas. Na primeira e na segunda era a mesma, era uma professora só. Era ótimo!

K: Na quinta série você já veio pra cá?

A1: Foi.

K: Então você ficou aqui nessa escola da quinta até a oitava. Eu queria saber assim: qual é a diferença entre ser aluno criança e ser aluno adolescente?

A1: Aluno criança eles dão mais atenção. Eles não ficam maltratando (porque às vezes eles ficam maltratando, assim...). Eu acho que era melhor aluno criança; eles ouvem, assim, melhor.

K: Você acha que eles ouvem mais a criança?

A1: Eu acho.

K: Por quê?

A1: Tipo assim, se eles não ouvir ou maltratar, as crianças chamam a mãe $e$ dá o maior barraco na escola.

$K$ : E com o adolescente isso não acontece?

A1: Não, os adolescentes nem liga mais pra esse negócio de chamar a mãe, eles que se vira, mesmo. Agora, quando é criança, não. Como você vai se virar quando é criança?

K: Então você acha que tem mais respeito com as crianças...

A1: É. Mas com os adolescentes alguns professores têm respeito, porque eles têm medo, né, como a gente tava falando [nos encontros em grupo]. Tem alguns que têm muito medo!

K: Você sente isso, né? Você acha que eles têm medo do quê?

A1: Sei lá, de alguém bater neles, esses negócio, por causa do vandalismo. Acho que eles têm medo de um aluno, por exemplo, assaltar a casa deles..., sei lá.

$\mathrm{K}$ : De violência?

A1: É.

K: Como vocês falaram nos encontros em grupo, né? A gente tava falando aqui sobre o passado e o presente. E sobre o futuro, o que você espera do seu futuro? 
A1: Ah, eu espero várias coisas!

K: O quê?

A1: Se eu conseguir um emprego bom, quero fazer turismo ou fotografia. Nossa! Qualquer paisagem aqui, se eu tivesse uma máquina, eu ia tirar! Ou senão ser dançarina, amo dançar. Eu tenho um grupo de axé, a gente dança... às vezes a gente se apresenta. Então, eu gostaria.

$K: E$, no turismo, o que te interessa?

A1: Ah, viajar! Tipo assim, conhecer o modo de viver em outros países, conhecer as línguas, falar também.

K: E o precisa acontecer pra que você seja fotógrafa, dançarina ou lidar com turismo?

A1: Eu tenho que estudar muito. Muito, mesmo! Porque se puder ser os dois, eu quero os dois, porque dançarina eu já vejo como muito sonho. Agora, o meu futuro, assim, é esse, o que eu quero mais.

K: Pra fazer turismo, você tinha falado até no grupo, que queria estudar línguas. Vocês têm aula de inglês aqui, né? Como é a aula de inglês?

A1: É mais ou menos.

K: Por quê?

A1: Não acho que é muito boa, mas também não acho que é muito ruim.

K: Não?

A1: Porque a professora explica. Mas, tipo assim, ela tem um problema na perna dela e todo mundo fica zoando com ela. Ela anda meio mancando assim e com uma muleta e aí todo mundo fica zoando ela. Mas só que o pessoal respeita, todo mundo fala: "Ê, mano, ela tem problema". Mas ela é boa.

K: Ah... Então, você tava falando que quando terminar o terceiro colegial, você pensa em --

A1: Fazer faculdade.

K: E o que precisa acontecer pra você fazer faculdade?

A1: Preciso ter um trabalho, pra mim poder pagar porque é muito caro. Turismo é 500 e pouco. Eu tenho uma amiga que faz. Uma amiga da minha prima faz turismo. É mó caro!

K: Então você pensa em trabalhar pra conseguir um dinheiro e entrar numa faculdade particular?

A1: É. Porque é difícil entrar numa faculdade pública. Se pudesse, eu preferia a pública.

K: Você tá falando que é difícil conseguir passar no vestibular de uma escola pública, né?

A1: É. Ô,é difícil!

$K$ : E aquela conversa que a gente estava falando da diferença entre estudar numa escola estadual, municipal ou numa escola particular? Você sente que tem diferença?

A1: Não com a municipal e a estadual, essas é como se fosse a mesma, mas [entre] essas duas e a particular.

K: Que diferença tem? 
A1: Aqui todo mundo fala: "Ah, ele estuda em escola particular, ele sabe mais coisa que você". Tipo assim, você faz uma conta e fala pra ele fazer, aí a sua dá um e a dele dá outro, acho que o resultado dele é o que tá certo, porque a dele é de escola particular. Mas de vez em quando não é, de vez em quando o estudo daqui, até dessa escola, pode ser muito melhor do que de escola particular.

K: Então você acha que depende do quê?

A1: Dos professores, nessa parte.

K: Pode ter professor bom na escola pública, pode ter professor ruim na escola particular--

A1: Acho que não depende de aluno, depende do professor, se ele conseguir ensinar coisa da oitava série e conseguir ensinar tudo... Depende do aluno também, só que mais do professor.

K: Quando se repete ou quando o ensino não é de qualidade, será que existe um culpado? O que você acha?

A1: Acho que não existe um culpado. É todos que faz a escola, a escola não é só o professor, é a gente também. A gente que faz mais a escola do que eles, porque a gente sempre vem pra aprender. Alguns não, vêm pra ficar zoando, pra passar o tempo.

$K: E$ o que mais faz a escola, então?

A1: Quem tá aqui dentro, todos que estão aqui dentro. E os pais dos alunos também, eles têm que ajudar, também.

K: Você estava falando da situação da educação, que tem coisa que é ruim, que a qualidade do ensino é ruim. O que você acha que daria pra ser feito pra melhorar a qualidade do ensino?

A1: Acho que era professores com mais capacidade, como o Pr1, assim. Nós vamo ter o SARESP, aí ele já tá ensinando a gente como é pra gente fazer. Vai ter muito esse negócio de leitura, vai ter texto, aí a gente tem que responder uma pá de pergunta sobre o texto. Ele já tá ajudando a gente, já tá explicando pra gente poder passar. Acho que devia ter professor igual a ele. Tem uns que já chega, passa uma pá de lição, manda a gente fazer e senta e ainda fala que tem que fazer.

$K$ : Então, não ensina, mesmo?

A1: Só passa porque tem que passar. Pra não ficar sem fazer nada.

$K$ : A gente tava falando das coisas que a gente conversou nos encontros em grupo, você falou o que mais te interessou. Você acha que teve algum assunto que era importante falar e não deu pra gente falar, você acha que tem mais alguma coisa importante pra falar sobre adolescência, sobre o que a gente conversou?

A1: O negócio de sexualidade, eu acho.

$\mathrm{K}:$ Ah, de sexualidade. É uma coisa muito importante, né?

A1: É.

K: $O$ que você acha que a gente poderia discutir sobre sexualidade?

A1: Por exemplo, falar... Eu sei que todo mundo sabe, só que nem toda pessoa quer ouvir. Acho que tem que usar camisinha, as menina usar anticoncepcional. Esses negócio assim, sabe? Que não vai ter risco.

$K$ : E sobre isso não é muito conversado nas escolas? 
A1: É muito difícil. Quando eu tava na sexta série... Não lembro se foi o ano passado. Foi o ano passado, a gente tinha uma professora de educação artística e ela começou a dar aula de sexualidade pra gente, era superlegal! Ela fazia a gente fazer desenho, tipo assim, um cartaz pra diferenciar o que era namoro e ficar. Aí nós fizemos, dividiu em grupo, nós fizemos. Era superlegal, todo mundo falava! Tem toda a diferença entre sexualidade e outras coisas, ela falou. Nossa, era superlegal a aula dela! Todo mundo participava, a gente fazia perguntas no papel, ela pegava e não falava o nome da pessoa, que é muito importante, porque tinha umas pergunta muito feia. Quando ela falava, tinha umas pergunta muito feia, só que não tinha o nome da pessoa, senão fica chato.

$K$ : Então você acha que precisava ter mais conversa sobre sexualidade na escola?

A1: Por causa que a maioria das pessoas não tem informações sobre isso, ou tem vergonha de perguntar. Acho que a escola também deveria tomar a iniciativa, porque todo mundo fica reclamando que tem uma pá de jovem grávida, esses negócio. Umas são porque ela quer, mas às vezes não tem informação e tem vergonha de perguntar. A maioria das minhas amigas aqui não conversa sobre esses negócio. Aí vou conversar com minha mãe, minha mãe explica.

K: Então você tem um diálogo bom com a tua mãe?

A1: Orra!!

K: Isso ajuda bastante, né?

A1: Quando eu tinha sete anos, por aí, minha mãe começou a falar de menstruação comigo. Aí eu fiquei menstruada e nem foi assim chocante. Fiquei com nove anos e falei: "Mãe, vem aqui". Ela ficou toda feliz, mas eu não fiquei chocada porque eu já sabia desses negócio.

K: Ela preparou você pra isso, então?

A1: Até meu irmão, quando ele era menor, foi lá e pegou um absorvente: "O que é isso?" Minha mãe explicava. "Pra que é?" Minha mãe falava também, porque não é só as menina que tem que saber, é os menino também.

$K$ : Então é uma coisa importante pra se falar na escola também, né?

A1: Na escola, fora, em qualquer lugar. É super importante!

$\mathrm{K}: \mathrm{O}$ que você acha que precisava ter mais na escola, além de conversas sobre sexualidade?

A1: Ensino bom também, os professores acreditar nos alunos e respeito.

K: Respeito é uma coisa que vocês falam bastante.

A1: Que não tem nessa escola. Os meninos às vezes faz umas brincadeira mó besta, de um ficar batendo no outro, brincando, mas pode ser que vire uma coisa mais assim... Um dá um soco na cara, o outro também quer ir lá dar.

K: Você tinha falado que isso de respeito tem que ser entre os alunos e entre os alunos e professores, né?

A1: É. Porque tem muito esse negócio de um xingar o outro.

$K$ : Vocês também falaram muito sobre preconceito.

A1: Isso que eu ia falar agora.

K: Você ia falar? Então o que você ia falar?

A1: Tem preconceito também pra gente mudar. 


\section{$\mathrm{K}:$ Mudar como?}

A1: Tipo assim, você estuda com uma pessoa, ela é negra, aí o pessoal: "Vai, sua neguinha". Ou que ela tem cabelo ruim, esses negócio. Não é só aqui na escola, é em todo lugar que tem isso, fora dela mesmo. Tinha que mudar, mas só que acho que não tem um jeito da gente falar pra pessoa mudar, porque é difícil se conscientizar!

K: Então, é difícil fazer com que as pessoas pensem sobre o preconceito... Você acha que dá pra fazer alguma coisa pra mudar isso?

A1: Eu acho que dá, mas não tenho a menor idéia! Acho que dá, se todos ajudassem. Porque não adianta só um, tem que ser todo mundo, senão, não adianta nada, vai ficar como tá hoje.

K: No último grupo a gente estava falando sobre aquela idéia da música, que os jovens têm que se unir, mas, ao mesmo tempo, vocês pensavam "ah, os jovens não têm poder nenhum". Ou então "os jovens têm que se unir, mas eu não, eu não tenho poder nenhum, o que eu posso fazer?" Vocês estavam naquela coisa de achar que o jovem tem que se unir, mas que não dava pra fazer nada pra mudar. $O$ que você pensa disso?

A1: Eu acho que a gente tem poder, sim, mas tem que saber usar. Tem que usar com atos bons, sabe? Tem que fazer uma coisa que a pessoa fica assim: "nossa, um adolescente fez isso?!" É difícil, mas você tem que fazer isso, aí ele vai se tocar mais. Agora, os adolescentes só fazem as mesmas coisas: é ficar pichando escola, quebrando tudo. Eles têm que fazer tipo assim, vê uma coisa quebrada, ia lá, unia uma turma: "vê se nóis consegue arrumar isso daqui". Aí todo mundo vai falar: "Nossa! Um adolescente deu essa idéia?!" Tem que ter umas idéias assim diferente.

K: Pra tentar romper um pouco com essa idéia de que adolescente não pensa nada..., começar a mudar o jeito de olhar para o adolescente?

A1: É.

K: Por falar em jeito de mudar o olhar do adolescente, vocês fizeram o PAN aqui, o Partido dos Adolescentes da Nação. Vou pedir pra você dar uma lidinha aqui e ver se você tem mais alguma idéia, mais alguma coisa pra colocar.

( $A$ aluna lê a primeira versão do PAM)

K: E aí?

A1: Eu acho que [o que ta escrito aqui] não devia ter só em São Paulo. Devia ter em outros Estados também. Porque não é só aqui que acontece isso. "Diminuição dos impostos para a população viver dignamente". Só em São Paulo? Oportunidades de emprego só pra quem tá em São Paulo? Tem gente que tá em outro lugar que precisa também. Então não pode ser só em São Paulo.

$K:$ Teria que ser no Brasil todo?

A1: É.

K: E de idéia pra melhorar, você tem mais alguma que não está aí?

A1: Podia não só ter um curso grátis. Podia ter tipo um curso novo.

$\mathrm{K}$ : Esse curso profissionalizante?

A1: É, mas com um preço mais assim que dá pra pagar.

K: Que as pessoas pagassem pouco, mas pagassem. Por que? Que diferença você acha que tem entre poder pagar um cursinho ou ser de graça? 
A1: Sei lá. Você pagando, você pode tá ajudando pra melhorar. Por exemplo, - computador ta quebrado... você pagando 20 reais por mês, por exemplo, já dá pra arrumar bastante coisa, dá pra comprar mais cadeira, dá pra ficar maior o curso $e$ pra mais pessoas. A gente não vamo ajudar? A gente quer que ajude a gente, mas não quer ajudar eles?

K: Ah, entendi. Uma colaboração mínima...

A1: Uma colaboração mínima, assim.

K: Aqui nas propostas pra "Educação" vocês colocaram uma coisa pra vigiar os alunos ${ }^{1}$. O que você acha disso?

A1: Acho que não precisa tudo isso.

$\mathrm{K}$ : De instalar câmera?

A1: É. Não tem porque, eu acho. É só a pessoa ficar de olho. $O$ aluno não vai nem poder conversar, vai tá tudo gravando lá? Isso daí já é abuso, eu acho.

$\mathrm{K}$ : Se isso aqui não é o ideal, o que você acha que daria pra fazer pra melhorar o ensino mesmo, pra ter um ensino de qualidade?

A1: Ter professores com vontade de ensinar e com disposição também. Tens uns que vêm, ensinam rapidão e aí sai. Tipo assim, semana que vem vai ter uma prova, então tem que repassar aquela matéria pro professor explicar. Eles dão a matéria o mês passado, aí vão dar a prova dessa matéria esse mês?! A gente não vai lembrar de nada!

K: É muito tempo de intervalo...?

A1: Não que aconteça, mas pode ser que aconteça isso também. $E$, eles fazerem uma reunião, tipo assim, quem quiser ir lá falar com o professor, "gostaria de saber isso daqui, que eu não entendi" aí falar pra ele explicar.

$\mathrm{K}$ : Ter algum espaço para o aluno conversar com o professor?

A1: A maioria das vezes os alunos têm vergonha também de perguntar alguma coisa. Por que aí o pessoal fica: "Ai, que burro, que burro".

$\mathrm{K}$ : Os alunos, mesmos, falam assim?

A1: É. Também acho que deveria fazer isso.

K: Um espaço pra o aluno poder tirar dúvida, então.

A1: Não é só isso de ficar vigiando, aí fica chato pro professor e pro aluno também, pra quem estiver na escola fica muito chato. Esse negócio de ter um ajudante é da hora. Se o professor ta ensinando, você fala: "Você pode me ajudar?" Se você quer uma opinião, uma ajuda, você fala com o ajudante, o professor vai estar ocupado.

K: Então esse ajudante que você tá falando não é só um inspetor de alunos que vai cuidar da disciplina?

A1: Vai ajudar também nos exercícios.

K: Tirar dúvida também, ensinar na sala de aula, né? Ajudar a passar 0 conteúdo também...

A1: Olha só, pensa bem, se ficar um ajudante só olhando pra gente, se você conversar pra pedir uma borracha, já vai tar o ajudante falando um monte, e vai

\footnotetext{
${ }^{1}$ Na primeira versão desse documento, os alunos haviam escrito uma proposta de instalar câmeras de vídeo na escola para vigiar os alunos.
} 
tar as câmeras! Acho que não devia ter câmera. De repente é melhor, tipo assim, lá no fundo da quadra, onde os meninos fica fumando maconha, aí sim devia ter. Agora, na sala de aula não tem porquê.

K: Então você tá falando de outras coisas que poderiam ajudar mais na qualidade do ensino do que ficar colocando câmera, que você acha que não ia resolver, só iria atrapalhar.

A1: Eles podem muito bem quebrar também a câmera. Vai ficar gastando dinheiro à toa? Aí tem que comprar outra ou arrumar aquela. Aí depois vai lá e quebra essa outra. Vai ter que ficar comprando?

K: Então, pra você, o importante seria ter professor que tirasse mesmo a dúvida pra garantir que o aluno aprenda?

A1: Que ele aprendeu mesmo. E tem a coisa da prova com consulta. Eu acho ruim prova que tem consulta.

K: Acha que não deveria ter prova com consulta?

A1: Não. É assim: a gente só lê o texto e escreve, não vai aprender nada desse texto!

K: Então, se consultar, não tá aprendendo porque já tá ali. Então você acha que deveria ser prova sem consulta.

A1: Apesar que é difícil, só que a gente também tem que se esforçar. Se eu for fazer uma prova sem consulta, não vou fazer nada, porque a gente já está acostumado desde a quinta série aqui, só prova com consulta, com consulta, com consulta. Quando tiver uma sem consulta, como você vai fazer? Teve um dia que a professora passou uma prova de geografia sem consulta, era uma pergunta só e eu não consegui fazer. E era em dupla ainda, a gente não conseguiu fazer a prova.

K: Você tá falando, então, que a prova não está avaliando se você sabe ou não, porque não é se você sabe ou não, é se tá ali no caderno ou não está; é isso?

A1: É. E, também, ter uma prova para todas as séries, ia ser super bom!

$\mathrm{K}$ : Como assim?

A1: Tipo assim, de tudo que você aprendeu o ano inteiro, mas aí podia ter uma consultinha até. Ia ser ótimo isso também, mas aí podia até ter uma consultinha sobre as coisas mais difícil, sei lá... . Acho que ia ser bom, porque vê o ensino, como que tá, se a pessoa aprendeu. Não adianta dar prova só pra a oitava série.

\section{K: O SARESP?}

A1: É.

K: Você acha que deveria ter em outros anos também?

A1: Pra todas as séries.

K: Você tinha falado que acha que tem para a sétima série, também.

A1: Tivemos. Mas não é todos os anos. $O$ ano passado teve, esse ano não sei se vai ter. Nós fizemos, aí o pessoal passou. Só alguns não passou por causa de falta. Não é sempre também que passa na sétima série. Minha amiga repetiu por falta. Então não é isso que todo mundo vai passar. Tipo assim, vinha um dia, faltava dez. Aí, como eles vão fazer que a menina passe? Mas também tem umas meninas lá que nunca vem e que passou! 
K: Você sente que precisaria ser mudado o jeito de avaliar; de ensinar e de avaliar?

A1: Acho assim: se a pessoa faltar muito tempo, devia tirar o nome dela e dar oportunidade pra outras pessoas. Tem uns que nunca vêm, só tá com o nome na chamada. Acho que devia tirar, porque tem uma pá de gente que quer estudar e não tem vaga.

K: Vamo pensar num caso: a pessoa falta, falta, falta e passa, aí ela vem no outro ano. O que acontece no outro ano? Faz a mesma coisa?

A1: Tem gente que nunca vem e passa de ano, não sei como! Sendo que outra da mesma sala faltou, faltou, faltou e repetiu!

$\mathrm{K}$ : A gente tava falando sobre repetir, sobre a situação da $8^{a} \mathrm{~A}$, por exemplo, que juntaram os alunos que repetiram. Aí teve gente que estava dizendo que quando não tem ensino bom é culpa do aluno, teve gente que disse que é culpa do professor, a gente discutiu sobre aquela história de que a culpa é da família ou então porque é pobre. Você tava dizendo que não existe um culpado para o que acontece, né?

A1: $O$ culpado é todos. Acho que depende de todos. A família não vai ser culpada porque a pessoa não tá indo na escola, ela não vai saber se a pessoa foi ou não, pra ela a pessoa vai tá na escola. Agora, pode ser que não esteja, só que pra família ela tá. Só que ela também tem que ir ver se o filho tá indo pra escola. Mas não ficar trazendo sempre o filho até a porta da escola; devia vir de vez em quando, de surpresa, pra ver se o aluno tá na sala. Ia ser bom, também.

$K$ : $E$, disso tudo que a gente conversou, tem mais alguma coisa que você queria falar?

A1: Não, acho que é só isso.

K: A gente tava falando [em um encontro] sobre reunião de pais. Os pais vêm, conversam com os professores, às vezes o professor fica reclamando que 0 aluno faz bagunça e tal. $O$ que você acha das reuniões de pais?

A1: Acho que é mais ou menos, porque nem todos os pais vêm. Os alunos que precisam mais, os pais não vêm pra reunião. Acho que devia vir todos!

$K$ : $E$ o que você acha que deveria acontecer nessa reunião pra ajudar também na qualidade do ensino?

A1: Os pais reclamar também.

$\mathrm{K}$ : Reclamar de quê, do ensino?

A1: Do ensino, das coisas que tem na escola. Eles iam ouvir, eles não iam ter como ficar falando um monte.

$K$ : Não ia ter como ficar falando o quê?

A1: Um monte.

$\mathrm{K}$ : De quem?

A1: Do adolescente. Eles iam ouvir.

$K:$ Ah, entendi. Eles, professores, iriam ouvir --

A1: Os pais dos adolescentes!

K: Então, você acha que eles ouvem mais os adultos do que os adolescentes, né? Se é o pai falando, aí o professor leva mais em consideração...

A1: É. 
K: Você acha que os pais deveriam falar e que os pais de vocês têm idéia de se o ensino está bom ou não está bom...

A1: Minha mãe acha que o ensino tá horrível aqui! Tanto que no ano que vem não vou vir pra cá não. Acho que vou estudar na escola E5, que é um pouquinho melhor. Aqui tá muito ruim!

K: Você acha que o problema maior dessa escola é o quê?

A1: Acho que é o ensino e educação.

$K$ : Educação dos alunos...

A1: É, com os professores.

$\mathrm{K}$ : $A h$, do respeito, que você tava falando. $E$ do ensino, você quer acrescentar mais alguma coisa?

A1: Só esse negócio da reunião. Se ele trabalhar, fala assim: "Vai ter reunião do meu filho, vou ter que ir, daqui a pouco estou de volta". Falava a hora $e$ ia. Porque com os mais bagunceiros, o professor quer conversar, mas os pais não vêm, aí complica. Acho que eles devia dar opinião também de melhorar a escola. Igual o banheiro, tá tudo quebrado, cheio de pichação. Deveria falar também. E os alunos ajudar, também, porque não adianta o pai falar o os alunos ficar bagunçando.

K: É aquilo que você falou, uma participação de todo mundo que faz a escola, todo mundo colaborando...

A1: Os pais podiam falar assim "Ó, minha filha ta dizendo que o ensino não ta muito bom, ela tá reclamando que os professores num tão ajudando ela, eu queria que você desse um pouco mais de atenção pra ela".

$\mathrm{K}$ : Ajudar pra que o professor dê mais atenção pro aluno--

A1: Só que não dar atenção só pra um; precisa dar pra todos; mas pros que vão procurar ele [o professor], porque os que não vão procurar, não querem nada com nada!

$\mathrm{K}$ : Aqueles alunos que demonstrarem interesse...

A1: Agora os que não tão [demonstrando], eles também deveriam ajudar, mas ajudar pouco.

K: E os pais também poderiam ajudar nisso, então? Falar pros professores...

A1: É, porque os professores também não sabem o que a gente tá pensando, né? Eles não vão adivinhar! Podem pensar "Eu acho que eles tão achando que minha aula ta boa", mas na realidade, não. Não tá boa.

K: Então, você também tá falando que ia ser importante os professores saberem o que os alunos estão pensando...

A1: É, porque eles não sabem. Acho que eles também deviam fazer reunião com os alunos!

$\mathrm{K}$ : Ah, então isso é uma outra coisa. Além de o aluno conversar com o professor sobre o que não está conseguindo aprender, poderia ter conversa de alunos e professores pra dizer--.

A1: Tipo uma reunião de alunos, como de pais, só que de alunos com os professores.

K: Pra poder dizer o que eles estão achando, o que acham que tá ruim, o que acham que tá bom? 
A1: É. Porque se começar a puxar... Que nem aquele dia, você começou a puxar, e todo mundo já foi falando.

$\mathrm{K}$ : Que dia?

A1: Do primeiro encontro.

K: Ah, do encontro em grupo. Um começa a falar uma coisa que está incomodando e aí todo mundo fala...

A1: Todo mundo começa a falar. Acho que deveria também, porque aí eles iam entender o que a gente tá querendo dizer pra eles! Que a gente não diz, né? Então acho que deveria ter.

K: Você tá falando que vocês não falam e eles não ouvem, então fica sem comunicação...

A1: Deveria ter uma reunião, fazer umas perguntas tipo assim: o que você acha que devia melhorar? O que você tá achando da escola? Dar umas idéias. Igual aqui. Podia dar uma folha pra gente responder. Ia ser uma boa idéia! Aí devia falar de tudo, do que tá acontecendo... de professor-aluno, desses negócios.

K: Você acha que poderia ser escrito ou conversado.

A1: Ia ser uma boa, eu acho. Aí eles iam entender a gente, iam ouvir também! Acho que ia ser uma idéia boa, também. A gente não pode só ficar esperando pelos outros fazer pela gente. A gente também tem que dar as idéias da gente, né? Eu acho que era isso!

K: Então, tem mais alguma coisa que você queria falar?

A1: Só isso.

$\mathrm{K}$ : Muito obrigada pela sua participação, A1! 


\section{ANEXO XVI \\ TRANSCRIÇÃO DE ENTREVISTA INDIVIDUAL COM \\ A PROFESSORA LUCILA (Pa2)}

K: O que você acha dos adolescentes de hoje, de um modo geral?

Pa2: Eu acho que eles estão bem "revoltadinhos", sabe? Revoltados.

$\mathrm{K}$ : Como?

Pa2: Não querem fazer nada... Eu acho que eles não têm perspectiva de futoro, mesmo, né? Então, nada interessa.

K: Por que não tem perspectiva, você acha, de futuro?

Pa2: Ah, eu acho que eles estão vendo o mundo lá fora, já, como é que está, né? Acho que por isso mesmo que num... É uma minoria que se interessa.

K: Você acha que essa revolta, essa coisa é típica dos adolescentes ou não?

Pa2: Eu acho que sim.

$K$ : E o que causa essa revolta?

Pa2: A revolta, acho, que é pelo mundo, mesmo, né? Tem o desemprego, tem a família, os pais... desempregados, alguns pais que se encontram na cadeia presos, né? Então, acho que dentro disso aí, os jovens não têm perspectiva na vida deles.

K: Você acha que essa revolta dos adolescentes é uma coisa natural, biológica... de todos ou não, é uma coisa que tem mais a ver com questões que não são biológicas?

Pa2: Acho que... a questão não é biológica, mesmo. Acho que é mais da sociedade.

K: Você sente diferença entre a geração dos jovens de hoje e da geração dos jovens da sua época de quando você era jovem?

Pa2: Totalmente. É totalmente diferente!

$K: O$ que você sente?

Pa2: Eu acho que antigamente, no meu tempo, era uma minoria que estudava. E hoje em dia não, todo mundo pelo menos tem..., eles estudam, pelo menos, de quinta a oitava série; e, antigamente, não. Não sei o que acontecia que os pais mesmos queriam que os filhos estudassem. Hoje em dia não, é a própria estrutura mesmo... você não sente que o governo, mesmo...; eles passam o aluno, fazendo ou não lição na sala de aula.

K: Quer dizer, é aprovado independente... 
Pa2: É. Independente do conhecimento, sabe? Acho que é isso.

$K: E$ você acha que isso muda, então? Interfere?

Pa2: Muda. Não tem interesse, mesmo. Pra que estudar? Eles vêm para a escola para quê? Ponto de encontro, né?

K: Você acha que o sentido de vir pra escola...

Pa2: É pelo ponto de encontro, né? Olha, dentro da sala de aula, a gente observa que só estão mesmo a fim, cinco alunos. Os outros vêm, mesmo, pra passear na escola, pra conversar, pra encontrar.

$K: E$ quando você está falando dessa falta de incentivo, você está falando dessa preocupação com a progressão continuada? Então, você acha que a progressão continuada interfere?

Pa2: Interfere.

$\mathrm{K}$ : Como?

Pa2: Pra que estudar, se ele vai passar? Ele não vai se sentir incentivado, se chegar no final do ano e ela vai ser promovido, mesmo, né? No fim do ano ele teria que estar, pelo menos, no mínimo estudando, assimilando o mínimo pra poder..., né? Hoje em dia não, chegam no final, ficam o ano inteiro brincando, a presença deles já é o suficiente pra ser promovido.

$\mathrm{K}$ : Você estava falando no começo de uma falta de interesse dos adolescentes de um modo geral e agora da falta de interesse dos alunos dentro da escola. Na sua geração, quando você era jovem, fora da escola como eram os alunos?

Pa2: Assim, de violência, comportamento... era o contrário. Eram um, dois que saíam da linha. Hoje é o contrário, um, dois se interessam e o restante não tem interesse nenhum.

K: Você estava falando que poucas pessoas estudavam, você acha que o comportamento deles na sociedade...

Pa2: Não sei se seriam poucas pessoas, como eu diria..., porque hoje, também, a população aumentou bastante, né?

$K: O$ acesso à educação aumentou...

$\mathrm{Pa2}$ : No meu tempo mulher eram poucas que estudavam; era uma minoria, também.

K: Você estudou quando era jovem?

Pa2: Sim. Não sei se é da própria cultura oriental, mesmo; que os pais querem que os filhos estudem, né?

K: Você acha que a juventude era mais recatada, não era tão solta.

Pa2: É. 

também?

K: Falando dos alunos, você dá aula pra cá e dá aula em outro lugar,

Pa2: Não. Só aqui.

$K$ : $E$ você sente diferença entre os alunos das salas daqui, que todo mundo fala da $8^{a} A$...

Pa2: Para a $8^{a} A$ não dou aula. Mas eu sinto uma diferença na $8^{a} B$.

$K:$ Qual a diferença?

Pa2: A indisciplina. Porque eu acho que atrai, sabe? As classes são formadas separando os alunos, tirando um daqui, colocando [outro ali]. Mas parece atrai, né? Parece que os alunos indisciplinados se juntam numa sala só. $A$ $8^{a} D$, se for ver, a disciplina na sala é boa, observando o posicionamento dos alunos, eles são disciplinadinhos... A $8^{a} B$ tem..., sabe aquela coisa de provocar a gente, mesmo? "Somos indisciplinados, mesmo"; "Eu vou afrontar a professora"... Então, na $8^{a} B$ a posição da sala, a disposição das cadeiras... tudo organizadinho. $E$ a $8^{a} D$, não; tudo é bagunçado, um põe aqui, o outro põe ali, fica tudo amontoado, sabe?

$\mathrm{K}$ : E como eles, os alunos, são dentro da sala?

Pa2: Interesse, zero!

K: E com relação à disciplina? O que eles fazem na sala de aula?

Pa2: Aí, é provocação. Jogam as coisas, papel. Aquela coisa de adolescente, de provocar mesmo.

K: Como "...aquela coisa de adolescente"? Fala um pouco melhor. Que coisa de adolescente?

Pa2: É aprontar, mesmo, com as pessoas.

$K:$ Você acha que o adolescente tem isso de desafiar mais?

Pa2: Tem, sim.

$K: E$ como você sente que é a sua relação com os alunos adolescentes?

Pa2: Ah... eu me dou bem com eles, até. Agora, não sei o que eles sentem.

K: Então, você acha que é tranqüilo? Quer dizer, tem duas coisas: você se dá bem, mas tem a questão de eles serem indisciplinados, também, né? Como é, por exemplo, sua relação com os alunos na $8^{a} B$ ?

Pa2: Como diria? Se eles me respeitam, é isso?

K: Pode ser.

Pa2: Eles são bem, assim, debochados..., como diria? Eles bagunçam...

$K$ : $E$ você sente isso mais na $8^{a} B$. E nas outras não? Nas outras eles te respeitam mais?

Pa2: Olha, a $C$ e a $D$ são classes mistas, mesmo, né? Tem alunos bons e alunos ruins. 
K: De uma forma geral, você acha que eles não respeitam, que eles vão além do limite do respeito?

Pa2: É.

$K: E$ que idéia você acha da imagem que eles fazem de você enquanto professora? Você acha que eles pensam o quê??

Pa2: Eu acho que pra eles professores e nada é a mesma coisa.

$\mathrm{K}$ : Por que você acha isso?

Pa2: Eu acho que eles não estão valorizando o ensino, sabe? A escola pra eles num... Eles não dão importância pra nada.

$K: E$ você especificamente, imagina alguma coisa da imagem que eles fazem de você, ou não?

Pa2: Não.

K: $O$ que você sente é que uns respeitam, outros não respeitam...

Pa2: Eles não querem nada. É que eu... Cada professor tem um modo diferente. O Pr1 é mais bravo, é exigente. Eu não quero ficar assim, pegando no pé do aluno, arrumando encrenca, sabe? Não leva a nada. O professor Pr2 comentou que quer fazer todo mundo fazer a lição, e ele fica afrontando os alunos. E adianta? Causa problema de saúde, até, né? Eu já tô, o ano que vem, se deus quiser, eu me aposento. Eu não vou ficar aí brigando, arrumando confusão, não. Acho que não vale a pena, não.

K: Você dá aula do que, mesmo?

Pa2: De matemática.

K: De matemática. Você orienta a sua prática de alguma forma pelo fato da alguns alunos serem assim "revoltados", como você está falando? O fato de os alunos adolescentes, para você, serem revoltados, isso muda de alguma forma o seu jeito de dar aula, a sua prática?

Pa2: Não.

K: Você dá aula do mesmo jeito, né? Independente de eles serem assim...

Pa2: Isso. Eu faço a minha parte. Você diz, assim, de utilizar um método diferente...?

K: Alguma coisa que: "Já que os alunos são assim, eu vou fazer assim ao invés de fazer de outro jeito".

Pa2: Não.

K: Então, você passa pra eles o conteúdo...

$\mathrm{Pa2}: \mathrm{O}$ que a gente ensina normalmente, né?

$K: E$ como você sente que está sendo o aproveitamento dos alunos?

Pa2: É aquilo que eu falei. Cinco, seis que estão aprendendo e o resto, não. 
K: E eles vão passar de ano, né?

Pa2: Vão passar. Eles não querem progredir. É isso que eu falei pra você. Ter que ficar o tempo inteiro brigando, se desgastando.

K: E essa coisa da progressão continuada interfere até na relação de vocês, né?

Pa2: Sim, depois que surgiu a Progressão Continuada, a coisa decaiu, foi só decaindo, cada vez mais.

K: Você está falando que eles não valorizam o professor. Você acha que a progressão continuada apareceu um pouco nessa direção também?

Pa2: Eu acho que é o interesse do governo, mesmo. Promover todo mundo $e$ eles não fazerem nada.

$K$ : E o que leva a repetência?

Pa2: Só frequiência. Lógico que se o aluno não tem bom aproveitamento, é retido; se for em todas as matérias; agora, se for em uma ou duas, não fica retido.

K: Tem um negócio de Conselho de classe, que passa por esse conselho, aí o conselho decide... E recuperação, não tem mais?

Pa2: Não. Não temo mais. A gente ta fazendo reforço, agora.

$\mathrm{K}$ : Agora no fim do ano?

Pa2: Agora, depois do SARESP. Estamos pensando em fazer. Para aqueles que estavam com mais dificuldades. Aquele aluno que o ano inteiro se interessou, participou, é lógico que vai passar. Então, a gente quer dar um... quer chamar ele pra fazer alguma coisa... no reforço.

K: Você estava falando que você deu aula aqui há muito tempo. Como é sua trajetória? Há muitos anos você trabalha com adolescente?

Pa2: A vida inteira. Sempre de quinta a oitava.

K: Há quantos anos você dá aula?

Pa2: 24.

K: Você que escolheu dar aula para os adolescentes, você escolheu a faixa etária, como é que foi essa escolha?

Pa2: Não, o próprio curso dá direito a de quinta a Ensino Médio, e essa escola só tem o Fundamental, né?

$K: E$ você escolheu essa escola?

Pa2: Não foi a gente que escolheu> Nós éramos do (...) [X escola] e com a reestruturação, todo mundo veio pra cá.

K: Não foi opção?

Pa2: Não, não foi opção.

K: Mas como você se sente dando aula para os alunos adolescentes? 
Pa2: Acho que... Não tenho nada contra! Você diz, assim, se é desgastante? É bastante desgastante, porque suga muito a gente, sabe?

K: Tem alguma coisa que te traz satisfação em dar aula para os adolescentes?

Pa2: Claro que sim! É o que falei, é uma minoria, mas acho que estão assimilando.

$\mathrm{K}$ : O que mais te marcou nesses anos todos como professora dos adolescentes? O que mais te marcou nessa trajetória?

Pa2: Sabe que agora na minha cabeça não tem nada... que marcou!

$\mathrm{K}$ : Alguma situação, alguma coisa que aconteceu?

Pa2: Cai na rotina, né?

$\mathrm{K}$ : Acabam ficando iguais, os anos se repetem, se repetem...?

Pa2: Lógico que você vê que tem alunos bons que hoje estão formados, né? Tem aluno que já se formou, que já conseguiu uma coisa na vida, fez uma boa faculdade.

$K: E$ isso te traz satisfação?

Pa2: Ah, sim. Tive aluno que fez medicina na USP!

$\mathrm{K}$ : E eles vieram contar?

Pa2: Ah, sim! O filho do professor Pr1 também foi meu aluno. Alguma satisfação, a gente tem.

K: E que frustração você tem dessa experiência?

Pa2: Frustração é os próprios alunos não se interessarem. Isso deixa a gente muito chateado.

$K: E$ você hoje tem alguma esperança? Que esperança você tem em relação ao seu trabalho como professora?

Pa2: Em primeiro lugar, se continuar do jeito que está, a tendência é só piorar, né? Os professores que virão, acho que vão sofrer muito!

K: Você estava falando que tem possibilidade de se aposentar o ano que vem. Você está esperando, está ansiosa para que chegue a aposentadoria? Como está essa sua relação com a aposentadoria?

Pa2: Estou cansada! É muito desgastante, não é fácil!

$\mathrm{K}$ : São quantos alunos por sala, mais ou menos?

Pa2: No mínimo 35 alunos. Se todas as classes fossem como a $8^{a} \mathrm{D}$, seria tranqüilo... poder dar atividade para os jovens, sabe? Mas nas outras salas, 0 rendimento é mínimo. Deixa a gente cansado!

K: Nesse período de sua trajetória você deu aula em uma outra escola também, você dá aula há 24 anos. Você sente diferença do começo dessa sua 
experiência, de como eram os alunos e de hoje? Porque 24 anos é muito tempo, né?

Pa2: É, cada ano vem decaindo! De uns 5 anos para cá, que eu acho que a coisa decaiu.

K: Que é a fase da progressão continuada, mesmo?

Pa2: É. E o desinteresse é quase que total. É uma minoria, mesmo, que se interessa.

K: E com relação a esse assunto você queria acrescentar alguma coisa?

Pa2: Não. Não sei se vai dar pra aproveitar alguma coisa...

K: Nossa! Muito do que você falou vai dar pra aproveitar! Muito obrigada, $\mathrm{Pa} 2 !$ 


\section{ENCONTRO EXTRA COM OS ALUNOS (Elaboração do PAN - Partido dos Adolescentes da Nação)}

K: Vocês vão escolher o jeito que vocês vão escrever. A idéia de hoje é escrever, como a gente tava conversando no outro encontro: ou como se fosse uma carta - e tem gente que vai ler, pegar a dissertação, como chama, na biblioteca - e no meio desta carta pode entrar a idéia do PAN, a idéia do partido e quais suas propostas. Ou então, escrever: o PAN é isso e tem essas propostas. Ou de alguma outra forma... o que vocês preferem?

(Falam ao mesmo tempo. Preferem a segunda alternativa)

K: Quem vai escrever?

(Discussão a este respeito - A1 pega a caneta para escrever)

O1: O primeiro documento tem que ser bonito, pra ficar no museu de arte.

$\mathrm{K}: O$ que vocês querem colocar no papel?

A1: PAN - PARTIDO DOS ADOLESCENTES DA NAÇÃO

O3: Partido Adolescente da Nação.

A4/A1/O1: Dos adolescentes!

A1: A gente precisa explicar o que é o PAN.

K: E aí? Vocês vão explicar o que é o PAN. Você começou falar, 01 "Nós somos"

O2: Nós somos...

O1: Nós somos o congresso de adolescentes indignados com a realidade--

A1: Calma, meu!

O1: Nós somos o congresso de adolescentes indignados com a atual situação--

A4: Desse país.

K: E aí?

(Falam ao mesmo tempo)

O3: E queremos demonstrar que não somos--

O3/A4: Aborrecentes.

$\mathrm{K}$ : Concordam?

A1: Eu concordo.

A1: Ah, isso aqui vai ser tipo uma carta!

$\mathrm{K}$ : Pode ser. Uma mistura. Vocês que decidem.

(Falam ao mesmo tempo)

O1: Somos condenados injustamente--

A1: Espera aí...

O1: Somos--

O3: Condenados!

O1: Somos--

O2: Oprimidos!

O1: Pode ser. Não, quando julgam você, como é?

A1: Somos julgados.

O1: Isso. Tão simples e todo mundo fica... Somos julgados injustamente principalmente pela nossa situação financeira e pelos atos de vandalismo que uma minoria, que não tem a nossa-O2: A maioria faz vandalismo.

O1: Ah gente! Mas nós tem que defender nosso lado também! Vai falar que é a maioria? Aí eles vão falar "vocês são vândalos!" 
(Relêem a frase)

K: Minoria do quê?

O1: Pessoas. Mas não quero colocar pessoas.

(Falam ao mesmo tempo)

O1: Vou colocar uma minoria de pessoas? Fica muito simples!

O2: Dos jovens.

O1: Uma minoria de jovens que não têm alta conscientização

O2: Põe respeito também.

O1: E respeito pelo ambiente que vive.

A4: Volta ali no comecinho! (Relêem... "E que remos demonstrar que não somos aborrecentes...")

A1: $E$ que temos muitas idéias em mente.

A4: E podemos mostrar o que temos de qualidade.

O1: Temos muitas idéias em mente e nossas opiniões são óbvias e diretas.

K: Então, nessa coisa do aborrecente aí, o que vocês querem completar?

O2: Que temos responsabilidade suficiente.

A4: E podemos mostrar o que a gente tem de qualidade.

O1: Nossas opiniões são obvias e diretas. E alguma coisa com a responsabilidade.

02: Temos responsabilidade suficiente o bastante--

A4: Para mostrar as nossas qualidades.

O1: Para mostrar as nossas opiniões.

O2: Temos responsabilidades e obrigações.

O1: E responsabilidade pela nossa cidadania.

A4: Temos responsabilidade (e capacidade) o suficiente--

O2: Para expor as nossas opiniões.

(Relêem e terminam a definição do PAN e começam escrever as propostas)

K: Quais são as propostas?

A1: O que a A4 falou [Dia dos Adolescentes].

O1: Ah, vocês só pensam em balada! Vamos pensar em uma coisa--

(Falam ao mesmo tempo)

O1: Vamo começar com a violência então, vai.

O2: Aumentar o policiamento.

O1: Tem que ter verba pra pagar os policiais.

O2: Se tem verba pra construir o CEU Saúde, não vai ter verba pra aumentar o--

A4: Eu também acho.

$K$ : Então, qual é a proposta da violência?

A4: Se a Marta falou que tem dinheiro pra construir esse CEU, por que ela não vai ter dinheiro pra colocar mais policiamento nas ruas?

K: Então, a proposta é colocar mais policiamento nas ruas?

O1: Eu acho que primeiro o que tem que fazer é orientação. Orientar a população para... porque quem rouba é o povo, mesmo

A4: Mas tem outra: sabe por que o povo rouba? A gente rouba, mata, vai para Febem, daqui três meses a gente sai e a ficha fica limpa! [A1: É, mesmo!] É isso que eu acho. Igual o menino que matou aquele casal lá: o cara tá solto! E eles diminuíram a pena para dezesseis anos! Eu acho assim: matou, roubou..., tem que ser preso!

K: É importante isso que ela tá falando--

O1: É importante, mas eu acho que-- 
K: De ser preso e sair--

A4: Sair e ter a ficha limpa!

(Falam ao mesmo tempo)

O1: Tem que ter uns voluntários pra vir aqui na escola, explicar sobre violência, dar explicação das leis, e não--

A4: Mas o que adianta vir aqui, falar e não entrar--

(Falam ao mesmo tempo)

O1: É a conscientização da própria população!

K: As duas coisas acontecem. Não é só um ou outro. Vocês podem colocar uma e a outra proposta.

A4: Fala, querido O2!!

02: Eu acho que os policiais deveriam usar as armas deles. Eles deixam as armas de enfeite. Se fosse alguém morrer, que morra o ladrão!

A1: É mesmo.

K: Então vamos colocar estas três coisas: uma coisa, o nome disso que você ta falando é impunidade: fazer e não ser punido.

O1: Isso. Impunidade. E a outra já é--

A4: As orientações.

O1: Antes da orientação, qual é a palavra mesmo? Conscientização! A própria população deve se conscientizar--

O2: Por que não escreve simplesmente aula de conscientização?

O1: Não! Que aula??!! Já é a própria conscientização! Não tem aula pra isso!

(Falam ao mesmo tempo)

$\mathrm{K}$ : $\mathrm{O} 2$ falou de aumentar o policiamento.

O3: E usar as armas.

K: Vocês podem ir colocando as idéias. Não precisa ser só uma; vocês podem ir colocando várias.

O2: Permitir o uso das armas aos policiais.

O1: Não, as armas já são permitidas. É que eles que não usam!

A1: É mesmo.

O1: Eu acho que a gente tinha que juntar todas estas idéias e botar uma proposta só, que resolvesse as três. Não botar as três.

A4: Vai ser meio complicado.

K: Tá. Então quais são as idéias? Aumentar o policiamento, diminuir a impunidade--

O1: O Código Penal tem que mudar!

A4: Primeiro: o Código Penal tem que mudar.

K: Então vocês falaram quatro coisas: Aumentar o policiamento, diminuir a impunidade, aumentar a conscientização e mudar o Código Penal.

(Falam ao mesmo tempo sobre fazer em uma frase ou uma proposta)

O2: Você acha que o Serra vai ganhar a eleição?

Juntos: Não...

K: Vamos pensar em vocês, agora.

A4: Não. Chega gente! Chega de política! Cara, quer que eu fale um negócio? Os políticos prometem, prometem, prometem, e não fazem nada! Eles falam que vão ajudar--

O1: Mas a gente tá aqui pra isso!

A4: Se é pra debater política, vamos debater, meu! 
K: Isso aqui que vocês tão fazendo também é política--

A1: Mas não pra--

A4: Mas ele tá falando [do Serra e da Marta]--

(Falam ao mesmo tempo)

K: Então qual é a proposta?

A1: Violência. Combater a violência.

A1: Ô, O3, ajuda também.

O1: Fica só olhando pra nossa cara.

A4: Tá ouvindo nós debater.

$\mathrm{K}$ : $O$ que você acha que dá pra fazer pra diminuir a violência? Cada um pensa.

(Falam ao mesmo tempo)

O1: Pra mim quem tira a vida de uma pessoa (...?)

03:[Fazer alguma coisa pra que ele fique com] medo e não fazer mais.

A1: É.

A4: Ah, sabe o que o (?) falou? Que toda vez que fossem roubar, tinha que cortar o dedo, o dedinho, assim.

O3: É.

A1: É mesmo. É uma boa.

$\mathrm{K}$ : E resolve?

A4: Cortando o dedo, cara!

O3: Mas tem gente que rouba porque precisa! Não tem jeito!

A1: É.

A4: Não. Mas tem gente que precisa e não rouba, meu!

A1: É.

(Falam ao mesmo tempo)

O1: Eu acho que a maioria não precisa e rouba.

A1: É.

A4: Filhinho de papai.

O1: Essa parte que rouba porque precisa, [é pra essa parte que tem que] arrumar uma solução.

K: E qual a solução?

O1: Não, agora é a violência.

K: Então coloca no papel pra não esquecer: proposta pra quem não tem dinheiro.

02: Olha, uma proposta que liga [violência] e dinheiro (Falam ao mesmo tempo) você vai criando empresas, vai criando empregos, e as pessoas que falam que tá roubando porque precisa, isso é uma mentira, mano! Uma mentira descarada!

A4: Olha, tem gente que não gosta mesmo de trabalhar. E prefere roubar pra não trabalhar. $E$ isso.

O1: Outro dia eu tava no buzão, entrou um cara, tal, falando "minha família, minhas crianças"... pedindo dinheiro, com cem conto no bolso.

O2: Eu já cheguei a ouvir gente falar "Pô, esse cara que estuda é maior burro. Ele estuda, estuda, estuda, depois não consegue emprego. Eles trabalham feito louco, pegam o salário, chega lá. A gente que é esperto, a gente chega com uma arma 'Passa o dinheiro'. Isso é um trabalho de verdade"!

A4: Eu não acho.

O1: Armamento tem que ser mais forte. [K:Então, continuando propostas para violência] Postos policiais em questão de-- 
O2: Tem um posto policial lá perto do--

O1: De dois em dois quilômetros tem que ter um.

A1: É mesmo.

(Falam ao mesmo tempo)

O2: Se a gente só ficar falando sobre violência, como fica a saúde, o emprego, o transporte?

A1: É.

O1: Tá, dois em dois quilômetros um posto policial. Blindado.

O2: Dois em dois quilômetros?

O1: É.

O2: Você é louco!

K: Isso não é aumentar o policiamento que o 02 tinha falado?

O2: Também, mas com o posto policial já é mais difícil ele roubar, assaltar carro, essas coisas.

O1: Posto policial blindado e altamente equipado, com rádio de última geração, tal. Com armamento mais forte.

02: Se aumentar o policiamento pode entrar polícia corrupta que vai distribuir arma pros ladrão.

O1: Ah, com um salário bom... Ah, isso é, né?

A1: $E_{\text {, isso é. }}$

O2: Ele chega lá com a arma "Me dá oitocentos".

O1/A1: Mas é.

$\mathrm{K}$ : E como é o nome disso?

Juntos: Corrupção.

K: Então é diminuir o que?

O1: Mas como?

O2: Eu sei como diminuir a corrupção: diminuir a falsidade.

(Risadas)

O2: Lavagem cerebral, cara!

O1: Orientação, meu! E o Código Penal. O policial que... tudo precisa do Código Penal.

A4: "E mudar o Código Penal". Eu acho.

O1: É melhor colocar assim: usar o Código Penal... deixa eu achar a palavra. Fazer uma coisa bem forte.

K: Intensa? Radical?

O1: Isso. Fazer uma mudança radical no Código Penal. Para não haver corrupção. Para que a corrupção seja diminuída e aniquilada cada vez mais da nossa sociedade.

O2: Ter pena de morte!

O1: [Se o Código Penal mudasse, eu não ia colocar pena de morte].

O2: Pronto. Saúde agora.

O1: E outra proposta [ainda sobre violência]: aulas de orientação nas escolas e lugares públicos.

O2: Ô, só vai ficar na violência...

K: Conscientização.

O1: Aí acabou.

K: Orientação do quê?

O1: Em geral, sexo.

K: Então coloca sobre sexo, crime, em geral, né?

O1: É. [Sexo, drogas, crime, violência] 
A4: É verdade. A última vez que teve alguma aula de orientação foi o ano passado, né? Sobre drogas...

(Terminaram de escrever o que discutiram sobre violência. Passam para a proposta de Saúde)

O3: Mais saúde para adolescentes.

O2: Mas aí como vai fazer isso?

O1: Tem que colocar tudo. Pra idosos--

K: Para toda a sociedade?

A4: É.

(Falam ao mesmo tempo)

O1: Equipar os postos. Ter remédio.

O3: E com alta segurança....E que acabem com as injeções.

A1: Não, O3, porque tem injeção que cura.

A4: Pô, O3, você tem medo de injeção. Não dói, cara!

O1: Médicos bem preparados.

O3: E que acabe com o câncer de próstata.

O1: Com postos bem equipados e médicos bem preparados para um atendimento mais humano para todos.

A1: Um atendimento melhor.

O2: Aumentar os remédios nos postos. Funcionar 24 horas os postos.

A4: Ah, não.

O2: Alguns postos, pelo menos.

A1: Pelo menos alguns.

O1: $50 \%$ dos postos da rede pública funcionando 24 horas e outros aos sábados e domingos. A1/O2: É.

O2: Vai que o cara toma uma facada no pescoço lá --

A4: Meu, levar uma facada no pescoço, primeiramente: você nem vive. Você morre.

O21: Tá bom, se você tomar um tiro.

$\mathrm{K}: \mathrm{O}$ que mais pra melhorar a saúde?

A4: Mais?

O2: Pode ter aula de higiene, né? Pra não pegar alguma doença.

O1: A orientação já tá na violência.

K: Tem saúde naquele parêntese? Então, põe saúde. Tem mais alguma coisa?

O1: Manda esse senhor pensar, aí.

A1: Precisa de mais posto de saúde também. Porque não adianta nada ter uma pá de coisas e não ter posto.

O1: Ah, mas tem posto pra caramba. É que não tem equipamento.

O3: Em (?) só tem dois.

A1: É. E só um é que é bem usado, porque o outro--

O1: Construção de mais hospitais.

A3: Ambulâncias novas.

O2: Prontidão de ambulância. Você liga pro (...) e demora três horas pra chegar

?: Distribuição de camisinha.

A1: De camisinha boa.

(Falam ao mesmo tempo)

A4: A melhor é a Jontex.

K: Já tem a distribuição de camisinha? 
A1: Já, mas só que de camisinha ruim.

(Falam ao mesmo tempo)

K: Então o que vocês acham?

A3: Coloca a distribuição de camisinha... Não. Anticoncepcional.

O2: Camisinha boa.

O3: Jontex.

O3: Camisinha de qualidade. Da boa, da boa. Daquela (?) tem que colocar duas pra não estourar, meu?

O1: O controle do Imetro mais rígido.

A4: Você sabia que se colocar duas camisinhas é mais fácil a menina engravidar?

O3: Como é que é?

A4: Com uma de qualidade é melhor do que com duas, que com duas ó, rasga rapidinho.

O3: Experiente, hein?

A4: Não... Eu tava lendo na [revista].

K: E tem mais alguma coisa de Saúde?

O3: Abaixar o preço dos remédios na farmácia.

A1: Verdade.

O1: É também. Mas é questão de laboratório, né? Já ia ter que ver esse negócio aí.

A1: Mas é saúde.

O2: Definição do preço de um remédio. Tipo, "Esse remédio não pode passar de cem reais".

K: Então é definição do limite do preço dos remédios.

A4: Mas tem a Ultrafarma, meu! Sabia que lá eles diminuem o preço dos remédios?

O2: Mas a Ultrafarma..... Não é só a Ultrafarma que existe. Tem Drogasil aqui perto.

A4: Ah gente, não é por nada não, mas a Drogasil é a mais cara.

O1: Eu acho que o governo tem que fazer umas farmácia deles próprio, mesmo. [02: Farmácia do Governo] Pra vender abaixo do custo. Porque são tudo feito em laboratórios do estado, então não tem porque cobrar taxa, imposto. (Terminam de discutir e escrever sobre Saúde)

K: E além de Violência e Saúde, o que precisa melhorar?

O1: É, vamos sair da saúde agora--

A1: Negócio de trabalho.

O1: Vamos pro transporte.

O2: Falô. Transporte.

A4: Transporte?

O1: Emprego, vai.

A1: É.

A4: Transporte nem tanto.

O1: A Marta já fez tudo pelo transporte.

$\mathrm{K}$ : $\mathrm{O}$ que dá para pensar no emprego, $\mathrm{O3}$, que a gente tava falando, que a pessoa rouba porque não tem dinheiro?

O1: Tinha que dar curso profissionalizante de graça para o pessoal--

O2: É mesmo.

01: Mas não os cursos técnicos do caramba aí. De graça, quer fazer faz, entendeu, só que tem que ter--

O3: Não que nem aquele cabeção do Serra que quer tirar o Telecentro.

O1: Os cara não sabem nem... Você chega lá, e ensinar que é bom, ele não ensina. 
03: Ele ensina sim, que eu já fiz o curso e eles ensinam bem mesmo. É um curso básico do Windows. Melhor que nada, não é?

O1: Cursos profissionalizantes gratuitos de qualidade com monitores altamente preparados.

O3: Material didático.

O1: Põe monitores altamente qualificados.

O?: Equipamentos de ultima geração, em boa condição de uso.

O3: Os computador do Telecentro é melhor que os da escola aí, mano! Muito mais melhor.

(Falam ao mesmo tempo)

K: Você tava falando de criar empresa pra criar emprego. Ele tava falando que pra ter isso precisava diminuir os impostos pra gerar mais empregos....

O2: Na verdade, precisa diminuir impostos--

A1: Não cobrar impostos tão altos.

(Falam ao mesmo tempo)

O2: Até pra virar camelô tem que pagar imposto. Tá doido?

$\mathrm{K}$ : Então faz isso? Diminui impostos pra que as empresas venham e façam o quê?

O1: Dêem oportunidades aos jovens.

O2: Não, aos menores de dezoito e aos maiores de--

A4: Não, já tem "Primeiro Emprego".

O1: Não gente, mas "Primeiro Emprego", vamos supor 500.000 que tem na cidade, 3.000

(...?)Tem, mas não funciona, o que adianta?

(Falam ao mesmo tempo)

O3: O1, você daria um bom prefeito. Não é O2? Ele não daria um bom prefeito?

O1: E auxílio e oportunidade para a população...

O2: Pra viver dignamente.

$\mathrm{K}$ : Agora entra o que o $\mathrm{O2}$ falou.

O2: Eu falo com as minhas palavras e o 01 'aperfeiçua'. Criação de empresas para... [lê de novo]

O1: Dando oportunidades para a população em geral, principalmente para jovens $e$ idosos, que idosos também sofrem pra caramba porque não têm emprego...! Que são muito excluídos na sociedade de hoje. Muito não, altamente fica mais bonito.

O1: E depois, pra onde que vai a carta?

K: Depois o trabalho, a pesquisa, vai ficar um livrão $e$ isso vai ficar numa parte que se chama "anexos" e todo mundo que ler, vai ler a proposta de vocês. Vai ficar lá na biblioteca da Psicologia da USP.

O1: Legal!

$K: E \circ$ que mais de emprego?

01: 03, o que você acha que tem que fazer pra melhorar? O que fazer?

O3: Projeto.

O1: Projeto tem e não funciona. Tem que ser alguma coisa que funcione.

O3: Emprego.

01: Mas aí a gente já falou.

O3: Curso.

O1: Isso a gente também já falou. O que você gostaria de fazer, por exemplo?

O2: Se começar criar escolas (O1 fala ao mesmo tempo)--

A1: Escola boa daí, né?

K: Aí vai entrar na educação, né?

O1: Então, mas aí orientação já vai dar emprego pra bastante gente. Se for remunerado, né? 
A4: A carta não vai dar pra terminar ainda hoje.

O2: Tem que criar escola, nossa, vai dar bastante emprego. Só em uma escola vai dar, quantos funcionários? Cem?

O1: O que?

A4: Na escola? Uns dez funcionários.

O?: Dez?

A1: É lógico.

O1: Um cozinheiro, um coordenador.

O3: CEU Saúde é um bom projeto pra gerar emprego.

O2: É mesmo.

O1: Gente, eu acho que não. É o fura-fila pra mim. [Um hospital bem equipado vai dar emprego do mesmo jeito. Só que um precisa de tipo o que? Quarenta empregos? Precisa ser o triplo].

A4: É uma policlínica.

O1: É um postinho.

O2: Um não, quarenta.

O1: O CEU Educação, esse funcionou. Agora o CEU Saúde não funcionou.

K: Vamos voltar ao emprego, mais alguma proposta?

O3: Centro de Solidariedade que é um projeto.

O2: Oficializar os camelôs.

O1: É uma boa idéia. Dar a liberação pros artesão trabalhar com o que ele bem entender. Porque é uma palhaçada isso. Não pirataria, é outra coisa pirataria. Agora artesão é diferente, entendeu?

K: O camelô, quando ele tá vendendo alguma coisa. Qual é a diferença deste camelô para o artesão?

O1: O artesão faz as próprias peças, é uma cultura deles. O piratarista tá tirando de outro pra ele--

A4: Só que uma coisa, é uma diferença, por exemplo, você quer comprar um CD. Meu, ó, só pra ter uma idéia: você quer comprar o CD original do Red Hot Chilli Peppers. Acabou de sair, o CD tá por quarenta e pouco. Pô, você vai ali no camelô, troca por cinco CDs.

O1: Mas acho que você tem que pensar nos cantor que vão pagar estúdio, isso, aquilo. Tem o prejuízo deles também. Queria ver se você fosse cantor, fosse num estúdio, pagasse trezentos pau pra gravar $C D$ e os outros viessem vender de graça, você não ganhasse um tostão em cima disso.

A4: Só que eu acho que eles também tinham que diminuir, igual o (?) quando saiu, ele veio botar lá o $C D$ por $R \$ 9,99$. Uma pá de gente comprou, não foi?

K: Vamos voltar "Oficializar os vendedores artesãos, e não os camelôs".

O1: Diminuir altamente a pirataria. Mas aí tá falando da violência, já.

$\mathrm{K}$ : O que mais pra emprego?

A1: Só.

O2: Pronto.

(Falam ao mesmo tempo)

K: E educação?

O1: Acho que tinha que ter mais coisa pra emprego ainda.

$K$ : Então vamos pensar mais coisa pra emprego.

O1: Vai escrever isso, só?

A4: Só que agora não tá vindo na nossa cabeça. 
K: Pode pensar mais um pouquinho e se não der pra acabar, a gente pode separar um tempo do próximo encontro, tá bom? E o que mais pra melhorar o emprego?

O2: Oficializar o cara que põe piercing, faz tatuagem....

A1: Isso tá oficializado já.

O2: Já?

K: $O$ que a gente também pode fazer é quando vocês chegarem em casa, se tiverem mais idéias, pode escrever também, traz pra cá e completa.

O2: Não tem o Projeto Renda Mínima? Vamos criar o Renda Máxima.

K: Vamos continuar só uma coisinha: eu queria saber o que vocês têm de proposta pra educação.

O1: Tem que ter professor ganhando bem.

O2: Mas se tiver professor ganhando bem, vai pensar: "Tô ganhando bem. Porque vou dar aula?"

O1: Lógico que não.

O2: Tem que pensar assim: ganhar pelo ensino; se estiver ensinando, ganha bem.

A1: Isso é.

A4: É verdade.

K: Será que vai ganhar pelo ensino? E depende do professor um ensino bom?

A4: Não, depende do aluno, mas se ele vê que, ó, que ele tá dependendo do ensino, mesmo que ele não... "Ai, não quero dar aula hoje", ele vai dar aula pra no final do mês ele ter o dinheiro dele.

K: Então, depende só de aluno ou professor? Será que não tem mais nada que--

A4: Depende também da diretora. Depende de todo mundo.

A1: Depende de todo mundo que faz parte da escola.

$K:$ E será que depende só de dentro da escola?

A4: Depende também de fora.

O1: A orientação. A orientadora também vai ajudar bastante os professores, pelo menos.

$\mathrm{K}$ : Mas o que de fora da escola, por exemplo?

O2: Uma boa é criar, aquele negócio de emprego também, é..., qual é o nome? Seguranças de..., tipo aquele cara que fica [olhando] enquanto o professor dá aula; é ou não é?

O1: Pode ser.

K: Como se fosse um inspetor de aluno?

A1: Só que não ficar pegando no pé por qualquer coisa.

A4: Se vê que tá já ultrapassando, [fala] tipo: "Ó, manera!".

K: Então o professor teria uma pessoa que ajudaria--

O1: Um monitor de sala.

O2: Só que monitor de sala, pô! Não faz nada.

A1: É mesmo. Se tá zoando, ele zoa também.

O2: [Tem que ser um] monitor adulto. Sem ficar: "Ó, se você me caguetar, te encho de porrada!" e o cara... [fica parado].

O1: Ter na sala ajudantes do professor para manter a ordem e a disciplina... Ajudantes adultos.

A4: Ai gente! Acho que não deveria ser adulto. Jovem.

A1: Não, adulto.

O1: (...) que ajude a manter a disciplina e o progresso da sala. Muito obrigado, A4. Votem em mim!

A4: 45, você, né?

O1: É. 45!

K: Você tinha falado a disciplina e a ordem? Agora você falou a disciplina e o progresso? 
O1: É. A ordem e a disciplina é a mesma coisa. Progresso--

(Falam ao mesmo tempo)

O1: $E$ instalar equipamentos de vigilância na escola.

A4: Mas daquelas câmeras que você nem vê--?

O1: Não precisa ser isso. Pode ser uma câmera normal.

A4: Pra quê colocar a câmera grande, se o aluno quebra?

O1: Ah, gente não é pra tanto! Aluno não vai fazer isso também!

A4: Ah, você não conhece?!

O1: Ah, sair, tipo... gangue? Ah, não é pra tanto! A maioria que vem aqui..., ah, não é pra tanto. Isso aí é cadeia!

K: Bom, a gente parou em o que precisaria resolver a violência dos alunos. Como já deu o horário e vocês precisam ir embora, no próximo encontro, a gente separa um bom tempo pra continuar essa discussão, tá bom? Então é isso. Obrigada, pessoal! 


\section{QUARTO ENCONTRO EM GRUPO COM OS ALUNOS}

É retomada a carta PAN que fora escrita encontro anterior. Conversa-se sobre a divisão de trabalho realizada para a tarefa (ler e escrevê-la). O3 lê a carta.

K: Quando a pessoa não sabe ler e escrever, ela é o quê?

O?: Burra de carga.

O2: Não.

A4: Não. É analfabeta.

O2: Essa pessoa simplesmente não usou bem sua inteligência!

A1: Só que tem gente que nem se interessa em usar a inteligência!

O2: Então!

O?: Que não se importou em aprender.

K: Que não se importou em aprender... Será?

A1: É sim, tem uma menina na minha classe que nunca aprendeu; ela não tem (interesse?) em aprender; ou tem dificuldade.

A3: Ou tem dificuldade.

A1: Não, mas se tem dificuldade, tem que tentar.

O2: $\hat{E}^{-}$

K: E depende só do aluno?

O3: Do professor.

A1: Os professores também. Só que, que nem aquela menina ( $a X_{1}$ ), ela não faz nada! Ela nunca vai pra escola e quando vai, ela não faz nada, então é falta de interesse dela!

O3: Ela bagunça... (que nem a $X_{2}$ ).

A4: Mas eu acho que a $X_{2}$ é um caso a parte. É diferente.

A1: É.

O3: Por que?

A4: Porque o dela é alguma dificuldade e 0 da $X_{1}$, não. Ela vem pra escola, mas não vem fazer nada...não se esforça, não faz nada!

$K: E$ quando acontece, por exemplo, de em uma sala inteira, pouquíssimos alunos sabem ler e escrever, o que acontece?

A4: É desinteresse da pessoa.

A3: Depende da professora.

A4: Por exemplo, $90 \%$ da sala não sabe ler e escrever e $10 \%$ sabe. Então, daí fica meio complicado, porque quando o professor tá explicando, você tá entendendo, aí vem aquela pessoa "Ai, explica tudo de novo". Aí lá vai ele, explicar tudo de novo. Aí vem uma outra pessoa "Ah, de novo, porque eu não entendi".

A1: Mas também tem que ajudar os que não sabe.

A4: Eu acho que deveria ter, sei lá, uma hora extra pra eles, pra eles desenvolver. Porque além deles atrapalharem a gente, a gente também... fica meio difícil a gente acompanhar esse ritmo deles, então fica meio complicado.

K: Então tem mais coisa que entra: por exemplo, na sala misturada, gente que sabe, gente que não sabe...

A4: Eu acho que deveria ser uma sala especializada para quem não sabe ler!

A1: É mesmo!

A4: É, eu acho que deveria ser, porque eu falo mesmo, a gente sabe que fica atrapalhando: a gente já não sabe quase nada e quando a gente quer aprender... 
$K: E$ o que vocês acham do que acontece que, às vezes, tem, por exemplo, uma sala inteira numa quinta série em que ninguém sabe ler e escrever. Chegou até a quinta-série sem aprender a ler e escrever. Isso pode acontecer?

A1: Não, porque--

(Falam ao mesmo tempo)

A4: Eu nunca vi.

A1: Eu também não.

(Falam ao mesmo tempo. Barulho)

A4:Não, na quinta, não; Eu nunca vi isso acontecer.

O2: Na sétima série da escola $E_{3}$ tem neguinho lá que não sabe ler.

A4: Igual a aqui. Na oitava série tem gente que não sabe ler!

O2: Quem?

A1: É mesmo.

O3: $O X_{3}$

A4: Tem gente que não sabe ler. Eu acho que isso tem um custo; uma pessoa que não sabe ler. Porque cada dia mais, ela vai ficando mais burra! Entendeu? Igual, por exemplo, se a $X_{2}$, se ela passar, for pro primeiro..., só que lá ela fica.

A1: É mesmo.

A4: Ela não passa.

K: Será?

A1: Acho que ela nem vai para o primeiro.

(Falam ao mesmo tempo)

O3: Tem gente na universidade que é analfabeta!

K: Será que tem?

A4: Ah, tem!

O4: O Pr1 falou.

A1: Eu acho que não.

O3: Eu acho que sim.

K: O Pr1 diz que tem? E será que pode isso? O que acontece? A pessoa não aprendeu a ler $e$ ela vai passando, passando...

A4: Eu acho que os professores não querem ensinar, mesmo!

A3: Eu acho que pode passar no colegial, tipo assim, na escola.

A4: De primeira até oitava. Só que eu acho que quando ela, tipo, o primeiro é bem difícil passar.

A1: É mesmo.

A4: Porque o primeiro colegial a gente pensa que é fácil, mas dizem que é mais fácil pra (?)

$K$ : Mas a pessoa então pode chegar até a oitava série sem saber ler e escrever?

A4: Pode, mas eu acho, na minha opinião, que deveria fazer tudo de novo. Mesmo que, meu, você seja grande, mas deveria fazer tudo de novo. Começar desde a primeira--

A1: Não, acho que tinha que ver qual é o-

A4: ...problema...

A1:...a dificuldade do aluno. Tipo, uma dificuldade que seja desde a primeira série, ele tinha que fazer a primeira série. Agora, se for desde a quinta, não precisa fazer desde o começo. A4: E não ficar, tipo, passando, passando, passando. Porque, tipo, vai passando e a pessoa vai se acomodando.

K: Mas então não tem uma prova, uma coisa que faz a pessoa repetir?

A1: Tem. 
A4: Tem.

A1: O Saresp.

K: O Saresp faz repetir?

A4: $O$ ano passado teve.

O3: O Saresp, já falaram, que não repete.

A4: Não repete, é o conhecimento que a gente tem.

O4: É um teste.

A4: Do conhecimento que a gente tem.

04: O Saresp é só um teste pra gente ter conhecimento do que vai ter o ano que vem.

$K: E$ aí, o que vocês acham disso? Repete ou não repete, o Saresp?

(A1 e A4 falam ao mesmo tempo)

A4: $O$ ano passado, eu achei que da quinta (série)--

A1: Na quinta [se você tiver] nota ruim e se tiver falta, repete.

O3: Dá medo!

A4: Dá. Dá medo!

K: Por que dá medo?

A4: Porque na hora que você entra assim na sala, maior silêncio, o professor já chega falando a regra: Não pode conversar, não pode --

A1: Não pode nem olhar pra trás!

A4: E o ano passado, a minha sala, a gente colou, era na borracha.

A1: É.

A4: Passava borracha..., mas dá medo!

A3: Tipo assim, eles passam uma coisa que vai cair no Saresp, e depois dão o Saresp para gente fazer, só que a gente não pode consultar nada. Então, fica um pouco difícil, né?

A4: Mas é por isso que eles pedem que é pra gente estudar.

A3: Mas a gente poderia consultar alguma coisa. Lembrar um pouquinho.

$K$ : Nas provas daqui de vocês, normalmente é com consulta?

A1: É com consulta!

A4: A maioria é com consulta.

$K: E$ aí vocês acham que avalia o que vocês aprenderam, não aprenderam...?

A1: Eu acho que não. A pessoa não sabe nada, vê no caderno, já tá a resposta.

$K:$ Vocês acham que isso pode acontecer então?

A1: O quê?

$K:$ A pessoa passar sem saber.

A1: Eu acho que pode! Porque eu mesmo não sei uma pá de coisa, mas eu to aí, com nota boa, mas eu não sei fazer.

K: Então, tem isso das pessoas passarem de ano em ano sem ter aprendido mesmo, não só ler e escrever, mas o conteúdo mesmo das aulas...

A4: Mas sabe por que também? Porque os professores, eles começam uma matéria hoje, amanhã eles põem outra--

A1: Isso é!

A4: E complica demais, demais, demais, demais! Igual o Pr1. Hoje ele já veio com uma nova matéria!

(Falam ao mesmo tempo)

O3: E ele hoje já chegou com uma prova!

A4: Segunda-feira ele tava passando um texto. Faltou ontem. Chegou hoje, ele passou uma outra coisa. Ô, que parada! Eu falei "E o texto?" "Ah, mais tarde vocês terminam". 
K: Fala, 03

O3: O Pr1 chegou com uma prova.

K: Foi com consulta?

O3: Foi.

$K:$ E aí, não adiantou?

O4: Pra mim não adiantou nada, que eu não tenho nada no caderno!

A1: A minha não adiantou muita coisa, por causa que--

O3: De onze questões, eu respondi só sete.

A1: Eu respondi todas, mas só que mó mal respondida, porque--

O3: Teve uma prova que ele passou super fácil [só deixei de responder uma]

A1: É. A do texto era fácil, agora a que ele passa, assim, na prova é muito difícil!

(Falam ao mesmo tempo)

K: Vocês estão questionando se ele já tinha marcado--

A4: Ele já tinha marcado pro dia 26, ai ele faltou e pra minha sala ele chegou hoje e falou que a prova foi adiada para o mês que vem. Em vez dele dar uma, ele vai dar duas.

O4: Por que a nossa não foi adiada?

A1: Porque ele quer dar uma só.

$K$ : Tem uma coisa que eu ainda queria perguntar pra vocês, que a gente tinha começado a falar no último encontro: a idéia do que acontece quando o ensino é de má qualidade, o que acontece pra ter um ensino de má qualidade. Aí cada um disse uma coisa. Teve gente que disse que é por causa de inteligência do aluno, teve gente que não, teve gente que disse que é por causa de professor, disseram que é por causa da diretora...

O2: São por três coisas: falta de interesse do aluno, do professor, da diretora.

(Falam ao mesmo tempo)

K: E aquela história que dizem que quando o aluno não tá aprendendo a culpa é da família do aluno?

Juntos: Nada a ver! Nada a ver!

A3: Eu acho assim, a família poderia ajudar, perguntar como tá indo na escola, não custa nada, olhar o caderno... então acho que também tem que ter interesse da família.

A1: É mesmo.

A3: Porque não é só do aluno, do professor e do diretor; tem que ter a família ajudando também. Só eles não vão dar conta, se a pessoa não tá..., não tá conseguindo seguir a escola, com todos os alunos juntos. Vai que ele tenha alguma pessoa, assim, na família que pode ajudar ele, ensinar...

K: E quem não concorda? Que diz que não tem a ver isso de dizer que a culpa é da família? Uma coisa é a família ajudar, outra coisa--

(Falam ao mesmo tempo)

A4: (?) família também. Eu acho que o aluno também tem que se esforçar, bastante, e precisa procurar. Igual ela falou, se tiver alguém pra ajudar, melhor ainda, porque você ganha mais conhecimento! Mas se a pessoa vê que na família não tem ninguém, então ela tem que se esforçar, se tem algum colega "Você pode ir em casa me ajudar?"--

A3: Vizinho.

A4: Ou vizinho ou alguém também. Não é só a pessoa que tá esperando um outro dia pra elaA1: ...esperar a pessoa chegar nela e perguntar. Ele também tem que tirar a dúvida e se esforçar

A4: É.

K: O4, o que você acha de dizer que a culpa é da família? 
O4: Tipo... Por um lado sim, por um lado não.

K: Que lado, não? Por que não é da família a culpa?

O4: Porque... pra mim se não quer aprender, o problema é dele.

K: Você acha que a culpa é do aluno? Que existe um culpado?

O4: (respondeu positivamente, mexendo a cabeça)

$K: E$ você $O 2$ ? Você estava dizendo que não acha que existe isso....

O2: Se o aluno quiser ele vai aprender, ele que aprenda! Ele tá na escola, tá vendo o que o professor tá passando! Não é os pais dele que tá vendo o que o professor tá passando, é ele; ele que vai aprender!

$\mathrm{K}$ : Mas tem uma outra coisa nisso também. O3, o que você acha: tem gente--

O3: Eu acho que os pais, de vez em quando têm que vir na escola.

O4: Num ponto é bom, né?

(Falam ao mesmo tempo)

O2: E a mãe dos que vêm dão lição de moral na sala, meu!

A4: A mãe do $X_{5}$ puxa a orelha!

(Falam ao mesmo tempo)

A4: A sala toda começou a chorar.

(Falam ao mesmo tempo)

A4: Nossa, a mãe dele falou que tá cansada, que ontem ela tava indo numa entrevista de serviço, ela voltou porque ligaram no celular dela falando que tinha [acontecido alguma coisa com ele aqui na] escola e ela chegou nele e falou assim "Hoje você poderia chegar em casa e eu falar 'Ó $X_{5}$, eu consegui um emprego', mas hoje você vai chegar em casa e não vai ouvir isso". Ela falou assim que "Hoje eu vou criar uma laranja; mas aquelas pessoas que fica com ele, amanhã vai ser um bagaço".

A1: Ai gente!

A4: Ela falou desse jeito. Falou, assim, que quer os maus elementos longe do filho dela. [Mas eu falei pra ele] "Sua mãe, tipo, ela acabou ofendendo". Uma parte ela tava certa, mas uma parte ela tava errada, porque não é culpado só os amigos; é ele que ta indo. Eu acho assim, que "cada cabeça, seu guia": se ele quiser se ferrar, ele que se ferre, porque ninguém tá levando ele; ele que tá querendo ir. Mas também tem amigo que ajuda, né, mas...

K: Mas eu queria perguntar para vocês uma coisa da família: tem gente que diz que a família é culpada porque a família é pobre--

Juntos: Não, não tem nada a ver!

K: Gostaria de saber o que vocês acham de dizer que a culpa é da pobreza, não aprende porque é pobre....

A4: Tem tanta gente que é pobre, que você olha assim, que tá lutando, que trabalha.

O4: Dinheiro não quer dizer nada, meu!

O2: Tem gente, que você vê, que é mó riquinho, vai em escola particular, não aprende nada!

A4: E uma coisa: eu acho, assim, que o pobre é mais feliz do que o rico. Porque o rico tem só dinheiro. A gente é pobre e a gente tem felicidade! A gente tem o amor dos nossos pais. Riquinho não. Sai por aí, usa droga, faz o que quiser, porque o pai não dá atenção, entendeu? Às vezes a gente fala "Pô, o nosso pai é super chato", mas não é. Ele gosta da gente, ele toma conta. O riquinho não, meu! Ele fala: "Pai, tô na delegacia". O pai dele vai lá e paga, sem falar nada.

K: $O$ que você ia falar A1? Quando a gente tava falando sobre a idéia de que não aprende porque é pobre, você falou "Nãããooo". Por que? 
A1: Por causa que quem é pobre sabe muito mais coisa que rico. Porque eu acho que essa coisa de dinheiro, não tem nada a ver!

$K$ : A3, o que você acha?

A3: Eu acho que não tem nada a ver. Dinheiro não vai ensinar, não vai fazer nada. Então eu acho que não tem nada a ver. [Não é porque você tem dinheiro, que você tem um bom estudo]. Tudo bem, você vai pagar a faculdade, tal, mas não tem isso de que só porque é rico que é mais esperto!

K: Essa história de rico ser mais inteligente, né? Fala, O3.

O3: Tem também [a atitude]. Minha vizinha lá na rua tem um carro e uma moto, ela empresta a moto pros meninos lá na rua--

(Falam ao mesmo tempo)

A1: Mas O3, tamo falando o que tem tudo, não o que tem moto ou carro. Ela pode muito bem ter uma moto ou um carro e estar se ralando. Acho que não tem nada a ver.

O3: Pra mim tem.

A4: Tem isso também, que o outro fala "Nossa, você é mó rico", mas às vezes ele fala "Eu não sou feliz, queria ser igual vocês. Vocês são pobres, mas são felizes. São contentes, a gente não. A gente é triste". Porque não tem o carinho da mãe: o pai trabalha, a mãe, fica mais (?) que tudo, ele fica em casa. Então, ele tipo "Ah, meu, se eu fumar..."

K: Vocês sentem isso aqui de alguém achar que vocês por serem pobres, não serem ricos, serem alguma coisa? "Ah, esse menino é assim porque é pobre".

A1/A3/A4: Eu não sinto isso.

A4: Aqui dentro da escola não. Acho que todo mundo é igual.

A1: Eu acho que aqui na escola tem esse preconceito, só que assim, de cor. Porque uma pá de gente fica zoando com o $03 \ldots$

A4: Também acho.

A3: É.

A juntas: É preconceito.

O4: Mas isso ai é brincadeira.

$A$ juntas: Não.

$\mathrm{K}$ : Como é isso de preconceito de cor? O que acontece?

(Falam ao mesmo tempo)

A1: A mãe de uma menina tava falando pro professor que a menina, tipo assim, tá pensando em se matar; só por causa da cor dela. Acho que tem muito disso.

$K: O$ que vocês acham disso?

A1: Tem também por causa de cabelo.

A4: Preconceito é a pior coisa.

(Falam ao mesmo tempo)

A4: Fica difícil pra chegar num lugar... igual, assim, em faculdade. Você não consegue. Se você for tentar uma faculdade aí, você não consegue. É mais fácil se tiver cinqüenta branco assim e um negro lá, pode passar os cinqüenta, mas o negro fica.

K: Pra selecionar, pra entrar numa faculdade, prova, vestibular?

A4: Esses negócio..., trabalho, qualquer coisa! Qualquer coisa é desse jeito, entendeu? Só que acho assim, que deveria ter, sei lá, mais respeito pela gente, porque a gente também é ser humano!

$\mathrm{K}: 02$, o que você ia falar de como vocês sentem o preconceito aqui na escola?

A1: Por exemplo, se uma pessoa é gorda ou magra, tudo isso. Agora, assim, de pobreza, eu nunca vi; é mais de se a pessoa é gorda, feia, tem cabelo ruim, esses negócio! 
O2: Se eu vejo um neguinho com preconceito, eu encho de porrada!

A4: É chato! Se a pessoa vem e fala uma coisa, assim, a gente se sente meio incomodado.

$\mathrm{K}:$ Você sente isso de preconceito aqui, 04 ? Com alguém, algum amigo?

O4: Preconceito, não.

K: Você sente isso O3? Igual ela tava falando--

A1: Sente sim!

(O3 responde negativamente, mexendo a cabeça. [K: Sente?] O3 responde com a cabeça, negativamente)

$\mathrm{K}$ : Mas eu queria voltar para o que a gente estava falando: pegando a proposta do PAN para ver se vocês querem acrescentar mais alguma coisa. (K resume o que foi falado em relação segurança, saúde, emprego) Parou na educação. O que pode acontecer para melhorar a educação? Antes, o que vocês acham da educação, do ensino no Brasil? Sem ser só aqui nesta escola, no Brasil. Vocês têm alguma idéia do que vocês acham?

?: Tá bom.

A1: Não tá tão bom assim.

A4: Depende da escola. E depende... Não, acho que depende do lugar.

A3: Depende do professor.

A4: E da escola também.

A3: Se o professor tem boa vontade de ensinar, ele vai conseguir ensinar. Agora se ele não tem. Se ele não tem, e o aluno não tiver, então.....

O2: Em um ano que eu estudei lá na Bahia, o ensino é ótimo! Os professores são muito respeitados. São deuses lá. Chega na sala, ninguém zoa com nenhum professor.

A4: Acho que é por causa do local.

(Falam ao mesmo tempo)

A4: Aquela escola $\left(E_{4}\right)$ ninguém merece. É a pior escola!

$K$ : Por que é ruim? O que tem de ruim?

A4: Nossa! É professores, alunos, direção. É tudo.

(Falam ao mesmo tempo)

O3: Naquela escola, a gente pula lá--

A4: Você entra--

O3: Eu já fui lá pra pegar lanche.

O4: Os alunos lá cola a hora que quiser.

A4: Sai a hora que quiser.

O2: Quando você olha assim pro chão, cheio de marca de sangue.

(Falam ao mesmo tempo)

A4: Entra lá, pra ver! É cheio de sangue lá!

O3: A quadra lá tá legal.

A4: Entra lá dentro e olha no chão pra você ver!

K: Mas e no resto, se for pensar no Brasil, vocês têm idéia de como está? Se as pessoas estão se alfabetizando, se estão aprendendo?

O2: Os únicos lugares que eu ouvi que tem ensino bom mesmo é Pernambuco e Salvador. São Paulo--

A4: São Paulo acho que tem um ensino melhor.

A?: Não tem.

A4: Tem professores legais,tem professores, você olha, eles têm vontade de dar aula. Olha sua sala. Tudo trambolho.

K: Trambolho? Como assim? 
A4: Gente que não quer nada, sobe em cima na cadeira, fica zoando, quebra a lâmpada, cospe, na cara de pau... assim, na cara de pau e ninguém fez nada!

$K$ : $E$ você $O 3$, o que falou aquela hora?

O2: Professor medroso.

K: Isso, 02. Obrigada!

O3: Tem professor medroso na escola, principalmente à tarde.

K: Medroso? Com medo do quê?

O3: Dos alunos.

A4: Dois professores morrem de medo dos alunos. O Pr2 e a Pa2. Você pode fazer o que for. Você pode falar "Amanhã seu carro vai explodir"; ele não vem de carro, ela não vem de carro.

(A1 e A4 falam ao mesmo tempo)

O2: Melhor! Nem vem, nem vem!

A4: A Pa2 já vem a pé mesmo. Aí é que ela vai começar vir a pé. O Pr2 não vem de carro nem a pau!

K: Deixa eu voltar. A gente começou já a falar disso, de medo dos professores. Mas eu queria pensar o seguinte, só pra gente voltar pra história da educação: pra gente achar que a educação tem que melhorar, a gente pode pensar no que precisa acontecer pra melhorar a educação. $O$ que precisa acontecer?

O2: Primeiro, os professores deviam ter armas.

(Risadas)

A4: Pra mudar a educação, tem que acontecer muita coisa! Não é assim de uma hora pra outra que você vai mudar.

K: Que coisas?

(Falam ao mesmo tempo)

A4: Policiamento dentro da escola.

O4: Os alunos têm que ter mais desempenho pra aprender, mais vontade de estudar.

A1: Eu acho.

A3: Eu acho, assim, que também não depende só dos alunos ou só da escola...

A4: $E$ dos amigos...

A3: Depende também de quem tá fora.

K: Como assim?

A3: Tipo assim, vamos supor: o prefeito também pode ajudar!

$\mathrm{K}$ : Como os prefeitos poderiam ajudar?

O2: Uma boa coisa pra acontecer seria se metade dos professores fosse igual à professora $\mathrm{Pa} 1$ e metade igual o Pr1.

(Falam ao mesmo tempo)

A4: Nossa! Eu também, ia vir todos os dias!

$\mathrm{K}$ : Vamos voltar para o que $A 3$ falou, que foi importante. O que os prefeitos poderiam fazer pra ajudar na educação?

A4: Tudo, tudo, tudo, tudo, tudo!

O2: Projetos!

A1: Ah, mas também não pode só ficar fazendo projeto.

(A1 e A4 falam ao mesmo tempo)

A4: Porque projeto --

A1: [Tem que fazer projeto e agir!]

$\mathrm{K}$ : E agir como? O que daria pra prefeito fazer? 
O2: A idéia de ontem (no encontro extra), pôr monitores na sala.

A1: É.

K: O que tava aqui era assim: "ter na sala ajudantes adultos, que ajudem a manter a disciplina e o progresso da sala, e instalar equipamentos de vigilância nas escolas públicas".

O2: Tipo o Fo1, ele entrou na sala, foi assim: "Quem que eu vou lubrificar (?) antes?" Daí a sala inteira ficou quieta!

$\mathrm{K}$ : Isso ia resolver?

A4: Na nossa sala, não.

(Falam ao mesmo tempo)

A1: tem que ver fora da escola.

K: O quê, fora da escola?

A1: A disciplina de fora também tem que, sabe, melhorar. Não é só daqui de dentro.

$K$ : A disciplina, você tá falando a violência?

A1: É.

$K$ : $E$ pros alunos aprenderem mais, os professores ensinarem mais, pra ter mais qualidade do ensino, o que precisa acontecer?

A4: Ah, eu acho que os professores deviam ter força de vontade e os alunos também. Porque se entrar alunos vagabundo na escola, ó, fica o ano todo sem fazer nada e ainda passa! Passa porque eles não querem ver de novo a pessoa.

$\mathrm{K}$ : Por que passa?

A4: Se ele não fizer nada e bagunçar, ele passa, ainda! Porque o professor não quer ver ele de novo!

K: É isso que acontece? O professor tem liberdade? Em qualquer escola em São Paulo, é o professor que decide se o aluno passa ou não? Quem decide?

A4: É o Conselho. E o Conselho é feito pelos professores. Então... vai dar no mesmo!

K: Mas não existe uma regra, uma lei que fala que vai passar se tem prova, não tem prova. Não existe nada, é da cabeça do professor?

A1: Não, não é da cabeça do professor.

K: É do que?

A4: É do Conselho mesmo.

A1: Só que não é da cabeça do professor.

$K$ : E o conselho é feito de professores?

A4: É feito de professores. Por exemplo, se tiver dois que quer te reprovar e o resto que quer te passar, você passa.

K: Não conta a nota, não conta a prova?

A4: É, tipo, nota conta. Mas se você não tiver nota e não faltou no ano, você passa! Você passa aqui na escola!

K: Então, não é uma coisa objetiva, é uma coisa que depende da cabeça das pessoas?

Juntos: É.

$K: E$ isso acontece em todos os lugares, vocês acham?

A4: Ah, eu não sei, pelo menos nessa escola é assim.

$K$ : Mas então vocês têm mais alguma proposta pra educação?

A?: Não.

A1: É porque depende de todos nós, não depende só de uma pessoa.

(Falam ao mesmo tempo)

O3: [Não adianta uma pessoa se esforça e a outra, não]. 
A1: Mas vai ser difícil colocar essa idéia na cabeça de todos. Porque muita gente não quer nem saber.

O2: Normalmente a gente sabe disso. Zoa porque quer.

K: Então, pra gente terminar o PAN, a gente pode fazer deste jeito: depois, quando eu for ter a conversa com cada um, vocês lêem, pensam direitinho, vêem o que vocês acham de mais propostas e colocam no papel. E aí a gente se reúne, discute e finaliza. Um de vocês pode passar a limpo, se quiserem, e vou ver se consigo tirar um xerox pra ir do jeito que está, com a letra de vocês. Vocês assinam, inventam um nome, ou uma sigla, ou uma letra pra ser o nome de vocês, porque não pode ser o nome de vocês de verdade.

A1: Tá faltando colocar um negócio que a A4 falou.

A4: Isso, gente! Do Dia do adolescente. Uma semana de festa--

O2: Ô lôco!

(Falam ao mesmo tempo)

O3: Tinha que ser um ano de estudo, um ano de festa.

(Risadas)

O2: As férias poderiam aumentar um pouco, pelo menos. Um mês só de férias, um mísero mês!

A4: Um mês no meio do ano, tá bom demais!

A1: Não.

O2: Dois meses no começo do ano--

A4: Tem três meses praticamente.

(Falam ao mesmo tempo)

A1: Dependendo do calendário, podia ter todas as sextas... não, nem todas; uma sexta no mês, podia ter um dia pra gente se divertir.

(Falam ao mesmo tempo)

K: Uma sexta no mês.

(Falam ao mesmo tempo)

O2: Chegar na balada, tomar vodca de graça.

(Risadas)

K: Segunda-feira deveria ser feriado sempre?

O2: Que vagabundo....

(Falam ao mesmo tempo)

A4: Eu acho que tinha que ser uma sexta por mês, porque toda sexta-feira, não é por nada não, mas a gente ia ficar um bagaço.

A1: Por causa que (?) não é todo domingo. Só tem um no ano, só que pra nós podia ser vários domingos.

A4: A gente merece.

A1: É.

O2: Ô, nós somo o futuro da nação.

A4: Isso mesmo, a gente é o futuro da nação.

K: Então vocês querem colocar esta proposta do Dia do adolescente?

A1: Aí, eu quero.

A4: O Lula vai ter que ir lá na USP ver isso daí.

O3: [Mas isso vai sair] no jornal?

K: Vai ficar um exemplar lá na biblioteca da Psicologia da USP.

O3: Ah!

K: Então escreve: Dia do adolescente? 
A4: Dia do jovem.

K: Então, o que ia acontecer nesse dia?

O3: Ia ser feito dia primeiro de janeiro até trinta de dezembro.

(Risadas)

A1/A4: Uma vez por mês.

A4: Porque toda sexta-feira, ó....

O3: Não exagera! Uma vez por mês??!!

A1: Toda sexta e sábado.

A4: Sexta e sábado, porque domingo...

(Falam ao mesmo tempo)

$K$ : Então é uma vez por mês que vocês decidiram?

A4: É, uma vez por mês, porque toda sexta-feira, nossa!! Quem gosta de dançar, ia sair com o pé todinho cheio de bolha.

$K$ : Vocês que resolvem como vai escrever isso.

A4: Uma vez por mês.

(Começam a escrever no PAN a proposta)

$\mathrm{K}: \mathrm{O}$ que ia ter nesse dia do adolescente?

O2: 27 de Janeiro.

A4: Tinha que ter várias bandas. Conhecidas também.

A3: Show grátis.

O2: Qual a banda ia querer fazer um show grátis?

A4: Não é show grátis. A prefeitura, o prefeito, ele ia pagar, entendeu? Ele que vai pagar, não é a gente.

A1: Ou então balada vip até um certo horário.

A4: Ah, não. Não precisa horário. Até as seis da manhã.

O?: Nossa, mãe!

K: Então vamos pensar: o que ia ser esse Dia do adolescente?

A4: Ah, um dia comemorativo.

(Continuam escrevendo no PAN o que disseram acima)

A4: Balada vip [balada de graça]

A1: Shows

O2: Jogos.

A4: Não, que jogos!!

A1: Tem que ser uma coisa divertida.... Passeios.

A4: Isso. Excursões

$\mathrm{K}: \mathrm{O}$ que mais?

O2: Cinema.

A4: Não, cinema!!?? Ai, O2!!

$\mathrm{K}$ : Cinema não?

A4: Ah não!

A1: Cinema você pode ir sempre.

(Falam ao mesmo tempo)

A1: [Mas tem que ser sem os pais ficarem pegando no pé.]

Juntos: É, com certeza!

A3: No lugar ter bastante segurança pros pais poderem ter confiança.

A4: Tem que fazer assim: o pai fala "Eu levo" e outro fala "Eu busco".

(Falam ao mesmo tempo) 
K: Então como coloca isso da segurança que a $A 3$ falou?

O?: Sem precisar levar o irmãos mais novos.

(Continuam escrevendo)

O2: Onde você vai, seu pai vai junto na balada.

A4: Ah não!

A1: Depende dos pais. Porque não é todo pai que vai deixar.

A4: Se é uma balada que dá pro seu pai ir, meu, mas tipo, ele fica lá embaixo, você lá em cima, beleza!

(Falam ao mesmo tempo)

A4: Sem o pai ficar pegando no pé. Tem pai que é assim: "Pai, vou ali" "Não, você vai". Aí se você tem uma prima, alguma coisa, e fala "Eu vou com a prima", aí ele chama "ô Fulana, vem aqui: te dou cem conto se você ficar a noite toda olhando minha filha"--

O2: Ô, lôco!

O4: E se o pai não deixar ir, como vai obrigar o pai a deixar?

A4: Por exemplo, chegar assim no dia e ver mesmo quem for falar na televisão que é obrigado a deixar a sair.

A1: $O$ filho que tem que dar segurança para o pai.

K: E aí?

A4: Ó, só pra ter uma idéia. É uma vez por mês. Então você faz assim: como você sabe que cada mês você vai sair porque é o dia, você ajuda em casa... meu, você faz o que for preciso... você lava até sua casa!

A1: É.

A4: Porque acho que afinal pra você sair tem que dar confiança, e tudo que a sua mãe pedir pra fazer tem que fazer e não falar "Ah, não vou fazer", "Ai, vou fazer depois".

$K: O 3$, você tava falando de confiança.....

A3: Eu acho que o filho tem que merecer também pro pai ter confiança, tem que ajudar, cumprir com suas obrigações.

A4: É. Não, tipo, chegar no momento "Mãe, vou sair" "Onde você vai?" "Não interessa". Ai chega no final do mês "Mãe, vou sair porque hoje é dia" "Não, você vai ficar em casa passando roupa".

K: Então como vocês vão colocar isso?

A1: Que queremos a colaboração dos pais também. Não adianta a gente querer--

O4: Fazer uma reunião.

(Escrevem)

O2: Não concordei com o que a A4 falou. Ela falou que confiança, tipo, você chegar lá, ficar passando roupa--

A4: Não, não é só isso.

A1: Mas você tem que ter obrigação também.

A4: Você tem que fazer suas obrigações, não é?

O2: Se seu pai não confiar em você... Se você não falar "Eu vou voltar às três", daí chegar em casa três da matina, daí seu pai não vai confiar em você. Se você falar "Vou chegar às três" e chegar duas e meia ou três, aí ele--

A4: Eu não entendi.

O3: [Ele tá falando de] Chegar antes do horário marcado.

A1: Ela quis dizer que a gente tem que cumprir com nossas obrigações. Ele entendeu outra coisa. 
A4: É, não é que ... não sei se vocês homens fazem alguma coisa, mas mulher tem que ajudar a mãe, fazer alguma coisa, não é só falar "Mãe, sábado eu vou sair" "Tudo bem". Aí você fica segunda, terça, quarta, quinta, sexta fazendo nada. Chega sábado você fala "Mãe, vou sair", aí sua mãe vai virar e falar "Ó, você não vai sair".

A1: Por causa que confiança e obrigação é diferente.

A4: Ainda mais se tem irmão.

$K:$ Mas aí tem diferença entre o homem e a mulher?

A1/A4: Teeemmm!!

A1: Por exemplo eu, que eu tenho um irmão, né? Mais novo; ele é só uma ano mais novo, mas só que tem diferença. Por causa que ele trabalha e tudo, mas só que ele não faz nada em casa. Agora eu tenho que ficar me matando lá, arrumando a casa. Isso é errado!

A4: Pra depois ele usar e sujar.

A1: Ele também tem que fazer.

O2: Ele pode sair?

A1: Pode. Mas eu também posso. Mas ele também tem que ajudar. Porque quando ele crescer e tiver a casa dele, vai ficar me chamando? "A1, vem aqui"!

$\mathrm{K}$ : Agora, eu queria saber se vocês querem acrescentar mais alguma coisinha?

Juntos: Não.

K: Então, vamos para a música agora? Antes, pra fechar, quando eu chamar cada um pra conversar, cada um vai ler, ver se tem mais alguma idéia. Depois, quando tiver de todo mundo, a gente passa a limpo, e todo mundo assina, tá bom?

O2: Eu vou mandar pro Lula esse documento! Vou tirar uma xerox e mandar pro Palocci, o ministro!

(É colocada a música "Não é sério" - Charlie Brown Junior e distribuída a letra. Em seguida, faz-se a discussão)

K: Bem legal essa música, né?

A1: É linda!

$\mathrm{K}$ : Eu queria perguntar se vocês concordam ou não quando ele diz que ele vê o que falam na tv sobre os jovens não é sério.

A1: Eu concordo, porque na música ele tá expressando o que a gente sente!

$\mathrm{K}$ : Por que o jovem não é levado a sério na tv, no Brasil?

A3: Porque eles acham que a gente não tem muita responsabilidade!

A4: $E$ eu acho que a gente pode ter mais responsabilidade que um adulto. Tem adulto que tem a mentalidade de uma criança. E tem adolescente que você olha assim, meu, você conversa, tem cabeça de adulto.

A1: E um negócio que ele tá falando aqui é verdade: "eu nunca tive chance". É verdade! Eles pensam que tudo que a gente vai falar é coisa que... sabe? Coisa besta! Coisa que não tem nenhum valor; mas pode ter muito mais valor do que eles pensam!

A4: Eles acham que a maioria desses negócios de política aí, eles pensam que é só adulto que vota, mas não, tem muita gente, assim, com dezesseis anos que vota. E a maior parte é a gente que elege, mesmo. Então acho que eles têm que participar e tentar... e não só ficar prometendo coisas pros adultos, e também pra gente. Porque a gente é humano! A gente não é animal!

$K$ : Isso é bem legal. E o que você acha $O 2$ dessa história de não ser ouvido? A gente começou falar um pouquinho outro encontro, de achar que adolescente não é ouvido, como ele fala "sempre quis falar nunca tive chance".

O2: Sem palavras, tô muito emocionado. 
A1: Tem outra coisa. No terceiro parágrafo "eu sei como é difícil acreditar", tipo assim, ele tá falando que é difícil acreditar, mas ele tem fé que isso vai mudar um dia!

$\mathrm{K}: \mathrm{O}$ que precisa acontecer pra mudar?

A1: Tem que ter... aqui ó: todo mundo "tem que estar a fim, tem que se unir".

$\mathrm{K}$ : Todo mundo quem?

A1: A juventude de hoje!

$K: E$ vocês acham que a juventude consegue se unir e mudar alguma coisa?

A1: Eu acho!

O2: Talvez.

A3: Se todos colaborar.

A1: É.

K: Então, dá pra juventude mudar a situação?

A1/O2: Dá!

$K: O$ que precisa acontecer então?

A1: Tem que se unir e estar a fim, né?

$K$ : E vocês, estão a fim?

A1: Ah, eu tô!

A4: Ah, eu tô..., nossa!!

O2: Eu também.

$K$ : E vocês já fizeram alguma coisa pra mudar?

A4: A gente, assim, como a gente vai tentar mudar se a gente não tem uma--

04: ...Autoridade!

A4: Uma oportunidade..., uma autoridade! Como a gente vai tentar mudar, se eles não dão nenhuma chance, porque acha que quando a gente vai falar, igual diz aqui "a polícia diz que eu já causei muito distúrbio". Ele tá tentando dizer que a gente é uma perturbação! É uma coisa que a gente não é, entendeu? Eles têm que pensar que eles já passaram por essa fase que a gente tá passando, só que a gente quer uma coisa melhor pra gente, não como só pros outros, mas a gente também quer uma coisa melhor. Só que eles não dão chance, não dá oportunidade da gente falar! Então fica..., sinceramente; fica uma porcaria!

(Falam ao mesmo tempo)

A3: Vai ficando cada vez pior e a gente não tem chance, então...

O2: A polícia acha que os jovens são tudo marginal! Só eu já fui enquadrado umas três vezes!

$\mathrm{K}$ : E como foi isso? Só de passar na rua, eles enquadraram?

A4: Se eles não vão com a cara da pessoa, e eles tão passando, eles param, e se bobear eles batem! Só que uma coisa, bater em adolescente dá cadeia. Porque é menor; não tem--

O2: Mas polícia pode.

A4: Não pode! Meu, não pode!!

(Falam ao mesmo tempo)

A1: Outra coisa aqui, na música: quer saber por que ele se droga, que tipo assim "eu também senti a dor". Ele se sente, sabe, muito desesperado--

(Passa avião)

O3: [Tem pessoas que se drogam pra esquecer os problemas.]

A4: Mas não esquecem, porque a droga faz a pessoa ficar por fora.

O2: A droga é o pior problema.

A4: Tipo, "Ah, eu tô na boa", mas quando ele volta a si, ele vê que os problemas não solucionaram, entendeu? Aí, ele vai lá-- 
O2: Os problemas deles tão lá e você ainda ganha mais um problema que são as drogas.

K: Hum... e essa coisa que ele disse: "a polícia diz que eu já causei muito distúrbio", que vocês tavam falando, e "o repórter quer saber por que eu me drogo, o que eu uso". Existe essa coisa de achar que é drogado, já vem revisando, ou não? Como é?

A4: Ah, tipo, existe sim. Por exemplo, se você faz alguma coisa, o repórter fala "Você usa droga? Você faz isso?" Você vê muita aí na.... Cidade Alerta.... Eles falam "Marginal é isso. Tá vendo? É um 'menor'!!". Mas, tipo, eles tem que pensar, entendeu, que a gente quer uma coisa pra gente, assim, não só ficar aí falando que a gente é marginal, não. Que é isso?

A1: Eles já enquadram e chegam procurando se você tem droga.!Só porque você é adolescente?! Só porque, sabe? Pensa que todo mundo usa isso??

O2: Se você entrar em um ônibus, um policial entrar em um ônibus, e for enquadrar alguém... quem vai ser o primeiro enquadrado?

A4: $O$ adolescente!

O2: Qualquer adolescente que estiver lá vai ser o primeiro--

A4: E uma coisa também. Por exemplo, você tá trabalhando..., tipo, um adolescente. E você tá de terno e gravata e entrar um policial..., pô! Os caras não ficam te olhando!

K: Então tem diferença do jeito que a pessoa tá, com terno e gravata, parece um pessoal mais rico, ou se acha que é pobre.

A1: "Se a pessoa se veste bem não vai ter porquê ela usar droga. E se ela se veste mal, com certeza".

A4: "Ah, é favelado! É maconheiro! É isso...!". Ah, acho que não é pra ter isso!

(Falam ao mesmo tempo)

A4: É sim, 02 .

A3: Tem muito preconceito com quem mora na favela!

A4: É.

K: Que preconceitos?

A1: De droga.

A4: Já senti preconceito também!

K: Já sentiu? Como?

A4: Porque eu já morei na favela--

A1: Falam que é traficante..., é ladrão..., é isso....

A4: Nem todo mundo que mora na favela é um traficante!

A3: Que nem minha mãe fala, na favela, pode ter pessoas boas, pode ter pessoas ruim também. Não é só porque mora na favela que--

(A3 e A4 falam ao mesmo tempo)

A4: A maioria do povo que mora ali na favela não tem um lugar melhor pra ir. Mas também, a maioria ali é trabalhador e a minoria é bêbado e traficante. Que é isso, meu? Vai trabalhar! K: Você já morou na favela?

A4: Eu já morei. Senti muito preconceito! Muito preconceito!!

K: Que tipo de preconceito?

A4: Ah, não dá nem pra falar!!

(Barulho externo muito forte)

A1: Quem não mora na favela não sabe as coisas que acontecem lá dentro.

A4: E quando tem toque de recolher! Nossa, você não pode sair na rua, eu te falo, eu já morei na favela, já teve isso. Meu, nunca vi tanta gente! O cara fica na viela: "Você desce, volta pra sua casa, se não a gente mete bala!". Igual quando mata alguém lá dentro, os outros falam "Ah, é, na favela, não sei o quê, meu". 
A1: Não, mas eu acho que quando mata alguém lá dentro todo mundo fica triste.

A4: Passa na televisão, nossa, parece que lá dentro é, tipo, o Carandiru. Mas quem viveu já lá dentro sabe como que é. Não é um lugar bom, mas dá pra viver, entendeu?

A1: Aqui na música também tem: "o que eu consigo ver é só um terço do problema". O que dá pra ela ver, assim, é só um pouquinho, mas só que tem muito mais. Eles não enxergam isso. $E$ também que a gente não pode parar de lutar, senão nunca vai mudar. A gente fica aqui, tem que ficar lutando, até conseguir!

$K: E$ "é o sistema que tem que mudar". O que vocês entenderam dele?

A4: O sistema? Eu acho assim que--

A1: Invés das pessoas falar mal dos adolescentes, pelo menos, falar bem, porque aí eles vão ficar sentidos (?) e vão começar melhorar.

A4: Isso!!!

A1:Porque se ficar falando mal, aí eles vão ficar fazendo só isso.

A4: Igual diz aqui "a juventude tem que estar a fim" e "tem que se unir" cada vez mais, e tentar mostrar pros adultos que a gente não é aborrecente. Que a gente pode ser capaz de conseguir o que a gente quer, entendeu? É isso que eu acho.

$K$ : $E$ como faz pra se unir? Parece uma coisa tão longe, tão distante...

A4: Todo mundo tem que colocar um propósito no coração e dizer "Pô, a gente tem que conseguir, nem que a gente tenha que fazer greve lá na Praça da Sé, mas...". Não, é verdade! Por que eles conseguem aumento? Porque vão lá na praça da Sé.

A1: A gente tem que começar a lutar pelos direitos!

A4: A gente tem que lutar, meu! Igual o abuso do trabalho infantil. E a ignorância. Também é um outro assunto que não pode: abusar de menores de dez anos.

$K$ : Mas então o que vocês pensam que vocês, que estão sentados aqui hoje, poderiam fazer para mudar alguma coisa?

O2: Nós, nada!

A4: É.

A1: Não, a gente poderia fazer. Teria que ter mais força de vontade!

K: Mas e aí?

O2: E nos unir a outras pessoas.

A1: Tipo criar uma ONG.

(Falam ao mesmo tempo)

K: Você tava falando "Se unir a outras pessoas que tenham--?"

A4: Poder, né? Poder de mudar!

$K: E$ vocês não têm?

A4: Olha, não é por nada não, mas os jovens não têm poder de nada!! Não querendo tirar com a gente não, mas a gente não tem poder de nada! Se os prefeitos não têm nem poder de comandar a vida deles direito, imagine o mundo...

K: Então, quem tem? Os jovens não tem, quem tem?

A4: Acho que ninguém.

O4: Bin Laden.

K: Então ninguém tem poder de mudar nada? Ninguém nunca muda nada? Sempre foi assim, sempre vai ser?

O3: Deus.

O2: Uma pessoa sozinha, não.

A4: Igual ele falou, Deus. É o único que pode mudar.

A1: Não é só Deus. 
A3: No momento, Deus não está presente.

$K: A 1$, você tava falando então ninguém vai poder fazer nada...

A1: Não, pode sim!

A4: Fundar uma ONG.

A1: Por causa que ONG, sabe, depois, tipo assim--

A4: Tem que fazer tudo certinho.

A1: Tentar pelo menos, se você não tentar, nunca vai conseguir nada na sua vida--

A3: Tem que ter bastante pessoas, pra ver se todas concordam com o projeto e vai cada um fazendo sua parte.

A4: Mas eu tenho certeza que [se vier com proposta pros adolescentes] eles vão apoiar, porque tudo que a gente passa, eles também passam.

$K$ : Vão se identificar com os problemas?

A4: É.

O2: [Poderia criar uma ONG com projetos]--

A1: É mesmo.

K: Criar uma ONG com projetos em quê?

A1: Pra ajudar o adolescente.

O2: Pode ser jovem, velho, adolescente..., uma pessoa sozinha, não faz nada!

A4: Uma andorinha... não faz...virar verão? Ah, não lembro direito desse ditado!

$\mathrm{K}$ : Tem mais alguma coisa aqui da música que vocês queriam falar?

A1: Tem. "O que eles falam sobre o jovem não é sério". Aquilo que eu disse: eles só sabem falar mal do jovem, não reconhecem ele como humano e sim como um animal.

A4: Outra coisa: só pode destruir a esperança. Igual os políticos; eles só prometem coisas pros adultos e pra gente nada. Então cada vez mais as nossas esperanças, meu, vai diminuindo, cada vez mais. Daqui a pouco, cara!

A1: Isso aí que a gente não pode deixar acontecer--

A4: Igual aquela música "Eu preciso viver a paixão".

A1: É.

A3: Tipo assim, aqui ó: "não cansava de tentar de novo", ele sempre tá tentando, tentando...Tá sempre com a esperança viva.

$K: E$ vocês, têm esperança?

A1/A4: Ah, eu tenho esperança!

$K:$ Do que?

A4: De mudar tudo! Tudo mudar. Ser uma coisa bem mais--

A1: Bem legal.

A1: Não sei assim, coisas tão boas, pode ter algumas coisinhas, mas não como tá hoje.

A4: Porque, sinceramente, não é por nada não, mas os adolescente tá esquecidos. Porque todo mundo, eles só tão lembrando dos adultos, prometendo, prometendo.

A1: Tem que fazer alguma coisa pra gente se divertir, mas o mundo não é só diversão.

O2: A única esperança de verdade que eu tenho, é porque nós somos o futuro. Quando (?) ganhar a presidência pode fazer alguma coisa pros nossos filhos, ou pelo menos pra próxima geração.

K: E será que é só quando vocês ficarem adultos que vocês vão poder fazer alguma coisa?

A4: Não, acho que tem que começar desde agora.

A1: É.

(Falam ao mesmo tempo. Barulho externo. Terminada esta discussão sobre a música "Não é sério", é lida e cantada a música "Minha voz") 
K: $O$ que vocês acham que tem a ver esta música com o que a gente tava conversando?

A4: Tuuudoooo a ver.

K: O quê?

A1: Ele não vai ficar combatendo os negócio só com violência e nem com intolerância.

$K: E$ com o quê?

A1: Ah, não sei.

A3: Ele não quer ignorância e nem intolerância.

A1: E nem violência.

K: $E$ isso: "se o grito de socorro daquela criança fosse capaz de comandar uma revolução". $O$ que vocês acham que tem a ver com o que a gente tava falando?

A4: Se o grito de uma criança pudesse comandar o mundo, acho que tudo seria mudado.

K: As crianças são ouvidas?

A4: São. Pior que elas são!

A1: Nem sempre elas são.

A3: Nem todas.

A4: Mas a maioria.

A1: Porque também a mesma coisa que eles pensa, a gente pode pensar deles: que eles só fala besteira.

(Barulho. A1 e A3 falam)

$\mathrm{K}$ : $\mathrm{E}$ o que mais?

A1: Na última linha que ela fala que um país assim, ele não quer pro filho, que é o país que nós tamo vivendo.

A4: Ele não quer um país pro filho dele desse jeito, ele quer um país melhor.

A1: É. Porque igual tá aqui "uns tem muito, outros não tem nada". Enquanto uns tem muito, outros não tem nada. Igual a gente como os mendigo, a gente tem tudo, eles não tem nada. Eles ficam pedindo esmola pra sobreviver, igual tá aqui.

O3: Mas tem mendigo também que entra nessa vida porque quer.

A1: Eu não acho.

A4/O2: Tem.

O3: Tem um maluco lá rua que o irmão dele vai lá na rua fala que ele tem carro, tem tudo e fala que ele foi acostumando a viver na... catando papelão.

A1: Mas só que catar papelão não é ser mendigo.

O3: Dormir na rua, ficar--

A1: Dormir na rua, mas só que catar papelão não é.

O2: Tem um maluco lá que ficava deitado, quando vai ver ele tá lá, comendo um lanchinho no bar, tomando pinga.

K: Tá acabando o tempo, é nosso último encontro, queria saber se sobre tudo isso que a gente falou vocês querem falar mais alguma coisa?

A3: Pra mim, tá bom.

A1: Eu já falei muito.

K: Então quando a gente for conversar individualmente quem tiver mais idéia vai me falando, tá bom? Então, pessoal, muito, muito obrigada! 


\section{TERCEIRO ENCONTRO EM GRUPO COM OS ALUNOS}

K: Retomando um pouquinho, eu tava falando agora pra quem não tava nos outros encontros que no primeiro, a gente começou a falar sobre como é para vocês ser adolescente. Quando eu comecei a falar isso, o 04 já falou "Ih, minha vó enche o saco!". Explica isso pra gente, 04.

O4: Quando a gente quer sair, ela não deixa. Ela é muito cheia de idade.

K: Ela é "cheia de idade"?

O1: Eu nunca vou esquecer quando a professora deu um tapa na bunda do O4. Nossa! Muito engraçado!

K: A professora deu um tapa na bunda do O4?

O3: É. Ele tava enchendo o saco da professora, a professora catou ele embaixo assim "Menino, vai pra fora!".

O1: A professora dá chavada na gente.

( Todos falam ao mesmo tempo)

K: Quando a gente começou a falar de adolescente, você, A4, falou o que os adultos acham do adolescente.

A4: Que é tudo aborrecente!

$K$ : E o que é aborrecente?

A1: Aborrecido com tudo.

K: Aborrecido com tudo?

O2: Na verdade, é porque pensam que os adolescentes aborrecem todos.

$\mathrm{K}$ : Isso é diferente, hein? Ou pode ser as duas coisas...

A1: As duas coisas.

K: A gente tava falando sobre o que era ser adolescente. Falaram o que tem de bom na adolescência $e$ o que tem de ruim. Uma coisa que tem de bom é que começa ter um pouquinho mais de independência, não é? Mas o que tem de ruim é o quê??

O2: Dependência.

$\mathrm{K}$ : Como assim?

O2: Na verdade, você vai ser dependente até o dia que você casar, ter seus filhos e morar sozinho. Mas ainda vai depender da sua mulher! $O$ dia que você morar sozinho; aí você vai ser independente! Porque agora, qualquer coisinha que você quer é... esqueci a palavra... dependente do pai ou do vô ou da vó.

$K:$ É? E vocês dependem do pai?

A1: Depende, sim.

K: Alguém falou que trabalhava no primeiro encontro.

A1: É a A2 [que não estava nesse encontro].

$K:$ E alguém aqui, já trabalhou?

O2: Trabalhava fazendo bijuteria.

K: Quanto tempo?

O2: Um ano.

$\mathrm{K}$ : Você tinha quantos anos?

O2: Foi o ano passado. 13 anos.

K: E aí, como é isso de trabalhar na adolescência?

O2: É muito bom! 
O1: É bom pra catar dinheiro.

O2: Trabalhava porque eu gostava. Foi despedido porque eu começava roubar peças para minhas.... amigas!

(risadas)

O1: Contando com seus mil foras, devem ter sido mil bijuterias!

O2: Não, teve a minha namorada. Dois anos. Roubei seis anéis, ela só usou um.

O3: $O$ resto ela deu pros amantes!

K: Espera aí, que a $A 4$ já tinha levantado a mão para falar.

A4: É bom trabalhar porque a gente começa a ter mais independência e responsabilidade, né? Ter as nossas coisas..., porque senão, pra comprar um sapato precisa falar: "Pai, compra?" e ele fala: "Ah, não. Não tenho dinheiro". Pô, é chato!

$\mathrm{K}: 03$, você ia falar.

O3: Pra ficar mais experiente na vida.

O2: Nada a ver, eu trabalhei porque eu gosto.

A1: Mas mesmo que você não goste, um dia, vai ter que trabalhar. Porque se não trabalhar vai o quê? Vai viver do quê?

(Falam ao mesmo tempo)

K: O3 tava falando que por enquanto é só o quê?

O3: Vida boa, soneca toda tarde.

O2: Não, não é isso.

K: Por enquanto onde? Na adolescência?

O3: É!

K: Na adolescência é só vida boa?

A1/A4/O2: Não!

O4: Obrigatório é nós trabalhar, porque você não vai depender dos seus pais o resto da vida.

$K: E$ você acha que adolescência é vida boa?

O4: Não, porque como eu moro com a minha vó e o meu vô, de vez em quando eu vou trabalhar com meu tio, com meu pai.

$\mathrm{K}$ : Como é isso de trabalhar e estudar ao mesmo tempo?

O2: Legal! Você sai da escola, vai trabalhar, o tempo passa mó rapidão! Nem vê o dia passar.

$K$ : Vocês concordam com ele?

A1: Não sei, porque nunca trabalhei.

$K:$ Conhecem alguém que já trabalhou enquanto estudava?

O2: Minha irmã, quando começou trabalhar, tinha 15 anos. Ela estudava de noite e trabalhava.

K: E essa história que dizem que estudar e trabalhar ao mesmo tempo atrapalha o trabalho e atrapalha o estudo?

O2: Depende, porque eu trabalhava em casa, fazia bijuteria em casa. Mas se for pra trabalhar fora..., depende do lugar. Se tiver que sair de casa, pegar buzão...

A4: É meio complicado. Você tem que dividir o tempo pros amigos, pra você, pra casa...

02: Amigos fica pro final de semana

A4: Ás vezes trabalha de final de semana e não dá pra você ficar com horário livre. Acho que tem que dividir tudo certinho.

A1: Meu irmão trabalha e estuda.

$K:$ E o que ele acha disso?

A1: Nada, porque ele não faz lição! 
K: Então não atrapalha em nada?

O2: Ele tá com quantos anos?

A1: 13.

O3: $A X_{1}$ também trabalha e estuda.

A1: Mas ela tem as nota boa.

(risadas)

O3: Há-há. Essa é boa!

K: Só pra dar um panorama geral, no segundo encontro a gente falou mais sobre a relação entre as pessoas daqui da escola; sobre a idéia de vocês sobre o que os professores pensam dos alunos adolescentes; o que a diretora, a coordenadora, os inspetores de alunos... Aí vocês acabaram falando de principalmente 4 professores. Professores que vocês acham bons e professores que vocês acham ruins. Quais foram os que vocês acham bons?

O2: O Pr1 e a Pa1.

O3: Fora a $\operatorname{Pr} 1$, todos professores são chatos!

O2: O Pr1 dá aula super bem.

O3: É chato, mas explica.

O2: Geralmente o mais chato é que explica melhor!

A1: É verdade!

O2: O Pr1, ele é professor de... ["k" matéria] de verdade!

A4: Ele é! Só que assim: ele começa dar aula, quando vem amanhã, ele já muda. Esse que é problema. A gente não consegue acompanhar!

A1: É verdade.

O2: A Pal também é uma super professora!

A4: Ela também.

O2: Ela que me ajuda a ganhar músculos.

K: Esses bons professores. Vocês acham que eles pensam o que de vocês alunos adolescentes?

A1: Não sei...

O4: Eles não falam nada.

K: Pelo jeito deles se relacionarem com vocês, vocês não têm idéia?

O4: Devem falar bem.

$K:$ E eles respeitam, ou não?

A1/A4/O2: Alguns.

$K:$ Quem respeita?

A4: O Pr1, a Pa1. Agora, os que não respeita é 0--

O2: OPr2.

A4: É. O Pr2, a Pa2 e a professora de... ["y" matéria].

A4: A Pa2 não se dá o respeito e quer que a gente tenha respeito por ela.

O2: A professora de (?) fica falando: "É, não faz as coisas e depois não quer que chame de veadinho!".

Todos: É!

O3: A Pa2 também zoa!

A4: Eles não te dão respeito. Então como a gente vai querer dar algum respeito pra eles, se eles não dão nenhum respeito pra gente?

$K$ : No primeiro encontro vocês começaram a falar um pouquinho disso: quando tem bagunça na sala... na verdade, a gente começou a falar da oitava $A$. A oitava $A$ que é a sala--

A4: Sem futuro! 
$K:$ Por que a oitava $A$ é a sala sem futuro?

A4: Eles não querem nada! Só zoam; não fazem lição... Essa sala era pra ser um projeto.

Cadê o projeto? Tão dizendo que essa sala já passou...

$K$ : E você acha que a culpa é de quem?

O?: Dos alunos.

K: Só?

A4: E também dos professores.

O3: Alguns, porque--

A4: Alguns professores. Tem uns professores que são muito folgados.

O2: $O X_{2}$ tá com [nota] $C$ de educação física e $B$ de português.

$\mathrm{K}$ : Espera um pouquinho. 03 , você ia falar alguma coisa da oitava $A$, que--

O3: Que não quer nada com a vida! Só quer zoar, bagunçar, fumar maconha.

K: Vamos voltar um pouquinho. A oitava $A$ é a sala dos alunos 'repetentes', como vocês falam. Algum de vocês já repetiu?

A4: Eu.

$K$ : Então, o que se fala dos alunos repetentes?

A4: Dizem que não presta, são tudo vagabundo, não fazem nada...

$K:$ E você acha o que?

A4: Que é verdade!

O2: Incompetentes.

A4: Tem uns que não, mas eu acho que a maioria ali daquela sala....

$K:$ E quando o aluno repete é porque aconteceu o quê?

(Falam ao mesmo tempo)

A4: Não foi bem na escola.

A1: Por falta.

O?: Falta de interesse.

A4: Na verdade, quando eu repeti, não foi só eu, a sala toda repetiu.

$\mathrm{K}: \mathrm{O}$ que aconteceu?

A4: A professora faltava, não dava matéria. E quando ela dava, ela só passava e não explicava, então ninguém tava nem aí mesmo, e a sala toda repetiu.

$\mathrm{K}$ : A gente conversou sobre o que acontece para que o ensino não seja de qualidade, no encontro passado. Eu queria entrar na conversa do encontro de hoje: o que vocês, alunos adolescentes, acham de estudar aqui na oitava série?

O3: Da horinha!

A1:Eu acho mais ou menos.

$\mathrm{K}$ : Por que mais ou menos?

O3: É melhor porque tem mais autoridade que os moleques da sétima.

O2: Pra mim é da hora estar na oitava série porque eu sou novo nessa escola. Então é muito louco estudar na oitava série e conhecer uma pá de gente, gente nova.

A4: Mas também às vezes é chato. Porque eu também tenho saudade da minha antiga sala... E a minha sala é uma porcaria: é a oitava $D$.

$K$ : Tem disso, de uma sala ser melhor que a outra?

O3: ( $A$ oitava $D$ ) é quase a mesma coisa que a oitava $A$.

A4: $E$, só que a oitava $A$ acho que é mais bagunceira que a minha sala.

O?: A oitava $D$ também é uma bosta, meu!

O3: A oitava $A$ está de suspensão. $A$ sala inteira.

(Falam ao mesmo tempo) 
A4: [Na nossa sala, se a gente grita, xinga, eles (professores) já falam (?), mas se os alunos da oitava $A$ gritam $e$ xingam, eles não falam nada]. Então existe muita diferença entre a minha sala e a oitava $A$

$K$ : Então, o jeito com que o professor se relaciona com a sua sala e a oitava $A$ e com cada sala é diferente?

A4: É. Igual o Pr1. Na aula dele, todo mundo fica quieto. Ele vai embora, aí começa. Semana passada, três vezes a gente expulsou o Pr2 da sala--

02: O Pr2 é tão perturbado!! Ele era aeronauta, mano!

O1: Era policial!

(Falam ao mesmo tempo)

A4: Mas ele chegou aqui do nada e começou a falar um monte de coisa, que eu falei "Nossa, que que é aquilo?"

$\mathrm{K}$ : Ele substituiu outra professora?

A4: Entrou no lugar de... (discussão do lugar de quem Pr2 entrou).

K: Deixa eu tirar uma dúvida: no começo do ano era uma professora e mudou algumas vezes de professor? Acontece bastante isso, de ficar mudando de professor?

(Falam ao mesmo tempo)

A4: Começou com a professora $X$, aí veio a professora $Y$, aí entrou Pr2.... É ruim porque ficou assim: um tava dando uma coisa, aí vem outro e já dá outra... isso atrapalha!

$\mathrm{K}$ : $O$ que vocês acham disso de ficar mudando de professor?

A4: É super ruim.

O2: Ah, é da hora.

O4: Quem acaba pagando o pato é a gente.

A4: Meu caderno tá todo dividido.

A1: E assim, quando nós começa aprender aquela matéria, aí depois o professor passa uma coisa que não tem nada a ver com aquela que a gente já tava aprendendo.

O3: E tem professor que passa coisa da terceira série.

A1: É. Ou terceiro colegial.

$K:$ E como é o dia-dia da escola aqui na oitava série?

A1/O4/O1: Zoeira!

O3: Beijo. Paquera.

K: Que mais? O que acontece? Vocês chegam, têm as aulas...

A4: A gente chega, vai pras salas, os professores vão ver se vão sair, se vão vir [A1: $A$ gente fica conversando...]. Aí bate o sinal, aí vem aquela 'multuação' na porta da sala: "Eu preciso falar com você", "Na hora do intervalo", "Não! Vem aqui, agora"!

$K$ : Tem uns cinco minutos de intervalo entre as aulas, que fica aquela--

A4: Multuação. "Eu tenho fofoca, acabou de chegar".

A1: É mesmo.

(Falam ao mesmo tempo)

K: E aí no intervalo... o que acontece de diferente, 04 ? Os homens não têm isso de fofoca?

O2: Tem homem que faz fofoca, sim, mano!

A4: Tem!

O1: Mas não tanto quanto as mulheres.

O2: Machismo é com o O1!

O1: Mulher é tudo tagarela!

A4: Nada disso! Tem homem que é muito mais... Eu acho assim: mulher, é feio fofocar, mas homem pega muito mal! 
$\mathrm{K}:$ Ah, tem diferença?

O1: Elas mesmas (?)

A1: Sabe por que? A gente fala de tudo. Eles só fala de mulher e futebol.

(Falam ao mesmo tempo)

A4: Uma pergunta: quem assistiu ontem a Fórmula 1?

(Começou-se uma conversa a respeito da maioria dos meninos não terem assistido a Formula

1. mas terem assistido a determinado jogo de futebol)

K: Voltando do futebol, quero saber o que acontece dentro da sala de aula.

(Barulho externo, que chama atenção dos alunos)

O2: Gosto de falar sobre carro, mas não gosto de futebol.

$\mathrm{K}: \mathrm{O}$ que acontece dentro da sala de aula normalmente?

A4: Muita bagunça!

A1: Muita conversa.

O4: Muitas discussões.

A1: É mesmo.

K: Em toda aula?

A4: Não, tem diferença entre professores, assim: na aula do Pr1 ninguém discute!

K: Por que?

A4: Porque ele tem autoridade! $E$ a gente respeita ele, porque ele respeita a gente, também! Agora outros professores chegam já gritando... como eles querem respeito com a gente? A gente acaba zoando mesmo! Eu falo: "Eu zôo mesmo"!

O3: Tem gente até que bate boca com os alunos.

A4: A Pa2 chegou pra $X_{3}$ e falou que ela era vagabunda! $A X_{3}$ falou assim: "Vagabunda é sua filha"!

O1: O Pr2 fica chamando a gente de veado do mato e do asfalto.

K: Tem vagabunda, veado... Existem vários xingamentos...?

A1: Lésbica!

O1: Bixola.

O2: O professor (?) fala assim "Ó, vou enfiar isso aqui no seu cu!", não fala?

Juntos: É!

O3: A Pa2 fica me chamando de "apagão"!

(Risadas)

A1: Também chamam de "cadela no cio".

O3: A Pa2 também me chama de "rei da cocada preta"!

$K$ : E vocês acham que tem diferença o jeito que eles tratam os adolescentes e os adultos?

O1: É lógico que tem!!

(Falam ao mesmo tempo)

A4: Com os adultos tem mais respeito porque os adultos já podem dar na cara. Falou mais alto, o bicho pega! E com a gente não... Eu acho que a gente é muito besta! Engole as coisas... A maioria dos adolescentes são meio bestas porque tem coisas que acontece $e$ engole.

K: Não reage?

A1: É.

O4: Se deixar eles (professores) batem e não tão nem aí...

$\mathrm{K}$ : Se deixar eles batem? Já aconteceu isso de agressão física?

A1/A4: Já!

O2: O $X_{4}$ tomou um rodo do professor bem no meio da testa! 
(Falam ao mesmo tempo)

K: A A1 tá falando uma coisa importante. Agressão com o professor já teve?

A1: Já.

K: Aluno agredindo professor?

A1: Aluno. Ela até foi expulsa! Acho que o professor mandou ela ir pra fora da sala, ela ficou (?), foi lá e bateu no professor. Aí ela foi expulsa da escola.

K: No encontro passado, a gente tava falando de situações de humilhação: aluno que humilha professor; professor que humilha aluno; aluno que humilha aluno--

04: $O 03$ é humilhado.

A1: É verdade.

O3: Mas eu também humilho, hein?.

$K: 01$, você lembra que no primeiro encontro a gente tava falando sobre indignação, o que deixa indignado? Na escola, o que acontece que deixa vocês indignados?

O1: Ás vezes acontece [alguma coisa com outra pessoa e] ele (professor) já acha que é você: "Vai pra fora!" e nem foi nós...

A1: É verdade. Ou também quando tá todo mundo conversando, igual a ontem. [A professora só ficou olhando pra gente, com as outras pessoas ela não falou nada]; só ficou chamando nossa atenção. Falou que ia abaixar a nota e não sei o quê...

A4: Isso que me deixa mais indignada!

$K: E$ o que mais?

O2: Os cara folgado.

O1: Os fumantes. Dá uma raiva, aquele fedor do caramba!

A1: É mesmo.

K: Os alunos? Que caras folgados?

(Barulho e falam ao mesmo tempo)

$\mathrm{K}$ : Tem mais alguma coisa que deixa vocês indignados?

A4: Ah, tudo!

O3: A diretora! A diretora é folgada! Nem aparece aí e quando aparece quer dar suspensão! Todos: É, isso é!

A4: Nem convive com a gente e--

O3: Quem tinha que ser a diretora era a $C$ !

Todo: É. Também acho.

A4: Ela deveria ser diretora, porque essa Y..., é Y [o nome dela], né?

K: É.

A4: Essa tal de $Y$ aí..., ela chega na sala... Teve um dia que o $X_{5}$ tacou papel no $\operatorname{Pr1}$, aí ela chegou com a maior naturalidade falando que ia dar suspensão para todo mundo. Todo mundo cruzou a perna e ficou ouvindo ela falando. Ninguém falou quem era. Todo mundo já sabia quem tinha tacado papel.

$K$ : E o que você ia falar aquela hora, que deixa você mais indignada?

A4: É a diretora mesmo! Ó, sinceramente, ela é uma porcaria!

K: No primeiro encontro e no segundo, vocês já falaram da diferença, que a $C$ ouve--

O3: Mas a $C$ eu acho que é muito boa. Tipo, se for pra ir expulso, acho que ela dá suspensão (ao invés de expulsar).

A4: Acho que não.

O3: É muito boa.

K: Muito boazinha? 
A4: Todo mundo gosta da $C$ ! Se fizesse uma pesquisa para mudar a diretora, [com certeza a escolhida ia se a $C$ ]. Porque ela ouve a gente, entendeu? Ela dá vários conselhos.... Às vezes a gente tá errado, ela passa a mão..., ela fala "Não foi esse (?), eu nem vi quem foi". Mas essa diretora, mal vem aqui pra escola. Quando vem, só quer dar uma de autoridade. Pra mim, eu falo "Ela é péssima diretora"!

O2: Quando eu fui pra diretoria porque eu briguei com $X_{6}$, ela olhou pra minha cara "Ah, você tem maior cara de marginal"!

A4: Ó, tá vendo?

$K$ : E sobre isso de ter cara de marginal, no primeiro encontro a gente tava falando de professor que tem medo de adolescente, medo dos alunos adolescentes. Como é isso?

O3: Com o Pr2 [uma vez], eu tava com aquele boné que eu vim ontem, entrei na sala, ele olhou pra mim com aquela cara de assustado. Eu falei "Sou aluno novo, deixa eu entrar". Ele ficou olhando pra mim, quase mijando nas calças. A gente saindo "O professor, abre a porta aí". Abriu a porta rapidinho, puxou, ficou olhando na porta. Aí eu fiquei com dó dele, falei pra ele quem eu era, que eu não fazia nada...

A4: Mas tinha uma professora que não dava mole pra gente. Aquela professora enfrentava quem viesse.

K: Não tinha medo?

A4: Não tinha medo.

K: Esses professores que vocês acham que têm medo, têm medo do que?

O?/A1: De morrer!

A4: Acho que têm medo da gente fazer alguma coisa com ele. Igual a Pa2: um dia eu cheguei nela e falei assim "Você vai morrer, meu!", brincando com ela, né? "Você vai morrer amanhã"! Pô, a velha ficou doida!

K: Medo por que? Acha que vocês são o quê?

O2: Marginais! Bandidos!

A1: É.

O1: Maconheiro!

O3: Ladrão!

A4: É, eles pensam que é assim aqui, que tudo --

O?: Trombadinha.

A4: Eu falei pra Pa2 "Não, professora. Eu não to falando sério! Eu não vou fazer isso!"

K: Então tudo isso é imagem que se tem dos alunos adolescentes. Se fosse aluno criança não ia ser assim?

A4: Não. "É tudo pivete".

O1: Não pega nada.

A4: Eles iam falar "Sua mãe é aquilo! Vai pro seu lugar!" e depois iam dar risada... Mas com a gente eles já falam: "Chama a mãe dessa menina!"

O4: A (? - algum profissional da escola) aqui à tarde, bota maior moral nos moleque, agora à noite...!

K: Como os alunos adolescentes reagem quando percebem que o professor tá com medo do aluno adolescente?

O2/A4: A gente tira mó sarro deles!

A1: É mesmo.

A4: Porque a gente fala zoando eles levam tudo na base do sério. O Pr1 fala "Eu tenho amigos que trabalham no Exército". E a gente "Nossa, meu!" 
K: A gente tá falando do que deixa indignado, do que deixa com raiva. E alegria? Não tem alegria na escola?

O2: Tem, lógico!

O3: A minha alegria é mulher!

O2: Alegria é conhecer gente! Alegria foi quando eu conheci a A1! Foi quase o dia mais feliz da minha vida!

K: Então, o que tem de felicidade nesta experiência de estudar aqui na oitava série, além da experiência de conhecer gente...?

A4: Ah, é uma experiência nova. Conhecer várias pessoas diferentes.

A1: [Conversar com os amigos]

04: Fofoca do fim de semana.

A4: Nossa! Chega segunda-feira a língua tá até coçando pra falar o que aconteceu na sexta, no sábado!

O3: Alegria pra mim é sair da escola, sabendo que no outro dia é sábado!

O2: Pra mim alegria é ter aquele seu amigo diário, mano! Aquele amigo que você pode chegar "Ô, meu pai bebeu ontem, chegou caidão em casa! Pô, mano... bateu na minha mãe, velho!". Eu me odeio, mano!

A4: Amigo que é amigo pra mim é aquele que dá conselho, puxa a orelha, fala "Pô, meu, isso tá errado"...

O2: A A4, ela é minha amiga! Sentei do lado dela, ela começou "O2, você é um mongo!" (risadas)

K: Além das amizades? Tem mais alguma coisa?

A1: Ah, só!

O2: Os namoros.

O1: A paisagem.

O2: A paisagem da escola é legal?

O1: É, a paisagem (apontando para as meninas do grupo).

(Risadas)

$\mathrm{K}$ : Ah, a paisagem...! Agora eu queria perguntar para que serve, qual o sentido de vir estudar aqui na oitava série?

(Falam ao mesmo tempo)

A4: Pra ter um futuro melhor!

O2: Pra aprender. Pra que mais a gente vem na escola, além de conversar, namorar? Tem que vir aprender, mano!

A4: Não, tem gente que vem igual ao $X_{7}$ e $X_{8}$. Eles vêm só pra zoar!

O2: Mas eles são os futuros mendigos ou traficantes! Alguns deles eu tenho certeza! Mas, vê eu por exemplo. Que exemplo! Eu venho pra escola pra aprender, pra estudar.

A4: Ô, o O2 faz (?) todo dia na sala. O Pr1 hoje falou: "Você não faz nada, faz alguma coisa, O2!"

O2: Eu mostrei meu caderno! Tava com a lição toda feita. Ele só reclamou porque eu tava fazendo um desenho muito louco.

K: 04 , você tinha falado que...

O4: Tem gente que vem pra aula só pra perder tempo, mano... que não faz nada! $X_{9} X_{10}$ não fazem nada. Eu estudo.

(risadas)

O1: Ah, não! Essa, não! A1, você sabe. Ele estuda? Não mente!

A1: Agora que ele tá começando a estudar, porque no começo do ano... 
O1: Ô, quem estuda é eu, mano! Eu perto dele sou o homem mais inteligente do mundo! Assim, de estudar, de fazer lição, eu tô falando.

(Falam ao mesmo tempo)

O3: Eu não zôo; eu brinco.

A4: Cada hora tem seu momento. Momento de estudar, momento de namorar.

O3: Zoar é uma coisa, brincar é outra. Zoar é, tipo... você acaba ofendendo. Brincar, já é outra coisa.

A4: Mas tem brincadeira que o outro fala "Pára", a pessoa não pára. "Dá pra você parar?" e a pessoa tá continuando e você não gosta e acaba sentando a mão.

K: A4, você tava falando que o sentido, o objetivo de vir para escola é pra um futuro melhor. Isso acontece?

O2: Pra muita gente acontece.

A?: Mas às vezes, não.

$\mathrm{K}$ : Como assim?

O4: Porque tem alguns que não se interessam.

K: E a gente tava falando, até no primeiro encontro, se acha que o ensino é bom, não é bom. $O$ que vocês acham da qualidade do ensino daqui da escola?

(Falam ao mesmo tempo)

A1: É ruim.

A4: É bom sim, mas acho que os alunos que não estão a fim de estudar, mas o ensino daqui é bom. Só que, por exemplo, se um menino fala pra diretora "Você vai me passar, se não eu te mato", ela passa.

$K: A 1$, por que você acha que o ensino é ruim?

A1: Ah, porque no colegial ensina coisa que é mais pra primeira série... não pra primeira série, mas tipo sexta ou sétima, não ensina coisa da oitava!

O2: $O$ ensino aqui é extremamente acima do ensino no $E_{2}$ (outra escola). No $E_{2}$ não tinha nem professor de matemática, nem de ciências. Aqui pelo menos o professor é ruim, mas tem professor. (risadas)

O3: Era a melhor escola uma época, quando era junto.

A4: Depois que separou, ficou muito ruim!

$K:$ E o que tem de ruim no ensino?

A2: Se todos professores pensassem como a professora "P". Porque ela não precisaria trabalhar, porque o marido dela é médico ortopedista, ganha bem pra caramba. $O$ carro dela é um Vectra verde. Todas filhas dela fazem faculdade de medicina.

K: E aí?

O2: Ela dá aula porque ela gosta! De coração, de alma!

$K$ : E vocês acham que isso não acontece, dos professores darem aula porque eles gostam?

(Falam ao mesmo tempo)

O1: O Pr1 só dá aula porque quer.

A4: É. Ele não precisa.

O1: Ele podia dar aula particular e ganhar 40 pau por aula e ele ganha uma miséria aqui!

O4: Ah, ele dá aula aqui só pra encher o nosso saco!

A4: Eu acho que eu nunca tive um professor como ele porque ele--

O3: Ele dá oportunidade pra quem não tem [dinheiro]. Lá na escola particular, quem estuda paga pra aprender. Mas aqui ninguém tem dinheiro, então, ele [vai ensinar aqui pra dar oportunidade].

A4: Tem algumas escolas que-- 
O2: $A E_{3}$ é a pior escola que tem!

(Barulho)

K: Então, vocês acham que pode ter uma escola estadual melhor que uma particular?

A4: Aqui era a melhor escola e o $E_{2}$ ficava segundo lugar. [Agora] olha o $E_{2:}$ uma porcaria!

O1: Porcaria mesmo!

$K$ : E o que faz uma escola ser uma boa escola?

A1: Os alunos.

O2: Os professores e os alunos.

A4: $E$ a diretora também. Porque se você tiver um professor porcaria; a diretora, nem se fala; e os alunos também..

O2: Aí vai ser que nem $E_{4}$

A4: Não, vai ser igual o $E_{2}$.

O2: No $E_{2}$, a diretora é uma droga; os alunos são uma droga...

A4: Lá, a turma fuma maconha dentro da sala. Eu tenho um amigo que estuda lá. Ele disse que conhece todas as gangues que tem lá. Diz que voltou um dia com roupa cheirando maconha, a mãe dela "Tá fumando?", ele disse "Eu vou perder meu tempo pra ficar fumando?". Disse que no dia da reunião, não vai nenhum pai!

O2: Lá ainda é aquela escola: mexeu com um, mexeu com todos.

A4: É. Se você arrumar briga com um, descem cinqüenta!

O1: Aqui também é assim. Que nem os nego da oitava $A$ (falou de uma briga em que vários se juntaram pra defender um aluno).

$K$ : Isso é da turma da oitava $A$ ?

O1: É.

K: Agora voltando um pouco na oitava $A$, no primeiro encontro, quando a gente tava falando do que acontece para repetir, eu lembro que vocês falaram porque não é inteligente, porque não tem interesse, porque não tem continuação...

O2: Inteligente todo mundo é; basta saber usar a inteligência. Tipo, Bill Gates; Bill Gates usou extremamente bem sua inteligência. Hoje ele é um milionário. Vê o Mike Taison, o cara é um ignorante, mano! Fala com ele, o cara "É...", "Hã...".

$K$ : Vocês acham que esses alunos que repetiram na oitava $A$, o que aconteceu pra eles repetirem?

A4: Bagunça.

O1: Falta de interesse.

A1: Não quer nada com nada.

K: Será? Mas e você? Repetiu. O que aconteceu pra você repetir?

A4: O pessoal não fazia nada, eu também não fazia nada. A professora, quando ela vinha, ela passava e não explicava. Então, como a gente ia entender? Então.....

O2: $O X_{10}$ tem um bom motivo pra ter repetido. Namorava o dia inteiro.

K: Quando a educação não é de qualidade, quando tem repetência, quero saber se existe um culpado por isso. Existe?

O2: Sim. O professor.

A4: $O$ diretor.

O1: $O$ quê?! Os alunos.

O2: $O X_{11}$ e o $X_{12}$ são os mais vândalos que eu já conheci na minha vida, em 14 anos de vida! Mas eles ainda não são vândalos na aula do Pr1.

A4: Nossa, eu já cheguei a sair na mão com eles na sala. Foi feia a coisa... 
K: $O$ que o $O 2$ tá dizendo é que não depende do aluno, depende do professor. Porque o aluno, por mais "vândalo", como ele disse--

O4: Os alunos têm que respeitar o professor, e não só os professores--

A4: $E$ os professores têm que também respeitar os alunos.

O3: Teve um dia que o $X_{13}$ e $X_{14}$ jogaram o lixo pra cima, o Pr1 ficou sabendo e chegou lá: "O3, vai pra outra sala" (...) Aí ele falou pra Pa1 e ela: "O3, vai pra minha sala", e eu "Professora, por quê?" "O3, vai pra minha sala!" "Não vou não. Por quê?" "Porque você sujou a sala" "Não fui eu, foi $X_{13}$ e $X_{14}$ " "O que você escolhe? Varrer a sala ou ficar fora da aula"? "Ficar fora da sua aula". Nesse dia eu não fiquei em nenhuma aula. Porque tinha bagunçado na aula de... ["k" matéria], fui pra fora em todas as aulas.

K: Quando se diz que o aluno está repetindo por culpa dele, ou que o ensino é ruim por culpa dele, tem a história de que ele é vândalo, não é inteligente, é aborrecente. Vocês concordam com isso?

(Falam ao mesmo tempo)

A4: Não, não tem nada a ver isso daí, que é burro, é idiota, que não faz nada.

$\mathrm{K}$ : Como é que funciona aqui o sistema de aprovação e reprovação?

A4: Tem que ter boas notas.

O3: Comportamento.

A4: Ir bem até o terceiro bimestre, no quarto pode relaxar, tirar $D, E$. Não pode ter falta, tem que ser um aluno aplicado.

$K:$ E se a pessoa tira notas baixas, mas ela vai sempre. Ela repete?

A4: Dependendo dos professores. Se eles acharem que a pessoa não fez nada, mas se esforçou, fez alguma coisa, eles passam. Mas se vê que não faz nada, bagunça...

A1: Tem uma menina na minha sala que ela não sabe escrever, ler, nem nada, e ela não se esforça pra fazer nada!

(Falam ao mesmo tempo)

O3: Esse chinezinho novo aí, $X_{15}$, ele chegou no mês passado e pode passar, ainda!

O2: Ele foi expulso do $E_{2}$.

A4: O maior comentário na sala é pra ele ser expulso do $E_{2}$ é que ele fez alguma coisa de--

O2: Grave, de muuuito grave.

A4: De grave. Porque o que acontece pra você ser expulso de lá. Nossa!

O2: Você precisa derrubar todos os armários e bater no professor.

A4: Não, acho que nem isso você é expulso.

$K:$ E pra ser expulso aqui?

A4: É só você dar na cara do professor.

A1: É.

(Falam ao mesmo tempo)

O2: Pr1 fala "Quem joga coisa no professor tinha que ser prees0oo, preeesooo!!"

A1: É.

$\mathrm{K}$ : E aqui tem prova pra passar de ano?

O1: Cinco por bimestre.

A1: Mas a prova é tudo com consulta, então é maior baba!

O?: Também tem trabalho e pesquisa.

O4: Mas tem provas que são difíceis .

O2: A professora de (?), ela chega com prova de consulta pra quase todas as salas, chega na minha, não vai ser não. (Falam ao mesmo tempo) Passa filme do exorcista pra sala dele.

O1: Que exorcista, o quê? 
O2: $O X_{16}$ que falou.

A1: Na minha sala, não.

K: Existe então, na sexta, na sétima, na oitava..., se você faz a prova, tira uma nota baixa, você é reprovado ou não? Vocês conhecem alguém que tirou nota baixa e foi reprovado?

A4: No final do ano?

K: É.

A4: Eu conheço. $A X_{16 .}$

$\mathrm{K}$ : Uma pessoa?

A1: Mas ela é porque nunca vinha pra escola.

K: É por falta.

A4: Não, tem mais uma pessoa... deixa eu ver... $X_{17}$. Ela veio, fez a prova

A1: Mas ela não sabia também.

A4: Ela fazia as coisas. Foi pelos pontos, né? Precisava ter tirado 2 e pouco...

$\mathrm{K}$ : Então existe isso? Porque eu queria entender se aqui existe progressão continuada. Vocês já ouviram falar em progressão continuada, que é assim: você chega na quinta série, aí passa pra sexta, passa pra sétima, passa para oitava, e só na oitava você pára, a não ser que você tenha um número de faltas muito grande, ou--

O2: No $E_{2}$ eu ia uma vez por semana, tipo ou segunda ou terça ou quarta ou quinta ou sexta. Nos outros dias eu ia pra casa das minhas amigas, eu tinha um monte de amigas, tinha 8 amigas.

K: E mesmo assim você passou? Foi aprovado?

O2: Fui.

K: Então é assim: precisa ter muita falta pra ser reprovado por falta?

A4: Precisa ter no máximo 250 faltas.

O1: No mínimo.

A4: A X $X_{18}$ tá com 198.

K: Vocês acham isso pouco ou muito, 250 faltas?

Todos: Muito! Nossa!

(Falam ao mesmo tempo)

O3: Precisa ter um mês de falta.

A4: Em uma semana você ganha 25 faltas. Imagine em 12 meses, quantas faltas que não dá? $O$ ano tem 365 dias, metade do ano fica faltando.

O3: Eu repeti por falta na terceira série.

K: $O$ que queria saber é se pela nota reprovava ou se é só pela falta.

A1: Pelos dois.

O3: Na oitava é pelos dois.

K: Na sétima não?

A1: Aí não, é pela falta.

K: E aí o que acontece se repete?

A1: Faz tudo de novo.

O2: Vê a mesma droga tudo de novo.

A4: Vê a cara dos mesmos professores.

K: Vocês falam que vir pra escola pode ser melhor para o futuro, e que se o ensino não é bom o que acontece? Dá ou não dá?

O2: Se o ensino não é bom, você tá vindo pra escola pra perder seu tempo.

A4: Ah, você vem pra se esforçar, né? Pra entender um pouco mais.

O2: Tem uns bobão que vêm pra escola pra cabular. 
O1: Eu não sei como vai acordar as sete da manhã pra cabular. Tem que ficar dormindo, é melhor. Acordar às seis horas, se arrumar, tal, pra chegar aqui as sete e sair fora...!

A1: É mesmo. Que graça que tem?

O2: Vai pro shopping às oito horas da manhã, não tem ninguém.

O1: É. Pode crer.

O3: Teve um dia que eu acordei, eu não ia pra escola né? Ninguém ia. Eu acordei acho que era seis e meia... pra quê? No dia de vir pra escola, eu não acordo. Mas aí eu acordei, não tinha nada pra fazer; foi o costume.

K: E o conteúdo das aulas? O que é passado, é ensinado pra vocês, a matéria, vocês acham que ela é bem passada, mal passada?

A1: Eu acho que é bem passada.

O2: Depende do professor.

O1: Os alunos é que não querem aprender.

A4: Depende dos professores.

O1: Lógico que é. Dá maior dó do Pr2! Dá vontade de chorar, coitado! Eu vejo ele, ele tenta ensinar. Ele chega na cadeira e todo mundo fica jogando papel na testa dele, mano!

A1: Ele é muito ignorante, não pode falar nada que ele já--

O1: Lógico! Tem dez (alunos chamando pelo apelido, xingando o professor)...você acha que ele vai fazer o quê?

A1: Mas ele não pode sair descontando em todo mundo.

A4: Ele passou uma prova, eu não tinha terminado, aí eu falei "Vou subir lá em cima, entregar um trabalho, aí já venho". Quando eu cheguei "Professor, cadê minha prova?", "Ah, eu peguei, ninguém vai fazer mais nada".

O3: Ele não dá prova pra nós.

O4: A prova que ele deu na minha sala, ele deu D pra todo mundo.

$\mathrm{K}$ : Como assim?

O4: Ele olhava assim, ol hava, olhava, sua prova $D$, sua prova $D$.

A4: Mas tipo, ele já vai dando as respostas, ninguém faz nada. Ele vai colocando e todo mundo já vai copiando.

K: Então esta coisa da nota da prova não é uma coisa tão real? Não avalia o quanto o aluno está sabendo ou não, pelo que entendi.

(Falam ao mesmo tempo)

O1: Mas o Pr2, coitado! Não é à toa que ele é tão perturbado assim.

O2: Primeiramente porque ele era aeronauta, depois porque ele era--

O1: Ele era policial.

K: Vocês acham que existe diferença dentro da sala de aula do tratamento do professor com alguns alunos e com outros?

O2: O professor pode gostar dela e não gostar de mim.

K: Aí ele trata diferente?

O2: Hã-hã.

O3: É claro que eles protegem os alunos que faz mais a lição, que faz tudo; agora, quem não faz....

$K: E$ vocês concordam com isso?

Juntos: Não.

A4: Tem que tratar todo mundo igual.

(Falam ao mesmo tempo)

A4: $O X_{19}$ era mó cdf e ta virando mó zoeiro! Jogando papelzinho... 
K: O3, você falou que tratam o aluno como ele merece.

O3: É, trata o aluno como ele merece.

O1: Quê? E como o Pr2 deve te tratar?

O3: Como um bom aluno sendo que eu não sou?

O2: É, você quer que ele trate a $A 2$ como eu? Eu sou um péssimo aluno. Quer que trate a A4do mesmo jeito que eu? Ou então quer que trate eu do mesmo jeito que o $X_{20}$ ?

$K: E$ a diferença entre as salas? Vocês acham que tem diferença do professor tratando a oitava $A$, oitava $B$, oitava $C$, oitava $D$ ?

O3: A Pal fala que trata a nossa sala melhor.

O2: Na minha sala ela fala a mesma coisa.

A4: Na minha sala ela falou que tem uns alunos que ela não gosta, que no final vai ferrar muita gente.

$K$ : Mas e se vocês acham que o ensino está ruim, o que vocês acham que poderia ser feito para melhorar o ensino?

O2: Trocar os professores.

A4: Não. Trocar os professores? E os alunos?

A1: Os alunos se conscientizar.

O3: Tem que passar os alunos logo, pra acabar as aulas, e pronto.

(Risadas)

$\mathrm{K}:$ O2, você falou em trocar os professores...

O2: Trocar os professores. Se os professores forem ruim, como você vai aprender?

A4: Mas, não depende só dos professores. Depende da gente também.

O2: Apesar que eu admiro uma coisa que aconteceu aqui nesta escola. $O X_{21}$, vários maus alunos foram tudo embora.

(Falam ao mesmo tempo)

O3: Mas português e matemática é o que mais importa; só.

K: E o resto?

O2: $E$ inglês.

O3: Pra que eu vou querer saber inglês? Eu não sou americano.

(Falam ao mesmo tempo)

K: O O3 perguntou pra quê aprender inglês.

A1: Eu vou precisar por causa que eu quero me formar em turismo.

O2: Turismo?

O1: Mas não tem como aprender inglês aqui na escola.

O3: Eu tenho um curso que você faz inglês e computação; se você indica quatro alunos você ganha um computador.

(Risadas)

K: Vamos voltar. Vocês já têm idéia do que vão querer fazer como profissão?

O2: Físico nuclear. Não, não é uma boa, não. Eu prefiro ser... analista de sistema.

$K:$ E o que precisa para ser analista de sistema?

O2: Não sei. Ou então ser professor de educação física ou mecânico. Mecânico ganha cinco mil.

A1: Ser fotógrafa e fazer turismo.

$K$ : $E$ o que precisa estudar para isso?

A1: Linguagem diferentes.

A4: Línguas.

$K: E$ você, O4? 
04: Ladrão.

(Risadas)

O4: Veterinário.

$\mathrm{K}$ : Precisa estudar o que na escola?

O2: Anatomia.

O1: Biologia.

04:Tem que estudar!

A4: Eu, medicina.

$\mathrm{K}$ : Precisa estudar?

A4: Muito.

(Falam ao mesmo tempo)

O3: Ginecologista.

(Risadas)

K: Precisa estudar ou nem precisa pra ser ginecologista?

O3: Precisa.

$\mathrm{K}: \mathrm{O}$ que?

O3: Biologia, ciências...

K: E você?

O1: Se eu não for da Aeronáutica, ou carreira militar, eu quero fazer Direito pra entrar pra política.

K: Você tinha falado. Pra fazer essas coisas que vocês estão falando precisa fazer uma faculdade?

O2: Não, eu só quero ser uma coisa que não precisa de faculdade! Vocalista de uma banda. Pronto! Perfeito!

K: Está livre?

O2: Não. Precisa estudar as cordas vocais.

K: Vamos voltar nas outras profissões que vocês tinham falado. Precisa fazer uma faculdade? Pra ser ginecologista não precisa?

O3: Precisa.

O2: Pianista também.

A4: Tudo que você vai fazer precisa ter faculdade.

$K: E$ o que vocês acham desta idéia de realizar um sonho de entrar numa faculdade? $E$ difícil ou não é?

A1: É difícil.

O1: Se você tiver dinheiro pra pagar, você paga e resolve

A4: Mas se você não tiver dinheiro, você vai precisar fazer um --

O1: Se eu tiver verba quando eu crescer, eu quero estudar lá na São Francisco. É setenta pau por mês a faculdade de Direito.

K: A São Francisco? Não é da USP?

O1: Não, São Francisco, a melhor, a primeira faculdade de Direito do Brasil. Lá no interior, se você falar que estudou lá, você arruma emprego na hora. Trezentos pau.

$K: E$ aí, como vocês vão fazer pra--

(Falam ao mesmo tempo)

O2: É melhor fazer curso no Senai.

K: Espera aí. Vocês falam trabalhar muito ou fazer na USP. E pra passar no Vestibular? 
A4: Eu tenho um tio meu que por causa de um ponto não passou na USP. Ele teve que fazer tudo de novo. Ele não tá conseguindo. E uma coisa eu falo. Na USP também, quem tem dinheiro, filhinho de papai, entra fácil. Nem precisa fazer curso, nem precisa fazer nada!

K: Paga pra entrar na faculdade?

O2: Não.

A4: Existe isso, sim.

O1: Este negócio de filhinho de papai, nada a ver, é por causa que eles estudaram mais que a gente. Por exemplo, na nossa idade, eles já fizeram curso de inglês, espanhol, computação, web designer, secretariado.

$K:$ E a escola? A qualidade das escolas?

O1: Pô, a deles é paga, né? [Melhor...]

A4: Mas também não é porque a deles são paga, que...; a gente pode também cursar. Eu sei que é difícil, entendeu? É difícil sim, mas eu acho também que não é porque eles são filhinho e papai que a gente também não pode tentar.

K: Será que é impossível?

A4: Não é.

K: Vocês sabem de pessoas que fazem a USP, algum curso lá e fizeram escola pública?

A4: Um amigo do meu pai já estudou em escola pública e conseguiu. Tem que ralar muito, tem que estudar pra caramba!

04: Se formar em veterinária é muito difícil, viu?

O2: Eu prefiro fazer o curso de Senai que eu fiz, agora eu vou fazer o técnico. $O$ curso que eu fiz era pago, só que o técnico vai ser de graça agora, você faz a prova pra entrar. A prova não é tão difícil assim, é coisa de oitava série mesmo. Só que tem que estudar pra caramba. Se eu entrar, se eu sair de lá com o diploma do Senai. Ó lá, é muito mais fácil fazer Senai. Se você sair com o diploma de lá, você consegue trabalho em qualquer lugar também.

K: $O$ que vocês acham disso, de fazer um curso profissionalizante?

O2: Eu ainda vou fazer um de graça. Esse é o melhor.

A1: É.

O2: Depende da sua grana, da sua verba.

K: Pra fazer curso profissionalizante, paga?

O1: Paga.

O2: Porque se você for fazer de graça,você tem que se matar estudando. Nossa, você tem que estudar três livros por dia. Nossa, você tem que ler três livros por dia.

K: É?

O2: Foi isso que eu fiz. E eu não sei ainda se eu passei.

A4: Nossa, se eu tivesse que ler três livros por dia, eu ia me matar, tem que estudar muito! A1: É mesmo.

A4: Se um livro eu já não consigo ler..., três! Imagine colocando dez livros assim "Você vai ter que estudar isso".

O3: Ainda tenho cem páginas pra fazer a ficha de leitura, tô lendo uma folha por dia!

O2: Eu tenho uma caixa assim de quando eu tava na quinta série. Nossa, é cheio de milhares de gibi, eu já li cada um cinco vezes.

(Falam ao mesmo tempo)

A4: [Gibi é mais fácil de ler, é interessante]. Agora outros livros assim --

O2: Gibi eu sempre tento guardar na minha cabeça: "Não, eu não posso esquecer, mano!" 
K: Quando tem um interesse, a coisa fica muito mais fácil? Mas, pra fechar essa nossa conversa, vocês estavam falando que para melhorar a qualidade do ensino tem que ter professores bons e os alunos... a participação dos alunos é o quê??

O2: Os alunos têm que ser um pouquinho melhor.

O3: O comportamento.

K: Como? O que é um comportamento bom?

O3: Um comportamento bom é não bagunçar, fazer o dia-a-dia da lição--

(Falam ao mesmo tempo)

A4: Se a gente não bagunçar, também não vai ter graça. Acho que tem que ser não aquela bagunça pesada, tem que ser aquela coisa levinha--

O3: Eu participo, mas só que de vez em quando o povo descontrola.

O2: Tem aluno que é bom, mas que por causa dos outros alunos fica ruim. Os alunos que é melhor não pode se deixar levar pelo papo. Tipo, um é ruim, daí o outro fica ruim, aí o outro fica pior ainda. Daí a sala inteira já tá jogando carteira um no outro!

$\mathrm{K}$ : Aluno bom é aquele que passa o dia inteiro sentadinho, sem falar nada?

(Falam ao mesmo tempo)

O3: Aluno bom é aquele que conversa, faz a atividade, o trabalho... Mas professor tem que dar um tempo pra bagunçar. Tem que passar lição e ter a hora da alegria.

O1: Aluno bom é aluno participativo, que participa das aulas e também faz a lição.

$K:$ E o que você acha, 04 ?

O4: Concordo.

O1: Ele não é um aluno bom.

K: É difícil ser um aluno bom?

O3: Pra mim é.

A1: Não.

(Falam ao mesmo tempo)

K: O3, o que você acha: o 04 tava falando que ser um aluno bom é só o quê?

O4: É só ter interesse. Não adianta o aluno ser quietinho e não ter interesse.

O3: Tem que ter interesse, né?

$K:$ Em que?

O3: Nas aulas. No professor. Tem gente que vê o professor explicando (...?)

O2: Isso quer dizer que se eu quero brigar com todo mundo, bater em todo mundo, e for interessado e prestar atenção na aula eu sou um bom aluno?

O1: Vai. Ele só vai ser um aluno anti-social, mas vai ser um bom aluno.

A1: É mesmo.

A4: Vai ser aquele centro das atenções. É o cara que bate em todo mundo "Ó, não olha pra ele, que vai te dar um soco".

A1: É.

A4: Vai ser o cara popular, igual esses filminhos que eu assisto na Sessão da Tarde.

K: Vocês querem completar mais alguma coisa, que a gente já ta acabando nosso tempo do encontro de hoje?

O2: Eu quero. A4, eu te amo!

K: Então, gente... muito obrigada!! 


\section{SEGUNDO ENCONTRO EM GRUPO COM OS ALUNOS}

K: No encontro passado a gente conversou sobre o que é ser adolescente pra vocês e sobre como é ser um aluno adolescente. Hoje a gente vai conversar mais sobre o que vocês adolescentes acham da relação entre todo mundo aqui da escola $e$ vocês alunos adolescentes. Pra aproveitar que tem gente que não tava no outro grupo, e 002 que estava no outro grupo ajuda a gente a conversar também, eu queria saber o que vocês acham de ser adolescentes.

O3: Pra mim é chato e ruim. Chato e bom. É bom porque tá crescendo, tá desenvolvendo melhor (...) e ruim porque tá ficando velho.

$\mathrm{K}$ : Isso é ruim?

O3: Pra mim é.

K: Que mais tem de chato na adolescência?

O2: As ordens.

O3: Eu vou falar do bom. Meu pai já tá deixando do meu pé, já tá liberando dinheiro na mão. Dá pra namorar mais. E o chato é que ... hum...

O2: Não tem nada de chato?

O3: Tem, só na hora. [Só na hora pra saber o que tem de chato]

$K$ : Leva o gravador pra sua vida, né? (risos) E você $A 3$, o que acha de ser adolescente?

A3: Ah, tem seus momentos bons e ruins. Dependendo da hora, do caso...

$K: O$ que tem de bom, pra você?

A3: $O$ bom é que vai amadurecendo, entendendo mais a vida, o que seus pais passaram, você pode passar pela mesma coisa, às vezes não.

O2: Você adquire mais responsabilidade também.

A3: É.

$K: E$ isso é bom ou ruim?

A3: Em uma parte é bom, na outra ruim, né? Bom porque você sabe o que passa; você tem que ser responsável pelo que você faz, pensa. E ruim porque..

O2: Uma coisa não sei é bom ou ruim, é que quando a gente é adolescente a gente pega malícia naturalmente.

$\mathrm{K}$ : Como assim, pegar malícia?

O2: Ah, sei lá, um exemplo, mulher. Quando eu era pequeno, lá pelo prezinho, eu já achava mulher bonita, mas agora eu acho muito mais.

$K:$ E além disso, de achar mulher bonita...

O3: Tem vários tipos de malícia, né?

O2: Tem muito tipo de malícia!

K: Quais são os tipos de malícia?

O3: Tem um tipo de uma malícia de queimar rosquinha; um coloca a rosquinha pra queimar e conta pro outro: "queimei a rosquinha".

K: A sexualidade começa a aflorar na adolescência, né? Começaram a falar disso no outro encontro. E além da sexualidade, a A3 tava falando o que tem de bom e ruim na adolescência. $O$ que tem de ruim?

O2: O problema é que a gente não é levado a sério!

A3: Ah, porque muitas pessoas criticam o adolescente, né? Muita gente critica... (Barulho externo) 
K: Falando agora neste assunto. A gente começou falar um pouquinho no encontro passado, você fala também 02 o que você quiser acrescentar, isso do que os adultos acham dos adolescentes. Quando vocês ouvem o que os adultos acham, o que a sociedade acha. Quando pensa "Ah, adolescente é tudo... o quê?"

O2: Tudo de ruim!

O3: [Mas] Tem gente que pensa que adolescente é o futuro, né?

O2: Pior que isso é o certo! Porque os adolescentes são o futuro! Aqui nós temos uma futura médica, um futuro advogado, um futuro analista de sistema.

K: Futuros profissionais...

O2: E aqui nós temos um futuro... vencedor!

$\mathrm{K}: \mathrm{O}$ que mais os adultos falam?

O2: Irresponsáveis!

A3: Aborrecente!

$K: O$ que vocês entendem por aborrecente?

A3: Que faz tudo errado, não tá nem aí pra nada.

O3: Só gasta dinheiro pra ir pra festa.

A3: Só quer saber de ganhar e não [de não fazer] nada.

$K: E$ vocês acham disso? Vocês acham que os adolescentes são assim?

O2: Não. Isso é um mau juízo que eles fazem de nós!

$K:$ E o que vocês acham dos outros adolescentes que estão aí no mundo?

O2: Depende do adolescente.

$\mathrm{K}$ : Existe alguma coisa assim que vocês acham com que na maioria dos adolescentes acontece? Que a maioria dos adolescentes é assim ou assado?

O2: Eu tenho a minha opinião para definir muitos adolescentes homens. Só pensam em sexo...; tarados!

K: Muitos adolescentes são tarados?

O2: Muitos!

O3: Safados.

O2: Não que este 'seje' meu caso.

K: Tá falando de forma geral dos adolescentes, o que vocês acham dos adolescentes de forma geral.

O2: Muitos são.

O3: Jogam muito bem.

$K: O$ que é jogar muito bem?

O3: Tipo, pra conquistar uma menina.

$\mathrm{K}:$ E além disso?

(Pequeno silêncio)

O3: Alguns são casqueiro.

(Risadas)

$\mathrm{K}$ : Casqueiro é o que?

O3: Que fuma.

O2: Usa droga.

O3: Que bebe muito.

O2: A maioria dos adolescentes são vândalos!

K: Isso aí a gente falou no outro encontro. Vocês concordam? Vocês acham que têm muitos adolescentes que são vândalos?

A3: Na escola sim. 
K: Como é ser vândalo?

A3: Como é ser vândalo, O3? Num sei...

(Risadas)

O3: O que significa vândalo pra vocês?

O2: Vândalo, as pessoas que jogam uma carteira, uma cadeira pela sala...

O3: Ah, isso eu num faço!

O2: Aqueles que atrapalham a aula, tiram a paciência do professor.

K: Isso é vândalo? O que é ser vândalo? Boa pergunta.

A3: Pichar, também. Pichar o muro.

O3: Pichar carteira.

O2: Roubar.

$K: E$ isso vocês acham que tem?

O2: Muito!

K: A gente tava falando um pouquinho sobre a experiência de ser um aluno adolescente; um adolescente que estuda aqui. Então agora a gente vai chegar no assunto do tema de hoje. Vamos começar falando da relação entre os professores e os alunos; depois a gente fala dos outros também. A gente começou a falar um pouquinho no encontro passado sobre a diferença da relação da diretora com vocês, e da diferença da coordenadora com vocês e de alguns professores com vocês. Então hoje a gente vai aprofundar um pouquinho mais neste tema. Mas vamos começar pensando nos professores e alunos.

O2: Depende do professor. Eu sou um ótimo aluno adolescente com a Pa1 e com o Pr1.

K: Que são professores que você considera que são...?

O2: São os melhores dessa escola! Não existe professor melhor que eles dois!

O3: O Pr1, que eu acho mesmo, é o melhor!

O2: A Pa1 também!

$K:$ E por que eles são bons professores?

O3: Ah, porque explica bem, o $\operatorname{Pr} 1$.

O2: Eles mandam, impõem ordem.

O3: Pr1 é chato, mas explica bem.

O2: Por isso que ele tem respeito, porque ele é chato! O Pr2 tentou ser legal e ficou daquele jeito.

O3: O Pr2 é...

O2: Perturbado! Ele era aeronauta antes de ser professor.

O3: É meio doidinho.

A3: Ele quase me machucou, só porque eu tava conversando com uma menina, eu peguei sentei, ele foi lá, puxou minha carteira com tudo, quebrou tudo... caiu tudo no chão!

$K$ : E vocês lembram de outras coisas que aconteceram, de professor que fez alguma coisa com vocês que vocês não gostaram?

O3: Ah, tem a professora de [" $x$ " matéria]. Ela mandou eu sair da sala, foi lá e [jogou] meu caderno no chão. Aí eu xinguei e [dei um chute na carteira].

$\mathrm{K}$ : Como você se sentiu com isso?

O3: Fiquei com raiva!

A3: Se sente humilhado até, né? Porque, tipo, não é legal.

O2: Eu me lembro--

O3: Foi bem no começo que ela chegou. Ela pegou, chegou, tava fazendo a chamada, aí eu falei "present", aí ela começou a me tirar, que eu tô me vendendo pros Estados Unidos. Aí eu zoei ela, taquei giz nela. 


\section{K: E aí, o que aconteceu?}

O3: Me mandou para fora e daí eu fiquei enrolando. Tipo, eu ia sair, só que chegou na minha frente bem devagarinho, pegou meu caderno, soltou lá no chão, aí eu xinguei ela. Ela fechou a porta, eu dei um chute.

$K: E$ aí, o que aconteceu depois?

O3: Não aconteceu nada, só fiquei pra fora, não aconteceu mais nada.

K: Foi pra diretora?

O3: Não.

$\mathrm{K}$ : Antes da gente continuar, a A3 tava falando uma coisa importante: tava falando sobre se sentir humilhado. Como é esta experiência?

O2: É horrivel!!

K: Gostaria que vocês me falassem um pouquinho mais sobre isso de se sentir humilhado.

O2: Imagino como o $X_{1}$ deve ter se sentido quando o professor deu um rodo nele!

O3: Deu o quê?

O2: Deu o rodo nele; derrubou ele na sala. Porque eu não sou de briga, mas eu tinha brigado com ele, daí a professor afastou ele, deu um rodo nele, derrubou ele no chão.

$\mathrm{K}$ : Retoma um pouquinho. Você falou que brigou com ele e aí?

O2: Aí o professor deu o rodo nele. Eu imagino que como ele ter sido humilhado!!

$\mathrm{K}$ : Ele derrubou ele no chão?

O2: Sim.

$K: E$ aí, o que aconteceu na hora que ele derrubou no chão?

O2: Na hora o $X_{1}$ ficou lá jogado, com uma cara estranha, meio chorando.

$\mathrm{K}$ : Como você acha que ele se sentiu nessa hora?

O2: Como qualquer pessoa se sentiria: humilhado!

O3: Não tinha cadeira perto dele não?

O2: Não. Por isso ele caiu.

$\mathrm{K}$ : $\mathrm{E}$ as outras pessoas da sala, como reagiram?

O2: Com bastante ânimo; eles riram.

O3: Que nem o X2. Outro dia, ele xingou o $\operatorname{Pr} 1$ de Cepacol. Aí o professor falou para ele usar Zentel, uma pomada que passa no ânus, porque ele não pára quieto no lugar. Aí todo mundo zoou dele. Ele ficou todo sem graça!.

O2: Eu lembrei como $X_{3}$ e $X_{4}$ devem se sentir, mano! Aqueles são os mais humilhados da escola!

K: Eles são humilhados por quem?

O2: Por todos.

O3: Alunos.

O2: Tudo e todos!

K: Alunos, professores... o que acontece, como é essa humilhação?

O2: É porque eles na verdade não querem receber respeito. Porque eles não faz nada pra merecer. Então eles são sempre zoados.

O3: Eles sabem que apanham e ficam mexendo.

O2: $O X_{4}$ se quisesse ia bater em muita gente...

K: Mas então $A 3$, conta que outra situação assim você lembra de humilhação que aconteceu com você ou com outra pessoa na sala.

A3: Eu acho que o Pr2, por ele ser baixinho, meio gordinho, ficam zoando com ele, xingando

(...) acho que ele deve se sentir mal, né?

O2: Na nossa sala ele é conhecido como Olhos Famintos. 
K: Olhos famintos?

O2: É, o filme.

A3: Eu acho que ele também deve se sentir muito mal, por ele ser professor, ele também quer respeito. Mas eu também acho assim: pra ele querer respeito ele também tem que respeitar os alunos. Ele não faz nada, ele só fica--

O3: Só explica as coisas pra, tipo, aluno "cd"zinho, aluno "cdf".

O2: Pior que o Pr2 não explica nada nem pra ninguém na minha sala. Você chega "Pr2, é verdade que você era policial?", ele fica "Oh?" "Pr2, é verdade que você era policial? Ou aeronauta?" Ele fica "Oh?"

A3: Marca prova sem...; "Amanhã vai ter prova"! Não quer nem saber se a gente entendeu a lição!

O2: Mas ele é um professor legal. Ele me deu B sem eu nunca ter feito nada na aula dele!

O3: Outro dia ele mandou fazer uma prova e, assim que eu acabei, ele colocou E. "Por que você colocou E?" "Porque você merece"!

(Risadas)

K: Nem leu o que você escreveu? O que você achou disso?

O3: É claro, não gostei né? Zoei ele.

O2: Todo mundo zoa ele!

$\mathrm{K}$ : A gente tá falando então que existe professores que humilham alunos e alunos que humilham professores. E tem alunos que humilham alunos também?

O3: A Pa1, ela brinca comigo também. Quando o $X_{5}$ zoa alguém, ela também ajuda... mas tudo brincando.

K: É diferente da humilhação que vocês tavam contando?

O2: Mas a professora Pr1 também humilha de verdade! Quando tava lá o $X_{6}$ sentado na nossa fileira tinha que ter uma mulher, só que não tinha. Ela veio "Cadê a mulher aqui?", aí todo mundo apontando pra trás, aí (...) ela olhou pro $X_{7}$ e falou "Eu tô falando mulher, mulher mesmo, não homossexual igual ele". Isso é humilhar!

(Risadas)

K: É engraçado?

O2: É, seria engraçado, se não fosse xingar.

O3: Mesmo assim, todo mundo zoa todo mundo! [E vai fazer o quê? Vai chorar?]

O2: [Quando é comigo] eu dou risada!

O3: Tem gente que quando zoa tipo assim com ele, ele chora. Não agüenta nada, já tá chorando!

O2: Depende. Se for pra zoar igual muita gente zoa, de dar tapa, esses negócio, eu não fico quieto não [eu não vou deixar passar não].

$\mathrm{K}$ : Mas a gente tava falando que humilhação é uma coisa muito ruim e que acontece na escola e vocês também tavam falando de raiva. Em que situações vocês têm raiva?

O2: A raiva me transformou em uma coisa. Quando eu entrei na quinta série, eu era um anjo. Aí depois quando eu tava na sétima eu virei uma pessoa normal, agora eu espero que eu não me torne um demônio. Porque eu era tão meigo, fofo... (risadas). Eu era fofo, mesmo! [Mas aí o pessoal] me zoava e veio o ódio... daí foi quando eu comecei a brigar, quando entrei pra fazer Kong Fu (mas depois eu saí porque acabou o dinheiro). Daí eu fiquei com ódio. Eu espero que eu não tenha mais ódio ainda.

K: Ficou com ódio do quê? 
O2: De muitas pessoas. Aí foi quando eu comecei a brigar. Não pra bater, mas sim pra matar, deixar inconsciente, coisa parecida. Pegar a cabeça do moleque, começar a bater na parede, até desmaiar ou coisa parecida.

K: Você acha que isso é raiva dele ou raiva de outra coisa?

O2: Na verdade é raiva da vida, raiva de tudo! É raiva de pessoas que me zoam, que pensam que podem..., raiva de coisas que acontecem na minha família, raiva do meu cachorro que morreu. Raiva de tudo!

A3: Às vezes tá com um problema, vai descontando...

O3: Mesmo quem tá quieto, nunca falou com ninguém o ano inteiro, é zoado! Não tem como!

O2: Eu faço a lição, eu sou um bom aluno, só que também eu converso na sala, conheço metade da escola. Não que eu queira, mas eles querem me conhecer...

O3: Não dá [pra ficar sentado o tempo todo]. Eu sento lá na frente, tô fazendo lição, tá todo mundo brincando aqui atrás. Eu olho pra trás, tá todo mundo se divertindo, zoando. Aí eu vou fazer o quêe? Tem que ir também [quando já me conhecem, eu levanto e já falam: "Senta"!]

O2: Eu não consigo zoar com $\circ X_{3}$. Dá maior dó do moleque, meu! Hoje ele chorou na sala, porque tavam zoando com ele. Dá maior dó do moleque!

K: Vamos só voltar um pouquinho. A gente tá falando da raiva, de que situações deixam vocês com raiva. $A 3$, você lembra de alguma situação?

A3: Hum... não...

O2: E quando o Pr2 puxou sua cadeira, você não ficou com raiva?

A3: Fiquei, né? [Mas não sou muito de] ficar nervosa, com raiva.

O2: Na verdade, não tenho raiva, não tenho ódio de ninguém. Mas, eu tenho muitos inimigos.

A3: Porque assim, eu fico nervosa só na hora, depois passa, eu vejo que isso aí.... Só o tempo dá resposta de tudo, tudo, tudo, tudo!

O3: Eu também.

$\mathrm{K}$ : Mas costuma acontecer situação, por exemplo, de outros alunos que deixam você com raiva, ou de professores?

O2: Nenhum te deixa com raiva? Parabéns!

O3: Eu consigo.

A3: [?] muito séria.

O2: Agora meu parabéns vai pra quem conseguir deixar ela nervosa. Muita gente já me deixou nervoso. Muita gente mesmo! Nesta escola não muitas pessoas, mas bastante.

$\mathrm{K}$ : Mas outra coisa agora que eu queria falar. A gente tá falando de sentimentos. A gente falou de humilhação, de raiva. E tristeza? O que acontece na escola que deixa triste?

O2: Quando a gente gosta de verdade de uma pessoa e essa pessoa te dá um fora, ou então te humilha. Aí vem aquela tristeza!

$K$ : Mas e aqui na escola, mesmo? Acontece alguma coisa que te deixa triste? O fora também pode acontecer na escola, mas tem outra situação que também deixa você triste?

O3: Na escola não fico triste não!

O2: Nenhuma situação deixou você triste?

O3: Que eu lembre não.

O2: Muita coisa me deixa triste. Uma coisa que me deixa triste é lembrar de como meu vô desperdiçou a sua vida. E como tá minha família agora. Isso deixa qualquer pessoa triste. Ninguém tem uma vida como eu.

$K: E$ você, $A 3$ ? 
A3: Ah, eu fico triste porque assim, meus pais são separados..., meu pai não tá nem aí pra nada, tanto faz, como tanto fez (...) e a outra filha dele só porque é menor, ele acha que tem que mimar muito ela. Pra gente não tá nem aí, o que fez, o que não fez, o que falou, não falou. Acho que isto me deixa bastante [triste].

$K$ : E aqui na escola mesmo, tem alguma coisa?

A3: Me dou bem com todo mundo, não tenho o que reclamar.

K: Eu queria voltar um pouquinho, a conversa dos professores. A gente tava falando de alguns professores que vocês acham que são bons, outros professores que vocês acham que são ruins. Pra vocês, o que é ser um bom professor?

O2: Explicar bem; impor respeito; dar respeito pros alunos... e ser alegre quando deve ser! O Pr1 hoje, por exemplo, ele tava tão feliz, tava dando tanta risada! Ele é um bom professor. Ele ri pelo menos uma vez por dia!

$\mathrm{K}$ : Isso é bom?

O2: Isso é bom!

A3: [O professor bom é aquele que também se dá bem com o aluno, né?] Que respeita o aluno, que tem respeito...; que entende o adolescente...

K: Isso é um ponto em que eu queria chegar. Um bom professor sabe entender um adolescente?

A3: Nem todos! Não é todos professores que hoje em dia que têm paciência com o adolescente! Já acha que... já chega gritando...; a gente não fez nada e já sai brigando!

O2: Tem professores que não gritam, mas também não gostam do aluno.

A3: É!

O2: A professora [de " $y$ " matéria], por exemplo. Ela seria uma boa professora se ela pudesse andar direito. Porque ela não pode andar direito, os alunos roubam a bengala dela pra ficar zoando pela sala, daí ela não pode levantar, não pode dar aula direito, não pode nem passar exercício na lousa.

O3: Na minha sala ninguém rouba a bengala dela não. Pede, ela dá. Ela que empresta...

K: Mas deixa eu voltar uma coisinha. Vocês tavam falando que a Pal e o Pr2 são bons professores. E aí a $A 3$ tava falando que acha que um bom professor é o que entende o adolescente. Vocês acham que esses dois professores que são bons, eles entendem 0 adolescente?

O3: Entendem.

A3: Ah, eu acho que a Pa1 não entende, não.

O3: A Pal, pra mim, entende.

O2: $\mathrm{Na}$ verdade, todos entendem o adolescente, só que não demonstram isso; porque todos já foram adolescentes um dia.

$K:$ E você acha que ter sido adolescente faz com que eles entendam o adolescente de hoje?

O2: Acho que se eles não se entendem, eles são loucos! Eu me entendo. É, na verdade eu não me entendo muito bem, mas eu me entendo, na medida do possível.

A3: Você tenta se entender, né?

O2: Tento. Não sei da onde vim, não sei pra onde vou, não sei o que eu vim fazer aqui. Mas eu sei que ...... eu sei que sou um adolescente, que eu tenho minha responsabilidade, que eu um dia vou me casar, ter meus filhos.

K: Vocês acham que as pessoas que hoje são adultas, que foram adolescentes--

O2: Na verdade, eles entendem o adolescente, mas não entendem o que o adolescente faz.

$\mathrm{K}$ : Como assim? 
O2: Eles sabem que nós temos responsabilidade, temos potencial, mas eles pensam que não sabemos gastar. Não sabemo usar direito nosso potencial.

K: Como assim? Explica melhor isso aí; dá um exemplo.

O2: Os pais não dão dinheiro pros filhos porque no tempo deles, eles iam lá, compravam um sorvetinho, ou então ia, sei lá, fazer qualquer coisa com o dinheiro. Mas se eles soltam dinheiro pra nós, nós vamo no cinema, aproveitamo muito melhor o dinheiro, mas eles não acham isso. Eles não acham que o dinheiro é bem gasto no cinema. Eles acham que o cinema é uma porcaria, não vai adiantar em nada.

$K$ : $E$, voltando uma coisinha: O3, você tinha falado que acha que a $\mathrm{Pa}$ l entende os adolescentes. Por que você acha isso?

O3: Porque ela demonstra; (...) tipo, quando a gente bagunça, ela faz tudo, né? Ela--

O2: Ela ainda é uma adolescente!

O3: É. Se comporta como um adolescente. Quer ser um. (...) E ela participa das coisas.

$K: E$ por que vocês acham que ela é um adolescente ainda?

O2: Ah, porque ela é, age como um adolescente, mas um adolescente mais responsável.

$K: O$ que ela faz que parece de adolescente?

O2: Ela brinca com nós, ah... sei lá! Ontem por exemplo, ela falou "Ei, você aí que tá de calça jeans! Você nem vai fazer exercício! Ou faz de cueca ou faz de (?)". Ele tirou a calça, fez de cueca, e a Pal deixou. Muitos professores não teriam deixado!

$K$ : $E$ você $A 3$, por que acha que ela não entende os adolescentes?

A3: Ah, porque... acho que ela não entende mesmo, assim... ela não ta nem aí, briga com a gente, xinga.....

O2: Xingar é característica de adolescente.

K: Vocês acham que ela ouve o que os adolescentes dizem, têm a dizer?

O2: Ouve sim.

A3: Às vezes não.

$K$ : Às vezes sim, às vezes não...

$K: E$ o $\operatorname{Pr} 1$, vocês tavam falando que ele é um bom professor. Ele tem uma imagem sobre os adolescentes como? $O$ que vocês acham que ele acha dos adolescentes?

O3: Ah, que alguns são uns vândalos; mas alguns! Como hoje, ele tava explicando, tavam fazendo bagunça, tavam tocando música, pintando, batendo a carteira, e ele tava reclamando. Aí depois ele parou a matéria e começou explicar sobre crime e começou explicar tudo. Falou que teve um aluno, falando de aluno folgado, os alunos dele que tão preso.

O2: Na verdade, eles acham que uns alunos são vândalos, mas têm conserto.

O3: É.

K: Quem acha isso?

O2: O Pr1.

O3: $O \operatorname{Pr} 1$.

O2: Ele sabe que muitos são vândalos e muitos não são. Ele pode pensar "o 03 , ah, vá pro inferno! $O 03$, mas a $A 3$ não! $A$ A3 vai ser uma médica, ainda, tem muita chance na vida, pode ser o que ela quiser na vida!".

K: E esse exemplo que você tá dando: se ele acha que O3 é vândalo. Ele acha "aquele tem conserto", assim?

O2: Porque ele acha que têm alunos que não têm jeito mesmo. Não você (O2 fala para O3).

O3: [Aluno como o $X_{8}$, por exemplo].

O2: $O X_{8}$ é internacionalmente conhecido! 
A3: Ah, o $X_{8}$, ninguém merece mesmo!

O2: É mesmo. O pior aluno--

A3: Estudei com ele na sexta e sétima...

O2: Que azar!

O3: Estudei com ele desde da quinta.

K: Deixa só eu perguntar uma coisinha que eu não entendi direito. $O \operatorname{Pr} 1$ pode achar que os adolescentes são vândalos (na cabeça de vocês). Mas ele respeita ou não respeita os adolescentes?

O3: Respeita!

O2: Depende do adolescente. $O X_{8}$, ele não respeita e nem deve respeitar! Mas eu, ele respeita, ele sabe que eu sou um bom aluno.

$\mathrm{K}$ : $A \mathrm{~Pa}$, por exemplo. A gente tava falando como a $\mathrm{Pa} 1$ reage com os alunos. $E$ ela, vocês pensam que ela acha que adolescente é o que?

O2: São pessoas com futuro! $O$ futuro da nação! Ela pensa isso!

O3: Ah, acho que não!

O2: É legal que ela fala que eu sou o melhor aluno, eu gosto disso. Não, porque eu, enquanto todos fazem 300 abdominais, eu faço 360 . Eu sou o melhor aluno realmente dela, porque eu amo a aula dela! Porque eu tenho paixão pela aula dela!

K: Mas então, quando você diz que você acha que ela acredita que o adolescente é o futuro da nação, por que você acha que ela pensa isso?

O2: (?) Porque ela nunca deixa a gente com raiva, nem frustrado com nada. Ela dá conselho. Então...

K: Agora eu queria perguntar: A gente tá falando de professores que são bons na opinião de vocês. E o que é ser um mal professor, um professor ruim?

(O2 e A3 falam juntos)

A3: É aquele que não explica bem, que tanto faz, como tanto fez.... Se o aluno entendeu, entendeu; se não entendeu, vai ficar sem entender...

O3: Que nem o Pr2.

$K$ : E você 02, o que ia dizer aquela hora?

O2: Exatamente o que ela disse. Os outros professores, os maus professores são aqueles que não respeita e dá muita liberdade pro aluno. Tipo o Pr2: no primeiro dia de aula, ele falou: "Meu nome é..."; [e a gente perguntou:] "Não vai ter lição, não?", [ele falou:] "Primeiro dia, não tem aula". Daí, ficou nessa por uma semana! Aí depois ele passou lição na lousa, ninguém copiava... todo mundo começava jogar coisa nele! Ele não tá nem aí!

O3: Mas acho que no primeiro dia, ele quis dar uma de professor legal. Quando o professor chega, passa lição, todo mundo faz, no primeiro dia. Ele não! Pegou tal, começou falar um pouquinho [e depois falou] "Pode guardar o material".

K: E ele continuou fazendo isso. Vocês sentem que ele não tem uma postura firme, pelo que vocês falam.

O3: Agora parece que --

O2: Hoje na minha sala, quem ouviu aquele som que tava tocando no $E$ [outra escola]? Os moleque tava tudo na janela, pulando, dançando, jogando carteira..., e o Pr2 ficou lá, parado..., pegou o material, jogou na mesa e saiu da sala. Ele é estranho! Vários professores são estranhos.

K: Muitos são assim?

O2: Muitos! 
K: Isso que eu queria perguntar. Vocês tavam falando mais de dois que são bons, e um, o $\operatorname{Pr} 2$, que é ruim e outro que vocês tinham falado que é ruim.

O2: A Pa2.

$K$ : Vocês concordam que ela é ruim?

A3: Ah, eu não sei --

O3: Ela não pode ver eu de pé. Pode tá a sala inteira, tudo em pé, mas se eu levantar, é guerra!

K: Tem marcação cerrada com você?

O3: É por causa que antes, antes de junho, julho, eu era... eu era...... bagunceiro (risos). Agora que tá melhorando, baixando um pouquinho o nível da bagunça.

O2: Outra professora que eu tô indeciso se ela é boa ou ruim é a professora de... ["y" matéria]. Porque --

O3: Ela gosta de tirar muito sarro. Tipo... humilhar!

O2: Eu saí da sala dela...; eu tava arrumando o que tinha caído e ela: "Guarda lá essa droga! Guarda essa bosta! Guarda essa porcaria"!

$K$ : Exingamento, tem muito?

O2: Depende do professor. A professora de... [" $z$ " matéria] não xinga o aluno, mas ela fala palavrão: "Vou enfiar isso aqui no seu cú". Ela é estranha, mas ela é legal!

$\mathrm{K}$ : Retomando 03 , você falou que era um aluno bagunceiro, que agora não tá mais bagunçando. $O$ que mudou, o que aconteceu?

O3: Não tô bagunçando taanto! $O$ que mudou é que é quarto bimestre, agora é decisivo. Mas também tento me segurar um pouquinho (...), agora não tô ficando mais bagunçando muito.

$\mathrm{K}$ : Eu queria perguntar uma coisinha, a gente até falou um pouco sobre isso no outro encontro. Tem um aluno que é o adolescente aluno ideal e tem o aluno adolescente "normal".

O2: E tem o aluno bom. E o ruim.

K: No encontro anterior, vocês falaram um pouquinho que este aluno ideal na verdade é até uma chatice, porque não faz nada..., fica parado.

O2: É aquele que só faz lição; que chega, conversa com a professora, que chega em casa, sempre quando acorda, acorda toda a família, faz café da manhã. Até agora eu tô sendo o aluno perfeito!

O3: Assim, em algumas aulas, tipo de... [" $z$ " e "w" matérias], eu sou um bom aluno.

$\mathrm{K}$ : Um bom aluno, como?

O3: Porque eu também sempre faço lição e acho que a professora também gosta de mim. Isto em " $w$ ". E em " $z$ " porque eu também faço a lição. [Mas na aula do] Pr2, eu sou o ruim; por isso eu bagunço muito na aula dele, [porque] também, ele não dá chance!

$K:$ É na aula dele que tem a bagunça que você fala? Nas aulas de " $w$ " $e$ " $z$ ", como fica a sala de aula, fica com a bagunça, sem bagunça?

O3: Na de "w" não fica bagunça não. Ah, tem vezes que dá uma descontrolada, mas --

O2: Na aula de "w", você tem participação, lê texto, ganha positivo fácil.

K: É diferente a dinâmica da aula de "w"?

O2: Ela fala "Quem quer ler?", daí na minha sala o pessoal não lê. Daí eu sempre leio, ganho positivo. A professora fica falando comigo da minha irmã, que ela dá aula pra minha irmã.

K: Agora eu queria perguntar uma outra coisa. Vocês acham que têm diferença entre, por exemplo, estes professores que tão dando aula pra vocês que são adolescentes, se fosse pra aluno criança ou adulto, ia ser diferente?

O2: Com certeza!!

K: Que diferença é essa? 
O2: Com criança, eles iam ser mais meigos! E com adultos--

$\mathrm{K}$ : Vocês acham que com criança eles iam ser mais meigos?

O2: É lógico!! Iam falar: "Ó, 1 + 1 é quanto?", [as crianças iriam falar:] "1", [e os professores:] "Não, não é 1"!

O3: Se fizessem bagunça, iam só dar uns tapinha no bumbum e mandavam sentar.

K: Será que é assim nas escolas?

O2: Se jogasse uma carteira no professor, ele [falaria]: "Você é um menino mau, eu vou falar pra sua mãe".

K: Falando baixinho, sem gritar...? Vocês acham que é isso que acontece?

A3: Pensa que criança não tem--

O3: Juízo.

A3: Não, não é juízo, é...; não entende o que faz. Faz, mas porque é criança, então não tem...

$K:$ Não tem consciência do que faz?

A3: Isso.

$K:$ E o adolescente?

A3: $O$ adolescente tem consciência do que faz.

O3: Tem mesmo. Por isso que a partir de 16 anos é preso! Apesar que desde de 3 anos já deveria ser preso. A criancinha vai lá, pega uma faca e joga no pai...

K: Que outras diferenças vocês acham que têm do professor que dá aula pra criança e aula pra adolescente?

O2: Ah....

K: Pensa que não tem consciência do que faz, então.....

O2: Tratam bem! Dá docinho até...

K: Vocês acham que trata melhor, que não grita?

O2: Dá doce, dá bala.

K: Vocês se lembram de vocês na primeira, segunda, terceira série?

O2: Acho que eu era meio (?), meio louco, então não me lembro de quase nada que eu fiz. Eu lembro das pessoas que estudei, mas não de muita coisa que eu fiz.

A3: Não lembro de nada!

K: Não lembra da primeira, segunda, terceira?

A3: [Não, só] da quarta e quinta em diante.

K: Quarta, quinta- série, já estava com uns dez anos, né?

O3: Da quarta eu era o melhor da sala! Mas não era aqui, era na... [outra escola] que eu estudava.

K: Você gostava de lá?

O3: Ô, era o melhor, né!

O2: Eu lembro, eu fui um bom aluno já.

$\mathrm{K}$ : E hoje é o que?

O2: Uma peste. Eu sou um aluno médio. Faço lição, não chego nas mina porque já sei o que vai acontecer... vou tomar um fora!

K: E qual a diferença entre dar aula para adulto e pra adolescente?

O2: Na verdade, acho que não tem muita diferença.

K: Não? Eles reagem igual, do mesmo jeito com os adolescentes e com os adultos?

O2: Se professores forem dar aula pra adulto, ia ficar conversando com o adulto. Porque eles adultos têm conversas--

A3: Adulto é mais amadurecido.

O2: Não. 
O2: Eu acho que sim.

O2: Adulto e adolescente fazem a mesma coisa.

A3: Não, eu acho que depende do adolescente. Tem adolescente que não tá nem aí pra vida...

O2: Porque eu gosto muito de política, eu faço meus planos pro futuro. Tenho responsabilidade, também.

K: Tem as coisas que os professores fazem hoje com vocês, alunos adolescentes; eles fariam a mesma coisa com os alunos se fossem adultos?

O2: Ah, comigo o professor Pr1 me trata igual como se eu já fosse uma pessoa adulta. No tempo que eu trabalhava, no começo do ano, de fazer bijuteria, daí eu punha pelo menos 150,00 reais por mês no banco. Daí ele falava "Você põe seu dinheiro, quando tiver dinheiro suficiente, você pode pôr no bando, comprar um terreno" "É uma boa, posso comprar um terreno". Daí ele "Quando você casar, tiver seus filhos, aí você vai construindo sua casa. Tem que começar já fazer seus planos pro futuro, pra você ser um jovem formado.... Você pretende fazer faculdade?" "Vou fazer Senai" "Então, Senai é uma boa, porque quando você chegar lá, você já vai trabalhar, aí você pode pôr mais dinheiro no banco ainda". Eu punha $R \$ 150,00$; quando eu voltar a trabalhar, vou por uns 300 reais na minha conta. Tô com $3.500,00$ reais na minha conta.

K: Queria saber o seguinte: como é a relação aqui entre vocês alunos adolescentes.

O2: Depende do aluno. Se for folgado, minha relação é de dar porrada! Se for um aluno legal, eu tenho uma boa atitude com ele, converso com ele, ajudo ele. Tipo, eu nunca vou deixar um amigo na mão. Nunca vou deixar um amigo meu para apanhar. Um amigo meu é um amigo meu. Um inimigo meu é um cara morto.

$K$ : $E$ você $A 3$, como você acha que os adolescentes aí se relacionam?

A3: Tem muitos adolescentes aqui na sala que pensa que manda na escola... vamos supor, que acha que é o melhor da escola, então pode mandar. "Me espera na saída que vou te catar"; partem pra briga já...

$K: E$ você, $O 2$, como acha que os alunos aí se relacionam?

O3: Com muita intimidade.

$\mathrm{K}$ : Como assim?

O3: Assim, de brincar, faz montinho, dá um tapinha na bunda, fica abraçado.

K: E a gente também tava falando da situação de aluno que humilha aluno. Acontece?

O3: Muito!

O2: Muito! [Com o $X_{3}$, não é só] nem questão dele ser humilhado pela professora, é questão dele ser humilhado pelo aluno. Não tem um na escola que nunca zoou com ele.

02: Você já zoou com ele?

O3: Todo dia!

O2: Eu só não consigo zoar com ele porque dá muita dó.

$\mathrm{K}$ : Eu queria saber--

O2: Ele pode crescer frustrado e daí vai virar um marginal. (...) Mas quem sabe um dia ele não fica frustrado. Ele dá risada, mas na verdade ele chora depois. [No intervalo], todo mundo zoa com a irmã dele: "Sua irmã vai lá em casa hoje, tô esperando sua irmã". Ele dá risada. Na verdade, ele tá querendo matar o cara, mas ele não tem força suficiente pra isso.

K: Quanto tempo vocês têm de intervalo?

A3: Vinte minutos.

$K: E$ aí, no intervalo, o que acontece entre os alunos? 
O2: Depende, os alunos que brigam, muita gente passa quieto. Todos, todos têm seu grupo, menos $X_{15}$, uma menina que fica sozinha na escada, durante o intervalo. Mas ela até merece também. Se alguém chega: "Tem alguma coisa pra limpar esmalte?" "Você tá vendo alguma coisa aqui, você tá vendo alguma coisa aqui?". Ela merece ficar sozinha então. Ela é arrogante com todo mundo.

K: Mas eu queria perguntar o seguinte: vocês se reúnem para fazer coisas fora do que acontece na sala de aula?

O2: Sim. Na rua?

K: Na rua também, se encontram...?

O2: Lógico!

K: O que vocês fazem de lazer?

O2: Eu, por exemplo, saio com a minha banda que são todos dessa escola, vou no shopping... vou fazer muita coisa! Vou na pista andar de skate. A maioria dos meus amigos são skatista. Todo mundo só curte rock, mas eu curto rock, reagge, black. Eu curto até um pouco de axé, se quiser.

$K: E$ você $A 3$, o que vocês fazem de lazer?

A3: Eu combino com as minhas amigas, a gente vai no cinema, no shopping, andar por aí..., uma na casa da outra.

$K:$ E são as amigas daqui da escola?

A3: Da minha sala.

$K: E$ você O3?

O3: Às vezes, eu não faço nada, mas de vez em quando eu venho aqui na escola à tarde, ou fico jogando Pop Strick.

$\mathrm{K}: \mathrm{O}$ que é isso?

O3: Pop Strick, um jogo.

$\mathrm{K}$ : Tem aqui?

O3: Na escola não tem internet. Na escola tem internet, mas--

O2: Nem tem nem computador. Ah, não, tem computador, mas nunca ninguém usa.

O3: Só pega, quando tipo assim, se aqui em baixo tiver funcionando, lá fica ruim pra pegar.

$K$ : Esta sala de informática que tem aí, não usa, não tem aula?

O3: Usa, só que pra fazer trabalho. Eu ia lá direto, aí eu tava no "bate-papo", mas agora a $C$ não deixa mais.

K: Vocês não têm aula na sala de informática?

O3: $O$ ano passado que tinha. [Esse ano], tipo, a professora às vezes leva pra fazer aquele jogo da matéria dela.

K: Tá, então tem alguns professores que levam?

O3: É bem difícil.

K: Eu queria saber o seguinte: tem grêmio aqui? No fim do encontro passado vocês tavam falando que tinha grêmio.

O2: Tem, eu até [tinha uma chapa], mas tiveram poucas pessoas que votaram em nós.

$\mathrm{K}$ : Como funciona o grêmio?

O2: O grêmio nunca fez nada nessa escola! Só votaram neles, por causa que ficaram com medo de apanhar. "Não vou votar no grêmio lá do chapado, não lembro o nome do grêmio.

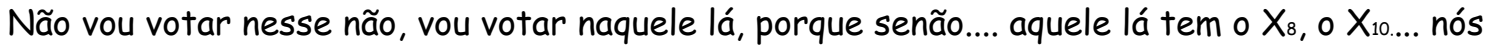
vamo tomar um cacete se a gente não votar neles"!

O3: [Ele já desceu o cacete no pai dele]... Ô, eu não deixava bater daquele jeito não!

O2: Eu já briguei com meu pai. 
O3: Ah, dava uns tapinha, então. Mas porrada...!! Dar um soco na cara na frente de todo mundo!! Deu um soco na cara e o coitado é quase uma pena! Um soco já desmonta todo.

K: Mas deixa eu perguntar: este grêmio não fez nada, tinha proposta?

O2: Todas as propostas que nós fizemos, foram lá e pegaram todas.

$K: E$ quais foram as propostas que vocês levaram?

O2: Nós levamo quadra coberta..., um monte de coisa legal.

$\mathrm{K}$ : Que mais?

O2: Usar mais a sala de computação, poder marcar horário pra usar, usar a sala de vídeo.

K: Vocês não usam a sala de vídeo?

O2: Poucas vezes, só quando a Pa1 leva.

O3: À tarde que mais usa mais; o período da tarde que usa mais a sala de vídeo.

O2: A Pa1 leva nós pra assistir. Nós tinha bastante projeto pra escola, não votaram em nós por causa de medo.

K: Conta mais um pouquinho, além da quadra coberta, usar a sala de vídeo e de informática, que mais vocês pensaram?

O2: Nem lembro mais. Eu lembro que tinha uma folha cheinha.

K: E aí, no fim esta outra chapa ganhou? Ganharam, e aí, o que eles fazem agora?

O2: Nada! Parece que nem tem grêmio! Nunca fizeram nada e nem vão fazer.

A3: E o ano praticamente já acabou.

O3: Eles fizeram um passeio pro Hopi Hare.

K: Como é que foi isso?

O3: Acho que eles combinaram com a coordenadora e--

O2: Isso foi eu e o $X_{11}$ que tava conversando com a coordenadora; aí ela falou: "Vou ver, vou ver". Daí nos fomo.

K: O O3 tava falando que a relação com a $C$ é legal. A gente começou falar isso no encontro passado: a diferença da relação da coordenadora com os adolescentes, vocês, e a diferença da diretora.

O2: $A C$ ainda é uma adolescente.

O3: Tipo, quando tiver bem encrencado mesmo, ela ajuda.

O2: O que ela tá fazendo aqui?

03: Teve um dia que ela ajudou.

$\mathrm{K}$ : Como assim ela ajuda?

O3: Ajuda, ela chama os pais quando é preciso mesmo, bem grave. Quando bagunça muito, ela também é legal...

O2: Quando eu briguei com $X_{12}$, ela não chamou nem meu pai, nem minha mãe.

$K: O$ que você acha $A 3$, da diferença entre a relação da coordenadora e da diretora com os alunos?

(Falam juntos)

O2: Ela [a coordenadora] me ajudou, me protegeu. A Fa [me cagüetou]; ninguém sabia, só os moleque, porque foi eu e mais dois moleques.

K: Por que aconteceu o que? Vocês colocaram foguinho no papel--

O3: A gente tava com isqueiro, papel, mas ninguém falou quem era; aí levaram o $X_{13}$ e $0 X_{14}$, tomaram suspensão, ninguém falou que fui eu.

K: E a Fa nesta história?

O3: A Fa sabe que eu sou bem bagunceiro, sabe? Bem bagunceiro. Aí, eu tava quietinho assim. Tava quietinho, falando com os moleque sobre um negócio e a Fa percebeu; ela viu 
que eu tava quietinho, não tava zoando, nada... Aí ela descobriu [porque] me chamou de lado, falou que ía deixar meus amigos levar suspensão. Aí eu tive que ir lá confessar, né?

$\mathrm{K}: \mathrm{A}$ Fa é inspetora de alunos, né?

O2: A Fa é maior cagüeta! Quando eu pulei de lá de cima, do segundo andar para o primeiro, eu saí correndo para sala, daí ela entrou. Chegou o $X_{15}$, daí eu olhei assim pra ela, porque ela tava olhando assim para mim, daí ela: "Mocinho, pode vir". Ela tinha que me cagüetar, meu?! Depois ela falou com a $C$, mas ela não fez nada.

K: A gente tava conversando destas três pessoas, da diferença. Então, deixa só eu voltar com a A3, que ela tava começando a falar da diferença que sente entre a diretora e a coordenadora na relação com os alunos. $O$ que você sente?

A3: Eu acho que a $C$ entende os alunos. Ela acompanha a gente, tipo assim...

O3: Ajuda.

A3: Ajuda a gente. Ela.... entende mais a gente. Agora, a diretora não; ela nem pára direito aqui na escola.

K: Vocês não têm muito contato com ela...

O3: A diretora, um dia desses aí, eu baguncei, tava indo pra coordenadora, ela [diretora] escutou. Aí, ela [diretora falou:] "Segura ele e chama o pai e dá suspensão". E eu: "que suspensão, que nada!"! Fui falar com a $C$ e ela não deu nada! Só conversou um pouquinho $e$ pronto.

$\mathrm{K}$ : Mas a $C$ só protege vocês e não faz nada ou quando tem que ser firme, ela é também?

O2: $O$ que tem que ser feito, faz. Quando o professor quebrou o rodo no $X_{16}$, a Fa falou [para a coordenadora]: "O professor falou que teve que dar o rodo nele pra separar aqueles dois". Daí ela [a coordenadora] falou: "Por que você bateu nele?" e eu [respondi]. E ela falou: "Mas também muita gente já quis bater nele este ano; ele é folgado com todo mundo". Aí eu: "Ah, dona $C$, você sabe que eu não sou de briga", aí ela: "Que isso não aconteça de novo! Vai pra sua sala!", aí eu fui. Aí o X ${ }_{16}$ tomou suspensão.

$K$ : Acho que uma coisa que você tá falando tem a ver com o que vocês falaram no encontro passado, de que parece que a $C$ tem uma coisa que é difícil de acontecer, que o adulto--

A3: Ela tem paciência.

K: Paciência..., que mais que ela tem, que é difícil de acontecer, e ela faz?

O2: Ela é bonita, legal.

K: Pelo que vocês tavam falando no outro encontro, ela ouve os adolescentes. Antes de ela sair dando suspensão, ela ouve o que vocês têm a dizer, quem estava com a razão, quem não estava. Vocês acham que isto acontece mesmo?

O2: Acontece.

K: E a última coisa que eu queria perguntar pra vocês da relação das pessoas que estão aqui, é como é a relação dos pais de vocês aqui na escola, quando é que eles vêm pra escola....?

O2: Meus pais, pelo menos, só vêm em reunião de pais.

$\mathrm{K}$ : E como é esta reunião de pais, o que acontece?

O2: Os professores falam tudo o que tem que falar dos alunos.

K: Tudo o quê?

O2: Se tem um mau aluno, eles falam "seu filho é um mau aluno, um ordinário..., ele que vá pro inferno". Não... não chega a tanto!

O3: A minha mãe só veio nas reuniões, umas três vezes.

$K: E$ o que acontece, depois da reunião eles conversam com vocês sobre o que o professor falou ou não? 
O2: Normalmente o $\operatorname{Pr} 1$ conversa com a minha mãe, apesar que minha mãe não veio na última reunião, porque ela tava fazendo exames. O professor fala: "Seu filho é um bom aluno, ele fechou com B, podia ter fechado com A". Porque eu tirei B nos dois primeiros e B agora.

$\mathrm{K}$ : Mas e os pais de vocês, conversam com vocês depois da reunião pra dizer o que 0 professor falou ou não?

O3: Conversa, não; reclama!

K: Reclama? Como é isso? Conta um pouquinho.

O3: Minha mãe repete tudo o que o professor fala que eu faço; que o problema é o comportamento.

O2: Eles falam a mesma coisa de mim.

K: Vocês fazem lição, mas aí bagunçam enquanto isso.

O2: Bagunça muito. Isso que estraga o aluno.

$K:$ E o que vocês acham disso?

O2: Se a gente já acabou a lição, nós somos livres. "Façamos o que quiserdes!" Porque já acabou a lição. Já aprendemo o que tinha que aprender. Então, vamo dar um rolê pela sala...

$K: E$ você, O3, o que acha?

O3: É claro.

O2: Porque quando acaba a lição, o que deveríamos fazer? Fazer isso? [Ficar sentado com a cabeça abaixada]

O2: É mesmo.

K: Rir não pode.

O2: Todos têm que acabar a lição, fazer isso, isso e isso. [Sentar, cruzar os braços e levantar a cabeça]

02: Cruzar os braços não precisa, mas também, se abaixar a cabeça, o professor já acha que você ta dormindo.

$K: E$ você $A 3$, o que acha desta idéia dele?

A3: Acho legal, a gente já terminou a lição, então, a gente já pode aproveitar um pouco pra descansar, né?

K: E sobra este tempo?

Juntos: Sobra!

K: Sempre sobra e é nessa hora que--

A3: Com alguns professores não sobra esse tempo.

O2: É mesmo.

A3: Com o Pr1 não sobra este tempo.

O2: Não, às vezes sobra sim.

A3: Na minha sala não sobra este tempo.

O2: $\mathrm{Na}$ minha sala [tem aluno que] não tem muita capacidade suficiente para ler $e$ conversar ao mesmo tempo. Eu escrevo, converso, escrevo, converso.

$K:$ Mas, O3, e na aula de " $w$ " e " $z$ ", isso também acontece?

O3: Acontece, sim. Na de " $z$ " que acontece mais. Todo mundo acha que como é aula de " $z$ ", tem que dar nota boa, mas acho que tem gente que faz coisa que não merece.

K: Desenho, estas coisas você tá falando?

O3: Gráficos.

O2: Ela passou aqueles negócio de corte ninja, assim.

O3: Umas coisas agora de pentágono.

O2: Que pentágono, o quê? É Pitágoras.

O3: Não, é pentágono. 
O2: É um tipo de corte ninja, mas tem outro nome.

K: Então, os pais de vocês vêm nestas reuniões, e aí depois eles dão bronca, o que acontece? O3: A minha,não.

$K: E$ o que os pais de vocês acham desta escola de vocês aqui?

O2: Minha mãe acha uma droga! Ela me pôs aqui, porque na $E$ [outra escola], eu tava sendo um mau menino na sétima série. Eu não ia direto para casa, saia, ia passear, aí eu falava "É que eu fiquei varrendo a escola". Também no $E$ é muito fácil cabular. No $E$ ela ficou sabendo, tive um problema com a escola, não quero falar sobre isso.

K: Tá, não precisa falar. Mas, ela acha que esta escola é ruim, por que?

O2: Porque nesta escola aqui só têm dois, três bons professores.

$\mathrm{K}$ : E ela sabe disso?

O2: Sabe.

K: Quem são estes três? $\operatorname{Pr} 1, \operatorname{Pa} 1$ e ....

O2: A de... ["w" matéria].

$K:$ E quem são os ruins? Por que vocês estavam falando só do Pr2 e Pa2.

O2: Pa2 e Pr2.

$\mathrm{K}$ : Só os dois são ruins?

O2: Não, as professoras de... [" $x$ " e " $z$ " matérias]. A professora de " $x$ " seria uma boa professora. Mas ela não é.

$\mathrm{K}$ : Por que?

O2: Porque ela não consegue levantar.

$K$ : Ah é, você falou que os alunos não deixam ela levantar, usam a bengala.

O3: Levantar, ela consegue...

O2: Uma vez, $0 X_{17}$ pegou a bengala dela e pendurou em cima da janela.

$K$ : Mas e aí, que mais? Eu lembro que você tinha falado que só tem dois professores bons, ou três, mas e os outros, cadê?

O2: São os quatro.

K: Só tem quatro?

O2: Quatro ruins, três bons e falta um. Qual é esse outro? Eu não lembro.... Ah, é a professora de " $y$ ". Ela tenta ser boa. Mas só que nos primeiros dias ela tava sendo ótima, depois.... os alunos começou a não dar mais bola para o que ela falava.

O3: [Eu acho ela muito] folgada. [Foi aquela que eu falei] que xinguei e chutei a porta.

$K:$ Ah, do dia do caderno?!

O3: É, foi o primeiro dia que ela chegou.

O2: O primeiro dia que ela chegou, já entrei atrasado na aula porque eu tava--

O3: Ela começou zoar todo mundo. Zoou eu e mais outros alunos.

O2: Cheguei atrasado na aula dela e ela falou: "Nunca chegue atrasado na minha aula, você nunca mais vai chegar atrasado na minha aula, hein, garoto!" e eu: "Eu não sei o que vai acontecer"; e ela: "Fala que não vai, se não te dou um E". E eu: "Que professora você é?", "Sou a nova professora de ' $y$ '". "Ah, então tá bom! Eu nunca mais chegarei atrasado". Depois eu acabei fechando com nota $D$.

K: Os professores dão nota com base em quê? Dão prova, como eles fazem para dar nota?

A3: Por comportamento, trabalho.

O3: Trabalho.

O2: Eles dão principalmente comportamento, caderno.

O2: Mas a professora Pa1 é muito legal! Ela passa umas provas muito legais. Ela é a melhor professora! 
A3: Que nada! Ela faz a gente fazer meia hora de exercício...

02: Ela é a melhor professora. Eu já faço exercício há muito tempo, só que daí na aula dela, eu faço exercício até a morte. Em casa: "Ai, tô cansado, e paro". Na aula dela: "Eu não posso parar, se não vou ficar com nota vermelha".

K: Mas tem uma diferença que a gente tá falando. Uma coisa é gostar da professora a outra é gostar da aula de educação física. Quer dizer: "Ai, porque é cansativo correr, pular", outra coisa é gostar do jeito que a professora dá a aula.

O2: Eu gosto do jeito que ela dá aula e gosto dos exercícios dela.

O3: Ainda mais subir e descer escada --

O2: É legal, meu!

$\mathrm{K}$ : Mas O3, você tava falando do $\operatorname{Pr} 1$, quando a gente tava falando como eles dão nota, que às vezes é por caderno, comportamento, pelo 'visto' que o professor dá. Você falou alguma coisa do $\operatorname{Pr} 1$ que não deu pra ouvir.

O3: O Pr1 nunca usa o caderno. Ele não olha o caderno.

(Falam juntos)

O2: Ele nunca viu meu caderno, eu que fui mostrar para ele. Falei: "Meu caderno tá completo?" e ele: "Ah, deixa eu ver ... falta só uma matéria".

$K: O$ que você ia falar, $A 3$ ?

A3: Não. Eu acho que o Pr1 olha meu caderno porque ele é o coordenador da minha sala, então...

K: Coordenador da sala? Como é isso?

A3: Cada professor tem uma sala pra coordenar, tipo assim, na minha sala é o $\operatorname{Pr} 1$, na sala do 03 é o Pr2. Ele tem que fazer reunião....

$K$ : Então o que significa ser coordenador em uma sala?

A3: Ah, não sei.

K: $O$ que será que ele tem que fazer? Qual a diferença?

O2: Eles são nossos mediadores.

K: Entre o quê?

O2: Entre a diretora e nós. Tipo, o que nós tá fazendo, ele vai interpretar isso pros professores. Se nós bagunçamo, ele que vai interpretar nossa bagunça.

$K$ : Então existe uma reunião entre os professores em que cada um fala sobre o que aconteceu em uma sala--

O2: Eles são os nossos vigilantes.

(Barulho)

K: Então, agora tá acabando nosso tempo e queria saber sobre esta história aí de vocês acharem da visão que todo mundo tem aqui na escola sobre vocês, sobre os adolescentes...

O2: Eu tenho uma boa visão; o pessoal tem uma boa visão de mim.

$K:$ De você. $E$ dos alunos adolescentes? Quer dizer, tem alguma diferença: tem gente que entende os adolescentes, tem gente que não entende... E a última coisa é que no encontro passado vocês tavam falando que a inspetora de alunos tem uma idade que é próxima de vocês, vocês acham.

O2: Acabou de sair da adolescência.

$\mathrm{K}$ : Mas isso vocês acham que atrapalha ou ajuda?

O2: Ah, pra ela atrapalha.

K: Por que atrapalha?

O2: Porque ela se acha!

K: Ela se acha? 
O2: Se acha acima de todos. Mas pra algumas pessoas, tipo Fo1, ele tem uma idade acima de nós, só que se ele não estivesse, não ia mudar nada, ele ia continua assim mesmo com nós. Ele é um cara legal. Ele é aquele cara que te encontra na rua, pergunta "Pra onde você vai?" "Ah, tô indo no bar, comer um lanche, comer um lanche"--

$K:$ Ah, é inspetor de aluno? Quem é X?

O3: $O$ porteiro.

K: Ah! Olha gente, agora está acabando nosso tempo..., passa rapidinho! No próximo encontro a gente vai falar mais sobre a experiência de estudar aqui, o que vocês acham do ensino aqui, o que vocês acham da história de se repete não repete, o que acontece pra repetir, pra que serve estudar... . A gente vai conversar sobre um monte de coisa daqui da oitava série, do que vocês acham, da vida de vocês. E no último, a gente combina de fazer aquilo de trazer música. $O O 2$ tinha falado do Charles Brown, da música "Não é sério". Tem "Minha Voz", que A1 ia trazer a letra--

O2: Tem a Pitty.

$\mathrm{K}$ : Ela fala sobre o que?

O2: Sobre o mundo, sobre os jovens.

K: Então, se vocês tiverem mais idéia de música que fale sobre adolescência, relação com a escola, dos jovens não serem ouvidos, qualquer coisa com relação com o que a gente tá falando, pode trazer também. Nosso último encontro vai ser ouvindo as músicas, conversando sobre as músicas, que idéias vocês têm com relação ao que está ali escrito. No próximo encontro a gente conversa sobre esta história de fazer a Proposta do Partido dos Adolescentes da Nação em um outro encontro. O que vocês acham desta idéia?

A3: Eu acho legal.

O2: Alguém imagina mais alguma música?

O3: Rap; deve ter vários!

K: Alguém tava falando dos Racionais.

O2: Foi o 01 que falou.

O2: Mas ela (se referindo a A3), eu creio que ela ia pedir axé.

A3: Não gosto de axé.

O2: Pagode? Samba? Black? Rap? Rock? Reagee?

A3: Reagee.

O2: Reagee, eu sabia!

$\mathrm{K}$ : Tem alguma de reagee que você ache que fale?

O2: Almagem e Natihuts.

K: $E$ se algum de vocês tiver um desenho, algum poema, ou alguma coisa que vocês já escreveram sobre os sentimentos de estudar aqui...

O2: Eu vou compor uma música ainda.

K: Compõe, aí você traz.

O2: O Rappa tem umas boas sobre adolescentes.

$\mathrm{K}$ : Bom, então, agora a gente encerrou esse encontro de hoje. Muito obrigada! 
ANEXO XIV

\section{PRIMEIRO ENCONTRO EM GRUPO COM OS ALUNOS}

K: Hoje a gente vai conversar sobre adolescência. Primeiro eu queria saber como é para vocês ser adolescente, o que vocês acham de ser adolescente.

A2: Eu gosto.

K: Você gosta?

A2: Eu acho que é a melhor fase que a pessoa passa.

$\mathrm{K}$ : Por que é a melhor fase?

A2: Porque, sei lá. Sem responsabilidade. Sem ... é.

K: Diz o que você acha. Você concorda?

O1: Concordo.

$\mathrm{K}$ : Você acha que é sem responsabilidade?

O1: É. Só jogo bola todo dia.

K: Por que é sem responsabilidade? Por que o adolescente não tem responsabilidade?

A2: Não, responsabilidade tem. Mas eu tô falando assim, você sendo adolescente você tem sua mãe, seu pai. Então, porque de maior você tem que pagar conta, tem que trabalhar... Se você trabalha, assim, tem todas as responsabilidades.

K: Quais são as responsabilidades dos adolescentes?

A2: Pelo menos a minha é meu emprego, minha escola, estudo.

A1: Arrumar a casa também. Ter nota boa.

K: Mas, qual é então a diferença entre a responsabilidade do adolescente e do adulto?

A1: Porque o adulto tem que ficar se preocupando com várias coisas.

A2: Conta para pagar, aluguel para pagar.

A1: É, compra. Fica no sufoco, assim.

$\mathrm{K}$ : Adolescente não tem que se preocupar com dinheiro?

A2: Eu me preocupo com dinheiro só pra comprar minhas coisas.

$K$ : Então, não é para se sustentar, é pra comprar as coisinhas que você quer? E você, o que você acha de ser adolescente?

A1: Eu acho ótimo. Por causa que é assim, é a fase que você sai com seus amigos, você conhece as pessoas novas. É a fase de descobrir tudo que você não sabia antes.

$K: O$ que vocês estão descobrindo, que vocês não sabiam antes?

A1: Eu nada.

(Risadas)

K: Mas vocês não falaram que é a fase das descobertas? O que existe de descoberta na adolescência?

(Pequeno silêncio)

A1: Por exemplo, beijar. Porque beijar, na hora que você começa beijar..., aí depois você não quer mais parar.

O1: É que as vezes vocês acha que [vai ser] uma coisa diferente, quando você não é adolescente.

$\mathrm{K}$ : Como assim?

O1: Acha que vai achar beleza, tudo legal, mas quando passa a conviver, mesmo, vê que não é tão só maravilha. 
A2: Meu irmão que fala "Você acha que o mundo gira ao seu redor, não é assim, tem que abrir o olho, ter cabeça, porque tem muita coisa lá fora que você vai ter que enfrentar, não vai estar protegida pela sua mãe, e aí quando chegar na idade de 20, 22 anos" [vai ter que] enfrentar lá fora.

$K$ : E sobre isso que o $O 1$ tava falando, que acha que assim, que antes de ser adolescente você tem uma idéia de que o mundo é tudo de bom e na adolescência já começa a mudar? É na adolescência que já muda?

O1: É.

K: Que visão que a gente começa a ter na adolescência sobre o mundo?

A1: Que tem que tomar cuidado.

$\mathrm{K}$ : Cuidado com o quê?

A2: Com suas amizades.

A1: É, principalmente, porque tem muitas amizades que não dá [que no começo é] uma beleza e depois só ficam falando mal de você.

A2: [Tem que tomar cuidado com os] lugares onde freqüenta.

A1: É, principalmente com os lugares que freqüenta. Fica preocupada com tiroteio aí, esses negócios...

K: De violência?

O1: E quando é adolescente tem que ser só melhor, senão se lasca depois. Tem que ser melhor que os outros. Fazer de tudo pra tentar ser melhor que os outros para ter seu espaço. Se não... Ou você corre atrás, ou você fica [bem atrás].

$K: E$ isso acontece na escola também ou não, de ter que ser o melhor, isso acontece onde? O1: Ah, na escola nem tanto. Todo mundo é tudo igual, da mesma forma. Agora sendo em outros lugares assim...

K: Onde, por exemplo? Dá uma idéia de onde.

A2: Posso falar?

$\mathrm{K}$ : Pode.

A2: Emprego.

K: Emprego?

O1: É.

A2: Eles querem os melhores. Escola também... você tem que ser o melhor.

O1: E hoje em dia (...) você pode ser o mais esforçado possível...

A1: Eles não querem nem saber.

K: Na adolescência também tem então esta preocupação de emprego?

A1: Acho que a nossa grande preocupação é emprego. É porque você quer ajudar sua família, assim porque sabe, você tem vontade de ajudar, mas não pode trabalhar por causa da sua idade, aí fica mó ruim.

A2: E tem o preconceito também. Tem umas histórias de lugares que não pega adolescente por causa da idade.

K: Então tem um preconceito? Nesta história de emprego tem uma coisa de ajudar a família, mas existe um preconceito de que não contrata porque...

A2: Porque não tem muita experiência. Mas como é que a gente vai fazer se ninguém dá chance?

K: Você tava falando do preconceito, das pessoas que não te chamam porque é adolescente. Mas que preconceito é esse, que tem a ver com a pessoa ser adolescente? 
A2: Acha que nós somos novos, não sabemos trabalhar, não temos capacidade de ter a responsabilidade de um emprego, prefere dar emprego para os mais velhos, que tem coisas para pagar; [que] o adolescente só quer saber de roupa, calçado, shopping, festa.

K: Então, que idéias, imagem, vocês acham que as pessoas na sociedade têm sobre os adolescentes? As pessoas pensam: "o adolescente é...?".

O1: Vândalos.

A2: É, exatamente.

A1: Vagabundo, que não quer fazer nada, só quer vida boa.

A2: Quer tudo na mão.

A1: É, eles pensam isso. A maioria das pessoas.

$K$ : E vândalo assim como?

O1: De quebrar, de brigas.

A2: Pichações.

K: Então quando se fala "adolescente" na cabeça deles vem tudo isso?

A1: Vem, só que eles não pensam nenhum lado positivo, porque tem gente que tem vontade de aprender as coisas, se esforça, mas eles não pensam nisso, só vêem pelo lado ruim, só. A2: A maioria.

K: E vocês acham o quê disso, das pessoas pensarem isso sobre os adolescentes? Vocês acham que é assim mesmo?

A2: Eu acho que não. Porque foi uma fase que eles também passaram.

A1: E nem todos os adolescentes são assim. Não é porque um é, que todos têm que ser.

A2: Não é porque o 01 é, eu tenho que ser, a $A 1$ tem que ser.

(Risadas)

K: O1, o que você ia falar?

O1: Eu acho que é assim mesmo, ué.

K: Você acha que adolescente é vândalo, é.....

01: É, de 100\%, 70 é!

K: $70 \%$ você acha que é? Vocês acham? É isso mesmo, tem que dar a idéia de vocês.

O1: $70 \%$ é.

K: Que idéia vocês fazem dos adolescentes, os outros jovens de hoje? Como vocês acham que eles são?

A2: Eu acho que neste século XXI os adolescentes são muito folgados!

$\mathrm{K}$ : Folgado como, em que sentido?

A2: Folgados. Não pensam em trabalhar, não pensam em fazer nada!

$K:$ E por que eles não querem trabalhar?

A2: Porque tem os pais.

K: Que sustentam....?

(O2 chegou e retomamos com ele a discussão, contando sobre o que havíamos conversado)

$\mathrm{K}: 02$, e pra você, ser adolescente é...?

02: Uma droga!

K: Por que uma droga, o que tem de ruim?

O2: Sinceramente, depende. Ser adolescente pro O1, por exemplo, deve ser uma coisa boa, pra mim não.

K: Por que não é uma coisa boa para você?

O2: Só tomo fora, sou feio, magro.

(Risadas)

O1: É a lei de Deus!!! 
O2: $E$ isso nunca vai mudar. Ou pelo menos pode mudar depois que passar a adolescência, posso encorpar.

(Risadas)

K: $O$ que pode mudar depois da adolescência, ser diferente?

O2: Ter minha vida própria.

K: Como assim, dá um exemplo.

02: Casar, ter meus filhos, conforto, ter a minha casa.

O1: Acho que entendi o ponto que ele quis botar. Ele quis botar que ele passando da adolescencia, se depender dele mesmo [ele não vai precisar do dinheiro pra ninguém, entendeu ? Vai pegar o dinheiro dele, comprar as coisas dele com dinheiro dele].

$\mathrm{K}: \dot{E}$ isso O2?

O2: $\dot{E}$

K: Você tava falando que é uma droga ser adolescente. Sobre esta coisa de ficar se achando feio, você acha que acontece com outros adolescentes, de olhar "Ai Meu Deus, isto aqui está crescendo mais do que isto, isto tá desengonçado, como eu sou feio?"

O2: É porque eu sou estranho. Eu sou diferente dos outros adolescentes.

K: Você acha que você é diferente dos outros em que?

O2: Fazendo uma comparação com o 01, mesmo. Não sei se o cara se acha feio ou não...

O1: Eu acho.

O2: Se se acha forte ou não...

K: Você acha que você é único adolescente que se olha no espelho e reclama de como você é?

O2: Provavelmente.

$\mathrm{K}: \mathrm{O}$ que vocês acham disso?

A1: Eu acho que não. Tem muitos adolescentes que é desse jeito também, que se acha feio, não vive a vida.

O2: Já tentei viver a vida e levei 48 foras!

$K: E$ o que foi esta tentativa de viver a vida? O que é tentar viver a vida?

O2: Eu ia pelo menos três vezes por semana na balada, tentei viver a vida.

A1: Mas também viver a vida não é só ficar saindo, tem muita coisa para fazer que você pode viver sua vida.

$\mathrm{K}$ : Além de sair, por exemplo?

A2: Trabalhar.

O1: E você também não pode se achar bonito se comparando com os outros.

A1: É mesmo.

A2: Você tem que gostar de você mesmo.

O1: Se nem você se ama, quem vai te amar?

O2: Minha mãe!

A2: Tirando ela.

$K$ : E o que mais tem de ruim na adolescência?

O2: Não tem muito tempo disponível.

K: O seu tempo fica em função do quê?

O2: Estudo de manhã, faço lição mais tarde, e de noite, se eu não vou na igreja, aí eu fico em casa fazendo exercício.

(Barulho)

$\mathrm{K}$ : Mas e vocês, juntando com $\mathrm{O2}$, o que acham que tem de ruim na adolescência? 
O1: Quando você quer sair, assim, tem que depender do seu pai, da resposta que ele der. Isso é ruim... e dinheiro também.

O2: Eterno prisioneiro.

A2: A minha mãe que fala "Enquanto você estiver na minha casa você vai fazer o que eu mandar".

A1: Isso ai é horrível!

A2: Aí elas falam "Quando você tiver seus 18, 20 anos, arruma seu emprego, compra sua casa e vai viver sua vida"!

A1: E muitas vezes as pessoas não ouve nossa opinião.

$\mathrm{K}$ : Como assim? Fala um pouquinho mais sobre isso.

A1: Eu não sei te explicar. Por exemplo, você quer a opinião de uma coisa, aí você começa a falar lá, aí ninguém quer saber, porque você é adolescente, sabe? Não ouve o que você tem pra dizer. Aí se vai outra pessoa adulta, eles ouvem! Aí é ruim também!

$\mathrm{K}$ : Se a pessoa adulta fala a mesma coisa que o adolescente, o adulto é ouvido e o adolescente não? Vocês concordam, vocês acham que isso acontece?

A2: O mais velho fala a mesma coisa que você falou, só que em outras palavras, aí: "Ai, é isso mesmo! E não sei o quê!".

O2: Ou repete nas mesmas palavras!

A2: É. Aí eles acham "Você é adolescente não sabe nada da vida, quer dar palpite, por que?"; "Nunca passou por [sacrifício na vida] nenhum".

$\mathrm{K}$ : Por que vocês acham que isto acontece? $O$ que passa na cabeça das pessoas quando não estão nem aí para o que o adolescente fala ou faz?

A2: Acho que porque eles também nunca foram ouvidos.

O2: [Acham que o adolescente é] inexperiente.

A1: De vez em quando o adolescente tem mais experiência que algumas pessoas, tem muito mais experiência... não que já passou, só de ver o que tá acontecendo.

A2: Na família mesmo.

A1 e O1: É.

O1: [Mas tem hora que tratam o adolescente como criança], só pode sair até meia noite!

A1: É, daí dá raiva!

K: Pois é. Algumas horas vocês são crianças, e outras horas vocês não são crianças. Pra

algumas coisas vocês são crianças, para outras não. Então, pra que coisas vocês são crianças?

Juntos: Sair!

O1: Ter muito dinheiro na mão.

K: Não pode ter muito dinheiro na mão porque não vai ter responsabilidade pra usar?

O1: É.

A2: Não pode trabalhar.

O2: [Dizem que o adolescente não pode ter dinheiro porque não vai saber] gastar. Lógico que vai saber.

A1: Eu também sei.

$K:$ e em que casos vocês não são crianças?

O1: No dia das crianças! Não ganhei nada!

A1: Pra fazer as coisas [obrigações]. Na hora de fazer alguma coisa, ninguém é criança, mas na hora de sair todo mundo é criança!

$K:$ E o que vocês acham disso?

O2: Injustiça! 
K: Por quê?

O2: Porque é, ué!

O1: Ou é criança ou não é criança!

A1: A gente também tem direito de viver nossa vida, igual eles vivem a da deles.

A2: Minha mãe nunca me conta nada quando ela era adolescente, essas coisas, mas de vez em quando ela deixa escapar "Quando eu namorava Fulano de Tal, aí ele chegava aqui na esquina, fui ficar com o outro ali" e eu "Ah mãe, a senhora fez, mas não deixa eu fazer!" O1: Meu pai que fala "Faça o que eu digo, não faça o que eu faço".

K: Hum... eles falam isso?

O1: Falam.

K: E que idéia, que imagem vocês acham que os pais de vocês têm sobre vocês? Acham que vocês são o que?

O2: Irresponsável.

O1: Minha mãe fuma e não quer que eu fume. Meu pai bebe e não quer que eu beba. E quem são eles para querer me dar exemplo se eles fazem?

A2: Eu acho que a minha mãe deve ter orgulho de mim. Não tenho muita amizade, sou muito caseira... [mas eu não gosto de ser assim]. Eu gosto de sair, mas só que ela que não deixa. K: Ela não deixa. Então tem como se fosse um jeito ideal, um adolescente ideal, perfeito? Como é que seria este adolescente perfeito?

02: Não sai, fica trancado no quarto, lê o dia inteiro.

A1: É, lê... só fica estudando.

K: Só estuda?

A1: É.

O2: O pai acorda, a casa tá limpa..., fica no quarto...

A2: [Leva o] cafezinho na mesa.

O2: Cafezinho na mesa? Então, eu sou um exemplo!

O1: Eu também, antes de ir para a escola, eu que faço.

O2: Mas eu faço para minha família. Eu acordo mais cedo.

K: Vocês estavam falando dos pais de vocês, que idéia os pais tem sobre vocês e aí o 02 começou falar "irresponsável". O que mais?

A2: Eu nunca saio de casa, é difícil. Eu queria vir aqui no (?), e ela: "Ai minha filhinha, você nunca saiu de casa, por que vai sair agora?". Eu nunca vou crescer para ela. Eu nunca vou ter idade suficiente para poder sair para uma balada...

A1: Minha mãe não é assim. Ela deixa eu sair, ela fala para mim tomar cuidado, de vez em quando ela até sai comigo. Desde pequena minha mãe conversou muito comigo sobre esses negócio.

K: Que negócios?

A1: De adolescência assim. Ela já passou, ela me fala. Ela não fica escondendo. Ela fala tudo para mim. Chega em mim e conversa. Ela é bem minha amiga.

$K$ : E você ia falar alguma coisa, O2?

O2: Minha mãe conversa comigo, tudo mais, mas ela já chegou a me dizer que preferia que eu não tivesse nascido.

(Barulho. Risadas)

K: E por que ela preferia que você não tivesse nascido?

O2: Numa briga que nós tivemos. Foi quando ela descobriu que eu saía de noite.

K: $O$ que aconteceu, ela descobriu...

O2: Ah, "Eu preferia que você não tivesse nascido se for para ser do jeito que você é". 
K: E o que você achou disso?

O2: Já perdoei.

K: Já perdoou?

O2: Já.

K: E eu queria perguntar... a gente tava falando aqui o que tem de ruim na adolescência.

Adolescência é só coisa ruim?

Juntos: Não!

K: Então também tem coisa boa? Então agora a gente vai falar sobre este outro lado da adolescência. O que tem de bom na adolescência?

O2: As garotas.

A1: Festas, assim... que tem muitas festas que são muito legais.

A2: Amigos.

O1: Loucura.

$\mathrm{K}$ : As loucuras, que loucuras?

O1: Ué, sei lá!

(Falam ao mesmo tempo)

A2: Fazer as coisas escondido.

A1: Ficar numa rodinha com seus amigos, conversando, zoando. É legal!

A2: Falar mal da mãe.

A2: Meu irmão fala que a gente só fala besteira.

$\mathrm{K}$ : Ele é mais velho?

A2: Tem 23 anos. Eu falo "Olha quem tá falando". Já foi adolescente. Todo mundo já foi adolescente um dia. Não tem que sair criticando a gente.

$K$ : Então, quem já foi adolescente critica quem é agora?

A1/A2: É.

K: Vocês estavam falando, vamos voltar um pouquinho na história dos pais. Os pais de vocês já foram adolescentes. Vocês acham que têm diferença da geração de vocês hoje, dos jovens de hoje e dos jovens da época dos pais de vocês?

(Falam juntos)

O2: Meu pai quando era adolescente ele pescava...

O1: É! Ó as idéia!

O2: [Jogava] pedrinha no rio.

O1: Catava cobra. - O2: Catava porco.

O1: É.

A1: A violência também [era diferente]. E a minha mãe fala que o namoro, essas coisas, [também]; que hoje tá muito avançado.

O1: Só depois de casar beijava!

A2: "Quando eu namorava com seu pai, era eu aqui, ele na esquina jogando pedrinha. Hoje não. Hoje já querem sair se agarrando"!

O1: E também a educação que eles tiveram antigamente foi muito rígida, né? Não tinha essa liberdade que a gente tem hoje.

$\mathrm{K}: \mathrm{O}$ que mais tem de diferença entre a geração de jovens dos pais de vocês e dos de hoje? A1: A maioria das meninas, não são todas, mas a maioria, são muito assanhadas, muito mesmo. Ela fica com o garoto e já fala (?)...

A2: Ah, tem uma coisa que eu acho errado também. Por exemplo, os menino, fica com um aqui, aí fica outra lá e outra lá, aí tá a turminha de amigos dele. Aí passa as menina. Aí os 
meninos fica zoando "Maior catador, catou aquela, maior garanhão". Aí se a menina faz, fica "galinha, vagabunda, não presta".

A1: É. $_{\text {. }}$

A2: É diferente [isso], entre os adolescentes mesmo.

K: Então quer dizer que existe diferença entre os meninos e as meninas na adolescência?

O1: Quanto mais, melhor.

A2: Pros homens.

O2: Eu não penso do jeito que o 01 pensa. Eu não fico, eu namoro. Eu não sei, se eu tiver uma namorada, eu namoro sério, até que a menina me dê um pé na bunda.

A2: Até casar. Eu já namorei, dá muita dor de cabeça.

O1: Eu não quero casar não.

A1: Também não. Não penso nada em casamento.

A2: Quero ter meu emprego, morar em uma casa e meu marido na outra.

O1: Quero morar em um apartamento sozinho.

O2: Eu [não] aguento morar sozinho. Eu posso morar pelo menos com crianças, porque eu gosto de criança. Por isso eu quero ter meus filhos.

O1: Eu quero morar sozinho para levar quem eu quiser para o apartamento.

A1: Eu também, por causa que muitas vezes quando você quer sair, seu namorado ou marido, né, se você casar, não deixa, e aí você tem que ficar presa, fazendo as coisas para ele, não é certo.

A2: Já viveu sua adolescência, sua vida obedecendo alguém, sua mãe, seu pai, aí o namorado, marido, pra continuar obedecendo...

O2: Isso varia do namorado. Por exemplo, se minha namorada me ama, que ela vai buscar com outro?

O1: Só busca quem não está satisfeita. Tem aquele ditado que diz que "arroz e feijão todo dia, enjoa".

K: A gente tava falando antes uma coisa assim: uma coisa sou eu, e outra coisa são os outros. A gente estava falando no começo "Eu, adolescente, sou uma pessoa responsável, estudo, tal". Os outros adolescentes como é que são? Aí vocês estavam discutindo. Você tava dizendo que a maioria você acha que são mesmo vândalos. Vocês acham que a maioria dos jovens, sem ser vocês...

O1: Eu me salvo.

A1: São poucos.

K: São poucos que se salvam? Por que? O que acontece?

A1: Porque, tipo assim, quando eles saem, eles não saem pra se divertir, eles saem pra ficar arranjando briga com as pessoas. A maioria é assim. Olha pra você e "Que que foi, que que foi?", já começa uma briga.

O2: Os que não são, deixa eu ver bem a palavra, 'vândalos', são, como eu posso dizer, 'putos'.

$\mathrm{K}$ : Como assim?

O2: Um fica agarrado o outro, pulando em cima do outro, fica encochando o outro. Isso enche né?

A1: É.

K: Então só tem isso ou vândalo, não tem mais outra coisa?

O2: Tem sim. Tem boas pessoas.

$\mathrm{K}$ : Como é que são estes bons adolescentes?

O1: Dedicado, obediente. 
K: Aí a gente vai entrar numa diferença. Uma coisa é o adolescente ideal e a outra é um bom adolescente. Existe diferença? A gente tava falando antes do ideal, aquele que não faz nada, que...

O2: $O$ ideal é o prefeito e o bom adolescente não chega a ser perfeito.

A1: É aquele que também gosta de viver a vida dele.

K: Vocês estavam comentando quando tavam falando do adolescente ideal que ia ser um saco ser este adolescente ideal. Você tava falando "Eu não queria ser assim". E este bom adolescente?

Juntos: Eu sou um bom adolescente.

K: Por que vocês são uns bons adolescentes?

O1: Ué...

A2: Porque eu ajudo minha mãe...

O1: Eu também.

A2: Trabalho, estudo.

O1: Eu também.

A1: Converso com a minha mãe.

O2: Eu acho que, sei lá, eu pelo menos não dou tanto trabalho para minha mãe, porque, tá certo que eu não tô mais conversando muito com ela, porque ela geralmente conversa mais com a minha irmã. Eu fico o dia inteiro jogado no quarto lá fora, assisto tv e faço exercício, quando eu volto do Senai.

$K$ : E você O1, você tava falando...

O1: Eu também não dou trabalho pros meus pais.

K: Não dá trabalho?

O1: Um pouquinho dá, né?

O2: [Sou] um bom menino.

K: Eu queria perguntar uma última coisa sobre a adolescência mesmo: vocês acham que tem característica que é só do adolescente? Tem coisa que só o adolescente é, ou não?

A1: Eu acho que não.

K: Não tem característica típica, o adolescente é aquele que faz isso, que o adulto não faz, e a criança não faz?

A1: Tem alguns adultos também que faz as mesmas coisas que nós fazemo. Por exemplo, colocar piercing, tatuagem, tem gente mais velha que põe. Tem gente mais velha que gosta de balada. Então.....

K: Não tem uma coisa que é só da adolescência?

(Concordam que não há uma característica típica)

K: Agora eu queria perguntar uma outra coisa: como é pra vocês ser um aluno adolescente?

A1: É chato!

O1: É da hora!

A2: (...) Você tá na escola, tá pensando "Meu namorado ali e eu aqui estudando"...

O2: Depende da situação.

(Falam juntos)

O1: É bem legal! Aqui [na escola] você faz seus amigos... Brinca pra caramba.

A2: Zoa os professores.

O2: $E$ também depende do aluno. Um aluno "cdf", por exemplo, um bom aluno, pra ele a escola é um saco, ele fica copiando lição durante seis horas, não olha para o lado, mas copia a lição. Já para alunos mais...

O1: ...Despojados... 
O2: ...Pra eles o dia passa rápido, porque eles fica... fica só fazendo "vandalisse".

O1: Pra mim não.

A1: Fica conversando.

O2: Conversa, joga cadeira.

A2: Eu converso assim, mas...

O1: Não somo mutante pra ficar parado!

O2: Mutante não, robô!

A2: Mas tem professores que entra na sala de aula, não quer saber de dar aula.

A1: Quando [o aluno] começa zoar, e começa chutar, aí fala "Aí, se você não parar vou colocar lição na lousa".

02: O Pr2 é o pior!

01: Coitado!

O2: Ele passa lição...

A1: Ele não ensina.

O2: Todo mundo joga bolinha de papel na cabeça dele, chuta ele, abre a camisa dele e ele não faz nada!

A2: Ele passa lição e deixa lá e não explica direito.

A1: E explica rapidão. Se a sala tá bagunçando, ele não quer nem saber. Na minha sala é assim.

O1: [Eu desconfio] que ele tem problemas mentais. Ele já teve três pontes de safena no peito, ele não bate bem.

$\mathrm{K}$ : Mas isso que vocês estavam falando: se a sala percebe que o professor não tá dando bola, que ele continua fazendo, o que acontece na sala?

O2: Alguns copiam a lição.

A1: Mas é poucos na minha sala.

O2: Um ou dois.

A2: Acho que o professor fala assim "Tô aqui pra ensinar, aprende quem quer, vou fazer minha parte".

$K: O$ que vocês acham disso?

$O$ ?: Tem gente que não pensa assim.

A2: Ele tá na razão dele. [Não tem que ficar se matando pra ganhar mixaria, pra ficar ensinando um monte de burro e ainda ficar levando nome, nome feio.]

O2: Tem gente que não pensa assim, que pensa "Eu já consegui ser professor, agora eu fico sentado, vou ganhar meu dinheiro do mesmo jeito".

A1: É mesmo, muitos professores falam isso na sala.

$K: A 1$, você tava falando que é chato ser um aluno adolescente. Por que?

A1: Porque eles cobram muito da gente, muito, muito, muito!

K: Cobram muito?

A1: Na minha sala sim.

A2: Tem professores que faltam com respeito também. Pensam assim "Porque é

adolescente, vou falar mesmo". Se fosse pessoa mais velha que tivesse ali sentado, duvido que falasse!

A1: É verdade!

K: Isso que eu queria saber de vocês. Que imagem vocês acham que os professores têm de vocês, alunos adolescentes?

A1: Acho que eles pensam que nós somo tudo uma merda!

O2: Se pudesse jogaria todos nós no inferno! 
K: Por que?

A1: Por causa que a maioria fica faltando com respeito com os professores. Alguns, nem todos.

K: Por isso esses professores acham que os adolescentes são "uma merda"?

A1: Tipo assim, passa prova, aí todo mundo tira nota ruim... conta muito isso.

O1: Eu acho que nóis também não é santo, não!

K: Por que não é santo?

O2: Tem muita gente aqui que faz muita bagunça.

(Falam juntos)

$\mathrm{K}$ : Antes de continuar, $\mathrm{O} 2$ você estava dizendo que acha que eles queriam "mandar tudo pro inferno". Por que vocês acham isso?

O2: Por que eles ao invés de ver a nossa imagem, de cada um, eles vêem a imagem de todos. Se todos são ruim, nós tamos no meio.

K: Generaliza, acha que todo mundo é uma coisa só? E essa coisa só é o que? É tudo ruim, é tudo o quê?

O1: Não. Se tipo, entre nós quatro, um é bom e três é ruim...

A1: $O$ outro que é bom vai ser [visto como] ruim também.

O2: Uma maçã podre estraga as outras; apesar que eu ainda não estou estragado.

O1: Nem eu.

A2: E às vezes tem uma professora que entra na sala de aula, ela não dá aula né, como eu tava falando... E a turminha das meninas, eu fico com as meninas lá da frente, a gente faz a turminha assim, fica uma muvuquinha...

O1: Eu domino atrás. Lá na sala [é assim] "E aí rapaz, quem é o número 1?" "Eu".

A2: Aí a professora fica falando "Putinha aí, fica falando de macho, não sei o que, só quer saber disso e aquilo outro".

K: Acha que porque tá falando de homem é "putinha"?

A2: É. Tem uma menina que ela começou a gritar, do nada, né? Deu a louca nela, ela olhou pra professora, aí a professora olhou assim para ela e falou "Cala a boca sua vagabunda"!

A1: "Tá parecendo cadela no cio" também.

A2: Aí chamou ela de outros nomes feio, lá.

O2: Então quer dizer que homem pode até ver Playboy e mulher não pode falar de homem?

A1: É.

K: Que a gente estava falando; a diferença entre homem e mulher.

O1: Machismo.

$\mathrm{K}$ : Tem machismo aqui na escola?

O2: Eu sou provavelmente o único homem feminista que tem neste mundo.

K: Você é único homem feminista?

O1: Todo lugar no mundo [só] tem machista.

$K$ : E como é o machismo aqui na escola?

O1: Todas meninas que catar mais de um já...

O2: Mulher não pode falar de homem, mas homem pode falar de mulher.

$\mathrm{K}$ : Você tava falando no caso de uma professora que xingou de vagabunda. Existe isso de xingamento, do professor xingar o aluno de alguma coisa?

A1: [Muito]

$\mathrm{K}$ : Existe muito? Mas eles xingam do quê?

A2: Por exemplo, xingou essa menina de vagabunda, depois de puta..., do nada!

A1: Quando fala assim "Tá parecendo cadela no cio", também. É horrível! 
A2: Na minha sala tem dois casais, né? Os professores ficam perguntando se eles já fizeram alguma coisa...

O1: É engraçado o Pr2, ele chama os meninos de veado. "Vá seus veados do mato, seus veados do asfalto".

$\mathrm{K}$ : Tem diferença?

A2: Do mato é de onde ele morava, do asfalto é da cidade grande.

O1: A professora [de " $x$ " matéria] fala pior: "Fica quieto se não vou enfiar (?) no seu cu".

A1: É.

A1: Tem dia que ela fala, assim, para os meninos, quando tão fazendo maior bagunça,

"Parece que os meninos tá tudo menstruado". Nada a ver! Ela é doidona também.

O2: Lógico, nós perturba eles!

A2: [Ela fala muito] palavrão.

A1: E quando algum aluno fala, né..., manda para diretoria.

A2: [? - falou algo sobre 'bater']

$\mathrm{K}$ : Acontece isso, de o aluno também ir lá, bater?

O2: Apesar que isso nunca aconteceu com Pr1.

O1: Ele é o cara! Esse é o professor mais [respeitado]

$\mathrm{K}: \mathrm{E}$ como ele consegue esse respeito?

A2: Ele dá respeito pra gente, não ofende ninguém.

O2: Ele põe ordem na sala.

O1: O Pr1 é o cara!

$\mathrm{K}$ : E ele tem que imagem de vocês adolescentes?

O1: Ah, ele sempre tenta ensinar o melhor.

A1: É, porque ele fala assim: "Quando você for prestar algum concurso, vai cair isso", ele ajuda bastante. Apesar que as aula dele é meio chata, porque ele só fala a aula inteira.

O2: Quando eu fui fazer a prova para entrar no Senai, ele foi quem mais me ajudou. Ele [me indicou os] livros "Usa este livro, este livro, que tem tudo". E ele ainda falou "Nestas provas sempre cai $A B C D$, se você não conseguir, você faz a regra do chute, a que você viu que não tinha nada a ver, as que sobraram você tira no dois ou um".

K: Então, vocês tão falando que ele tem um respeito e ele respeita o adolescente? Pelo que vocês tão falando, parece que ele tá se preocupando com vocês.

?: É, se preocupa.

O2: Dependendo da aula, ele brinca com nós também.

(Falam juntos)

A2: Ele é sério.

A1: Tem alunos também que não dá nem pra brincar.

A2: Na minha sala, acho que é a sala que tem mais vândalos, né? Aí a coisa mais difícil que tem é ele dar um sorriso na minha sala de aula.

K: Mas o que você estava falando é que ele impõe limites, então?

O2: É.

K: Como é que ele impõe esse limite? É gritando?

O1: Não!!

O2: Não, teve um dia que jogaram um lápis nas costas dele, ele mandou metade da sala para diretoria. Ele falou "Deixa eu ver quem eu acho que jogou. Você, você, você". Depois a D

falou "Quem aqui tem mais manha, lábia? Você pode sair, você também pode".

K: Então quer dizer, parece que ele respeita e é respeitado, pelo que vocês estão falando... 
A1: Não, ele não é o mais respeitado. Assim, porque ele tem o hálito ruim, aí fica todo mundo zoando.

O1: Não, não é hálito, ele tem um problema no esôfago. Mas nunca vi ninguém chegar [e dizer na cara dele que ele tem bafo ruim, xingando ele, por exemplo].

A1: Eu já vi.

K: Mas na sala de aula, enquanto ele tá dando aula, acontece isso que vocês tavam falando, de jogar papel..

Juntos: Na aula dele, não!!

O2: Se jogar, acontece a mesma coisa que eu falei, vai metade da sala para a diretoria!

K: Então esse tipo de respeito tem? Vocês tavam falando que tem professor que parece que não ta nem aí, daí os alunos não respeitam, mas ele não. Na sala de aula....

A2: Tem vezes que ele manda todo mundo calar a boca, e se alguém jogar um papel, ele humilha mesmo as pessoas!

O2: Ele tem uma cultura muito grande também. Fala espanhol, latim, francês. Escreve em grego, lê em grego!. Ele tem mó cultura, ele passa uma segurança!

O2: Uma professora que eu acho que põe ordem também é a Pa1. Ela põe ordem, até bate se for o caso!

O1: Ah, ela já deu uma porrada --

(Falam ao mesmo tempo)

A1: Ela brinca bastante.

O1: Ela bate brincando. Não é uma agressão.

A2: Mas quando é pra falar sério, ela [também é] séria.

O2: Eu gosto dessa professora, porque ela faz a gente fazer força, mesmo. Ela é quem faz a gente fazer exercício de verdade. Ela não é aquela professora que pega uma bola e faz assim (gesticula)

A?: [Não só fala] "Faz o que você quiser".

O2: Ela não. Manda a gente fazer abdominal, pra gente ficar com o braço forte.

A1: Ela fala assim, que é pra gente fazer o exercício pra ficar "com a barriguinha bonitinha no verão". Pra gente não passar vergonha.

K: Então, vocês acham que ela tem um cuidado, assim, com vocês?

O2: É. Ela é uma ótima professora!

A1: É mesmo!

A2: Mas no outro dia ninguém consegue andar!

O1: É, isso, é!

O2: É o efeito, você tem que ficar assim por uma semana, mas depois...

(Falam juntos)

K: Eu queria perguntar mais uma coisa. A gente tava falando da visão que os professores têm de vocês. Tem professores que parece que respeitam, tem professores que parece que respeitam menos, que dizem que adolescente é isso, é aquilo, a menina adolescente é chamada de 'vagabunda'... e os meninos? Vocês falaram mais das meninas.

A2: Elas não são loucas de falar nada para os meninos!

A1: Os meninos ameaçam até de matar. Ano passado uma professora, não lembro quem era, foi ameaçada de morte, porque foi falar lá de um menino.

K: Então acontece isso dos meninos não serem muito insultados... e vocês acham que os professores têm medo dos meninos adolescentes?

O2: Tem.

$\mathrm{K}$ : Todos professores? 
A1: Não.

O2: Depende do aluno. $O$ aluno, por exemplo, eu. Ela sabe que eu sou inofensivo, eu não vou matar ela. Na verdade tem muitos professores que têm medo. A Pa2, se você chega nela e fala "Aí, se você não me der dez conto e cinco [notas] "A" no semestre, eu te mato". Ela pega a carteira, te dá cem conto, te dá sete "A"!

K: Então vocês percebem quem são os professores que têm medo, os professores que não têm...

A1: A Pa1 não tem medo não! Nem um pouquinho!

$K$ : $E$ o que vocês acham que a Pa1 pensa de vocês adolescentes, que vocês são o quê?

O1: Máquina!

O1: Em qualquer um, ela chega chegando!

A2: Ela não tem muito diálogo com a gente, ela passa os exercícios e pronto. Conversa um pouco, mas...

$\mathrm{K}$ : Mas, você tava falando que você não gosta muito dela. Por quê?

A2: Não é que eu não gosto dela, são os exercícios que ela passa.

O2: Sai toda doída depois.

A1: Eu gosto dos exercícios dela.

O2: Eu gosto.

O1: Eu também.

A1: Só que tem dia que ela pega muito pesado.

A2: Pega pesado demais!

O2: Eu gosto principalmente quando ela pega pesado, porque, depois mesmo que fique doendo, você fica mais forte. É porque eu não faço só o exercício dela. Faço exercício em casa,também.

K: A gente tá aqui falando da visão dos professores. E a diretora? Vocês acham que ela acha-

O2: É aquela que parece a Marta Suplici ou a outra?

A1: A que parece a Marta Suplici nunca tá aqui.

O2: É, nem aparece!

K: É a D, a que vocês dizem que parece a Marta Suplici. Então, vocês não sabem direito quem é a diretora?

A1: Pensei que é a $C$, lá.

$K: A D$ é diretora e a $C$ é coordenadora.

A1: A diretora nunca tá aqui!

O1: É. Nunca tá aqui!

O2: A D na verdade é meio arrogante!

O1: Eu só vejo ela quando vou para diretoria, só.

O2: Eu também. Ela é meio arrogante.

K: Arrogante, como é que é? Por exemplo, quando vai para diretoria. Só tem contato com a diretora quando vão para diretoria porque são levados pra lá por algum motivo?

A?: Eu nunca [tive contato] com ela.

O2: Ou quando vai pedir giz, alguma coisa... Mas se você chegar na frente dela, ela já fala "Que que você fez agora? Mais uma, você está expulso".

$K:$ Então, ela não ouve--?

A2: [Só faz] mandar.

K: Então não tem muito contato?

O2: Ela pensa que manda mais [aqui na escola]. 
O1: Ela não pensa, ela manda, ué! Fazer o quê?

K: Então quer dizer, às vezes vocês podem chegar na diretoria por qualquer outro motivo, não tem nada a ver com o que fizeram na sala de aula, ela já vai achando que vocês fizeram? A1: Pra mim, não.

O2: Se você falar simplesmente que veio pedir giz, ela fala "Que que você tá fazendo aqui, que que fez desta vez?"!

O1: Ela até me conhece já.

K: De quando você foi na diretoria? Como é a reação dela quando a pessoa vai para diretoria?

O1: Normal ué! Senta e --

O2: [Quando] vai pra diretoria porque brigou ou pra pedir alguma coisa?

K: Porque brigou.

O2: Daí ela não pergunta o motivo.

K: Não?

O2: Não.

K: O que ela faz então?

O2: Ela simplesmente olha assim..., dá advertência para os dois ou suspensão.

A2: [Sem saber o que aconteceu.]

$\mathrm{K}$ : Sem entender o que aconteceu.

O2: Já a C é tão legal!! Ela fala "Por que vocês brigaram?" Daí, se tipo você fala, ["Eu tava quieto no meu canto,] daí ele veio e enfiou o dedo no meu olho". Daí ela vai mandar eu para a sala e dar advertência para ele. E ainda vai falar parabéns para mim!

A2: E ela ainda fala "Por que você fez isso, não faça isso com seu amiguinho"! Tenta fazer a união.

K: Então tá. Qual a diferença entre D e C?

A1: Porque a $C$ sempre tá presente!

O1: Ela é legal!

K: E como é esse jeito dela estar presente? Tão falando que ela entende mais--

A2: Ela está pra ajudar a gente.

A1: O dia que eu tava passando mal e queria ir embora, só que não podia ir sozinha, né, aí ela foi lá, ligou na minha casa, pediu pra minha mãe me buscar, minha mãe veio, aí ela ficou conversando com minha mãe...

O1: Ela ouve a história, e fala pra você consertar. Ela fala "Você vai fazer de novo?" "Não" "Se fizer de novo vocês sabem né?"

A1: Ela ouve!

O2: Ela dá uma segunda chance!

K: Vocês estão falando que ela ouve e dá uma segunda chance. Isso de ouvir é importante, vocês tavam falando--

A1: E dá conselho.

$K$ : Vocês tavam falando antes que "Ai Meus Deus, ninguém ouve o que o adolescente fala" $e$ vocês estão falando aqui de uma pessoa que ouve o que vocês têm a dizer; e parece que isso faz toda a diferença, pelo que vocês tão falando...

O2: Ela é extremamente melhor! É aquela pessoa que se você abraça ela, ela te abraça de volta, você beija ela, ela te beija de volta.

A1: Os meninos brinca com ela, ela brinca também. Quem tinha que ser diretora era ela!

O2: Ela é a diretora ideal!

A1: É. 
K: Como é que é então, uma diretora ideal?

O2: Ela!

A2: Eu acho que se ela fosse a diretora ela seria [toda grossa].

$\mathrm{K}$ : Como assim? O que ia mudar?

A2: Eu acho que quanto mais alto no topo você estiver, mais você vai estar... Tipo a diretora e ela, ela é a vice. A outra é a diretora, né?

$\mathrm{K}$ : Vocês concordam com ela, que quanto mais alto...

O1: É, ué !

A1: Eu acho que depende da pessoa. Eu acho que ela ia continuar a mesma.

O2: Ia mesmo!

$\mathrm{K}$ : Existe diretora boa?

O2: Existe.

A2: Ah, existe. Eu já tive!

K: Então quer dizer que a diretora pode estar lá no topo...

O2: A diretora da minha antiga escola, ela até me dava carona para casa, me emprestava dinheiro, era legal.

$\mathrm{K}$ : E os funcionários aqui? Tem a Fa, que é inspetora...

O2: O Fo2 é legal.

K: Quem é Fo2? Também é inspetor de alunos?

A1: É. A Fa tem um jeito chato. Ela não fala meu nome, já fala brigando!

$K: E$ vocês acham que ela acha o quê sobre o adolescente?

A1: Não sei, porque eu acho que ela também é. Ela tem uma carinha de criança!

O2: Agora o Fo1 é muito legal.

O1: Ele é legal, que ele conhece a escola inteira!

$K: A 2$, o que você ia falar?

A2: Que acho que a Fa tem uns 18 anos.

K: Então ela é adolescente?

A1: É

O2: O Fo1, ele é muuuiiiito legal mesmo, muito louco! A gente passa na rua "O Seu Fo1, tá indo pro bar?", e ele "Não, vou comer um lanche, vou comer um lanche". O cara é legal! O2: A Fa é a única funcionária que não é uma boa funcionária, quer dizer, não é muito legal. Tipo, quando eu fui buscar a caixa de som lá [pra usar lá] embaixo, aí cada vez que encontrava com ela "Vai pra sua sala, vai pra sua sala, vai agora pra sua sala, tchau, some"! A2: Ela fala com arrogância!

sente adolescente!

A1: É.

K: Por que você acha isso?

A2: Porque ela brinca com todo mundo, fala de igual para igual!

O2: Ela volta a ter 15, 14 anos. É legal!

K: Diferente de D?

(Muito barulho externo)

K: Como vocês estavam contando do outro professor que não coloca limite, daí todo mundo aproveita...

O2: Se você não impor respeito, aí ninguém vai te dar respeito. Você vai ser zoado, vai tomar tapa.

A2: Quem quer respeito, tem que dar respeito também.

$K$ : E parece que isso não é assim só aqui na escola... 
O2: Ah, mas [é importante] esse negócio de dar respeito; tem que ter respeito.

A2: Claro que é!

O2: O Pr2, quando ele chegou, ele respeitava todo mundo. Ele chegava "Oi, não vai ter lição hoje"!

O1: É.

O1: Às vezes dá até dó!

A1: É, dá maior dó!

A2: [Mas tem sala que se] aproveita disso.

O2: É, oitava D é a pior sala. O Pr2 quase sempre chora.

O1: Ah não é. A oitava $A$ é pior.

O2: O Pr2 chega [e parece até que quer] chorar.

A1: Dá maior dó.

$K$ : Então vocês tavam falando que a oitava $D$ é a pior, qual que é a pior?

O1: Não, não é. Na oitava $D$ quem faz zoeira é só o $X 1$ e o X2. Na minha sala é o X3...

O2: É só? X4, X5, X6, X7 ... [fala o nome de vários alunos], o X8, não, porque é aluno novo. $E$ todos, todos, todos. $X 9$ não zoa, mas só que é zoado.

K: Mas vocês acham que existe entre os professores essa idéia de qual é a pior oitava série?

O2/A2: Existe.

O1: A nossa é a mais melhor.

A2: $A$ oitava $D$ sempre foi a pior. Agora a oitava $D$ tá em primeiro, a $C$ em segundo...

A2: [Eu acho que] é a $B$.

K: E a oitava A?

O1: É só de repetente.

A2: Ninguém fala da $A$.

A1: (?) vai ficar igual eles, repetindo.

O2: A oitava $A$ é uma boa sala, porque eles repetiram, então eles já têm o exemplo, não querem repetir de novo.

K: Você acha?

A2: Alguns, acho que vão repetir tudo de novo.

A1: Também acho.

A2: Eles não conseguem aprender, não porque eles não querem, porque, tipo [se já passou de ano, mesmo...]

O1: [Acho que é porque] não tem QI alto.

K: Você diz que acha que eles não aprendem porque eles pensam "Pra que aprender?" e você tá dizendo que é porque não tem $Q I$ alto. O que vocês acham?

O2: [Acho que eles] têm capacidade.

A1: Também acho.

O2: O mesmo tanto de capacidade que todo mundo tem. Mas simplesmente não usa seu potencial.

K: $O$ que vocês acham, não só na oitava $A$, mas em qualquer oitava, quando o aluno não aprende, o que acontece pra que isso aconteça?

O2: Ele não presta atenção.

A1: Falta de interesse.

O2: Ele não quer.

A2: Eu acho que é também a companhia que fica ao redor. 
O2: Ah, mas só que tem gente que tem coordenação motora suficiente pra escrever $e$ conversar ao mesmo tempo.

A2: Que adianta você escrever -

O2: [Tem que chegar em casa e estudar]. Eu chego em casa, eu leio o que eu fiz.

A1: Eu não.

K: Vocês falaram de três coisas: falta de interesse, falta de vontade, que é a mesma coisa ou ficar conversando com outras pessoas ou falta de QI, capacidade.

O2: Capacidade todos têm.

K: Algum de vocês já chegou a repetir o ano?

A2: Eu já. Onde eu estudava, no $E$, os professores davam prova, mas pra ficar livre logo de você, se você tirasse nota baixa, ele metia logo um 10. Aí eu burra pensei "Não aprendi nada". Daí tinha uma última prova, um provão, eu faltei e aí eu repeti, pra recuperar.

$\mathrm{K}$ : Por que você acha que foi burrice?

A2: Porque eles ensinam sempre a mesma coisa!

O2: Aluno que quer, aprende!

K: E depende só do aluno?

O2: Do professor também. Se o professor for bom, tipo o $\operatorname{Pr1}$, tem gente que não aprende nada na aula dele; fica quieto, mas também não faz lição. Quem quer aprender na aula dele, vai aprender com certeza!

A1: É mesmo!

K: Vocês acham que depende um tanto do professor, um tanto do aluno? É isso?

O2: É, mas já com o Pr2, mesmo quem quiser aprender, não vai aprender nada!

A1: É mesmo, porque ele não sabe explicar.

O1: Falaram que ele é ex-policial, quis virar professor agora. Não tem nem --

O2: Eu acho que ele é samurai, porque ele tem um corte aqui na barriga.

O1: É ponte de safena.

A1: Ele passa umas coisas que não tem nada a ver.

A2: O professor $\operatorname{Pr1}$, ele é assim: quanto mais você souber, mais ele quer que você saiba.

Porque assim, na aula dele eu tirei uma nota vermelha. Aí ele olha pra mim "A2, você tá ruim hem, vai, se esforça, não fica atrás". Quanto mais ele puxar de você, melhor.

$K$ : Essa idéia do que acontece que o aluno não aprende. A pergunta não é nem por que o

aluno não aprende, mas: o que acontece para que não tenha aprendizagem, ou pra que tenha repetência?

O2: Depende.

A2: Preguiça de vir pra escola.

O2: Às vezes o aluno não aprende porque não quer, às vezes porque o professor não ensina.

$\mathrm{K}: \mathrm{O}$ que mais?

(Silêncio)

K: Vocês acreditam que a pessoa nasce com uma inteligência e então tem gente que nasce com inteligência, tem gente que nasce burra?

A1/A2: Não.

O2: Não. Na verdade, eu tenho a mesma inteligência que ela, que ele...

A1: Só que tem que saber usar.

O2: Tem que saber usar.

A2: Mas tem muita criança que nasce superdotado né, sabendo o nome dos países, tudo.

Coisa que [eu, por exemplo, teria que] ralar se eu quiser aprender.

O1: Mas tem gente também que nasce com retardamento mental. 
K: Mas o que é saber usar a inteligência?

O2: Saber usar é tipo, você [tá vindo pra] aula. Você não vai ser idiota o suficiente para não aprender. Você não vai ser idiota o suficiente pra acordar cedo, sair da sua cama, vir pra escola, agüentar aquele bafo horrível do professor e...... não fazer nada?!

A1: Eu concordo. Melhor ficar em casa.

A2: E outra coisa também sobre usar a inteligência. [Por exemplo] o professor fez uma pergunta, aí perguntou pra mim e eu, pra não forçar muito a cabeça, falei que não sabia. Quando eu cheguei em casa [pensei] "Eu sabia, porque eu não pensei um pouquinho pra responder?"

A1: De vez em quando também é medo de arriscar, responder errado.

K: E esse medo? Vocês acham que existe na sala um medo de falar uma bobagem?

(Falam juntos)

A2: Vergonha.

A1: Assim, quando eu fico pensando comigo, eu vejo que tava certa, mas não gosto de falar.

O2: Qualquer pergunta que o professor faz pra sala inteira responder, eu respondo

baixinho, mas só que depois os que ouve, fala o que eu falei, se aproveita da minha resposta. A2: É

K: Mas, e se uma pessoa vai e responde uma coisa errada, o que acontece na sala de aula?

O2: Todo mundo zoa ele.

A1: É mesmo.

O1: Eu não tô nem aí...

K: Mas existe muito aqui nesta escola, isto de dizer "Olha, aqueles ali são repetentes, são burros". Existe isso de burrice aqui?

O2: O professor [falou pro pai] "Olha, seu filho, não vou falar que ele é burro, mas não é inteligente".

K: Já ouviram isso de outros professores também?

A1: Eu já ouvi.

A2: Eu nunca ouvi.

O2: O Pr1 faz a mesma coisa: "Ele não é burro, mas também não é inteligente. Mas se ele quiser aprender alguma coisinha, pode aprender, mas isso não significa que ele é inteligente". Ou seja, chamou o cara de burro, indiretamente.

$K:$ E essa ameaça aí de que se vocês não estudarem viram como os repetentes da oitava $A$, como é isso?

O2: Eu não tenho medo.

A1: Eu também não.

O2: Minha maior preocupação não é isso. Minha maior preocupação é repetir de ano, daí eu vou ter que sair do Senai. Se for pra ficar na escola, posso ficar até os 50 anos na escola. A1: Minha maior preocupação é, tipo, [quando] eu passar de ano, porque isso aqui é muito abaixo do nível, eu tenho medo de chegar lá depois e não saber nada. Ano que vem vou pra outra escola. Mas eu não vou estudar aqui não, tá muito ruim.

$K$ : Vocês acham que o ensino daqui está muito ruim?

A1: Eu acho, mas não é os professores que faz a escola, é os aluno.

O2: Apesar que na escola inteira eu só acho que tem dois bons professores que é a Pal e o Pr1. E a Pal ainda é de (" $x$ " matéria). Se ela fosse de matemática, eu já teria aprendido! $K$ : Vocês tavam falando que quem faz a escola, o ensino, é o aluno, mas agora vocês estavam falando esta história de que o professor também conta. E a direção, coordenação, não conta? 
O1: (falou algo do tipo que a diretora nem aparece na escola)

O2: Depende da diretora. Tipo um aluno que briga, vai pra diretoria uma vez, aí de novo, de novo, mil vezes. Aí "Se você for mais uma vez pra diretoria, você vai ser expulso" e ele "Se eu for expulso, eu nunca mais vou poder sair de casa, minha mãe vai me odiar".

A1: Mas tem alguns que não pensa assim não.

A2: Antes de ser expulso não tão nem aí.

O2: Pior que eu não posso dar o mínimo trabalho pra minha mãe. Qualquer coisa que ela manda, eu sou obrigado a fazer. Não tem outra alternativa, porque se não, ela vai ter uns problemas [de saúde]. Ela já teve [um problema]. Daí se ela irritar muito, eu tenho medo do que pode acontecer.

K: Agora eu quero perguntar uma outra coisa. Vocês tavam falando da imagem que os professores fazem de vocês alunos.

O2: Péssima imagem!

K: Por que péssima imagem?

O2: Porque eles tão sentados aqui e o $O 1$ ali; e o $O 1$ levanta e joga uma cadeira. $O$ professor vai olhar "Esses alunos! Esses alunos... meu Deus do céu, são vagabundos"!

K: "Estes alunos são vagabundos". Vocês acham que o fato de vocês serem adolescentes influencia nesta imagem que eles têm do aluno?

A1: Eu acho que sim.

O2: Sim.

A2: Eu acho que sim, que nem ele falou, ele tá quieto, ele joga a cadeira. Aí acho que o professor associa "Um faz, todos fazem".

A1: É.

K: Mas isso ai é por que é aluno... é adolescente... ou é aluno adolescente?

O2: É tudo.

A1: É porque é adolescente.

O2: Se fosse um adulto, por exemplo, de 30 anos que pegasse uma cadeira e jogasse, 0 professor ia dar risada.

A1: Ou se fosse uma criança. Eles iam conversar com a criança.

O2: Iam falar "Você é um menino mau".

A1: É.

$\mathrm{K}$ : Junta o que eles acham sobre adolescente, aquelas coisas ruins que a gente tava falando de vândalos, e junta o que acha dos alunos e fica esta mistura de coisas: "Aí é porque é adolescente, que faz isso"--

O2: Fica aquela péssima imagem.

A2: Tem professores que falam que aluno adolescente é revoltado.

$K: O$ que vocês acham disso?

O2: Existe adolescente revoltado.

A2: Não é só o adolescente revoltado. Tem muita gente que é revoltado com a vida, revoltado com alguma coisa, não é só o adolescente.

O2: [É, mesmo] Por que você acha que têm pessoas que matam?

A2: É.

K: Então não é uma coisa que é só da adolescência? Porque existe uma coisa que é assim: porque é adolescente é revoltado. Vocês acham que existe associação?

A1: Não.

O2: Mas na verdade existe mais adolescentes revoltados que adultos. Adulto revoltado tem sua própria vida. Ele é revoltado, sei lá, ele deve ter suas questões. $O$ adolescente, ele vai 
ser revoltado porque alguns pais não gostam dele, por causa dos professores, porque só tira nota ruim, só toma fora...

A1: Por causa que os amigos ficam zoando.

A2: Você é revoltado, O2?

O2: Um pouco.

K: A questão toda é achar assim, por exemplo: "Porque é adolescente então é...", aí vem um pacote de coisas. Então é isso que a gente tá questionando. Será? Eu tinha perguntado se vocês acham que têm características só do adolescente e vocês tão falando que não. Existe uma coisa que pode ser revolta em relação ao mundo, que criança, adolescente, adulto pode ter. Não é porque é adolescente que é revoltado... É isso que vocês tão dizendo?

Juntos: É.

K: Tem mais alguma coisa que vocês queriam falar sobre a experiência de ser adolescente? A1: Ah, eu acho ótimo!

K: Vocês tavam falando sobre o que têm de ruim; e sobre o que têm de bom, vocês falaram "Sair à noite, conhecer gente nova, novas experiências". O2, o que você acha que tem de novas experiências na adolescência?

O1: Sexo.

A1: Eu ia falar isso.

O2: É que eu não achei a palavra adequada.

$K: E$ 'sexo' não é adequado?

A1: Melhor que falar outra coisa.

O2: Mas não é fazer sexo, é imaginar sexo.

A2: Se eu falar [essas coisas], minha mãe me mata!

O2: Porque creio que ambos os homens aqui já teve aquela fase de se trancar no banheiro $e$ ficar lá 2, 3 horas.

O1: Vixi! 3 horas é bastante!

K: Mas e essa coisa que você tá falando "Minha mãe me mata se eu falar sobre essas coisas"? Então ainda existe hoje? Vocês tavam falando da diferença dos pais de vocês quando eram jovens, que não podia nada e aí hoje é tudo liberado, só que ao mesmo tempo-A2: Alguns pais prendem. Minha mãe nunca conversou comigo sobre isso. Graças a Deus que eu tenho uma irmã.

O2: Meu pai, por exemplo, pergunta. "O2, você tá fumando O2?" Se eu falasse que sim, ele não ia falar nada. Ele fala "Você já bebeu, O2?" "Você sabe pai, bebo champagne todo Ano Novo" e ele "Já caiu de bêbado, O2?" e eu "Uma vez". Isso aconteceu comigo duas vezes, mas eu só contei uma. Ele pergunta, mas ele não cobra. Ele fala o que é melhor pra mim, mas ele não cobra nada. "Se você quiser ir numa balada, se você quiser transar, à vontade, mas depois acerta as contas com Deus".

A1: Mas fala assim--

A2: ...Porque ele é um homem.

A1: Isso que eu ia falar agora. Pra mulher eles não falam nada disso.

A2: Muito pelo contrário.

$\mathrm{K}$ : Como é que é?

A2: A preocupação da mãe é a barriga.

K: É a barriga a preocupação da mãe? Que mais?

A1: Eu acho que não é legal você engravidar cedo, por causa que você perde a sua vida, vai ter que ficar criando uma criança. Eu acho que não é legal.

$\mathrm{K}$ : Mas é só por causa da barriga que pra mulher é diferente? 
A1: Pode ficar [falada]. Porque tipo assim, falam né - eu não sei - que quando você começa a fazer..., você não consegue mais parar. Pode ficar com, tipo,

O2: A honra [pode ficar suja]

O1: [Tem a] DST.

$K$ : Agora assim, mulher e homem podem pegar DST, mas existe aí uma outra diferença que a gente tá falando: por que pro homem que também pode pegar a doença, é permitido ter relação sexual, sem que ele fique com uma fama ruim...?

O2: O meu pai todo dia chega e pergunta "O2, você ainda é virgem, você ainda é virgem?"

K: Tem essa preocupação, então?

O2: Ele fala com aquele sorriso querendo ouvir um "Não". Quando minha irmã está com o namorado dela, meu pai sobe no quartinho que tem lá em cima e fica olhando assim por um buraquinho, olhando os dois, qualquer coisa assim, que tenta descer a mão, aí meu pai desce "Vai embora, cachorro".

K: Aquilo que o 02 tá falando tem tudo a ver com o que a gente tava falando de diferença de homem e mulher. $O$ homem tem toda essa cobrança da sociedade "O homem virgem não pode, com tantos anos já tem que ter tido relação sexual e a mulher não, tem ficar virgem". $O$ que vocês acham disso?

O2: Virgem até o resto da vida.

A?: Guardar pra terra.

A2: Tem homem que não é virgem, não é nada, e a menina gosta do cara, se entrega pra ele, e aí o cara tá numa rodinha e a menina passa "Era cabaça, era virgem, tirei, não vale mais nada. É uma vagabunda agora". Eu já ouvi.

$\mathrm{K}:$ O1, concorda?

O1: Eu acho que é mais certo o homem ter mais liberdade do que a mulher.

A1/O2: Eu não acho.

O1: Eu acho que a mulher é diferente. Sei lá, é mais sensível.

O2: É mais pura.

O1: Se ilude mais fácil e... se apaixona muito rápido.

O2: É mesmo.

$\mathrm{K}:$ E vocês, mulheres, o que acham disso?

O1: Você dá um beijo nela e ela já [quer casar daqui uma semana].

A1: É mesmo.

A2: Eu sou assim.

A1: Eu não. Eu já me iludi fácil... porque mulher sofre muito quando ela se apaixona. É difícil ela terminar o namoro --

O2: Homem quando não tá mais apaixonado por uma [mulher, se já passa] na esquina e tem outra, tá apaixonado [pela outra].

O1: É.

A1: É difícil homem se apaixonar. Eu acho.

(Falam ao mesmo tempo)

O2: Eu me apaixonei ciiinco vezes. Levei três foras. Dois não foram fora [só um]; eu namorei com ela por três anos. Ela destruiu minha vida quando terminou.

A1: Eu acho super legal homem falar isso.

K: Vocês tavam falando mulher é tudo isso, homem é tudo aquilo. O 02 acabou de dizer "Eu sou homem e penso uma coisa que não é isso". 001 tava falando "A mulher dá um beijo e quer casar". Será que toda mulher--

A1: Não. 
O2: Só as inocentes.

A2: Eu acho que os homens querem as mulheres assim como--

O2: Objetos.

A2: Vaso de cristal, que se cair vai quebrar, tem que ser cuidadinha. Não se tocam que as mulheres estão tomando conta.

K: Será que a mulher é esse potezinho de cristal, frágil, indefeso?

A1: Não.

O2: É exatamente por isso eu sou um homem feminista. Enquanto os homens estão no poder, ele se acha. E quando as mulheres estiverem no poder? Quando cada mulher que estiver no poder mandar em alguns homens, pelo menos nos mais--

O1: Babacas.

K: E será que não existe mulher que já está no poder?

A1: A minha mãe que diz que tá no poder.

K: Porque você está falando "No dia em a mulher chegar". Mas será que não existe?

O2: Por enquanto, tem algumas mulheres no poder, mas daqui a um dois, sete anos,

provavelmente todas as mulheres vão estar no poder ou então pelo menos igualitariamente, em comum acordo. Porque este é o meu mundo, onde as mulheres e os homens são contentes e pacificamente amorosos.

A1: É legal isso.

O1: Eu acho que a mulher nunca vai dominar o mundo, rapaz!

A1: Por que não?

O1: Sei lá, meu! --

A1: Se você pensa assim, vá para a Síria, ou Arábia, onde os homens mandam nas mulheres!

A2: O1, você falou que "Eu acho que as mulheres nunca vai dominar o mundo", mas cuidado que elas já podem estar dominando!

A1: É mesmo!

K: Na política como é que tá isso?

O1: Só tem a Marta de mulher.

A1: Nossa prefeita, por exemplo, é mulher.

A2: A Marta só não vai ganhar porque [só quer saber de enfeitar a cidade]; ninguém come cimento ou come pedra. Quem vai ganhar é o Serra, com certeza. Mas não por ele ser homem; pelas idéias dele.

A1: É que nenhuma mulher se candidatou à presidência. Se se candidatasse, poderia ganhar.

A2: A Vani do Partido Verde.

O1/O2: É do Prona.

O2: Partido Verde é aquele cara lá, o Papai Noel.

O1: Enéas é do PAN.

O2: Não, eu tô falando aquele cara lá.

(Falam sobre a fisionomia do político, ironizando e dando risadas)

O1: [E aquela propaganda do "Peroba neles"! Ridícula!]

K: Então assim, vocês estão por dentro do que está acontecendo na política.

O1/O2: Eu tô.

O1: Se não me engano, se a pessoa ela não tirou o título de eleitor (? - barulho externo)

O2: Se não tira título de eleitor, fica um pouco mais difícil para arranjar serviço, trabalho.

O1: Você viu o Canoa? Não sei como esses cara se candidata.

A1: É mesmo

O1: Fica só lendo, não tem naturalidade, não sabe falar, não tem idéia própria. Ridículo! 
K: Vocês estão com quantos anos agora?

O1/A1: 14

O2: 15

A2: 16

K: Vocês podem tirar título de eleitor aos 16 . E aí, o que vocês pensam, vão querer tirar?

O2: Eu vou querer tirar e vou querer votar.

A1: Eu não vou querer, porque, sei lá, eu acho muito chato. Por enquanto eu não quero não.

Só quando for preciso mesmo, obrigatório. Aí sim.

K: Você acha chato?

A1: Eu acho, tem que ficar assistindo aqueles políticos. Ai, é horrível!

$K:$ E vocês, assistem?

A1: Eu não assisto não. Só vi acho que no Fantástico.

$\mathrm{K}:$ O1, você vai querer tirar o título de eleitor?

O1: Eu vou. Eu adoro política!

O2: Todos nós temos que votar no melhor pra nossa cidade. Porque se nós fica pensando assim-

O1: [A gente precisa exercer] nossa cidadania.

O2: Se ninguém for votar, voto em branco, em branco, em branco, em branco, vai pro que tá ganhando.

O1: Mas a Erundina é muito esquisita. Parece o Pingüim do Batman.

K: O1, você falou que gosta de política, né? Você vai querer seguir uma carreira política?

O1: Eu vou.

O2: Vai ser governador.

O1: [Quero ser juiz e ir pra política] Aí já vou conhecer leis, tudo, já vai ser mais fácil.

$K: E$ o que você vai querer fazer quando chegar na política?

$\mathrm{O} 1: \mathrm{Ei}$, até lá tem muito tempo pra pensar ainda!

O2: Você vai ser o quê? Senador, presidente?

O1: Vou me candidatar pra governador de São Paulo.

O2: [Já pensou se só tiverem] mulheres se candidatando?

O1: Vou fazer um protesto!

K: E essa idéia de que adolescente não quer saber de política, que adolescente é alienado?

O2: Nada a ver! Tô sempre discutindo com a minha mãe pra ver quem é o melhor político.

Ela fala que é o Serra e eu falo que é a Marta.

O1: Não gosto do PT, não.

A1: Eu odeio política! Não converso de política.

O1: A Marta tem [o problema do] secretário. O secretário da Marta é o do Pitta.

O2: Mas ela provou... ela fez os CÉUS, fez 21 CEUs.

O1: 21 CEUs, mas você vai lá e não tem vaga pra entrar! E aí?

O2: Duas faculdades. Não, a maioria dos meus amigos estão lá.

O1: O Serra fez o melhor programa do mundo!

A2: E ele não era nada.

O1: Ministro.

K: Você tava falando que tem amigos que tavam no CEU...

O2: Muitos amigos.

K: Vocês conhecem alguém que tá no CEU?

O2: Muitas pessoas...

A1: $E$ umas meninas que estudavam aqui, agora tão lá no CEU. 
O1: [Minha prima diz] que esse CEU parece o inferno.

O2: É nada, o que parece um inferno é esta escola de latinha. Lá no CEU é tudo perfeito.

Tem cinema, quadra, teatro...

A1: Piscina.

O2: Eu tô aprendendo a tocar violão lá no CEU.

A1: Eu [queria fazer (?)], só que tava cheio.

O2: Lá tem o CEU Saúde, onde eu instalei jogos em todos os computadores.

O1: Olha a verba que esta prefeita tinha, comparando com o Fernando Henrique! O Serra fez muita coisa quando ministro. Fez a campanha da Catarata que deu visão para o pessoal aí.

O2: E quem renovou as frotas de ônibus? E quem--

O1: Olha o dinheiro que ela tinha, filho! O Serra tinha, supondo, 500 mil pra gastar e ela três milhões.

O2: Mas ainda assim, o Fernando Henrique era o presidente. Ele podia mandar mais verba pro--

A2: Agora vem cá. O Lula é o presidente. O que o Lula tá fazendo? Que que você acha que a Marta vai fazer?

O2: Ah, em dois anos, eles tão mandando mais verba pra prefeitura que pro governo.

$K: E$ depois dizem que adolescente não têm idéia sobre política...

A1: Eu não gosto.

O1: Adoro política!

O2: Mó legal!

K: Vocês já ouviram isso?

O1: Lógico. Agora, nossa, horário político é ridículo. João Manoel... o desgraçado não sabe nem o que falar e quer ir pra propaganda política. (Imita-o) Não sabe nem falar e já quer se candidatar a prefeito!

O2: É que ele vai naquela "Pô, se eu falar 'Peroba neles', os cara vai achar engraçado e votar em mim".

$K$ : E o que vocês acham que deveria ser feito, então, quais as propostas para poder resolver os problemas da sociedade?

A2: Saúde e emprego.

O1: Saúde.

A1: Segurança.

O1: A saúde melhorando.... Só segurança e aí?

O2: Na verdade, a construção dos CÉUs deu muito emprego pra professores, vigilantes--

O1: Pelo amor de Deus! A Marta não fez um leito de hospital, gente! Um leito!

O2: Ela vai começar Saúde agora.

O1: Vai fazer agora? De que adianta? E quem morreu ontem? Vai adiantar alguma coisa fazer amanhã?

O2: E quem não morreu? Ela vai fazer o CEU Saúde, igual ela falou que ia fazer o CEU e o bilhete único.

$\mathrm{K}:$ E além de segurança--?

O1: O bilhete é maior ladrão. Você põe 50 na lotérica e chega no buzão tem 25.

O2: Só se for com o seu cartão.

O1: O quê? Meu amigo já fez B.O (boletim de ocorrência) contra essa porcaria.

O1: Essa lotérica rouba pra caramba!

O2: Então a culpa é da lotérica, não do bilhete único. 
A2: Quem ta acabando com o Serra é esse vice dele.

O1: Ah, mas o Serra é competente.

O2: E se o Serra for viajar?

A2: Mas você acha que ele vai abandonar o cargo dele de prefeito? Ele lutou tanto pra isso.

O2: $O$ outro foi viajar pelo mundo inteiro.

O1: O Geraldo Alkimim, é ele chegou com um projetinho de 13 milhão, só.

O2: Ô 01, na verdade são 13 milhões.

K: E tem promessas aí que não são cumpridas pelos políticos?

O1: É, todo prefeito, não conheço um que fez tudo que falou.

O2: O presidente não tá fazendo o que falou, mas a prefeita sim.

O1: E a saúde? Ela falou que ia reformar não sei quantos hospital--

O2: Fazê o quê, mano?

O1: Não fez uma cama pro doente; se liga!

O1: Que que adianta ter CEU pro pessoal ir lá, se tá todo mundo doente na cama? Que adianta ter piscina, se tem neguinho que não pode sentar na cama com soro na veia, que adianta?

K: O que tem que ter, então? Segurança é uma conseqüência...

O1: Emprego e saúde. É o que tem que vir primeiro.

A1: E dar mais chance para o adolescente, eu acho.

O2: Isso!!

K: Por que?

A1: Porque ele tá precisando, eu acho.

O1: A gente é o futuro do Brasil.

O2: É, igual o Serra falou que a Marta tá gastando milhões de cargo com cargo de confiança--

A1: Tem um negócio também que apareceu na televisão. Algumas pessoas que são bem de vida tá com renda mínima e quem precisa mesmo não tá ganhando.

A2: Eu tava tirando 15 reais do Bolsa-escola.

O2: Quatro feiras.

O1: Pelo Amor de Deus! 25 reais e fala que tem não sei quantas famílias beneficiadas. Isso

é uma esmola!

$K$ : E vocês adolescentes têm, então, uma proposta pra melhorar a sociedade--?

O2: Eu vou criar o PDAN- Partido dos adolescentes da nação.

K: E o que ia ter aí no Partido dos Adolescentes da Nação?

O1: [Podia ser] PAN, a mesma coisa, Partido dos adolescentes da nação.

$K$ : E o que o PAN ia falar?

O2: 01 pra presidente, prefeito, governador. Eu pra-

A1: Eu não ia ser nada.

$\mathrm{K}: O$ que ia ter no PAN?

O1: Muitas idéias.

O2: Ele ia tratar principalmente da Saúde, eu principalmente do emprego, porque quem tem emprego tem dinheiro pra pagar o convênio.

A2: Segurança.

O1: Convênio tinha que ser de graça.

O2: Emprego.

A2: Esse negócio de ter que pagar pra quando você morrer, ter caixão, essas coisas. Tem gente que explora até um real de quem não pode. 
O1: A Marta cobra taxa de luz, enquanto não tem nem poste de luz.

A1: É.

O1: Taxa de lixo!!

A1: É, isso aí é um absurdo!!

K: A gente pode pensar mais nesse PAN. Quem sabe a gente pode colocar essas propostas de vocês no papel, ai todo mundo vai ler as idéias do PAN. Vamos fazer isso?

O2: Vamos, é uma boa!

K: No último encontro a gente escreve o que o PAN propõe e isso pode ficar registrado lá na pesquisa!

A2: Com nosso nome?

K: Não, porque é sigiloso.

O2: Voltando a falar sobre a política, uma boa idéia seria empregos para os mais jovens e também continuar com esse negócio de taxa do lixo, taxa de luz, porque, olha só, isso na verdade foi um grande pretexto, porque eles tavam pegando o dinheiro destas taxas para ajudar a construir os CÉUs.

O1: Eu tô indignado com os CÉUS. Vai ter neguinho saindo pelas janelas e você quer saber de CÉU?

O2: É lógico, milhares de pessoas que moram na favela tão estudando no CEU.

O1: E aí, ué??!!

K: Pessoal, nosso tempo acabou, mas depois a gente pode conversar sobre o que deixa vocês indignados e o que a gente pode colocar nesse PAN.

Juntos: Legal!

K: Então, pessoal... muito, muito obrigada! 


\section{ENCONTRO EXTRA COM OS ALUNOS}

(Retomada das propostas do PAN - releitura do documento escrito em grupo pelos alunos e votação sobre propostas que alguns alunos elaboraram individualmente em suas casas. 0 encontro inicia com uma discussão sobre propostas para Educação, partindo de uma sugestão apresentada pela aluna $A 1^{1}$ referente à idéia de se criar um espaço de diálogo entre alunos e professores)

K: Então, A1 trouxe a proposta de ter uma conversa entre alunos e professores sobre o que tá acontecendo aqui na escola, como a gente fez aqui no grupo. Aí o 02 tava perguntando quando seria isso, se seria uma vez por semana.

O2: E agora vem o como.

$K: O$ que vocês acham, que deveria ser uma vez por mês ou uma vez por semana?

A4: Eu acho que deveria ser uma vez por mês.

A1: No fim do mês.

O2: Pra ver o que aprendeu no começo do mês.

K: Então vocês estão falando duas coisas: pode ter uma vez por mês essa coisa de tirar dúvidas sobre a matéria e pode ter também uma vez por mês isso de os alunos conversarem com os professores sobre o que acham que está sendo problema na escola, sobre o que está atrapalhando o aprendizado. Foi isso que a $A 1$ estava falando na entrevista.

O1: Posso falar minhas propostas?

K: Então vamos ouvir as propostas todas de vocês e aí vocês discutem.

O1: De educação primeiro. Tem vários temas, né?

(O1 lê suas propostas) $)^{2}$

O1: "Instalação de câmeras de vigilância nas escolas públicas"

(Falam ao mesmo tempo)

K: Tá bom. Tem a coisa de se coloca ou não coloca câmera. A A1 acha que não coloca, A4 também acha que não...

A4: Eu acho que não. Só porque a câmera tá aqui, não vai fazer nada? Quem quiser fazer, faz!

K: Deixa o 02 falar, ele tinha começado a falar.

O2: Tem que colocar porque daí não vai ter aquela coisa que um faz alguma coisa e fala que não fez.

A1: Só que vai ter aqueles ajudantes e eles vão ficar tomando conta da sala. Então não vai precisar de câmera.

O2: $O$ ajudante não fica dentro do banheiro.

A4: Quando a pessoa quer fazer, ela faz, ela consegue. Não vai dar certo.

O1: Mas se ver pela câmera, ela vai ser punida!

O4: Punida!!! Meu, que...!! Ó, não vai der certo!

O3: Vai colocar uma coisa (um papel) na frente da câmera.

A4: Não é isso? É isso que vai acontecer, é isso que eu estou falando.

A3: Vai quebrar...

O3: Quando a gente sair daqui, não vai precisar de câmera não, porque (...?).

K: Por quê? O que você falou, O3? Quando vocês saírem daqui não vai precisar, porque só vai ter gente...

\footnotetext{
${ }^{1}$ Durante a entrevista individual com essa aluna

${ }^{2}$ Essas propostas estão na versão final do PAN, com exceção de três, com relação às quais os demais alunos discordaram, realizando a seguinte discussão).
} 
O3: Que não é da turma da $8^{a} \mathrm{~B}$.

K: Não vai ter mais oitava? No ano que vem vai ter a turma da oitava. E o pessoal que vai estar na oitava no ano que vem não vai fazer nada?

A4: Eu concordo com a A1. Eu discordo com esse negócio de câmera.

O1: No banheiro dos meninos (?)

A4: No banheiro das meninas não faz isso, não.

K: Vamos fazer assim: o $O 1$ vai ler todas as propostas e depois a gente discute sobre tudo, ta bom? O 01 está dizendo que tem propostas radicais, então vamos ver o que vocês acham do que ele falou aqui. Primeiro, tava falando do negócio da câmera.

A1/A4: Não tem que ter nada disso, não!

(O1 lê as propostas que elaborou. Os alunos concordam até a seguinte idéia:)

O1: "Punição rigorozíssima para estabelecimento que vender bebidas para menores de 20 anos"

A3: Ah, não! Meu, o que adianta proibir nos bares, se em casa o pai compra, aí ele vai lá e toma?! Não vai adiantar nada! Você vai no supermercado, falsifica o seu RG, compra uma bebida, e daí? O que adianta? Nada!

A1: É mesmo!

O1: $80 \%$ dos acidentes que acontecem por ano no trânsito é por causa de motoristas embriagados! Ou por violência, droga ou por tudo quanto é bebida...

O3: Acho que bebida devia ser proibido pra menores de 15 anos!

O1: Por isso que dizem que a gente é aborrecente, vândalo... por causa disso aí! Porque enchem a cara...

( Todos falam ao mesmo tempo)

A4: Esse negócio de beber aí... Falam que bêbado não sabe o que faz. Sabe muito bem, entendeu? Faz porque quer e bebe, também, porque quer! Eu acho que cada um cuida da sua vida. Esse negócio de bebida tem que ser pra menores de 15 anos; concordo com O3!... E a culpa também é deles; não é da gente...

A1: Eu acho que devia deixar a lei normal, do jeito que tá. Também porque a culpa do vandalismo não é só beber. Tem muitas outras coisas.

(Falam ao mesmo tempo)

$\mathrm{K}: \mathrm{O}$ que vocês acham da idéia do 01 , assim: adolescente é visto como "aborrecente" porque bebe e é violento?

Juntos: Ah, nada a ver! Isso aí não tem nada a ver, meu!

(Falam ao mesmo tempo)

A1: Mas não é só isso, tem outras coisas.

A3: Tem várias coisas!

O1: Mas tudo começa na bebida, gente!

A3: Não, não, não.

O1: Começa a tomar cerveja, daqui a pouco já tá fumando maconhinha...

A3: Fuma maconha quem quer, entendeu?

A1: É a mesma coisa que beber, bebe quem quer.

K: Vocês estão falando que acham que "aborrecente" não tem a ver só com estar bêbado.

A3: Ah, tem muito pouco.

$K$ : Com o que tem a ver mais?

A1: Ah, com muitas coisas.

K: Que coisas? Dá um exemplo.

A1: Não sei. Tem que ouvir a opinião de cada um.

A3: Eu concordo com a A1.

K: Então, deixa eu fazer uma pergunta: é só adolescente que fica bêbado?

Juntos: Não! 
A3: Não, é o velho também.

O1: Estou falando que a maioria dos casos de vandalismo é por causa da bebida. Adolescente que morre que fica embriagado, faz isso e faz aquilo.

(Falam ao mesmo tempo)

K: Na proposta do $O 1$ o que está tendo muito é uma coisa de repressão, da polícia cair em cima, de controle e vigilância da sociedade. Então ele estava falando de uma coisa moral: "vamos vigiar em todos os lugares e impedir que aconteça violência". E vocês duas não estão concordando com isso--

O1: Por isso que eu falo: mulher não entende nada; e quando entende dá problema! (Risos)

O3: É isso aí.

A3: Vocês também não entende nada, mal sabe fazer uma comida. Por isso que falam: homem não vive sem mulher. É isso mesmo. Não sabe nem lavar uma cueca direito..., quem tem que lavar é a mulher, não é?

$K: E$ então, o que vocês vão decidir com relação a essa proposta do 01 ?

A3: Esse negócio da bebida aí eu não concordo.

O3: (?) Por exemplo, mercados e bar em favela, lá é ponto de droga.

$\mathrm{K}: \mathrm{E}$ aí o que você faz?

O3: Manda invadir o morro.

A3: Que invadir o morro, meu?! Pirou!

(Falam ao mesmo tempo)

A1: E se eu falar, tipo assim, pra você comprar uma bebida pra mim e você for?

A3: A polícia não vai pegar ela não. Quem vai descobrir?

O1: Mas já melhora muito.

A1: Não melhora. Você pode muito bem comprar uma bebida e tomar na sua casa.

O2: Querer impedir a bebida é a mesma coisa que querer impedir o cigarro. Se o bar não vende fiado, ele vai roubar pra beber, vai fazer o que for pra beber.

A1: $E$ também tem que beber com responsabilidade.

A3: É uma droga legalizada.

$K: O$ que é que faz com que tenha violência?

A3: Ah, tudo.

K: O quê?

A1: Tem uma história aqui que um cara matou o outro por causa de uma coxinha, e ele não estava nem drogado.

K: Quando a gente estava conversando sobre o PAN, vocês disseram que a pessoa que assalta é a pessoa que não tem dinheiro, pra se manter, então teria a ver com a questão do desemprego--

A3: Às vezes nem precisa e assalta.

$K$ : Então quero saber se vocês acham se desemprego gera violência ou não.

A3: Claro que gera.

O?: Um pouco

A3: Um pouco, mas gera.

K: Um pouco? O que faz com que tenha mais violência, então, se não é o desemprego?

O2: É o respeito.

O1: E o que aconteceu no Carandiru?

(Falam ao mesmo tempo)

O2: Uma pessoa que mata uma pessoa, quando sair da cadeia, vai matar de novo.

A1: Só que mata porque a vida dela tá em jogo. Tem que ver também tudo.

A3: Não tem investigação aqui. Mata, vai pra cadeia, não sabe por que foi. Não adianta!

?: Uma pessoa porque tá com a outra vai presa-- 
A3: Aí a pessoa fica mofando na cadeia e depois de não sei quantos que ficou presa vão descobrir que ela não tem nada a ver. E aí?

K: Vocês estão falando de pessoas que estão presas sem ter culpa e pessoas que têm culpa não estão sendo presas...

A3: Isso!

K: Então, a pessoa de repente pode ter sido julgada por uma coisa que ela não fez e ela pode morrer por uma coisa que ela não teve culpa. E aí, o que vocês acham?

O2: A solução é não ter cadeia?

A3: Eu não estou falando que a solução é não ter cadeia.

A1: É prender as pessoas certas!

O1: Se a polícia trabalhar bem e for bem empenhada, primeiro apura os fatos, a investigação--

O3: E depois vai pra cadeira elétrica.

(Falam ao mesmo tempo)

O1: $80 \%$ são culpados!

A3: Mas não tem que só pensar no culpado, tem que pensar nos inocentes também. Uma pá de gente morre aí, meu!

O1: À toa, você percebe?

A3: À toa mesmo, à toa.

O1: Por que as cadeias estão superlotadas?

A3: Por quê? Responde.

O1: Ele vai preso e fica lá 30 anos.

A3: Não fica 30 anos. Tendo bom comportamento, ele sai. É isso que é o mau! Ele sai! [Sabe - que eu acho engraçado? Eles só investigam se morre gente rica. Se é pobre, ó! E só os pobres são presos; os ricos, não]

K: E aquela idéia de que se tivesse emprego, não ia ter esse problema da violência?

A3: Não ia ter.

O1: Mas hoje, hoje não ia ter como resolver esse problema.

(Falam ao mesmo tempo)

K: O que poderia se fazer pra dar emprego e aí não acontecer isso?

O3: Manda pro Iraque. (Risos)

O2: Mas é uma boa. Vamos pôr, em vez de pena de morte, manda pra fora do país.

$\mathrm{K}: \mathrm{Na}$ ditadura acontecia isso, exílio.

O2: Exílio.

$\mathrm{K}$ : Na ditadura tinha um controle enorme e, se alguma pessoa fazia alguma coisa que os militares achavam que estava errado, eram torturados e muitos eram exilados. Por exemplo, o Caetano Veloso, o Chico Buarque, eles foram exilados porque fizeram músicas que diziam "olha, a ditadura é brava; você não tem espaço pra falar, pra pensar... você não pode fazer nada". Aí eles escreveram as músicas pensando em conscientizar as pessoas sobre essa repressão e foram mandados pra fora do Brasil. Tem o Geraldo Vandré que fez aquela música "Caminhando e cantando e seguindo a canção...". Sabe qual é? Ele foi torturado e teve que durante dias ouvir no máximo volume a música dele.

A3: [Essa idéia de mandar pra fora] não adianta nada!

O?: É uma boa.

O2: $E(?)$ que roubou porque não tinha comida em casa?

A3: Então!

K: Se a pessoa não tem o que comer, ela vai arrumar como?

O1: [Com o projeto como o Renda Mínima, por exemplo...]

$K$ : Então vocês acham que o Governo deveria dar um dinheiro pra pessoa se manter?

O1: Um dinheiro, mesmo, e não um... 
K: E o problema de a pessoa não ter onde morar?

O1: [O Governo deveria garantir isso também].

$\mathrm{K}$ : $\mathrm{Se}$ as pessoas tivessem comida e tivessem casa, elas iam roubar?

O3: Não.

O2: Acho que tem gente que ia até roubar, porque quanto mais tem mais quer [... tem ganância].

(Barulho externo)

$\mathrm{K}$ : E o que mais você trouxe de proposta, O1?

O1: Transporte e saúde.

(Leitura dessas propostas. Os alunos concordam com todas, com exceção de: "Armar os cobradores de ônibus, para caso de as câmeras não funcionarem" e discutem)

A3: Com essa coisa de armar os cobradores, eu não concordo, não!

(Falam ao mesmo tempo)

?: Só ia ter mais violência

A1: Eu também acho!

A3: Como vai saber se vai estar funcionando ou não? Esse negócio de arma aí... cada vez mais vai piorando. A [proposta] do álcool é uma boa idéia.

O2: [Tem que ter] o policiamento do ônibus.

A1: Isso eu concordo!

(Leitura das propostas relativas a Saúde. Os alunos concordam com todas as propostas)

K: Vocês têm alguma coisa pra acrescentar sobre essas propostas?

A1: No Hospital das Clínicas tem que ter senha! Nossa, você fica umas três horas só pra pegar um retorno!

K: Então, com essas propostas sobre saúde, todo mundo concordou.

Juntos: É.

K: E além dessas propostas sobre Educação, o que mais vocês acham que daria pra fazer pra melhorar essa escola aqui, de vocês?

O1: Pintar a quadra, [ter uma boa mesa de pingue-pongue; ter um bom espaço pros jogos]

A3: E dar lanche ao invés de comida de almoço.

$\mathrm{K}$ : E essa carta da $A 1$ aqui, todo mundo concordou ${ }^{3}$ ?

O2: $\tilde{A}-h \tilde{a}$.

K: O que ela escreveu, discordando da primeira versão do PAN e que vocês tavam discutindo antes foi que não precisaria instalar as câmeras de vigilância nas escolas. Quem apóia a $A 1$ pra não ter câmera?

A3: Eu.

O1: Não apóio.

O3: Não concordo que tenha câmera na sala.

K: Então, a gente vai pegar primeiro essa carta da $A 1$, que só tem essa coisa pra discutir, o resto vocês estão concordando. A gente vê se tira ou coloca. Depois a gente pega essas propostas e vocês decidem o que vai e o que fica na versão final do PAN. Então da A1: fora essa coisa da câmera, tem essa idéia de conversar com os professores, conversar sobre os problemas da escola com os professores e essa coisa de fazer reunião dos pais, os pais contarem também a visão que eles têm da escola pra tentar melhorar a escola. Vocês concordam com isso?

Todos: Concordo!

K: Então, o que precisa colocar mais aqui é essa coisa de os alunos conversarem com os professores sobre os problemas da escola?

A1: É.

\footnotetext{
${ }^{3}$ As propostas elaboradas por A1 estão digitadas no final da transcrição deste encontro em grupo com os alunos.
} 
K: Só acrescentar isso. Outra coisa que a A1 colocou aqui: sabe o assistente que vocês colocaram, o ajudante pra ficar na sala de aula? Ela falou que teria que ser um ajudante que soubesse dar aula também. Além do ajudante manter a disciplina, ele pode ajudar a tirar dúvidas também na hora da aula. Então, com isso, vocês concordam?

Juntos: Sim.

K: Agora vamos reler todas essas propostas pra vocês decidirem quais vão para a versão final do PAN.

(Releitura de cada proposta e votação - todas as propostas foram aceitas, em sistema de votação, com exceção das referentes a "instalar câmeras de vigilância nas escolas públicas"; "armar os cobradores de ônibus"; "punição rigorosa para venda de bebidas aos menores de 20 anos" e "iniciativa da polícia federal: invadir morros e pontos de tráfico que a polícia sabe que existe, mas não combate com pulso firme")

K: Pronto, acabou. A última coisa que eu queria perguntar pra vocês é quando, em que momento..., o que acontece pra vocês virarem adultos. Que mudança que tem? Uma pessoa é adolescente; o que precisa acontecer pra virar adulta, que mudança?

A1: Quando tem mais responsabilidade.

O?: Idade.

O3: Ter filhos.

A1: Tem adolescente que tem filho.

O2: A partir da hora que você transa, você é um homem.

$\mathrm{K}$ : Homem adulto ou homem adolescente?

A1: Adolescente.

A3: Ou mulher adolescente.

K: Então é ter mais responsabilidade...

A1: Começar a sustentar a casa.

K: Auto-sustentar? Vocês tinham falado que adolescente também tem responsabilidade, né? Então a questão é mais quando ele se sustenta.

O1: É.

K: Então, tá bom, gente! Depois que essa versão final do PAN estiver passada a limpo, com todas essas propostas com que vocês concordaram, vocês vão assinar esse documento, mas não com seus verdadeiros nomes, por causa do sigilo, tá bom? Então, mais uma vez: muito, muito obrigada!!

Propostas elaboradas por A1:

"Não precisaria instalar equipamentos de vigilância nas escolas públicas, pois iria parecer uma prisão; só deveria ter câmeras no fundo das quadras ou pátio para verem se tem alguém com maconha e outros tipos de drogas, mas nas salas de aula não haveria necessidade.

Deveria sim ter ajudantes para que pudessem ajudar a manter a disciplina $e$ progresso na sala, mas também para ajudar os alunos que precisassem tirar suas dúvidas.

Deveria ter também um dia especial para que cada aluno tirasse a dúvida com o professor ou marcar um horário depois da aula para fazer perguntas da matéria que não entendeu. 
Os pais dos alunos deveriam participar das reuniões de pais e falar o que estão achando do ensino da escola, o que deveria melhorar, o que deveria mudar dar opiniões para que a educação melhore. E os pais deveriam ser obrigados a ir nas reuniões, principalmente os pais do aluno que dá muito trabalho." 


\section{ANEXO XV \\ TRANSCRIÇÃO DE ENTREVISTA INDIVIDUAL COM \\ A ALUNA JANAÍNA (A1)}

K: Nos encontros em grupo a gente conversou sobre um monte de coisas. Só para você lembrar um pouquinho, a gente conversou sobre como era ser adolescente, sobre o que os adultos acham dos adolescentes, sobre como era ser aluno adolescente, sobre a relação entre vocês e as pessoas aqui da escola, alunos, professores, coordenação, todo mundo. Vocês escreveram as propostas do PAN e a gente conversou sobre as músicas também. $O$ que você achou desses encontros?

A1: Achei ótimo!

K: Por quê?

A1: Ah,por causa que muita gente não ouve a gente, aí uma pessoa vem e fica perguntando. É legal. E também pra conhecer os outros, a opinião de cada um. Que cada um tem uma opinião, né?

K: Você ouviu a opinião de todo mundo e falou a sua. De tudo o que a gente conversou, o que mais te interessou?

A1: As músicas eu acho que me interessou mais.

$\mathrm{K}$ : No encontro que a gente conversou sobre as músicas você falou bastante, mesmo! E por que te interessou mais falar das músicas?

A1: Porque [o que fala] nas músicas é o que acontece mesmo. E eu gostei ainda mais da primeira música.

K: Inclusive, com relação a essa música, você falou sobre aquela coisa de olhar 0 jovem $e$ já achar que porque é jovem é drogado, é marginal. Aí vocês falaram também sobre a história de olhar o jovem pobre. Pra você, o que você acha quando olham um jovem pobre, pensam que ele é o quê?

A1: Marginal, eu acho. Pensa que ele não tem nada de bom pra oferecer e de ter muita coisa do que um rico pode ter. Acho que rico já tem dinheiro, mas a alegria, esses negócios, não tem. $O$ pobre tem coisa pra expressar, tem uma pá de coisa pra ensinar porque ele passa muito mais dificuldade. $O$ rico nem passa dificuldade. Agora, o pobre que se lasque!

$K$ : E quando vocês escreveram o PAN, logo no comecinho, falaram que queriam dizer que vocês não são "aborrecentes" e que vocês ficam muito indignados porque acham que são julgados por causa da situação financeira. $O$ que você acha disso?

A1: Eu acho que é verdade!

$\mathrm{K}$ : Por que é verdade?

A1: Por causa que a maioria das pessoas dá mais oportunidade pra quem é rico, tem mais curso pra rico. Agora, acho que eles deveriam fazer um negócio pro pobre também, ter cursos, porque não é só rico que precisa, a gente também, que é pobre, precisa muito mais do que eles, né?

K: Então, você acha que o fato de vocês serem pobres faz com que as pessoas pensem o quê?? 
A1: Pensam que nós somos marginal, esses negócios!

$\mathrm{K}$ : Aquilo que você estava falando, né? Você sente isso, já sentiu isso acontecer com você ou com alguém conhecido?

A1: Tem esses negócios. Só na televisão que passa, mas na vida real nunca vi. Mas tem uma amiga da minha sala, parece que é (?), não sei se ela é ou não, mas todo mundo fica zoando com ela: "Ah, aquela lá não se esforça pra nada".

$K: A$ que você falou que não sabe ler e escrever?

A1: É. Mas só que ela também não se esforça, tem que se esforçar.

$\mathrm{K}$ : Vocês aqui têm essa coisa de ficar falando se alguém é mais pobre, ou menos pobre...?

A1: Não, porque a maioria das pessoas aqui é tudo que mora na favela.

$K$ : A maioria mora aqui.

A1: Na favela " $x$ ".

$K$ : Então não tem muito essa diferença de "alguém é mais pobre do que eu".

A1: Aqui não. Não tem nada de "ah, você é o maior pobre". Não tem esses negócio aqui nessa escola. Mas em outras, com certeza, né?

$\mathrm{K}$ : Você sente alguma coisa de professores achando alguma coisa pelos alunos serem pobres ou não?

A1: Eu não sinto.

K: Quando vocês estavam falando do PAN, fizeram propostas pra saúde, educação, emprego. A da educação deu pra começar e não deu pra terminar. O que você acha da educação, qual é o maior problema da educação hoje?

A1: Em que sentido?

K: Da educação escolar. O que tem de problema, o que está acontecendo que precisaria ser melhorado?

A1: $O$ ensino precisaria ser melhorado, porque o ensino tá muito ruim, eu acho. Por causa que da aula de matemática não sei fazer quase nenhuma lição, porque a professora explica rapidão e os aluno também fica conversando, não dá pra entender nada. Aí a professora fala que tavam conversando, não explica mais, e mesmo prestando atenção, eu não consigo entender nada! A gente vai perguntar pra ela, ela explica com a maior rapidez, ela mesmo faz a conta lá e pronto: "Faz igual eu fiz". Grande coisa, né? Não dá pra entender nada!

K: Vocês estavam falando que com vocês mesmos acontece de passar de ano sem saber. $O$ que você acha disso?

A1: Ah, eu acho isso horrível! Igual meu irmão, ele não sabe nada, nem tá vindo mais pra escola porque minha mãe quer que ele repita por falta.

K: Quem?

A1: Meu irmão. Ele estuda aqui na sétima série, as nota dele tá ruim, ele falta pra caramba, aí minha mãe deixou ele sem vim pra escola porque ela quer que ele repita, porque ele não sabe nada, tabuada do dois ele sabe mais ou menos, aí a do três já... [não sabe].

K: Mas se ele só tiver nota ruim, mas ele vir, aí ele passa?

A1: Passa! Da quinta, sexta e sétima, passa! E quando chega na oitava, tem esse provão, aí não passa.

K: Que provão? 
A1: É o SARESP.

$K:$ E é o SARESP que faz passar ou não passar?

A1: Não, ele não faz passar, mas só que ele também ajuda.

$\mathrm{K}$ : Ajuda como?

A1: Ajuda pra ver o conhecimento do aluno, se ele tá indo bem. Só que tem que fazer de 15 pra cima de pontos. Se fizer 14, ou fica retido ou eles dão recuperação, né?

K: Então o SARESP pode fazer você ficar de recuperação ou ficar retido, se você não tem um número de pontos mínimo.

A1: Eu não sei se agora é assim, mas antigamente era. Agora todo mundo fala que não é assim, mas eu não sei. Porque ano passado a gente teve, só que não podia reprovar, então... mas esse ano vai reprovar.

K: A oitava é diferente, né?

A1: Se você tiver falta e nota mal, assim, você repete. Se você tiver nota mal, você repete. E se você não vim, também repete. Nem precisa vim pra escola, porque você vai passar!

K: Você tava falando [no encontro em grupo] que mesmo pra repetir na oitava tem que ter mais de 200 faltas.

A1: É.

$K$ : E mesmo na oitava vocês podem passar para o primeiro colegial sem saber...

A1: É. Igual eu, eu não sei os negócio de matemática e eu vou passar. Eu tenho nota boa, só que eu não sei fazer. Tipo assim, do que eu sei fazer, ela [professora] não dá prova, do que eu não sei fazer, ela dá prova!

K: Mas aí você tira nota boa?

A1: Aí a sala inteira fica olhando pra cara dela e ela ainda dá nota, lá!

K: Então, a nota não mede o que a pessoa sabe e o que ela não sabe?

A1: Ninguém da sala sabe, só alguns que ficam sentado na frente. Até os que estão na frente ainda não sabem muito bem, você pergunta pra eles... a maioria não sabe. Aí é ruim.

K: A gente está falando da experiência de ser aluno adolescente, só que eu queria perguntar uma coisa antes. Quando você começou a estudar, estudou na préescola ou entrou na primeira série?

A1: Na pré-escola.

K: Você lembra alguma coisinha de como era ser aluna lá na pré-escola?

A1: Era legal!

$\mathrm{K}: \mathrm{O}$ que acontecia?

A1: Por causa que a gente nem sabia ler, aí passava uma liçãozinha lá... Tinha bastante coisa pra pintar, depois chegava a hora de brincar. Aí todas as sextasfeiras, não lembro, tinha um dia da semana que era só brincar, levava brinquedo, brincava de tudo. Acho que era de sexta-feira, podia levar boneca, corda..., era muito legal! Eu gostava!

K: Era bom ser aluna na pré-escola, né? E depois na primeira série você estudou em que escola?

A1: NaE4. 


\section{K: Ficou até que série?}

A1: Até a quarta, porque é só até a quarta série.

$K: E$ o que você achava de estudar lá?

A1: Era mó bom porque, nossa, em geral era ótimo! A lição que passava era boa... tudo! Eu tinha mó dificuldade pra escrever, aí sempre a professora ficava me ajudando..., todos os alunos. Tinha uns que já sabia escrever, mas outros não. Eu não sabia, ela ficava me ajudando, era mó bom!

$\mathrm{K}$ : Aí você aprendeu?

A1: Nossa, é a melhor escola que eu estudei até hoje!

K: É mesmo?

A1: Se tivesse até a oitava série, eu não ia sair de lá! Ia ficar estudando lá até agora.

K: E lá a relação do professor com o aluno como era? Você falou que a professora ajudava. Era uma professora, né?

A1: É. Só que na terceira série a gente tinha duas, ficava dividido, e na quarta também era duas. Na primeira e na segunda era a mesma, era uma professora só. Era ótimo!

K: Na quinta série você já veio pra cá?

A1: Foi.

K: Então você ficou aqui nessa escola da quinta até a oitava. Eu queria saber assim: qual é a diferença entre ser aluno criança e ser aluno adolescente?

A1: Aluno criança eles dão mais atenção. Eles não ficam maltratando (porque às vezes eles ficam maltratando, assim...). Eu acho que era melhor aluno criança; eles ouvem, assim, melhor.

K: Você acha que eles ouvem mais a criança?

A1: Eu acho.

K: Por quê?

A1: Tipo assim, se eles não ouvir ou maltratar, as crianças chamam a mãe $e$ dá o maior barraco na escola.

$K$ : E com o adolescente isso não acontece?

A1: Não, os adolescentes nem liga mais pra esse negócio de chamar a mãe, eles que se vira, mesmo. Agora, quando é criança, não. Como você vai se virar quando é criança?

K: Então você acha que tem mais respeito com as crianças...

A1: É. Mas com os adolescentes alguns professores têm respeito, porque eles têm medo, né, como a gente tava falando [nos encontros em grupo]. Tem alguns que têm muito medo!

K: Você sente isso, né? Você acha que eles têm medo do quê?

A1: Sei lá, de alguém bater neles, esses negócio, por causa do vandalismo. Acho que eles têm medo de um aluno, por exemplo, assaltar a casa deles..., sei lá.

$\mathrm{K}$ : De violência?

A1: É.

K: Como vocês falaram nos encontros em grupo, né? A gente tava falando aqui sobre o passado e o presente. E sobre o futuro, o que você espera do seu futuro? 
A1: Ah, eu espero várias coisas!

K: O quê?

A1: Se eu conseguir um emprego bom, quero fazer turismo ou fotografia. Nossa! Qualquer paisagem aqui, se eu tivesse uma máquina, eu ia tirar! Ou senão ser dançarina, amo dançar. Eu tenho um grupo de axé, a gente dança... às vezes a gente se apresenta. Então, eu gostaria.

$K: E$, no turismo, o que te interessa?

A1: Ah, viajar! Tipo assim, conhecer o modo de viver em outros países, conhecer as línguas, falar também.

K: E o precisa acontecer pra que você seja fotógrafa, dançarina ou lidar com turismo?

A1: Eu tenho que estudar muito. Muito, mesmo! Porque se puder ser os dois, eu quero os dois, porque dançarina eu já vejo como muito sonho. Agora, o meu futuro, assim, é esse, o que eu quero mais.

K: Pra fazer turismo, você tinha falado até no grupo, que queria estudar línguas. Vocês têm aula de inglês aqui, né? Como é a aula de inglês?

A1: É mais ou menos.

K: Por quê?

A1: Não acho que é muito boa, mas também não acho que é muito ruim.

K: Não?

A1: Porque a professora explica. Mas, tipo assim, ela tem um problema na perna dela e todo mundo fica zoando com ela. Ela anda meio mancando assim e com uma muleta e aí todo mundo fica zoando ela. Mas só que o pessoal respeita, todo mundo fala: "Ê, mano, ela tem problema". Mas ela é boa.

K: Ah... Então, você tava falando que quando terminar o terceiro colegial, você pensa em --

A1: Fazer faculdade.

K: E o que precisa acontecer pra você fazer faculdade?

A1: Preciso ter um trabalho, pra mim poder pagar porque é muito caro. Turismo é 500 e pouco. Eu tenho uma amiga que faz. Uma amiga da minha prima faz turismo. É mó caro!

K: Então você pensa em trabalhar pra conseguir um dinheiro e entrar numa faculdade particular?

A1: É. Porque é difícil entrar numa faculdade pública. Se pudesse, eu preferia a pública.

K: Você tá falando que é difícil conseguir passar no vestibular de uma escola pública, né?

A1: É. Ô,é difícil!

$K$ : E aquela conversa que a gente estava falando da diferença entre estudar numa escola estadual, municipal ou numa escola particular? Você sente que tem diferença?

A1: Não com a municipal e a estadual, essas é como se fosse a mesma, mas [entre] essas duas e a particular.

K: Que diferença tem? 
A1: Aqui todo mundo fala: "Ah, ele estuda em escola particular, ele sabe mais coisa que você". Tipo assim, você faz uma conta e fala pra ele fazer, aí a sua dá um e a dele dá outro, acho que o resultado dele é o que tá certo, porque a dele é de escola particular. Mas de vez em quando não é, de vez em quando o estudo daqui, até dessa escola, pode ser muito melhor do que de escola particular.

K: Então você acha que depende do quê?

A1: Dos professores, nessa parte.

K: Pode ter professor bom na escola pública, pode ter professor ruim na escola particular--

A1: Acho que não depende de aluno, depende do professor, se ele conseguir ensinar coisa da oitava série e conseguir ensinar tudo... Depende do aluno também, só que mais do professor.

K: Quando se repete ou quando o ensino não é de qualidade, será que existe um culpado? O que você acha?

A1: Acho que não existe um culpado. É todos que faz a escola, a escola não é só o professor, é a gente também. A gente que faz mais a escola do que eles, porque a gente sempre vem pra aprender. Alguns não, vêm pra ficar zoando, pra passar o tempo.

$K: E$ o que mais faz a escola, então?

A1: Quem tá aqui dentro, todos que estão aqui dentro. E os pais dos alunos também, eles têm que ajudar, também.

K: Você estava falando da situação da educação, que tem coisa que é ruim, que a qualidade do ensino é ruim. O que você acha que daria pra ser feito pra melhorar a qualidade do ensino?

A1: Acho que era professores com mais capacidade, como o Pr1, assim. Nós vamo ter o SARESP, aí ele já tá ensinando a gente como é pra gente fazer. Vai ter muito esse negócio de leitura, vai ter texto, aí a gente tem que responder uma pá de pergunta sobre o texto. Ele já tá ajudando a gente, já tá explicando pra gente poder passar. Acho que devia ter professor igual a ele. Tem uns que já chega, passa uma pá de lição, manda a gente fazer e senta e ainda fala que tem que fazer.

$K$ : Então, não ensina, mesmo?

A1: Só passa porque tem que passar. Pra não ficar sem fazer nada.

$K$ : A gente tava falando das coisas que a gente conversou nos encontros em grupo, você falou o que mais te interessou. Você acha que teve algum assunto que era importante falar e não deu pra gente falar, você acha que tem mais alguma coisa importante pra falar sobre adolescência, sobre o que a gente conversou?

A1: O negócio de sexualidade, eu acho.

$\mathrm{K}:$ Ah, de sexualidade. É uma coisa muito importante, né?

A1: É.

K: $O$ que você acha que a gente poderia discutir sobre sexualidade?

A1: Por exemplo, falar... Eu sei que todo mundo sabe, só que nem toda pessoa quer ouvir. Acho que tem que usar camisinha, as menina usar anticoncepcional. Esses negócio assim, sabe? Que não vai ter risco.

$K$ : E sobre isso não é muito conversado nas escolas? 
A1: É muito difícil. Quando eu tava na sexta série... Não lembro se foi o ano passado. Foi o ano passado, a gente tinha uma professora de educação artística e ela começou a dar aula de sexualidade pra gente, era superlegal! Ela fazia a gente fazer desenho, tipo assim, um cartaz pra diferenciar o que era namoro e ficar. Aí nós fizemos, dividiu em grupo, nós fizemos. Era superlegal, todo mundo falava! Tem toda a diferença entre sexualidade e outras coisas, ela falou. Nossa, era superlegal a aula dela! Todo mundo participava, a gente fazia perguntas no papel, ela pegava e não falava o nome da pessoa, que é muito importante, porque tinha umas pergunta muito feia. Quando ela falava, tinha umas pergunta muito feia, só que não tinha o nome da pessoa, senão fica chato.

$K$ : Então você acha que precisava ter mais conversa sobre sexualidade na escola?

A1: Por causa que a maioria das pessoas não tem informações sobre isso, ou tem vergonha de perguntar. Acho que a escola também deveria tomar a iniciativa, porque todo mundo fica reclamando que tem uma pá de jovem grávida, esses negócio. Umas são porque ela quer, mas às vezes não tem informação e tem vergonha de perguntar. A maioria das minhas amigas aqui não conversa sobre esses negócio. Aí vou conversar com minha mãe, minha mãe explica.

K: Então você tem um diálogo bom com a tua mãe?

A1: Orra!!

K: Isso ajuda bastante, né?

A1: Quando eu tinha sete anos, por aí, minha mãe começou a falar de menstruação comigo. Aí eu fiquei menstruada e nem foi assim chocante. Fiquei com nove anos e falei: "Mãe, vem aqui". Ela ficou toda feliz, mas eu não fiquei chocada porque eu já sabia desses negócio.

K: Ela preparou você pra isso, então?

A1: Até meu irmão, quando ele era menor, foi lá e pegou um absorvente: "O que é isso?" Minha mãe explicava. "Pra que é?" Minha mãe falava também, porque não é só as menina que tem que saber, é os menino também.

$K$ : Então é uma coisa importante pra se falar na escola também, né?

A1: Na escola, fora, em qualquer lugar. É super importante!

$\mathrm{K}: \mathrm{O}$ que você acha que precisava ter mais na escola, além de conversas sobre sexualidade?

A1: Ensino bom também, os professores acreditar nos alunos e respeito.

K: Respeito é uma coisa que vocês falam bastante.

A1: Que não tem nessa escola. Os meninos às vezes faz umas brincadeira mó besta, de um ficar batendo no outro, brincando, mas pode ser que vire uma coisa mais assim... Um dá um soco na cara, o outro também quer ir lá dar.

K: Você tinha falado que isso de respeito tem que ser entre os alunos e entre os alunos e professores, né?

A1: É. Porque tem muito esse negócio de um xingar o outro.

$K$ : Vocês também falaram muito sobre preconceito.

A1: Isso que eu ia falar agora.

K: Você ia falar? Então o que você ia falar?

A1: Tem preconceito também pra gente mudar. 


\section{$\mathrm{K}:$ Mudar como?}

A1: Tipo assim, você estuda com uma pessoa, ela é negra, aí o pessoal: "Vai, sua neguinha". Ou que ela tem cabelo ruim, esses negócio. Não é só aqui na escola, é em todo lugar que tem isso, fora dela mesmo. Tinha que mudar, mas só que acho que não tem um jeito da gente falar pra pessoa mudar, porque é difícil se conscientizar!

K: Então, é difícil fazer com que as pessoas pensem sobre o preconceito... Você acha que dá pra fazer alguma coisa pra mudar isso?

A1: Eu acho que dá, mas não tenho a menor idéia! Acho que dá, se todos ajudassem. Porque não adianta só um, tem que ser todo mundo, senão, não adianta nada, vai ficar como tá hoje.

K: No último grupo a gente estava falando sobre aquela idéia da música, que os jovens têm que se unir, mas, ao mesmo tempo, vocês pensavam "ah, os jovens não têm poder nenhum". Ou então "os jovens têm que se unir, mas eu não, eu não tenho poder nenhum, o que eu posso fazer?" Vocês estavam naquela coisa de achar que o jovem tem que se unir, mas que não dava pra fazer nada pra mudar. $O$ que você pensa disso?

A1: Eu acho que a gente tem poder, sim, mas tem que saber usar. Tem que usar com atos bons, sabe? Tem que fazer uma coisa que a pessoa fica assim: "nossa, um adolescente fez isso?!" É difícil, mas você tem que fazer isso, aí ele vai se tocar mais. Agora, os adolescentes só fazem as mesmas coisas: é ficar pichando escola, quebrando tudo. Eles têm que fazer tipo assim, vê uma coisa quebrada, ia lá, unia uma turma: "vê se nóis consegue arrumar isso daqui". Aí todo mundo vai falar: "Nossa! Um adolescente deu essa idéia?!" Tem que ter umas idéias assim diferente.

K: Pra tentar romper um pouco com essa idéia de que adolescente não pensa nada..., começar a mudar o jeito de olhar para o adolescente?

A1: É.

K: Por falar em jeito de mudar o olhar do adolescente, vocês fizeram o PAN aqui, o Partido dos Adolescentes da Nação. Vou pedir pra você dar uma lidinha aqui e ver se você tem mais alguma idéia, mais alguma coisa pra colocar.

( $A$ aluna lê a primeira versão do PAM)

K: E aí?

A1: Eu acho que [o que ta escrito aqui] não devia ter só em São Paulo. Devia ter em outros Estados também. Porque não é só aqui que acontece isso. "Diminuição dos impostos para a população viver dignamente". Só em São Paulo? Oportunidades de emprego só pra quem tá em São Paulo? Tem gente que tá em outro lugar que precisa também. Então não pode ser só em São Paulo.

$K:$ Teria que ser no Brasil todo?

A1: É.

K: E de idéia pra melhorar, você tem mais alguma que não está aí?

A1: Podia não só ter um curso grátis. Podia ter tipo um curso novo.

$\mathrm{K}$ : Esse curso profissionalizante?

A1: É, mas com um preço mais assim que dá pra pagar.

K: Que as pessoas pagassem pouco, mas pagassem. Por que? Que diferença você acha que tem entre poder pagar um cursinho ou ser de graça? 
A1: Sei lá. Você pagando, você pode tá ajudando pra melhorar. Por exemplo, - computador ta quebrado... você pagando 20 reais por mês, por exemplo, já dá pra arrumar bastante coisa, dá pra comprar mais cadeira, dá pra ficar maior o curso $e$ pra mais pessoas. A gente não vamo ajudar? A gente quer que ajude a gente, mas não quer ajudar eles?

K: Ah, entendi. Uma colaboração mínima...

A1: Uma colaboração mínima, assim.

K: Aqui nas propostas pra "Educação" vocês colocaram uma coisa pra vigiar os alunos ${ }^{1}$. O que você acha disso?

A1: Acho que não precisa tudo isso.

$\mathrm{K}$ : De instalar câmera?

A1: É. Não tem porque, eu acho. É só a pessoa ficar de olho. $O$ aluno não vai nem poder conversar, vai tá tudo gravando lá? Isso daí já é abuso, eu acho.

$\mathrm{K}$ : Se isso aqui não é o ideal, o que você acha que daria pra fazer pra melhorar o ensino mesmo, pra ter um ensino de qualidade?

A1: Ter professores com vontade de ensinar e com disposição também. Tens uns que vêm, ensinam rapidão e aí sai. Tipo assim, semana que vem vai ter uma prova, então tem que repassar aquela matéria pro professor explicar. Eles dão a matéria o mês passado, aí vão dar a prova dessa matéria esse mês?! A gente não vai lembrar de nada!

K: É muito tempo de intervalo...?

A1: Não que aconteça, mas pode ser que aconteça isso também. $E$, eles fazerem uma reunião, tipo assim, quem quiser ir lá falar com o professor, "gostaria de saber isso daqui, que eu não entendi" aí falar pra ele explicar.

$\mathrm{K}$ : Ter algum espaço para o aluno conversar com o professor?

A1: A maioria das vezes os alunos têm vergonha também de perguntar alguma coisa. Por que aí o pessoal fica: "Ai, que burro, que burro".

$\mathrm{K}$ : Os alunos, mesmos, falam assim?

A1: É. Também acho que deveria fazer isso.

K: Um espaço pra o aluno poder tirar dúvida, então.

A1: Não é só isso de ficar vigiando, aí fica chato pro professor e pro aluno também, pra quem estiver na escola fica muito chato. Esse negócio de ter um ajudante é da hora. Se o professor ta ensinando, você fala: "Você pode me ajudar?" Se você quer uma opinião, uma ajuda, você fala com o ajudante, o professor vai estar ocupado.

K: Então esse ajudante que você tá falando não é só um inspetor de alunos que vai cuidar da disciplina?

A1: Vai ajudar também nos exercícios.

K: Tirar dúvida também, ensinar na sala de aula, né? Ajudar a passar 0 conteúdo também...

A1: Olha só, pensa bem, se ficar um ajudante só olhando pra gente, se você conversar pra pedir uma borracha, já vai tar o ajudante falando um monte, e vai

\footnotetext{
${ }^{1}$ Na primeira versão desse documento, os alunos haviam escrito uma proposta de instalar câmeras de vídeo na escola para vigiar os alunos.
} 
tar as câmeras! Acho que não devia ter câmera. De repente é melhor, tipo assim, lá no fundo da quadra, onde os meninos fica fumando maconha, aí sim devia ter. Agora, na sala de aula não tem porquê.

K: Então você tá falando de outras coisas que poderiam ajudar mais na qualidade do ensino do que ficar colocando câmera, que você acha que não ia resolver, só iria atrapalhar.

A1: Eles podem muito bem quebrar também a câmera. Vai ficar gastando dinheiro à toa? Aí tem que comprar outra ou arrumar aquela. Aí depois vai lá e quebra essa outra. Vai ter que ficar comprando?

K: Então, pra você, o importante seria ter professor que tirasse mesmo a dúvida pra garantir que o aluno aprenda?

A1: Que ele aprendeu mesmo. E tem a coisa da prova com consulta. Eu acho ruim prova que tem consulta.

K: Acha que não deveria ter prova com consulta?

A1: Não. É assim: a gente só lê o texto e escreve, não vai aprender nada desse texto!

K: Então, se consultar, não tá aprendendo porque já tá ali. Então você acha que deveria ser prova sem consulta.

A1: Apesar que é difícil, só que a gente também tem que se esforçar. Se eu for fazer uma prova sem consulta, não vou fazer nada, porque a gente já está acostumado desde a quinta série aqui, só prova com consulta, com consulta, com consulta. Quando tiver uma sem consulta, como você vai fazer? Teve um dia que a professora passou uma prova de geografia sem consulta, era uma pergunta só e eu não consegui fazer. E era em dupla ainda, a gente não conseguiu fazer a prova.

K: Você tá falando, então, que a prova não está avaliando se você sabe ou não, porque não é se você sabe ou não, é se tá ali no caderno ou não está; é isso?

A1: É. E, também, ter uma prova para todas as séries, ia ser super bom!

$\mathrm{K}$ : Como assim?

A1: Tipo assim, de tudo que você aprendeu o ano inteiro, mas aí podia ter uma consultinha até. Ia ser ótimo isso também, mas aí podia até ter uma consultinha sobre as coisas mais difícil, sei lá... . Acho que ia ser bom, porque vê o ensino, como que tá, se a pessoa aprendeu. Não adianta dar prova só pra a oitava série.

\section{K: O SARESP?}

A1: É.

K: Você acha que deveria ter em outros anos também?

A1: Pra todas as séries.

K: Você tinha falado que acha que tem para a sétima série, também.

A1: Tivemos. Mas não é todos os anos. $O$ ano passado teve, esse ano não sei se vai ter. Nós fizemos, aí o pessoal passou. Só alguns não passou por causa de falta. Não é sempre também que passa na sétima série. Minha amiga repetiu por falta. Então não é isso que todo mundo vai passar. Tipo assim, vinha um dia, faltava dez. Aí, como eles vão fazer que a menina passe? Mas também tem umas meninas lá que nunca vem e que passou! 
K: Você sente que precisaria ser mudado o jeito de avaliar; de ensinar e de avaliar?

A1: Acho assim: se a pessoa faltar muito tempo, devia tirar o nome dela e dar oportunidade pra outras pessoas. Tem uns que nunca vêm, só tá com o nome na chamada. Acho que devia tirar, porque tem uma pá de gente que quer estudar e não tem vaga.

K: Vamo pensar num caso: a pessoa falta, falta, falta e passa, aí ela vem no outro ano. O que acontece no outro ano? Faz a mesma coisa?

A1: Tem gente que nunca vem e passa de ano, não sei como! Sendo que outra da mesma sala faltou, faltou, faltou e repetiu!

$\mathrm{K}$ : A gente tava falando sobre repetir, sobre a situação da $8^{a} \mathrm{~A}$, por exemplo, que juntaram os alunos que repetiram. Aí teve gente que estava dizendo que quando não tem ensino bom é culpa do aluno, teve gente que disse que é culpa do professor, a gente discutiu sobre aquela história de que a culpa é da família ou então porque é pobre. Você tava dizendo que não existe um culpado para o que acontece, né?

A1: $O$ culpado é todos. Acho que depende de todos. A família não vai ser culpada porque a pessoa não tá indo na escola, ela não vai saber se a pessoa foi ou não, pra ela a pessoa vai tá na escola. Agora, pode ser que não esteja, só que pra família ela tá. Só que ela também tem que ir ver se o filho tá indo pra escola. Mas não ficar trazendo sempre o filho até a porta da escola; devia vir de vez em quando, de surpresa, pra ver se o aluno tá na sala. Ia ser bom, também.

$K$ : $E$, disso tudo que a gente conversou, tem mais alguma coisa que você queria falar?

A1: Não, acho que é só isso.

K: A gente tava falando [em um encontro] sobre reunião de pais. Os pais vêm, conversam com os professores, às vezes o professor fica reclamando que 0 aluno faz bagunça e tal. $O$ que você acha das reuniões de pais?

A1: Acho que é mais ou menos, porque nem todos os pais vêm. Os alunos que precisam mais, os pais não vêm pra reunião. Acho que devia vir todos!

$K$ : $E$ o que você acha que deveria acontecer nessa reunião pra ajudar também na qualidade do ensino?

A1: Os pais reclamar também.

$\mathrm{K}$ : Reclamar de quê, do ensino?

A1: Do ensino, das coisas que tem na escola. Eles iam ouvir, eles não iam ter como ficar falando um monte.

$K$ : Não ia ter como ficar falando o quê?

A1: Um monte.

$\mathrm{K}$ : De quem?

A1: Do adolescente. Eles iam ouvir.

$K:$ Ah, entendi. Eles, professores, iriam ouvir --

A1: Os pais dos adolescentes!

K: Então, você acha que eles ouvem mais os adultos do que os adolescentes, né? Se é o pai falando, aí o professor leva mais em consideração...

A1: É. 
K: Você acha que os pais deveriam falar e que os pais de vocês têm idéia de se o ensino está bom ou não está bom...

A1: Minha mãe acha que o ensino tá horrível aqui! Tanto que no ano que vem não vou vir pra cá não. Acho que vou estudar na escola E5, que é um pouquinho melhor. Aqui tá muito ruim!

K: Você acha que o problema maior dessa escola é o quê?

A1: Acho que é o ensino e educação.

$K$ : Educação dos alunos...

A1: É, com os professores.

$\mathrm{K}$ : $A h$, do respeito, que você tava falando. $E$ do ensino, você quer acrescentar mais alguma coisa?

A1: Só esse negócio da reunião. Se ele trabalhar, fala assim: "Vai ter reunião do meu filho, vou ter que ir, daqui a pouco estou de volta". Falava a hora $e$ ia. Porque com os mais bagunceiros, o professor quer conversar, mas os pais não vêm, aí complica. Acho que eles devia dar opinião também de melhorar a escola. Igual o banheiro, tá tudo quebrado, cheio de pichação. Deveria falar também. E os alunos ajudar, também, porque não adianta o pai falar o os alunos ficar bagunçando.

K: É aquilo que você falou, uma participação de todo mundo que faz a escola, todo mundo colaborando...

A1: Os pais podiam falar assim "Ó, minha filha ta dizendo que o ensino não ta muito bom, ela tá reclamando que os professores num tão ajudando ela, eu queria que você desse um pouco mais de atenção pra ela".

$\mathrm{K}$ : Ajudar pra que o professor dê mais atenção pro aluno--

A1: Só que não dar atenção só pra um; precisa dar pra todos; mas pros que vão procurar ele [o professor], porque os que não vão procurar, não querem nada com nada!

$\mathrm{K}$ : Aqueles alunos que demonstrarem interesse...

A1: Agora os que não tão [demonstrando], eles também deveriam ajudar, mas ajudar pouco.

K: E os pais também poderiam ajudar nisso, então? Falar pros professores...

A1: É, porque os professores também não sabem o que a gente tá pensando, né? Eles não vão adivinhar! Podem pensar "Eu acho que eles tão achando que minha aula ta boa", mas na realidade, não. Não tá boa.

K: Então, você também tá falando que ia ser importante os professores saberem o que os alunos estão pensando...

A1: É, porque eles não sabem. Acho que eles também deviam fazer reunião com os alunos!

$\mathrm{K}$ : Ah, então isso é uma outra coisa. Além de o aluno conversar com o professor sobre o que não está conseguindo aprender, poderia ter conversa de alunos e professores pra dizer--.

A1: Tipo uma reunião de alunos, como de pais, só que de alunos com os professores.

K: Pra poder dizer o que eles estão achando, o que acham que tá ruim, o que acham que tá bom? 
A1: É. Porque se começar a puxar... Que nem aquele dia, você começou a puxar, e todo mundo já foi falando.

$\mathrm{K}$ : Que dia?

A1: Do primeiro encontro.

K: Ah, do encontro em grupo. Um começa a falar uma coisa que está incomodando e aí todo mundo fala...

A1: Todo mundo começa a falar. Acho que deveria também, porque aí eles iam entender o que a gente tá querendo dizer pra eles! Que a gente não diz, né? Então acho que deveria ter.

K: Você tá falando que vocês não falam e eles não ouvem, então fica sem comunicação...

A1: Deveria ter uma reunião, fazer umas perguntas tipo assim: o que você acha que devia melhorar? O que você tá achando da escola? Dar umas idéias. Igual aqui. Podia dar uma folha pra gente responder. Ia ser uma boa idéia! Aí devia falar de tudo, do que tá acontecendo... de professor-aluno, desses negócios.

K: Você acha que poderia ser escrito ou conversado.

A1: Ia ser uma boa, eu acho. Aí eles iam entender a gente, iam ouvir também! Acho que ia ser uma idéia boa, também. A gente não pode só ficar esperando pelos outros fazer pela gente. A gente também tem que dar as idéias da gente, né? Eu acho que era isso!

K: Então, tem mais alguma coisa que você queria falar?

A1: Só isso.

$\mathrm{K}$ : Muito obrigada pela sua participação, A1! 


\section{ENTREVISTA INDIVIDUAL COM A ALUNA ADRIANA (A2)}

K: A2, dos encontros em grupo, você participou do primeiro, que foi bem completo, pegou vários assuntos. A sua participação foi bem importante, você falou bastante coisa, trouxe contribuições. Então, só para você saber, de uma forma geral, nesses encontros a gente falou no primeiro sobre como era pra vocês ser adolescentes e aí vocês já começaram a falar de como era ser aluno adolescente, já começaram a falar da idéia dos adultos, do que vocês acham que os adultos acham dos adolescentes, a imagem desses adultos, já começaram a falar da relação entre os professores e entre os alunos mesmo, direção, coordenação. Vocês já começaram a falar de muita coisa. Nos outros encontros a gente foi aprofundando um pouquinho esses assuntos. Teve um outro encontro em que eles escreveram a proposta do Partido dos Adolescentes da Nação, que eu trouxe pra você ler, e a gente discutiu as letras das músicas. Então, nesse primeiro encontro em que a gente falou sobre tudo isso dos adolescentes, da imagem dos adultos e tal, a coisa mais central foi como era para vocês ser adolescentes, e vocês levantaram coisas boas, coisas ruins. E do grupo, naquele encontro, você era a única pessoa que estava trabalhando ou já tinha trabalhado, alguma coisa assim. E agora você estava me contando que você conseguiu um outro emprego. Como é esse seu novo emprego?

A2: Eu trabalho como atendente numa vídeo-locadora.

K: É à tarde, à noite?

A2: É das duas e meia às sete horas da noite.

$\mathrm{K}$ : Como é pra você essa experiência de trabalhar e estudar, o que você acha dessa experiência?

A2: Acho que eu me sinto valorizada! Trabalhar e estudar não é qualquer um que leva! E não é meu primeiro emprego, eu já trabalhei como garçonete, saía meianoite de lá pra acordar às seis horas. Eu tava agüentando muito bem, só que eu tava achando que tava me atrapalhando muito aqui na escola, aí saí e arrumei esse outro.

$\mathrm{K}$ : Porque fica até sete e meia da noite; e você acha que vai dar pra conciliar trabalhar e estudar?

A2: Dá tempo de ler um livro, olhar o caderno.

$K$ : Eu queria perguntar se isso, se você acha que atrapalha ou não o estudo.

A2: Não tá me atrapalhando em nada.

K: Porque você tem o tempo da noite--

A2: Tenho o tempo da noite pra estudar.

$\mathrm{K}$ : Então, essa experiência pra você é uma coisa boa.

A2: Ah, é claro que é! É, sim!

$K: O$ que tem de bom nessa experiência de trabalhar?

A2: De trabalhar?

$K$ : O que te faz achar que é uma coisa boa?

A2: Ah, dinheiro é bom, e [também porque] você tá aprendendo.

$\mathrm{K}$ : É mais um aprendizado...

A2: É.

K: No Partido dos Adolescentes da Nação, logo no comecinho, eles disseram que escreveram pra dizer pro mundo que eles não são adolescentes "aborrecentes", 
que eles têm idéias na cabeça, têm propostas. Vocês, não é nem eles, é vocês. E aí eles colocaram que eles se sentem injustiçados, julgados pela situação financeira, por não ser rico, por ser pobre. $O$ que você acha dessa idéia de ser julgado injustamente por ser pobre?

A2: Eu acho que isso não é só na adolescência!

$K$ : Não é só na adolescência?

A2: Claro que não! Quem falou isso, eu acho que pensou assim: quando vai numa festa, vai simples e aí chega lá tem os boyzinhos que já quer provocar, quer bater. Acho que é isso. Mas não é só na adolescência, é em geral.

K: Uma coisa que a gente discutiu bastante foi também sobre essa idéia de quando o ensino não é de qualidade, quando não se aprende e quando se repete, perguntando se existe algum culpado por isso. $O$ que você acha?

A2: $O$ único culpado é o aluno, né?

$K$ : Você acha que é o aluno.

A2: É o aluno. Mas tem professor que não ensina muito. Tem uma professora aqui na escola, que a gente falou muito dela no primeiro encontro, ela é assim: ela passa na lousa, explica uma vez, já é pra todo mundo aprender e no final do bimestre só mostra o caderno e tira $A$. Copiando a lição tá bom demais, só que não interessa se você aprendeu ou não. Acho que a culpa é do professor também.

$K: E$ do aluno. Como é essa história do aluno ser responsável por isso, o que acontece?

\section{A2: Como assim?}

K: Você falou que acha que tem um culpado quando não aprende, quando repete, o aluno é culpado.

A2: Eu acho que o professor é mais culpado.

$\mathrm{K}$ : Mais do que o aluno?

A2: Tem professor que não tá nem aí e o aluno também já não tá nem aí..., já era. E tem professor que é bem rígido, como o $\operatorname{Pr} 1$. Então, se ele pega no pé de um aluno, por mais desinteressado que o aluno seja, ele vai procurar se esforçar também!

$\mathrm{K}$ : Então a coisa é mais do professor do que do aluno?

A2: É, na minha opinião, é.

$K: O$ que você acha do ensino aqui dessa escola?

A2: Acho que tá bom.

$K$ : E por que tá bom?

A2: Por causa dos professores. Os professores são bons. Tirando uma.

$\mathrm{K}$ : Aquela que você falou. Entendi. Tirando ela, você acha que os outros conseguem passar o conteúdo?

A2: Conseguem. Explicam direitinho, passam trabalho, pesquisa... e você aprende.

K: Se a gente pensar quando a educação não tá boa, quando o ensino tá ruim, você acha que existe alguma coisa que se possa fazer pra melhorar essa situação do ensino?

A2: Eu acho que só mudando os professores! Eu estudei numa escola que o professor chegava, todo mundo quieto, o professor chegava e começava a ler 
revista, sentado, não ensinava nada. O que a gente pode fazer se ele é o professor e não quer ensinar? A gente não pode fazer nada! Só chegar em casa e estudar.

K: Então, pra melhorar a situação do ensino precisaria mudar o professor, né?

A2: $E^{\prime}$

K: O que é um bom professor pra você?

A2: Um bom professor é o Pr1. Ele é um bom professor, ele manda o aluno ir na frente pra falar o que não entendeu, passa pesquisa, manda você explicar o que você pesquisou, passa muita leitura. Mas é professor de português, né? Tem que ser bem rígido!

K: A gente estava falando do presente, de como é pra vocês ser um aluno adolescente, só que eu queria pensar um pouquinho no passado. Você já falou de uma outra escola em que estudou, da diferença que tem. Mas você começou a estudar na primeira série ou no prezinho?

A2: No prezinho.

K: Você se lembra de alguma coisa do prezinho, alguma coisa de como era?

A2: Lembro, assim, que só brincava, só! (Risos) Brincava com massinha... só.

K: Era fácil ser aluno na infância?

A2: A-hã.

$K:$ E na primeira série você começou a estudar onde?

A2: Não foi aqui em São Paulo.

$\mathrm{K}$ : Foi onde?

A2: Foi em Fortaleza, eu morava com minha avó, foi lá.

K: Você ficou lá da primeira até que série? escola.

A2: Até a terceira. Aí vim pra cá, estudei aqui no... Esqueci o nome da

$\mathrm{K}$ : Mas é uma aqui por perto?

A2: É aqui perto do (...).

K: De primeira a terceira série, você era aluna e era criança, ainda não era adolescente. Como era ser aluna criança?

A2: Era bom..., não tinha muita responsabilidade.

$K: E$ como os professores tratavam vocês alunos?

A2: Deixa eu lembrar. Hum... Tratava bem, tratava bem.

$K:$ Não gritava, não fazia nada?

A2: Não lembro! (Risos)

K: Mas na quarta série você lembra mais ou menos de como era? Aí você já estava aqui perto do (...).

A2: Você tava falando no prezinho, como a professora tratava. No prezinho minha professora era ótima, eu adorava ela!

K: E você não lembra da primeira a terceira série, marcou mais o prezinho.

A2: $E$ eu era bem menor!

$K$ : Era bem menor e marcou mais. $E$ o que mais te marcou dessa experiência no prezinho?

A2: Acho que tudo! Gostava da professora, dos amigos, de todo mundo de lá eu gostava! 

lembra?

K: Então da primeira a terceira você não lembra. Mas e da quarta você

A2: Lembro que estudei aqui pertinho.

$\mathrm{K}:$ Você já estava com quantos anos?

A2: Tinha uns sete ou oito.

$K:$ Acho que devia ser dez, não?

A2: Dez?

$\mathrm{K}$ : Na quarta série se costuma estar com dez anos mais ou menos, a não ser que tenha repetido ou entrado mais velha.

A2: É, tinha uns dez. Os professores, não dava nem pra você decorar o nome, porque mudava direto!

$K:$ Ah, na quarta série já mudava?

A2: Mudava de professor direto, direto.

$K$ : Então não tinha uma relação muito próxima.

A2: Não, com professor não tinha.

K: Você acha que muda alguma coisa quando você é aluno criança e quando é aluno adolescente?

A2: Demais!!

$\mathrm{K}: \mathrm{O}$ que muda?

A2: Muda tudo!! Muda a relação entre o aluno e o professor, o professor acha que... Ah, não sei nem como falar... O professor acha que você é vândalo, essas coisas. E da criança não vai pensar isso.

K: Pensa da criança, o quê? Que imagem você acha que o professor tem das crianças?

A2: Quando eu vejo uma criança, eu falo: "Ai que bonitinho!". Ninguém vai falar pro adolescente: "Ai que adolescente bonitinho". Ninguém vai falar.

K: Tem toda essa diferença. Então você acha que os professores tratam diferente os alunos, assim.

A2: Criança é inocente e adolescente já......

$K$ : Já tem toda essa diferença. E o que você espera do teu futuro?

A2: Eu não queria fazer faculdade.

$K:$ Por que não?

A2: Ah, eu queria casar. Minha irmã fala assim: "Que louca, casar". Eu quero casar, acho que é difícil fazer faculdade. Eu estava pensando em fazer educação física ou biologia. E ser feliz!

K: Então você pretende casar, também.

A2: Primeiro eu queria ter um filho e que o marido sumisse; que o pai sumisse. Eu quero só o neném, só.

$K$ : Você tinha começado a falar isso no primeiro encontro, ficar sozinha com o bebê, não ter pai; por enquanto, você pensa em ter um bebê e não ter um marido.

A2: É bom ter, né? Porque como o adolescente é discriminado, a mãe solteira também é, tem muito preconceito sobre isso. É bom ter um pai, mas também é chato.

K: Você acha que é chato o quê? Ter o pai?

A2: Não é ter o pai, é ter um marido ([...?] - trecho incompreensível). 


\section{K: Então que profissão você pensa ter?}

A2: Quero ser bióloga.

K: Você estava falando que queria fazer biologia ou educação física. E pra isso o que precisa fazer?

A2: Precisa estudar muito!

K: Então você pensa em terminar o terceiro colegial... Agora você está na oitava, então daqui a uns três anos você termina o terceiro colegial.

A2: Mais quatro de faculdade.

$\mathrm{K}$ : E pra entrar na faculdade o que você pensa?

A2: Eu penso assim: se não tiver dinheiro pra entrar numa faculdade particular, tem que ter peito de ferro, peito de aço pra poder encarar tudo que o pessoal que faz faculdade na USP encara.

$\mathrm{K}$ : Tudo o quê? $O$ que você acha que as pessoas encaram?

A2: $A i$, não sei. Acho que encara assim: pra fazer uma inscrição leva um dia inteiro, ficar esperando. Também tem muito preconceito ali dentro.

$\mathrm{K}$ : Você acha que tem preconceito com relação a quê?

A2: Aos negros! O professor $\operatorname{Pr} 1$ mesmo falou que sofreu muito preconceito!

$K$ : E pra entrar lá na USP, numa universidade pública, o que você acha que tem que acontecer?

A2: Como assim?

K: Você pensa em fazer cursinho ou não, tentar nas duas, particular $e$ pública, tentar juntar dinheiro para a particular ou só tentar na pública?

A2: É muito caro! Mas até que compensa... se conseguir dinheiro.

K: Aí você pensa em fazer a faculdade, na particular ou na pública. Particular só se você conseguir o dinheiro.

A2: Só se tiver dinheiro.

K: Então o professor Pr1 é um exemplo de alguém que fez uma universidade pública. Você conhece mais alguém?

A2: Tem duas amigas da minha mãe, uma estava fazendo a de Letras, só que ela saiu.

K: Então essa é sua esperança para o futuro, ser bióloga e ficar com seu filhinho, com seu bebê.

A2: Filho vai ser lá pros meus 30 anos, agora não.

$\mathrm{K}$ : Só depois que terminar a faculdade.

A2: Só depois que terminar a faculdade. Se tiver filho, vou dar tudo pra ele que eu não tive. ler.

K: Agora eu gostaria de te mostrar as propostas do PAN. Vou pedir pra você

(A2 lê o documento do PAM)

$\mathrm{K}$ : Lendo as propostas do PAN, você disse que esse Dia do Adolescente não devia ser uma vez por mês...

A2: [Devia ser] uma vez por ano.

$K$ : É muita coisa uma vez por mês?

A2: Lógico!

$\mathrm{K}$ : O que você achou do que eles colocaram? 
A2: Achei que foi bem pensado, bem planejado, bem colocado. Só que esse negócio sobre a saúde tudo foi o Serra que falou.

K: Então tem as propostas do Serra aqui. E essa coisa da educação, o que você acha de colocar ajudante pra manter a disciplina e câmera nas escolas?

A2: Sinceramente, eu acho que não vai adiantar de nada!

K: Não adianta.

A2: [Não faz diferença] Só a diretora mesmo é que faz. Não vai adiantar nada.

K: Não era isso que iria melhorar a qualidade do ensino...

A2: Não. Nem câmeras. Câmera poderia até ser para segurança, mas para vigiar os alunos... Já tem um monte de grade! Câmera...

K: Então o que você acha que deveria colocar aqui no lugar da educação ao invés disso?

A2: É como eu falei, com respeito a educação é o professor, só isso.

$\mathrm{K}$ : E como dá pra melhorar o professor?

A2: Eu acho que tem que analisar bem os professores e... tem que mudar 0 professor.

K: E um professor que não está sendo muito bom, tem como ele melhorar?

A2: Eu acho que não, porque aí já vem anos de experiência, não é a primeira escola que ele ensina. Se ele saiu de outra escola é porque não está ensinando muito bem, mesmo.

K: Pra ele aprender a ensinar melhor, você acha que não tem como? Se ele não ensina bem, não vai ter como ele ensinar bem?

A2: Ah, tem, é só querer! Se ele teve capacidade de aprender e se ele é professor, tem que ter capacidade de ensinar. Ensinar direito, né?

$\mathrm{K}$ : E como ele iria aprender a ensinar direito, o que precisaria acontecer pra ele começar a ensinar direito?

A2: Acho que ele perder o emprego, né? Aí ele vai se conscientizar que não estava ensinando direito e vai se esforçar pra não perder o emprego.

$\mathrm{K}$ : Aí ele precisaria se esforçar mais? Você acha que, se ele se esforçasse, ele conseguiria um professor melhor. Todo professor que não é bom se se esforçar vira um bom professor?

A2: Mas é como a gente tava explicando no primeiro encontro, que esses professores bons como o Pr1 é menos valorizado aqui na escola. Ele ensina e a professora não ensina direito e todo mundo adora ela.

K: Ah, é? Por quê?

A2: Porque ela fica sentada na dela, deixa todo mundo zoar!

$K:$ Ah, entendi. Então você acha que acham melhor assim: se não ensina, não preciso aprender também. Você acha que os alunos têm essa idéia?

A2: Tem gente que pensa assim: "Fala sério! Tem mais três anos por aí, o que eu não aprendi agora posso aprender lá na frente". Quando chegar lá na frente já é tarde.

K: Sobre isso, você tem mais alguma coisa pra falar?

A2: Acho que não. Sobre a violência, eu gostei do que falaram, também.

$\mathrm{K}$ : Mais alguma coisa? 
A2: Da minha parte, não.

K: Então eu queria te agradecer. E queria só perguntar mais uma coisa: o que você acha desses encontros, de participar de encontros assim com essas conversas sobre adolescência?

A2: Acho legal.

K: Por quê?

A2: Às vezes o adolescente... nós queremos falar alguma coisa, não tem com quem e vocês aparecem pra ajudar a gente. Acho que isso é legal.

K: Aqui na escola não tem muito esse espaço de ouvir esses adolescentes?

A2: Imagina!! Só ficou entre nós, mesmo. Às vezes você quer escutar uma opinião de alguém com mais experiência, mas não tem quem. Às vezes a gente vai perguntar... eu já perguntei pra minha mãe e ela "Ah, não vem com essa conversa agora, vai! Vai pra lá! Vai estudar, vai!"

$\mathrm{K}$ : Fica difícil ter essa comunicação...

A2: Fica.

(Bate o sinal)

K: Deu o sinal na hora! $A 2$, obrigada! 


\section{ENTREVISTA INDIVIDUAL COM A ALUNA CRISTINA (A3)}

$K$ : A3, acabaram os nossos encontros e agora vocês vão falar o que vocês quiserem do que aconteceu. Mas antes eu vou fazer umas perguntinhas. Nos encontros em grupo a gente falou sobre muita coisa, a gente falou sobre como é pra vocês ser adolescente, a imagem que os adultos fazem de vocês, como é ser um aluno adolescente, como é a relação de vocês aqui na escola com todos os outros, professores, alunos, todo mundo que está aqui. Vocês escreveram propostas do PAN e também discutiram as músicas. Disso tudo o que você achou? $O$ que você achou de participar desses encontros?

A3: Foi muito interessante, a gente conversou sobre tudo, sobre... (risos)

$K$ : Pode falar o que você quiser.

A3: A gente discutiu um assunto que hoje em dia tá muito interessante pra gente, porque os adultos falam muito da gente e a gente não gosta. Tem adolescente que se revolta com o que eles falam e entram nas drogas. Achei muito legal!

K: Do que a gente falou, o que mais te interessou?

A3: Sobre a convivência com os alunos da escola.

$K: A h$, você gostou mais disso. Por que você achou que isso interessou?

A3: Ah, porque a gente pôde falar do que a gente acha dessas pessoas, 0 que eles pudessem mudar, como seria melhor. Foi legal.

$K$ : Você falou bastante de aluno que não respeita aluno...

A3: Ficou grande, não respeita mais os alunos, os professores, diretores.

K: Você acha que teve algum assunto que a gente não falou, mas você achava que seria importante conversar também?

A3: Acho que não.

$\mathrm{K}$ : Acha que o que vem na cabeça sobre adolescência a gente falou?

A3: $E$, porque a gente falou de tudo, falou até sobre política e tal.

K: Quando vocês estavam falando sobre política, vocês escreveram a proposta do PAN e logo no comecinho da cartinha tava escrito que vocês não queriam ser considerados "aborrecentes", tavam escrevendo pra dizer que vocês têm idéias e que vocês sentem que são julgados pela situação financeira de vocês. $O$ que você acha disso?

A3: Acho que tipo assim: ninguém deve julgar ninguém, né? Só porque é pobre não pode fazer isso e aquilo... Muitas pessoas falam isso, né? Só porque é pobre não tem condições de ter uma casa, de ter um carro, faculdade, ser alguém na vida. Acho que não deveriam pensar isso. Porque se todos têm, tipo assim, se as pessoas maiores que cresceram tiveram chance de crescer, a gente hoje em dia também vai poder. Porque é só estudar. Como todos dizem, é só o estudo mesmo, sem estudo você não é nada.

K: No último encontro a gente estava falando daquele preconceito de que, se o aluno não aprende, a culpa é da família ou então da pobreza.

A3: Acho que isso não tem nada a ver! A família tem que ajudar também, mas não é assim que a família vai ter culpa. Acho que não é isso, não. 
K: Você já ouviu falar disso de que quem é pobre pode ser menos inteligente ou não aprende porque é pobre? Você já ouviu isso assim?

A3: Eu já ouvi bastante.

$K: E$ como é que vem essa fala? O que acontece com quem é pobre?

A3: Ah, fica falando que quem é pobre não tem futuro, só porque estuda em escola pública não aprende nada, só aprende em escola particular.

K: Você não concorda com isso?

A3: Eu não, porque o ensino não vai pela escola, vai pelos professores, vai pelo interesse do aluno também. Então não é por causa da escola.

K: Quando vocês escreveram o PAN, vocês falaram de propostas para saúde e educação. Começaram a falar da educação e não deu tempo de terminar. Pra você, qual é o maior problema da educação hoje?

A3: Ah, é a falta de respeito com as pessoas.

K: Por quê? Como assim?

A3: Porque muitas pessoas não respeitam os outros. Tem um moço varrendo a rua, vai lá e joga lixo na rua, não tá nem aí. Vendo que o moço tá limpando, não custa pegar e jogar no lixo..., não custa. É falta de respeito mesmo. Ficar xingando os idosos, não respeitam os idosos também.

K: E na escola, na educação escolar, o que você acha que é o maior problema?

A3: Xingar os professores, jogar giz no professor, jogar papel no professor, pichar a escola. Ah, de alunos mesmo falta de respeito com o outro, ficar brigando, machucando eles mesmos.

K: Então o maior problema da educação na escola são os alunos?

A3: Os alunos.

$\mathrm{K}$ : Você acha que são eles?

A3: Hum, hum.

$\mathrm{K}: \mathrm{O}$ que você acha que poderia fazer pra melhorar essa situação?

A3: Ah, eu acho que todos poderiam ter consciência e melhorar, vamo fazer isso porque essa escola pode ser até pra meus filhos, todos precisam ter essa consciência de não fazer nada de errado, respeitar pra ser respeitado. É isso.

$K$ : No último encontro a gente falou do que precisaria fazer pra melhorar a educação, pra melhorar a situação. Aí a gente estava falando das escolas, teve gente que falou dos alunos, teve gente que falou dos professores e você falou assim: "Mas tem que ver coisa fora da escola também". Aí você falou da violência na sociedade e também falou assim: "mas o prefeito poderia fazer alguma coisa pra ajudar a situação da educação na escola também". O que você acha que o prefeito poderia fazer?

A3: Ele poderia... Não vou dizer comparecer nas escolas, mas sempre tá ligando, mandando e-mail, não sei, vendo como tá a educação na escola, vendo o que ele pode fazer pra ajudar. Quer dizer, ele pode fazer muita coisa, né? Mas é ter comunicação com a escola, com todas as escolas, pra poder ajudar, ver o que tá faltando. Os inspetores também, precisa ter mais inspetores na escola.

$\mathrm{K}: O$ que você acha que precisa ter mais na escola?

A3: Inspetores, o respeito. Ah, deveria ajudar mais os alunos. Os professores também ter incentivos pra incentivar os alunos. 
K: Mas incentivo como para os professores?

A3: Tipo assim: tem professor que não tá nem aí, quer aprender aprende, se não quer aprender não tá nem aí, passa o aluno sem ele saber, mesmo. Então, eles podiam incentivar mais, ajudar, ver se tá com dificuldade.

$K$ : Essa coisa de passar o aluno sem o aluno saber, mesmo, a gente conversou um pouquinho. Você acha que isso acontece, de aluno que não tá sabendo e acabar passando?

A3: Acho que acontece, sim. Porque os professores são assim: pra eles tanto faz como tanto fez. Eles passam lição na lousa e, se o aluno quer copiar, copia; se não quer copiar, ele também não fala nada, dá nota. Se o aluno fez, fez; se não fez, dá nota do mesmo jeito!

$K$ : Não faz diferença?

A3: Não faz diferença.

K: Eu lembro que vocês estavam falando que vocês têm a sensação de que nem estão aprendendo muito conteúdo e estão passando cada vez mais, né?

A3: É.

K: Estavam falando de gente que está na oitava série e não sabe ler e escrever...

A3: É.

$K$ : Então queria te perguntar sobre a qualidade do ensino. $O$ que você acha sobre o conteúdo que é dado, as pessoas estão aprendendo ou não estão?

A3: Depende do professor. O professor de português mesmo puxa bastante, ensina bastante pra gente. Agora, o professor de matemática, o de ciência, eles brigam pra não fazer bagunça, mas no ensino, mesmo, explicam uma vez só e noutro dia estão passando matéria nova, a gente não entende nada! Aí confunde tudo na cabeça!

K: Pra melhorar isso o que poderia acontecer?

A3: Poderia incentivar mais o aluno, explicar direito, fazer questão que 0 aluno aprenda. Não só o professor também, né? Poderia ter recuperação pra quem não entendesse. Acho que é isso.

$K:$ Tem aqui aula de reforço, não tem?

A3: Tem, mas eu acho que é pra sétima.

K: Ah, pra oitava não tem?

A3: Não, acho que pra oitava ainda não tem.

$K: E$ você sabe como funciona essa aula de reforço?

A3: Não.

K: Você acha que deveria ter um horário separado pra explicar pra quem não está aprendendo, quem não está acompanhando a matéria?

A3: Hum, hum.

$K$ : E seria com os mesmos professores ou não?

A3: Ah, poderia ser com o mesmo professor, porque ele sabe o que ele explicou, sabe o que passou de matéria, conhece os alunos, sabe os alunos que têm dificuldade.

K: E qual a diferença você acha que ia ter entre essa aula de recuperação $e$ a aula normal da sala de aula? 
A3: Porque a aula normal são todos os alunos, né? É aquela bagunça, aquela gritaria, então ninguém entende, ninguém fica concentrado. Agora, reforço ia ser só alguns alunos, porque tem muita gente que entende. Então teria uma diferença, ficariam perto, renderia mais.

K: Daí ia ter um ensino de melhor qualidade nessa aula. Agora eu queria te perguntar uma coisinha. A gente falou sobre como é ser aluno adolescente. Você se lembra do começo da tua experiência na escola? Você começou a estudar na primeira série ou fez pré-escola?

A3: Fiz pré.

K: Você se lembra de alguma coisa no pré?

A3: Não lembro.

K: E na primeira série você estava estudando onde, em que escola?

A3: Na primeira série não lembro porque eu morava em Pirassununga, não lembro o nome da escola.

K: Você lembra alguma coisa dessa primeira série?

A3: Nadinha, nadinha!

$K$ : Você ficou lá até que série?

A3: Até a terceira. Na quarta fui pro E8 e na quinta vim estudar aqui.

K: Da primeira até a terceira série, você se lembra de alguma coisa, de como era ser aluna?

A3: Não.

K: E na quarta já se lembra de alguma coisa?

A3: Na quarta?

K: Você estava no E8, né?

A3: É. Na quarta eu não lembro porque era mó quietinha, ficava só no meu canto, todo mundo ficava me zoando. Aí não lembro muito, não.

$K$ : E você lembra alguma coisa da escola, achava que era uma boa escola?

A3: Eu não gostava da escola.

$\mathrm{K}$ : Por quê? O que tinha de ruim?

A3: Os alunos era tudo da favela, né? Aí todo mundo falava que, só porque era da favela, queria bater nos outros. $O$ ensino também não era bom, não aprendi nada na quarta série. Foi isso.

K: Não é uma escola que no encontro em grupo eles tavam falando que é uma escola muito ruim, foi essa que eles reclamaram, né?

A3: É.

$K$ : Então você estava na quarta série lá e na quinta você veio pra cá.

A3: Hum, hum.

$K$ : E aí na quinta série, você tava com quantos anos?

A3: Acho que 11 ou 12.

K: Aí você lembra de alguma coisa?

A3: Ai, não lembro!

$K:$ Não? Você gostava?

A3: Ah, eu gostava da escola, porque minha prima estudava aqui, aí sempre vinha com ela e voltava com ela. 
K: E teve alguma coisa nesse tempo que te marcou, que chamou tua atenção, que você não esquece até hoje, alguma coisa que aconteceu na sala de aula? Você estava falando que os alunos ficavam zoando porque você era quietinha, né? É a coisa que você lembra até hoje. Então você não lembra de alguma diferença de você ser aluna criança e ser hoje aluna adolescente, tem alguma diferença?

A3: Porque quando é criança, os maiores ficam sempre zoando, né? Agora, hoje em dia, não, hoje, eles já vê que é maior, já respeitam mais. Respeitam assim: não fica mexendo, não fica zoando, porque sabe que já é maior e já sabe o que faz.

$K$ : E tem alguma diferença de como o aluno criança é tratado pelo professor e como o aluno adolescente é tratado?

A3: Tem, porque a criança sempre é mais mimada, sempre o professor tá ali no pezinho e tal. Agora, adolescente, não! Adolescente sabe o que faz, sabe o que é certo e o que é errado, então o professor já... Cresceu, já tá pronto.

$K$ : Não precisa ficar juntinho. Você se lembra disso de o professor ficar junto de você?

\section{A3: Lembro!}

K: Tinha um professor só, né? Não eram vários.

A3: É.

K: Então você acha que isso também faz alguma diferença?

A3: Hum, hum.

K: A gente tava falando agora do passado, a gente falou bastante sobre 0 presente e agora eu queria perguntar uma coisinha sobre o futuro. $O$ que você espera do teu futuro?

A3: Ah, espero, tipo assim, ter uma boa condição de vida, realizar meu sonho que é ser dentista. Ah, poder ter minha casa, meu carro, fazer minha faculdade, ter meu consultório. Ficar bem de vida, como dizem.

$\mathrm{K}$ : Pra você ser dentista o que precisa acontecer?

A3: Estudar muito! Muito!

K: Você vai acabar o terceiro colegial e aí vai fazer o quê?

A3: Cursinho pra entrar na faculdade.

K: Você quer tentar entrar em faculdade pública, particular? O que você quer tentar?

A3: Aí não sei, ai é minha mãe.

$\mathrm{K}$ : Sua mãe? Como assim?

A3: Ah, se eu for pra particular, minha mãe que vai pagar, minha mãe e meu pai. Como eles são separados, aí a gente vê.

K: Você acha que dá pra pagar uma faculdade particular?

A3: Ah, não sei. Meu pai tem condições de pagar. Agora, minha mãe tem mais ou menos. Aí eu não sei..., sei lá; podem dividir, cada um dá um pouco.

$K$ : Então você tem esperança de que você passe numa faculdade, pode tentar passar, né? Às vezes tem bolsa.

A3: É.

$K$ : Teve gente que falou que quer casar. O que você acha disso?

A3: Casar bem depois. Depois que eu tiver minha casa, meu carro, minha faculdade, meu consultório. Só depois. 
$\mathrm{K}$ : Tem mais alguma coisa sobre tudo que a gente falou que você queria falar ou não deu tempo de falar e você achava importante?

A3: Não, acho que não.

$\mathrm{K}$ : Agora eu queria te pedir pra dar uma lidinha no que vocês escreveram do PAN, aí você fala pra mim se tem mais alguma coisa que não está aqui e que você acha que seria importante fazer. Dá uma lida.

(A3 lê a primeira versão do documento do PAN que escreveram em grupo)

$\mathrm{K}$ : Você acha que tem mais alguma coisa pra fazer em algumas dessas áreas?

A3: Não, acho que não. Tá bom.

$\mathrm{K}$ : Acha que assim tá bom?

A3: Tá.

$K$ : Aqui na educação vocês falaram mais sobre manter a ordem, tá um pouco como você estava falando que pra você o maior problema são os alunos, que precisava fazer alguma coisa pra que os alunos respeitassem mais. Então o que tem aqui é um pouquinho nessa direção de tentar controlar os alunos, né?

A3: Hum, hum.

$\mathrm{K}$ : Então, pra a qualidade do ensino, o que poderia mais fazer pra que os alunos aprendessem mais, pra ter um ensino de melhor qualidade?

A3: Ah, os professores poderiam ajudar mais, incentivar o aluno.

$\mathrm{K}$ : Tem aquilo que você tinha falado de ter aula de recuperação, isso também entraria aqui na proposta de educação, né?

A3: Hum, hum.

$\mathrm{K}$ : Tem mais alguma coisa que você queria colocar?

A3: Não.

K: Então isso aqui eu vou mostrar pra cada um e então cada um diz se quer colocar mais alguma coisa. Aí a pessoa vai escrever, depois todo mundo vai ler e aí todo mundo assina, tá bom?

A3: Tá.

K: Muito obrigada pela sua participação, $A 3$ ! 


\section{ENTREVISTA INDIVIDUAL COM A ALUNA TAMARA (A4)}

K: Lembrando um pouco o que a gente já discutiu durante os encontros: a gente falou sobre bastante coisa, falou sobre como era ser adolescente, falou da imagem que os adultos fazem de vocês...

A4: Isso é bem complicado!

$\mathrm{K}$ : ...Sobre como é ser aluno adolescente, sobre a relação entre vocês e todo mundo da escola, os outros alunos, os professores.

A4: Também é complicado com professor, aluno... porque tem gente que é muito folgada. Igual hoje mesmo, quase agora, eu fui levar um livro lá na biblioteca, aí a X1 [uma aluna] me falou: "Eu quase briguei aqui na sala". Aí eu falei pra ela: "Com quem?" "Com a pernambucana". Eu falei: "Ai, X1, por quê?" "Porque ela me chamou de galinha. Falou assim: "Sai da frente sua galinha". Aí ela falou assim: "Ah, não falei nada". Eu falei pra ela: "É bom mesmo você nem brigar, vai acabar se rebaixando e é isso que ela quer". Então você nem briga, se brigar...

$\mathrm{K}$ : Complica, né?

A4: Complica.

K: Então, no outro encontro vocês escreveram as propostas do PAN e aí a gente falou sobre as músicas. $O$ que você achou desses encontros?

A4: Ai, bem legal! Bem legal! Eu não vim nos primeiros, mas desde o momento em que comecei a vir as coisas lá em casa melhorou bastante.

K: Melhorou?

A4: Melhorou.

K: Por quê?

A4: Acho que pelo jeito que tava me desabafando, porque eu sou filha única, aí não tem ninguém lá em casa pra mim conversar. Tem a turma da rua, mas nem dá pra conversar porque eles são muito bestas, só falam assim: "Com quem ta namorando?"... não dá nem pra conversar direito. Aí cheguei e desabafei, minha família achou bem legal! Minha avó falou assim: "Ah, por que não tem mais? Devia ter o ano todo, assim você manera!". Pra você ter uma idéia, eu nem falava com a minha tia, aí depois comecei a falar com a minha tia, ela que veio falar comigo. Eu sou assim, parou de falar comigo, eu não volto a falar não.

$\mathrm{K}$ : Você acha que na escola não tem muito esse espaço pra se conversar sobre adolescência?

A4: Na minha opinião, acho que a escola devia fazer um dia pra falar. Eu sei que os meninos não vão querer falar porque menino só gosta de futebol, mas pra meninas conversar mesmo com alguém, psicólogo, conversar mesmo sobre tudo que tá se passando na escola, como é a adolescência..., sei lá! Acho que isso é legal! Mas não tem como, acho que a direção não aceita, ela acha que o que ela tá fazendo é o melhor pra gente. Eu não acho não.

K: Você acha que precisava.

A4: Precisava mesmo. Se Deus quiser, o ano que vem eu estou indo pro primeiro e a turma que tá na oitava vai passar um bom bocado.

K: Por quê? 
A4: Ah, porque todo mundo fala assim: "Eu gostava de passar pra oitava". É assim. Quando chega na oitava, a gente vê a realidade, é muito mais complicado.

$\mathrm{K}$ : É muito mais complicado porque é mais puxado?

A4: É mais puxado. Os professores começam uma coisa, aí quando a gente tá entendendo já mudam pra outra, do nada, e vão indo e aí a gente acaba se perdendo. No caderno tá escrito assim: Projeto Europeu. Aí tava escrevendo aí no outro dia a professora: "Vamos pra Oceania". Tá bom, meu caderno tem duas páginas do Projeto Europeu e três páginas do Projeto Oceania. É complicado.

$\mathrm{K}$ : Dos assuntos que a gente conversou, o que mais te interessou?

A4: Ah, foi o projeto do PAN!

K: Do PAN?

A4: Ah, foi o que mais me interessou!

K: Por quê?

A4: Ah, porque você tava falando que vai levar pra USP e esse negócio de ir pra USP, pô! Sei lá..., o presidente podia ir lá! Até o prefeito podia ir lá na USP, dá uma olhada lá na biblioteca... se ele folheasse e desse uma olhada no nosso projeto pra fazer alguma coisa. Foi isso que mais me interessou, mesmo. Claro, tudo me interessou, mas acho que essa cartinha vai ajudar bastante. ouvidos--

K: Você falou bastante sobre essa coisa de os adolescentes não serem

A4: É verdade isso de a gente não ser ouvido! Eu acho que eles acham que a gente é muito besta, que a gente não tem nem responsabilidade. Igual esse negócio de trabalhar: eu trabalho! Trabalho lá no [bairro " $x$ "], a gente sai daqui e vai lá. Lá só trabalha gente de 15 pra cima, até os 18 trabalha; gente mais velha não trabalha.

K: Não?

A4: Não, não trabalha. É lá no (...), eu acho muito legal.

K: $O$ que você acha de trabalhar enquanto tá estudando, como você sente?

A4: Às vezes eu falo: é mó chato trabalhar. Às vezes falo: não, é legal! A minha mãe fala que é bom pro aluno tá trabalhando porque você tem mais responsabilidade, sabe administrar seu dinheiro. Eu acho que tem que dar mais oportunidade pra gente, que é jovem; porque se derem mais oportunidade pra gente, a gente vai saber aproveitar. Agora, se não dá... Por isso que esse mundo ta cheio de jovem que fuma, que é isso e aquilo, porque não tem um emprego adequado. Acho que deveria ter mais emprego pra gente.

K: Você trabalha quantas horas? De horas a que horas?

A4: Eu entro no serviço às quatro [da tarde]. Por causa do reforço, aí eles falaram pra entrar às quatro, enquanto não acabar o reforço entro às quatro. Entro às quarto até às nove [da noite].

K: Você acha que atrapalha alguma coisa ou não?

A4: Não, não atrapalha, porque eu sei dividir certinho meu tempo. Em final de semana também eu trabalho. Em final de semana eu entro às nove e vai até na hora que fechar. Não tem problema, eles dão vale-refeição, tudo certinho. É registrado tudo. Aí é bom.

$K: E$ o que você acha do reforço? 
A4: Tá sendo bom pra mim.

$\mathrm{K}$ : Tá sendo bom?

A4: Tá sendo ótimo! Em português, eu não sei por que, o $\operatorname{Pr} 1$ acha que eu tenho uma dificuldade, mas eu não acho. Acho que tenho mais dificuldade em matemática.

K: Você está no reforço dos dois?

A4: Dos dois. Amanhã é da uma às duas. Aí o que eu faço? Saio daqui meiodia, já almoço, me troco, quando dá duas horas eu já desço, pego o ônibus (...), desço no (...) e pego o ônibus (...).

K: Por que você falou que está bom o reforço? Tá te ajudando como?

A4: Tá me ajudando assim: em português, nem tanto, acho que eu sei, mas em matemática tá me ajudando a entender as equações, os números... Porque a minha professora é aquela lá, a Pa2. Ela passa na lousa e nem explica nada! Então todo mundo copia e no outro dia sabe que vai ter a correção mesmo! Aí todo mundo copia, ela dá nota, ela vai dando nota..., ela nem explica! $E$ aqui no reforço, não! $A$ professora X fala: "Agora vou explicar". Vai explicando e a gente faz tudo certo. $E$ na sala, com aquele barulho que tem lá, pelo amor de Deus, não dá pra fazer as coisas.

K: Então você sente essa diferença grande.

A4: É, porque a minha sala eu acho que tem muita gente, a minha sala tem 48 pessoas. $A 8^{a}-B$ parece que tem 41 e as outras também. Só a minha sala tem 48 pessoas!

$K:$ E no reforço?

A4: No reforço, deixa eu ver, de matemática: eu, O4... oito pessoas. $E$ de português é nove pessoas. Aí tem uma aula diferente, né? É poucas pessoas, então todo mundo presta mais atenção e a professora comanda a sala. Olha a diferença entre oito pessoas e 48 pessoas! É muita coisa! Você viu lá, não dava nem pra você falar, é gente gritando, é gente brigando: "vai pra aquele lugar". Às vezes eu paro e falo: meu Deus, olha a sala que eu tô!

K: Você acha que teve algum assunto que a gente não conversou no grupo, mas você acha importante conversar?

A4: Não. Acho que a gente falou sobre todos os assuntos que era necessário; até sobre política a gente conversou. Ficou entre eu, o 02 e o 01; a A1 e o 04 ficaram de fora.

$K$ : Eles acrescentavam umas coisas, também.

A4: Começa assim: vamos falar sobre política e um ficava defendendo a Marta, o outro o Serra e eu a Erundina.

K: Quando vocês estavam fazendo o PAN, vocês colocaram que vocês são julgados injustamente pela situação financeira de vocês.

A4: É verdade!

$K: O$ que você acha disso?

A4: Ah, é uma coisa super errada! Igual o 04 tava falando, pra entrar numa universidade é difícil, a gente que é pobre tem que ralar, batalhar pra caramba! $E$ o rico não, pô! Você olha assim, ele tem dinheiro, paga, faz tudo, nem se esforça; é só ele tirar uma notinha lá, qualquer notinha pra ele tá ótimo. E a gente não. Igual... eu 
faço o possível pra tirar a melhor nota! O possível, mesmo. Nossa, quando eu chego em casa, saio do serviço nove horas, aí o ônibus passa nove e meia, então a gente sai correndo pro ponto, chego em casa quase dez e meia, sozinha, à noite..., me dá um medo, um medo! Chego à noite, chego cansada, minha avó afobada, meu pai... eles perguntam como foi o serviço... Você já não consegue dormir mesmo. Aí tem trabalho pra mim fazer, acabo dormindo tarde, às vezes eu nem durmo, quando eu olho já é cinco horas, não dá tempo nem de deitar na cama, já tenho que ir pra escola e estudar. E eles não. Eu saio, às vezes vou pra balada. Eu fico vendo, é tão difícil eu sair. E eles, se bobear, é segunda, terça, quarta, quinta, sexta, sábado e domingo, é a semana toda que eles sai. A gente que é pobre não, tem que ficar aqui ajudando, batalhando, porque é uma diferença muito clara!

$K$ : E você acha que tem preconceito com relação aos pobres, como a gente tava falando nos encontros? Que tipo de preconceito você acha que tem?

A4: Ah, tem..., claro que tem preconceito! Por exemplo, você vai numa loja, aí você fala: "Nossa, que bonito". Aí você fala bem baixo porque tem tipo um rico do lado: "Mas eu não posso comprar, esse mês estou muito endividada". Se ele escuta, ele olha bem na tua cara e fala: "Ai, eu já vou comprar". Igual o casamento do meu tio, meu pai não podia comprar, aí eu mesma, com meu dinheiro que eu tenho guardado, que eu estou guardando pra faculdade, peguei e tirei pra comprar um vestido que nunca mais eu vou usar. Mas comprei, gastei 120 reais no total, tirei do meu dinheiro porque meu pai não podia. Foi lá no Shopping Iguatemi que eu fui comprar, foi eu, mais umas amigas minhas e o meu namorado. Dentro da loja todo mundo ficou olhando pra nossa cara. Aí eu vi o vestido, mandei a moça pegar, ela falou assim: "Que número é o seu?" Eu falei assim: "Ah, não sei direito (porque eu estou um pouquinho mais gorda); você pode pegar?" Tipo, ela foi pegar com o maior nojo! Nossa!! Eu fiquei parada e falei: "Vamos sair daqui". E minhas amigas: "Não, você veio aqui pra comprar. Se ela falar alguma merda, você vai vê o que a gente vai falar". Falei: "Ai, gente, não vamos fazer isso não". Aí meu namorado percebeu de longe, aí ele falou: "O que tá acontecendo aqui?" Aí as meninas falou. Aí ele chegou na mulher e falou assim: "A gente tem dinheiro, a gente tá a fim de comprar, acho que vocês não deveriam ser tão assim com o mais pobre". Falei assim: "Eu tô fazendo o favor de vir aqui nessa loja". É um absurdo, ela é muito cara. Aí ele falou: "Vamo embora, a gente procura em outra loja e dane-se o povo daqui".

$K$ : E você falou alguma coisa pra moça da loja?

A4: Não, fiquei... fui besta! As minhas amigas fala que eu sou tonta, eu não falo quando vejo as coisas. Eu sou mais naquela, eu fico mais chorando, sou mais chorona. Eu percebo, aí começo a chorar.

K: Traz sofrimento, né?

A4: Já pensou? Aí começo a chorar. Meu namorado conhece, quando eu tô chorando, alguma coisa fizeram pra mim.

K: Aí você saiu da loja, não comprou...?

A4: Aí a gente foi pra outra loja, a loja de uma conhecida da mãe dele, ela me tratou super bem $e$, por incrível que pareça, ela fez um desconto do mesmo vestido, ela fez um desconto pra mim ainda.

$\mathrm{K}$ : De alguém que era conhecido de vocês. 
A4: É, ela fez um desconto pra mim. O vestido era 80 e pouco, ela fez um desconto, ficou em 59 reais pra mim levar.

K: Outra coisa: a gente estava falando sobre educação. No PAN vocês também colocaram propostas pra saúde, educação, trabalho. E não deu tempo de completar a educação. Pra você, qual é o maior problema da educação escolar?

A4: Acho que são os alunos; que não respeitam os professores e também são os professores que não respeitam os alunos. E dos pais também, que não educam os filhos e os filhos acham que a escola é a casa deles. Então acho que na verdade a culpa é de todo mundo. Não é só do professor, do aluno ou dos pais; é de todo mundo.

K: Então você acha que o maior problema disso na verdade é o comportamento, a disciplina...

A4: A disciplina. E também a diretora.

$K:$ Por quê? $O$ que tem a diretora a ver?

A4: A diretora mal vem pra escola $e$, quando ela vem, ela acha que ela manda, entendeu? Quando ela entra, ela fala sozinha; porque ninguém... Eu mesmo, às vezes eu tô conversando, eu continuo conversando, porque, quando ela vem, ela quer mandar nos outros. Por isso todo mundo prefere a $C, a C$ tá mais por dentro dos assuntos da escola.

K: E essa coisa da qualidade do ensino? Você estava falando da diferença do reforço, que tem poucos alunos, a professora dá aula melhor e da sala de aula. $O$ que você acha da qualidade do ensino aqui?

A4: Dessa escola?

K: É.

A4: É uma bosta! Ô, ensino ruim!

$K$ : E o que tem de ruim?

A4: Tudo! Professor, aluno..., é professor que não tem vontade de dar aula.... Igual o Pr2: segunda-feira, a primeira aula é do Pr2, ele entra, só fez a chamada, sentou na cadeira, não fez nada, nada, nada! "Professor, o senhor não vai passar lição, não?" - "Ah, não tô com vontade de passar lição". - "Então não tô com vontade de ficar na sua aula". Aí ele: "Ah, pode conversar, pode fazer o que quiser". A turma tava quase quebrando a carteira lá e ele rindo pra todo mundo!

$K$ : $E$ o que você acha que poderia ser feito pra melhorar a qualidade do ensino?

A4: Acho que deveria mudar bastante o professor. Igual a gente tava falando [em um dos encontros]; deveria ser assim: se você não dá uma aula boa e que a sala tá aprendendo, você não vai receber o seu salário. Enquanto a gente não vê que você deu uma aula de qualidade, você não vai receber o seu salário. Acho que deveria ser assim. Rapidinho ele ia começar a dar aula bem melhor! Porque, nossa! $O$ ensino daqui... Minha avó já falou que aqui foi uma das melhores escolas, nossa! Agora é uma das piores escolas!

$\mathrm{K}$ : A gente estava falando do presente de vocês, de vocês como alunos adolescentes hoje. Quando você começou a estudar, você entrou na primeira série ou na pré-escola?

A4: Entrei na pré. 
K: Você se lembra de alguma coisa de você na pré-escola?

A4: Ai, não lembro nada!

K: Não lembra?

A4: $A i$, só lembro que a minha mãe comprou minha mochila, que era de carrinho... tenho até vergonha de falar... era de carrinho! Tinha a lancheirinha... $\mathrm{Na}$ verdade não estudei em pré-escola, estudei numa escolinha ali perto da (...). Meu pai pagou, era particular, estudei naquela escolinha. Eu lembro, era amarelo $e$ preto. Minha mãe colocava lanchinho, eu lembro que a gente desenhava pra caramba.

K: Desenhava? O que acontecia lá?

A4: Eles ensinavam a gente também a ler. Quando eu entrei na primeira série, eu já sabia ler mais ou menos.

$\mathrm{K}$ : E na primeira série você começou a estudar onde?

A4: Estudei na primeira série no E7.

K: Quanto tempo?

A4: Até no meio da segunda. Na segunda eu fui pro E8, até o final da segunda. Da segunda eu voltei pro E7, no terceiro ano de lá. No terceiro ano eu fui pro E8 de novo. Aí o que aconteceu? Fui pra Campinas, em Campinas estudei em três escolas!

\section{K: Mudou bastante!}

A4: Porque uma era muito longe da minha casa, aí fui pra mais perto. Depois voltamos de novo pra São Paulo, aí fui pra Carapicuíba, estudei lá na quinta série. Da quinta eu vim pra cá, aí estudei aqui na quinta, sexta, sétima e oitava agora. Estudei em várias escolas.

$\mathrm{K}$ : Mudou muito. O que você achou disso?

A4: Ah, esqueci de uma, a da (...) também.

$K: E$ o que você achou disso de mudar de escola?

A4: É muito ruim. Você conhece vários amigos. Quando você tá se enturmando a gente vem embora, aí começa a chorar.

$\mathrm{K}$ : E pra aprender o que você achou?

A4: Ah, é mó ruim! Eu não aprendia nada, porque em cada escola era totalmente diferente: em uma eu tava atrasada, em outra tava adiantada demais. Quando eu vim pra essa escola, ela tava muito atrasada para o que eu já tinha aprendido.

K: Essa escola tava atrasado?

A4: Tava atrasada. A primeira aula foi geografia, aí a professora: "O que você tá aprendendo?" Aí eu falei, e ela: "Ai, a gente ainda não chegou aí, você vai ter que ter um pouco de paciência". Falei: "Eu tenho paciência, sim".

$K: E$ o que você achou de ser aluna criança, como era ser criança?

A4: Ah, era muito bom! Bom demais!

$\mathrm{K}: \mathrm{O}$ que acontecia?

A4: Você brincava..., criança não tem preocupação. Quando chega nos 11 anos, já fica meio complicado.

$K:$ E como era a relação dos professores com os alunos crianças? 
A4: Ah, era muito bom, eles não gritava com a gente. Era aquele negócio de bilhetinho, eu nem mostrava meu caderno pra minha mãe. Aí eu ia pra escola: "Sua mãe viu seu caderno, o que ela falou?" - "Ah, falou pra eu não fazer isso".

$\mathrm{K}$ : E pronto?

A4: Pronto. Agora não. "Vou ligar pra sua mãe". Aí eu falo: "Liga, pode ligar". Igual a Pa2 falou que ia ligar pra minha mãe, eu falei: "Se a senhora ligar, pode ligar, mas eu vou lá na diretoria e falo que a senhora me xingou de ladra". Ela falou: "Você não é louca".

K: Mas ela xingou você?

A4: Xingou mesmo! Eu fui lá e falei pra dona $C$ : "Ó, dona $C$, ou você tira essa batatona aí da sala ou eu vou matar ela". [Risos] Aí cheguei na sala e falei: "Toma cuidado comigo, hein? Quando vê um corpo gordo boiando no rio Tietê é a senhora que vai tá boiando". Aí ela: "Você tá me ameaçando?" "Eu não só ameaço, eu faço". Nunca mais ela me xingou.

$K$ : Ela ficou com medo?

A4: Até hoje ela tem medo de mim! Ela olha assim pra minha cara meio desconfiada... eu falei "Não fala comigo, não!"

K: A gente estava falando, em um encontro, de como os professores têm medo dos adolescentes, acham que eles ameaçam e vão fazer mesmo...

A4: Mas tem uns que fala e faz. Só que eu não tenho coragem de fazer isso, não. Fico só brincando com os professores.

$K: E$ que diferença você acha que tem, então, entre ser aluno adolescente $e$ aluno criança?

A4: Ah, é muito diferente! Ai, como é bom ser criança! É tudo inofensivo..., sua mãe não fica pegando no teu pé. $O$ aluno adolescente já é meio complicado porque você tem responsabilidade, tem que trabalhar, faculdade e tudo. Acho que tem uma bela diferença. Porque criança é inofensivo, você olha e fala: "Que criança linda". Adolescente, não; você olha e fala "ai, que [horror]". É tudo assim. Então é uma diferença muito grande.

$\mathrm{K}$ : Você estava falando que teve um ano que você repetiu, né?

A4: Repeti a quarta no E8, foi quando eu voltei de novo pro E8. Morava em Campinas, voltei pra São Paulo, voltei e fui pra lá.

K: Você tinha começado a falar no grupo que tinha tido uma história de repetência. $O$ que aconteceu?

A4: Porque a professora não dava aula pra gente. Quando ela vinha, ela passava matéria e então ninguém entendia. Lição de casa ela não passava. Aí eu repeti, todo mundo repetiu.

K: Todo mundo repetiu da sala? A gente tava conversando sobre repetência, aí os alunos tavam falando o que eles achavam que acontecia para ter repetência. $O$ que você acha?

A4: Falta de interesse dos alunos e falta de interesse também dos professores. Claro, os professores também têm culpa. Mas era um professor só que dava aula, tinha que ensinar português, história, geografia, inglês... era complicado. Era uma só professora que dava aula de todas as matérias, aí você fica assim. Minha mãe falou: "Vou te mudar de escola". "Não, mãe, me deixa aí". Aí 
quando fui ver se tinha passado, olhei lá: repetente, repetente, repetente, repetente...

$K$ : A sala inteira repetiu.

A4: A sala toda: repetida, repetida, repetida... Aí eu pensei "Ah, eu não repeti, né?" Aí olhei "A4: repetida" e falei "É". Aí cheguei em casa rindo, e minha mãe: "Repetiu, né, A4?" Minha mãe nem me bateu, já sabia que eu ia repetir mesmo. Os pais nem falaram nada. Aí minha mãe foi lá falar com a professora: "Que professora que você é que mal vem e quando vem, não explica nada?" Ela: "Ai, eu tive problema". Minha mãe: "Dane-se. Você é uma má professora".

K: Então, a gente estava falando do passado e do presente. Agora vamo falar do futuro. $O$ que você espera do seu futuro?

A4: Eu espero uma coisa boa, melhor. Como eu estava falando, como eu trabalho, eu divido uma parte do dinheiro pra mim gastar e outra pra mim guardar. Estou guardando. Quando falam: "Nossa, A4, tá cedo ainda", eu falo: "Não, gente, é bom guardar um dinheiro agora porque é uma possibilidade que você vai ter de entrar numa faculdade".

K: Então você pensa em terminar o terceiro colegial e fazer uma faculdade...

A4: Não terminando logo o terceiro e já entrar numa faculdade, mas dar um tempo de uns meses assim pra fazer vestibular e entrar na faculdade.

K: Você pensa em fazer o quê? Que profissão?

A4: Medicina.

$\mathrm{K}$ : E pra conseguir fazer medicina o que tem que acontecer?

A4: Ah, tem que estudar biologia, corpo humano, tem que saber essas coisas. Então estudar bastante!

K: Você estava falando que tá juntando dinheiro, então pensa em entrar numa particular?

A4: Eu vou tentar na USP. E aqui tem boas faculdades ótimas: a UniNove, a UniBan e a UniP. Eu vou tentar entrar numa dessas três. Acho que vai ser meio difícil conseguir entrar na USP, mas nas outras, com você pagando, consegue.

$K$ : Aí você acha que vai conseguir pagar?

A4: Ah, se Deus quiser, vou conseguir entrar e ralar muito, muito pra conseguir o que eu quero.

$K$ : $E$ disso tudo que a gente falou, tem mais alguma coisa que você queria falar?

A4: Não.

K: Você falou que se interessou bastante pela política, né? As pessoas estão lendo o que vocês escreveram do PAN e daí vocês falam se querem acrescentar mais alguma coisa ou não. Agora bateu o sinal do intervalo, então eu vou deixar com você uma cópia e se você quiser acrescentar alguma coisa, você traz na terça-feira, que é quando todo mundo vai trazer. Aí, na terça o grupo todo se reúne, a gente lêe as propostas, vocês vêem com quais vocês concordam, aí alguém passa a limpo e depois vocês assinam com um outro nome (por causa do sigilo), tá bom?

A4: Tá bom.

K: Eu queria lhe agradecer muito! Muito obrigada, A4! 


\section{ENTREVISTA INDIVIDUAL COM O ALUNO DENIS (O1)}

$\mathrm{K}$ : Só pra lembrar um pouquinho do que a gente falou nos grupos, vocês falaram sobre várias coisas: sobre como era pra vocês serem adolescentes, o que os adultos acham dos adolescentes, sobre como era ser um aluno adolescente, sobre a relação entre vocês e todo mundo que está na escola, alunos, professores, direção, coordenação. Vocês escreveram as propostas do PAN, que depois eu vou te mostrar como ficou, e a gente discutiu no último encontro, em que você não tava, as letras das músicas: "Não é Sério" do Charlie Brown Jr. e a "Minha Voz" do Almagem. Sabe quais são? A gente discutiu sobre isso, do Charlie Brown, a idéia de que o jovem no Brasil nunca é levado a sério... . Inclusive essa coisa toda do adolescente, você discutiu bastante. Então, o que você achou desses encontros?

O1: Foi legal!

$\mathrm{K}$ : Por que foi legal?

O1: Em geral, assim, a idéia que surgiu.

$\mathrm{K}$ : De tudo que a gente falou, o que mais te interessou?

O1: Política!!

K: Por que te interessou mais a política?

O1: Eu gosto de política.

K: Você foi o que mais deu idéias pra escrever a proposta do PAN, muita coisa veio de você, você foi puxando, as pessoas iam acrescentando, mas você foi o que mais trouxe idéias de política, de cada uma das propostas e tal. Logo quando vocês começaram a escrever o PAN, vocês colocaram que não queriam ser considerados "aborrecentes", que vocês têm idéias e que vocês ficam indignados com a situação do país. O que mais te deixa indignado?

O1: A exclusão social da gente!

$\mathrm{K}$ : A gente quem?

O1: Dos adolescentes.

K: Você acha que os adolescentes são excluídos?

O1: São.

K: E por que você acha que eles são excluídos?

O1: (frase ininteligivel - algo de que os adultos pensam que os adolescentes são irresponsáveis e então não Ihes oferecem emprego)

$\mathrm{K}$ : Aquela frase foi sua, da idéia de que vocês são injustamente julgados pela situação financeira. $O$ que você acha disso?

O1: Se não deixam eles trabalhar, como é que vai ter dinheiro? Se o pai pudesse dar, aí...

$\mathrm{K}$ : Você acha que as pessoas pensam o que sobre os que são pobres pobres?

O1: Ah, delas eles têm dó.

K: Têm dó?

O1: Têm. Da gente, eles não têm não.

$\mathrm{K}$ : Da gente quem?

O1: Dos adolescentes.

$K: E$ dos adolescentes pobres? 
01: Também. Fala que é tudo nóia, assim, só quer usar droga, essas coisas. Às vezes não é isso.

K: Na música "Não é Sério" tem uma parte que diz que "o repórter quer saber se eu me drogo, o que eu uso", e os alunos do grupo começaram a falar que às vezes no ônibus tem preconceito. Se chega um adolescente mal vestido e se chega um adolescente engravatado, é aquele mal vestido que vai ser julgado. Os próprios alunos falaram de situação de andar na rua e chegar policial e já perguntar se está fazendo alguma coisa, já ser barrado, parado porque estava com uma roupinha simples. Aí a gente começou a falar sobre isso, sobre o preconceito com relação à pobreza, ao adolescente pobre e aí eles falaram que já vai pensando que está drogado, isso que você falou. Com relação à pobreza eu queria te perguntar outra coisa: existe uma idéia de que, se a pessoa não aprende, se o ensino não está bom, se tem repetência, também culpam a família, e a família pobre é a mais culpada, se pensando assim: "porque o aluno é pobre ele não aprende". O que você acha disso?

O1: Eu acho que não tem nada a ver, não!

K: Não tem a ver? Por que?

O1: A família não tá na escola, quem tá na escola é o aluno. Ele é que tem se conscientizar e aprender. Se quiser, todo mundo aprende. Tem uns que são meio burro, mas aprende alguma coisa.

K: Quando a gente estava discutindo o que acontece quando tem repetência, você falou que acha que tem a ver--

O1: ... Com QI (risos).

K: Então, com QI. Aí começou a discussão se tem a ver com QI ou não. Fala um pouquinho mais sobre essa idéia de que a questão é a inteligência.

O1: Porque às vezes, se não estimula... Tudo é prática, né? Se você não pratica, você não vai se aprimorar. Se quer brincar só, nunca vai se aprimorar e acaba ficando pra trás dos outros.

K: Quando, por exemplo, o aluno repete é porque ele é burrinho, não tem inteligência?

O1: Quando ele repete?

K: É.

O1: Não, é porque ele não tá acompanhando o desenvolvimento dos outros. Ele vai ficar pra frente como, se...? Ele vai se sentir mais perdido ainda. Melhor ficar aqui, recuperar o tempo perdido do que ir pra frente e ficar [sem saber].

$\mathrm{K}: \mathrm{O}$ que acontece quando os alunos repetem? Por exemplo, está fazendo de novo a oitava série, o que acontece nessa segunda vez que faz, você acha que aprende, não aprende?

O1: Não sei, eu nunca repeti. Mas acho que não aprende, não! Ah, depende, se você quiser mesmo passar de ano e prestar atenção, dá pra aprender.

$\mathrm{K}$ : A gente estava falando daquela idéia do que precisa para melhorar a qualidade do ensino, se existe algum culpado pelo ensino não estar bom, você acha que é mais o aluno?

O1: Também. É a... escola inteira, assim... em geral, desde os professores ao coordenador, inspetor, alunos, todo mundo.

$\mathrm{K}$ : O que daria para ser feito, então, para melhorar a qualidade do ensino? 
O1: Ah, ter mais segurança, mais vigilância, prestar atenção no aluno. Ser mais rigoroso, também.

K: Como assim, rigoroso como?

O1: Ser mais rigoroso nas coisa errada que o pessoal faz. Acho que tem que puxar mais.

K: Acha que tem que puxar.

O1: É, pra aprender.

K: Além da disciplina, a coisa do conteúdo ser passado ou não, de se ter um ensino mesmo de qualidade ou não, o que daria pra fazer?

O1: Ah, tinha que ter professores bem mais treinados, também. Mesmo depois da faculdade tinha que ter uns cursos pra aprimoramento das coisas.

K: Para os professores, né? Você está falando de uma maior capacitação dos professores e tal? Então isso ia ajudar a ter um ensino de maior qualidade...

O1: É.

$K$ : Várias coisas a gente conversou, então o que mais te interessou foi a política. Você acha que teve algum assunto que a gente não conversou, mas você acha que é importante falar?

O1: Acho que a gente conversou pouco sobre drogas. drogas?

K: Drogas é uma coisa importante. E aqui na escola tem conversa sobre

O1: Não, nunca teve! Teve só um lance aqui, veio um pessoal dar uma palestra.

$\mathrm{K}$ : Você acha que era importante ter isso?

O1: Acho.

K: Além de conversa sobre drogas, você tinha colocado na proposta do PAN coisas sobre saúde, sexo, violência, droga... você já tinha incluído ali também naquela coisa geral para a escola. E a gente estava falando sobre a experiência de ser aluno hoje, adolescente, mas eu queria lembrar do passado. Você começou a estudar na primeira série ou fez pré-escola?

O1: Na primeira série, direto.

K: Você lembra como era essa experiência de ser aluno na primeira série?

O1: Nova. A gente se sente meio assustado quando não fez prezinho, fica meio sozinho, mas depois se acostuma.

K: Você estudou onde na primeira série?

O1: Nem lembro! Hum... E9. Sabe onde é o E9?

$K:$ Não. É aqui mesmo?

O1: Deve ser, nem sei. Sei que o nome era E9.

K: E como era essa escola? Você estudou lá da primeira até qual série?

O1: A primeira só. Depois pro E10, fiz segunda e terceira. Quarta, eu fui pra Campinas. E agora eu tô aqui.

$\mathrm{K}$ : Na primeira série, você lembra como o professor tratava os alunos, como era essa relação dos alunos e professores, quando é criança?

01: Mais ou menos. Era legal, porque criança tem inocência, não tem tanta... não era tão pesado o clima que nem aqui.

K: Que nem o quê? 
01: Que nem aqui com os alunos maiores. É bem mais fácil, tipo..., alertar a criança que ela tá mal na escola do que o adolescente.

$\mathrm{K}$ : Eu ia perguntar isso: pra você lembrar um pouquinho como foi a sua experiência como aluno criança, da primeira até a quarta série. Da segunda e da terceira, você lembra alguma coisa que te marcou?

O1: Não.

K: Alguma coisa de como era ser aluno na terceira série, na segunda.

O1: A gente jogava bola, pelo menos.

K: Jogava bola.

O1: É, era bem isso.

$K$ : Então, você acha que existe diferença entre ser aluno criança e ser aluno adolescente? O que muda?

O1: Você é mais inocente, criança; não tem briga...

$K:$ Não tem?

O1: Não. Que nem aqui, não. Brigou, fica de mal do outro. Aqui, não.

$K: E$ você acha que os professores tratam diferente?

O1: Acho!

$\mathrm{K}$ : Como?

O1: Trata como criança. Se tratar as criança que nem aqui, estão perdido.

$K$ : E o que é tratar como criança?

O1: Tipo chamar atenção uma vez só. Criança você chama atenção uma vez só, ela já se toca.

$\mathrm{K}$ : Você acha que criança é boazinha?

O1: É, algumas são boazinha. Se não for, também, é muito mais fácil fazer ela ser um bom aluno do que um adolescente.

K: É mais fácil?

O1: É lógico!

$\mathrm{K}$ : Por que é mais fácil?

O1: Porque é mais inocente, não tem muita maldade que nem o adolescente.

$K$ : Você acha que vocês têm maldade?

O1: Têm. Todo mundo tem.

K: E que maldade é essa do adolescente?

O1: É quando fala do erro dos outro, taca giz nos outro, essas coisas. Criança não tem isso, na primeira série você não vê ninguém tacando giz no outro, apagador tacando nos outro.

K: Você acha que as crianças são mais disciplinadas, são mais quietas, não fazem muita bagunça?

O1: Não diria que são mais disciplinadas, é que elas ainda não aprenderam a ser indisciplinadas, elas são disciplinadas porque não aprenderam a ser indisciplinadas. Aí depois aprende, todo mundo aprende; não tem como fugir do mal desse mundo aqui!

$K$ : A gente tava falando do presente, do passado e eu queria perguntar um pouquinho sobre o futuro agora. $O$ que você espera do seu futuro?

O1: Se eu não seguir carreira militar na Aeronáutica, vou fazer Direito e virar juiz ou vereador, qualquer coisa desse tipo. 
K: Entrar nessa área política, que te interessa bastante... O que você precisa fazer pra chegar nisso que você quer?

O1: Estudar, né?

K: Você pensa em terminar o terceiro colegial, e aí?

O1: Me alistar. Se eu seguir carreira, vou ser major. Senão, vou fazer faculdade, né?

$K: E$ o que você precisa fazer pra entrar na faculdade?

O1: Não sei. Se for faculdade paga, pagar. Se for faculdade pública, estudar.

K: Estudar pra passar no vestibular...

O1: É.

$\mathrm{K}: \mathrm{E}$ você acha que dá pra pagar essa particular?

O1: Acho que não, é muito cara, 600 e pouco. A não ser que eu esteja ganhando bem.

K: Que arrume um trabalho... Então, se você for seguir essa carreira política, você pensa em fazer uma faculdade de Direito.

O1: Pra me aprimorar, pra saber como posso atacar, como posso me defender, porque a maioria dos partido é tudo punido porque fez o que não podia pela lei tal, tal, tal. Se eu fizer Direito, não vou cometer esses erros.

K: Vai estar sabendo em que terreno está pisando, das leis e tal... Agora vou te pedir pra ler como ficou a proposta do PAN. Você, na verdade, acrescentou isso aqui, mas eu queria que você desse uma lida pra lembrar.

(O1 lê o documento do PAM)

K: Agora que você leu, queria te perguntar: o que você está achando das propostas do PAN?

O1: Tá boa. Mas acho que o grupo só quer balada primeiro.

K: $O$ que eles acrescentaram além do dia em que você estava foi esse Dia dos Adolescentes, né?

O1: Aproveitaram que eu não estava. (Risos)

$\mathrm{K}$ : Eu lembro que você mesmo tinha falado: "Tem mais coisas" [propostas].

O1: Tem.

K: Qual você acha que é o maior problema da educação hoje?

O1: Hoje, o maior problema? Eu acho que é a falta de orientação do pessoal da direção, assim. $O$ aluno pra ele aprender também tem que estar tendo lazer na escola! Não estou falando balada, bebida, essas coisas..., mas lazer, esporte, uma quadra, uma bola pra jogar, uma escola pintada, cadeiras decentes! Tendo o monitoramento da escola funcionando bem, não tem como não funcionar. Você só aprende bem quando você se diverte também! Aí você vai saber a hora de brincar e a hora de estudar. Se eu não estudar, não vou poder ir lá jogar bola com meus amigos. Agora não, a gente não tem nada pra fazer, a pessoa vai zoar na sala, mesmo!

K: Não tem espaço pra extravasar, extravasa na sala?

O1: É.

K: Então você acha que deveria ter um espaço pra isso, né? E também tem aquela coisa que você tinha falado da capacitação dos professores-- 
01: Mas não é especificamente ter espaço. Espaço tem, não tem é capacidade de equipar o lugar. Tem a quadra, mas não tem bola! De que adianta? Tem cantina, mas não tem nada pra comprar.

K: Por exemplo, na educação deu pra falar da questão da disciplina. O que você gostaria de acrescentar nas propostas pra melhorar a educação?

O1: A gente botou que tem que dar umas palestras?

K: Vocês tinham colocado na violência. Aqui também, né?

O1: Encaixa aqui. Tanto é que nós já botamos droga, sexo.

K: Um espaço na escola pra ter conversas sobre isso, né? Tem várias idéias que você ainda tem, você falou que ia pensar em várias propostas. Então você leva uma cópia do PAN, pensa e escreve as coisas que quer acrescentar, como eu to falando pra todo mundo do grupo. Daí vocês podem trazer na semana que vem. Segunda não tem aula, podem trazer na terça--

O1: Não tem aula por quê?

$K$ : É feriado, dia 15 de novembro. Na terça tem e a semana inteira tem normalmente. Aí vocês podem levar, acrescenta se vocês quiserem e cada um traz em outro papel acrescentado. Aí a gente se reúne de novo e vocês lêem e discutem. Se vocês concordarem com as idéias que todo mundo está trazendo, alguém passa a limpo de novo e vocês assinam com um nome que vocês vão inventar; não pode ser o nome de vocês por causa do sigilo que eu já tinha falado. Então pense nas idéias que você queria acrescentar, nas propostas. Aproveita que você se interessa bastante por isso... Você topa?

01: Claro!

$\mathrm{K}$ : Tem mais alguma coisa que você queria falar?

O1: Não. Achei que foi bem legal; foi bem feito.

K: Então, tá bom, O1. Muito obrigada pela sua participação! 


\section{ENTREVISTA INDIVIDUAL COM O ALUNO JOÃO (O2)}

K: A gente nos encontros conversou sobre um monte de coisas. Você participou de todos os encontros, né?

O2: Todos!

K: Então você tá desde o começo, acompanhou tudo. Só pra te lembrar um pouquinho, a gente falou principalmente sobre como era ser adolescente pra vocês, sobre a imagem que os adultos fazem dos adolescentes, sobre como era ser aluno adolescente e sobre a relação entre vocês e as outras pessoas da escola, alunos, professores, diretora, tudo. E aí vocês também escreveram as propostas do PAN e a gente também conversou sobre as músicas. Sobre os encontros, o que você achou?

O2: Foi divertido e lucrativo; uniu o útil ao agradável.

K: Por quê?

O2: Ah, porque a gente teve a chance que a gente queria de poder expressar tudo que a gente queria! Lembro que a $A 4$ falou nessa livre expressão. $E$ também foi divertido, foi legal! Uniu o útil ao agradável.

$K: O$ que você achou de divertido no grupo?

O2: Conhecer a A3, a A1, a A2 e meus amigos também, O O3. Mas, detalhe: preferi conhecer elas. Isso é legal, essa conversa. Talvez daqui uns dias eu esteja namorando com a $A 3$, graças aos encontros. (Risos)

$K:$ Ah, quem sabe vai dar um fruto aí esses encontros...

O2: Casamento. Você vai ser minha madrinha. (Risos)

$K$ : Tá bom... . E de tudo que a gente conversou, o que mais te interessou?

O2: Discutir sobre a música.

K: Por quê? O que te interessou, o que você achou de legal aí?

O2: Porque a música fala. Se você lesse nas entrelinhas, ia falar a mesma coisa que a gente falou em todos os encontros.

K: Foi você que deu a idéia da música Não é Sério, lembra? A outra não lembro quem falou.

O2: Fui eu ou a $A 3$.

K: E realmente a "Não é sério" foi a que o pessoal mais pôde discutir porque tem principalmente a ver com o que vocês estavam falando. Então isso foi interessante porque veio de vocês, né? A escolha da música, que música vai ser, vocês que falaram. E você acha que teve algum assunto que a gente não falou, mas você achava importante falar?

O2: Drogas.

K: Você acha que é importante conversar sobre drogas também?

O2: Hum, hum.

$K:$ E aqui na escola não tem espaço pra isso, né?

O2: Tem espaço pra falar bem das drogas.

$K$ : Pra falar bem, entre os alunos.

O2: Hum, hum.

K: Mas pra se conversar sobre o assunto drogas assim com os adultos, com alguém... 
O2: Eu converso sobre isso com a minha mãe. Mas não dá pra conversar assim, acaba em discussão.

K: Mas você acha que seria importante tratar desse assunto aqui na escola?

O2: Seria.

K: Por quê?

O2: Orientação. Porque não adianta você falar pra um fumante que o cigarro faz mal, porque ele vai continuar fumando. Se você falar pra um não fumante, aí é outra coisa, porque ele ainda não fuma.

$K$ : Então você acha que poderia ser no sentido da orientação para os alunos mesmo, né?

O2: Perguntar o que ele acha sobre as drogas.

K: Ouvir os alunos... E você tava falando da importância que teve no nosso grupo os alunos falarem. Isso também poderia acontecer na escola, ter mais espaço pra eles falarem, você acha que é uma coisa importante ou não?

O2: É uma coisa importante.

K: Por quê?

O2: Porque qualquer adolescente gosta de falar o que pensa, tem assunto pra debater, pra discutir, mas não tem com quem discutir. Eu se for discutir de política, agora posso conversar com o 01 , mas sem ser ele ninguém gosta de falar de política, de jornal.

K: Por falar nisso, em política e tal, quando vocês escreveram o PAN, vocês colocaram ali que vocês sentem que são julgados injustamente pela situação financeira, por vocês não serem ricos, por vocês serem pobres. O que você acha disso?

\section{O2: Verdade!}

K: Verdade? Como assim? Explica melhor um pouquinho.

O2: Qualquer brasileiro é julgado pela sua situação financeira. O pobre cada vez fica mais pobre e o rico cada vez ganha mais dinheiro.

K: Você mesmo tinha dado um exemplo de uma situação de preconceito, de ser enquadrado na rua, de policial pegar e perguntar se--

O2: Só porque você sai de terno, indo pra igreja, eles pensam que é uma máfia ou qualquer coisa parecida, mas tem que te enquadrar, principalmente se você estiver sozinho!

\section{$K: E$ se estiver mal vestido?}

O2: Enquadra porque pensa que é vagabundo!

K: Você viveu isso, né? Não é uma coisa que você só ouviu falar. Além de ouvir falar...

O2: Eu vivi isso.

$\mathrm{K}$ : E como foi viver isso? O que você sentiu?

O2: É humilhante a polícia te enquadrar só pelo jeito que você é, só pela roupa que você veste!

$\mathrm{K}$ : Acontece muito esse preconceito, preconceito é um assunto que a gente discutiu bastante.

O2: O preconceito não é só financeiro. O preconceito é por cor, por dinheiro, por origem. 
$K: E$ isso acontece também aqui dentro, não é só fora da escola, mas aqui dentro também, né? Como vocês tavam falando, tem preconceito com relação a cor...

O2: Acontece.

K: Acontece bastante, né? Quando vocês estavam montando o PAN, vocês colocaram propostas para saúde, emprego e educação. Começou a fazer educação e acabou o tempo, lembra? Então eu queria perguntar assim: o que você acha que é o maior problema da educação?

O2: Os professores.

K: Por quê?

O2: Não vou generalizar, porque tem professor bom. Mas muitos professores são vagabundo, chega e senta ou passa qualquer coisa, eles não impõe respeito, por isso não têm respeito e ninguém vai confiar.

$K$ : $O$ que você acha que daria pra fazer pra melhorar a qualidade do ensino?

O2: Pôr bons professores na escola, professores que realmente estejam interessados em ensinar! Como o Pr1 ou a professora $X$. Ela dá aula porque ela gosta.

K: Essa professora é do quê? Vocês tinham falado sobre ela?

O2: De [" $x$ " matéria]. $O$ esposo dela é pediatra, ganha extremamente bem, uma filha dela é médica e a outra tá fazendo medicina. O carro dela é carro do ano. Ela não precisa dar aula, ela dá aula porque ela gosta, por paixão!

$K$ : Ah, eu lembro que você tinha falado isso em um encontro. $E$ a gente tava falando do presente, da experiência de vocês serem alunos adolescentes. Agora eu quero lembrar um pouquinho do passado. Você começou a estudar na primeira série ou fez pré-escola?

O2: Fiz o pré.

K: Você se lembra de alguma coisa de você estudando no pré?

O2: Lembro!

K: Do quê?

O2: Da A3; eu estudava com ela. criança?

$K$ : $E$ o que mais, o que acontecia no pré, como era ser aluno no pré, aluno

O2: Era muito louco! Você ainda não tinha malícia, você era inocente, brincava despreocupado, não tava nem aí com a vida, só pensava em brincar.

K: E depois na primeira série você começou a estudar onde?

O2: $\mathrm{NaE10.}$

K: É uma escola que fica aqui perto?

O2: É uma escola que fica um pouquinho longe.

$K$ : E você estudou lá da primeira até que série?

O2: Da primeira a quarta.

K: Nessa experiência da escola, criança também, como era ser aluno lá nessa escola?

O2: Era a mesma coisa. Até o comecinho da quinta era aquele moleque bobo, despreocupado com a vida, inocente, puro!

$K$ : E como era a relação entre os professores e os alunos crianças? 
O2: Da primeira até a quarta?

K: É.

O2: Vixi: "Ô, escurinho, não faz isso, muda de lugar, fica aí... ô, que bonitinho!". Falavam: "Ó que bonito", me apontando. Era fácil.

K: Você sente alguma diferença entre ser aluno criança e aluno adolescente?

O2: Ah, muita! No adolescente o professor pega mais.

$\mathrm{K}$ : Pega mais?

O2: O professor gruda em você, no aluno adolescente.

$\mathrm{K}$ : Como assim gruda?

O2: Você tá lá sentado e você fala bem baixinho: "Não vou fazer lição". Aí ele vem: "Não vai fazer lição? Tchau, vai embora". Aí você tá lá escrevendo, a sala inteira conversando, ele chega: "Nego, pra fora". O professor fica na tua cola.

$K: E$ você tava falando que o professor vê a criança como ingênua e que você acha que a criança é ingênua--

O2: Vê uma criança falando palavrão: "Ah, que bonitinho, que fofo". Se vê um adolescente: "Ô, moleque, cala a boca! Vou passar sabão na tua boca!". Tem uma grande diferença, uma enorme diferença!

$K: E$ da relação de como o aluno trata o professor, também muda?

O2: Muda. $O$ aluno com o professor, hoje em dia pelo menos, não tem mais respeito, bate em professor, briga, ignora. Professor não tem o respeito que tinha antigamente.

$\mathrm{K}$ : A gente estava falando do passado, do presente e agora do futuro. O que você espera do teu futuro?

O2: Prefiro não esperar nada pra não me decepcionar.

$\mathrm{K}$ : Como assim?

O2: Deixar acontecer. Se eu for esperar alguma coisa do futuro, mais pra frente eu sei que vou me decepcionar.

K: Por quê?

O2: Se for pra mim esperar alguma coisa do futuro, eu espero me casar, ser professor de educação física, sustentar minha família, ter dois a quatro filhos, ser casado.

$\mathrm{K}$ : E por que você acha que vai se decepcionar?

O2: Primeiro. porque acho que não vou casar tão cedo.

K: Acha que não vai casar tão cedo. Que mais?

O2: Não tem menina que queira casar com 18 anos.

$\mathrm{K}$ : Você queria casar com 18 anos?

O2: A-hã. Ter filhos também. Ter filho é fácil, o difícil é aturar o filho. Eu sei que quando meu filho crescer vai ser igual eu, vai dar uma dor de cabeça infernal! Emprego também... pelas minhas notas, professor de educação física de escola particular acho meio difícil.

$K$ : Por quê? $O$ que tem a ver as suas notas e ser professor de educação física?

O2: Porque precisa ter curso de anatomia pra ser professor de educação física. Eu faço. Mas como vou chegar pra apresentar minhas nota lá? Minhas nota eles vão ver: um lixo. 
K: Você acha que as suas notas daqui da escola contam pra você ser professor de educação física?

O2: Creio que contam.

$\mathrm{K}$ : Contam como, em que momento?

O2: Eles vão ver o meu currículo, vão ver que eu nunca trabalhei, ver que meus trabalhos foram bicos, fazendo bijuteria, ajudante de marceneiro... Daí eles vão ver que eu não tenho nada no meu currículo, daí eles vão ver minhas notas, vão ver que não tenho nenhuma nota boa. Aí vai dar um puta de um problema, eu sei que não vou conseguir ser professor.

K: Você espera ir até o terceiro colegial e pra ser professor de educação física o que você precisaria fazer, o que precisaria acontecer?

O2: Pegar a herança do meu avô, que ele deixou, agora deve estar em 15 mil, fazer curso de anatomia e vamo em frente!

$\mathrm{K}$ : Mas curso de anatomia pra ser professor? Tem que fazer faculdade, não tem? Como é?

O2: Não sei. Vou fazer o curso de anatomia e pimba na chulipa, vamo ver 0 que vai dar!

K: Então você acha que se fizer esse curso de anatomia pode ser professor de educação física?

02: Por que não?

$\mathrm{K}$ : E onde faz, existe curso de anatomia, assim?

O2: Hum, hum.

$K:$ Só de anatomia, onde?

O2: É uma boa pergunta. Quem sabia era meu avô, mas ele morreu. Quem deve saber é meu pai.

K: E a professora de educação física não sabe o que precisa pra ser um professor?

O2: Ela é minha professora, ela tá na casa dos 90 , ela tem que saber, é que eu ainda não perguntei pra ela.

K: Quem tá na casa dos 90 ?

O2: A professora de educação física. Acho que ela deve ter 90 ou 80.

$\mathrm{K}: \mathrm{A}$ daqui?

O2: Hum, hum.

K: O que você falou, você vai pergunta pra ela? Não entendi.

O2: Acho que vou perguntar, eu vou.

K: Então você acha que não precisa fazer faculdade, acha que pode fazer um curso de anatomia?

O2: Se existir.

K: E se não existir?

O2: Aí, vamo entrar na faculdade.

$K:$ E o que precisa pra entrar na faculdade?

02: Primeira coisa é ter dinheiro e o resto minha mãe que sabe. Vou perguntar pra ela.

K: Você tinha falado também que você está fazendo curso--

O2: No Senai. 

isso?

K: E que você vai fazer uma prova pra saber se vai conseguir bolsa. Como é

O2: Eu já fiz a prova, mas agora falta só o resultado.

$\mathrm{K}$ : Você faz o que no Senai?

O2: Curso de mecânica. Mecânica eu vou fazer pra, se eu não conseguir ser professor de educação física, não ficar no vácuo, daí vou ter emprego.

K: Esse curso profissionalizante como é, ele não é pago?

O2: Não, por isso que eu estou fazendo.

K: E essa prova que você fez é pra quê?

O2: Pra ver se eu vou entrar.

$\mathrm{K}$ : Entrar em quê?

O2: No Senai.

$\mathrm{K}$ : Mas você já não tá fazendo?

O2: Eu tô fazendo outro curso, que é o de mecânica. Fiz a prova agora pra saber se vou fazer de caldeireiro, porque quanto mais curso eu fizer, mais difícil ficar desempregado.

K: Ah, entendi. Então você hoje já está com a preocupação de ter emprego--

O2: No futuro. Eu tenho preocupação de no próximo ano tá trabalhando.

$\mathrm{K}$ : Tem mais alguma coisa que você queria falar?

02: Como assim, alguma coisa que eu queria falar?

$K$ : Mais alguma coisa. A gente está terminando a entrevista, eu queria saber se você queria falar mais alguma coisa antes de terminar.

O2: Não.

K: Não?

$\mathrm{K}$ : Vou te pedir pra dar uma lidinha em como ficou o PAN.

(O2 lê a versão inicial do documento do PAM)

K: Você participou bastante pra escrever o PAN, falou um monte de coisas. Lembro a hora que você falou: "Ah, ninguém tá ouvindo o que eu estou falando".

O2: Ninguém ouve o que eu tô falando, sou um incompreendido.

$\mathrm{K}$ : Você falava uma coisa, aí o $O 1$ interrompia e pensava como ia escrever. Você falou assim: "Ah, O1, então eu falo e você vê como é que vai escrever". Chegou uma hora que ficou assim, você falava essa coisa da empresa, de ter possibilidade de emprego e tal. O que você achou do que está escrito aí, das propostas?

02: Divino! O que tá escrito aí é o que o prefeito ou o presidente... Não, que o prefeito devia fazer pela cidade, o prefeito tem quatro anos aí e nunca faz bosta nenhuma!

K: Quando você leu aqui de educação, você falou: "Nossa, só isso de educação".

O2: É muito pouco!

K: $O$ que você acha que devia ter aí para educação?

O2: É que agora eu tô sem idéia. Sei lá, falar no salário por educação, por exemplo.

$\mathrm{K}$ : Ah, aquilo que você tinha falado, o professor que ensina, recebe. Se o professor ensina, recebe um salário? 
02: Se o professor pelo menos tentar e a gente ver que ele tá se esforçando, ai ele recebe. $E$ recebe mais: ensina mais, recebe mais; se ensina menos, recebe menos.

$\mathrm{K}$ : Mais alguma coisa da educação?

O2: Não.

K: Agora não, né? Depois, quem sabe. E do Dia do Adolescente, quando você leu aí, o que você falou?

02: É o que eu queria, porque tem que sair pra balada de "rapel" de casa, assim: pendurado na cordinha.

K: Fugido?

O2: É, fugindo.

K: Aqui teria uma autorização pra poder sair nesse Dia do Adolescente...

O2: Ô, coisa boa!

$\mathrm{K}$ : Tem mais alguma coisa que você queria falar aqui?

O2: Não.

K: Você que se interessou bastante pela política, talvez se interesse pelo que a gente tá fazendo, que é o seguinte: eu tirei uma cópia das propostas do PAN $e$, se você quiser, pode levar pra casa e pensar com mais calma. Você pensa em outras coisas que por enquanto não estão na sua cabeça, mas estão por aí.

O2: Tem a letra do Almagem?

K: Deixa eu ver se tenho, acho que não. Só tem a Não é Sério.

O2: Já tenho a letra.

K: Eu trago a letra do Almagem na semana que vem. Aí o que acontece? Quem tá querendo tá levando pra casa, aí completa com o que quiser, coloca as idéias que quiser pra melhorar e depois traz, só na terça-feira da semana que vem.

O2: Você vai chamar todo mundo?

K: Aí eu vou chamar vocês de novo.

O2: Juntos?

K: É.

O2: Oba!

K: Eu vou chamar todo mundo pra vocês mostrarem o que vocês pensaram $e$ vocês dizerem com o que você concordam. Se vocês concordarem com o que está, alguém vai passar a limpo e depois que estiver tudo escrito, passado a limpo vocês vão assinar com um nome falso, aquilo que a gente falou já.

02: 007.

K: 007 , pode ser. É o que vai ficar como o produto final e é isso que vai pra lá pra pesquisa também. Você quer levar pra colocar aí as idéias? Tem bastante na sua cabeça, né? Então leva e traz na terça-feira. Segunda-feira é feriado.

O2: Ah, é? Oba!

$K:$ A partir da terça já tem aula normalmente, então venho na terça-feira. Vamos ver pra todo mundo vir aí na terça-feira.

O2: Vai ter bolacha?

K: Não vai ter bolacha, vai ser uma coisa rápida, vocês só vão ver se concordam ou não com o que tá aí pra alguém passar a limpo. Então queria te agradecer muito, O2! Muito obrigada pela tua participação. Foi muito bom! 


\section{ENTREVISTA INDIVIDUAL COM O ALUNO JHONATAN (O3)}

K: O3, para você lembrar: você participou de vários encontros e aquele em que você não participou era um que no começo eu já lembrei do que aconteceu, então você sabe o que a gente falou nos encontros todos. A gente falou sobre como era ser adolescente para vocês, sobre a imagem que os adultos tinham sobre vocês adolescentes, sobre como é ser aluno adolescente, sobre a relação entre vocês e todo mundo da escola, alunos, professores, diretora, coordenação. Vocês escreveram as propostas do PAN e a gente conversou sobre as músicas. Eu queria te perguntar o que você achou desses encontros.

03: Acho que foi bom. Ainda mais para fazer um "livro", acho que vai dar uma oportunidade boa para os adolescentes se explicar, para falar que a gente não é "aborrecente"!

K: Eu queria falar sobre isso. Quando vocês tavam escrevendo o PAN, você que fez questão, você falou: "Escreve aí: a gente quer mostrar para as pessoas que a gente não é aborrecente". Então fala um pouquinho mais sobre isso. Você não é aborrecente como? O que é aborrecente?

O3: Pra mim, aborrecente é a pessoa que é chata... chata, que fica aborrecendo. Tipo assim: se eu peço pra meu pai me dar um dinheiro e ele não quer dar, eu fico insistindo e ele chama aborrecente, né? Pra mim aborrecente é isso, chato, ficar aborrecendo.

$\mathrm{K}: \mathrm{E}$ te incomoda isso de os adolescentes serem vistos como aborrecentes?

O3: Um pouquinho.

$K$ : Por que incomoda?

O3: Ah, é chato ficar sendo chamado de aborrecente. Falo: "Eu sou adolescente". "Você é aborrecente, isso sim". É chato, né?

$\mathrm{K}$ : Isso acontece muito, né?

O3: É.

$\mathrm{K}$ : Do que a gente conversou, desses assuntos todos, o que mais te interessou?

O3: Foi a parte dos postinhos.

K: Dos o quê??

O3: Dos postos de saúde.

K: Ah, dos postos. Então, de quando vocês escreveram a proposta do PAN e falaram sobre os postos de saúde.

O3: É.

$K: E$ por que isso interessou mais?

O3: Ah, porque os postos de saúde é o que precisa mais de segurança, precisa de mais remédios, de tudo. Tem posto de saúde que não tem tudo isso.

K: Você acha que teve algum assunto que a gente não conversou no grupo, mas que você acha que seria importante conversar?

O3: Agora que eu lembre, não.

K: Você era um que trazia bastante coisa de sexualidade, assim de que 0 importante é paquerar. Você falava até brincando: "Ah, quero ser ginecologista" ou então "o bom é a paisagem, dá pra ver as menininhas". Então a descoberta da 
sexualidade é uma coisa muito importante na adolescência e não tem muito espaço pra conversar sobre sexualidade na escola. O que você acha disso?

O3: Ah, não sei.

K: Você acha que seria importante ou acha que não precisa ter conversa sobre sexualidade na escola?

O3: Na escola precisa.

K: Precisa?

O3: Precisa. No ano passado a professora falava de sexualidade.

K: Professora do quê?

O3: De educação artística.

K: Ela falava?

O3: Falava, tipo dava conselhos, falava pra usar camisinha por causa da Aids, mostrava até os vídeos.

$\mathrm{K}$ : Vocês aprenderam bastante coisa assim?

O3: A-hã.

$K: E$ não tem mais isso?

O3: Não.

K: Você acha que seria importante ter?

O3: Seria. Mas ela era a única, né? Os outros professores só pensam em dar lição. Ela era a única.

K: Seria importante ter um espaço desses, né?

O3: Acho que no privado é assim, né? Tem que ver a grade da escola também.

K: Às vezes falta informação, tem muita informação importante que não é dada...

O3: Tem. A mesma professora falava que a gente tem vergonha de perguntar aos pais, aí ela falava.

K: Também não tem muito essa conversa com os pais hoje, né? Parece que os adolescentes têm que conversar só com eles mesmos sobre esse assunto, não tem adulto que conversa; de repente seria uma coisa importante, né? Quando vocês estavam fazendo o PAN, teve um pedacinho que vocês escreveram que era assim: vocês sentem que são julgados injustamente pela situação financeira de vocês, por vocês não serem ricos. O que você acha disso?

O3: Ah, eu acho que, como a gente é pobre, sei lá, a gente é... Não sei explicar. Sei lá.

K: Discriminado, né?

O3: É.

K: Preconceito. Você falou disso, o 02 também, daquela coisa de quando a pessoa está mal vestida já chega o policial.

O3: Tipo assim: no supermercado, se for comprar uma coisinha só, e tá mal vestido, os guardinhas já param, começam a reclamar.

K: Já aconteceu isso?

O3: Já. Um dia tava eu e mais dois moleques e a gente só tava zoando, né? A gente só foi comprar batata e umas bolachas. A gente entrou, aí veio o segurança, perguntou se a gente tava com alguma coisa, falou pra gente levantar a camisa. Aí a 
gente não levantamo, né? A gente falou: "Você tem alguma prova?" E nem foi ele, ele falou que foi um cliente que falou que a gente estava pretendendo pegar alguma coisa.

$\mathrm{K}$ : Mas vocês estavam zoando como, fazendo o quê?

O3: A gente foi até de bicicleta, foi comprar batata..., batata e comprar bolacha.

K: Aí vocês deixaram a bicicleta lá fora?

O3: É.

$\mathrm{K}$ : Mas tavam zoando como, o que eles entenderam como bagunça?

O3: Bagunça pelo seguinte: tava mal vestido, tava de chinelo.

$\mathrm{K}$ : Mas vocês estavam mexendo em alguma coisa, correndo, brincando?

O3: A gente pegou umas bolas.

$\mathrm{K}$ : Ah, pegaram bola e ficaram brincando com a bola.

O3: É. Aí um cliente viu, acho que foi lá e reclamou na gerência.

K: Então isso acontece bastante, né? Vocês estavam falando sobre o preconceito que também acontece. Hoje você mora por essas ruas aqui perto da escola ou mais para o lado da (...)?

O3: Aqui perto.

K: Você já morou em alguma favela alguma vez na vida?

O3: Não.

K: Quando a gente estava falando de preconceito, a A4 falou muito sobre isso de preconceito quando mora na favela.

O3: Tipo: muita gente que olha assim, vê que é da favela, já pensa que é ladrão, alguma coisa. E também o pessoal da favela é muito mais fácil para entrar no mundo das drogas. Eu estudava no E8, hoje o pessoal que estudou comigo está todo no mundo das drogas.

K: E8 é essa escola que vocês falaram que tem muito problema, que o ensino lá não é bom...

O3: Os professores de lá não quer nada. Na minha rua tem uns três ou quatro que estuda lá e sempre volta à tarde falando que não teve aula! E lá também é muito fácil pra cabular, muita gente cabula.

K: Quando vocês escreveram o PAN, falaram de propostas pra saúde, educação.... Quando estavam fazendo para a educação, acabou o tempo. Pra você, o que você acha que é o maior problema da educação na escola?

O3: Na escola?

$\mathrm{K}:$ A educação escolar. $O$ que você acha?

O3: Acho que o professor tem que ter mais respeito, o professor precisa mais que 0 aluno.

K: E o que poderia fazer para melhorar a situação da educação?

O3: Da educação? Sei lá.... colocar mais ordem na escola. Tipo uniforme, já foi umas dez vezes falado que era pra vir de uniforme, ninguém vinha. Tipo assim: todo mundo vem de blusinha, sem uniforme e ninguém fala nada. Tem que ter mais autoridade!

K: Você acha que tem pouca autoridade? 
O3: É. Colocar pelo menos um segurança na escola pra não deixar ninguém fumar. Tem gente até que fuma maconha lá no fundo da sala. É não deixar.

$\mathrm{K}$ : Você acha que o problema maior é o do comportamento?

O3: É o comportamento. A... direção.

K: Qual você acha que é o problema da direção?

O3: A diretora não faz nada aqui dentro na escola! Nunca vi ela falando alguma coisa para os alunos.

K: Vocês falaram falando que achavam que ela era ausente, distante dos alunos e tal. Então, a gente estava falando da experiência hoje de vocês como adolescentes, alunos adolescentes. Eu queria perguntar um pouquinho sobre 0 passado: quando você começou a estudar, foi na primeira série ou foi na préescola?

O3: Foi na primeira série.

$\mathrm{K}$ : Você estudou onde na primeira série?

O3: E8.

K: Ah, você entrou na primeira série no E8? Aí ficou lá até que série?

O3: Eu repeti a terceira e fui para o E9.

$K: E$ depois?

O3: Depois eu fui até a quarta e na outra quarta vim aqui [pra essa escola].

$\mathrm{K}$ : Como foi essa experiência de repetir, o que aconteceu?

O3: Eu tinha quebrado a perna, aí fiquei internado, aí... muita falta. E acho que a professora também não ensinava bem.

$K:$ Por que você sentiu que ela não ensinava bem?

O3: Quando ela queria, tipo assim, ferrar alguém, ela conseguia; ela colocava toda a sala contra. Tipo assim, quando faz alguma coisa, ela aumenta, aí leva o pai, o pai pergunta, a gente fala, ela pede a opinião da sala e a sala toda vai com ela.

K: A gente estava conversando sobre repetência, né? Quando o ensino não é de qualidade, quando os alunos repetem, será que existe um culpado, será que não existe? O que você acha disso?

O3: Ah, acho que o único culpado é o aluno ou o professor.

K: Você acha que é o professor ou o aluno.

O3: É o aluno. $O$ aluno, se ele quiser, ele passa, não tem nenhum professor nem ninguém que não faça ele passar. Que nem os "cdc", não sei.

$\mathrm{K}:$ "Cdf"?

O3: É, "cdf". Se ele faz tudo, fica quieto, na dele, faz tudo, é claro que vai passar!

K: Você lembra um pouquinho da experiência de ser aluno criança? Como era quando você era aluno e era criança da primeira até a terceira série, o que acontecia na sala de aula?

O3: Ah, era bem mais melhor! A professora explicava bem mais e também não tinha essa bagunça, essa zoeira. Era bem mais divertido. Aprendia mais.

K: Aprendia mais. Quando era criança, era mais divertido e não tinha tanta bagunça.

O3: É.

$\mathrm{K}$ : Como os professores tratavam vocês alunos quando era criança? 
O3: Ah, que eu lembro, ela me tratava bem, muito bem. Que eu lembro. Eu só lembro da quarta série.

$\mathrm{K}: \mathrm{O}$ que acontecia na quarta?

O3: Na quarta era muito bom! Não tinha bagunça, todo mundo fazia a lição, ela explicava bem. O E9 eu também acho uma escola melhor.

$K:$ Por que era melhor?

O3: Ah, era tudo em ordem, era todos com uniforme, não tinha nada disso.

$\mathrm{K}$ : Então pega naquilo que você estava falando do comportamento, do respeito, tinha mais... Eu estou perguntando isso para saber se você acha que tem diferença entre ser aluno criança e ser aluno adolescente.

O3: A criança respeita mais o adulto do que o adolescente. A criança é mais... como é que se diz? É mais frágil perto do adulto. $O$ adolescente já é mais forte. Aí a criança, tipo, fica com medo, né? Aí respeita mais o adulto. $O$ adolescente já não. $O$ adolescente, se o adulto levanta a voz, ele levanta também!

$K: E$ como você acha que é a diferença entre os professores tratando os alunos crianças e os alunos adolescentes, tem diferença de como esses professores tratam?

O3: Ah, pouca. Os professores que tratam de alunos crianças tratam quase do mesmo jeito, só que tratam com mais carinho, eu acho.

$K$ : E com os adolescentes você acha que não têm carinho?

03: Nem tanto. Eles só ensinam porque... O Pr1 ensina porque ele quer ver 0 aluno bem, né? Mas não desse jeito que os professores tratam as crianças.

$\mathrm{K}$ : Você acha que tem mais carinho nesse aspecto.

O3: É.

K: E a última coisa que eu queria te perguntar. A gente está falando de presente e passado e agora eu queria te perguntar do futuro. $O$ que você espera do teu futuro?

O3: Ah, não sei.

$\mathrm{K}$ : Tá longe, ainda?

O3: Tá.

K: Você pensa em terminar o terceiro colegial ou não?

O3: Quero terminar o terceiro.

$\mathrm{K}: \mathrm{E}$ depois que terminar?

O3: Ah, vou querer fazer faculdade na USP.

$K: E$ você tem idéia do quê?

O3: De veterinária.

$\mathrm{K}$ : Você se interessa pelos animais?

O3: $\tilde{A}-h \tilde{a}$.

$K:$ E o que precisa para fazer a faculdade na USP?

O3: Não sei.

$K:$ Não sabe o que você precisa fazer?

O3: Não.

$K: E$ você conhece alguém que estuda lá na USP?

O3: Eu conheci, mas agora não conheço mais ninguém. 
K: Você acha que é uma coisa muito difícil, que é impossível ou que dá para entrar?

O3: Acho que dá, mas é bem difícil! Ou então eu queria fazer curso de informática no Senai. Falam que tem que fazer uma prova e se passar na prova não paga nada. Se não passar, vai ter que pagar mensalmente.

K: Aí é caro, né?

O3: É.

$K:$ E por que você pensa em fazer a USP?

O3: Acho que não paga nada, né? Também falam que é bom e encaminha para qualquer veterinário mais perto.

K: Então os veterinários têm mais clientes, encaminha pros veterinários, é isso que você está falando?

O3: É.

K: Só mais uma coisa. Eu queria te mostrar como ficou o PAN. Lembra que você leu no grupo pra todo mundo? Queria você desse uma lidinha de novo para dizer o que você achou.

O3: Alto?

K: Não, lê baixo, lê pra você mesmo.

(O3 lê a primeira versão do documento do PAM)

$\mathrm{K}$ : Agora que você leu, o que você achou?

O3: Bom.

$\mathrm{K}$ : Tem alguma coisa que você queria acrescentar?

O3: Era bom colocar mais coisa aqui na educação.

$\mathrm{K}$ : O que você acha que dá pra colocar mais na educação?

O3: Colocar mais respeito..., menos discriminação. É isso.

K: Você acha que aqui tem muita discriminação sobre o quê?

O3: Aqui na escola?

K: É.

O3: Aqui por causa da zoeira. Gostam muito de zoar tipo assim: se a pessoa tem um defeito, começam a zoar, é normal.

K: Acontece bastante, né? No grupo vocês estavam falando que tem com relação a cor, com relação ao tipo de cabelo, se é gordo, se é feio. Tem muito isso, né?

O3: Hum, hum.

K: Então você acha que poderia colocar mais essas duas coisas aqui. Eu tenho uma cópia disso, as pessoas estão levando pra casa $e$ aí elas pensam se querem colocar mais. Por exemplo, você pode colocar mais isso de ter mais respeito e a questão da discriminação, de diminuir a discriminação. Na terça-feira todo mundo vai trazer, aí eu chamo vocês pra ler o que todo mundo colocou e vocês vêem se concordam ou não. Depois alguém passa a limpo e vocês assinam com nomes que não são o de vocês. Você quer levar e tentar escrever?

O3: Posso.

K: Se você tiver alguma outra idéia, pode colocar também. Mas não é obrigado, é se você tiver vontade.

O3: Pode dobrar? 
K: Pode, pode dobrar, pode ficar pra você. Então, O3, eu queria agradecer bastante a tua participação. Muito obrigada! 


\section{ENTREVISTA INDIVIDUAL COM O ALUNO EVARISTO (O4)}

K: O4, a primeira pergunta é a seguinte. Para você lembrar, nos encontros em grupo a gente falou várias coisas, você participou praticamente de todos e aqueles em que você não participou eu retomei um pouquinho, então você está sabendo de todos os assuntos. A gente começou a falar sobre como era ser adolescente pra vocês, sobre a imagem que os adultos fazem sobre os adolescentes, sobre como é ser um aluno adolescente, sobre a relação entre vocês $e$ todo mundo aqui da escola, alunos, professores, diretora, coordenadora, um monte de gente. Vocês escreveram também as propostas do PAN e no último a gente ouviu as músicas e conversou bastante sobre as músicas. De uma forma geral, o que você achou desses encontros?

O4: Ah, achei legal. Falamos sobre os jovens, o que acontece com jovens, 0 que acontece no dia-a-dia. Achei legal falar sobre isso!

$K$ : Desses assuntos que a gente falou, o que mais te interessou?

O4: Sobre a violência e que a gente não tem segurança. (Barulho externo)

$\mathrm{K}$ : Acho que esse barulho vai atrapalhar um pouquinho, vamos sentar mais pra lá. Pronto, acho que aqui está melhor. Você estava falando que o que mais te interessou foi quando a gente estava falando da violência e que aqui não tem segurança. Mas no mundo em geral ou na escola?

O4: No mundo, em qualquer lugar; não é só na escola.

$K$ : No último encontro a gente falou sobre a coisa da polícia, vocês falaram de que só porque está mal vestido, às vezes, é discriminado, às vezes o policial pára, essa diferença de uma pessoa bem vestida e uma mal vestida. Você acha que tem algum assunto que era importante falar e não deu pra gente falar?

O4: Que eu saiba, não. Falamo sobre tudo, sobre violência, o que acontece... de tudo, em geral.

K: Você achou que foi suficiente o que a gente falou.

(Interrupção - mudança para outra sala por causa do barulho externo)

K: Agora sim, agora que a gente mudou de sala tá com menos barulho. Posso te perguntar de novo? Acho que não gravou nada. Eu estava te falando dos encontros em grupos e de tudo que a gente falou, daí eu perguntei o que você achou de participar dos encontros, você falou que achou legal. Por que achou legal?

O4: Porque falaram sobre os jovens, sobre a violência que acontece mais lá fora e aqui dentro, estudo em geral também. E que os policiais discriminam quem se veste bem e quem se veste mal.

K: Aquele assunto de ser discriminado. Aí eu tava te perguntando se tem algum assunto que você acharia interessante falar e que a gente não falou e aí você disse que não.

O4: Que eu saiba, não.

K: Quando vocês estavam escrevendo a proposta para o PAN, escreveram no começo que vocês não queriam ser conhecidos como "aborrecentes" e que se sentem julgados injustamente pela situação financeira de vocês, por não ser rico. $O$ que você acha dessa história? 
O4: Sei lá, tem um pessoal que não gosta. Tipo onde eu morava, a gente jogava bola na rua, o pessoal não gostava, tinha gente que chamava a polícia... A polícia ia lá conversar com a gente, tinha policial que batia.

K: Você acha que isso acontece porque vocês são adolescentes ou porque vocês não são ricos?

04: Ah, não sei. Sei lá, a gente não é prisioneiro, não podem fazer isso daí.

$\mathrm{K}$ : Você estava falando que morava num outro lugar. Agora você mora lá na (...)., na favela mesmo, ou nas casas aqui ao redor?

04: Moro aqui perto da escola.

$\mathrm{K}$ : Onde você morava antes era o que, uma comunidade?

O4: Era uma rua normal.

K: Você nunca morou numa favela?

04: Já morei numa favela com meu pai, só que o pessoal não se preocupava, era todo mundo legal. Tinha gente que se incomodava porque morava longe, mas não tinha preconceito.

K: Então você sente mais preconceito quando tá fora?

O4: É. Quando eu morava com meu pai e chegava na rua, o pessoal começava a zoar.

K: Eu lembro que a A4 estava contando que ela também já morou numa favela e sentia muito esse preconceito, o pessoal dizia: "Ai, quem mora na favela é$-"$

O4: Bandido, ladrão, esse tipo de coisa. Tem gente que mora em favela que é mais honesto do que esse pessoal que mora na cidade.

K: Outra coisa do PAN que eu queria te falar é que vocês fizeram várias propostas sobre saúde, emprego, educação. Quando vocês estavam começando a falar sobre educação, acabou o tempo. Qual você acha que é o maior problema da educação?

04: Na escola?

K: É.

O4: Acho que é os alunos e os professores. Sei lá, os alunos não estão com vontade de aprender. Eu também não gosto, mas precisa, senão não vou ser ninguém na vida. Minha mãe sempre fala isso: "Precisa estudar, senão aí é que vai ser mais discriminado ainda"!

K: Pior, né? Se está desempregado, já tem o preconceito de desemprego e tal. O que se poderia fazer pra poder melhorar a situação da educação?

04: Os alunos se esforçar pra aprender e os professores se esforçar pra ensinar também.

$\mathrm{K}$ : A gente está falando sobre o presente, eu queria perguntar um pouquinho sobre o passado também. Você começou a estudar na primeira série ou fez préescola?

O4: Fiz pré-escola. Mas não lembro muito bem.

$\mathrm{K}$ : Você tem alguma lembrança de você aluno criança, de como era estudar quando era criança?

O4: Eu só brincava, fazia desenho. Tudo na brincadeira quando a gente é criança. 
$\mathrm{K}$ : Como era a relação entre os professores e vocês, os alunos criança?

04: Com os alunos crianças eles sabem que têm que ter respeito, não vai intimar se o aluno tá conversando, não vai xingar.

$\mathrm{K}$ : $O$ que eu queria te perguntar era isso, se você sente alguma diferença entre ser aluno criança e ser aluno adolescente.

04: É bem diferente!

$K: E$ que diferença maior você acha que tem?

04: Tem professor que xinga o aluno adolescente. Uma vez eu estava brigando na escola, a professora queria me bater! Na escola de criança não, eles conversam, chama os pais.

$\mathrm{K}$ : Muda bastante...

04: Muda bastante.

K: Você estudou numa mesma escola da primeira até a quarta série?

04: Não. Na primeira e na segunda estudei em Sergipe. Na terceira morava em Itaquaquecetuba e na quarta morava aqui em São Paulo.

K: Você sentiu alguma diferença entre essas três escolas?

04: Até a terceira série, não, normal, os professores ensinavam bem. $\mathrm{Na}$ quarta série também. Depois que eu vim pra cá, era diferente, o professor não tinha condição de ensinar porque tem mais alunos. Aqui é diferente.

K: Já desde a quarta série, né? A partir da quarta série você mudou, então você acha que aqui em São Paulo tem muito aluno e eles já não dão tanta atenção quanto podem dar quando a sala é menor.

O4: Quando eu morava em Sergipe, a professora era muito atenciosa com a gente! Ia nas casas falar com os pais.

$\mathrm{K}$ : Ah, ia até em casa falar com os pais. Você sente que isso faz diferença?

O4: A gente se sente mais seguro com os professores.

$\mathrm{K}$ : A gente estava falando sobre o presente e o passado. Agora quero te perguntar sobre o seu futuro. $O$ que você espera do seu futuro?

04: Ter algo melhor pra mim e pra minha família... Tô querendo seguir a carreira militar.

K: E o que precisa fazer pra seguir a carreira militar? Você pensa em fazer até o terceiro ano colegial ou não?

04: Quando terminar meus estudos, entrar no Exército. Se não conseguir entrar, vou procurar emprego. Tem um colega do meu pai que é da polícia, ele tinha falado se eu não conseguir entrar no Exército, pra mim trabalhar na polícia.

K: Então você vai esperar terminar o terceiro colegial e ver se entra na carreira ou então consegue um emprego lá na polícia com esse amigo do teu pai.

04: É.

$\mathrm{K}$ : Na verdade é interessante, porque desde o começo você falou que a violência é uma coisa que mais chamou a atenção e você tá querendo seguir a carreira militar ou ser policial, de alguma forma tentar lidar aí com essa violência, né? E qual você acha que é o maior problema da violência?

04: Ah, tudo. Tinha uma vez que eu tava com meu tio e os policial parou uns cara lá na Praça da Sé, aí eles conversaram, os caras deram um negócio pros policial, soltaram os caras, deixaram ir embora! Assim não adianta nada! 
K: Tem muito dessa coisa de suborno, né?

04: É. Tem policial que fuma maconha, esses troço. Não adianta nada! $A$ polícia é pra diminuir a violência.

K: Agora eu queria te pedir pra dar uma lidinha nas propostas que vocês fizeram do PAN.

O4: Eu li ontem.

K: Ah, já leu. O que você achou do que tá aí?

04: Ah, tá bom.

$\mathrm{K}$ : Tem alguma coisa que você quer completar?

O4: Eu mesmo, não.

$\mathrm{K}$ : Então tá bom. Mais alguma coisa que você queria falar?

04: Não.

K: Então, tá bom. Eu vou te dar uma cópia disso, como eu tô fazendo com todos vocês, pra vocês levarem pra casa e pra pensarem se querem colocar mais alguma proposta. Na terça-feira todo mundo vai trazer, aí eu chamo vocês pra ler o que todo mundo colocou e vocês vêem se concordam ou não. Depois alguém passa a limpo e vocês assinam com nomes que não são o de vocês, tá bom? Então, 04, muito obrigada pela sua participação! 


\section{ANEXO XVI \\ TRANSCRIÇÃO DE ENTREVISTA INDIVIDUAL COM \\ A PROFESSORA LUCILA (Pa2)}

K: O que você acha dos adolescentes de hoje, de um modo geral?

Pa2: Eu acho que eles estão bem "revoltadinhos", sabe? Revoltados.

$\mathrm{K}$ : Como?

Pa2: Não querem fazer nada... Eu acho que eles não têm perspectiva de futoro, mesmo, né? Então, nada interessa.

K: Por que não tem perspectiva, você acha, de futuro?

Pa2: Ah, eu acho que eles estão vendo o mundo lá fora, já, como é que está, né? Acho que por isso mesmo que num... É uma minoria que se interessa.

K: Você acha que essa revolta, essa coisa é típica dos adolescentes ou não?

Pa2: Eu acho que sim.

$K$ : E o que causa essa revolta?

Pa2: A revolta, acho, que é pelo mundo, mesmo, né? Tem o desemprego, tem a família, os pais... desempregados, alguns pais que se encontram na cadeia presos, né? Então, acho que dentro disso aí, os jovens não têm perspectiva na vida deles.

K: Você acha que essa revolta dos adolescentes é uma coisa natural, biológica... de todos ou não, é uma coisa que tem mais a ver com questões que não são biológicas?

Pa2: Acho que... a questão não é biológica, mesmo. Acho que é mais da sociedade.

K: Você sente diferença entre a geração dos jovens de hoje e da geração dos jovens da sua época de quando você era jovem?

Pa2: Totalmente. É totalmente diferente!

$K: O$ que você sente?

Pa2: Eu acho que antigamente, no meu tempo, era uma minoria que estudava. E hoje em dia não, todo mundo pelo menos tem..., eles estudam, pelo menos, de quinta a oitava série; e, antigamente, não. Não sei o que acontecia que os pais mesmos queriam que os filhos estudassem. Hoje em dia não, é a própria estrutura mesmo... você não sente que o governo, mesmo...; eles passam o aluno, fazendo ou não lição na sala de aula.

K: Quer dizer, é aprovado independente... 
Pa2: É. Independente do conhecimento, sabe? Acho que é isso.

$K: E$ você acha que isso muda, então? Interfere?

Pa2: Muda. Não tem interesse, mesmo. Pra que estudar? Eles vêm para a escola para quê? Ponto de encontro, né?

K: Você acha que o sentido de vir pra escola...

Pa2: É pelo ponto de encontro, né? Olha, dentro da sala de aula, a gente observa que só estão mesmo a fim, cinco alunos. Os outros vêm, mesmo, pra passear na escola, pra conversar, pra encontrar.

$K: E$ quando você está falando dessa falta de incentivo, você está falando dessa preocupação com a progressão continuada? Então, você acha que a progressão continuada interfere?

Pa2: Interfere.

$\mathrm{K}$ : Como?

Pa2: Pra que estudar, se ele vai passar? Ele não vai se sentir incentivado, se chegar no final do ano e ela vai ser promovido, mesmo, né? No fim do ano ele teria que estar, pelo menos, no mínimo estudando, assimilando o mínimo pra poder..., né? Hoje em dia não, chegam no final, ficam o ano inteiro brincando, a presença deles já é o suficiente pra ser promovido.

$\mathrm{K}$ : Você estava falando no começo de uma falta de interesse dos adolescentes de um modo geral e agora da falta de interesse dos alunos dentro da escola. Na sua geração, quando você era jovem, fora da escola como eram os alunos?

Pa2: Assim, de violência, comportamento... era o contrário. Eram um, dois que saíam da linha. Hoje é o contrário, um, dois se interessam e o restante não tem interesse nenhum.

K: Você estava falando que poucas pessoas estudavam, você acha que o comportamento deles na sociedade...

Pa2: Não sei se seriam poucas pessoas, como eu diria..., porque hoje, também, a população aumentou bastante, né?

$K: O$ acesso à educação aumentou...

$\mathrm{Pa2}$ : No meu tempo mulher eram poucas que estudavam; era uma minoria, também.

K: Você estudou quando era jovem?

Pa2: Sim. Não sei se é da própria cultura oriental, mesmo; que os pais querem que os filhos estudem, né?

K: Você acha que a juventude era mais recatada, não era tão solta.

Pa2: É. 

também?

K: Falando dos alunos, você dá aula pra cá e dá aula em outro lugar,

Pa2: Não. Só aqui.

$K$ : $E$ você sente diferença entre os alunos das salas daqui, que todo mundo fala da $8^{a} A$...

Pa2: Para a $8^{a} A$ não dou aula. Mas eu sinto uma diferença na $8^{a} B$.

$K:$ Qual a diferença?

Pa2: A indisciplina. Porque eu acho que atrai, sabe? As classes são formadas separando os alunos, tirando um daqui, colocando [outro ali]. Mas parece atrai, né? Parece que os alunos indisciplinados se juntam numa sala só. $A$ $8^{a} D$, se for ver, a disciplina na sala é boa, observando o posicionamento dos alunos, eles são disciplinadinhos... A $8^{a} B$ tem..., sabe aquela coisa de provocar a gente, mesmo? "Somos indisciplinados, mesmo"; "Eu vou afrontar a professora"... Então, na $8^{a} B$ a posição da sala, a disposição das cadeiras... tudo organizadinho. $E$ a $8^{a} D$, não; tudo é bagunçado, um põe aqui, o outro põe ali, fica tudo amontoado, sabe?

$\mathrm{K}$ : E como eles, os alunos, são dentro da sala?

Pa2: Interesse, zero!

K: E com relação à disciplina? O que eles fazem na sala de aula?

Pa2: Aí, é provocação. Jogam as coisas, papel. Aquela coisa de adolescente, de provocar mesmo.

K: Como "...aquela coisa de adolescente"? Fala um pouco melhor. Que coisa de adolescente?

Pa2: É aprontar, mesmo, com as pessoas.

$K:$ Você acha que o adolescente tem isso de desafiar mais?

Pa2: Tem, sim.

$K: E$ como você sente que é a sua relação com os alunos adolescentes?

Pa2: Ah... eu me dou bem com eles, até. Agora, não sei o que eles sentem.

K: Então, você acha que é tranqüilo? Quer dizer, tem duas coisas: você se dá bem, mas tem a questão de eles serem indisciplinados, também, né? Como é, por exemplo, sua relação com os alunos na $8^{a} B$ ?

Pa2: Como diria? Se eles me respeitam, é isso?

K: Pode ser.

Pa2: Eles são bem, assim, debochados..., como diria? Eles bagunçam...

$K$ : $E$ você sente isso mais na $8^{a} B$. E nas outras não? Nas outras eles te respeitam mais?

Pa2: Olha, a $C$ e a $D$ são classes mistas, mesmo, né? Tem alunos bons e alunos ruins. 
K: De uma forma geral, você acha que eles não respeitam, que eles vão além do limite do respeito?

Pa2: É.

$K: E$ que idéia você acha da imagem que eles fazem de você enquanto professora? Você acha que eles pensam o quê??

Pa2: Eu acho que pra eles professores e nada é a mesma coisa.

$\mathrm{K}$ : Por que você acha isso?

Pa2: Eu acho que eles não estão valorizando o ensino, sabe? A escola pra eles num... Eles não dão importância pra nada.

$K: E$ você especificamente, imagina alguma coisa da imagem que eles fazem de você, ou não?

Pa2: Não.

K: $O$ que você sente é que uns respeitam, outros não respeitam...

Pa2: Eles não querem nada. É que eu... Cada professor tem um modo diferente. O Pr1 é mais bravo, é exigente. Eu não quero ficar assim, pegando no pé do aluno, arrumando encrenca, sabe? Não leva a nada. O professor Pr2 comentou que quer fazer todo mundo fazer a lição, e ele fica afrontando os alunos. E adianta? Causa problema de saúde, até, né? Eu já tô, o ano que vem, se deus quiser, eu me aposento. Eu não vou ficar aí brigando, arrumando confusão, não. Acho que não vale a pena, não.

K: Você dá aula do que, mesmo?

Pa2: De matemática.

K: De matemática. Você orienta a sua prática de alguma forma pelo fato da alguns alunos serem assim "revoltados", como você está falando? O fato de os alunos adolescentes, para você, serem revoltados, isso muda de alguma forma o seu jeito de dar aula, a sua prática?

Pa2: Não.

K: Você dá aula do mesmo jeito, né? Independente de eles serem assim...

Pa2: Isso. Eu faço a minha parte. Você diz, assim, de utilizar um método diferente...?

K: Alguma coisa que: "Já que os alunos são assim, eu vou fazer assim ao invés de fazer de outro jeito".

Pa2: Não.

K: Então, você passa pra eles o conteúdo...

$\mathrm{Pa2}: \mathrm{O}$ que a gente ensina normalmente, né?

$K: E$ como você sente que está sendo o aproveitamento dos alunos?

Pa2: É aquilo que eu falei. Cinco, seis que estão aprendendo e o resto, não. 
K: E eles vão passar de ano, né?

Pa2: Vão passar. Eles não querem progredir. É isso que eu falei pra você. Ter que ficar o tempo inteiro brigando, se desgastando.

K: E essa coisa da progressão continuada interfere até na relação de vocês, né?

Pa2: Sim, depois que surgiu a Progressão Continuada, a coisa decaiu, foi só decaindo, cada vez mais.

K: Você está falando que eles não valorizam o professor. Você acha que a progressão continuada apareceu um pouco nessa direção também?

Pa2: Eu acho que é o interesse do governo, mesmo. Promover todo mundo $e$ eles não fazerem nada.

$K$ : E o que leva a repetência?

Pa2: Só frequiência. Lógico que se o aluno não tem bom aproveitamento, é retido; se for em todas as matérias; agora, se for em uma ou duas, não fica retido.

K: Tem um negócio de Conselho de classe, que passa por esse conselho, aí o conselho decide... E recuperação, não tem mais?

Pa2: Não. Não temo mais. A gente ta fazendo reforço, agora.

$\mathrm{K}$ : Agora no fim do ano?

Pa2: Agora, depois do SARESP. Estamos pensando em fazer. Para aqueles que estavam com mais dificuldades. Aquele aluno que o ano inteiro se interessou, participou, é lógico que vai passar. Então, a gente quer dar um... quer chamar ele pra fazer alguma coisa... no reforço.

K: Você estava falando que você deu aula aqui há muito tempo. Como é sua trajetória? Há muitos anos você trabalha com adolescente?

Pa2: A vida inteira. Sempre de quinta a oitava.

K: Há quantos anos você dá aula?

Pa2: 24.

K: Você que escolheu dar aula para os adolescentes, você escolheu a faixa etária, como é que foi essa escolha?

Pa2: Não, o próprio curso dá direito a de quinta a Ensino Médio, e essa escola só tem o Fundamental, né?

$K: E$ você escolheu essa escola?

Pa2: Não foi a gente que escolheu> Nós éramos do (...) [X escola] e com a reestruturação, todo mundo veio pra cá.

K: Não foi opção?

Pa2: Não, não foi opção.

K: Mas como você se sente dando aula para os alunos adolescentes? 
Pa2: Acho que... Não tenho nada contra! Você diz, assim, se é desgastante? É bastante desgastante, porque suga muito a gente, sabe?

K: Tem alguma coisa que te traz satisfação em dar aula para os adolescentes?

Pa2: Claro que sim! É o que falei, é uma minoria, mas acho que estão assimilando.

$\mathrm{K}$ : O que mais te marcou nesses anos todos como professora dos adolescentes? O que mais te marcou nessa trajetória?

Pa2: Sabe que agora na minha cabeça não tem nada... que marcou!

$\mathrm{K}$ : Alguma situação, alguma coisa que aconteceu?

Pa2: Cai na rotina, né?

$\mathrm{K}$ : Acabam ficando iguais, os anos se repetem, se repetem...?

Pa2: Lógico que você vê que tem alunos bons que hoje estão formados, né? Tem aluno que já se formou, que já conseguiu uma coisa na vida, fez uma boa faculdade.

$K: E$ isso te traz satisfação?

Pa2: Ah, sim. Tive aluno que fez medicina na USP!

$\mathrm{K}$ : E eles vieram contar?

Pa2: Ah, sim! O filho do professor Pr1 também foi meu aluno. Alguma satisfação, a gente tem.

K: E que frustração você tem dessa experiência?

Pa2: Frustração é os próprios alunos não se interessarem. Isso deixa a gente muito chateado.

$K: E$ você hoje tem alguma esperança? Que esperança você tem em relação ao seu trabalho como professora?

Pa2: Em primeiro lugar, se continuar do jeito que está, a tendência é só piorar, né? Os professores que virão, acho que vão sofrer muito!

K: Você estava falando que tem possibilidade de se aposentar o ano que vem. Você está esperando, está ansiosa para que chegue a aposentadoria? Como está essa sua relação com a aposentadoria?

Pa2: Estou cansada! É muito desgastante, não é fácil!

$\mathrm{K}$ : São quantos alunos por sala, mais ou menos?

Pa2: No mínimo 35 alunos. Se todas as classes fossem como a $8^{a} \mathrm{D}$, seria tranqüilo... poder dar atividade para os jovens, sabe? Mas nas outras salas, 0 rendimento é mínimo. Deixa a gente cansado!

K: Nesse período de sua trajetória você deu aula em uma outra escola também, você dá aula há 24 anos. Você sente diferença do começo dessa sua 
experiência, de como eram os alunos e de hoje? Porque 24 anos é muito tempo, né?

Pa2: É, cada ano vem decaindo! De uns 5 anos para cá, que eu acho que a coisa decaiu.

K: Que é a fase da progressão continuada, mesmo?

Pa2: É. E o desinteresse é quase que total. É uma minoria, mesmo, que se interessa.

K: E com relação a esse assunto você queria acrescentar alguma coisa?

Pa2: Não. Não sei se vai dar pra aproveitar alguma coisa...

K: Nossa! Muito do que você falou vai dar pra aproveitar! Muito obrigada, $\mathrm{Pa} 2 !$ 


\section{QUESTIONÁRIO RESPONDIDO PELO PROFESSOR RONALDO $(\operatorname{Pr} 2)^{1}$}

"Experiência com alunos da Rede Pública do Ensino Fundamental"2

- O que você acha dos adolescentes de hoje em geral?

Os adolescentes de hoje, em geral, são rebeldes e agem como se fossem auto-suficientes.

- Eo que acontece para que eles sejam assim, na sua opinião?

$\mathrm{Na}$ minha opinião eles agem dessa forma porque vivem as crises de identidade.

- Que diferenças você sente que existem entre a geração dos jovens de hoje e a geração de jovens de sua época?

Os jovens de hoje são mimados desde o seu lar ao estabelecimento de ensino. No lar, sem poder aquisitivo são presenteados com roupas e calçados de grife, imitando os seus ídolos esportistas ou artistas. Na escola, são promovidos para séries sem mérito.

- E como são, na sua opinião, os alunos adolescentes? (Por quê?)

Esses fatos são oriundos da própria estrutura política educacional dos pais que agraciam os adolescentes com direitos, sem em contrapartida, delegar deveres.

- Como você sente que é a sua relação com os jovens alunos?

Como trabalho com salas heterogêneas, procuro contornar o conflito cotidiano com diplomacia.

- Você sente alguma diferença entre a relação com os jovens alunos desta escola e de outra escola em que você deu (ou dá) aula? Qual? A que você atribui essa diferença?

Na própria escola tenho observado dois aspectos distintos:

- Adolescentes do Curso Diurno da Rede Pública não se empenham com seus deveres:

- Adolescentes do Curso Noturno da Rede Pública entusiasmado para alcançar os seus objetivos por meio de estudos.

\footnotetext{
${ }_{1}^{1}$ Ao revisar o material transcrito referente à entrevista realizada com o professor Pr2, este solicitou a substituição de tal material pelas respostas redigidas por ele, de acordo com as questões do roteiro utilizado em tal entrevista. Suas respostas foram fidedignamente copiadas para este documento.

2 Título elaborado por Pr2.
} 
- Motivo: Os alunos adolescentes do curso diurno são impedidos de exercer atividades remuneradas de acordo com uma das MPs do Governo FHC e os jovens do curso noturno são estudantes engajados para atividades profissionais e impelidos a competir no mercado de trabalho.

- E com relação às quatro turmas de $8^{a}$ série dessa escola: na sua opinião, existem diferenças entre cada sala? O que você acha da 8 . A (dos alunos 'repetentes' e da proposta de montar essa sala)? Na sua opinião, o que leva à repetência?

Sou contra a formação da turma de repetente, haja vista, a experiência vivida na $8^{a} A$, retrata que essa turma foi pretérito para aprimorar os seus conhecimentos, envolvendo os conteúdos dessa série. Esse paradigma contribuiu para os alunos perderem o entusiasmo ao estudo $e$, conseqüentemente a auto-estima.

- Você acha que o fato de os jovens alunos serem assim (...) interfere de alguma forma na sua prática de ensino? Como?

Os jovens alunos alocados a esse modelo de ensino encontrarão barreiras para prosseguir seus estudos. Basta analisar como são submetidos aos jovens candidatos que tentam ingressar no Ensino Médio da Rede Pública, digo, Fundação Paula Souza ou CETEF que encontrará resposta.

- Como você se sente dando aula para as $8^{a}$ séries? Você sempre deu aula para os jovens? O que o levou a optar por isso? E para você hoje, qual é o sentido (e a motivação) em dar aulas para os adolescentes?

De modo geral, lecionar é uma profissão gratificante porque prepara os seus pupilos para tornar-se um cidadão dentro da sociedade.

- Qual foi o fato que mais lhe marcou durante sua trajetória enquanto professor destes jovens alunos? Por quê?? Que satisfações este processo lhe trouxe? Eque frustrações? Ehoje, que esperanças você tem, enquanto professor?

Tive oportunidade de contatar com ex-alunos que tiveram sucesso no concurso público, bem como, atingir o curso superior. 


\section{ENTREVISTA INDIVIDUAL COM A PROFESSORA ALBERTA (Pa1)}

K - Eu queria começar de uma forma geral. O que você acha dos adolescentes de hoje, o que pensa sobre os adolescentes de uma forma geral?

Pa1 - Da nossa região, que você quer?

$K$ - Pode ser de qualquer uma. $A$ idéia que você tem dos adolescentes em geral.

Pa1 - Olha, eu acho que existem, na minha opinião, dois tipos de adolescentes: aquele adolescente que tem raízes, que tem a família atuante e que participa das atividades familiares, mesmo que o pai ou a mãe obrigue. Assim: "Eu vou passear, você vai junto". Ele tem um perfil diferente daqueles que são educados, por exemplo, com os avós ou com os pais ausentes.

$K$ - Que diferença você acha?

Pa1 - São mais agressivos, eles não têm... não conseguem direcionar a sua vida em uma direçãozinha certinha, acompanhada. Na verdade, esses eu acho que eles são uns vitoriosos em continuar até estudando até hoje.

$K$ - Esses da família que não é com o pai...?

$\mathrm{Pa} 1$ - Exato. Eu acho que a religiosidade, por incrível que pareça, e família são os pontos que fazem diferença em um adolescente.

$K E$ por que a religiosidade faz diferença?

$\mathrm{Pa} 1$ - Porque eles têm um limite. A religiosidade dá um limite pra ele; pra ele inteiro. Porque aquele limite família, limite rua e limite escola não existem. Não está dentro, é de fora pra dentro. A religiosidade, não; impõe limites de dentro para fora.

$K$ - Eu lembro até o primeiro momento em que eu coloquei o pé aqui na escola... lembro que vim falar com a coordenadora, você chegou e falou da questão da família. Assim que eu falei que a pesquisa era sobre adolescentes, você falou: "Ah, o problema deles é a família" e complementou essa frase, pensando sobre a comunidade daqui, especificamente, falando: "Ah, o que eles vão querer? Vai virar tudo marginal!" Vamos falar disso um pouquinho. O que você acha dos adolescentes dessa comunidade, e dessa questão da família?

Pa1 - Pra mim, de certa forma, eles já são uns vencedores. Eu, que já vim de uma família estruturada, uma família que..., sempre estudei em colégio de freiras, então eu tive esse limite interior bem enraizado e com os pais, com irmão, convivendo, brigando, etc. Então, não sei se eu conseguiria ser alguém como eles e como muitos alunos meus, alguém na vida que está conseguindo viver no meio disso daqui, alguns estudando e estudando bem, outros não. Então isso daí é que pega. Agora, família aqui é importante, eles têm uma necessidade da família, de ter; e jogam a família em cima da figura da mãe. Se você chamá-lo, vamos dizer, "seu veado", ele discute, mas não briga. Mas se você falar "seu filho da puta", eles vão com tudo, porque está xingando a mãe. E por que isso? Ainda eu falo: "Espera aí, tua mãe está ouvindo? Tua mãe é?" - "Não, mas xingou minha mãe". É ponto pacífico.

$K$ - E você acha que existe alguma coisa que é típica da adolescência?

Pal - Ah, sim. 


\section{K - O quê?}

$\mathrm{Pa} 1$ - A rebeldia, essas falações altas, esse tentar impor, tentar ver até onde eles conseguem dominar os adultos, se mostrar diferentes. Mas, ao mesmo tempo, eles são daqueles assim: se você aceita alguma coisa deles, eles te recebem (aceitam) em seu meio.

$K$ - Como assim? Explica melhor essa idéia.

Pa1 - Por exemplo, vamos dizer... Não digo eu porque já eu estou bem mais... Agora, por exemplo, se você pega um professor de Português ou Matemática... de Português, vai... [matérias] que eles odeiam, não gostam, não gostam e também não entendem. Se o professor de Português desse lá uma hora de lição, fazendo o joguinho deles, e fala assim: "Eu vou apitar seu jogo"..., os alunos pensam: "Ô, já ficou legal esse professor".

K - Você está dizendo, assim, se o professor entrar na onda dos alunos?

$\mathrm{Pa} 1$ - Nem assim de entrar, mas mostrar muitas vezes um pequeno interesse. Pode ser até a primeira vez que ele vá lá e não vá nunca mais depois, é a única. Você entendeu? Mas para eles dá a entender que o professor entende.

$K$ - Então, se demonstrar um interesse pelo adolescente...

$\mathrm{Pa} 1$ - Um interessezinho qualquer, por pequeno que seja. Aí ele já começa a encarar de uma outra forma, começa a tratar de uma outra forma: "Pô, esse professor é legal". Então ele já troca, já consegue se aproximar.

$K$ - Essa coisa que você estava falando da imagem do adolescente rebelde, você atribui a que a rebeldia do adolescente? $O$ que acontece para que 0 adolescente seja assim rebelde, desafiador?

Pal - Para chamar atenção. Com certeza, é pra chamar atenção!

$K-E$ tem alguma coisa que faz com que eles sejam assim?

Pa1 - Olha, eu acho que é a própria fase onde você acha que "oh, meu Deus, eu tenho que ser diferente pra poder aparecer no meu meio e eu tenho que tentar ver até onde eu posso ir, onde eu ganho de você, do adulto".

$K$ - Tem esse desafio?

Pa1 - Com certeza! Isso passa!

$K$ - Você acha que é uma fase da vida?

$\mathrm{Pa}$ 1 - É, com certeza. E a tendência dessa [fase] é passar, porque não tem uma maior... . É o que menos preocupa, na minha opinião, mas é uma fase que é perigosa porque eles caem aí mesmo.

$\mathrm{K}$ - Como assim?

Pal - Eu tive muitos alunos aqui que nessa fase toda experimentaram drogas, acabaram morrendo, acabaram presos. Dificilmente um deles se recuperou.

$K$ - Eu lembro que você estava falando daquela idéia de que: "aqui os adolescentes dessa comunidade esperam o que da vida? Futuramente vão pegar um caminho mais fácil, vão virar traficantes ou alguma coisa assim". Você acha que eles têm essa visão ou perspectiva de futuro?

Pa1 - Não têm perspectiva, é muito pouco ainda. Isso me machuca muito, porque eu acho que tem que ter alguma coisa, algum negócio que a gente possa estar fazendo, sei lá, mesmo na Psicologia, que cutuque, que faça com que eles vão pra frente. Eu consigo fazer isso, mas não de maneira geral, porque você sabe que 
a educação, infelizmente, cada vez se afunila mais e nesse afunilamento eles tiram muitos, colocam muitas crianças na rua.

\section{K - Como assim?}

Pa1 - Por exemplo, o que eu mais trabalho com eles, o que eu mais cutuco neles? É o esporte. No esporte eles têm muita coisa, conseguem fazer. Mas chega numa certa época, na época pior deles, que é de 15, 16 anos, eu não tenho onde desaguar essas crianças.

$K$ - Você acha que não tem, você acha que tem um limite?

$\mathrm{Pa} 1$ - Não, não tem.

$K$ - Por que não tem?

Pa1 - É aí que está, é um problema de governo. Por exemplo, o Instituto Ayrton Senna vai até 15. Agora abriram até os 18 anos, mas de 16, 17, 18 é muito difícil. Por quê? Porque eles já estão no mercado de trabalho, mas você não consegue de lá mandar pra um clube. Hoje eles estão vendo "eu estou ganhando, eu não preciso ir lá na feira, eu não preciso catar papelão, eu ganho o mínimo". Então tudo que o governo na verdade faz, as coisas boas que saem certo, ele consegue estragar.

$\mathrm{K}$ - Ele quem?

Pa1 - O governo. Fizeram o quê? Vou dar um exemplo: no ano retrasado eles lançaram o "Criança Cidadã".

\section{$K$ - Como era esse projeto?}

$\mathrm{Pa} 1$ - Na verdade tinha o dinheiro sobrando na Caixa Econômica e o Geraldo Alckmin fez. Foi mais um motivo por que eu votei nele, porque ele fez e eu falei: "Não abro mão disso". O que ele fez? Essas crianças teriam que freqüentar a escola, você teria como cobrar resultados na escola e eles ganhavam, sem burocracia nenhuma, mediante cartão do banco, $R \$ 120,00$ por mês.

$K$ - Por participar do projeto?

Pal - Participar, ou seja, eles tinham que treinar, treinavam três vezes por semana e ganhavam $R \$ 120,00$.

$K$ - Alguma atividade física?

Pa1 - Exato. Claro, no meu caso foi o basquete. O que aconteceu? Eu tinha 100 crianças - só eu -, que participavam. A maioria, lógico, eu puxei um pouco pra a minha sardinha, pra minha redondeza aqui. Mas, juntando com o futebol, religiosamente eles participavam. O que eu comecei a notar? Olha que coisa interessante: era de 12 anos a 17. Primeira coisa que essas crianças fizeram: compraram um tênis com os primeiros $R \$ 120,00$. Mas não compraram qualquer coisa, foram pesquisar pra comprar.

$K$ - Pesquisar a melhor marca ou o melhor preço?

Pa1 - Melhor preço! E era assim: "Nossa, onde você comprou, quanto você pagou?" Ou: "Em tal lugar está mais barato". E eles iam. Já tinha a responsabilidade de ir com o cartão tirar o dinheirinho dele e empregar. Ajudavam na casa deles, não precisavam ficar pela rua, compraram os tenizinhos deles, compraram as camisetazinhas deles, dos Blaker, do time deles, onde era mais barato, não foi em qualquer local e com cuidado. E o detalhe importante que eu exigi: que comprassem a camiseta da escola pra serem identificados. Não tiveram dúvida, o orgulho deles: 
"Quanto custa?" Tiraram os R\$10,00 da carteira pra comprar a camiseta. Olha, é uma coisa bárbara! Eu tinha gente que vinha de São Mateus treinar, que saía meiodia da escola e à uma e meia já estava treinando lá comigo!

$K$ - Isso de 12 a 17 anos?

Pa1 - Exato. Detalhe: é humilhante eles passarem debaixo da catraca [do ônibus]. Falei pra eles, eles vieram aqui, tiraram carteirinha escolar e pagavam. Eles não precisavam ser humilhados.

$K$ - E a questão da humilhação pega forte aqui?

Pal - Pega muito forte!

$K$ - Você presencia isso da humilhação?

Pa1 - Com certeza!

K - Dá um exemplo.

Pal - Eles estão tão acostumados; que eu falo pra eles: "Cadê a camiseta do (...) [dessa escola?]? Você tem que ter uma identidade com a escola, eu tive, você teve e todo mundo tem que ter. Vocês também têm, os pais de vocês estudaram aqui em cima". - "Não tenho, dá uma pra mim, compra e dá pra mim". O que é isso?

$K$ - Você está falando da diferença dos alunos que participavam do projeto...

Pal - A diferença é que eles ganhavam esse dinheiro. Eles iam com febre! Quantas vezes eu tive que tirar essa molecada com 39 de febre e mandar para o chuveiro para poder abaixar a febre? Ficava sentado lá porque não agüentava de febre, encostado em mim, mas não faltavam! Quer dizer, têm essa responsabilidade, eles têm tudo isso, mas esse paternalismo do governo estragou muito. Eu não compactuo com isso, acho que estraga os nossos adolescentes. Eles acham que o governo é obrigado a dar tudo e você sabe que não, mas quando eles têm um meio de ganhar alguma coisa, eles começam a se tornar gente.

$K$ - Você está falando da responsabilidade.

$\mathrm{Pa} 1$ - É. Eles se sentem importantes.

$K$ - De que forma, você está falando, que o paternalismo do governo atrapalha?

Pa1 - Hoje você pode ver: eles vêm sem um caderno, sem um lápis, sem uma borracha, sem uma caneta. Vêm para a escola como se fossem passear no shopping?

$K$ - Você acha que isso quer dizer o quê?

$\mathrm{Pa} 1$ - Você acha que uma pessoa que não tem responsabilidade (que não tem porque acha que você é obrigada a dar tudo) vai chegar em algum canto? Não vai. Ele vai chegar lá naquela avozinha, que cuida dele desde pequenininho, e vai exigir também. Isso vai acabar levando pra onde? Qual é o meio mais fácil de ganhar dinheiro? "Eu vou ser aviãozinho e ganhar 10 paus".

$K$ - Com drogas.

Pal - É óbvio!

K - Você acha que esse é o destino da maioria dos alunos daqui?

Pa1 - Olha, depois de 20 e poucos anos de trabalhar nessa escola, eu tenho medo dessa fase. Eu acho que a Universidade [" $X "]$, porque é nossa vizinha e nós estamos muito juntos, deveria aproveitar todos os seus alunos em cima dessa comunidade, que tem gente muito boa e que cai de terceiros. Eu vou te contar um 
caso. Há pouco tempo encontrei com um ex-aluno meu subindo, ele que era única e simplesmente um 'brocoió' aqui dentro dessa escola.

$K$ - Não fazia nada?

Pa1 - Um bobão, aquele bobão, filho único bobão, daqueles que você tem vontade de dar uns tabefes pra ver se acorda. Aluno 'cricri', que não é ruim, tem família e não sei o que. Até que resolveu "querer coisas maiores", como ele mesmo disse. O que aconteceu? O pai dele falava: "Não posso dar um tênis de 30 reais, posso te dar de 20". - "Não quero. Então vou com meus próprios meios". Foi "passar", acabou na Febem, está todo machucado, está com carinha de bandido..., está com seus 17 aninhos, está machucado pro resto da vida, por dentro e por fora. Por fora aquilo é uma marca pra ele: "Eu não sou aquele brocoió", mas por dentro, daqui a pouco ele está preso ou morto.

$K-E$ o que você acha que mais te dá medo nessa fase?

$\mathrm{Pa} 1$ - Exatamente isso. Se você tiver alguma coisa que faça com que eles se sintam gente: "Eu posso estar jogando bolinha de gude, se estou ganhando $R \$$ 50,00 , eu sou alguém, eu não vou precisar subir para pegar fio de cobre". Entendeu? Isso muda, ele não vai ser mais catador de nada, não vai ser a presa fácil, porque ganha.

$K-E$ a visão que você tem dos alunos especificamente aqui na escola: o que você acha dos alunos adolescentes daqui?

Pa1 - São uns vencedores! Se eu me coloco no lugar deles, não consigo. Você conseguiria viver aqui, viver desse jeito? Eles se apegam, ainda bem que eles se apegam a alguma coisa.

$K-A$ que eles se apegam?

$\mathrm{Pa}$ 1 - Olha, falando dessa escola, eles se apegam muito a mim.

$K$ - $O$ que você acha que acontece para que eles se apeguem muito a você?

$\mathrm{Pa} 1$ - Olha, eu até nem sabia, mas acabei ouvindo uma conversa e acabei sabendo o porquê. Foi numa classe inclusive, quando chegou uma aluna nova. Eu sou sempre muito brava com eles todos, não dou moleza, exijo respeito; e falei pra essa menina nova que aqui nós tínhamos regras a serem seguidas, que eu não abria mão dessas regras com ninguém. Ela começou a responder e eu falei que não aceitava; aliás, não aceito mesmo que me respondam. Os outros da classe foram falar com ela: "Você tem que entender que a professora fala isso pro nosso bem, ela só quer o nosso bem". Apesar de eu ser do jeito que eu sou - brava - eles pensam: "Ela é brava porque ela gosta de nós, ela é brava porque ela quer o nosso bem, ela exige porque ela pensa na gente". Quer dizer, com nem tudo que eles fazem querem que você concorde. Aí é que pega o negócio. Eles têm que ser amados? Têm que ser amados, sim, mas ninguém gosta de moleza. Moleza acostuma, acomoda $e$ isso faz mal para qualquer pessoa.

$K$ - Eu queria te perguntar exatamente isso agora. Como você sente que é a sua relação com os alunos?

Pa1 - É bem mãezona, mas mãezona brava.

$K$ - Como é essa mãezona brava?

Pa1 - Eles sabem quando fazem as coisas erradas, então vêm de cabeça baixa, eles sabem que eu sei de tudo, eles fazem questão de me contar, os próprios 
colegas me contam, mas não como se fosse "eu vou entregar", porque eles sabem que podem contar, porque eu vou pegar no pé.

$K$ - Você estava falando de você como uma pessoa que eles têm como referência, de alguém que gosta.

Pal - E que faz por eles.

$K-E$ você sente isso, né?

Pal - Sinto, sinto, sim! Sinto porque já vi. Eles fazem é para ter o meu elogio. Não é gratuito, eu não dou nada para eles. Como eu falo para eles: "Vocês querem? Na boa, vêm tirar de mim".

$K$ - Então queria que você falasse um pouquinho mais sobre essa sua postura. Você sente carinho por eles?

Pa1 - Demais! Adoro! Como eu já falei pra eles, inclusive pra a nossa querida $8^{a}$ A: "Olha, minha família é de fora, eu tenho mais convivência com vocês, agora, do que com meus próprios irmãos. É óbvio que eu tenho um carinho especial por vocês". Carinho não quer dizer que é uma relação de igual para igual, mas é o carinho. É o carinho porque, de certa forma, a gente fica isolada da nossa parte familiar, que não é sempre que você pode ir visitar, você pode estar ligando, mas isso faz com que você acabe se apegando a eles, conhecendo mais a eles. Eu acho que sou uma privilegiada. Porque como eu trabalho há muitos anos aqui, o que acontece? Já veio o pai, já veio a mãe, já veio irmão mais velho e eu noto que é importante esse vínculo: "Professora, você conhece fulano?" Às vezes eu não lembro, mas finjo que lembro, nunca digo não. Acho que as pessoas fazem questão disso. Comentam: "Professora, a senhora conhece fulano? Ih, ele falou que a senhora é brava...". Os outros que saem têm também essa questão de voltar, que é importante, eles voltam para mostrar que "eu sou alguém".

$K$ - Eles vêm dizer como é que eles estão?

$\mathrm{Pa} 1$ - "Eu passei na faculdade". Geralmente vêm uniformizados. E o detalhe: quando é da educação física, voltam para fazer estágio junto comigo.

$\mathrm{K}$ - Interessante.

Pa1 - E querem voltar para dar aula aqui. Quer dizer: "Olha, eu venci". É bem assim: "Eu venci".

$K-E$ você acredita neles, assim, no potencial deles?

Pal - Acredito piamente, acredito mesmo! E eles gostam. Quando eles querem, eles fazem; também, quando não querem... . Eu acho judiação, porque eu perdi muitos alunos aqui, porque se o governo tivesse dado, fizesse alguma coisa aqui... . Falam tanto em esporte, em tirar o menino da rua e jogar para o esporte, por que não fazem? Tive meninos que morreram o ano passado aí, cheios de tiros, que eram excelentes! Olha, seriam um potencial olímpico com toda a certeza!

$K$ - Você está falando que não depende unicamente do aluno, tem uma coisa do governo que poderia ser feita para conscientizar...

$\mathrm{Pal}$ - Na adolescência... veja bem! Que é o perigoso! Tem o caso de um aluno nosso, o coitado trabalha a noite toda fazendo sanduíche, é pai de um molequinho claro, faz parte! -, vem para a escola de manhã. Deve ganhar o quê? Vamos dizer, 150, 200 reais. Aí chega o dono da boca e oferece para ele 80 reais por dia! Ele veio perguntar pra mim e eu falei pra ele: "Se fosse 100; mas e aí? Você acha que 
compensa?". Qual discurso você pode ter? Ele tem um filho, responsabilidade, tá duro, fica até de madrugada e vem pra escola, é adolescente de 16 anos... . Só que eles estão cansados de ver gente morta. Eu falei assim: "E aí?" Mas aí bate: "Eu posso morrer, mas meu filho precisa de dinheiro!" Também temos uma outra menininha aqui que o pai era traficante da pesada. Ela tinha tudo que você pode imaginar. Morreu, agora não tem.

$\mathrm{K}$ - Morreu o pai?

Pa1 - Mataram, claro, né? Isso tudo que você imaginar que ela tinha, agora não tem. Quer dizer, você sabe que nada dura eternamente. O que você vai fazer com essa criança? São adolescentes. Não adianta ter paternalismo de dar livro. Talvez fosse muito mais interessante como, no tempo da Rede, você entrava na APM da escola e a APM não distribuía. Agora você olha por aí e vê caderno de qualquer jeito, não tem valor, não saiu do bolso dele.

$K$ - Pegando aquilo que você estava falando antes, qual você sente que é a diferença entre a geração dos jovens de hoje e a sua geração quando era jovem?

Pa1 - Família! Olha, eu tenho plena convicção disso.

$K$ - E qual é essa diferença básica da família?

Pa1 - Familia é o pilar. Olha, professor não educa. Eu tenho até restrições quanto à palavra educador. Eu acho que nós somos profissionais, nós somos contratados para ensinar.

$K$ - E a família teria essa função de educar?

Pal - Tem que educar, tem que dar limites, tem que dar ética, tem que saber o que é bom e o que não é.

$K$ - Você acha que nas diferentes gerações isso mudou bastante, esse referencial da família?

Pa1 - Mudou!

K - Mudou como?

Pa1 - A mãe não vem, não se importa com eles. Como eu falei, eu sempre pego pesado. Hoje esse menino já está na faculdade, eu fui orientadora da classe dele quando ele estava na $2^{a}$ série e eu sempre bati com eles o seguinte: "Vocês não são filhos de chocadeira, vocês têm pai, vocês têm mãe, vocês têm alguém, então esse alguém tem que vir aqui". Essa pessoa tem que vir nas reuniões. Falo, falo, falo, falo. Chegou na reunião, o irmão mais velho dele não aparecia. Aqui você ouve assim: "Minha mãe trabalha". Eu falei: "E daí, meu bem, você é filho de chocadeira?". Ele chorava de soluçar e de repente apareceu o irmão mais velho dele. Eu falei assim: "Nossa, ainda bem que você veio". Ele falou assim: "Ah, eu me perdi aqui dentro da escola". Mas esse moleque chorava de soluçar. Depois eu fiquei meio assim: "Nossa, acho que peguei pesado". Mas depois achei que não, porque agora ele faz faculdade. Ele se sentiu tão rejeitado, eu acho, se sentiu tremendamente rejeitado naquela hora. Mas Deus é bom, ele chegou. Sentou do lado do irmãozinho, veja como é importante. Na verdade eles camuflam dizendo: "Minha mãe não pode vir, minha mãe trabalha".

$K$ - Você acha que na verdade é o quê?

Pa1 - É bem assim: "É bonitinho isso aqui, mas eu não posso comprar. Você não vai me dar?" Então: "Olha, isso está ultrapassado, é feio, isso você perde 
porque você não vai saber onde anda". Eu disfarço para dar desculpa porque não posso ter.

$K$ - Você acha que a relação com a família é assim?

Pa1 - Lógico, com certeza.

$K$ - Não tem esse amparo...?

Pa1 - Não, não tem. Muitas vezes não tem mesmo, porque não dá. Outra vez, numa $5^{a}$ série, eu briguei com um moleque até não querer mais: "Você está chegando tarde. Por que você não estuda?" O molequinho quietinho assim.

(interrupção)

Pa1 - O que eu estava falando?

$K$ - Que você acha que é uma reação deles pelo fato de não terem o apoio da família, então eles diriam "ah, mas eu também não queria"... .

$\mathrm{Pa} 1$ - É. Eu noto que eles procuram e essa coitadinha dessa criança, como eu estava te contando, novinha, depois que eu dei aquele tremendo esporro no moleque: "Ah, minha mãe sai cedo". "Então você acorda cedo para estudar". Ele lá quietinho, não abria nem a boca de medo. "Que horas sua mãe acorda?" "Três horas da manhã". "Que horas ela sai?" "Quatro horas". Aí você já começa a baixar, né? Dez aninhos, coitadinho! Dá pra você entender? Essa criança fica sozinha, a mãe quando chega vai ter que cuidar da casa, lavar roupa, fazer comida, deixar pronta para ele comer de manhã. Muitas vezes nem come, vem comer às quatro da tarde aqui. Que horas essa criança vai acordar? Vai chegar tarde na escola e não vai fazer lição.

$K$ - Mas deixa eu te perguntar uma coisa. Você está falando da diferença do apoio da família e de gerações também. Tem uma coisa de classe social também misturada?

Pa1 - Não acho, não.

$K$ - Não acha? Eu ia te perguntar se você acha que influi a classe social ou não na questão da família.

Pa1 - Não.

K - Não influi? Você acha que tanto na classe alta quanto na classe baixa tem essa questão?

Pal - Tem, tem. Só que na classe mais alta é o seguinte: a mãe controla via celular.

$K$ - Não está em casa também.

Pal - Eu digo que a classe econômica não é importante, porque você pode notar que também muitos aqui têm celular. É um negócio que eu não compreendo! Não sei dizer se é roubado, não sei dizer como eles fazem, eu sei que tem um esquema, eles arrumam, trocam não sei o quê - em tecnologia sou meio, não sei de tecnologia... . Não sei se é achado, não sei se eles compram mais barato, deve ter também esses lances. Mas tem outros que a mãe dá. Dá por quê? Porque até para as mães endurecidas aqui, como eles chamam, deve bater aquela dor na consciência de não cuidar do seu filho. Então de certa forma para aliviar a consciência dá alguma coisa. 
K - Então é uma coisa que você acha que é mais da geração, que antigamente, mesmo nas mais baixas, tinha uma maior preocupação e hoje já tem uma displicência em qualquer classe?

Pal - Antigamente tinha aquele negócio: "Eu não sei ler, mas o meu filho vai estudar, eu vou batalhar para ele estudar". E hoje? Hoje, não. "O governo tem que dar um jeito".

$K$ - Ah, é aquela questão paternalista que você estava falando?

$\mathrm{Pa} 1$ - Exatamente. Eu odeio isso! Está acabando com as nossas crianças!

$K$ - Você falou "a nossa querida $8^{a} A$ ". Você sente diferença entre as oitavas séries, entre os alunos das diferentes classes aqui nas salas de aulas, ou não?

$\mathrm{Pa} 1$ - Não. Eu acho que é assim: eles foram punidos.

$K-A 8^{a} A$ ?

Pa1 - Exato.

$K$ - Pelo o que entendi, a $8^{a} A$ é a turma daqueles alunos que ficaram retidos, que no ano passado fizeram a $8^{a}$ e continuam fazendo a $8^{a}$ esse ano.

Pa1 - Mas foram punidos por que? Porque ficavam fumando crack e maconha, cabulavam aula para isso.

$K$ - Isso no ano passado?

Pa1 - No ano passado. Veja bem... aí, eles ficaram retidos. Eles sabem que estavam errados.

$K$ - Eles ficaram mais por essa questão?

Pa1 - Isso. Realmente ficaram e ficaram muitos! Veja bem, foi uma sala inteira, deu para fazer uma classe!

$K$ - Era aqui na quadra que eles ficavam fazendo isso, era aqui dentro da escola?

Pa1 - Dentro e fora. Isso daí é muito normal eles fazerem. Na quadra, não. Se bem que no ano passado não tinha muita aula de manhã como agora. Quando eu estou dando aula na quadra, eles não vêm.

$K$ - É só quando ela fica vazia.

$\mathrm{Pa} 1$ - Ou algum outro professor que eles sabem que eles medem aquela força $e$ sabem até onde ir. Eles não entram nem quando bate o sinal do recreio e eu estou lá na quadra. Eles ficam no portão olhando, com olhão arregalado, com olho de cachorro pedinte, para eu sair para eles entrarem. Enquanto eu não saio, eles não entram.

$K$ - Mas continuando o que você estava falando da $8^{a} A$, foi uma punição...

Pal - Foi uma punição que eu achei pesada, porque na verdade nós não conseguimos mudar mesmo isso, eles tiveram um ano jogado fora.

$K$ - Você sentiu que foi jogado fora?

$\mathrm{Pa} 1$ - Foi.

$K$ - Por que foi jogado fora?

$\mathrm{Pa} 1$ - Porque não aproveitaram nada.

$K$ - Como é que foi essa idéia? Ficou uma sala só com os alunos retidos, tinha alguma proposta, algum trabalho diferenciado? 
Pal - Vem sempre de cima, né? É aí que entra o problema. Era para fazer um trabalho diferenciando, mas é assim, você vai na reunião e tem: ele é repetente, então pressupõe que ele saiba conteúdo.

$K$ - Pressupõe que ele saiba?

Pa1 - É. Você já parte do princípio de que ele tem conteúdo, ele já sabe tudo.

$\mathrm{K}$ - Contraditório, né?

Pa1 - Total! Por exemplo, um deles foi da classe de aceleração na $5^{a}$ série. $\mathrm{Na} 5^{a}$ série eu trabalhei com eles, fiz inclusive um projeto de aceleração e ele tinha dificuldade já na $5^{a}$ série, apesar da idade defasada, de ler e escrever. Continua, está na $8^{a}$ com dificuldade de ler e escrever. Não pode ser retido e você não tem como forçar esse aluno a fazer um reforço para aprender, porque quem sabe ensinar ler e escrever é o primarinho (o primário).

$K$ - Você acha que não adianta colocar para fazer reforço?

Pa1 - Não adianta, não adianta! Adianta assim: algumas pequenas dificuldades que você vai tirar, mas você pegar e fazer um trabalho totalmente diferenciado. Não sei por que e o que é essa diferenciação. Trabalho diferenciado para mim é quando eu pego você e você tem dificuldade em escrever e eu fico em cima para sanar essa dificuldade. Mas nem todo mundo tem essa dificuldade, tem aquele ali que não sabe ler, o outro tem dificuldades em escrever e assim vai indo. O que você vai fazer?

$K$ - E o que você acha que causa essa dificuldade? Não a dificuldade, mas o que causa essa situação de ter aluno na $8^{a}$ série sem conseguir ler?

Pal - Quando você passa (que é obrigado a passar) no primeiro ano primário sem ele estar alfabetizado. Ele vai ser agressivo a vida inteira, porque ele não vai querer mostrar que não sabe. Vai querer mostrar na $8^{a}$ ? Não, vai ser agressivo, vai xingar para não mostrar que não sabe ler. Se não sabe ler, não vai acompanhar nada.

$K$ - E aí vai se somando, passando da $1^{a}$ série pra $2^{a}$, da $2^{a}$ pra $3^{a} \ldots$

Pa1 - Vai. Aí ele pára na $4^{a}$ série com uma defasagem de três anos sem saber ler! Como eu dou aula também na $4^{a}$, eu tenho uma classe que tem crianças que vêm obrigatoriamente, já que não pode ficar aluno retido. Aí ele vem sem saber ler e vai parar na $8^{a}$, e vai ficar mais um ano. E na $8^{a}$ ele é adolescente - bate no seu ponto da pesquisa. Ele tem vergonha. $\mathrm{Na} 4^{a}$ série não tem tanto, mas com 15 anos tem vergonha, é grande, já está bonito, já está forte. O que vai fazer? Vai agredir, vai xingar o professor que está mandando fazer..., e na hora de sentar pra fazer, o professor vai ver que ele não sabe ler.

$K$ - Então você acha que esse ano todo foi um ano que não valeu para eles?

Pa1 - Não valeu, não.

$K$ - Então eles continuaram sem saber?

Pal - Ah, já pressupõem que ele saiba todo o conteúdo! Se você tem 500 faltas, você não sabe conteúdo nenhum bem!

$K-E$, pressupondo que sabem o conteúdo, qual é a proposta então? 
Pa1 - Aí você vai fazer algumas fichinhas da aceleração da $5^{a}$. Pegaram as mesmas fichas da $5^{a}$... olha o absurdo! Não tem nada com nada! Eu pego aquela ficha e jogo para trabalhar na $8^{a}$ ! O mesmo material.

K - E esse pressuposto vem lá de cima; "de cima" seria da Secretaria da Educação?

Pal - É, vem.

K - Então de lá de cima tem-se a idéia de que se sabe tudo. Aqui os professores, na realidade, entram em contato. Ao apresentar essa fichinha da $5^{a}$ série vêem que não sabe, e aí?

Pa1 - Você não fala que é da $5^{a}$.

$K$ - Não fala para eles?

Pa1 - Não.

$\mathrm{K}$ - Mas o professor sabe...

Pa1 - Lógico que sabe!

$K$ - Diante da realidade que é diferente dessa proposta que vem lá de cima, - que acontece, o que se faz? Então, percebe-se que não é a realidade que eles estão falando. E aí, o que acontece?

Pa1 - Aí vai sair esse pessoal que vai entrar no Ensino Médio sem saber contar, sem saber nada. Vai parar tudo, porque ele vai precisar de matemática, vai precisar ler. Ele vai depois sair daqui, vai arrumar um emprego decente? Não vai dar.

$K$ - Tem toda essa questão. E não existe esse espaço para então, diante desse quadro real, que é diferente daquele imaginado ideal, não tem espaço para se fazer outra coisa? Tem também uma coisa de tolher, não dá para se fazer proposta?

Pa1 - Você está partindo de adolescente, ele é difícil.

$K$ - Nesse sentido que você vinha falando?

Pa1 - Exatamente. Ele vai esconder as falhas! Adolescente é assim: ele pode nunca ter beijado, mas ele nunca vai assumir, falar. É uma idade muito preocupante! Agora, você até pode fazer alguma coisa por essa criança se ela assumir. Adolescente não assume os limites, "eu não sei ler", e nem as falhas. Você não pode esquecer também que tanto crianças como adolescentes são malvados com eles mesmos.

$K$ - No sentido de superexigentes?

Pa1 - Não, não. Eles são malvados mesmo.

$K$ - Em que sentido?

Pa1 - Em todos! Eles não deixam passar absolutamente nada; eles são altamente críticos entre eles e eles não perdoam entre eles.

$K$ - Com essa sua visão, que você tem com base na sua experiência da sua relação com os adolescentes e tal, você direciona tua prática de alguma maneira em função de os adolescentes serem assim, do jeito que você falou?

Pal - Ah, com certeza! Eu tento resgatar, tento puxar para mim, mas também chega uma hora que eu fico podada. O que eu posso fazer, para onde eu vou mandar essa criança?

$K$ - Como assim? Explica melhor. 
Pa1 - Olha, eu acho que a gente tem muita coisa que pode fazer. Tanto é que, veja bem, mesmo quem estuda de manhã e não tem o que fazer fica aqui comigo e todo mundo vem atrás. E eu prefiro que fique. Mas esses melhores, para onde eu mando, o que faço? Só falar no ouvido deles? Falta um elemento de ligação. É perigoso, é uma idade perigosíssima? É, como eu já te mostrei. Mas, gente, faz um elozinho aqui.

\section{$\mathrm{K}$ - Entre o que e o quê?}

$\mathrm{Pa} 1$ - $\mathrm{O}$ adolescente. Como eu falo, o "aborrecente" com o adolescente.

$K$ - Como assim? Explica melhor essa idéia.

Pa1 - O "aborrecente" que é essa criança perdida. Veja bem, se nesse meio aqui tiver alguma coisa que ele goste, esporte (que é o que eles mais gostam), informática... As nossas crianças não gostam muito de televisão, elas gostam de esporte. Então o que você vai fazer? Fazer alguma coisa que seja simbólica. Por exemplo, esse "Bolsa Família" eu achei fantástico, mediante alguma coisa faz esse elo. Ou seja, algum programa. A Caixa está sem programa? Coloque aqui, pega esse aluno aqui e põe aqui, faz esse elo. Ele vai assumir que não sabe ler, vai ter assumir para ele poder ter. Infelizmente, quem manda é o dinheiro.

$K$ - Você está falando para fazer um elo entre o aluno "aborrecente" perdido e o adolescente...?

Pa1 - Porque os dois não vão assumir.

$K$ - $O$ adolescente que você está dizendo é aquele que tem responsabilidade?

$\mathrm{Pa} 1$ - Mesmo aquele adolescente que não tem, mas não tem tanta falha na aprendizagem nem nada. Então o que você faz? "Rapaz, você tem essa falha aqui, você não sabe ler. Se você não der um jeito nisso, você vai perder essa regalia". Com certeza ele vai dar um jeito!

$K$ - Você está falando em coisas que podem contribuir para que ele saia dessa posição do "aborrecente" e...

Pa1 - E não vá para o lugar onde você tem esse dinheiro mais fácil. Com qualquer dinheirinho eles se sentem muito importantes.

$K$ - É aquilo que você estava falando da responsabilidade.

Pa1 - Exatamente.

$K$ - Então, você direciona a sua prática com base nessa idéia...

Pal - De mostrar: "você vai pode conseguir, você vai conseguir fazer e chegar ali". Tem condições. Eu falo para eles: "não estava escrito na testa do Lula, quando ele nasceu, que ele seria presidente. Se tivesse escrito na testa de cada um, a gente pegava estupradores e assassinos e afogava assim que nascessem". É bem chocante, mas é o que eles entendem mesmo! Ou seja, "vai à luta!". Aí eu mostro: fulano foi. Quando eles vêm aqui, eu falo: "Esse daqui foi meu, começou como vocês, é daqui mesmo, dessa comunidade". Eles ficam assim: "Nossa!"

$K$ - Então, no seu trabalho você procura mostrar para eles que eles podem ir além?

Pa1 - Mostro, mostro. Dá para dar um lugar onde eles tenham uma convivência. Eu consegui fazer isso aqui, eles são muito unidos entre eles, eles jogam nos lugares em que eles se encontram, então um ajuda o outro. Eu já tive casos aqui interessantes. Da equipe toda, um dos meninos mais ricos começou a 
fumar. Não deu outra, pegaram dentro do banheiro, deram uma surra no moleque, o moleque nunca mais fumou. Depois vieram contar para mim que bateram e eu falei: "Bem feito! Você fez ele comer o cigarro?". Ainda cutuco. É antiético, é antipedagógico? Não sei, mas funcionou. $O$ irmão dele morreu e foi enterrado como indigente, mexia com drogas.

$K$ - Você tinha falado no começo que nessa fase, o aluno é 'rebelde'. De que forma você tenta na sua prática colocar alguma coisa que vai nessa direção de tentar lidar com essa rebeldia?

Pa1 - Eu mostro para eles que, querendo ou não, eles vão ter que fazer o que eu quero.

$K$ - Aquela questão das regras?

Pa1 - É. E acabou; eu sou mais velha e acabou. As regras são minhas e acabou. Quando eles começam a entrar, pode até tentar um diálogo. Mas com adolescente não tem muito diálogo não, viu? Porque, na verdade, o diálogo deles é te testar. O diálogo deles é assim: "eu vou chegando, eu venci, então não tenho mais interesse aqui, aí vou ao outro". Talvez eles tenham interesse em mim e na matéria porque exatamente não conseguiram me vencer. Talvez no dia em que eu abrir...

K - Eu queria te perguntar uma coisa. Há 20 anos você dá aula aqui, né? Você sempre trabalhou com jovens, sempre deu aula para jovens?

Pal - Sempre.

K - Há quantos anos você dá aula para jovens?

Pa1 - Ah, tem 30 anos já. Eu adoro!

$K$ - Você adora? Eu iria te perguntar isso $e$, antes, queria perguntar: o que te levou a dar aula para os adolescentes?

Pal - Eu acho que a vida encaminha. Além disso, eu também dou aulas de natação para adultos. Eu dou aula mais ou menos assim, porque adulto para você ensinar a nadar é um adulto que tem muito mais medo do que qualquer coisa na vida, que treme na base só de ver uma torneira pingando.

$K$ - Tem que lidar com essa questão?

Pa1 - Exato. Eu trato como trato os meus, minha aula é assim. E também outra coisa: eu não me abalo nem de um lado e nem do outro, nem com eles aqui e nem com o outro. Eu aceito. Porque os adolescentes já olham pra mim e dizem: "oi, velha; oi, bruxa; oi, gorda". Você deixa falar isso? E daí, meu bem? Se a pessoa te chamar "oi, linda", dependendo do tom, você sabe qual é.

$K$ - É uma relação que vocês vão conquistando...

Pa1 - Exato. Esse trabalho é que vai... Quer dizer, você entra, você trabalha. Eu adoro!

K - Você falou que adora. Eu ia perguntar como você se sente dando aula para os jovens. Adora, como?

$\mathrm{Pa}$ - Ah, me sinto realizada, eu me realizo!

$K$ - Como? Por quê?

Pal - Quando eu vejo que consigo... nem que seja um pouco, é muito bacana! Eu fico triste quando não vão na carreira certa. Já deu uma porção de bichinho na cabeça, mas agora não dá mais não, porque infelizmente você não pode pegar com 
todo mundo, mas o a gente conseguir vai ser bom. Mas é muito gratificante, sabe por quê?

K-Por quê?

Pa1 - Você vê essa criançada crescer, eles voltam, você olha aqueles rapazes bonitos e fala assim: "gente, ele está fazendo uma coisa que preste e eu tive um negocinho aí".

K - Uma parcela...?

Pa1 - É. Deve ser igual a uma professora como a " $x$ ", que começa o ano fazendo leitura e no final do ano eles estão escrevendo. Eu acho que é chocante, é lindo! Por exemplo, eu estou em todas essas fotos, porque eles cobram.

$K$ - Tem várias fotos dos times de alunos, pela escola, né?

$\mathrm{Pa}$ 1 - E tem mais ainda para fazer! Eu quero levar todo mundo, mas não consigo. Então eles olham e cobram, sempre voltam aqui: "Cadê meu quadro?" É identidade, gente!

$K$ - E o que mais te motiva nessa experiência de dar aula por jovem?

$\mathrm{Pa} 1$ - É que nem o primário a minha matéria, você pega eles crus. $E$, de repente eu olho e vejo coordenação fantástica, vejo aquela vontade de vencer. Eu sou muito contra, mesmo na minha área, quando dizem que competição não é importante. É importante, sim. Eles sabem que vão ser obrigados a competir, a vencer, a ser o melhor.

K - Nessa trajetória em que você deu aula para os jovens, o que mais te marcou?

Pa1 - Eu acho que o que mais me marcou, mesmo... realmente é isso, muitas vezes conseguir conquistar essa criança, trazer de volta... É difícil, viu? Eu tive um só.

K - Trazer de volta o quê?

Pa1 - Sempre foi um excelente aluno, foi o meu melhor velocista, até ao Espéria foi. Depois começou a mexer com drogas. Eu cheguei para ele e falei assim: "Eu não vou te perguntar, porque não quero que você minta. E se eu te perguntar eu sei que você vai mentir, por respeito. Só que o que é que você espera da tua vida?" Ele falou: "Do jeito que eu estou, eu sei que não passo dos 20". Me deu muita vontade de chorar, porque não tem mais volta. Ele ainda teve sorte porque ficou preso por três anos no Carandiru, saiu e voltou, veio estudar à noite; quando acabou - colegial eu falei assim: "agora, quero te ver na faculdade"; e ele entrou na faculdade. Acho que foi assim, em 20 anos, foi um caso. Valeu, porque eu incentivo. Eu acho que esses jogos cooperativos que eles falam muito são muito bem-vindos, mas não é o bastante.

$K$ - Mas você falou de outros exemplos de gente que está na faculdade, de gente que está na carreira ainda...

Pal - É, e tá lutando... . Mas é isso que eu quero! Gostaria que todos fossem! Estão fazendo, estão estudando. Tem uma aí que veio falar muito contente que estava fazendo engenharia, passou na engenharia saindo daqui direto. Acho um espetáculo, fiquei contente. Mas casou com um que era nosso também daqui, começaram a namorar com 13 aninhos, e no final, ele não era assim... Aliás, ele entrou no esporte por causa dela, mas não tinha a garra de quem entra no esporte 
não devido a outro, mas porque está vendo que é isso que queria fazer. Casaram, têm um filho, ele está preso e ela vai visitá-lo em Vinhedo.

$K$ - Quando você falou que tem um só, foi um só que o quê, que conseguiu a conquista de estar na faculdade?

Pa1 - Que saiu das drogas. Porque não sai, mesmo.

$K$ - Ah, entendi. Outros que você estava falando estão na faculdade ou trabalhando. Você falou de um só com relação a sair das drogas.

$\mathrm{Pa} 1$ - Infelizmente! Daí a minha frustração!

$K$ - Eu ia te perguntar quais foram as suas frustrações, a sua maior frustração.

Pa1 - Foi essa. E minha maior conquista foi ele!

$K$ - A maior frustração foi essa menina e a maior conquista foi ele, né?

$\mathrm{Pal}$ - É. A frustração toda mesmo é que eu gostaria de ter um local onde pudesse encaminhar, que tivesse... . Eu falo para eles que futuramente podem fazer uma faculdade jogando, aqui já teve vários que fizeram, jogando. Eu falo: "Vocês são pobres, põe na cabeça isso, não são mendigos". Na verdade, eu falo que existem três categorias de pessoas: o rico, a classe média, que aqui eles chamam de trabalhador, no nosso pedaço, e o miserável. Quem trabalha para esses três é só a classe média, esse paga pra esse fazer e esse acomodou e vive chupinzando esse daqui, porque "eu sou pobre, eu sou negro". Grande porcaria. Você deve ter notado aqui que todos querem ser negrão na minha escola.

$K$ - Como assim, tem isso?

Pa1 - Aqui tem, Nossa Senhora!

$\mathrm{K}$ - Como assim?

Pa1 - Se chega um moreno: "Não, eu sou negrão, professora". Daí eu digo: "Sai pra lá, você é cinco e meia, não chega a seis horas". Por quê? Porque eu falo pra eles, que gostam de jogar basquete: "Porque basquete é de negro, os brancos entraram de metidos".E eles amam, adoram. Eu falo assim: "Nossa Senhora, meu time está branqueando, pelo amor de Deus". Então eles querem ser negrão na marra, é moreno, mas fala que é negro. Você vê como esse racismo não pega? Não existe. Aqui o racismo é diferente.

$K$ - Eu gostaria de lhe perguntar: qual é hoje a sua esperança?

$\mathrm{Pa}$ 1 - A minha esperança é que os meus negão do meu basquete (meus negão são meus jogadores) voltem, assumam. Aí eu me aposento.

$\mathrm{K}$ - Os teus alunos...

Pa1 - Já estão voltando. Graças a Deus!

$K$ - Viraram professores e estão voltando para cá?

Pal - Isso. Não que eu incentive fazer educação física, nem ser professor. Mas já que estão e já que são daqui, que venham! Eu espero o ano que vem, quando você voltar aqui, se você voltar, já tenham dois nossos trabalhando aqui.

$K$ - Que bom.

$\mathrm{Pa} 1$ - Que fiquem com tudo, que continuem, porque eu não quero deixar esse trabalho, é muito bonito, muito gostoso! A minha esperança é essa! Aí eu paro. Eu falo que a primeira coisa, juro por Deus, que eu dou para eles é a coisa que eu mais amo, dou minha turma de basquete para eles. Já foram jogadores. Tem as fotos 
que mostram. Eles chegam aqui, a primeira coisa depois do beijo é: "Cadê minhas fotos?".

$K$ - É um reconhecimento...

Pa1 - Auto-estima, né? Que falam tanto hoje em dia.

(interrupção)

Pal - Você viu como eles chegam macho, como eles abusam de mim? Olha o sorrizinho, que anjo! E não some bola de basquete.

$K$ - Tem todo um respeito pelo material.

Pa1 - Não some e não chutam. Se alguém chuta, eles vêm me contar, algum malandro assim que eles apanham, eles vêm me contar.

$K$ - Tem mais alguma coisa que você queria falar?

Pa1 - Não, não.

K - Pal, eu queria te agradecer muito. Muito obrigada! 


\section{ENTREVISTA INDIVIDUAL COM O PROFESSOR VANDERLEI (Pr1)}

$\mathrm{K}: \mathrm{O}$ que você acha dos adolescentes de hoje em geral?

Pr1: Sempre gostei de trabalhar com adolescentes, sempre dei aula para o aluno do Ensino Médio (com 16, 17 e 18 anos), que é o adolescente com um pouco mais de brio.

$\mathrm{K}$ : Como assim?

Pr1: Porque ele tem mais vivência, conhecimento de mundo, está mais avançado, tem mais experiência, certa "educação" (entre aspas) e é mais fácil fazê-lo compreender que é importante aprender, ficando mais desligado da questão da avaliação tradicional, da questão da nota, sem querer estudar pra nota e sim para conhecer mais. Ele tem mais capacidade para analisar, sintetizar, para sobreviver, analisar o mundo e alcançar melhores posições na sua vida.

$K$ : $E$ como são, na sua opinião, esses alunos adolescentes da oitava série? Que diferenças existem entre esses alunos e os de Ensino Médio?

Atualmente, o aluno da escola pública é outro.

$\mathrm{K}$ : Em que sentido?

Pr1: Por causa da democratização do ensino, recebemos uma clientela de alunos com diferenças, tanto no sentido sócio-econômico como no de aprendizagem escolar.

K: A que você atribui essa pluralidade de aprendizagem escolar?

Pr1: Acho que há várias coisas a serem ditas a esse respeito. Primeiro, há a questão familiar. A família não tem muita culpa, porque se desestruturou (alunos com pais separados, que trabalham, não têm tempo para pegar no pé dos seus filhos para fazer as tarefas). Por outro lado, quando se chama os pais, faz-se necessária uma análise: o aluno é muito bom, perto dos pais que tem. Há falta de berço, de educação em casa - não há mais parâmetros de educação.

Além disso, a escola também está pecando porque está desestruturada (com falta de funcionários).

K: Desestruturada, como?

Pr1: Não há pessoal qualificado para exercer as funções de "direito" (entre aspas): há um número reduzido de funcionários, e se há funcionários, há falta de capacitação para isso. É preciso ter a capacitação em serviço de forma contínua.

K: Como é essa capacitação em serviço e contínua?

Pr1: É diferente de fazer algo no fim-de-semana; deve ser feita no próprio horário de serviço. Mas isso envolve muito dinheiro, então a Secretaria nunca quer fazer isso porque, é claro, aumenta a receita.

K: Você trabalhou na Secretaria de Educação; e em que essa experiência contribuiu para a sua visão sobre o que se passa no processo educacional?

Pr1: Conheci toda a rede estadual de ensino (da capital e do interior). $O$ contato que tive foi desde o nível superior ao menos superior deste quadro, ou seja, até o professor. Há uma diferença crucial entre o interior e a capital, pois, professor de interior não precisa tanto de grana para sobreviver. A sobrevivência em São Paulo é mais cara e há um maior desgaste. Além disso, o aluno do interior é mais dócil que o da capital, pois a família é mais estruturada, não sei bem porque, 
talvez seja pelo próprio tamanho da cidade (não sei analisar exatamente o que acontece). Há escolas no interior que parecem escolas particulares.

K: Voltando para a questão da desestrutura da escola, tem mais alguma coisa que você gostaria de falar sobre isso?

Pr1: $O$ aluno sendo muito heterogêneo com relação à aprendizagem, precisa de um maior cuidado pedagógico. E, por falta de funcionários (etc, como eu já falei), há uma sobrecarga muito grande em cima de certas pessoas que têm essa incumbência. E essa pessoa acaba fazendo coisas mais urgentes, do dia-a-dia, prejudicando a parte pedagógica. Por causa dessa heterogeneidade de aprendizagem dos alunos, seria necessário ter um pessoal qualificado para sanar, ou tentar sanar, todos os problemas de aprendizagem dos alunos. Há aluno que chega analfabeto na oitava série; deveria ter um profissional qualificado, alfabetizador, para lidar com ele. Ter esse pessoal desqualificado não é culpa desse profissional, e isso tem que ficar bem claro! É o sistema todo que está falho.

$K$ : A que você atribui esse fato de se chegar à oitava série um aluno que não está alfabetizado?

Pr1: O não cuidado com esse aluno que está defasado, a escola com uma sobrecarga de coisas... não há tempo, é problema em cima de problema. A diretora, se abrir a porta para resolver problemas de pais e alunos, não poderá fazer mais nada. A coordenadora, que é ótima, tem que ficar resolvendo problemas de disciplina, o tempo todo. A diretora é chamada para reuniões, seminários etc e não pode ficar presente na escola. Isso prejudica o andamento da escola. Se eu falto, por exemplo, 200 alunos ficam com defasagem. A coordenadora precisa resolver esse problema da falta; e arrumar rapidamente um substituto. Tudo isso prejudica a questão pedagógica.

Esta escola tinha 30 salas [era junto com a escola ao lado, mas fizeram um muro e dividiram em duas escolas]. Antes, havia laboratório aqui, mas hoje não tem, porque ficou lá e a biblioteca ficou para cá; é um absurdo isso! Toda escola tem que ter laboratório, biblioteca... .

Com a democratização do ensino - que é positiva! Não considero negativa; todo mundo tem que estar na escola, mesmo. Mas, a inclusão do aluno é feita desde quando ele quer estar incluso; se ele não quer, tem que sair da escola. Para mandálo pra fora é a maior dificuldade (há o ECA, etc). A população, principalmente o adolescente, se sente acobertado e se acha no direito de fazer as coisas, torna-se petulante, mal educado, desrespeita o professor, coordenadora, diretor, vicediretor... só quer saber de seus direitos; deveres... de jeito nenhum!

K: Você está falando destas características do adolescente; e o que você acha que acontece para que eles sejam assim?

Pr1: Os pais são mal educados também. Há alunos que moram na favela e são excelentes. Então, a questão é a família; ela pode ser pobre, miserável, e ter boa conduta. A miséria, a pobreza não é sinônimo de desrespeito, intolerância.

Além disso, o que não entendo no adolescente de hoje é essa vontade de destruir tudo. Ele quer deixar a parede suja, quebrar porta, quebrar vidro. Se a escola coloca uma lâmpada nova, eles quebram. Eles têm um espírito de destruição; mas não é a maioria que é assim, são poucos! 
Esses alunos [os que quebram as coisas] não querem se inserir na sociedade. Passaram de um ano para outro sem fazer nada, e quando tem professor que exige, não agüentam, detonam; é a lei do menor esforço. Essa é uma escola que tem uma preocupação com a aprendizagem do aluno; temos professores com muitos anos de carreira (20, 30 anos), que, além de experientes em lidar com esse tipo de adolescente, grande parte tem capacidade intelectual, conhece a disciplina que leciona. Eu procuro mudar sempre minhas aulas, diversificar o tempo todo para motivá-los, mas é complicado. Os alunos que querem estudar pra valer dão valor, mas os que não, detonam. No entanto, nada me detona; já estou experiente nisso.

$\mathrm{K}: O$ que você acha que acontece para que tenha repetência? (A que atribui a repetência?)

Pr1: As faltas, não fazer nenhuma atividade em aula.... Com as faltas, se perde o chão, fica sem pernas, desmotiva. É a falta e a família.

Também tem quem sai de casa para vir para a escola, mas na verdade não entra na escola e, quando a família descobre, fica desesperada.

K: Você sempre deu aula para adolescentes? Como é, para você, dar aula pros jovens?

Pr1: Sempre dei aula para adolescentes e sempre adorei porque ele me oferece mais emoções e o professor acaba aprendendo com isso, e isso é muito importante. Em outros tempos, eu via o adolescente como alguém muito criativo. Hoje, deixou de ser tão criativo pela situação de não querer fazer nada, não quer pensar de jeito nenhum (não só o adolescente, mas todos). Talvez a televisão esteja influenciando isso, ela oferece tudo mastigado.

$K$ : $E$ você sente que existem diferenças entre a geração dos jovens de hoje e a geração de jovens de sua época? Quais?

Pr1: Nós íamos para escola com uma idéia muito clara de aprender e apreender (apreender tem a ver com uma aquisição sua, que fica com você). Eu tive a felicidade de estudar em um colégio interno, de padres; tive essa necessidade de conhecer coisas, com idéia de formar minha própria filosofia de vida. Ofereceramme todas as ferramentas para formar minha filosofia de vida - essa é a função da escola - com muito empenho e muita alegria.

Hoje, a situação é mais complicada. Mesmo para o professor, que exige. Dou aula de português e tenho uma preocupação enorme em não ser autoritário. Essa é uma preocupação, tanto na escola quanto em casa, na educação dos meus filhos. Pouquíssimos alunos têm preocupação em aprender e apreender; parece que nada é importante.

$K: E$ você acha que existem características que são típicas da adolescência? Alguma especificidade do adolescente (como a questão da destruição, que você falou)?

Pr1: Essa questão da destruição (de destruir as coisas) aparece em poucos alunos, mas esses conseguem desestruturar a situação. Ainda bem que são poucos! Por isso ainda vale a pena trabalhar com jovens. Ainda tem, ainda sabem um pouco dos limites (apesar da família desestruturada). No grupo, um acaba até acobertando o outro e aumenta a moral desses poucos; talvez, até psicologicamente, isso aconteça para o aluno se sentir dentro do grupo, não ficar 
diferente, como não ficar "cdf", por exemplo (até os "cdf" ficam com pé atrás por isso). $O$ aluno aplicado acaba decrescendo e isso é mau para a escola; tem que descer o nível para ficar igual ao outro. Isso é mau para a sociedade - vão bater palma para os assaltantes? Na favela, são até obrigados a acobertar assaltantes, $e$ eles devem sofrer com isso, sabendo o que está acontecendo e tendo que acobertar.

$O$ adolescente está descobrindo o mundo, quer liberdade; só que tem que ser com responsabilidade. Isso não é definido para eles. O grande problema do adolescente e dos pais é a impunidade (reflexo da sociedade). Então, a escola é o produto da sociedade; o que acontece lá, acontece aqui e toma força dentro da sala de aula. As atitudes do aluno em grupo são diferentes das atitudes de quando este está sozinho - não só do aluno, mas de todos (como nas torcidas em jogos de futebol, em que as pessoas agridem umas às outras, de graça).

K: Você falou que dá aula para adolescentes há muitos anos. O que o motivou a dar aula para os jovens?

Pr1: Eu dou aula para adolescentes há 32 anos. Tive uma formação humanística e minha intenção era apreender muito, para dividir essa aprendizagem com os outros. Também há a questão de dar aula como meio de sobrevivência. Dava aula em cursinho, universidade... e fui verificando minha competência (queriam me segurar nos lugares em que trabalhava), então fui criando uma auto-estima.

$O$ jovem ensina muita coisa, faz com que você cresça e tire conclusões claras a respeito da vida (o que é certo e errado). Minha preocupação sempre foi dar ferramentas para que o aluno pudesse discutir sobre as coisas, ter capacidade de análise e síntese, através de textos, por exemplo.

$K$ : E como você se sente hoje, dando aula para os jovens?

Pr1: Um pouco desanimado porque não estou conseguindo fazer com que esse aluno apreenda certos conhecimentos.

K: Por que você acha que isso não está sendo possível?

Pr1: Por falta de vontade dos alunos, porque eles não têm clareza ainda. $O$ aluno só vai sentir isso a longo prazo; só vai dar importância quando tiver que fazer uma redação para um emprego, e não conseguir. Tenho recebido muitos ex-alunos que queriam ter aula de novo comigo porque agora dão valor. Mas eu digo: agora? Agora a "Inês é morta" - falo isso para fazê-los pensar. adolescentes?

$\mathrm{K}$ : $O$ que mais the marcou nessa sua trajetória de dar aula para

Pr1: A satisfação de alguns alunos, mesmo a curto prazo, de terem apreendido certos conhecimentos e revelarem isso através de redações e posturas. Tenho coisas escritas que guardo a sete chaves; coisas muito bonitas, escritas com muito carinho. $O$ carinho é muito importante.

$K: E$ como você sente que é a sua relação com os jovens alunos?

Pr1: Eu não me aproximo muito, não. Depende do tipo de aluno; à medida que percebo que ele é dócil, afável, me aproximo. Sou amigo quando o aluno me respeita. Eu dou o meu recado e, se o aluno aprender ou não, o problema é dele.

K: Você acredita no potencial desses alunos?

Pr1: Eu acredito no potencial dos alunos, se não, não daria aula. 
K: E você direciona de algum modo sua prática em função do modo como são os alunos adolescentes?

Pr1: Eu direciono para que o aluno tome consciência da realidade, questiono como é para eles ser adolescentes, passo textos para isso, também falo sobre a questão da sexualidade. No começo do ano, eles respondem a uma entrevista que eu passo, colocando a situação de vida deles, então eu direciono a aula, com base no que eles gostam. Há os projetos da escola, que são considerados também.

Os alunos sabem quem é um bom professor e quem não é. E alguns alunos vão começando a ter consciência. Eu promovi saídas para o teatro, mas poucos se interessaram, enquanto a maioria se inscreveu para ir ao Hopi-Hari hoje. Então, eu questiono com eles: culturalmente, qual é o passeio mais interessante? $O$ teatro ou o Hopi-Hari?

Leitura e escrita são aprendizagens; a leitura faz com que a pessoa veja outros tipos de vida, ela colabora para que a pessoa tenha uma filosofia de vida, é uma ferramenta para que tire conclusões na sua vida. Fulano escolhe ser médico, mas a vida vai brecá-lo; não é fácil fazer universidade. Escola pública não oferece ensino para passar no vestibular.

$K: E$ hoje, que esperanças você tem, enquanto professor?

Pr1: Hoje tenho uma visão um pouco negativa. Espero que alguns alunos possam ser cidadãos, mesmo, que aproveitem tudo o que se oferece a eles. Garanto que vão ter sucesso na vida, se seguirem meus conselhos. Quero o bem deles, quero o sucesso deles; faço de tudo para que eles tenham sucesso.

$\mathrm{K}$ : Você sente que os alunos captam isso?

Pr1: Alguns alunos captam isso, graças a Deus. Ainda existem pessoas espertas. Uma aluna (que veio entregar uma ficha de leitura) - uma ótima aluna -, que é muito influenciada pela amiga que estava a seu lado, tentou fazer a prova dessa amiga. Eu tenho que mostrar para ela que isso é errado, então, dei nota " $E$ " para as duas. A outra não se "tocou" muito (a questão moral está meio complicada no caso dela), mas a aluna que estava fazendo a prova para a outra veio pedir desculpas, viu que estava errada. Esta é uma questão bonita do mestre: mostrar o que está certo e o que está errado - a própria sociedade desaprova esse tipo de coisa, no vestibular, por exemplo.

[OBS - acréscimo ao final da entrevista:]

Pr1: Durante 13 anos, fiz orientações técnicas para professores de diferentes cidades. Foi uma experiência muito rica em minha vida. Tive contato com professores da USP, fazia análise dos vestibulares, palestras para alunos das universidades. Fiz Filosofia Pura, Letras e Pedagogia; comecei mestrado em Teoria Literária e [?], mas parei por conta da questão da sobrevivência. 


\section{ENTREVISTA COM A DIRETORA TEREZA (D)}

$K$ - O que você acha dos adolescentes de hoje, de uma forma geral?

D - Eu acho que eles estão sem limites. A família é a causa principal disso, porque a estrutura familiar mesmo não existe mais, ela está comprometida. Então o que acontece? Ela não é mais como antigamente. A educação, não digo o aprendizado, mas a educação de que eu me refiro é o respeito, base, ética, tudo ficou comprometido. Muitas vezes, temos problemas com um ou outro adolescente e quando tentamos comunicar o pai, o procuramos para conversar e sentimos a ausência da família, o pai está separado da mãe, ou o pai está em outro lugar ou a mãe saiu e não responde ou não vem. Então, ficamos com aquela criança em nosso poder sem saber de que maneira conduzir a situação. Quando não temos com quem falar, com quem conversar, nos sentimos, na verdade, abandonados, sozinhos. Quando um adolescente desrespeita as regras e muitas vezes acho que ele infringe as regras justamente para chamar a atenção, ele está se sentindo sozinho. Eu acho que ele se sente sozinho, abandonado, porque ele, mal ou bem, é reflexo dos adultos. Eu costumo dizer que o aluno é um pouco reflexo do que ele vê no professor ou no pai ou num outro maior. Então, eu acho que eles se sentem muito assim... com essa ausência. Na verdade, o adolescente está se formando, está se tornando um cidadão, um adulto. No início, sem parâmetros, ele não consegue visualizar o que ele vai ser. Então é nesse aspecto que eu acho que ele acaba ficando sem limites, quando ele ofende um professor. Tem aluno que chega a ponto de estar o tempo todo testando para ver até onde ele pode ir, a gente sente muito isso aqui. Acredito que pelo fato de estar muito perdido, sem limites e muitas vezes, para chamar a atenção, ele acaba se encaminhando para um caminho que não é o melhor, de repente uso de drogas, de estar se envolvendo em brigas, uma coisa ou outra. Ele quer chamar a atenção.

$K$ - Você acha que isso da família é uma coisa, por exemplo, da classe social mais baixa ou de qualquer classe social?

D - Não. Não, antigamente podia-se dizer assim "ah, o pai sai trabalhar, a mãe sai para trabalhar" e ele fica sozinho. Isso acontece? Acontece, ele fica sozinho. Só que, com a entrada da mulher no mercado de trabalho, muito mais crianças estão ficando sozinhas e não é mais questão de classe social. E a separação? Antigamente era mais comum você ver mãe solteira na classe baixa. Hoje, não. Não é por que tem ou não dinheiro. O que acontece com os casais? Ah, incompatibilidade de gênios, sei lá o motivo..., é muito grande o número de crianças criadas só com a mãe. Inclusive eu vi uma reportagem que não tem nada a ver com isso, falando sobre habitação. Eles estavam fazendo um levantamento sobre habitação, então é assim: antigamente o levantamento era baseado em número de família por habitações, a família seria o pai, a mãe e o filho. Hoje você não vê mais isso por questão familiar, é considerada também aquela mulher que mora com o filho como uma família, não leva mais aquele nome de família, mas é uma mãe morando com o filho como um número que cresceu. É uma nova constituição da família, ela falou o nome, mas eu não lembro, no momento. Não é que falta dinheiro, 
na verdade eles têm um apartamento, uma moradia, uma residência, que é coisa difícil no Brasil. Mas ela mora só com o filho.

$K$ - Você acha que isso influencia nessa coisa de o adolescente ficar sem limites?

D - Ele fica também dividido, acaba tendo duas famílias, conseqüentemente, sem regras (talvez seja a causa da falta de limites). É uma coisa engraçada isso, minha filha tem uma amiga que segunda, quarta e quinta mora com a mãe e terça, sexta e sábado mora com o pai. Ela tem duas casas. Eu perguntei para a minha filha como é que ela faz com o material escolar, porque cada dia é montado de maneira diferente. Como é que essa criança monta isso? "Ah, mãe, ela tem que carregar todo o material dentro da mochila". Na troca de dia, onde fica esse material de História no dia em que não há aula de História, na casa do pai ou na casa da mãe? Minha filha perguntou: "Por que você quer saber isso?" Era uma curiosidade. Como é que a criança administra a vida dela dentro dessa loucura? E são pessoas que têm dinheiro, uma mora aqui no (...), que é um bairro chique, e a outra mora aqui perto do (...), duas casas na verdade. Então eu penso assim: e quando a criança faz alguma coisa que não gostamos e temos que castigar? Tirar aquelas coisas de que elas gostam? Existe muito isso: não vamos bater, vamos dar castigo. Por exemplo, a minha filha andou abusando na Internet, o pai dela castigou. Ela ficou uma semana sem navegar na Internet. E essa criança, como dar um castigo por uma coisa que ela fez errada? Ah, então vou te privar de tal coisa. Mas vou te privar segundas, quartas e sextas? E terças e quintas? Então como é que fica, como é que essa criança cresce? Não é um problema só daqui, de uma escola pública, esses problemas existem também nas particulares, do aluno responder aos professores, funcionários. Compromete o trabalho educacional.

$K$ - Você acha que tem diferença entre a criança e o adolescente, nesse sentido?

D - Há muita diferença! Aos 12 anos já inicia a adolescência. Com 11, 12 anos ele entra na $5^{a}$ série. Eu só tenho adolescentes. Então eu uso o nome criança querendo dizer que é minha $5^{a}, 6^{a}$. Daí eu tenho $7^{a}$ e $8^{a}$ que já são maiores. É uma maneira de generalizar, mas eu só tenho adolescentes aqui.

$K-E$ você acha que tem diferença dos alunos da $8^{a}$ para os da $5^{a}$ ?

$D$ - Percebo, claro, muita diferença! Quando ela [criança] chega, ela está muito meiga. Primeiro, ela quer estar próxima do professor. Aquele com 12 anos me agarra no corredor, ele me beija, ele quer conversar, é esse negócio de contato mesmo. Ele não tem receio de se aproximar de mim, de estar chegando e me abraçando. Um aluno da $8^{a}$ série não se aproxima de jeito nenhum. Daí ele tem quantos anos? Com 15, 16 anos, ele já não se aproxima mais dos professores, de mim. Nós passamos a ser não mais um amigo, sei lá, ele acaba enxergando a gente como se eu fosse um inimigo. Isso eu percebo.

$K$ - Você acha que te vê como inimiga...

D - Não sei, é como se ele vivesse na clandestinidade, o que ele faz ninguém pode saber. Não sei, é uma coisa engraçada. Mas isso eu sinto na minha filha conforme vai passando o tempo.

$K$ - Ela está com quantos anos? 
D - Ela tem 12, mas ela já está mudando. Por exemplo, tem coisas que eu não posso saber. Outro dia eu peguei uma carta. Sabe quando ela abre o caderno e escorrega alguma coisa? Ela quis esconder. Aí eu fiquei preocupada: o que ela quer me esconder? Nossa, tive que convencê-la a me deixar ver o que era aquilo. Aí ela me mostrou uma cartinha para o namorado, que ela tinha escrito para o paquera, 0 "ficante", né? Aí ela perguntou: "Você quer que eu abra?" Eu falei: "Não, não quero que você abra, mas eu queria saber o que é, não custa responder". "Ah, não conta para o pai". Então na cabeça dela aquilo é muito sério, ela não pode me falar.

$K$ - O que mais você acha que é característica do comportamento dos adolescentes? Desses de $8^{a}$ série, o que você acha que caracteriza mais?

$D$ - Eles testam um pouco o limite na escola; eu não sei em casa... e como é que vai ser daqui uns anos? Eu percebo uma mudança muito grande quando chega nessa idade, de contestar o que você fala. Não sei como vai ser, mas percebo que eles contestam. Ela já percebeu que muitas vezes eu falo: "Não, M. Então vai". Aí ela quebra a cara e eu falo: "Eu avisei. Eu não falei? Mas eu não sei de nada, né? Não é assim?" Então muitas vezes quando ela chega e começa a me questionar, eu falo: "Então tá bom, filha, faça da sua maneira". É um momento em que ela repensa. Ela sabe que estou deixando apenas para não estar contestando. Mas eu também consigo enxergar isso um pouco no que eu fiz. Eu lembro que meu pai falava assim: "Vai". Como a gente é impulsivo, sabe? A gente acha que o que está fazendo é certo.

$K$ - Eu ia te perguntar isso. Você sente diferença entre a geração dos jovens de hoje e a geração da sua época?

$D$ - Eu acho que eles são mais ousados hoje.

$K$ - Por que você acha que eles são mais ousados?

D - Não sei. Porque a sociedade é outra, a sociedade caminha, assim os costumes, os valores são diferentes.

$K$ - Então você acha que o que faz o adolescente ter as características dele não é biológico, não é uma coisa inata, tem a ver mais com a sociedade?

$D$ - Eu acho. Porque na verdade a gente está inserido dentro da sociedade, então você não pode dizer que é uma questão só familiar. Quando eu falo na questão familiar, não digo que seja uma questão biológica. Quero deixar claro, essa família não existe mais. Então como é que eu vou educar uma criança que fica segunda, quarta e sexta comigo, sendo que terça, quinta e sábado ela fica com uma outra pessoa? Hoje, a instituição familiar está limitada em mãe e filho.

$K-E$ você acha que isso atrapalha...

D - Eu achei até engraçado quando vi essa questão ser levantada numa pesquisa habitacional, a questão da estrutura familiar. Eu acho que não é uma questão biológica. A família é um problema social, tudo é uma questão social. Se fosse uma questão biológica, só uma questão biológica tão forte assim - sendo transmitida geneticamente - não teria mudando tanto. Então, é claro que é social. Se fosse biológica, nós estaríamos assim: se o meu pai, o meu avô, a minha família tem muita educação, não haveria os calos. Outra coisa também: por que está em todas as classes sociais esse tipo de coisa? Então, eu acho que a sociedade muda, 0 adolescente muda, o adulto é diferente, tudo vai em função disso. Antigamente a 
mulher agüentava, ela era aquela casada com a finalidade de cuidar da família, ela ficava em casa. Minha mãe ficou em casa, ela nunca trabalhou. A minha filha tem uma realidade completamente diferente da que eu vivi. Hoje a minha filha tem acesso a muitas coisas que eu não tinha, acesso a informação. Quando você conhece uma coisa nova, você questiona, isso serve para você crescer, amadurecer $e$ questionar. Então a minha filha faz coisas que eu não fazia.

$K$ - Estão questionando mais a realidade?

D - Eu acho. Não posso dizer que o adolescente está diferente do que era em função de genética, não; eu não acredito nisso. Eu acho que nós estamos inseridos no social e o adolescente está tendo acesso a conhecimentos de maneira muito mais rápida, através da Internet ou através de amizades, do que eu tinha.

$K$ - Tem teorias que dizem que adolescentes não têm limites porque é uma coisa biológica, porque é natural que na fase da adolescência tenha isso e que passa. É uma coisa natural que passa. O que você acha disso?

D - Eu acho que não. Pode existir uma parte. Claro, nossos filhos carregam a herança biológica, ela existe. A gente vê tomar certas atitudes. Por exemplo, a minha filha hoje está liderando um grupo. Então alguém diz: puxou a mãe. Identifica, mas eu não vou dizer que os jovens só reagem por questões genéticas. Você identifica alguma coisa parecida? Identifica, mas é o adolescente com herança genética inserido numa nova sociedade, o que muda muita coisa, pois a sociedade muda muito com o passar do tempo. Ele está formando seu perfil, parte é o reflexo do que ele vê, ele nos tem como um espelho. Ela está presente comigo, então muitas vezes ela faz algo não porque puxou a mim, mas porque me viu fazê-lo em certas situações.

$K$ - Pensando agora nos alunos adolescentes daqui, você falou na $8^{a}$ série, os mais velhos, você estava falando que sente que eles não têm limites. $O$ comportamento deles na escola tem alguma coisa diferente disso que você falou sobre os adolescentes em geral?

D - Na questão da escola não é muito correto você estar trabalhando aluno com medo. Mas antigamente você podia estar falando para o aluno assim... E é o que você faz em casa ou em outros lugares, é uma troca como se fosse um negócio. Ele tem que entender que tem que ter vantagem sobre aquilo. Então você falava assim: "se você não fizer tal coisa, se não tiver um bom comportamento, se não fizer não sei o que, você vai reprovar de ano". Isso não existe mais. É como a minha dirigente acabou de falar: "Você não pode dizer que a folha do SARESP será aproveitada, se ele não fizer, será prejudicado, porque isso aqui é um diagnóstico". Eu questionei: "Mas eu não posso aproveitar a nota dessa prova e inserir como um conceito para ele?" Pode. Então existia muito isso de você fazer assim: "se você não fizer tal coisa, você vai reprovar, olha lá". Com a progressão continuada, o aluno se sente descompromissado. Então, está difícil trabalhar dentro da sala de aula porque ele não vê que, se faz tal coisa, vai ter vantagem sobre isso, vai ter um retorno. É uma troca. Hoje não existe mais isso, com a progressão continuada ele passa independente... se ele ficar de braço cruzado, ou não tendo freqüência. $O$ rendimento não é satisfatório, você vê aqui pelo montante de notas, ele não tem rendimento satisfatório, mas teve presença. A gente vai entender o seguinte: ele 
absorveu alguma coisa, por menos que tenha absorvido, conhecimento ele teve. Ele não aprendeu agora? Vai aprender mais tarde. É onde desmotiva o adolescente. Muitas vezes ele está achando mais interessante uma conversa, muito mais interessante uma outra coisa e acaba indo para aquele caminho porque é muito mais interessante do que estar fazendo um cálculo matemático. Consequiência: o professor perdeu o valor que ele tem. É uma série de fatores, eu acho que um é esse. Muitas vezes ele não tem aquela família que lhe dê respaldo. Então, o aluno não tem comprometimento com o trabalho, por que? Porque, independentemente dele fazer ou não - ele faz quando tiver vontade -, ele não terá prejuízo. Então, é uma somatória de fatores que faz com que ele não tenha assim mais tanto compromisso com a escola.

$K$ - Aqui a gente entra na escola e todo mundo fala: "Ah, a $8^{a} A$, a $8^{a}$ dos repetentes". O que você acha dessa classe da $8^{a} A$ ?

$D$ - $A 8^{a} A$ foi uma sala que no ano passado não tiveram rendimento satisfatório e também não tiveram frequiência. Quando chega na $8^{a}$ série é o final de um ciclo, vai iniciar um outro que é o Ensino Médio, como está concluindo um ciclo, pode-se reprovar. [É o que acontece.] A CENP determinou que deveríamos alojá-los todos num mesmo lugar para fazer um trabalho diferenciado. Porque eles entendem assim: se não aprendeu da primeira maneira, vamos tentar um modo diferente. Então, o trabalho lá é diferente. Eles são todos retidos, então já trazem com eles... Como é que eu posso colocar? Eles já trazem maus hábitos. Eles conhecem a escola, conhecem todos os professores, sabem como é que funciona. Por isso eu fico perto da sala, para poder ajudar. Então eles já sabem que a frequiência é muito importante, não faltam. Só que muitos estão fora da idade. E outra coisa: por que eles estão aí? Muitos têm defasagem de conhecimento, têm problema de... de absorver o conteúdo... não é absorver... é dificuldade, mesmo, de aprendizagem.

$K$ - Você acha que eles têm?

$D-$ Têm.

$K$ - Qual é a causa dessa dificuldade de aprendizagem?

D - Olha, nós temos alunos que têm dificuldades de aprendizagem. São disléxicos. Eles não conseguem desenvolver um raciocínio assim de estar escrevendo. Nós temos esse tipo de problema? Temos; e o duro é isso. Com a progressão continuada, essas crianças que são disléxicas... acabam avançando de série sem condições.

K - Mas é um problema deles? Eles têm uma dificuldade de aprender?

D - Isso. De aprendizado. Então o que acontece? Eles vão passando, muitos deles são freqüentes, eles vêm, fazem tudo, o professor ajuda e tal, são bonzinhos. Mas quando chega nesse final é um problema da criança mesmo. Inclusive a gente fica pensando que podia mandar para a psicóloga, a gente muitas vezes fica procurando acompanhamento, de que maneira tratar, compramos até uns livros para a gente estar lendo para tentar ajudar. É um problema de aprendizagem mesmo, eles têm dificuldade de aprendizagem, de estar assimilando o conteúdo e de reproduzir esse conteúdo. Então, ele acaba reprovando por isso e o fato de o aluno não acompanhar os demais desmotiva dentro da sala de aula. Ele sente dificuldade, 
a professora dá uma atividade para todo mundo, aí ele fica olhando para a atividade e não consegue fazer. Aí é onde ele vai puxar o cabelo de um outro aluno, vai conversar, vai cutucar. A gente costuma dizer que esses alunos que ficam fora da sala é porque são muito bagunceiros e tal. Se você for ver todos eles, a maioria deles, ele não é bagunceiro porque é bagunceiro, é bagunceiro porque não acompanha os outros 39 alunos. Porque numa classe com 40 alunos fica difícil você pegar um aluno na mão e ficar em cima dele sozinho. É muito aluno por sala.

$K$ - E o que você acha que aconteceu com essa $8^{a} A$, você acha que durante esse ano eles puderam aproveitar?

$D$ - Muito pouco. É uma sala menor, porque ela é um projeto.

$K$ - Tem quantos alunos?

$D$ - Tem 30 alunos, se não me engano. Perde-se muito tempo com a indisciplina. Eles já são alunos que conhecem toda a escola, o trabalho da escola, eles já vêm com vícios, maus vícios, eles já testaram o limite de cada um. Sabem até onde eles podem ir. Então são descompromissados, não fazem nada, querem ficar ouvindo música, uns porque têm a dificuldade que eu te falei de aprendizado, outros porque não sei o que pensam, a gente conversa, faz isso, faz aquilo. 0 desinteresse dessa classe é muito grande, muito grande! Tanto é que trabalhamos de maneira diferente, eles têm um portfólio, todas as atividades deles ficam ali. Mas é coisa muito básica, você não consegue caminhar nessa sala. Mesmo fazendo um trabalho diferente, o resultado da sala é muito pequeno.

$K-E$ o que você acha dessa idéia de juntar todos numa sala?

$D$ - É terrível, foi a pior coisa!

K - Por quê?

$D$ - Porque eu acho que uma pessoa que sabe mais pode ajudar o outro que não sabe. Melhor do que ficar dentro de uma sala em que ninguém sabe. Aquele que tem problema, mas está inserido dentro de uma sala grande, vai fazer bagunça porque aquela atividade não está interessante para ele. Ele não sabe fazer, ele não quer perguntar para a professora, então é onde ele fica rabiscando o caderno dos outros, puxando o cabelo e tal, aí o professor fica bravo e manda para cá. Todos os alunos que nós recebemos aqui por bagunça, se você for na sala dele olhar o caderno dele, ele não está entendendo nada! É por isso que ele foi fazer bagunça, porque na verdade ele não consegue fazer a atividade, não é que ele não queira. Agora, imagina 29 alunos que não sabem fazer aquilo! Eles não caminham, vêem que não têm resultado, que não estão progredindo, desanimam. Então foi péssima essa idéia.

$K$ - E tem uma coisa de $8^{a} A$, aquele peso...

$D$ - Eles ficaram marcados. Eles não podem ser apontados e marcados da maneira que eles foram. Isso é péssimo para o adolescente!

$\mathrm{K}$ - Por quê?

$D$ - Ah, porque ele é visado pela escola toda: "Ah, você é da $8^{a} A$, então você é repetente". Ele ficou já com essa marca, é como se ele tivesse sido carimbado. Se ele estivesse inserido dentro das demais classes, ele não teria isso. Isso é péssimo para o adolescente, carregar uma plaquinha apontando a incapacidade. Isso foi péssimo! Nós tínhamos inclusive no início do ano colocado em turmas diferentes. 
Não foi autorizado. A ordem é: "Não, não. Se os alunos retidos formarem uma classe, eles deverão ficar juntos para se fazer um trabalho diferente". Só que esse "fazer um trabalho diferente" é uma sala no contexto da escola. Eles não pensam nisso! Para o aluno um trabalho diferente é ótimo. Por quê? Porque ele não vai repetir tudo aquilo que ele já fez. Só que eles esquecem que o aluno ficou marcado dentro da unidade. Então é assim: é visto como aluno da $8^{a} A$, que todo mundo conhece. Você ficou por aqui algum tempo e já sabe: $8^{a}$ série A. Por quê? $A h$, então é aluno retido, é aluno que tem dificuldade. E aí eles ouvem por aí. Como é um monte de aluno com problema, um monte de aluno que tem interesse em ouvir música, tem interesse em fazer não sei o que, então tudo que acontece é lá: "Ah, porque é a $8^{a}$ série $A^{\prime \prime}$. $O$ aluno não pode ser indicado, apontado, não pode de maneira alguma!

$K$ - Os professores também tentaram direcionar o trabalho incluindo música, como é?

$D$ - Cada um tenta fazer da maneira que consegue. Uns conseguem mais, outros conseguem menos e outros não conseguem nada. Vai do professor, da dinâmica do professor, da postura do professor. Tem professor que eles respeitam, eles produzem. Mas você percebe que é um trabalho muito mais lento do que das outras salas, você perde muito tempo com a questão disciplinar, é onde o trabalho fica muito mais lento, o problema disciplinar é maior.

$K$ - Mas todos os alunos que estão ali têm essa questão do problema de aprendizagem ou é por causa da falta?

$D$ - Não é só falta.

$\mathrm{K}$ - Tem as duas coisas?

D - Tem. Porque, qual é o critério? Como nós pensamos? Isso não obedece a regra, é uma postura do Conselho de Escola. Quando o aluno consegue conceito satisfatório, mas a presença dele não foi suficiente, entendemos o seguinte: tudo bem, excedeu em faltas, mas não foi importante para que ele obtivesse mérito, não comprometeu o aprendizado. Então, o aluno está aprovado porque não precisa estar $100 \%$. Você já ouviu dizer que para um bom entendedor um pingo é letra. Então eu não precisei de $100 \%$ de presença para adquirir o conhecimento satisfatório. Existe aquele aluno que falta, falta, falta, atinge o total da porcentagem, mas o desempenho do aluno é altamente satisfatório. Não temos dúvida, é aprovado. Então não é problema de frequiência na $8^{a}$ série $A$. É freqüência e conceito. $\mathrm{Na}$ verdade, ele não assimilou.

K - Você acha que o fato dele não ter assimilado é por uma incapacidade dele?

$D$ - Não.

$K$ - É por que?

$D$ - Muitas vezes o aluno não consegue. Ele se esforça, é aquele problema que eu te falei de aprendizagem. Ele tem um problema que é dele de assimilar conteúdo mesmo, ele tem dificuldade.

$K$ - Às vezes tem aquela história de que, se faltou, não teve a aula, então não poderia aprender.

D - Não. 


\section{K - Como você vê?}

$D$ - Inclusive a avaliação serve para medir o que o grupo conseguiu. E outra: é seqüencial. Se você perdeu uma aula, na próxima aula eu não estou tratando de um novo assunto, muitas vezes estou fazendo exercícios sobre aquele assunto. Não é que você perdeu e nunca mais vai conseguiu recuperar, não é assim. É uma questão de continuidade, em tudo existe a continuidade. Você faltou duas aulas, o professor nessas duas aulas já deu toda a parte teórica e na terceira aula já está desenvolvendo um exercício, você pode muito bem perguntar para um outro aluno, não precisa nem ser para o professor, o aluno que pegou toda a parte teórica passa ou o professor explica de novo, você consegue realizar e na hora da avaliação consegue fazer.

$K$ - Em que situações você tem contato com os alunos?

D - Pelos corredores. Quando eu sou solicitada na sala de um professor, infelizmente, é sempre que ocorre algum problema, daí eu acabo indo lá. Mas eu sou muito de ficar pelos corredores, circular. Ou de ouvir falar. Então, eu não sei... Eu conheço os alunos problemáticos, porque ou eles descem aqui ou eu vou até a sala. Então é aquela mão e contramão, ou eles vêm até mim ou eu vou até eles. Temos alunos que gostam de se envolver. Por exemplo, temos uma excelente aluna, que fica na sala de informática. Nós pegamos um aluno e treinamos para ficar lá, eles são bons alunos, aproveitamos na escola para outras coisas. Agora, aqueles alunos que não dão problema disciplinar e não são aqueles de destaque acabam meio que ficando... Então às vezes eu cruzo com algum aluno: "Oi, diretora", e eu não conheço, nem sabia que era aluno meu.

$K$ - Mais nos casos extremos, né?

$D$ - É onde a gente mais conhece os alunos.

$K$ - E como é a sua relação com os alunos aqui na escola?

$D$ - É boa, não tenho problema. Porque eu sempre procuro mostrar para o aluno onde ele está errado. Como um aluno que teve um problema com um professor ontem, ele falava assim: "Eu apanhei, o professor me bateu, eu vou chamar minha mãe". Eu pensei: "Nossa, agora vou ter problema com boletim de ocorrência $e$ tudo". A hora que eu saio da sala e vejo o aluno, já pego o aluno ali, porque eu conheço o aluno. A hora que eu o olhei, disse: "Mas é você?" Então eu já desmontei um pouco o aluno. Ele já sabe que é conhecido por mim, ele não tem muitas vezes uma boa conduta, ele é danado mesmo. Daí eu falo assim: "Ah, é você". Quer dizer, - que ele fala por aí: "Vou fazer um boletim de ocorrência, o professor bateu em mim". Na hora que eu olho para ele, ele já fala: "Hum!" Quer dizer, eu sei quem ele é e ele sabe que eu sei quem ele é. Então eu falo: "Ah, é você? Senta aqui, vamos lá. O que aconteceu, o que você estava fazendo na sala do professor?". "Ah, eu estava lá". "Você não devia estar lá". "É, eu sei que não devia estar lá". "Então, me conta o que aconteceu". Aí ele vai contando: "O professor pegou a chave e colocou na minha barriga". "Ah, mas ele quis te intimidar, não foi?" Aí você vai conduzindo e ele vai dizendo.

(interrupção)

D - O que eu estava falando? 
$K$ - Você estava contando o caso do aluno que falou que o professor bateu nele.

D - Ah, sim. Aí eu perguntei: "Vamos lá, o que você entende por apanhar? Você sabe o que significa apanhar, pensa no seu conceito de apanhar". Até pensei: será que ele vai entender o que é conceito? "Pensa no que é apanhar para você. Agora vou te fazer uma pergunta: o professor bateu em você?" Aí ele falou que não. E eu continuei conversando: "Mas mesmo assim ele foi agressivo com você, eu acho que ele foi muito duro, mas apanhar, assim..." "Ele não me bateu, não". "Mas quando ele colocou a chave na sua barriga, ele também não empurrou a chave para te machucar". "Não, ele não me machucou. Aqui assim (ele mostrou o pescoço) está meio vermelho, mas é porque ele pegou forte". Ele pegou o aluno por aqui. Aí eu falo: "Isso o professor não pode fazer. Então eu vou chamar a tua mãe?" Eu jogo a decisão para ele: "Eu chamo a tua mãe?" "Não, não precisa chamar minha mãe". Então é a maneira de você conduzir as coisas, mostrar para eles o que é isso, o que é aquilo. Primeiro você mostra para ele o que é apanhar, o conceito de apanhar, então você faz o aluno entender que ele teve a sua parte de culpa. Eu não estou com o livro aqui, mas ele assinou o livro dizendo que sabe que está errado. Você tem que mostrar para o aluno o que é certo e o que é errado. Muitas vezes eu mostro para o aluno qual é a minha obrigação aqui dentro: você fez isso, isso, isso, é minha obrigação agora estar chamando a tua mãe, estar te suspendendo. Eu tenho que mostrar para o aluno aonde ele está errado e ele tem que entender isso. Não é que ele tem que entender, mas, você mostrando para ele, ele enxerga aonde ele está errado e daí ele aceita muitas vezes o que é imposto para ele. Acabamos registrando assim: "O aluno foi abordado pelo professor, que o pegou de maneira agressiva pelo pescoço e apontou a chave na sua barriga. $O$ aluno alega ter recebido ameaças verbais. $O$ aluno reconhece ter desrespeitado o professor e estar ciente dos seus erros. O professor será convocado e será registrado em livro de ocorrência". Eu mostrei para ele que ia chamar o professor também. Então, ele reconhece ter desrespeitado o professor e estar ciente disso. Quer dizer, a princípio o aluno estava fazendo e acontecendo, e depois você mostra para ele. Ele acabou me dizendo: "O professor não me bateu".

$K-E$ que imagem você sente que os alunos fazem de você?

$D$ - De autoridade. Eu vejo que eles me respeitam mais do que os professores, o que eu acho uma visão equivocada. É isso que eu falo para eles: "Não é porque ele é um professor que você tem que ter menos respeito por ele do que por mim". Então eu não aceito muito isso. E percebo que eles respeitam muito menos a vice-diretora do que a mim, isso eu não acho certo.

$K$ - Ah, você sente?

$D$ - Sinto! À noite são adultos, não são crianças, muitas vezes eles não querem conversar com ela e eu não entendo por que... Eu falo: "Você está me representando. Quando acaba o meu horário e entra o seu, você é a autoridade maior aqui dentro, eles têm que te respeitar". Eu não entendo se é questão hierárquica, não sei por que.

$K$ - Respeitam mais você. 
$D$ - Mais eu do que a vice, mais a vice do que professor, mais o professor do que os funcionários. $E$ isso não pode existir, eu sempre digo que não pode existir. Eu falo para os professores: "Eu não quero ir na sua sala, porque vou tirar a sua autoridade e você vai precisar de mim sempre. Eu quero que você resolva". Eu falo isso para os professores: "Resolva o problema. Você tem que entender que você é a autoridade e você tem que exigir esse respeito dentro da sala de aula".

$K$ - Para terminar, eu queria saber um pouquinho da sua trajetória. Você hoje é diretora, há quanto tempo você é diretora dessa escola?

D - Independente dessa trajetória, desse tempo, é um pouco a postura da pessoa. Eu sempre consegui controle dentro da sala de aula, então é muito de mim.

$K$ - Você era professora?

$D$ - Era.

$K$ - Tem que ser professora para ser diretora?

D - Não tem. Espera aí, eu acho que para fazer o concurso precisa de cinco anos de experiência docente, é um dos requisitos.

$K$ - Você foi professora por muito tempo?

$D$ - Eu fiquei durante um tempo trabalhando concomitante. Eu comecei em 85, quando era estudante ainda. $O$ ano de 87 foi um ano em que eu não quis lecionar, eu trabalhava num banco, trabalhava no departamento de acionistas do Bradesco. Foi um ano em que eu fiquei fora da educação. Em 88 eu voltei. Não sei se foi em 89 ou 90 que eu resolvi me desligar do banco e estar realmente me dedicando ao magistério em período integral; pensei: é aqui que eu vou ficar e é aqui que eu quero desenvolver o meu trabalho.

$K-E$ foi sempre com adolescente?

$D$ - Sempre, porque a minha formação não é para trabalhar com criança, eu não sei alfabetizar. O meu trabalho é direcionado a uma disciplina para um determinado grupo de alunos. Então eu trabalhei com ensino médio, que é de 15 a 17.

K - Que disciplina?

$D$ - Português e inglês. Fui efetiva em dois cargos no Estado, em inglês e português. Aí exonerei de inglês quando vim trabalhar na direção. Não sou diretora efetiva. Passei no concurso, mas não assumi ainda.

$K$ - Então durante quantos anos mais ou menos?

$D$ - Desde 84, mas acho que foi em 89 que eu me desliguei do banco e me dediquei exclusivamente à educação.

$K-E$ ficou até...

$D$ - Até hoje. Só que em 2000 eu vim para o cargo de direção.

$K$ - Então, você ficou dez anos enquanto professora.

$D$ - Isso.

$K$ - Um pouquinho mais de dez anos.

$D$ - Mais.

$K-E$ o que você sentia como professora, a experiência de ser professora de aluno adolescente?

D - Eu sempre fui assim. Inclusive eu chamo aluno para participar do Conselho. Uma vez um aluno falou assim para mim: "Você é muito autoritária". Ele 
me chamou de autoritária e na verdade eu sou muito democrática. Ele confundiu a minha postura, a minha maneira de falar, que eu sou muito assim de falar alto, com firmeza, então me chamou de autoritária. E nesse dia uma coordenadora falou: "Pelo contrário, ela é muito democrática". Porque eu ouço muito o que as pessoas me colocam. É difícil trabalhar democraticamente, porque você ouve muita coisa $e$ não faz muito. É a reclamação que eu ouço por aí: quando você se torna democrática, você acaba patinando e não faz nada, porque você quer ouvir muita gente e no fim fica por ali, não sai dali, você fica dando voltas. Quando eu quero fazer tal coisa, eu pergunto: "O que você acha?" Então eu sou muito de perguntar para os meus coordenadores e ouço muito os professores, e conduzo de uma maneira... não sou assim de dizer "faça". Quando o aluno falou isso, eu coloquei a questão da água, acabou a água na escola e eu chamei o funcionário para tirar um pouco do hidrante e limpar o banheiro. Porque eu quero que o banheiro esteja limpo. Não tem água para beber, dá para agüentar. Agora, não dá para ficar num lugar em que não dá para usar o banheiro, necessidades fisiológicas não podem esperar muito tempo. E justamente o noturno chegou e quis ir embora, armou o maior banzé. Eu fui dizer nesse dia que não é fazendo rebelião e não é dessa maneira que se conduz o problema, que existe o diálogo. Eu tenho o tom de voz alto e sou assim muito objetiva, então ele falou: "Você é muito autoritária, parece ditador". Aí a minha coordenadora falou para ele: "Mas você está tendo uma idéia completamente errada da D., ela não é nada disso, ela é muito, muito democrática". Aí, eu falei pra ele assim: "Acho que você está confundindo pelo meu tom de voz, porque tudo que eu faço aqui é com a opinião de todos".

$K$ - Mas você gostava de dar aula para os adolescentes?

D - Gostava, porque eu tinha controle, eu tenho controle dentro da sala de aula, eu nunca chamo um diretor. Porque é o meu trabalho e eu acho que ele tem que me respeitar, então só em casos esporádicos eu exijo da direção uma postura. Tem muito professor que não consegue se impor dentro da sala de aula e você tem que estar trabalhando junto com o professor, senão ele não consegue nada dentro da sala de aula, nada.

K - Hoje você faz as duas coisas, é diretora e dá aula ainda?

$D$ - Só diretora.

K - Desde 90 você está como diretora?

D - Não, desde 2000.

$K$ - E o que mais te marcou nessa experiência de direção?

$D$ - De direção? É... é diferente, é muito diferente, de docência para direção é muito diferente. Enquanto docente, você está muito ligada à parte pedagógica, então é você no seu mundo com a sua disciplina e com seus alunos. Quando você vem para a direção de uma escola, você acaba deixando (e é uma das minhas reclamações) esse pedagógico de lado, porque o administrativo te toma muito tempo. É merenda...; olha aqui o que eu estou fazendo: tem que cuidar da parte gerencial do SARESP, da merenda, da compra que está chegando verba do $M E C$, eu tenho que estar comprando material de limpeza.

$K$ - Mais a parte burocrática. 
D - Burocrática e pouca relação. No HTPC eu entro uma vez ou outra e só interfiro mesmo quando já é problema, que aí precisa de mim. Então eu fico muito envolvida na parte administrativa e pouco na parte pedagógica, que é aluno. Agora, como eu circulo bastante, eles me conhecem, vêm conversar comigo e tal. É aí onde a gente sente essa diferença da $5^{a}$ série. A $5^{a}$ série é mais próxima de você. $A 8^{a}$ série já não, porque eles estão nessa idade entre 15 e 16 anos e acham que esse contato não é bom.

$K$ - De que forma você acha que dá para você contribuir com os alunos adolescentes, como diretora?

D - A escola está sempre procurando parcerias, projetos, uma maneira de ocupar o tempo do adolescente. Estamos muito preocupados com o tempo do adolescente. Eu vi até ontem uma pesquisa sobre meninos de rua, do uso de drogas, por que eles caem nisso, por que eles estão na rua.

$K$ - O que te preocupa nessa coisa de ocupar o tempo?

$D$ - É porque é com o tempo ocioso que eles estão envolvidos com os amigos e fazendo coisas que não deve. A Universidade (...) tem aquele projeto do circo, temos muitos aluno lá. Há também um projeto esportivo, eles jogam bola, são grupos de futebol. Não sei se são diversas modalidades de esporte. Tem esse pessoal na informática que eu te falei. Então é abrir a escola um período a mais e oferecer alguma coisa para fazer. $O$ que nós observamos? Enquanto ele está aqui na escola, ele está sendo cuidado. No horário em que não está na escola, ele não está com ninguém, não tem ninguém na casa dele.

$K-E$ o que acontece?

D - Daí é onde ele fica na rua. Ele não tem o que fazer, então vai arrumar, vai ver o que o amigo está fazendo. Porque enquanto ele é criança, mal ou bem ele está assistido. Se a mãe vai trabalhar, deixa as crianças em creches para ficar o dia todo. Só que, quando ele tem mais idade, já é adolescente, de 12,13 anos, o adolescente não quer ninguém o vigiando. Ele não vai mais ficar em creche o dia todo. Quando ele fica com um tio, eu vejo isso, eles não aceitam que o tio tome conta deles. Porque ele se acha dono da razão, dono dele próprio, responsável por ele, etc. e tal. A mãe não tem a preocupação de estar deixando ele em algum lugar, ou deixando alguém cuidando dele. Os alunos desta idade costumam ficar sozinhos em casa. É onde eles ficam sem atividade, na rua.

$K$ - Você acha que então a contribuição é ocupar o tempo ocioso deles.

D - Não, é administrar este espaço, poder oferecer mais condições, atividades educativas, para que vivam em ambiente de respeito, amizade, companheirismo, para crescerem e se desenvolverem como cidadãos.

$K$ - Você tem alguma esperança, assim enquanto diretora, de que alguma coisa possa melhorar?

D - Olha, cada dia que passa eu vejo aumentada a preocupação da sociedade com a questão do tempo ocioso. Tanto é que todas essas atividades que estão fora da escola são em período oposto ao escolar, é uma maneira de estar tirando a criança da rua. $O$ adolescente da rua, porque a criança não fica na rua, a criança precisa de cuidados. Tem uma escola aqui perto que oferece o CJ, que é um projeto da igreja. Nós percebemos o quê? Que o jovem fica perdido nesse período em que 
não está na escola. Enquanto ele está aqui, nós vamos estar em cima. Só que o errado ele pode fazer nesse outro horário, quando não tem ninguém olhando por ele. A igreja está preocupada com isso. São parcerias dessas entidades. Muitas vezes elas têm incentivo fiscal, descontam de alguma maneira, esses incentivos que - governo dá assim: se você fizer alguma coisa para a comunidade, você tem desconto, algum tipo de isenção. Então existem essas parcerias que são empresas privadas que dão. Agora, o circo da Universidade [" $x$ "] eu não sei quem é que banca, mas tem. Então você vê a sociedade em todos os sentidos envolvida nisso, porque esse é o maior problema, é enquanto o adolescente está fora da escola, o que ele está fazendo nesse tempo disponível. Muitas vezes ele é curioso, é comum no adolescente, ele vai por curiosidade e acaba num caminho sem volta muitas vezes. Eu percebo que seria assim um ponto fraco dele esse tempo que ele tem disponível.

$K$ - Você quer acrescentar alguma coisa? Vocês têm alguma coisa de formação especial para lidar com adolescentes?

D - Com adolescente, não. A gente tem formação na disciplina, então você é formada naquela disciplina. Esse professor que eu estava te contando que teve problema com o aluno, é o despreparo do professor, ele ingressou agora, então o que ele aprendeu na faculdade de matemática não tem esse negócio de como lidar com o adolescente. Ele é um excelente professor, ele veio com muita vontade, tanto é que ele começou a trabalhar muito antes de ter o exercício propriamente dito. Na semana do planejamento ele se envolveu, se relacionou muito bem com os professores, entrou, tinha vontade, participou do planejamento sem estar ganhando, porque ele estava tomando posse, estava preparando o documento de posse. Então ele estava se preparando para entrar em exercício, exercício é com o aluno. Já é o segundo caso que ele tem problema com aluno, mas ele é muito bom, é muito competente, é muito interessado, ele veio aqui antes do tempo, ele se inteirou do planejamento, do que dar para que série e de que maneira dar. Mas na hora em que ele efetivamente está com o aluno, na relação professor-aluno, ele começou a ter problemas. Por quê? Porque essa formação não existe para nós. Aí é onde gera conflitos, aí começam os conflitos. Isso na verdade a gente aprende assim no dia-a-dia, de que maneira você vai conduzir... você vai se aprimorando no passar do tempo, é acerto e erro. Isso é difícil. $O$ adolescente... é muito difícil. Você pega uma $5^{a}$ série, por exemplo, você lida de uma maneira com ela, com uma $8^{a}$ é completamente diferente.

K - Você gosta de lidar com adolescente?

D - Olha..., quando eles estão entrando na adolescência, que eu ainda acho que é um pouco criança... eu nunca trabalhei com criança. É um desafio para mim $e$ eu vivo dizendo isso. Antes de eu vir para essa escola, antes da atribuição, eu comentei com o grupo de diretores que estava comigo: "Ah, vou pegar a $X$, que é uma escola de $1^{a}$ à $4^{a}$, eu tenho muita vontade de trabalhar com crianças". É o que falta para eu conhecer. Porém, me foi designada esta escola.

$K$ - E o que você achou disso?

$D$ - Do que?

$K$ - De voltar para o Y. 
$D$ - Não, eu não trabalhava no Y. Eu trabalhava numa escola que era também de $5^{a}$ à $8^{a}$ e ensino médio, como aqui.

K - Então o que você acha disso de voltar a ter o contato com os adolescentes?

$D$ - É cansativo! É, porque eles questionam. Por isso eu queria de $1^{a}$ à $4^{a}$. Esses dias eu fui numa escola de $1^{a}$ à $4^{a}$ aqui perto e no pátio veio uma menina chorando desesperada: "Ela me sujou, olha o que ela fez na minha blusa". Eu olhei para o diretor e comentei: "Ah, eram esses tipos de problema que eu queria, queria que esses fossem os problemas desta escola". Fosse aqui já descia um sangrando, porque eles resolvem. Se um aluno faz alguma coisa para outro, eles já resolvem o problema da maneira deles. Na verdade, não recebemos aluno chorando porque aconteceu alguma coisa e temos que tomar providências. Já desce um sangrando, porque o outro já resolveu o problema dele.

$K$ - Tem muita violência?

$D$ - Tem. $O$ aluno, o adolescente tem o costume de resolver os problemas dele. A criança procura o pai ou a para mãe resolver. $O$ adolescente já se acha capaz de estar resolvendo os problemas dele, da maneira dele. Então, quando o problema vem para a gente, já é de um grauzinho mais elevado, mais sério. Por isso eu falo que queria tanto ter esses problemas pequenininhos assim. Aqui, não. Aqui a coisa é mais séria.

$K$ - Então, $D$, tem mais alguma coisa que você queria falar?

$D$ - Não, não.

K - Tá ótimo, D! Muito obrigada! 


\section{ENTREVISTA INDIVIDUAL COM A COORDENADORA SIMONE (C)}

$K-C$, eu queria saber primeiro qual é a sua visão, o que você acha dos adolescentes em geral, os de hoje.

$C$ - Dos adolescentes em geral?

K-É.

$C$ - Os adolescentes em geral acho que são rebeldes; querem chamar a atenção o tempo. Mas essa fase passa, com certeza. Ainda bem!

$K$ - Você acha que é uma fase?

C-Sim. É uma fase, ela passa. É claro que agora ele quer ser atendido na hora, ele quer uma resposta rápida. Como o mundo está mais rápido, o adolescente também quer uma resposta mais rápida.

$K$ - Eu queria te perguntar: por que você acha que tem essa rebeldia, por que 0 adolescente é rebelde?

$C$ - Acho que ele está se conhecendo e tentando mostrar o seu poder dessa forma, está querendo chamar atenção mesmo. Alguma coisa pra ele. Por isso eu falei uma resposta rápida, porque ele quer pra ele, ele quer que se resolvam as coisas pra ele, ele não quer estar resolvendo e acaba sendo rebelde. Você vê que não se envolve muito com o social. Parece que ele quer as coisas dele, 0 individualismo, ele acha que é só ele. Falta família aí? Falta. Também falta tempo para a escola falar dessa rebeldia com o aluno.

$K$ - Em que sentido você acha que falta a família pro adolescente?

$C$ - Ah, ele não tem uma base familiar, não tem a mãe presente no dia-a-dia, não tem o pai. Eu estava conversando com um, agora pouco, e ele falou: "Meu pai está internado e minha mãe trabalha até anoitecer, eu não a vejo". - "A que horas sua mãe trabalha?" - "Minha mãe sai às cinco e meia da manhã e volta as seis da tarde". Não tem tempo para ele. Um outro, conversando disse: "Traz seu pai aqui, vamos conversar com ele". - "Não, meu pai só bebe". Então ele não tem família, não tem estrutura.

$K$ - Você acha que isso é com o adolescente, assim, da classe mais baixa, ou de qualquer classe social, ou seja, não é uma questão de classe social? O que você acha?

C - É de classe social também, mas acho que acontece em função de pais também. Não sei se os pais estão preparados para essa nova geração de filhos, não estão preparados pra estar assumindo tudo isso.

K - Pra quê?

C - Pra criar uma família, pra direcionar os filhos, pra fazer alguma coisa na vida. Os pais de hoje não tem objetivos claros para a educação de seus filhos, a vida deles também é muito rápida, trabalho - casa- trabalho. A classe social está envolvida sim, porque envolve Educação. Se você está num ambiente que leva à rebeldia, um ambiente que, sei lá, em que se tem mais estrutura, isso já ajuda muito, já melhora. É claro que tem um ou outro, que acontece, de se desviar.

$K$ - E você sente diferença entre o jovem da geração de hoje e o jovem da sua geração?

C - Sinto, completamente! 


\section{$K$ - Qual é essa diferença?}

C - Aí vou ver três gerações. Na minha geração acho que nós éramos oprimidos, não podíamos pensar, não podíamos falar, você tinha que sentar numa sala de aula e ficar quieto ouvindo. Não podia se expressar, senti muito essa repressão. Mas mesmo assim acho que era uma escola, uma sociedade em que você não podia se manifestar. Depois disso vem uma geração que é a geração da minha filha, por exemplo.

$K$ - Ela está com quantos anos?

$C$ - Vinte e cinco anos. E que é mais consciente. Eu noto pelos amigos, um pessoal sabendo o que quer da vida, sabendo se comunicar, sabendo o que quer mesmo da vida. Agora, o de hoje está perdido, ele não sabe o que ele quer, ele não sabe o que ele vai fazer, ele não sabe decidir coisas. Eu acho mais difícil hoje. Eu tenho um filho, vamos dizer, um pouquinho mais que a faixa etária dos alunos daqui, mas nele também eu noto. Não sei, foi criado da mesma forma, mas também não sabe decidir, não sabe o que quer da vida. É mais difícil a liberdade de expressão.

$K-E$ qual você acha que é a causa disso?

$C$ - Acho que é uma série de coisas: é família, a sociedade, a escola e as políticas sociais.

$K$ - De que forma você acha que a escola contribui para que aconteça isso?

$C$ - A escola continua a mesma escola da minha geração.

$K$ - Em que sentido?

$C$ - A escola não avançou. Nós tivemos aí as novas leis, a Lei de Diretrizes e Bases, a LDB, mas a escola não está preparada pra isso. O que a escola tem para oferecer para o aluno e para o professor, de novo? Continua a mesma escola que eu estudei, inclusive a parte física. E a família, porque se dispersou, o filho é criado com avó, é criado com uma tia, ele vem e se vira sozinho, vai para a escola ou para recreação sozinho. Ele não tem parâmetros, ele está perdido.

K - Você acha que essa rebeldia do adolescente é uma coisa biológica ou não?

C - Eu não sei se biológica, mas penso muito em índole. Não sei, de repente você não tem como mudar porque ele nasceu não sei se predestinado ou nasceu com aquilo que ele seria. Acho que se conseguirmos fazer uma boa orientação, ele melhora muito. E muitas vezes o carinho, sabe? Muitas vezes você elogia um aluno adolescente, e ele muda de atitude.

$K$ - Eu queria te perguntar agora o que você acha dos alunos adolescentes daqui. Os alunos adolescentes daqui você acha que são como essa tendência geral de rebeldia? Qual é a sua visão dos alunos daqui?

$C$ - Adolescente é adolescente em qualquer lugar, mesmo aqui eles querem se mostrar, impor suas decisões e não é bem por ai, não adianta se revoltar se aceitou estar nesta escola e junto com isso as regras desta escola. Esse caminho de rebeldia, de destruição é porque não dá valor ao social, ao do outro também. Deveriam parar e refletir. Essa reflexão deve vir da escola, da sala de aula, porque é aqui que enfim ele tem contato com as regras e a sociedade. Eles são muito impulsivos dentro do coletivo. 
$K$ - Aqui na escola todo mundo fala sobre a $8^{a} A$, destacam a $8^{a} A$. Eu queria perguntar: o que você acha dessa sala?

$C$ - Eu acho que os alunos dessa sala querem punir a sociedade, querem punir a escola, querem punir o professor, porque foram abandonados talvez, acho que eles se sentiram podados e aí eles fazem tudo isso. Eles querem mostrar que eles têm poder, que eles mandam.

$K$ - Mandam de que forma?

C - Atrapalhando o andamento da escola, atrapalhando os colegas e os professores.

$K$ - E sobre essa idéia de juntar todos numa sala, o projeto da $8^{a} A$ como é?

$C$ - Esse projeto é excelente, é bonito, eu trabalho nesse projeto há muito tempo e é muito bom.

K - Como é?

$C$ - "Ensinar e aprender" é uma nova pedagogia. Não é uma pedagogia que existia na minha geração, é uma pedagogia de hoje acompanhando a Lei de Diretrizes. Você só trabalha com projetos, o professor prepara aulas para se descobrir às habilidades dos alunos, incentivando-os sempre. Surge uma oportunidade dentro da sala, por exemplo: vamos saber o que é uma psicóloga, o que ela está fazendo aqui, como ela vai atuar, o que ela quer atingir, vamos pesquisar juntos. Então dentro daquele momento vamos trabalhar isso, ensinar sobre uma profissão, projetos para descobrir habilidades na escrita, na leitura e ou interpretação de um texto ou de um contexto.

(interrupção de professora)

Veja bem, o "Ensinar e Aprender" é um projeto, após avaliar o perfil dos alunos o professor direciona seus objetivos.

$\mathrm{K}$ - Para todas as séries, para que série? Para que serve?

$C$ - Classes de aceleração para alunos retidos, para alunos que estavam fora da escola e/ou evadidos, monta-se uma sala digamos especial, desenvolve as habilidades e competências e após um período, avalia esse aluno para que ele cursar a série seguinte, podemos também acelerar esse aluno para uma série superior, da $6^{a}$ para a $8^{a}$ por exemplo, aqui temos uma sala de alunos retidos na sua maioria por faltas. Sairão aptos para cursar o Ensino Médio.

K- Todos da oitava estão aptos?

C-Sim. Estão aptos.

$K$ - Mas e os alunos daqui, como você acha que está o ensino deles, a aprendizagem?

C - De um modo geral tem bons professores, pessoal capacitado para trabalhar com projetos os alunos sabem disso e conseguem se sair muito bem.

$K$ - Quer dizer que o projeto "ensinar e aprender" na prática funciona?

$C$ - Funciona, sim. $\mathrm{Na}$ verdade, você não pode seguir à risca o que tem de modelo no "Ensinar e Aprender", você tem que ir modificando esses modelos e adaptando à sua realidade. Eu trabalhei com classes de aceleração, você tem que ir adaptando mesmo, tem que ir tirando, inventando, criando. Isso é que é legal, o professor está criando, está inventando, está fazendo de outra forma.

$\mathrm{K}-\mathrm{Na} 8^{a} \mathrm{~A}$ tem essa proposta desse Ensinar e Aprender? 
$C$ - Sim. Tem essa proposta. O aluno que não sabe escrever, que não conhece as regras gramaticais, que não sabe formar frases e não tem interesse, os professores interagem de uma forma que esse aluno acaba conseguindo aprender sem que ele perceba que está aprendendo regras e tudo mais.

$K$ - E tem toda uma coisa que a $8^{a}$ A gera, né? Todo mundo fala: "Ah, da $8^{a}$ $A^{\prime \prime} \ldots !$

$C$ - Tem, tem. Cria uma sensação assim. Quer dizer, muitos deles não sabem aproveitar a chance. Porque o grupo não permite isso, não dá espaço, acabamos tendo que intervir o tempo todo para manter a ordem.

$K$ - $O$ que vai acontecer com eles nesse ano? Acaba o ano e eles já tiveram esse ano de retenção.

C - O aproveitamento que eles tiveram foi avaliado, sim. Eles não deixaram de fazer atividades, não. Eles estão produzindo o tempo todo. Tem desavenças com um professor ou com outro, ou com entrada e saída de alunos fora do horário, mas tudo acaba se resolvendo. Então o tempo todo eles estão sendo avaliados. Vão sair com deficiência? Pode ser que sim, mas eles foram avaliados o tempo todo, durante as atividades, e vão passar de ano realmente porque houve uma recuperação do ciclo. Agora, no final, os professores conseguiram concluir o último volume, com todo esse sofrimento e toda essa tortura. É claro, tem dois ou três que não sabem porque são especiais.

(interrupção - telefonema)

$K$ - Então você estava falando da história da $8^{a} A$, do que acontecia, que eles vão passar de ano e tal. Eu queria perguntar o que levou à retenção dos alunos da $8^{a} A$ ?

$C$ - Faltas. Frequiência é o que repete aluno, por isso o aluno fica retido, a maioria deles. Existem uns casos de alunos especiais aí, mas esses alunos você não pode também estar retendo, os que ficam retidos é por causa de falta.

$K$ - Mas o que acontece? No fim do ano, principalmente na oitava série, que é o fim do ciclo, eles vêm o quê? Quando a pessoa não tem falta, tem outra coisa para ver, por exemplo, os conceitos?

$C$ - Ah, sim, tem conceitos. A maioria da $8^{a} A$ foi por falta, mas temos uns casos que foram por conceitos. Mas aí você percebe que é um aluno com dificuldade mesmo, um aluno com dificuldade de aprendizagem.

$K$ - E essa dificuldade de aprendizagem você acha que vem de onde?

C - Não foi detectada lá no início. Aí, com a LDB também, você não pode discriminar esse aluno, ele tem que estar inserido nesse contexto.

$K$ - Você acha que essa dificuldade de aprendizagem é uma coisa que é do aluno, o aluno que tem uma limitação ou é alguma coisa, assim, por detrás?

$C$ - Em alguns casos... Tem casos que você percebe que é o aluno. Muitos eu sei que é o aluno, conversei com a mãe, conversei com o pai.

(interrupção)

$C$ - Tem casos de alunos que eu percebi que é do aluno e outros que você vê que é desvio de comportamento pela situação em que ele vive: pai preso, a mãe bebe, não tem dinheiro, não tem comida, não tem nada, não tem estrutura nenhuma. 
Então você vê que tem uns casos em que ele nem vê o pai e a mãe porque os dois trabalham o dia todo. Cada caso é um caso.

$K$ - Eu ia te perguntar isso. $O$ que você acha que leva à repetência?

$C$ - Cada caso é um caso. Os professores desenvolvem todas as habilidades e as competências desses alunos, mas cada um tem o seu ponto que ele não consegue.

$K$ - Como é o seu contato com os alunos, em que situações você tem contato com os alunos?

C - Em que situações? Ah, em toda situação. Ele quer ajuda no pedagógico, ele quer ajuda no físico porque precisa de material, ele quer um carinho também. É isso, tudo.

$K$ - Eles vêm conversar com você?

$C$ - Vêm bastante, porque eu não brigo, eu não xingo, eu estou ali com eles o tempo todo, estou vendo e falando: por que você não fica dentro da sala de aula, por que você não faz isso, por que não faz aquilo? Então o meu papel é diferente do professor na sala de aula. O professor está cobrando mais, talvez, e aí não tem uma resposta tão satisfatória. Aqui você percebe o que está acontecendo e fala: fulano, entra na sala de aula, vai lá, colabora, faz a sua parte e tal.

$K$ - Você acha que o seu papel é mais qual, então?

$C$ - Coordenar mesmo. Eu falo: professor, calma, daqui a pouco muda e vai dar certo.

$K$ - É uma intermediação entre o aluno e o professor.

$C$ - Entre o aluno e o professor. É mais por aí mesmo, estar contornando a situação.

$K$ - Eu ia te perguntar como você sente que é a sua relação com os alunos.

$C$ - Ah, é uma relação boa, legal, mas na hora que ele senta aqui e eu tenho que falar com ele, que eu tenho que falar sério, eles ouvem. Parece que fora da sala de aula, num outro ambiente, eles ouvem mais. Então eu tenho uma relação muito boa com eles, mesmo fora dessa sala, mesmo ali no: "Ah, tudo bem?" - "Tudo bem". Eles me respeitam, gostem ou não.

$K$ - Você fala que tem carinho, né?

$C$ - Exato, isso ajuda muito.

$K$ - Dos dois lados, tanto de você com relação a eles e eles com relação a você.

C - Vamos dizer, se entrar aqui sem pedir licença: "Opa, volta e pede licença". Você vê que eles conseguem respeitar isso.

$K$ - Tem carinho e respeito, né?

$C-\dot{E}$.

$K$ - Que imagem você sente que eles fazem de você?

$C$ - Que imagem? Ah, não sei, nunca parei pra pensar! Não, não tenho idéia.

$K$ - $O$ que eles acham... acho que a $C$ é assim.

$C$ - Ah, sim. Eles falam: "Ah, você é legal, você é muito legal. Ou "você é mais legal! É demais!". (risos) Eu sinto que gostam.

$K$ - Há esse reconhecimento deles e tal. A gente está chegando ao fim e eu queria te perguntar se você trabalha como coordenadora há muitos anos.

$C$ - Não. 
$K$ - Eu queria que você falasse da sua trajetória.

$C$ - Eu estava na sala de aula até o ano passado.

K - Dava aula para que série?

$C$ - Ensino fundamental e ensino médio. $E$ trabalhei na Febem por três anos.

$K-A h, e ́$ ? Trabalhou em que lá?

C - Como professora. Dando aula. Na sala de aula da Febem. Lá é diferente porque não é uma sala de aula comum, não é um lugar comum, lá tudo é um outro mundo. Comecei há 10 anos atrás, como professora eventual, consegui no mesmo ano algumas aulas. Depois fui convidada para atuar na Febem, foi uma experiência e tanto, aprendi muito lá. Em 2004, consegui aulas em uma escola próxima daqui e aí veio um convite para a Coordenação Pedagógica. Ė uma nova etapa e estou em fase de conhecimento. Acabo falando: até onde eu posso chegar? Não sei...

(interrupção)

$K$ - Você estava falando da experiência na Febem. $O$ que você achou de trabalhar lá?

(interrupção - briga de alunos)

C - Olha lá, brigou e bateu. Está vendo como é gerenciar conflitos? Você perguntou da experiência lá na Febem.

$K$ - $O$ que você achou de trabalhar lá e como é que foi?

$C$ - Eu acho que tudo é válido. Foi uma experiência fantástica, do ponto de vista do ser humano. Aquele lugar denigre a imagem de qualquer um, é o fundo do poço. Sabe, essa coisa que eu falei de dar atenção? Acontece lá também. Às vezes, uma palavrinha que você diz consegue mudar tudo. Então só você vivendo lá o dia-adia para você ter uma idéia do que é aquilo. É um ambiente deprimente. Não é essa coisa de risco, é pelo lugar, o local. Tentar direcionar a experiência adquirida lá de outra forma também, tomando atitudes rápidas. É muito difícil lidar com pessoas, com grupos, grupos diferenciados. Veja que na minha profissão tenho grupos de alunos, grupos de professores, grupo da direção, grupo da secretária e o grupo de pais também.

$\mathrm{K}$ - Tem grupo de pais aqui?

$C$ - Não. Estou dizendo quando você chama ou que o pai vem por causa de um assunto ou de outro. Então você está fazendo essa ligação. É uma posição muito difícil, muito difícil. Você não mexe só com o pedagógico.

$K$ - Como você se sente, neste ano, com essa nova função, com essa nova experiência? Como vai essa nova experiência aí de coordenadora?

$C$ - Ah, agora que está chegando o final do ano eu me sinto um pouco mais assim eu gosto de fazer o que estou fazendo, gosto de estar fazendo essa ponte. Só que, por outro lado, fico muito preocupada com esse lado pedagógico que não rende nada, sabe? Eu sinto que está na mesma. $O$ que eu vou conseguir mudar e como eu vou conseguir mudar? Eu vou continuar aqui? É difícil você ter uma afinidade, mas não ter um vínculo. Tenho uma afinidade com o cargo, com as situações que acontecem aqui, com os grupos, mas sem o vínculo fica difícil.

$K-E$ o que mais te marcou nessa experiência deste ano? 
C - O que mais me marcou? É o poder de decisão, o poder de decisão que acabou caindo nas minhas mãos, que eu não imaginava que teria esse poder, que teria dentro da escola.

$K-E$ você acha que pode, como coordenadora, trazer alguma contribuição para os adolescentes?

$C$ - Acho que sim. Acho que sempre dá para trazer alguma coisa, dá para fazer alguma coisa, mas só o tempo vai dizer. Não se sabe se o aluno vai seguir ou não. Às vezes você tem uma conversa com o aluno percebi que ajudei. Já outras vezes... Ah, não sei, é difícil. Acho que ainda é muito pouco tempo.

$K$ - $O$ tipo de contribuição que você acha que você pode dar é mais no nível da relação?

C - Da relação, talvez hoje mais da relação. Eu acho muito pouco tempo de história.

$K$ - Você participou alguma vez de algum projeto, alguma coisa voltada para a juventude mesmo ou de alguma palestra sobre os jovens de hoje, sobre a juventude, alguma coisa assim?

C - Aí é que está. A minha formação já faz com que eu goste disso. Eu gosto de estar sabendo sobre tudo do adolescente, gosto de estar observando, gosto de saber o que ele está pensando, o que o adolescente está falando. Isso faz parte da minha formação. Participo lendo, ouvindo entrevistas e também participando de atividades voltadas para os jovens. Então eu gosto sempre de estar me informando sobre tudo, sobre o que a juventude faz, o que ela ouve, o que ela gosta, o que ela lê. Disso eu gosto.

K - Você gosta de lidar com adolescentes?

$C$ - Eu gosto!

$K-E$ o que te encanta aí?

$C$ - O adolescente não fica contando a mesma historinha sempre: "Ah, porque meu pai bebeu, não sei o que eu vou fazer". Não. Ele falou do pai dele, aí já estava falando da música, já está falando da dança. Acho que é mais fácil. Os mais velhos, sei lá, os da minha geração, é o mesmo tipo de assunto. Encontra com uma amiga que trabalha em escola também e que só sabe falar de escola, não muda 0 assunto. O jovem não, fala de tudo: "ah, sabe aquela música assim?" Na minha casa com meus filhos: "Mãe, você viu o que aconteceu?" $E$ daqui a pouco já fala de cinema.

$K$ - Tem uma diversidade.

C - Tem. Então gosto muito de adolescente por causa disso. Sei lá, sempre convivi com adolescentes.

$\mathrm{K}$ - Quantos anos você deu aula?

C - Aula? 10 anos em sala de aula.

K - É bastante tempo...

$C$ - Eu não acho, não. Você pega o $\operatorname{Pr} 1 \ldots$ ele tem quase 30 anos de sala de aula!

K - Você gostava dessa experiência de dar aula para adolescente?

C - Nossa! E como!

$\mathrm{K}$ - Como era isso? 
$C$ - É legal porque quando você pega um gancho de um assunto e ele se situa é muito gratificante. Ah, isso é muito bom. $O$ aluno percebe isso também e ele acaba debatendo com você. $E$ isso muitas vezes sem ele perceber: nossa, nós falamos sobre isso. Coisas que ele não falaria na sala de aula.

$K$ - Você dava aula de quê?

$C$ - Português e inglês para o Ensino Médio, em que você trabalha com literatura, ai é melhor ainda. Você não quer falar pra eles lerem Machado de Assis. Se você falar para lerem Machado de Assis, vão falar: "Não, não gosto". Nem sabe - que é, mas já fala que não gosta. Aí você vai falando, faz um comentário de alguma coisa da tevê, sabe, de repente consegue inserir o Machado de Assis na história e fala.

$K$ - Desperta o interesse.

$C$ - É, é mais despertar o interesse, mesmo.

$K$ - Você sentia essa coisa da rebeldia?

$C$ - No Ensino Médio também tem a rebeldia, ela está sempre a nossa volta. Agora, para as $5^{a}$ e $6^{a}$ séries foi muito pouco tempo, foi mais para $8^{a} s$ ao Ensino Médio.

K - Você começou falando da rebeldia. Você sentia isso dentro da sala de aula ou não?

C - Sim. Eu vejo isso na sala de aula e no dia-a-dia.

$K$ - Você está falando de uma dosagem. Existe isso, mas existe também um lado afetivo, um lado de respeito e tem uma diversidade. Quer dizer, tem isso, mas também tem aí um encanto.

C - Há muitos encantos, muitas vezes ele não sabe escrever o nome corretamente, não sabe escrever o nome do pai e da mãe, mas, de repente eles despertam, se é só apertar um botão e ele sabe comandar algo, para que ficar aprendendo teorias? Então, realmente, talvez seja mais fácil convencê-lo de que ele pode ser igual a todos. A sociedade está pedindo umas respostas diferentes. Não é "você vai sentar aqui e só vai ficar fazendo isso". Não é assim.

K - É o que você estava falando da importância da educação também perceber essas coisas?

$c-\dot{E}^{\prime}$

K - Essa coisa pedagógica o que seria, você teria que ter a função de achar coisas?

C-De passar conteúdos.

$K$ - Para os professores?

$C$ - Mas o conteúdo de uma forma com projeto: se ele vai aprender através de um vídeo, se vai aprender através de uma visita, se ele vai aprender através de pesquisa.

K - Você está falando de formas de considerar elementos da juventude?

$C$ - Da juventude.

$K$ - Então, seria isso de sair um pouco da escola, e o que mais poderia ser aí?

$C$ - Pesquisa, leitura, vídeo, através de música. Nós fizemos agora o projeto "Água", tivemos o projeto "São Paulo 450 anos", em que conseguimos realizar 
algumas atividades fora da escola. Tivemos um resultado muito bom, os alunos participaram bastante.

K - Esse projeto "Água" é o quê?

C - Para finalizarmos o semestre o projeto foi: "Água". Os alunos viram tudo sobre a água, ele vai saber porque tem que economizar, o que está acontecendo com a água, ele vai saber tudo sobre a água. Só não conseguimos marcar com a Sabesp, mas ainda assim tentarei uma palestra, que venham até a escola fazer alguma coisa, falar alguma coisa.

$K$ - Quer dizer que são coisas que você na sua própria experiência com os adolescentes capta nessa coisa da diversidade.

C - Da diversidade. Eu não vou sair brigando porque tenho aluno que está fora da sala de aula por alguma coisa. Por quê? Porque de alguma forma ele está aprendendo alguma coisa. Hoje, essa pedagogia, esse projeto, é muito melhor, ele é amplo.

K - Então você acha que não está dando para se dedicar tanto para essa questão pedagógica?

C - Sim. Mas se você começa a pensar também, é o Estado que não dá a estrutura, é o país que não te dá estrutura. Então, não adianta me magoar se não conseguir realizar projetos. É decepcionante? É. Sei lá, se eu estivesse numa outra escola da vida, a estrutura é outra, o contexto é outro. Mas aqui não, é a minha realidade, é o meu dia-a-dia.

$K-E$ que esperanças você tem com relação a esse trabalho que você pode vir a fazer ou faz com os adolescentes?

$C$ - Esperança e sonhos. Só que eu não vejo muita coisa assim grandiosa por causa dessa estrutura. Falta funcionário, falta professor, falta material, falta tudo. Então não vejo muito isso. Claro, pequenos trabalhos e tal a gente consegue, sim, de uma forma ou de outra você consegue realizar. Mas, por exemplo, eu não posso planejar muito porque não sei se vou estar aqui no ano que vem.

$K$ - Isso atrapalha.

$C$ - Muito. Então você faz, enquanto está aqui você cumpre o seu papel.

K - Você gostaria de continuar como coordenadora?

C - Gostaria, gostaria mesmo. Eu acho que estou aprendendo, essa experiência é muito positiva e vai me ajudar muito. Eu gostaria de continuar, sim. Mas é tudo tão incerto! Claro, hoje eu fico pensando: se eu estiver aqui, tal coisa não faria como faço hoje, vou tentar mudar. Algumas coisas você pensa. Por outro lado, se eu não estiver aqui, já sei o que vou fazer lá fora.

$K$ - Que é voltar a dar aula?

$C$ - É voltar para a sala de aula, que é um cargo muito mais cômodo.

$K$ - É mais cômodo?

$C$ - É mais cômodo. Coordenação é muito desgastante.

$K$ - Como você falou.

C - Como eu te falei, eu sou assim, não me estresso com facilidade. Não deu certo, não deu, vamos fazer outro. Vamos fazer o quê? Se não está dando, larga tudo isso, vamos partir pra outro.

$K$ - Mais tranqüilidade. 
C - Mais tranqüilidade. É o que acaba dando certo para continuar aqui também. É necessário.

$K$ - Tem mais alguma coisa, $C$, que você queria falar com relação a isso?

$C$-Talvez [eu acabe ficando como uma referência na escola] porque todo dia às sete horas estou aqui e só vou sair à tardezinha. Então realmente não tem mais ninguém. Quem está aqui? Está a $C$ aqui.

$K$ - Então, o contato que eles têm com você é uma coisa que também chama para que eles saibam que podem contar com você?

$C$ - Que podem contar, talvez. Ou então: vou falar com a $C$ porque ela me ouve.

$K$ - Você estava contando isso, que você ouve com facilidade.

C - Ouço, considero. Não sei, eu sempre pensei em fazer assistência social, eu gosto disso. A assistência social cai também um pouco nessa parte que talvez seja a sua, a psicologia, de você ouvir as pessoas antes de você falar. As pessoas estão precisando falar, conversar. É psicóloga, é mãe, é tudo! Acabo virando tudo! Se não tem ninguém pra resolver, quem vai resolver? $A C$ !

$K$ - Você gostaria de falar mais alguma coisa, $C$ ?

$C$ - Não, não.

K - Então, está ótimo! Muito obrigada! 


\section{REFERÊNCIAS}

ABERASTURY, Arminda (e colab.). Adolescência. Porto Alegre, Artes Médicas, 1980.

ABERASTURY, Arminda. "O adolescente e a liberdade". In: ABERASTURY, Arminda; KNOBEL, Maurício (orgs.). Adolescência Normal. Porto Alegre, Artes Médicas, 1981.

ABRAMO, Helena W. "Considerações sobre a tematização social da juventude no Brasil". In: Juventude e Contemporaneidade. Revista Brasileira de Educação. São Paulo, ANPED, n.5-6, 1997.

ABRAMO, Helena. "Condição juvenil no Brasil contemporâneo". In: ABRAMO, Helena; BRANCO, Pedro (orgs). Retrato da juventude brasileira: análises de uma pesquisa nacional. São Paulo, Editora Fundação Perseu Abramo, 2005.

ABRAMO, Helena; BRANCO, Pedro. "Apresentação". In: ABRAMO, Helena; BRANCO, Pedro (orgs). Retrato da juventude brasileira: análises de uma pesquisa nacional. São Paulo, Editora Fundação Perseu Abramo, 2005.

ABRAMOVAY, Miriam; CASTRO, Mary G. (orgs.) Ensino Médio: Múltiplas vozes. Brasília, UNESCO, MEC, 2003.

AGUIAR, Wanda Maria; BOCK, Ana Mercês; OZELLA, Sergio. "A orientação profissional com adolescentes: um exemplo de prática na abordagem sóciohistórica". In: Psicologia Sócio-histórica: uma perspectiva crítica em Psicologia. São Paulo, Cortez, 2001.

AGUIAR, Wanda; OZELLA, Sergio. "Desmistificando a concepção de adolescência". Manuscrito submetido para publicação em abril de 2006.

AGUIRRE, Maria José. Afeição, cólera e medo entre adolescentes estudantes de São Paulo. São Paulo, Tese (Doutorado). Faculdade de Filosofia, Ciências e Letras. Universidade de São Paulo, 1953.

ANDRÉ, Marli. E. D. A, de. "Texto, contexto e significados: algumas questões na análise de dados qualitativos". In: Cadernos de Pesquisa. São Paulo, v.4, p.66-71, maio de 1983. 
ANDRÉ, Marli. E. D. A, de. Etnografia da prática escolar. 2ed. Campinas, SP, Papirus, 1995.

ARIÈS, Philippe. História Social da Criança e da Família. Rio de Janeiro, LTC Editora, 1978.

BOCK, Ana Mercês. "As aventuras do Barão de Munchhausen na Psicologia da Educação". In: TANAMACHI, Elenita; PROENÇA, Marilene; ROCHA, Marisa. Psicologia e Educação: desafios teórico-práticos. São Paulo, casa do psicólogo, 2000.

BOCK, Ana Mercês. "A psicologia sócio-histórica: uma perspectiva crítica em psicologia". In: BOCK, Ana; GONÇALVES, Maria da Graça; FURTADO, Odair (orgs). A psicologia sócio-histórica: uma perspectiva crítica em psicologia. São Paulo, Cortez, 2001.

BOURDIEU, Pierre. "A 'juventude' é apenas uma palavra". In: BOURDIEU, Pierre. Questões de Sociologia. Rio de Janeiro, Editora Marco Zero, 1983.

BOSSA, Nádia. "O normal e o patológico na adolescência" In: OLIVEIRA, Vera; BOSSA, Nádia (orgs.) Avaliação psicopedagógica do adolescente. Petrópolis, Vozes, 1998.

CONTINI, Maria de Lourdes J. Prefácio. In: KOLLER, S. H. (org.) Adolescência e Psicologia: concepções, práticas e reflexões críticas. Rio de Janeiro, Conselho Federal de Psicologia, 2002.

CAMARGO, Carmen. O bom professor do Ensino Médio na representação do alunado. Franca, 2000. 132p. Dissertação (Mestrado), Programa de Pós Graduação em Ciências e Práticas Educativas. Universidade de Franca.

CRUZ, Silvia Helena. Representação da escola em crianças da classe trabalhadora. São Paulo, 1987. 274p.+anexos. Dissertação (Mestrado), Instituto de Psicologia, Universidade de São Paulo.

CRUZ NETO, Otávio; MOREIRA, Marcelo; SUCENA, Luiz. "Grupos Focais e pesquisa social qualitativa: o debate orientado como técnica de investigação. In: Ser Social - Revista do Programa de Pós-Graduação em Política Social do Departamento de Serviço Social da Universidade de Brasília. Brasília, Ser Social UnB, n.9, jul-dez 2001. 
DAYRELL, Juarez. "Juventude e escola". In: SPOSITO, Marilia Pontes (org.).

Juventude e Escolarização (1980-1998). Brasília, MEC/Inep/Comped, 2002.

DEBESSE, Maurice. A Adolescência. Lisboa, Publicações Europa-América, 1946.

ERIKSON, Erik. Identidade, Juventude e Crise. Rio de janeiro, Zahar Ed., 1972.

FERREIRA, Aurélio. Novo Dicionário Aurélio da Língua Portuguesa. Curitiba, Positivo, 2004.

FORACCHI, Marialice. A juventude na sociedade moderna. São Paulo, Pioneira, 1972.

FRELLER, Cíntia. Crianças portadoras de queixa escolar: um enfoque winnicottiano. São Paulo, 1993. 213p. Dissertação (Mestrado), Instituto de Psicologia, Universidade de São Paulo.

FRELLER, Cíntia. "Crianças portadoras de queixa escolar: reflexões sobre o atendimento psicológico". In: MACHADO, Adriana; SOUZA, Marilene (orgs).

Psicologia Escolar: em busca de novos rumos. São Paulo, Casa do Psicólogo, 1997.

FREUD, Anna. O ego e os mecanismos de defesa. Rio de janeiro, Civilização Brasileira, 1986.

GALLATIN, Judith Estelle. Adolescência e Individualidade: uma abordagem conceitual da Psicologia da Adolescência. São Paulo, Harper \& Row do Brasil LTDA., 1978.

GROPPO, Luiz Antônio. Juventude: Ensaios sobre Sociologia e História das Juventudes Modernas. Rio de Janeiro, DIFEL, 2000.

HALL, Granville STANLEY. Adolescence - its psychology and its relations to physiology, anthropology, sociology, sex, crime, religion and education. (Vols. I-II). New York and London. D.Apletton and Company,1925.

KNOBEL, Mauricio. "Introdução". In: ABERASTURY, Arminda; KNOBEL, Mauricio (orgs.). Adolescência Normal. Porto Alegre, Artes Médicas, 1981a.

KNOBEL, Mauricio. "A Síndrome da Adolescência Normal". In: ABERASTURY, Arminda; KNOBEL, Maurício (orgs.). Adolescência Normal. Porto Alegre, Artes Médicas, 1981b. 
KNOBEL, Mauricio. "Normalidade, responsabilidade e psicopatologia da violência na adolescência". In: LEVISKY, David (org.). Adolescência e violência: consequiências da realidade brasileira. São Paulo, Casa do Psicólogo, 2000.

KUPFER, Maria Cristina. "O que toca à/a Psicologia Escolar". In: MACHADO, Adriana.; SOUZA, Marilene. (orgs.) Psicologia Escolar: em busca de novos rumos. São Paulo, Casa do Psicólogo, 1997.

LEVISKY, David. Adolescência: reflexões psicanalíticas. São Paulo, Casa do Psicólogo, 1998.

LEVISKY, David. "Aspectos do processo de identificação do adolescente na sociedade contemporânea e suas relações com a violência". In: LEVISKY, David (org.).

Adolescência e violência: conseqüências da realidade brasileira. São Paulo, Casa do Psicólogo, 2000.

MANNHEIM, Karl. "O problema da juventude na sociedade moderna". In: BRITTO, Sulamita de (org.). Sociologia da Juventude I: da Europa de Marx à América Latina de hoje. Rio de Janeiro, Zahar Editora, 1968.

MANNHEIM, Karl. "O problema sociológico das gerações". In: MANNHEIM, Karl. Coleção Grandes Cientistas Sociais, 25. São Paulo, Ática, 1982.

MARGULIS, Mario; URRESTI, Marcelo. "La juventud és más que uma palabra". In: MARGULIS, Mario. La juventud és más que uma palabra: ensayos sobre cultura y juventud. Buenos Aires, Edital Biblos, 1998.

MEIRA, Marisa. "Psicologia Escolar: Pensamento Crítico e Práticas Profissionais". In: TANAMACHI, Elenita; ROCHA, Marisa.; PROENÇA, Marilene. (orgs.) Psicologia e Educação: desafios teórico-práticos. São Paulo, Casa do Psicólogo, 2000.

MEIRA, Marisa; ANTUNES, Mitsuko (orgs). Psicologia Escolar: Teorias Críticas. São Paulo, Casa do Psicólogo, 2003.

MEIRA, Marisa; ANTUNES, Mitsuko (orgs). Psicologia Escolar: Práticas Críticas. São Paulo, Casa do Psicólogo, 2003.

MELUCCI, Alberto.; FABBRINI, Anna. L'età dell' oro: Adolescenti tra sogno ed esperieza. Milão, Feltrinelli, 1992.

OZELLA, Sergio. "Adolescência: uma perspectiva crítica". In: CONTINI, Maria de Lourdes (coord.). Adolescência e Psicologia: concepções, práticas e reflexões 
críticas. Rio de janeiro, Conselho Federal de Psicologia, 2002.

OZELLA, Sergio. "A adolescência e os psicólogos: a concepção e a prática dos profissionais". In: OZELLA, Sergio (org.). Adolescências construídas: a visão da psicologia sócio-histórica. São Paulo, Cortez, 2003.

OZELLA, Sergio (org). "Apresentação". In: OZELLA, Sergio (org.). Adolescências construídas: a visão da psicologia sócio-histórica. São Paulo, Cortez, 2003.

PAPARELLI, Renata. Trabalho precoce e escolarização: uma trama complexa. São Paulo, 2001. 193p. Dissertação (Mestrado), Instituto de Psicologia, Universidade de São Paulo.

PATTO, Maria Helena. Psicologia e Ideologia: uma introdução crítica à Psicologia Escolar. São Paulo, TA Queiroz, 1984.

PATTO, Maria Helena. A produção do fracasso escolar: histórias de submissão e rebeldia. São Paulo, Casa do psicólogo, 1996.

PATTO, Maria Helena. Introdução à Psicologia Escolar. 3ed. São Paulo, Casa do Psicólogo, 1997.

PATTO, Maria Helena. Mutações do cativeiro: escritos de Psicologia e política. São Paulo, Hacker Editores/Edusp, 2000.

PFROMM NETO, Samuel. Psicologia da Adolescência. São Paulo, Pioneira, 1976.

QUEIROZ, Maria Isaura. Variações sobre a técnica do gravador no registro da informação viva. São Paulo, CERU e FFLCH/USP, 1983.

RAMA, Germán. "La situacion de la juventud y los problemas de la insecion em la sociedad". In: FRANCO, Maria Laura; ZIBAS, Dagmar (orgs.). Final do Século: desafios da Educação na América Latina. São Paulo, Cortez, 1990.

SALLES, Leila. "A representação social do adolescente e da adolescência: um estudo em escolas públicas". In: Cadernos de Pesquisa, São Paulo, n.94, p.25-33, 1995.

SALLES, Leila. Adolescência, escola e cotidiano: contradições entre o genérico e o particular. Piracicaba, Editora UNIMEP, 1998.

SCHMIDT, João Pedro. Juventude e Política no Brasil: a socialização política dos jovens na virada do milênio. Santa Cruz do Sul, EDUNISC, 2001. 
SOUZA, Beatriz. "Professora desesperada procura psicóloga para classe indisciplinada". In: MACHADO, Adriana.; SOUZA, Marilene. (orgs.) Psicologia Escolar: em busca de novos rumos. São Paulo, Casa do Psicólogo, 1997.

SOUZA, Marilene P.R. de; MACHADO, Adriana. "As crianças excluídas da escola: um alerta para a Psicologia". In: MACHADO, Adriana; SOUZA, Marilene (orgs.) Psicologia Escolar: em busca de novos rumos. São Paulo, Casa do Psicólogo, 1997.

SOUZA, Marilene. Proença. $R$ de. "A queixa escolar na Formação de Psicólogos: Desafios e Perspectivas". In: TANAMACHI, Elenita; ROCHA, M.arisa; PROENÇA, Marilene (orgs.) Psicologia e Educação: desafios teórico-práticos. São Paulo, Casa do Psicólogo, 2000.

SOUZA, Marilene P.R. de; CHECCHIA, Ana Karina A. "Queixa escolar e atuação profissional: apontamentos para a formação de psicólogos". In: MEIRA. Marisa E. M: ANTUNES, Mitsuko (orgs) Psicologia Escolar: Teorias Críticas. São Paulo, Casa do Psicólogo, 2003.

SOUZA, Regina Magalhães de. Escola e Juventude: o aprender a aprender. São Paulo, EDUC/Paulus, 2003b.

SPOSITO, Marília. "Juventude: crise, identidade e escola". In: DAYRELL, Juarez (org.) Múltiplos olhares sobre educação e cultura. Belo Horizonte, UFMG, 1996.

SPOSITO, Marilia Pontes. "Estudos sobre juventude em educação". In: Juventude e Contemporaneidade. Revista Brasileira de Educação. São Paulo, ANPED, n.5-6, 1997.

SPOSITO, Marília. "Considerações em torno do conhecimento sobre juventude na área da educação". In: SPOSITO, Marilia Pontes (org.). Juventude e Escolarização (1980-1998). Brasília, MEC/Inep/Comped, 2002.

SPOSITO, Marília. "Algumas reflexões e muitas indagações sobre as relações entre juventude e escola no Brasil". In: ABRAMO, Helena; BRANCO, Pedro (orgs). Retrato da juventude brasileira: análises de uma pesquisa nacional. São Paulo, Editora Fundação Perseu Abramo, 2005.

TANAMACHI, Elenita. "Mediações Teórico-práticas de uma Visão Crítica em Psicologia Escolar". In: TANAMACHI, Elenita; ROCHA, Marisa.; PROENÇA, Marilene (orgs.) Psicologia e Educação: desafios teórico-práticos. São Paulo, Casa Do Psicólogo, 2000. 
ULHOA, Maria José. Características do comportamento do adolescente brasileiro. Petrópolis, Vozes, 1974.

VENTURI, Gustavo; BOKANY, Vilma. "Maiorias adaptadas, minorias progressistas". In: ABRAMO, Helena; BRANCO, Pedro (orgs). Retrato da juventude brasileira: análises de uma pesquisa nacional. São Paulo, Editora Fundação Perseu Abramo, 2005.

VIÉGAS, Lygia. Progressão Continuada e suas repercussões na escola pública paulista: concepções de educadores. São Paulo, 2002. 250p. Dissertação (Mestrado), Instituto de Psicologia, Universidade de São Paulo.

YIN, Robert. K. Estudo de caso: planejamento e métodos. 2ed., Porto Alegre, Bookman, 2001. 